GUILHERME BRYAN

\title{
A AUTORIA NO VIDEOCLIPE BRASILEIRO: estudo da obra de Roberto Berliner, Oscar Rodrigues Alves e Mauricio Eça
}

\author{
São Paulo
}

Fevereiro de 2011 


\section{GUILHERME BRYAN}

\section{A AUTORIA NO VIDEOCLIPE BRASILEIRO: estudo da obra de Roberto Berliner, Oscar Rodrigues Alves e Mauricio Eça}

Tese de Doutoramento apresentada ao Programa de PósGraduação em Meios e Processos Audiovisuais, Área de Concentração Práticas de Cultura Audiovisual, Linha de Pesquisa Técnicas e Poéticas da Comunicação, da Escola de Comunicações e Artes da Universidade de São Paulo, como exigência parcial para obtenção do Título de Doutor em Ciências da Comunicação, sob a orientação do Profa. Dra. Marília da Silva Franco.

São Paulo

Fevereiro de 2011 
BRYAN, Guilherme

A Autoria no Videoclipe Brasileiro: Estudo da obra de Roberto Berliner, Oscar Rodrigues Alves e Mauricio Eça / Guilherme Bryan. São Paulo, 2011. $369 \mathrm{f}$.

Tese (doutorado) - Apresentada ao Programa de Pós-Graduação em Ciências da Comunicação da Escola de Comunicações e Artes da Universidade de São Paulo, São Paulo, 2011.

Área de Concentração: Estudo dos Meios e da Produção Midiática Linha de Pesquisa: Técnicas e Poéticas da Comunicação

Orientação: Profa. Dra. Marília da Silva Franco

1. Cinema 2. Televisão 3.Autoria 4. História do Videoclipe 5. MTV I. Título 


\section{FOLHA DE APROVAÇÃO}

GUILHERME BRYAN

A Autoria no Videoclipe Brasileiro:

Estudo da obra de Roberto Berliner, Oscar Rodrigues Alves e Mauricio

Eça

Tese de Doutoramento apresentada ao Programa de Pós-Graduação em Ciências da Comunicação, Área de Concentração Estudo dos Meios e da Produção Mediática, Linha de Pesquisa Técnicas e Poéticas da Comunicação, da Escola de Comunicações e Artes da Universidade de São Paulo, como exigência parcial para obtenção do Título de Doutor em Ciências da Comunicação, sob a orientação do Profa. Dra. Marília da Silva Franco.

BANCA EXAMINADORA:

Prof.(a) Dr.(a)

Prof.(a) Dr.(a)

Prof.(a) Dr.(a)

Prof.(a) Dr.(a)

Prof.(a) Dr.(a) 
Para minha família, que sempre me apoia e aposta nos meus sonhos. 


\section{AGRADECIMENTOS}

O caminho de pesquisa para esse doutorado só foi possível graças ao apoio e colaboração de inúmeras pessoas que disponibilizaram materiais importantes, escutaram, deram importantes conselhos em momentos de angústia e contararam suas histórias. O apoio incansável de minha família e amigos, em todos os momentos, fez com que, mesmo nos momentos de maior desespero e angústia, eu encontrasse forças para seguir em frente.

Meus pais Rosa Maria Bryan e Newton Antonio Paciulli Bryan, e meu irmão Francisco Bryan, pela total confiança e apoio em todos os momentos dessa empreitada. André Luiz Branco, pela dedicação e empenho na edição do DVD que acompanha essa tese. Inahiá Castro e Cibele Rocha, pelas traduções e o carinho de sempre. Otavio Freire, Maria Lourdes Freire, Ana Luisa Cavallari, Vincent Villari, Ivan Clever e Sônia Costa, pela amizade e torcida incansável. Mônica Carbone Russo, por ter acompanhado boa parte dessa trajetória.

Professora Doutora Marília da Silva Franco, que, desde o início, apoiou e incentivou essa pesquisa, com toda sua imensa experiência e conhecimento. Foi ela que, durante a banca de defesa da dissertação de mestrado, despertou em mim a vontade de desenvolver com mais profundidade o tema do videoclipe brasileiro. $\mathrm{E}$, desde que ingressei no doutorado desta escola, foi incansável no auxílio, nos conselhos e nas trocas de opinião.

Professor Doutor Eduardo Vicente, que fez sugestões extremamente construtivas e importantes durante o Exame Geral de Qualificação, apontando novos rumos para essa pesquisa. Foi graças a sua contribuição, por exemplo, que me detive a colher depoimentos dos artistas e profissionais que trabalharam diretamente com os três diretores de videoclipe selecionados para esse estudo.

Professor Doutor Fábio Cintra, que, durante o Exame Geral de Qualificação, comentou o trabalho de maneira tão profunda e entusiasmada que fez com que conquistasse ainda mais força para seguir adiante. Seus conselhos e sugestões também foram muito importantes para que a pesquisa ganhasse novos horizontes e ficasse mais focalizada na questão autoral propriamente dita dos três diretores.

Professora Doutora Izabel Aurora Branco, por ter acompanhado com bastante proximidade a realização de todas as etapas da pesquisa, com seus conselhos e 
sugestões. Os comentários dela deram novos rumos para o estudo em momentos cruciais.

Todos os professores e funcionários da Escola de Comunicações e Artes da Universidade de São Paulo. As disciplinas realizadas durante o curso de doutoramento foram de grande valia para a pesquisa.

Roberto Berliner, Oscar Rodrigues Alves e Mauricio Eça, que se disponibilizaram em todos os momentos a relatar suas experiências, sugerir videoclipes que foram analisados, localizar e auxiliar no contato com os outros entrevistados. Sem eles, esta tese realmente não faria o menor sentido.

Todos os entrevistados, que dispuseram de tempo e força de vontade para auxiliar na pesquisa, transmitindo conhecimento e informações que nortearam esse estudo em suas mais diferentes etapas e fases. São eles: Alê Briganti, Billy Bond, Carlos Carneiro, Claudio Torres, Cyro Del Nero, Djavan, Dulce Quental, Eid Walesko, Fernando Meirelles, Francisco Rodrigues Alves, Herbert Richers Jr., Herbert Vianna, João Barone, Jodele Larcher, Johnny Araújo, José Emilio Rondeau, Leo Jaime, Márcia Santos, Mari Stockler, Nando Cohen, Nelson Motta, Nilton Travesso, Paulo Trevisan, Pedro Luís, Raul Mourão, Ricardo Silveira, Rogério Gallo, Roger Moreira, Rui Mendes, Samuel Rosa, Sandra Kogut, Sergio Britto, Tadeu Jungle, Tony Tiger e Yone Sassa. 
A diferença entre um videoclipe banal e um genial é, via de regra, a cabeça de seu diretor. Um bom roteiro vale por mil canções bobas. Pior que um artista sem carisma é um diretor sem imaginação

(BAHIANA, Ana Maria, 1984). 


\section{RESUMO}

Este trabalho tem, como principal objetivo, investigar a questão da autoria na obra de três dos mais importantes diretores de videoclipes brasileiros - Roberto Berliner, Oscar Rodrigues Alves e Maurício Eça -, os quais se aproximam em função do caráter documental e se distinguem por marcarem três momentos específicos e diferentes da história dessa produção.

Palavras-chave: cinema - televisão - autoria - história do videoclipe - MTV 


\begin{abstract}
This research has as its main objective to investigate the matter of the responsibility for the creation on work of three of the most important Brazilian videoclip directors - Roberto Berliner, Oscar Rodrigues Alves and Mauricio Eça who approach themselves due to the documental character and distinguish for marking three specific and different moments of this production history.
\end{abstract}

Key-Words: cinema - television - creator - videoclipe history - MTV 


\section{SUMÁRIO}

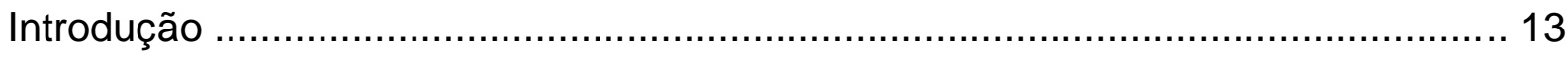

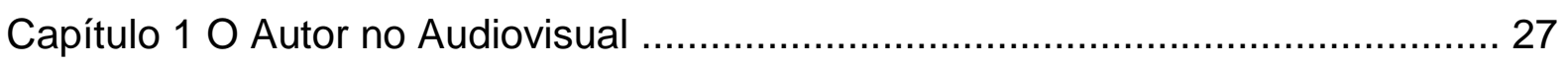

1.10 surgimento da questão autoral nas artes ...................................... 28

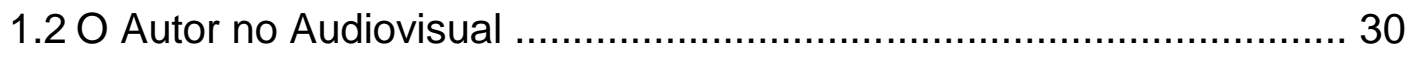

Capítulo 2 História do Videoclipe .................................................................. 39

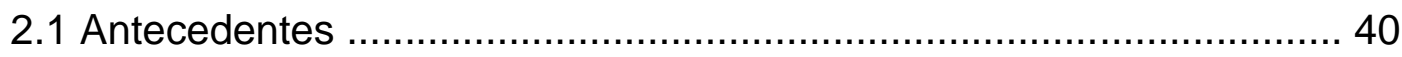

2.2 Cultura Jovem nas décadas de 1950 e 1960 ................................... 46

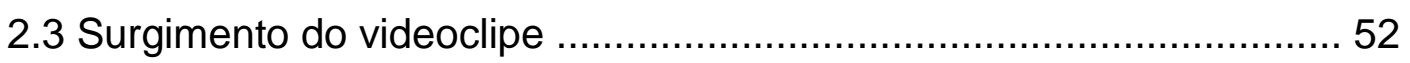

2.4 Nasce a Music Television (MTV) …………………...................... 56

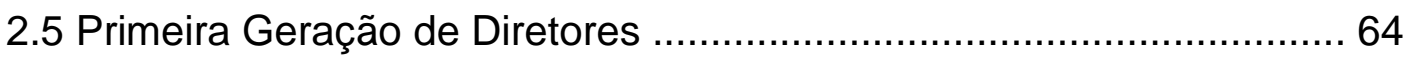

2.6 "Rei e Rainha do Videoclipe": Michael Jackson e Madonna ............... 69

2.7 Hip Hop e Heavy Metal Invadem a MTV .......................................... 77

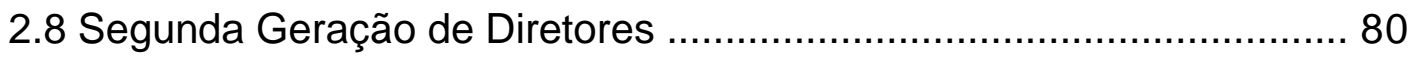

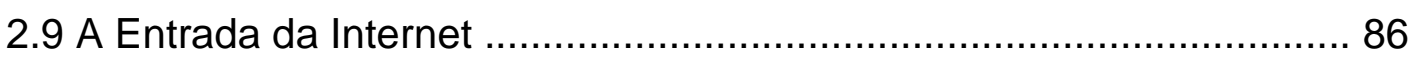

Capítulo 3 História do Videoclipe Brasileiro ..................................................... 95

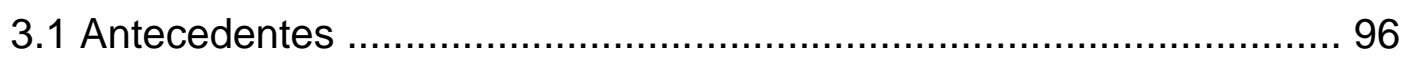

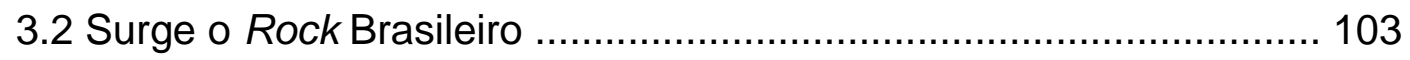

3.3 Videoclipes do Fantástico .......................................................... 109

3.4 O Cenário Pop Rock dos Anos 80 ............................................. 118

3.5 Programas Segmentados e Produtoras Alternativas ...................... 122

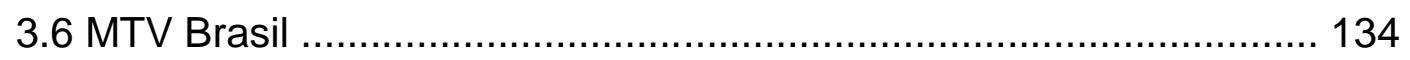

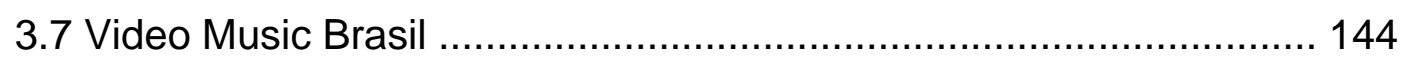

3.8 Pop Rock Nacional dos Anos 1990 e 2000 ................................... 154

3.9 Abril Music e Outros Ritmos e Estilos Musicais .............................. 166

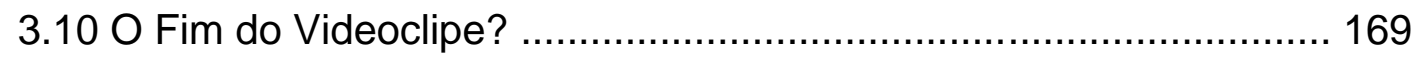

Capítulo 4 O Diretor Documental Estudo de Caso - Roberto Berliner ................... 177

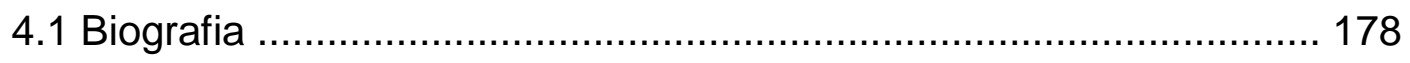

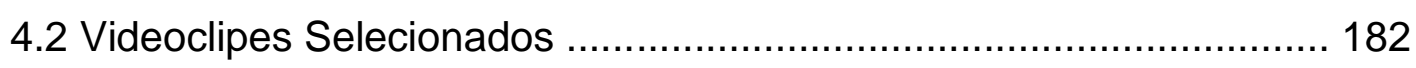

4.3 Considerações Gerais ............................................................... 195 
Capítulo 5 Um Autor A Serviço da Música Estudo de Caso - Oscar Rodrigues Alves ... 199

5.1 Biografia ............................................................................... 199

5.2 Videoclipes Selecionados .................................................... 202

5.3 Considerações Gerais ........................................................... 217

Capítulo 6 A Busca Pela Essência do Artista Estudo de Caso - Mauricio Eça ..... 223

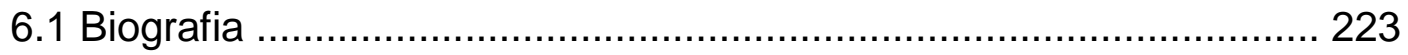

6.2 Videoclipes Selecionados ...................................................... 226

6.3 Considerações Gerais ............................................................. 238

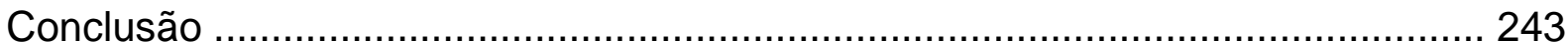

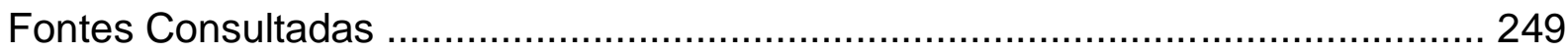

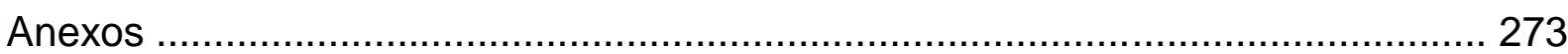




\section{INTRODUÇÃO}

Vinculado a uma única canção e de duração em média de três a quatro minutos, o videoclipe surgiu por volta do último quarto do século $X X$, como fruto da cultura jovem, desenvolvida a partir da década de 1950, e das experiências audiovisuais de relação entre imagem e música. Desde então, ele mostrou ser um ótimo espaço para exercícios de realizadores estreantes ou que buscavam novos ares para a produção, e que, nele, conseguiram desenvolver um trabalho mais autoral. Comprovar tal afirmação é o objetivo principal da presente pesquisa.

O videoclipe é um formato audiovisual que se constitui de uma história única e independente, na maioria das vezes baseada numa canção pré-existente e que, segundo Arlindo Machado ${ }^{1}$, parece suprir uma necessidade, exigida pela música pop, de desenvolvimento de capacidades cênicas em que a imagem do artista tornase tão importante quanto a música em si, visando a satisfazer os desejos de uma geração que aprendeu, não apenas a ouvir música, mas também a "vê-la". Não é à toa que a indústria fonográfica que, inicialmente, tinha a televisão como espaço de exibição por excelência, encontrou no videoclipe uma ótima ferramenta de marketing para a divulgação de uma canção, do disco a qual pertence e do próprio artista.

Essa é questão das mais importantes, quando se reflete sobre o potencial autoral do videoclipe. Afinal, ele une dois aspectos que antes pareciam inconciliáveis - o aspecto promocional e o aspecto artístico - muito em função das heranças trazidas da publicidade televisiva e da videoarte da década de 1970. Ou seja, buscase um diretor que tenha marcas autorais que se identifiquem mais com determinado artista da música pop. Assim, a autoria se dá principalmente na relação intrínseca entre realizador das imagens e intérprete da canção.

A produção de videoclipe também está diretamente baseada em experiências relacionadas com o que há de mais avançado em termos tecnológicos. Basta saber que, quando houve a mudança do formato analógico para o digital, o videoclipe foi um dos primeiros formatos audiovisuais a experimentar a novidade. O momento em que essa produção parecia perder espaço na televisão foi, justamente, quando ela mostrou ser o formato que melhor se adequava aos sites de vídeos da internet como o Youtube e as telas dos telefones celulares.

\footnotetext{
MACHADO, Arlindo. A Televisão Levada a Sério. 2ªed. São Paulo, SP. SENAC. 2001. p. 177.
} 
A questão autoral na produção artística está presente e é motivo de reflexão desde quando os artistas passaram a conquistar certa autonomia e prestígio. Por isso, mostrou-se necessário iniciar este trabalho com uma breve análise de como a ideia da autoria aparecia nas outras artes, que antecederam o audiovisual, e como a visão em torno dela foi sendo alterada ao longo do tempo. Este é o tema do primeiro capítulo, que prioriza a abordagem da questão autoral sobretudo no cinema e na televisão, mais especificamente nas telenovelas, dado a influência que elas mais diretamente exerceram sobre 0 videoclipe. A principal obra de referência para 0 primeiro capítulo é o livro "O Autor no Cinema - A Política dos Autores", de JeanClaude Bernardet, considerado um dos mais importantes a respeito do tema no cinema brasileiro.

Se o cinema e a televisão foram duas das mais importantes influências para a constituição do videoclipe como formato audiovisual autônomo, várias outras experiências da relação entre imagem e música foram determinantes para que ele se caracterizasse como tal. Esse é o caso dos jazz shorts, soundies, scopitones e promos $^{2}$. Também é importante conhecer o fato de que ele só se tornou possível graças ao desenvolvimento de uma cultura jovem, principalmente nos Estados Unidos e na Inglaterra, que são os principais pólos produtores de música pop e sedes das maiores gravadoras, com reflexos em quase todo o mundo. É basicamente com os artistas apreciados pelos jovens, com os quais os videoclipes irão trabalhar e dialogar, que será possível observar que o aspecto autoral dessa produção dá-se sobretudo pela relação intrínseca entre o diretor que muitas vezes assume também a função de roteirista e editor, e o intérprete da canção para a qual as imagens são criadas.

Uma vez conhecida a origem do videoclipe, torna-se importante refletir a respeito de como a questão autoral foi se desenvolvendo na produção internacional, ainda mais dos Estados Unidos e da Inglaterra, ao longo da história desse formato audiovisual, que conseguiu, de certo modo, revolucionar a indústria do disco e da televisão, a ponto de ganhar uma emissora exclusiva para ele, a norte-americana Music Television (MTV) (hoje com afiliadas no mundo inteiro) e consagrar realizadores, como o caso de Michel Gondry, Spike Jonze e Valerie Faris e Jonathan

\footnotetext{
${ }^{2}$ Trata-se de formatos audiovisuais de curta duração, que foram realizados desde o surgimento do cinema, sucedendo uns aos outros, como modo de intensificar a relação entre música e imagem no audiovisual, que tornará possível o aparecimento do videoclipe. Eles serão abordados no Capítulo .
} 
Dayton, entre outros, que se destacaram também no cinema e servem de referência para os realizadores brasileiros de videoclipe. Para esse capítulo destinado à história do videoclipe, as principais referências bibliográficas são "Money For Nothing A History of Music Video from the Beatles to the White Stripes", de Saul Austerlitz; "Dancing in the Distraction Factory: Music Television and Popular Culture", de Andrew Goodwin; "Rocking Around The Clock: Music Television, Postmdernism and Popular Culture", de E. Ann Kaplan; e "Videoclipe: o elogio da desarmonia", de Thiago Soares, assim como a dissertação de mestrado por mim desenvolvida sobre o tema ${ }^{3}$.

O terceiro capítulo abordará a história do videoclipe brasileiro, que, para este estudo, será considerado aquele que foi realizado por profissionais brasileiros, radicados no Brasil ou contratados por produtoras brasileiras, utilizando como base uma canção interpretada e/ou composta por artistas também brasileiros, independentemente do ritmo ou do gênero musical nele presentes ${ }^{4}$. Esse critério, portanto, vai privilegiar a nacionalidade da produção e não apenas o conteúdo musical do videoclipe.

A história do videoclipe brasileiro é reflexo direto da história da produção internacional, misturada com a apropriação de elementos da cultura nacional, o que, aliás, é parte intrínseca da produção artística brasileira, uma vez que são temas, por exemplo, do Cinema Novo: a favela e o morro dos grandes centros urbanos e a seca nordestina. A ligação com o cinema brasileiro é intensa. Não é à toa que um de seus antecedentes diretos é o curta-metragem A Velha a Fiar (1964), do cineasta Humberto Mauro.

A duração é uma das particularidades do videoclipe, pois, via de regra, o que determina seu tempo é a duração da canção, em média, de dois a três minutos. Além disso, é importante lembrar que, desde a última década do século $X X$, os realizadores de videoclipes em geral têm sido os mesmos de peças publicitárias e de filmes de curta, média e longa-metragem, com cada gênero influenciando diretamente o outro. É esse universo que mediará o trabalho dos três realizadores

3 BRYAN, Guilherme. Videoclipe Brasileiro - História, características e internacionalidade. Dissertação de Mestrado. Escola de Comunicação e Artes da USP. São Paulo, SP. 2005.

${ }^{4}$ Nesse caso, não deveria ser considerado o primeiro videoclipe exibido pela MTV Brasil, pois, apesar de ser estrelado por Marina Lima, com uma canção brasileira, "Garota de Ipanema", e produção nacional da MTV Brasil, a direção ficou por conta do britânico John Klein, em 1990. Por ter inaugurado a emissora especializada em videoclipes no Brasil, ele será considerado como uma produção importante para este trabalho. 
apreciados nesta pesquisa - Roberto Berliner, Oscar Rodrigues Alves e Mauricio Eça - representantes de três momentos distintos da história do videoclipe brasileiro.

Formado em Jornalismo pela Universidade Federal do Rio de Janeiro (UFRJ), Roberto Berliner trabalhou no centro de documentação da TV Globo, onde ficou de 1980 a 1983. Em 1982, abriu a produtora Antevê e começou a filmar os shows das bandas que se apresentavam no Circo Voador, importante casa de espetáculos do Rio de Janeiro nos anos 1980. Seus primeiros videoclipes foram realizados em 1986, para o programa Fantástico, da TV Globo - onde teve início a produção de videoclipes no Brasil, como fruto do trabalho de profissionais pertencentes à emissora, que o produziam nas ilhas de edição pertencentes a ela, utilizando-se do videoteipe e do registro em vídeo. Desde então, Berliner continuou dirigindo-os até a presente data, quando divide essas produções com a direção dos documentários de longa-metragem: A pessoa é para o que nasce (1998); Herbert de Perto (2006), codirigido com Pedro Bronz; e Pindorama, a verdadeira história dos sete anões (2007).

A produção de Roberto Berliner iniciou-se na primeira fase do videoclipe brasileiro, quando ele era realizado por profissionais da emissora de maior audiência no país, a TV Globo, como uma atração específica do programa dominical de variedades Fantástico. Portanto, era preciso respeitar a estética e o padrão de qualidade utilizado pela emissora. O que configura uma característica histórica que distingue o videoclipe brasileiro do norte-americano e do inglês, já que, por exemplo, essa realização começou principalmente do trabalho de profissionais ligados às artes plásticas, à videoarte e ao cinema.

O destaque da produção de Berliner se dá na segunda fase, momento em que o videoclipe passa a ser realizado por videomakers, que são profissionais em sua maioria vindos das artes plásticas e que trabalhavam com vídeos e possuíam as próprias produtoras. Essa produção mesclava a linguagem videográfica com a televisiva e era exibida principalmente em programas segmentados da televisão, de outras emissoras, além da TV Globo, que também abriu mais espaço em sua programação, não se limitando apenas ao Fantástico.

O videoclipe brasileiro, ao longo desse período, conquistou uma autonomia em relação às outras produções televisivas e videográficas, e consolidou-se como importante ferramenta, não apenas de marketing das gravadoras musicais para a 
publicidade de determinada canção, disco e artista, mas também para o envolvimento e identificação dos jovens brasileiros com sua cultura, uma vez que ali eles encontram seus ídolos, seus pares, seu visual e seu estilo de comportamento. Do ponto de vista dos realizadores, na maioria egressa das faculdades de Artes e Arquitetura, o videoclipe foi tomado como importante espaço de manifestação artística e, portanto, autoral, em busca da criação de um padrão estético específico.

O segundo diretor, Oscar Rodrigues Alves, é formado em Jornalismo pela Escola de Comunicações e Artes da Universidade de São Paulo (ECA-USP) e começou sua carreira ocupando cargos de jornalista em emissoras de televisão como a MTV Brasil, afiliada brasileira da norte-americana MTV, voltando-se, posteriormente, para a realização de videoclipes. Sua produção corresponde ao início da terceira e mais duradoura fase da história do videoclipe brasileiro, que vai de 1990 até por volta de 2006. Possui como marco inicial a estreia da MTV Brasil, em 20 de outubro de 1990, que representou a primeira interferência local de um grupo internacional que opera com a segmentação de mercados. No caso, uma emissora de televisão musical, tendência atualmente predominante nas grandes corporações da mídia mundial. Termina quando a direção dessa emissora opta por não mais exibir e premiar videoclipes.

Inicialmente, a MTV Brasil recrutou novos profissionais da publicidade e do cinema para realizar 21 videoclipes financiados por ela para canções brasileiras. Os jovens diretores vão encontrar no videoclipe um espaço que, por contingências políticas que serão abordadas posteriormente, não existia no cinema, para se manifestarem em linguagem artística, ainda que respeitando as vontades da indústria fonográfica e buscando enriquecer visualmente a canção e o artista com os quais trabalham. Nesse contexto, Oscar Rodrigues Alves foi contratado como um dos diretores da emissora, com a responsabilidade de cuidar da linguagem dos VJs (video-jockeys), que anunciam os videoclipes, de modo similar ao que realizam os locutores de emissoras de rádio FM. Apenas dois anos após a estreia da emissora, em 1992, é que ele dirigiria o primeiro videoclipe, Quitambô, para a banda Batakotô, exibido pela própria MTV Brasil. Desde então, não parou mais de dirigi-los.

O surgimento da MTV Brasil representou um novo e vasto espaço para a produção de videoclipes brasileiros, tanto que alguns estudiosos consideram-na o fato mais importante para a produção musical do Brasil desde os festivais de música 
popular da década de 1960. No entanto, outros a acusam de segregar a música realizada no país e vêem-na como uma frente avançada da cultura pop norteamericana, uma vez que exibe em grande parte de sua programação videoclipes vindos da matriz, atualizando, direcionando e interferindo no gosto do público jovem daqui. Polêmicas à parte, é importante ressaltar o papel representado pelo videoclipe no Brasil, sobretudo a partir da década de 1980, como fonte de diálogo com esse público.

Um desafio que se colocou para os diretores de videoclipes brasileiros, desde o surgimento da MTV Brasil, foi o de que, diferentemente do programa Fantástico, em que o videoclipe era exibido de modo quase isolado, como uma das atrações de um programa de variedades, a produção nacional poderia ser precedida ou seguida de uma produção internacional. Sendo assim, era preciso ter qualidade estética e artística à altura dos padrões dos videoclipes mais bem realizados no mundo, tanto em termos de investimentos financeiros, quanto de novos recursos audiovisuais, como efeitos especiais. Ao mesmo tempo, era preciso, mesmo respeitando os padrões estéticos de certo modo estabelecidos pela emissora multinacional, desenvolver - e rápido - uma estética nacional para os clipes aqui realizados, a fim de que eles se destacassem dos demais.

O terceiro diretor é Mauricio Eça, formado em Cinema pela Fundação Armando Álvares Penteado (FAAP), em São Paulo, e que, antes mesmo de terminar o curso, começou a dirigir videoclipes. Esse momento, 1994, corresponde basicamente ao maior impulso dado à produção nacional pela própria MTV Brasil: a criação da premiação Video Music Brasil (VMB), versão brasileira do Video Music Awards (VMA), da matriz norte-americana, que impulsionou o desenvolvimento do mercado de videoclipes no Brasil.

A premiação foi pensada para que profissionais da indústria fonográfica e aqueles envolvidos na realização dos videoclipes, além de estudiosos e críticos, pudessem, a convite da emissora, escolher as melhores produções de cada ano em diferentes categorias, como melhores videoclipes de rap, pop, MPB e rock, e melhores edição, fotografia, direção de arte e direção em videoclipe. Essa parecia a melhor maneira de se divulgar não apenas as principais peças audiovisuais exibidas pela MTV Brasil, como também mostrar e prestigiar quem as realizava, fomentando assim um aumento, tanto na produção, como na qualidade da produção. Curioso, entretanto, é notar que, entre os jurados, estavam os profissionais que financiavam 
as produções - o departamento de marketing das principais gravadoras em atividade no país, no caso as multinacionais Warner, EMI, Sony, BMG-Ariola e Universal, e a brasileira Som Livre, pertencente à Rede Globo.

Mauricio Eça é hoje um dos mais produtivos diretores de videoclipes no Brasil, com mais de 100 obras realizadas e caracteriza-se por, apesar de trabalhar num ritmo por assim dizer industrial, como vários outros realizadores da geração dele, impor marcas autorais na produção que realiza, a ponto de ser procurado justamente em função delas por vários intérpretes das canções que se transformarão em videoclipes. Ele também é um exemplo de diretor que conseguiu realizar videoclipes que se tornaram referência para outras produções audiovisuais, ainda mais no cinema. O caso mais expressivo é Diário de Um Detento, dirigido em 1998, para a canção dos Racionais MCs, e um dos primeiros registros a serem realizados no presídio paulistano Carandiru, após o massacre de 2 de outubro de 1992, que resultou na morte de 111 presos. Posteriormente, o doutor Dráuzio Varela transformaria no livro "Estação Carandiru" o relato das experiências, como médico dos presidiários. O livro, por sua vez, seria adaptado para o cinema, em 2002, pelo diretor Hector Babenco.

Ao longo da história recente do videoclipe, vários realizadores enfrentaram a difícil mudança da montagem e inserção de efeitos especiais na montagem analógica, em vídeo ou película, para a edição digital, realizada em computadores. As principais diferenças entre elas são a maior rapidez, os custos reduzidos, o envolvimento de menos profissionais na sala de edição, o acesso mais fácil ao material, a possibilidade de rever o original sem cortes, a ausência dos antigos ruídos, a preservação de diferentes versões do filme, a possibilidade de se trabalhar com várias pistas de som e imagem simultaneamente, e a maior integração com os efeitos especiais.

Por esse motivo, pode-se afirmar que o videoclipe é o gênero por excelência de uma nova fase da televisão, como acredita Arlindo Machado:

Em pouco mais de dez anos, o videoclipe se impôs como uma nova forma de expressão dentro do universo do vídeo e rapidamente ganhou espaço dentro e fora da televisão, conquistando amplo contingente de adeptos e provocando uma pequena revolução no interior das indústrias do vídeo e do disco ${ }^{5}$. 
É assim que, nesta pesquisa, mesmo compreendendo que o videoclipe brasileiro é fruto do trabalho de vários profissionais, portanto uma obra coletiva como o é qualquer peça audiovisual, espera-se fornecer subsídios para uma maior compreensão dos meandros da realização da produção, por meio do trabalho desses três realizadores e também de como ele tem servido para o exercício autoral de profissionais que levarão a experiência para o cinema e para a publicidade, e vice-versa.

Para este estudo foram selecionados, de início, vários diretores de grande relevância para o videoclipe realizado no Brasil, que serão abordados via depoimentos e exemplos de produção, principalmente no capítulo destinado à história do videoclipe brasileiro. Roberto Berliner, Oscar Rodrigues Alves e Mauricio Eça, porém, destacam-se dos demais pelo volume da produção - entre mais de três mil videoclipes, nacionais e internacionais, gravados aleatoriamente da televisão, entre 2002 e 2007, foram os que mais se fizeram presentes. Eles também tiveram a produção premiada no VMB, realizado pela MTV Brasil, desde 1994, e considerado o mais importante prêmio destinado a essa produção.

Outros critérios que fizeram com que Berliner, Alves e Eça tivessem a obra pesquisada de forma mais atenta neste trabalho foram temáticas diferentes de produção; a representação de três momentos distintos da história do videoclipe brasileiro; o fato de trabalharem com artistas da música pop, consumida principalmente pelos jovens brasileiros de cada período; e considerarem importante o estabelecimento de um novo tipo de comunicação com esse público, que é o principal apreciador e admirador de videoclipes.

O aspecto autoral de cada um dos três realizadores será analisado em três capítulos, a partir de sete videoclipes de cada um, sem perder de vista a produção como um todo. Foi escolhida a primeira produção de cada autor por essa produção seminal conter a virtualidade do conjunto da obra. Para Paulo Emilio Salles Gomes, conforme citado por Jean-Claude Bernardet ${ }^{6}$, a obra de um cineasta (o mesmo talvez possa ser dito com relação à do diretor de videoclipes, o que se procurará analisar) é um conjunto percorrido por temas recorrentes. Daí poder-se utilizar o método da leitura retrospectiva, com as obras recentes iluminando as anteriores, e

6 BERNARDET, Jean-Claude. O Autor no Cinema. Editora Brasiliense. São Paulo, SP, 1994, págs. 119 e 120. 
estas anunciando as posteriores, em busca de uma unidade a ser encontrada. Isso sem deixar de lado as rupturas e contradições internas à obra, como realçado por outros teóricos.

Os aspectos destacados acima serão investigados em outras seis produções selecionadas pelos próprios diretores, em função do prazer pela realização, da presença do aspecto autoral e também do reconhecimento do próprio mercado e do público, por meio das premiações. A fim de facilitar a apreciação desses videoclipes, foram realizadas fichas que listam os profissionais envolvidos com o trabalho e a maneira como os próprios realizadores descrevem aspectos como história, heranças e avanços, relação imagem-música e marcas dos seus trabalhos. Essas fichas, que foram fundamentais para a elaboração dos capítulos que abordam cada um dos autores, estão agrupadas, como anexo, no final do trabalho.

Os capítulos não envolvem apenas o conjunto da produção, mas também a vida do autor. Daí a necessidade de se realizarem entrevistas com os três diretores. A finalidade principal é conhecer melhor o "fazer videoclíptico", do ponto de vista de seu realizador, em suas diferentes etapas de produção. Desse modo, acredita-se, tornou-se possível conhecer mais a fundo como as obras foram produzidas, contando com o reforço do depoimento de alguns artistas e outros profissionais com quem eles trabalharam nos seis videoclipes, dando-se preferência para aqueles que tiveram canções lidas em imagens por mais de um deles, caso do Skank, presente tanto na lista de Roberto Berliner, quanto na de Oscar Rodrigues Alves. Foi possível, assim, observar a maneira como esses realizadores trabalham e se relacionam com o intérprete da canção. As entrevistas com os três diretores estão anexadas em sua íntegra, no final da pesquisa.

Uma vez identificadas as particularidades e as marcas autorais das realizações de Roberto Berliner, Mauricio Eça e Oscar Rodrigues Alves, supõe-se ter sido possível relacioná-las de modo mais abrangente e aprofundado, localizando o que elas possuem de diferente e de semelhante, e que, portanto, podem ser constituintes do próprio videoclipe brasileiro. É preciso salientar que, nesse capítulo, não foi feito qualquer juízo de valor que pudesse levar a uma super valorização e/ou depreciação de um determinado realizador em detrimento de outro, mas apenas identificar o que os distingue. São essas distinções, presentes na maioria dos clipes de cada realizador, importantes para a reflexão em torno das marcas autorais. 
Acredita-se que uma pesquisa a respeito da questão autoral no videoclipe brasileiro poderá gerar conhecimentos a respeito da televisão e da cultura pop, e de outros aspectos ligados à cultura midiática, cujos estudos apenas se esboçam, pelo fato de, segundo Arlindo Machado ${ }^{7}$, a televisão ainda ser abordada como uma mídia de menor qualidade artística, impedindo, dessa maneira, que se preste atenção a experiências singulares e fundamentais para definir um panorama da cultura do final do século $X X$, dentre as quais pode-se destacar o videoclipe. A produção audiovisual ainda é muito pouco estudada em razão de muitas vezes ser ela apontada como descartável e voltada para o consumo imediato do público jovem.

Assim, conhecer a produção de videoclipes dos autores selecionados para compor a pesquisa com relação à autoria no videoclipe brasileiro - Roberto Berliner, Oscar Rodrigues Alves e Maurício Eça - é de grande importância para se compreender o grau de liberdade artística que possuem para produzir sua obra e, desse modo, observar no que tal fator interferiu em seus trabalhos na publicidade e no cinema, além da maneira como dialogaram com o momento histórico em que atuam.

Formato audiovisual relativamente novo, de cerca de 35 anos de história, o videoclipe sempre foi tema de meu interesse acadêmico, especificamente quando cursava Jornalismo na Faculdade de Comunicação Social Cásper Líbero e percebi como ele era e continua sendo importante na formação do imaginário de gerações de jovens brasileiros no contexto do que se denomina cultura globalizada. Embora como apenas mais uma das manifestações artísticas estudadas, a produção de videoclipe fez parte do trabalho de conclusão do curso de graduação (tendo começado em dezembro de 1996, foi avaliado e aprovado como Trabalho de Término de Curso de Jornalismo em $1998^{8}$ ), estendendo-se até setembro de 2004, com a publicação do livro "Quem Tem Um Sonho Não Dança - Cultura Jovem Brasileira nos Anos 80".

Foi durante o desenvolvimento desse trabalho que descobri o prazer e a importância da pesquisa, pois investigar fatos históricos e formatos artísticos são alicerces significativos também para a minha formação, como para a das outras gerações.

7 MACHADO, Arlindo. A Televisão Levada à Sério. Editora Senac. São Paulo, SP, 2001, p. 15.

8 BRYAN, Guilherme. Quem Tem Um Sonho Não Dança - Cultura jovem brasileira nos anos 80. Ed. Record, Rio de Janeiro, RJ. 2004. 
O interesse pela cultura jovem brasileira, em específico, fez com que, no curso de Mestrado em Comunicação e Cultura, na Escola de Comunicações e Artes da Universidade de São Paulo de 2002 a 2005, eu me dedicasse à história e à linguagem do videoclipe brasileiro, começando por abordar as primeiras experiências da relação entre música e imagem nas manifestações culturais - com destaque para as produções audiovisuais, a partir de seu nascimento até a observação de cinco videoclipes nacionais.

O envolvimento com o tema, no período da realização da dissertação de Mestrado, levou-me a organizar um acervo de videoclipes, que conta atualmente com cerca de dois mil títulos. Também passei a assinar uma coluna, primeiro no site da MTV Brasil, entre 2004 e 2006, De Olho No Clipe, que foi destacado no livro “Admirável Mundo MTV Brasil” (Saraiva, 2005), e, a partir daí até dezembro de 2008, no site do Multishow, Clipe-se. As duas emissoras de televisão, MTV Brasil e Multishow, são reconhecidas como as principais exibidoras de videoclipes no país, o que estimulou ainda mais meu interesse pelo assunto. Atualmente, desenvolvo trabalho semelhante para o portal da internet Yahoo! Brasil.

Trabalhar com mais de 50 videoclipes diferentes para as três colunas, levoume ao interesse pela questão autoral presente nesse tipo de produção audiovisual, que, se por um lado, destaca-se pela liberdade de invenções que proporciona aos seus realizadores, por outro lado, está fortemente associada à divulgação comercial de uma determinada canção, do artista que a interpreta e do disco a que pertence.

Não obstante, é preciso reconhecer que uma das dificuldades encontradas, durante a elaboração da dissertação de Mestrado, continua presente ainda hoje: existe pouco ou quase nenhum material escrito em língua portuguesa a respeito dos videoclipes e, menos ainda, da produção brasileira de videoclipes. Na Internet, é possível encontrar alguns poucos artigos publicados em revistas ou em sites especializados e de universidades. Mesmo na produção internacional, o número é pequeno e necessita de tradução para o português.

O interesse de novos pesquisadores pelo tema, no entanto, é inversamente proporcional à bibliografia existente. Desde que comecei a escrever a coluna De Olho no Clipe para o site da MTV Brasil, venho sendo consultado a respeito da história e da linguagem do videoclipe, e pude acompanhar de perto novos artigos e trabalhos científicos que estão sendo desenvolvidos sobre a temática. De um deles, 
"Do Fantástico ao Youtube - A História do Videoclipe Musical no Brasil", trabalho de conclusão de curso de Jornalismo da Pontifícia Universidade de São Paulo (PUCSP), em 2007, fui convidado para integrar a banca examinadora. O mesmo ocorreu com "Videoclipe: Um Universo Intersemiótico", trabalho de conclusão de curso de Rádio e TV do Centro Universitário Belas Artes de São Paulo, em 2010. Também realizei, em 2005, uma reportagem para o caderno "Folhateen", do jornal "Folha de S. Paulo", a respeito da história do videoclipe no Brasil e no mundo - "30 Anos num Clipe". Participei de palestras e seminários a respeito do tema - "Aumenta Que Isso Aí É Rock'n Roll", evento no Sesc da cidade de Campos (RJ) em 2007 e da Mesa "Videoclipe", da VIII Semana do Audiovisual da ECA-USP, em 2007.

Ainda que possamos verificar o progressivo interesse pelo videoclipe, parece estranho que, com quase 35 anos de história, ele ainda seja visto com descaso por alguns estudiosos das linguagens audiovisuais e da cultura brasileira, o que fica mais acentuado quando se percebe que o espaço de exibição por natureza do videoclipe - a televisão -, também ocupa pouco espaço de estudos e análises nas escolas de cinema e de comunicação brasileiras.

Apesar de nunca ter atuado ou acompanhado de perto, na prática mesmo, a realização de um videoclipe, este formato sempre me encantou e tem se mostrado, ao longo de minhas pesquisas, fundamental para uma época essencialmente visual e musical, e de fácil adaptação aos mais diferentes meios de comunicação. Prova disso é que uma das "bibliotecas virtuais" de vídeo do mundo, Youtube, possui, entre as produções mais acessadas e vistas, justo o videoclipe.

Além disso, é importante lembrar que muitos dos profissionais do audiovisual reconhecidos como os realizadores mais interessantes do cinema e da televisão tiveram passagem pelo videoclipe! É o caso, por exemplo, de diretores e roteiristas cinematográficos, como Spike Jonze, Sofia Copolla, Michel Gondry, Fernando Meirelles, Breno Silveira, Andrucha Waddington, Cláudio Torres e José Henrique Fonseca, dentre outros.

Diante do exposto e preocupado em preencher um espaço que estava meio vazio em termos de estudos acadêmicos e a fim de realizar uma pesquisa com o rigor exigido pelo tema, resolvi me inscrever no doutorado, com o propósito de dar continuidade aos estudos iniciados e desenvolvidos no mestrado. Acatei a sugestão da Profa. Dra. Marília Franco, integrante da banca examinadora de minha 
dissertação e que sempre se mostrou interessada por pesquisas envolvendo o assunto, assim como pela produção audiovisual brasileira de um modo geral.

O meu interesse é fazer com que este trabalho contribua não só para o mundo acadêmico, na esperança e expectativa de que novos estudos sejam realizados, mas também contribua para satisfazer os interesses dos que tenham curiosidade pelo tema, principalmente os jovens, que, desde o nascimento, convivem com esse formato e com seus realizadores, que transformam uma determinada canção em imagens, com o intuito de deixá-la ainda mais atrativa, e, com isso, influenciam de forma marcante os outros audiovisuais, nos quais atuam com cada vez mais intensidade, sem dúvida nenhuma deixando o público "jovem", acostumado com o dinamismo do mundo moderno, ainda mais encantado com as produções artísticas. 



\section{CAPÍTULO 1}

\section{O AUTOR NO AUDIOVISUAL}

O videoclipe, como toda produção audiovisual, insere-se no que chamamos de Indústria Cultural $^{9}$ e é fruto de um trabalho realizado por diversos profissionais, desde os da parte técnica, como câmera, iluminador, fotógrafo, produtor e preparador de elenco até aqueles que aparecem na frente da câmera, caso de atores e figurantes.

Refletir a respeito do aspecto autoral desse tipo de obra, portanto, deve levar em consideração o fato de ela ser fruto de um trabalho coletivo e não envolver apenas a mente de um único criador. No entanto, há sempre um diretor, que, na maioria das vezes, assume outras funções na produção, desde operador de câmera até roteirista e editor.

Outro aspecto importante é o fato de o videoclipe quase sempre ser um produto originário de uma canção pré-existente, tendo na sua criação a relação intrínseca entre o autor do videoclipe e o intérprete da canção, que pode ser ou não o autor da música e da letra em questão. Na maioria das vezes, há também a interferência do departamento de marketing da gravadora, em relação a qual ??? o fonograma a ser trabalhado pertence e a quem cabe contratar um determinado diretor para a função.

Desse modo, uma análise da questão autoral no videoclipe precisa levar em conta todos esses aspectos internos e externos da realização. Ao mesmo tempo, porém, é preciso levar em consideração o fato de que ela é fruto também de todo um pensamento que foi se desenvolvendo no mundo das artes ao longo dos tempos, até desembocar na produção audiovisual, com destaque, nesse capítulo, para o cinema e a televisão.

9 Termo usado pela Escola de Frankfurt, de teóricos como Theodor Adorno e Max Horkheimer, a partir de 1947, para designar uma verdadeira indústria de produtos culturais voltados para o consumo, o que, de certa forma, desqualifica e banaliza as obras artísticas, ao transformá-las em mercadorias. 


\subsection{0 surgimento da questão autoral nas artes}

Vários séculos de História foram necessários para que o artista passasse a ter algum valor considerável dentro da sociedade e ter seu nome reconhecido dentre os apreciadores das artes.

Na Grécia Antiga, por exemplo, o filósofo Platão desconsiderava o artista que, para ele, era apenas um imitador da "sociedade perfeita" descrita em sua principal obra "A República".

Durante a Idade Média, na Europa, o artista era visto como uma espécie de artesão, que se submetia às regras de produção e do mercado, em oficinas familiares, nas quais se destacavam, principalmente, os filhos e parentes próximos dos ourives e escultores.

A identificação do autor, através da singularidade da escrita, surgiu nas civilizações orientais cerca de 4 mil a.C., quando foram realizadas obras literárias conhecidas até hoje como anônimas, em sua maioria, ou assinadas por pseudônimos. Porém, ao mesmo tempo, interessava aos seus autores divulgar a "mercadoria" e não o "mercador".

Foi apenas durante o Renascimento (1300 a 1650) que os artistas arquitetos, músicos, atores e escritores - passaram a ser mais reconhecidos por alguns de seus clientes, que eram os comerciantes recém-enriquecidos e os nobres. Aos poucos, esses artistas foram se tornando independentes das oficinas, passando a ser mantidos pela nobreza, interessada no caráter exclusivo e original da obra de arte, realizada por um artista com excelência em seu ofício, caso de Leonardo Da Vinci, que também era cientista e filósofo.

A seu respeito, a socióloga Cristina Costa explica:

A partir dessa profusão de obras de arte, agora já produzidas independentemente das oficinas e vendidas diretamente aos clientes, dava-se início à organização da produção artística propriamente dita. $O$ artista foi ganhando autonomia e importância dentro da sociedade e deixando de se confundir com o artesão, aquele produtor manual, cuja produção obedecia aos modelos tradicionais de uma cultura, como os tecelões e os entalhadores. Ao contrário, o artista era estimulado à criação inovadora, à expressão individual e à produção de obras originais, capazes não só de distingui-lo como de notabilizar seu cliente ou mecenas. ${ }^{10}$

10 COSTA, Cristina. Questões de Arte. Editora Moderna. São Paulo, SP. 1999, p. 36. 
Durante o século $\mathrm{XV}$, os artistas assinaram os primeiros contratos individuais com seus clientes, quase simultaneamente ao surgimento dos primeiros acervos, que eram coleções particulares de obras de arte. Começaram a surgir as primeiras orquestras e companhias teatrais, responsáveis por um mercado de espetáculos ao mesmo tempo em que há uma maior valorização da técnica do artista do que do material utilizado nas obras. Ele passa a receber um "salário", ou seja, uma quantia estipulada para pagar o tempo necessário para a produção, o número de ajudantes e auxiliares, e, sobretudo, o uso da habilidade pessoal para realizá-la.

É no século XVIII, entretanto, com o desenvolvimento industrial, que o artista conquista, de certo modo, uma maior liberdade criativa, uma vez que empresários passam a patrocinar obras de pintores e escritores, não apenas voltadas para o gosto da burguesia emergente, mas também obras que retratavam a realidade da época, sob a ótica individual de seus autores. Surge a figura do mecenas, pessoa conhecida por patrocinar as artes, a ciência ou o ensino, como fizera o romano Caius Mecenas durante o Império Romano, com relação aos escritores Homero, Virgilio e Propertius.

O desenvolvimento do modo de produção capitalista e o acelerado processo de industrialização, responsáveis pelo surgimento da imprensa, transformaram, também, a produção e a divulgação dos bens culturais. Se antes apenas uma parcela privilegiada da sociedade tinha acesso à produção cultural, a partir da divulgação das obras de arte pelos meios de comunicação, o restante da população passou a ter acesso a elas também.

O folhetim, exemplo desse tipo de produção da época, permitia que escritores, como o francês Alexandre Dumas, pudessem divulgar seu estilo particular de analisar a realidade, mesmo sendo enquadrados na categoria de "autores menores", devido ao caráter "popular" de suas obras. Os autores criavam marcas, independentemente da linha adotada pelos jornais onde eram publicados seus trabalhos, o que fazia com que fossem acompanhados por admiradores de suas criações. Esse aspecto não é muito diferente do que viria a acontecer em época posterior no cinema, na televisão e no próprio videoclipe. Um exemplo é a quantidade de pessoas que acompanham os filmes de cineastas como Woody Allen, Martin Scorsese, Quentin Tarantino, Robert Rodriguez e os irmãos Joel e Ethan 
Coen, e de novelistas como Maria Adelaide Amaral, Silvio de Abreu, João Emanuel Carneiro e Gilberto Braga nos dias atuais.

\subsection{O Autor no Audiovisual}

A proposta de analisar a importância do autor na produção do videoclipe reporta às reflexões realizadas a respeito da autoria no cinema, uma vez que a produção de videoclipe possui uma ligação direta (ou íntima) com a produção cinematográfica. Como boa parte da produção televisiva, o videoclipe herdou profissionais, além de linguagens e técnicas desenvolvidas no cinema. Por outro lado, verifica-se que muitos profissionais que se lançaram inicialmente no videoclipe são formados em escolas de cinema. No caso da pesquisa, dos três diretores selecionados, apenas Mauricio Eça possui esse tipo de trajetória. O objetivo deles é, portanto, sempre utilizar o videoclipe como espaço para experimentações, que, no futuro, levarão para o cinema, para a publicidade e para outras produções televisivas.

São justamente essas marcas, que, unidas, formam um estilo, que se procura encontrar na produção cinematográfica, quando se analisa a possível autoria de um determinado filme, em que, de acordo com o crítico e diretor francês Alexandre Astruc, conforme destacado por Jean-Claude Bernardet ${ }^{11}$, o artista pode expressar seu pensamento, por mais abstrato que seja, ou traduzir suas obsessões, como no ensaio ou no romance.

Com tal finalidade e no intuito de defender o cinema como algo artístico, e não meramente comercial, o que se procurará fazer aqui também em relação ao videoclipe, Astruc se vale da idéia de "caméra-stylo", termo criado pelo pensador em 1948, de modo que, assim como um escritor se expressa por meio de um texto, o cineasta se expressa através de um filme ${ }^{12}$.

Por ser considerada uma arte majoritariamente visual, apesar do importante papel desenvolvido pelo som - daí tratar-se de uma produção audiovisual -, em geral destaca-se o diretor como sendo o responsável pela autoria da obra, mesmo sendo o cinema uma arte que envolve o trabalho de centenas de profissionais,

${ }^{11}$ BERNARDET, Jean-Claude. O Autor no Cinema. Editora Brasiliense. São Paulo, SP, 1994, p. 20.

12 SAYAD, Cecília. O Jogo da Reinvenção Charlie Kaufman e o Lugar do Autor no Cinema. São Paulo, SP. Alameda. 2008, p. 14. 
assim como as outras produções audiovisuais, incluindo o videoclipe. Esse papel atribuído ao diretor passará a ganhar maior destaque a partir da década de 1950.

A questão da autoria cinematográfica, no entanto, já estava presente em 1919, de acordo com Jean-Claude Bernardet, na reflexão do crítico Henri-Diamant Berger $^{13}$, que atribuía a autoria cinematográfica ao roteirista, uma vez que, em sua opinião, é no roteiro que está escrito o filme do modo como ele será impresso em película.

Em outras produções televisivas, como as telenovelas, a autoria permanece vinculada ao responsável pelo texto e não pelas imagens. Para o novelista Aguinaldo Silva, essa produção é fruto de trabalho de equipe, onde o escritor não é o dono do trabalho, pois depende de vários profissionais e a telenovela só funciona quando todos estão antenados. ${ }^{14}$

O também escritor de telenovelas, Manoel Carlos defende a autoria do escritor das tramas, assim como do responsável pelas imagens, afirmando que:

No cinema, o autor principal, digamos assim, é sempre o diretor. O roteiro de cinema passa por muita gente. A novela de televisão, não. Ela é minha. Eu sou o autor, sou o responsável por tudo que está sendo dito. Tenho colaboradores que escrevem cenas, mas tenho que avalizar tudo. Quando a novela deixa de ser um script, ou seja, quando ela deixa de ser literatura - com ou sem aspas - e passa a ser imagem, ela ganha a autoria do diretor. Trata-se de uma co-autoria. ${ }^{15}$

O novelista Carlos Lombardi tem outra opinião a respeito:

A autoria na TV é diferente de todas as outras. Na literatura, o autor age em parceria imediata com a imaginação do leitor. Cada um lê um livro de um jeito diferente. No cinema, o texto é parte do espetáculo. Na televisão internacional, o conceito de autoria é muito marcante: os seriados mais bem-sucedidos - e até os malsucedidos - têm em um ou dois roteiristas os criadores principais, conhecidos como showrunners. A novela brasileira já foi assim, nos tempos de Ivani Ribeiro e Janete Clair. Por uma distorção única no mundo, a ideia do diretor como autor da narrativa, comum no cinema dos anos 1960, foi encontrar eco na TV brasileira a partir do final dos anos $1990 .^{16}$

\footnotetext{
13 BERNARDET, Jean-Claude. O Autor no Cinema ..., p. 15.

14 MEMÓRIA GLOBO. Autores Histórias da Teledramaturgia Vol. 1. Editora Globo. São Paulo, SP, 2008, p. 50.

IDEM, p. 102.

16 IBIDEM, p. 314.
} 
A questão referente à importância do autor do roteiro ou do storyboard será levada em consideração no momento em que se analisar a autoria no videoclipe.

Dos sete videoclipes selecionados pelos três realizadores brasileiros destacados neste estudo - o que totaliza vinte e um videoclipes -, nove têm a assinatura do roteiro e da direção não apenas por eles, mas também por outros profissionais, incluindo os compositores e/ou intérpretes da canção. É o caso, por exemplo, de "Diário de Um Detento", em que o roteiro é assinado por Mauricio Eça e Mano Brown, este último compositor da canção e vocalista da banda que a interpreta, Racionais MC's.

A associação de autoria com o diretor, no cinema, parece ter começado em 1921, quando o ensaísta e realizador francês Jean Epstein, segundo Jean-Claude Bernardet, ${ }^{17}$ menciona a multiplicidade de funções assumidas pelo diretor. Mas o papel do diretor ganha destaque mesmo com o surgimento das teorias da "política do autor" ${ }^{\prime 18}$, iniciada na década de 1950 pelos críticos da revista francesa "Cahiers du Cinéma", dentre os quais citamos os futuros cineastas François Truffaut, Claude Chabrol e Jean-Luc Godard, e também abordada pela revista inglesa "Movie" e pelo crítico norte-americano Andrew Sarris. De acordo com vários desses críticos, mesmo cercado de máquinas, técnicos e atores, o autor, sempre o diretor, encontra-se só no estúdio procurando expressar suas próprias histórias e seus pontos de vista.

O crítico inglês Edward Buscombe defende que o principal propósito da "política do autor" é elevar o status cultural do cinema, firmando-o como uma forma artística, tal qual a pintura ou a poesia, uma vez que oferece ao indivíduo a mesma liberdade de expressão pessoal. Não é muito diferente daquilo que se pretende analisar, nesta pesquisa, sobre o videoclipe brasileiro.

Jean-Claude Bernardet ${ }^{19}$ considera que a "política do autor" baseia-se em três premissas: a primeira é a competência técnica do diretor; a segunda é o conjunto de estilos recorrentes, que constituirão sua assinatura; e a terceira é a denominada "mise en scène", ou seja, os aspectos que fazem do cinema definitivamente uma

\footnotetext{
17 BERNARDET, Jean-Claude. O Autor no Cinema ..., p. 10.

18 Esse termo é utilizado pela primeira vez em fevereiro de 1955 no artigo de François Truffaut para o "Cahiers du cinéma", "Ali Baba et la politique des auters", a respeito do filme Ali Baba et les quarante voleurs (1954), do diretor Jacques Becker, o qual, de acordo com Truffaut, consegue imprimir ao filme um estilo próprio, que se torna uma assinatura e, por isso, merece o título de autor. SAYAD, Cecília. O Jogo da Reinvenção ..., p. 18.

19 BERNARDET, Jean-Claude. O Autor no Cinema ..., p. 27
} 
arte (aspectos que serão analisados nesta pesquisa, quando se abordar a autoria do videoclipe).

Charles W. Eckert, crítico inglês, analisa assim a "teoria do autor":

\begin{abstract}
O que a teoria do autor argumenta é que qualquer filme, com certeza um filme de Hollywood, é uma rede de afirmações diferentes, cruzando-se e contradizendo-se simultaneamente, elaboradas em uma versão final 'coerente'. Como um sonho, o filme que o espectador vê é, digamos, o 'filme fachada', o produto final de uma 'revisão secundária', que esconde e mascara o processo que permanece latente no filme 'inconsciente'. Por vezes, esta 'fachada' está tão trabalhada, tão polida, ou então tão marcada por coágulos de elementos díspares, que é impossível ir para lá dela ou, melhor, ver algo mais que não sejam as personagens, o diálogo, o enredo, etc. Mas em outros casos, por um processo de comparação com outros filmes, é possível decifrar não uma mensagem ou mundividência coerentes, mas uma estrutura que está subjacente ao filme e o modela, Ihe dá um certo padrão de energia catéctica. É esta estrutura que a análise proposta pela teoria do autor liberta do filme. ${ }^{20}$
\end{abstract}

Não é necessário ainda que o autor desenvolva o roteiro dos filmes, mas, sim, que os interprete de modo bastante pessoal. A escolha do tema a ser abordado também implica uma questão de estilo, portanto, autoral. Desse modo, ele pode ser prejudicado pelo produtor, mais interessado em fornecer uma fórmula comercial, daí ser tomado como uma espécie de vilão que impede o autor de realizar suas proezas artísticas, mas do qual é incapaz de se livrar. Mesmo o chamado "cinema independente" depende da indústria para sobreviver. M. Drouzy, segundo JeanClaude Bernardet ${ }^{21}$, observa, então, que os filmes não são resultantes de um autor cujo inimigo é o produtor, mas, sim, são fruto de um quadro de produção que envolve tanto autor, quanto produtor, mantendo as marcas dessa relação profissional no resultado final.

As marcas autorais de um determinado diretor são manifestadas também por meio das condições técnicas e culturais, exigidas pelo comércio cinematográfico. Como observa o cineasta italiano Federico Fellini" ${ }^{22}$ : "o ideal seria, como no caso de 2001, Uma Odisséia no Espaço, de (Stanley) Kubrick, que essas extraordinárias equipes de técnicos estivessem a serviço de uma ideia, de um sentimento, da fantasia de um autor" e não apenas a serviço de uma indústria cinematográfica.

${ }^{20}$ ECKERT, Charles W. The English Cine-Structuralists, p. 49. In. RAMOS, Fernão Pessoa (org.). Teoria Contemporânea do Cinema Volume 1 ..., p. 313.

21 ROCHA, Glauber. In BERNARDET, Jean-Claude. O Autor no Cinema ..., p. 47.

22 BERNARDET, Jean-Claude. O Autor no Cinema ..., p. 56. 
O diretor e crítico brasileiro Rubem Biáfora analisa os possíveis prejuízos que podem ser atribuídos ao autor cinematográfico pelos produtores:

Em Hollywood, verdadeiros diretores de cinema (...) devido ao controle exercido pela indústria, são obrigados a sufocar a sua capacidade criadora e a aplicar somente uma mínima parte do mundo de conhecimento cinematográfico que realmente possuem. Quando seus filmes não são as obras-primas que eles podem realizar a qualquer momento, tal fato nunca se dá porque falharam em qualquer um dos mil elementos que compõem uma direção, mas sim, quase sempre, tais inconsistências ou debilidades já estavam impostas pelo plano de produção devidamente aprovado pelo estúdio e pelo produtor e ao qual é quase impossível fugir. ${ }^{23}$

O romancista e roteirista colombiano Gabriel García Márquez tem opinião semelhante:

Há que reconhecer que o ofício de diretor é um dos, senão o mais esforçado e difícil do mundo. Não só porque se trata de alguém que deve se expressar através de um meio tão complexo, mas também pelas condições em que tem de trabalhar: um set cheio de gente, de equipes $e$ de luzes, com um calor insuportável e sob a estrita vigilância do produtor, que não solta o chicote porque cada demora ou cada minuto extra de filmagem Ihe custa os olhos da cara. ${ }^{24}$

No videoclipe, não é diferente. Seguindo muitas vezes os moldes da publicidade televisiva, o trabalho de um diretor é contratado pela equipe de marketing de uma gravadora para realizar imagens para a canção que pretende divulgar. Assim, muitas vezes, as ideias que o diretor terá para um videoclipe deverão contar com a aprovação de quem o contratou e também de quem interpreta a canção. Desta forma, é possível avaliar até que ponto a liberdade criativa do realizador de videoclipes é tolhida em função de razões comerciais, o que também será analisado melhor posteriormente.

A maneira como o filme é recebido pelo público também pode prejudicar a unidade do conjunto da obra de um autor, uma vez que esse último tem a possibilidade de modificar seus propósitos quando, por exemplo, perceber que sua obra foi afetada pela falta de comunicação com que a assiste. Ou seja, os rumos da

$23 \quad$ IDEM, p. 74.

24 "Hay que reconocer que el oficio de director es uno de los más esforzados y difíciles del mundo. No solo porque se trata de alguien que debe expresarse a través de un médio tan complejo, sino por las condiciones en que hay que trabajar: un set lleno de gente, de equipos y de luces, con un calor insoportable y bajo la estricta vigilancia del productor, que no suelta el látigo, porque cada demora o cada minuto extra de filmácion le costa un ojo de la cara". MÁRQUEZ, Gabriel García. La Bendita Mania de Contar. Editorial Sudamericana. Buenos Aires, Argentina. 2008, p. 59. Tradução realizada pelo autor dessa pesquisa. 
produção artística total de um artista dependem não apenas dos propósitos defendidos por ele, mas também se obteve sucesso ou não na comunicação desejada com o público, influenciado diretamente pelo contexto social, político e artístico de determinado momento histórico.

Mais radical, em 1968, o filósofo francês Roland Barthes decretará "a morte do autor", uma vez que por ele cada leitor - ou no caso do cinema, espectador atribui à obra significado diverso, influenciado pelo contexto histórico, político e social no qual está inserido, o que levou Jean-Claude Bernardet a afirmar que, para Barthes, nenhum texto é original, mas dialoga com as obras que o precederam, citando-as e reciclando-as ${ }^{25}$.

Visão similar a de Barthes apresenta o teórico inglês Stephen Heath:

\begin{abstract}
A função do autor (o efeito da idéia de autoria) é uma função de unidade: o uso da noção de autor envolve a organicização do filme (como 'obra') e, com isso, evita - o que é a sua verdadeira função - pensar a articulação do texto do filme com relação à ideologia. Uma teoria do sujeito representa precisamente uma tentativa, em um nível determinado, de apreender as construções do sujeito na ideologia (os modos da subjetividade). Permite, portanto, imediatamente, a articulação de outras contradições no texto do filme, além daquelas relativas à idéia de uma consciência abrangente. ${ }^{26}$
\end{abstract}

Em 2000, os professores de cinema Robert Stam e Ella Shohat, ao analisarem o cenário das novas mídias, problematizaram a noção de autoria: "(...) a criação puramente individual torna-se ainda menos provável em um cenário onde os artistas criativos multimidiáticos são dependentes de uma rede extremamente diversificada de produtores de mídia e especialistas técnicos" ${ }^{27}$. Todavia, a entrada das novas mídias e a realização de videoclipes quase artesanais e independentes da indústria fonográfica, por exemplo, para serem exibidos no portal de vídeos da internet Youtube, não poderia indicar justamente o contrário, em nome de uma criação cada vez mais individual? Esse será outro aspecto a ser analisado posteriormente.

O cineasta Glauber Rocha, ao referir-se ao cinema comercial, afirma que, nesse tipo de trabalho, não há autor, mas, sim, artesão. Portanto, para ele, só interessa o cinema autoral, aquele que reflete sobre a realidade e age sobre ela:

25 BERNARDET, Jean-Claude. O Autor no Cinema ..., p. 24.

26 RAMOS, Fernão Pessoa (org.). Teoria Contemporânea do Cinema Volume 1 ..., p. 298.

IDEM, p. 416. 
O ser autor de filmes é uma condição mais dramática e absurda - que sofre pressões externas, mas é esmagada pelo conflito inevitável do autor, esta forma de olhar o mundo é tão individual que, mesmo nos casos forçados, é impossível disciplinar a visão aos regulamentos dos visores tradicionais, formulados para divertir e dar lucro. ${ }^{28}$

O teórico Edward Buscombe diferenciará, então, o diretor da estrutura que leva seu nome:

Qual seria a relação exata entre a estrutura chamada 'Hitchcock' e o diretor chamado Hitchcock, que toma decisões sobre a história, o trabalho dos atores, os cenários, a colocação da câmera? É possível revelar, na obra de Hitchcock, estruturas que de modo algum são inteiramente inconscientes, como o uso de certos ângulos de câmera para envolver e implicar o público na ação. ${ }^{29}$

Gustavo Dahl, por sua vez, acrescentará, segundo Jean-Claude Beranrdet, que não se trata, evidentemente, de um problema de domínio ou não da linguagem e da gramática cinematográfica, mas de utilizar o cinema para explicitar uma visão de mundo. ${ }^{30}$ Poderia haver diferenças então, por exemplo, entre o Roberto Berliner diretor e a estrutura chamada "Roberto Berliner", presente nos videoclipes? O escritor Gore Vidal ${ }^{31}$, nas palavras de Bernardet, observará que há tantas incidências individuais num filme que é quase impossível determinar ao certo como ele foi criado.

Por essa via é possível questionar como o faz a pesquisadora Cecília Sayad $^{32}$, um conceito romântico de autoria como original e exclusiva, uma vez que o diretor depende da colaboração de outros profissionais, como atores, fotógrafos e editores, tão fundamentais quanto ele no resultado final de uma obra. É preciso, no entanto, reconhecer o papel importantíssimo exercido pelo diretor de orquestrar todos os elementos visuais e sonoros de um projeto artístico.

Moniz Viana, para quem o diretor orquestra a equipe técnica, acredita que é possível manter liberdade autoral:

Como o escritor de novelas, o cineasta concebe em casa as suas obras; o estúdio, como a tipografia, seria apenas a oficina impressora e o diretor se

BERNARDET, Jean-Claude. O Autor no Cinema ..., p. 142.

RAMOS, Fernão Ramos. Teoria Contemporânea do Cinema ..., p. 292.

BERNARDET, Jean-Claude. O Autor no Cinema ..., p. 135.

IDEM, p. 185.

SAYAD, Cecília. O Jogo da Reinvenção ..., p. 27. 
posta ali sem outro intuito que o de preservar a sua concepção de alterações ou erros que outros possam introduzir. ${ }^{33}$

Para o cineasta espanhol Luis Buñuel, não era bem assim o processo de realização de seus filmes:

Embora em minha opinião nada seja mais importante na realização de um filme do que um bom roteiro, nunca fui um homem da escrita. Para quase todos os meus filmes (com exceção de quatro), precisei de um escritor, um roteirista, para me ajudar a colocar o argumento e os diálogos preto no branco (a partir de 1963, Jean-Claude Carriere, com quem trabalhou em seis filmes). Isso não significa que esse colaborador seja um simples secretário encarregado de registrar o que digo. Ao contrário. Ele tem o direito e o dever de discutir minhas ideias e propor as suas, ainda que seja eu, no fim das contas, quem decide. ${ }^{34}$

O diretor Oscar Rodrigues Alves explica, então, porque se considera autor dos videoclipes que realiza:

Eu nunca sou o autor único e exclusivo, mas o fato de você imprimir a sua visão à música que o artista te entregou e o fato de você ficar alguns dias pensando e comandar uma equipe em torno do que você pensou é claramente muito autoral. Eu olho para todos os meus clipes e me identifico muito ali. ${ }^{35}$

Roberto Berliner, outro diretor, tem opinião semelhante:

Considero-me autor, porque são idéias que, em geral, vieram da minha cabeça. Escrevo o roteiro, dirijo e edito, com outros. Mesmo quando não assino com alguém, esses colaboradores exercem muita interferência. Mas sempre coloco-os como co-diretores, porque acho que são mesmo e me lembro quando fazia tudo e não assinava. Então considero que eu e esses colaboradores somos realmente autores desses trabalhos, porque fizemos todo o processo, do início ao final. Em alguns casos, sofremos interferências da gravadora, mas muito pouco. ${ }^{36}$

O terceiro diretor/autor estudado nesta pesquisa, Mauricio Eça, reconhece que, mesmo na maioria dos casos, sendo também responsável pelo roteiro, não há como esquecer o papel exercido pelo compositor e/ou intérprete da canção:

Eu me considero co-autor, a partir do momento em que o cantor ou a banda fez a música (...) Considero-me autor uma vez que faço

IDEM, p. 78.

BUÑUEL, Luis. Meu Último Suspiro. São Paulo, SP. Cosac Naify. 2009, p. 338.

Entrevista dada ao autor entre 2006 e 2009.

Entrevista dada ao autor em fevereiro de 2009. 
o roteiro, penso na idéia e na criação do clipe, absolutamente junto com a banda. Não sei se em 100\%, mas em muitos dos meus videoclipes, a banda é muito importante no que ela pensa e acredita ${ }^{37}$.

Conhecendo essas reflexões a respeito do fazer envolvido na produção audiovisual e do aspecto autoral nela inserido, torna-se necessário observar como o videoclipe surgiu e, aos poucos, foi conquistando sua autonomia, com características próprias que formaram um novo formato audiovisual. A partir daí, será possível avaliar de que modo as questões acima abordadas em relação ao aspecto autoral da produção cinematográfica podem, se é que podem mesmo, ser aplicadas ao videoclipe.

$37 \quad$ Entrevista dada ao autor entre 2006 e 2009. 


\section{CAPÍTULO 2}

\section{HISTÓRIA DO VIDEOCLIPE}

No capítulo anterior, foi demonstrado como a questão autoral está presente no audiovisual, desde o seu surgimento, e como foi importante para o desenvolvimento de uma linguagem específica principalmente para o cinema e para a televisão. Agora será analisado como a busca pela autoria em experimentos audiovisuais contribuiu para o aprimoramento da relação imagem-música que culminou no videoclipe.

Como todo gênero audiovisual mais recente, o videoclipe é fruto de um longo processo de desenvolvimento de outros gêneros e formatos, seja como trechos de uma obra maior, no caso do cinema musical, ou como uma obra de curta duração que trabalha com uma única canção e que, portanto, pode ser considerada prenunciadora direta do videoclipe, caso dos jazz shorts, dos soundies, dos scopitones e dos promos. Nesse processo, também foi importante a relação entre a música, principalmente erudita, e os desenhos animados e os filmes de animação em longa-metragem.

É interessante observar, como será feito neste capítulo, como alguns realizadores conseguiram impor marcas autorais muito fortes, como nos filmes musicais caleidoscópicos realizados por Busby Berkeley; nos ousados exercícios audiovisuais em animações realizadas por Walt Disney e por Norman McLaren; nas experimentações de Richard Lester nos filmes estrelados pelos Beatles; na vídeoarte de Nam June Paik e nos videoclipes dirigidos por Bruce Gowers, Spike Jonze, Michel Gondry, Valerie Faris e Jonathan Dayton, entre outros. Todos eles realizaram trabalhos tão marcantes e próprios que se transformaram em espécies de grifes autorais, que fizeram com que eles passassem a ser procurados por artistas e gravadoras que se identificavam e estavam em busca dos traços que eles impunham na tela.

Neste capítulo, também serão destacadas as características que fizeram do videoclipe uma arte com sua linguagem própria e específica, uma vez que a investigação contribuirá para a compreensão do desenvolvimento do videoclipe no Brasil e do trabalho autoral de três realizadores de videoclipe selecionados para a 
pesquisa, cuja obra é herdeira do processo de desenvolvimento audiovisual aqui abordado.

Entretanto, ciente de que as experiências e os momentos históricos relatados, assim como seus realizadores já receberam destaques em pesquisas específicas e bastante aprofundadas, o que se propõe aqui é compor um grande painel, nem por isso menos importante, que possa auxiliar na compreensão dos movimentos que levaram ao surgimento do videoclipe. Foi dada grande atenção à história deste formato audiovisual, sem, no entanto, a preocupação ou intenção de se esgotar tema tão vasto, mas sim de estimular e contribuir com pesquisas futuras.

\subsection{Antecedentes}

Quando o inventor norte-americano Thomas Edison criou, em 1876, o fonógrafo $^{38}$ - primeiro instrumento capaz de reproduzir uma canção -, a sensação foi a de que algo importante faltava: a imagem, ou melhor, a expressão cênica do músico ou intérprete da canção. Não é à toa que, em 1895, Edison inventou o cinefone, com o qual buscava associar em sincronismo as imagens animadas que se viam no interior de uma caixa de madeira (o cinetógrafo), com o som gerado pelo fonógrafo, mediante o girar de um cilindro. Uma versão melhorada dessa invenção foi apresentada em sessão pública em 1913, mas o aparelho nunca teve aplicação industrial. Até então, a interpretação musical estava ligada intrinsecamente à apresentação ao vivo, em que, tão importante quanto à música em si, era a expressão facial, gestual e corporal do artista.

Na década de 1950, mais precisamente em 1955, o compositor Max Steiner, mais conhecido pela composição da música do filme King Kong (1955), gravada por uma orquestra de 45 músicos e que pontua com precisão movimentos e ações dos personagens, de maneira até então inédita, foi chamado de "inventor da música de cinema”, mas ele logo desfez essa imagem lembrando, numa entrevista, que essa atribuição deveria ser feita ao compositor alemão Richard Wagner que, em seu trabalho, sempre procurou representar a canção em óperas que compunha, como,

38 A reprodução do som só se estendeu à esfera do entretenimento musical quando o alemão Emil Berliner, em 1887, criou o gramofone. Dois anos depois, a gravadora Columbia Records já gravava os primeiros artistas e, em 1901, eram ouvidas músicas em jukeboxes. RODRIGUES, Rodrigo Fonseca e. Música Eletrônica A Textura da Máquina Annablume. São Paulo, SP, 2005, p. 43. 
por exemplo, em Tristão e Isolda (1857-1859). Por isso mesmo é que muitos dos primeiros filmes musicais apresentados no cinema nada mais são do que adaptações de óperas famosas. Além de "inventor da música de cinema”, Wagner também é considerado um dos criadores do leitmotif, posteriormente muito utilizado no cinema e nas produções ficcionais da televisão: é o uso recorrente de um tema musical para caracterizar determinado personagem ou situação dramática ${ }^{39}$.

Voltando um pouco no tempo, vamos encontrar, em 1894, compositores como os norte-americanos Edward B. Marks e Joseph W. Stern que criaram imagens projetadas como slides para acompanhar a apresentação ao vivo de canções que haviam realizado, caso de The Little Lost Child.

A invenção, denominada "llustrated Song", pode ser considerada uma precursora bastante remota do videoclipe e fez com que fossem vendidas mais de dois milhões de cópias da partitura da canção. Esse sucesso espantoso atraiu estrelas musicais como Eddie Cantor e Roscoe Arbuckle, entre outros, para terem ilustradas as canções que interpretavam.

A presença da música era tão importante nos espetáculos de variedades que, ao realizarem a primeira exibição do filme Chegada do Trem à Estação (1895), os irmãos Louis e Auguste Lumière contrataram músicos para acompanhar com seus instrumentos as imagens projetadas na tela. A partir daí, todas as salas exibidoras de filmes tiveram que contar com a infra-estrutura necessária para a apresentação musical, fosse de um pianista, fosse de uma orquestra completa, que acompanhassem a exibição. Para auxiliar os músicos que se apresentavam nas salas de exibição, na década de 1910, surgiram livros de partituras com seleções e músicas para serem tocadas durante os filmes, com temas específicos para cenas de horror, humor, caçada, impaciência, alegria etc. Como destaca Jacques Aumont, a filmagem era igualmente acompanhada de um "fundo musical", em geral tocado por um violonista presente no set de filmagem, a fim de sugerir a atmosfera buscada pelo diretor ${ }^{40}$. Houve até casos de filmes, como $\boldsymbol{O}$ Nascimento de Uma Nação (1915), de David Wark Griffith, que receberam acompanhamentos orquestrais especialmente criados para eles!

A música ao vivo, somada ao irritante som produzido pelos projetores dos filmes, é o que leva a maioria dos estudiosos a denominar esse primeiro período da 
história do cinema como sendo "silencioso"; período interrompido com a chegada do som (música, fala e ruído) a partir do filme em longa-metragem $\mathbf{O}$ Cantor de Jazz $(1927)^{41}$, que tinha apenas quatro segmentos sonorizados e no qual o personagem do ator Al Jolson declara: "Esperem um instante. Vocês ainda não ouviram nada".

Fruto do desenvolvimento de aparelhos da Warner Bros. e Fox Film Corporation, $\boldsymbol{O}$ Cantor de Jazz teve como grande mérito tornar possível a sincronização entre música e imagem, cada vez mais adequada, mesmo em cenas que mostravam um palco com artistas realizando "performances musicais". Com isso, a música deixou de se adequar apenas à ação filmada, para criar uma interrelação maior com os movimentos visuais. Do ponto de vista autoral, nesse momento, o técnico de som tornou-se mais importante do que o produtor, o roteirista e o diretor, os quais, de certo modo, se submetiam às orientações dele em um set de filmagem.

O filme Don Juan (1926), de John Barrymore, foi o primeiro a ter trilha musical oficialmente composta para um longa-metragem, no caso por William Axt, David Mendoza e Edward Bowes, e gravada pela Orquestra Filarmônica de Nova lorque. E a canção Charmaine, de Erno Rappe, incluída no filme What Price Glory? (1926), de Raoul Walsh, foi a primeira música-tema a fazer sucesso e extrapolar as salas de cinema e tocar no rádio.

Em 1942, os compositores Miklos Rozsa e Alexander Korda foram responsáveis pela primeira trilha musical lançada em disco - a do filme Mogli, 0 Menino Lobo, de Zoltan Korda. Já em 1961, o compositor Henry Mancini incluiu a clássica canção de sua autoria, Moon River, no filme Bonequinha de Luxo, de Blake Edwards, como modo de capitalizar seu potencial de divulgação. Tinha, assim, início um processo que apontaria a canção como fator importante na divulgação de um filme e vice-versa, constituindo-se assim um dos mais importantes instrumentos de marketing, tanto para a indústria cinematográfica, quanto para a indústria musical.

O compositor e produtor musical Tony Berchmans destaca a importância do autor da música de um filme, afirmando:

41 Em 1926, os irmãos Harry, Albert, Sam e Jack Warner, proprietários da Warner Bros. Entertainment, adquiriram a patente da Vitaphone, com o objetivo de desenvolver um sistema sonoro para os filmes, iniciado com curtas-metragens e que culminou em $\boldsymbol{O}$ Cantor de Jazz. Como havia dúvida com relação à reação do público ao novo sistema, o primeiro filme totalmente falado só veio à tona em 1928 - o longa-metragem sobre gângsteres Luzes em Nova York, de Brian Foy, com duração de 57 minutos. 
De fato, quando compõe a música do filme, o compositor acaba se transformando numa espécie de dramaturgo musical. Sua atenção está voltada para a história e para o modo como ela é contada. Um verdadeiro compositor de música de cinema possui talento e imaginação de um dramaturgo, bem como a habilidade de transformar os seus sentimentos e pensamentos em música. Alguns compositores têm 0 dom de intuitivamente achar o tipo certo de melodia, textura, clima ou estilo musical que reflete o que reconhecem como um aspecto dramático essencial ao filme. ${ }^{42}$

A relação entre compositor e diretor cinematográfico será fundamental para o desenvolvimento da linguagem audiovisual e, consequentemente, do videoclipe. Não obstante, como destaca Berchmans, no cinema, a música é um elemento criado em função da imagem e, muitas vezes, composta após a edição do filme. Ou seja, durante o processo de produção e edição, ainda não se tem material musical original disponível. Assim, será o diretor quem apresentará ao compositor a ideia que possui do conceito musical. Já no videoclipe ocorrerá, na maioria das vezes, o contrário: as imagens serão criadas para canção pré-existente.

Para o desenvolvimento da relação imagem-música no cinema, o gênero musical será dos mais importantes. Iniciado em 1929, com Hollywood Revue, dirigido por Chuck Riesner, ele servirá, inicialmente, como espécie de tentativa de se reproduzirem diante das câmeras o estilo e o sucesso dos musicais apresentados no teatro da Broadway. Porém, aos poucos, ele se consolidará como espaço por excelência da realização de verdadeiras coreografias musicais cinematográficas. Dentre os clássicos como Cantando na Chuva (1952), de Stanley Donen e Gene Kelly, e a consagração de talentos como Ginger Rogers e Fred Astaire, destacam-se os filmes realizados por Busby Berkeley. Com o auxílio de centenas de figurantesdançarinos e câmeras posicionadas na maioria das vezes no alto do palco, esse cineasta filmava, ao ritmo das canções, verdadeiros caleidoscópios visuais, desenvolvendo aí uma forte marca autoral. Numa das sequências de Entre a Loira e a Morena (1943), por exemplo, Carmen Miranda aparece acompanhada por dezenas de dançarinas que, junto com ela, coreografaram a canção The Lady In The Tutti-Frutti Hat, com duração de quase oito minutos, tendo como elemento unificador as bananas, marca registrada da cantora. No entanto, por mais inovador

42 BERCHMANS, Tony. A Música do Filme. Tudo o que você gostaria de saber sobre a música de cinema. São Paulo/SP. Escrituras Editora. 2006. P. 20). 
que fosse para a época, esse espetáculo permanecia sendo realizado em estúdio, com aspectos similares ao das apresentações teatrais.

Desta forma, para o aparecimento do videoclipe, algumas invenções e formatos serão importantes. Entre 1923 e 1927, o inventor Lee De Forest produziu cerca de mil curtas-metragens denominados Phonofilms, com som sincronizado, incluindo musicais, caso de A Few Moments with Eddie Cantor (1923), que reproduz o espetáculo cômico e musical realizado no Rivoli Theatre, em Washington, nos Estados Unidos, sem movimentos de câmera.

Entre 1926 e 1930, foi a vez dos Vitaphones, produzidos pela Warner Bros., no estúdio First National, com duração de no máximo seis minutos e estrelados por artistas de vaudevilles, cantores populares e de ópera, dançarinos, estrelas da Broadway, caso de, entre outros, Ginger Rogers, Judy Garland, Bob Hope, Cary Grant e Sammy Davis Jr. O objetivo era se apresentar ao público e, assim, vender discos e shows. Portanto, nada muito diferente do que, no futuro, farão os videoclipes. Um exemplo desse formato é Tiger Rag: Dance Band (1929), com a banda de jazz New Orleans Rhythm Kings, em que a câmera está posicionada na frente do palco focalizando a banda toda em plano aberto e apenas alguns músicos em planos aproximados.

Nenhum desses novos formatos ficou mais conhecido do que os jazz shorts ${ }^{43}$, realizados entre o final dos anos 1920 e meados da década de 1940. Os curtasmetragens, quase sempre exibidos antes do filme de longa-metragem, durante uma média de dez minutos, apresentavam uma única banda de jazz - gênero musical que atingia sua maturidade e popularidade - e três ou quatro canções ligadas entre si e em geral nada mais do que a reprodução de números de palco. Em Minnie The Moocher (1942), estrelado pelo cantor Cab Calloway, mais uma vez o que se vê é a câmera praticamente estática e alguns poucos cortes para identificar ao espectador de onde vem o som que se ouve, focalizando músicos e cantores.

Por volta da década de 1940, o músico norte-americano Louis Jordan, pioneiro de blues, jazz e rhythm'n'blues, ficou famoso por gravar e distribuir pequenos vídeos musicais pelos cinemas dos Estados Unidos. Porém, diferente dos Vitaphones e dos artistas que os estrelavam, Jordan se preocupava com os figurinos e em contar uma história para a plateia, principalmente com sua interpretação, o que 
se tornará cada vez mais comum a partir do desenvolvimento do rock and roll. Essas características podem ser vistas em The Green Grass Grows All Around (1941), com Louis Jordan e sua banda Timpany.

Técnica similar a dos jazz shorts e dos filmes de Louis Jordan foi desenvolvida, na mesma época, nos soundies - pequenos filmes que duravam de três a cinco minutos e exibiam apenas performances em preto e branco de músicos de jazz, além de cantores, dançarinos e comediantes, numa máquina chamada Panoram $^{44}$, também conhecida como "vitrola de fichas visuais", que projetava as imagens ao ser acionada por moedas. Eles apresentavam maior variação de cenários e movimentos de câmera do que os experimentos anteriores e os artistas apareciam praticamente representando. Um exemplo é A Zoot Suit (1942), com Dorothy Dandridge \& Paul White. Entretanto, anos mais tarde, esse formato entrou em decadência, principalmente em função de ser um equipamento caro e apresentar sempre a mesma programação.

A maneira mais usada para se transformar uma canção em imagens parecia ser, num primeiro momento, a animação. O animador Max Fleischer, por exemplo, criou as Screen Songs, pequenas animações para serem exibidas antes e depois dos filmes de longa-metragem, como é o caso da história do amor de dois passarinhos em Hawaiian Birds (1936). O cineasta canadense Norman McLaren daria "continuidade" a essa experiência, de modo mais experimental, ao desenhar diretamente a onda sonora na película ou editar os sons através do seu equivalente visual, não apenas em animações. Entre os seus trabalhos mais importantes, estão Neighbours, de 1952, e a animação Synchromy, de $1971^{45}$, que brinca com faixas de cores na tela.

\footnotetext{
${ }^{44}$ Mais de dois mil soundies foram realizados de 1941 a 1947 pela empresa norte-americana Mills Novelty Co. Cada bobina continha até oito soundies, editados e exibidos em seqüência, com imagens de pés dançantes fundindo-se com cenas de trompetistas e de artistas como Louis Armstrong e Bing Crosby. Graças a eles, artistas como Ginger Harmon \& The Mercer Brothers tornaram-se conhecidos e passaram a lotar shows pelos Estados Unidos. Alguns soundies possuíam certa conotação pornográfica. Na década de 1960, eles deixaram de ser exibidos na Panoram e começaram a ocupar intervalos comerciais de programas de televisão dos Estados Unidos. GOODWIN, Andrew. Dancing In The Distraction Factory Music television and popular culture. Minnesota, USA. University of Minnesota Press. 1992, p. 202. SOARES, Thiago. Videoclipe, o elogio da desarmonia. Olinda, PE. Editora do Autor. 2004, p. 16. MILLER, Gustavo. Do Fantástico ao Youtube A História do Videoclipe Musical no Brasil. Projeto Experimental (TCC). PUC-SP. São Paulo, SP. 2007.

45 AUSTERLITZ, Saul. Money For Nothing. Continuum. Londres, Grã-Bretanha. 2007, p. 13.
} 
Poucos realizadores mergulharam mais a fundo na busca por transformar canções de sucesso em desenhos animados do que Walt Disney, nas Silly Symphonies e nas animações estreladas pelo personagem Mickey Mouse, que apareceu, pela primeira vez, no filme Steamboat Willie, em 1928. No filme, a marcação do tempo para a orquestra musical foi realizada com uma bolinha desenhada à mão, pulando ao lado de cada frame da película, acompanhando cada movimento dos personagens na tela.

Em 1940, Walt Disney realizaria o que Saul Austerlitz denomina de "primeira não-intencional forma longa de videoclipe", no caso o filme Fantasia, que introduz no cinema o sistema estéreo de reprodução sonora. Logo na abertura, o narrador esclarece: "Existem três tipos de música em Fantasia. Primeiro, a que conta uma história definida. Depois, aquela que sem uma história específica, pinta uma série de quadros mais ou menos definidos. $\mathrm{E}$, por último, aquela que existe simplesmente porque é música". A sequência que abre o filme, "Toccata in Fugue", de Johann Sebastian Bach, é do terceiro tipo, contando com animação do artista plástico e animador alemão Oskar Fischinger. Esse filme também ficou famoso por lançar o primeiro sistema estereofônico de sonorização cinematográfica, o Fantasound.

\subsection{Cultura Jovem nas décadas de 1950 e 1960}

O aparecimento da cultura jovem e do rock and roll na década de 1950 tornou o visual do intérprete da canção tão importante quanto a canção, o que Louis Jordan parecera prenunciar. Havia a necessidade de que o artista se preocupasse com a qualidade de sua música e também com a maneira como apareceria diante das telas. Encontrava-se, justamente no visual, boa parte do fascínio exercido pelos novos ídolos, na juventude, o que ficaria claro no filme Ao Balanço das Horas (Rock Around The Clock, de 1956), dirigido por Fred F. Sears, com números musicais dos grupos Platters (The Great Pretender e Only You) e Bill Halley and his Comets, intérprete de See You Later Alligator e da canção-título, que era acompanhada por casais adolescentes dançando freneticamente.

Um dos primeiros artistas a se destacar tanto pela canção quanto pelo visual foi o norte-americano Elvis Presley. Com brilhantina no cabelo e jaqueta de couro, aspectos considerados rebeldes para a época, o "rei do rock" imortalizou sua 
maneira peculiar de dançar, chacoalhando as pernas e os quadris ${ }^{46}$, o que incomodava os padrões tradicionais de sua época, nos primeiros programas musicais da televisão chamados American Bandstand ${ }^{47}$ que apresentavam festinhas de rock and roll.

No cinema, os filmes musicais estrelados por Elvis Presley deram continuidade a uma já longa história desse gênero de filmes do cinema norteamericano, estabelecendo uma relação definitiva entre eles e o rock and roll. Dos trinta e um musicais estrelados por Elvis, um dos mais destacados foi $\boldsymbol{O}$ Prisioneiro do Rock (1957), dirigido por Richard Thorpe, que chamou a atenção pela agilidade dos seus números musicais ${ }^{48}$. Esse é o caso da sequência em que Elvis Presley aparece como presidário para interpretar a canção-título Jailhouse Rock acompanhado de vários figurantes vestidos exatamente iguais a ele em cenário bastante semelhante ao dos filmes musicais que o antecederam.

Esse modelo de cultura jovem - ligado ao consumo do rock and roll - era fortemente presente nos Estados Unidos e, com a industrialização, com o crescimento urbano e com o desenvolvimento das telecomunicações, foi espalhando-se pelo resto do mundo, ganhando ainda mais força na década de 1960 , na Inglaterra, com a mais popular banda de banda de rock, os Beatles, grupo que bateu recordes sucessivos de vendagens de discos e lotou os cinemas com um público jovem interessado em assistir a seus filmes.

O primeiro dos filmes foi Os Reis do lê-lê-lê (1964), dirigido por Richard Lester $^{49}$, que misturava influências da publicidade com tendências cinematográficas

${ }^{46}$ Essa dança provocou tanta discussão que, em seu terceiro show na televisão, Elvis Presley passou a ser focalizado apenas da cintura para cima a pedido de uma parte conservadora da sociedade norte-americana. Em 2002, o diretor Scott Lyon criou um videoclipe para o remix da canção A Little Less Conversation, de Elvis Presley. In. BRANDÃO, Antonio Carlos; e DUARTE, Milton Fernandes. Movimentos culturais de juventude. São Paulo, SP. Moderna. 2004, p. 29.

47 American Bandstand foi apresentado por Bob Horn e exibido pelas emissoras norte-americanas WFIL-TV, CBS e USA Network, de 1952 a 1989.

${ }^{48}$ A jornalista Mariana Zanini aponta a origem do videoclipe nos números musicais de encerramento das produções cinematográficas de Bollywood, pólo cinematográfico da Índia, como explica: "Os produtores tiravam alguns pedaços dos filmes, e logo estava pronto o que viria mais tarde a ser um videoclipe". ZANINI, Mariana. Músicas em imagens e movimento. Sobrecarga. 17 de fevereiro de 2005. In. http://www.sobrecarga.com.br/node/view/4796.

${ }^{49}$ Outro filme estrelado pelos Beatles foi Help!, dirigido por Richard Lester em 1965. Esse mesmo sentido de números musicais funcionando como espécie de videoclipes unidos uns aos outros seria visto, em 1982, no filme Pink Floyd - The Wall, dirigido por Alan Parker, a partir de canções do grupo de rock progressivo Pink Floyd. Em 2003, o mestre dos mangás e dos animês orientais coordenaria a animação musical Interstella 5555, dirigida por Kazuhisa Takenouchi \& Daisuke Nishio, e que reúne 14 espécies de videoclipes produzidas para o álbum Discovery, do duo-techno francês Daft Punk. 
de vanguarda como a Nouvelle Vague francesa e o Free Cinema inglês, produzindo um filme que é considerado por muitos autores um dos mais importantes precursores do videoclipe, tal a agilidade visual impressa em vários de seus números musicais. É o caso de $\boldsymbol{A}$ Hard Day's Night, na abertura, exibindo a histeria existente em torno dos Beatles, e no final mostrando brincadeiras visuais com fotografias acompanhadas dos créditos; e de Can't By Me Love, em que os Beatles descem uma escada de metal em espiral e pulam num jardim e numa quadra de concreto.

O sociólogo José Mario Ortiz Ramos denomina o trabalho de Richard Lester com os Beatles de "filmes pré-videoclipes" ${ }^{\text {", }}$, com "músicas-narrativa", em que as imagens que acompanham determinada canção constituem uma única história. Esse é um dos traços autorais do cineasta, que pode ter motivado o convite para trabalhar com a banda mais popular do momento, justamente os Beatles.

Um outro filme de destaque dos Beatles foi o especial para televisão, Magical Mystery Tour (1967), dirigido pela própria banda a pedido da emissora britânica BBC e que mostrava um tom irracional próximo ao surrealismo cinematográfico e ao psicodelismo. Já o filme de animação O Submarino Amarelo, dirigido por George Dunning em 1968, contava com orquestração do produtor George Martin e apresentava uma colorida e eclética mistura visual para mostrar a tentativa ficcional dos Beatles de salvar Pepperland (Terra de Pimenta), localizada a 80 mil léguas submarinas, dos Blues Meanies que a atacaram para acabar com a música ali existente. Sem dúvida essa produção era uma alusão às pressões que o novo gênero musical sofria na época.

O psicodelismo também possibilitou a criação de um tipo de pequeno filme realizado na França durante os anos 60 , batizado de scopitone. Considerado uma continuidade dos soundies, por também ser exibido em máquinas que funcionavam com moedas, ele era mais rápido e não pretendia ser um mero registro da atuação de um grupo musical. Criado pela filial francesa da empresa multinacional do setor musical Philips, ele tinha como intuito agradar o público que frequentava bares e restaurantes e funcionava por meio de um projetor leve, de 16 milímetros, destinado a exibir vídeos de artistas em evidência, sobretudo de rock francês.

${ }^{50}$ RAMOS, José Mario Ortiz. Televisão, Publicidade e Cultura de Massa. Petrópolis, RJ. Vozes. 1995, p. 234. 
Os scopitones foram produzidos até 1979, quando a máquina que os reproduzia foi retirada do circuito, e ganhando versões na Itália e na Inglaterra batizadas de "cinebox" e, nos Estados Unidos, de "colorsonics". Segundo Arthur Jackson e John Russell Taylor ${ }^{51}$, os aparelhos exibiam três minutos de "paisagens" ou de "registros psicodélicos de luzes coloridas".

Tendo como período áureo de 1962 a 1965, os scopitones registraram números musicais de artistas como Jacques Brel e Brigite Bardot, que também na época tentou a carreira de cantora. A direção coube, entre outros, ao cineasta Claude Lelouch, que realizou cerca de 80 produções desse tipo, caso de Pour Moi La Vie Va Commencer, que era uma espécie de pastiche dos filmes de faroeste com o ídolo francês Johnny Hallyday cavalgando e cantando em cima de um cavalo, com direito a citação da música-tema do filme de faroeste Onze Homens e Um Destino (1960), de John Sturges, e dos comerciais dos cigarros Marlboro. Outro plano-sequência realizado por Lelouch pelas ruas de Paris, em 1976, resultaria, em 2007, no videoclipe Open Your Eyes, dirigido por Robert Hales para a banda Snow Patrol. A produtora e empresária Daidy Davis-Boyer foi responsável pelas turnês de shows pela Europa de astros como Edith Piaf e Charles Aznavour, filmou cerca de 2 mil scopitones na mansão que possuía na França e onde costumava reunir os artistas mais famosos da época.

Na mesma época, Louis D. Snader filmou na Califórnia, nos Estados Unidos, performances musicais vendidas em blocos para serem exibidas por emissoras de televisão. Batizadas Snader Telescriptions, elas eram realizadas em curtametragem, em 35 milímetros e registravam performances ao vivo de artistas como Peggy Lee e Nat King Cole. O cantor estrelou, entre outros, o filme Always You (1951), acompanhado pelo The King Cole Trio e que apresentava mudanças delicadas no tom das cores ${ }^{52}$.

Os Beatles também fizeram grande sucesso nos programas de auditório da televisão, quando suas músicas eram abafadas pelos gritos histéricos vindos da platéia. Como quase não era possível escutar a canção, essas aparições na

\footnotetext{
51 JACKSON, Arthur; e TAYLOR, John Russell. The Hollywood Musical. Grã-Bretanha. MCGraw-Hill Book. 1971, p. 97.

52 GOODWIN, Andrew. Dancing In The Distraction Factory Music television and popular culture. Minnesota, USA. University of Minnesota Press. 1992, p.202; em SOARES, Thiago, Videoclipe, o Elogio da Desarmonia ..., p. 17; em MILLER, Gustavo. Do Fantástico ao Youtube ...; e em AUSTERLITZ, Saul. Money and for Nothing ...
} 
televisão ajudavam a ressaltar a imagem e o carisma dos integrantes do grupo inglês. Cansada da rotina atribulada de shows, turnês, entrevistas e gravações, e impossibilitada de comparecer a todas as emissoras de televisão dos mais diferentes lugares do planeta que exigiam sua presença, a banda montou uma equipe altamente profissional, que realizou uma série de curtas-metragens para serem exibidos em programas de variedades. Esses filmes extrapolavam os números musicais habituais da televisão e ficaram conhecidos como promos, que mostravam, no início, apenas números de palco. Por exemplo, enquanto um promo de Help! mostra os quatro integrantes da banda sentados em fila, com o baterista Ringo Starr segurando um guarda-chuva. Em Day Tripper, o mesmo Ringo aparece pedalando uma bicicleta dentro do estúdio; em I Feel Fine, os quatro rapazes aparecem comendo peixe e batata frita; e, em Hello Goodbye, eles aparecem vestidos com a mesma roupa com que aparecem na capa do álbum Sgt. Pepper's Lonely Hearts Club Band, de 1967. Os primeiros promos realizados para os Beatles foram três versões para as canções We Can Work It Out e Day Tripper e duas para Help!, Ticket to Ride e I Feel Fine. As versões, que variavam de país (ou continente), custaram, em média, cerca de 750 libras, foram financiadas pela própria banda e vendidas por 1750 libras para as emissoras de televisão. Há ainda três versões de Hello Goodbye, todas dirigidas por Paul McCartney, integrante dos Beatles - uma delas sem playback, recurso proibido pelo Sindicato dos Músicos da Inglaterra.

O diretor que mais trabalhou com os Beatles, nessa fase, foi o britânico Michael Lindsay-Hogg, responsável pelas 4 versões de Paperback Writer, três versões de Rain, duas versões de Hey Jude e de Revolution, e da única versão de Get Back, Don't Let Me Down e Let It Be, último estrelado pela banda em $1969^{53}$. Também houve promo de Back in the U.S.S.R., que mostra os rapazes em

\footnotetext{
${ }^{53}$ Michael Lindsay-Hogg também dirigiu, entre 1967 e 1982, 23 vídeos musicais para os Rolling Stones. Entre eles, Jumpin' Jack Flash (1968), Angie (1973), It's Only Rock'n Roll (But I Like It) (1974), Start Me Up (1981) e Hang Fire (1982). Outras bandas também tiveram seus promos, caso do Pink Floyd, com Arnold Layne (1967), que teve duas versões, sendo uma na praia bem irreverente com os músicos mascarados e com uma boneca inflável; The Scarecrow (1967), com os rapazes num milharal com um espantalho; e See Emily Play (1968). Outros promos foram Dead End Street (1966), dos Kinks, onde os membros da banda carregam um caixão; Happy Jack (1966), do Who, que conta com uma narrativa em que os integrantes da banda praticam um assalto de doces; e Iron Man (1970), do Black Sabbath, que abusa de efeitos em chroma-key, ou seja, imagens projetadas num painel geralmente verde ou azul, instalado no fundo do estúdio. Todos os episódios do seriado televisivo dos Monkees terminavam com um promo. PUGGIALI, Ricardo. Beatlemania. Ediouro. São Paulo, SP. 2008. AUSTERLITZ, Saul. Money and for Nothing ...
} 
excursão pelo mundo. Essas produções são mais modernas do que as citadas acima, uma vez que extrapolam os estúdios e são registradas ao ar livre, com alguns recursos mais sofisticados, caso da mistura de preto e branco com colorido numa das versões de Rain ou da brincadeira com a capa do álbum Let It Be, de 1970, no promo para a canção de mesmo nome.

Dois promos realizados para os Beatles merecem atenção especial: Strawberry Fields Forever e Penny Lane, ambos rodados no Knole Park Kent, em Londres, em 1967 e dirigidos pelo diretor de televisão sueco Peter Goldmann. Eles exibem com perfeição a visão psicodélica que os próprios músicos tinham das canções, trazendo do cinema underground, do qual fazia parte Richard Lester, luz utilizada com função dramática, takes em câmera lenta, cenas em velocidade reversa e filtros de cores usados na pós-produção.

Alguns estudiosos, como Saul Austerlitz, denominam esses dois promos como sendo os primeiros videoclipes da história, realizados antes mesmo de receberem esse nome, por extrapolarem completamente os números de palco. Apesar de terem muitas proximidades estilísticas com alguns scopitones, eles foram realizados para divulgar uma canção, um álbum e um artista na televisão, e serviram como importantes peças de marketing, até então inéditas no mercado musical.

A jornalista Ana Maria Bahiana destaca que, antes dos Beatles, em 1956, o cantor Tony Bennett havia sido filmado caminhando pensativamente às margens do lago Serpentine, do Hyde Park, em Londres, ao som de Stranger in Paradise. Já em 1967, o documentário Don't Look Back, realizado por D. A. Pennerbaker, sobre o cantor e compositor Bob Dylan, contou com duas versões de um número em que ele, ao som de Subterranean Homesick Blues, aparece mostrando cartazes com palavras contidas na letra da canção.

Comprovando a força da música pop britânica para esse momento do promo e para o surgimento do videoclipe, no início da década de 1970, o cantor e compositor britânico David Bowie contratou o fotógrafo Mick Rock para dirigir vídeos de suas músicas, "em que sua imagem andrógina importava mais do que a música" "54. São eles: John, I'm Only Dancing (1972); Jean Genie (1972); Life on Mars? (1973), que privilegia a imagem do artista de terno azul claro e olho pintado com a mesma cor; e Space Oddity (1973), onde o diretor cria efeitos de iluminação

${ }^{54}$ AUSTERLITZ, Saul. Money and for Nothing ... 
e tons cromáticos bem modernos para a época. Diante de tantas experiências e poder de divulgação de uma canção e de seu artista, torna-se muito difícil não considerá-lo videoclipe.

\subsection{Surgimento do videoclipe}

Alguns pesquisadores, como E. Ann Kaplan e Andrew Goodwin, garantem que o primeiro videoclipe da história foi Bohemian Rhapsody, dirigido pelo inglês Bruce Gowers, com a ajuda do vocalista do grupo Queen, Freddie Mercury, em 1975. Com seis minutos de duração e um orçamento de 3500 dólares, esse videoclipe foi gravado durante três horas no estúdio de ensaios da banda e num caminhão de externa de gravação. Sua primeira exibição ocorreu no programa Top Of The Rocks, da BBC britânica. Rapidamente, ele se transformou em grande êxito comercial para o grupo e para seu disco, A Night at Opera, distinguindo-se dos promos, por ser financiado por uma gravadora (no caso EMI-Parlophone, a mesma dos Beatles), devido a seu suporte - vídeo e não mais película -, por ter efeitos especiais reproduzindo o clima da capa do álbum, pela maneira mais ágil de relacionar música e imagem e, também, pela marca autoral desenvolvida pelo diretor Bruce Gowers.

O próprio formato videográfico começava, na segunda metade da década de 1970, a conquistar espaço nas produções televisivas em função de ser mais barato e rápido do que a película 16 milímetros, que envolvia processamento em laboratório e dificultava o imediatismo exigido pela comunicação eletrônica. Por isso, os experimentos com vídeo foram muito importantes para a realização do que é considerado o primeiro videoclipe.

Estudiosos como Arlindo Machado são taxativos ao apontar a grande importância da vídeo-arte para o caráter inventivo do videoclipe ${ }^{55}$, principalmente a que foi realizada pelo artista sul-coreano Nam June Paik. É o caso de Global Groove (1973), com imagens que aparecem pulsantes e eletrificadas ao som de vários rocks, inclusive Rock Around The Clock, com Bill Haley e Seus Cometas. Isso foi possível principalmente graças ao sintetizador, que possibilitou, pela primeira 
vez, que se estabelecesse uma relação instrumental da música com a imagem, caracterizando o que Machado denomina "ouvir a imagem e ver a música" 56.

Voltando ao videoclipe Bohemian Rhapsody lembramos que ele se inicia com a sombra dos integrantes do Queen - além de Mercury, o guitarrista Brian May, o baterista Roger Taylor e o baixista John Deacon - cantando à capela com fundo cor-de-rosa. Mal entra o primeiro acorde e tem-se um corte para o rosto dos mesmos integrantes num fundo preto. Esse videoclipe é praticamente um balé audiovisual que transporta o telespectador para um mundo onírico, onde é possível sentir e ver toda a mudança rítmica da canção apenas pelo visual. Não há nele uma narrativa linear, mas, sim, a tentativa de prender quem o assiste com efeitos visuais quase hipnóticos. Sendo assim, a letra é utilizada muito mais para passar um clima do que para fins narrativos. Está justamente aí o trabalho autoral desenvolvido por Bruce Gowers, uma vez que essas características embrionárias serão levadas por ele para as produções seguintes.

Praticamente estreante em Bohemian Rapsody, o diretor Bruce Gowers pode ser considerado um dos, senão o primeiro, realizadores a ter longa carreira em videoclipes e estabelecer neles algumas marcas autorais, como a sobreposição de imagens e a intensa utilização de cores fortes na iluminação no registro dos músicos tocando em estúdio. Tais características não são exclusividade desse diretor e, ao longo dos anos, foram se tornando quase intrínsecas ao próprio videoclipe, mas ganham intensidade nos trabalhos que realiza. Entre 1975 e 1996, ele dirigiu mais de 100 videoclipes, entre eles, Ripples (1976), do Genesis, Stayin' Alive (1977), dos Bee Gees; Tom Sawyer (1981), do Rush; e Sexuality (1981) e Automatic (1982), ambos do Prince.

Devido ao sucesso de Bohemian Rhapsody ${ }^{57}$, todas as gravadoras, apesar de inicialmente se mostrarem temerosas pelo fato de os videoclipes exigirem altos investimentos e fornecerem poucas garantias de retorno comercial, começaram a providenciar esse novo instrumento de divulgação para a maioria de seus artistas.

56 MACHADO, Arlindo. A Televisão Levada a Sério. $2^{a}$ ed. São Paulo, SP. Senac. 2001, p. 181.

${ }^{57}$ A banda Queen estrelou outros videoclipes importantes como Bicycle Race (1978), I Want Break Free (1984), em que o vocalista Freedie Mercury aparece travestido de dona de casa, e Radio Ga Ga (1984), com referências ao clássico do expressionismo alemão Metrópolis (1927), de Fritz Lang, todos dirigidos por David Mallet. Foi da banda também o primeiro videoclipe proibido de ser exibido pela MTV - Body Language (1982), dirigido por Mike Rodges, em função de trazer insinuações de sexo, mordidas, jatos de água fria em partes íntimas e arremesso de obesos num bolo gigante. 
Ao mesmo tempo, os programas jovens da televisão também abriram espaço em sua programação para a novidade. Em menos de quatro anos, surgiram inúmeros programas específicos para os videoclipes, caso de Nightclubbing (Manhattan Cable, 1975), Album Tracks (NBC, 1977), Kenney Everett Video Show (GrãBretanha, 1978), dirigido por David Mallet, e America's Top Ten (independente, 1979). Até uma emissora de televisão da Nova Zelândia criou o Radio with Pictures, de título bastante sugestivo, para ocupar o espaço deixado pela ausência de artistas internacionais no país.

O britânico David Mallet, além de diretor do programa Kenney Everett Video Show, tornou-se um importante diretor de videoclipes e, talvez, um dos poucos profissionais do ramo, nos Estados Unidos, oriundo da própria televisão, diferentemente do que aconteceu no início do videoclipe brasileiro, como será visto no próximo capítulo. Ele dirigiu, entre outros videoclipes, Bicycle Race (1978), da banda Queen; Hanging on the Telephone (1978), do Blondie; White Wedding (1982) e Eyes Without a Face (1984), os dois de Billy Idol; e Made In Heaven (1985), de Freddie Mercury. Em comum, eles valorizam a performance dos artistas, que, em geral, cantam olhando para a câmera, processo levado ao extremo em Eyes Without a Face, que se resume a mostrar apenas a cabeça de Billy Idol, cantando durante mais da metade da produção ${ }^{58}$. Mallet sempre procura ou é procurado para trabalhar com artistas bastante performáticos, os quais ele transforma em quase super-heróis. Não é à toa que ele realizou para David Bowie vários videoclipes, como Boys Keep Swinging (1979) e D.J. (1979); e a ficção científica Ashes to Ashes (1980), além de Let's Dance (1986) e China Girl (1983), co-dirigidos com o artista, do qual todos mantêm a ambiguidade típica da androginia ${ }^{59}$.

Na década de 1970, o filme Guerra nas Estrelas, de George Lucas, contou com um videoclipe exclusivo para sua divulgação. Sua estréia ocorreu em 1978, acompanhada do videoclipe Light The Sky On Fire, da banda Jefferson Starship, talvez o primeiro com trechos do próprio filme e outros elementos remetendo a ele, o

58 Ideia semelhante seria utilizada em Nothing Compares $2 \boldsymbol{U}$ (1990), dirigido por John Maybury para a irlandesa Sinéad O'Connor, e no brasileiro Devolva-me (2000), dirigido por Palito, Suzana Moraes e Lírio Ferreira para Adriana Calcanhotto, com a tela divida em três.

59 Essa androgiinia também se manifestaria nos videoclipes dirigidos por Steve Barron para a banda Culture Club, caso de Do You Really Want To Hurt Me (1982), Karma Chameleon (1983), It's a Miracle (1984), Love is Love (1984) e Miss Me Blind (1984). 
que tornaria essa prática cada vez mais comum ${ }^{60}$. O videoclipe seria tido, a partir daí, importante instrumento de marketing, não só de uma canção e do artista que a interpreta, mas também de outros produtos associados a ele.

Dada a largada, pode-se dizer que o videoclipe passa a desenvolver algumas características próprias. Na opinião de Ney Carrasco ${ }^{61}$, a mais importante delas é, ao contrário do que ocorre no cinema, o estabalecimento de relações entre movimento visual e sonoro como primordiais, com possibilidades de sincronia sendo levadas ao extremo, buscando uma plasticidade própria.

No videoclipe existem diferentes formas de as imagens se relacionarem com a música: elas podem estar mais presas à canção, buscando encenar sua letra ou tratar do tema que ela aborda, ou podem passar mais longe, apenas criando um clima agradável à audição da música ou até - esquecendo o seu conteúdo - resultar de uma simples edição de imagens que capta o ritmo da composição. Serge Daney categoricamente afirma que não se compreende nada de um clipe se ele não for visto com os ouvidos. ${ }^{62}$

Outro aspecto intrínseco ao videoclipe, segundo Arlindo Machado ${ }^{63}$, é a fragmentação, devido à presença de diversas tomadas dentro do mesmo quadro e aos planos de curtíssima duração, cuja passagem de um para o outro é marcada pela descontinuidade, em que os cenários, a luz e a indumentária dos intérpretes são alterados. Ou seja, a dispersão e a síntese imperam demasiadas no videoclipe.

Outra característica importante é a união dos aspectos artísticos e comerciais, como instrumento de marketing das gravadoras, principais financiadoras, muitas vezes de modo semelhante à publicidade. Inclusive, há alguns aspectos técnicos que aproximam ainda mais os dois tipos de produção, como: as mudanças de sequências de imagens controladas por computador, o uso da câmera lenta, as

${ }^{60}$ Esse é o caso de, entre outros, A View to a Kill, do Duran Duran, para 007 Na Mira dos Assassinos (1985); (Everything I Do) I Do It For You, de Bryan Adams, para Robin Hood - O Príncipe dos Ladrões (1991); I Will Always Love You e I Have Nothing, de Whitney Houston, para o filme O Guarda-Costas (1992); My Heart Will Go On, de Celine Dion, para Titanic (1997); e Lady Marmalade (2001), de Christina Aguilera, Mya, Pink e Lil'Kim, para Moulin Rouge - Amor em Vermelho (2001), entre outros. Ao invés de cenas de A Pantera Cor-de-Rosa (2006), o videoclipe da canção presente na trilha musical, Check On It (2005), dirigido por Hype Williams, traz a performance da cantora Beyoncé. O mesmo seria repetido no Brasil, com, entre outros, Esperando na Janela, de Gilberto Gil, para Eu Tu Eles (2000).

${ }^{61}$ CARRASCO, Ney. Sygkhronos a formação da poética musical do cinema. São Paulo, SP. Via Lettera:Fapesp. 2003, págs. 192 e 193.

62 DANEY, Serge. In. BLANCHARD, Gerard. Les Videoclips. Communications et Langages. Paris. 72, 2e., trim. 1987, p. 56.

63 MACHADO, Arlindo. A Televisão Levada a Sério ..., p. 178 a 180. 
imagens de corte rápido, as mudanças frequentes de formato e perspectiva, os choques de imagens e os ângulos inusitados de câmera, entre outros. Há também o mesmo intuito de conquistar, em poucos segundos, o telespectador. No videoclipe há ainda a tentativa de tornar uma canção pop mais facilmente assimilável e mais atraente para o consumidor. Por essa semelhança e proximidade é que a maior parte dos profissionais do audiovisual trabalha com muita naturalidade nos dois tipos de produção.

As características descritas podem ser vistas como fontes de produção e desenvolvimento de trabalhos autorais no videoclipe, possibilitando que ele se torne um formato autônomo na televisão, ganhando até emissora exclusiva para sua exibição. Ele também extrapolará o espaço de veiculação oferecido na TV para se tornar o formato mais facilmente adaptado às novas mídias, como internet, telefone celular etc., e também às antigas, caso do cinema, assunto que será analisado posteriormente neste capítulo.

\subsection{Nasce a Music Television (MTV)}

O interesse dos telespectadores pelo videoclipe foi confirmado através do programa semanal Popclips ${ }^{64}$, exibido em 1980 pela emissora norte-americana Nickelodeon, voltada ao público infantil. O mesmo havia ocorrido com relação ao canal a cabo de Atlanta, nos Estados Unidos, Video Concert Hall, dedicado a videoclipes e shows musicais. A própria Warner havia lançado em 1977, em Ohio, também nos Estados Unidos, um sistema de transmissão de televisão a cabo, chamado QUBE, onde, entre vários canais especializados, havia um de música, em que o telespectador poderia escolher os videoclipes preferidos por meio de botões do controle remoto.

O primeiro ápice vivido pelos videoclipes foi o surgimento de uma emissora de televisão especializada na exibição deles, a MTV (Music Television), lançada oficialmente em $1^{\circ}$ de agosto de $1981^{65}$ pelo conglomerado WASEC (Warner Amex

$64 \quad$ O programa Popclips foi exibido pela emissora norte-americana Nickelodeon em 1980.

65 O primeiro videoclipe a passar na MTV norte-americana foi Video Killed The Radio Star, dirigido por Russell Mulcahy para a banda Buggles, exibido ao meio-dia de $1^{\circ}$ de agosto de 1981 e apresentado pelo VJ (video-jockey) John Lack. Em meio a rádios explodindo num laboratório com televisores e mulheres fabricadas em tubos de ensaios, a banda interpreta a letra desta canção, de Trevor Horn, Geoff Downes e Bruce Woolley, que é, de certa maneira, premonitória: "I heard you on the wireless back in Fifty Two / Lying awake intent at tuning in on you / If I was Young it 
Satellite Entertainment) ${ }^{66}$, interessado em encontrar uma saída para o mercado discográfico, com vendas em queda. A indústria fonográfica perdeu $18 \%$ do faturamento entre 1980 e 1983, passando de US\$11,4 bilhões para US\$9,3 bilhões $^{67}$. Apenas o Instituto Fonográfico Britânico, um dos mais renomados em pesquisa de mercado, perdeu, em 1981, mais de 1 milhão de libras por dia em giro de capital por causa das fitas cassete domésticas, consideradas fruto da pirataria.

Desde o início, a MTV é voltada para um público que varia de 12 a 34 anos, das classes $A$ e $B$, o que levou a própria direção da emissora a preocupar-se em transmitir uma linguagem irreverente e inovadora para o mundo e que atingisse esse público. Havia uma nítida intenção em tornar os videoclipes objetos de satisfação incomparável para o consumo de fantasias, ideais, aspirações e sonhos que habitavam o imaginário dos jovens da época. Além disso, também se buscava transformá-los numa espécie de grife de forte identificação com o público dessa faixa etária ${ }^{68}$. "A MTV é associada com as forças da liberdade e da democracia em todo o mundo. Quando o Muro de Berlim caiu, havia guardas da Alemanha Oriental portando guarda-chuvas MTV", comentava Summer Redstone, presidente da Viacom International, em outubro de 1994, na revista Forbes. Para Saul Austerlitz, a emissora criou o que foi denominado de "estética MTV", constituída de montagem

didn't stop you coming through / They took the credit for your second symphony / Rewritten by machine and new technology / And now I understand the problems you can see / I met your children / What did you tell them? / Video killed the radio star / Video killed the radio star / Pictures come and broke your heart / And now we meet in an abandoned studio / We hear the playback and it seems so long ago / Andy ou remember the jingles used to go". ("Eu ouvia você no rádio antes, em 1952 / Deitado sem sono, atento em sintonizar você / Se eu fosse jovem, não teriam impedido você de cumprir seu dever / Eles levaram o crédito pela sua segunda sinfonia, / Reescrita pela máquina e pela nova tecnologia / E agora eu entendo os problemas, você pode perceber / Eu encontrei as crianças / $O$ que você disse a elas? / O vídeo acabou com a rainha do rádio / O vídeo acabou com a rainha do rádio / Filmes chegaram e partiram seu coração / $E$ agora nós nos reunimos num estúdio abandonado, / Nós ouvimos a gravação e parece a tanto tempo atrás / $\mathrm{E}$ você recorda que os jingles costumavam funcionar").

${ }^{66}$ Em 2001, a MTV Networks era o canal mais visto do mundo, atingindo cerca de 386 milhões de lares distribuídos em 140 países através de 31 canais locais e 17 websites, e era uma marca da holding Viacom, sediada em Nova lorque, nos Estados Unidos, que operava em sete segmentos: TV aberta (CBS), TV a cabo (MTV, Showtime), cinema (Paramount, UIP), entretenimento (parques temáticos, cadeia UCI), editorial (Simon \& Schuster), Internet (Ásia, TV Digital), vídeo (Blockbuster) e o Infinity, que possui uma rede de rádios. Em 1996, foi lançado o MTV 2, exclusivo de videoclipes. Ver mais em LUSVARGHI, Luiza Cristina. A MTV no Brasil - a padronização da cultura na mídia eletrônica mundial. Dissertação de Mestrado. ECA/USP. 2002, p. 7 a 10.

${ }_{67}$ VICENTE, Eduardo. Música e Disco no Brasil: A trajetória da indústria nas décadas de 80 e 90. Tese de Doutoramento. ECA/USP. 2001.

68 BRANDINI, Valéria. Panorama Histórico MTV Brasil. In PEDROSO, Maria Goretti, e MARTINS, Rosana (org). Admirável Mundo MTV Brasil ..., págs. 4 a 6. 
rápida, com limpeza, coerência e estilo visual imediatamente assimilável, que impregnou as outras produções audiovisuais, incluindo a publicidade e o cinema.

A MTV foi o primeiro canal a cabo segmentado da história da televisão, que transmitia, durante 24 horas por dia, trezentos videoclipes, da mesma maneira como as rádios tocam suas músicas. Para conseguir isso, na primeira metade da década de 1980, a emissora precisou co-produzir a grande maioria dos videoclipes que exibia: primeiro, porque ainda não havia videoclipes em tão grande escala e nem com a qualidade desejada; segundo, porque precisava atrair as principais gravadoras, que estavam interessadas em encontrar novos nichos de mercado, demonstrando ser o videoclipe uma ótima maneira de, a custos relativamente baixos comparados aos de outras produções audiovisuais, atingir audiência bem específica cujo hábito de consumo ainda não estava totalmente delineado. Em maio de 1981, apenas 23 canções presentes no "Top 100 Hit Singles", da revista norte-americana Billboard, possuíam videoclipes, número que passou para 82, em maio de 1986, e para 97, em dezembro de 1989.

O aparecimento das emissoras a cabo transformou o próprio objetivo dos proprietários das redes de televisão. Antes, havia obstinação em alcançar os diferentes setores da população, nivelando a programação por baixo, com o intuito de obter massa uniforme de consumidores. Mas, com o aparecimento da televisão segmentada, procurou-se atingir parcelas de público interessadas em programações mais específicas. Afinal, não seria possível acreditar que todas as pessoas quisessem ver exatamente as mesmas coisas ${ }^{69}$.

É possível questionar, então, se foi o desenvolvimento do videoclipe que possibilitou o surgimento de emissoras musicais, como a MTV, ou se foram elas que asseguraram a continuidade do videoclipe. Para Andrew Goodwin ${ }^{70}$, a experiência de Bohemian Rhapsody teria sido um caso isolado sem o surgimento da MTV, que possibilitou a emergência do videoclipe. Afinal, ele é quase sempre realizado para atender a uma demanda da emissora que, assim, consegue estabelecer um nicho de mercado. Prova disso é que, em 1984, a MTV assinou contrato com quatro grandes gravadoras de direito exclusivo de transmissão dos novos videoclipes, no

${ }^{69}$ HOINEFF, Nelson. A Nova Televisão - desmassificação e o impasse das grandes redes. Rio de Janeiro, RJ. Relume Dumará. 1996. págs. 15 a 19.

70 GOODWIN, Andrew. Dancing In The Distraction Factory Music television and popular culture ..., págs. 29 a 41. 
momento em que já dava sinais de que passaria para elas a função de produzi-los e que poderia cobrar para exibi-los.

De acordo com Paul Friedlander ${ }^{71}$, a MTV exibia apenas a produção que the interessava, o que fez com que sua programação ficasse restrita ao que acreditava ser o desejo da maioria dos que lhe davam audiência. Porém, mesmo selecionando os videoclipes a serem exibidos, muitas posturas estéticas diferenciadas e com temáticas variadas foram ao ar, cabendo ao público aproveitar ou não o material transmitido.

O sucesso da MTV era tão grande que levou os integrantes da banda Dire Straits a anexarem no refrão da canção Money for Nothing, parceria de Mark Knopfler (membro do grupo) e Sting (vocalista da banda The Police), o seguinte: "Agora que você está sem trabalho / É isso que você tem que fazer / Tocar guitarra na MTV / ... / Dinheiro fácil e garotas à vontade / Eu quero minha MTV"72. Esse último verso, aliás, serviu de slogan para a emissora, e foi repetido por grandes estrelas do rock, como a banda The Police, o guitarrista e compositor Pete Townsend e os cantores Boy George, Cindy Lauper e Billy Idol, entre outros.

O videoclipe dirigido por Steve Barron ${ }^{73}$ e que contava com a aparição do logotipo da emissora, citava uma série de falsos videoclipes, que parodiavam visualmente várias tendências musicais e comportamentais da época, dos baladeiros aos heavy metal boys, e foi o primeiro a ser exibido pela MTV Europe. Essa espécie de paródia em metalinguagem é um nítido exemplo de como as tendências e os estilos musicais são importantes para a identificação de um artista com seu público, assim como para o desenvolvimento de marcas autorais, a partir

${ }^{71}$ FRIEDLANDER, Paul. Rock and Roll Uma história social. Rio de Janeiro, RJ. Record. 2002, págs. 370 a 372.

72 "Now that ain't workin' that's the way you do it / You play the guitar on the MTV / ... / You play the guitar on the MTV / ... / Money for nothin' and chicks of free / I want my MTV". Tradução do autor. Outras menções famosas à MTV são MTV-Get Of The Air ("MTV Saia do Ar"), canção do Dead Kennedys; e a fala do ator Jack Black no filme Escola de Rock (2003), dirigido por Richard Linklater: "o rock foi assassinado por uma coisinha chamada MTV".

73 Steve Barron manteria, em dezenas de outros videoclipes que dirigiu, o mesmo fascínio pela utilização de televisores e de narrativas no interior de outras narrativas: Don't You Want Me (1981), do Human League; Africa (1982), do Toto; o megasucesso Billie Jean (1983), do Michael Jackson, inspirado no filme Três Dias do Condor (1975), de Sidney Pollack, Baby Jane (1983), do Rod Stewart; Pale Shelter (1983), do Tears For Fears; Heaven (1984), do Bryan Adams; e Burning Up (2006), da Madonna. Barron também dirigiu vários videoclipes para a banda norueguesa A-Ha, como o clássico Take On Me (1985), onde uma garota entra na história em quadrinhos estrelada pela banda; Hunting High and Low (1986); Cry Wolf (1986) e Crying in the Rain (1990). Também foi bastante profícuo o trabalho com o Culture Club, em que imperam trabalhos bastante teatrais e espalhafatosos, bem ao estilo andrógino do vocalista Boy George. 
de referências estilísticas já conhecidas e aprovadas, o que será visto mais adiante neste capítulo.

Money for Nothing foi eleito o melhor videoclipe do ano no Video Music Awards (VMA), de 1986, prêmio criado pela MTV norte-americana para premiar os melhores videoclipes em diferentes categorias a cada ano. Também recebeu a premiação do Grammy, como melhor vídeo musical, o que prova que esse tipo de produção já começava a ter espaço na maior premiação da música dos Estados Unidos. A canção se tornou o único single da banda a vender mais de um milhão de cópias e levou o álbum Brothers in $\boldsymbol{A r m s}^{74}$ a ter 12,9 milhões de unidades vendidas.

O Video Music Awards tornou-se uma importante referência para os realizadores de videoclipes. Afinal, ser premiado por ele passou a representar para os diretores, não apenas se tornarem mais respeitados pelos pares, mas também reconhecidos pelo grande público. Os prêmios principais, no entanto, nem sempre foram dados aos videoclipes mais originais e autorais, mas, sim, àqueles que fizeram grande sucesso na MTV e cuja canção geralmente liderou as paradas de sucesso durante aquele ano. Às produções mais inventivas, com grande carga autoral por parte dos realizadores, couberam, na maioria das vezes, os denominados "prêmios técnicos" e do melhor videoclipe do ano, escolhidos por um corpo de especialistas selecionados pela própria MTV.

Na primeira edição da premiação, o melhor videoclipe do ano foi You Might Think (1984), da banda The Cars, dirigido por Jeff Stein \& Charlex. ${ }^{75}$, que parece bastante ultrapassado em suas brincadeiras audiovisuais, mas era uma novidade para época, o que não refletiu, no entanto, em vendagens expressivas de discos. Tim Newman, por sua vez, foi premiado como melhor diretor por Sharp Dressed Man (1983), que realizou para a veterana banda ZZTop divulgar seu álbum Eliminator, que vendeu mais de 8,5 milhões de cópias. Portanto, um sucesso tanto comercial como de crítica.

${ }^{74}$ Esta canção também rendeu um elogiado videoclipe dirigido por Bill Mother, em 1986, marcado pela busca da reprodução na tela de uma animação com sombras desenhadas a lápis, inaugurando uma estética que depois seria consagrada no cinema em Sin City - A Cidade do Pecado (2005), dirigido por Frank Miller, Quentin Tarantino e Robert Rodriguez.

${ }_{75}$ Nesta primeira edição, também foram premiados os melhores videoclipes masculino e feminino, de banda, de artista estreante, performance ao vivo em videoclipe, concepção de videoclipe, diretor, efeitos especiais, edição, direção de arte, cinematografia e experimental. 
O artista mais premiado numa única edição do VMA é o cantor Peter Gabriel, que, em 1987, teve o criativo e original Sledgehammer (1986), dirigido por Stephen Johnson e com animação de Peter Lord e Nick Park (famosos pelo filme A Fuga das Galinhas), premiado em nove categorias, incluindo videoclipe do ano e escolha da audiência. Ou seja, os dois prêmios mais importantes e que asseguraram tanto 0 sucesso comercial, quanto o prestígio junto aos pares da realização. Nela, o cantor e compositor aparece numa versão modernizada de cena do clássico do ator e diretor Buster Keaton, Sherlock Jr. (1924), no trecho em que a cabeça do cantor aparece rodeada de objetos que vão de trens a frutas. Por sua vez, a canção permaneceu entre as cem melhores da revista Billboard durante vinte e uma semanas, e o álbum que a contém, So, vendeu quase seis milhões de cópias, também muito em função do sucesso do videoclipe na MTV.

Andrew Goodwin ${ }^{76}$ elaborou um interessante esquema para ilustrar a maneira como a indústria fonográfica beneficiou-se com o aparecimento do videoclipe e da MTV. Pagando pouco, em geral, para produtores independentes realizarem os videoclipes, as gravadoras começaram a comercializá-los diretamente com 0 público, através de coletâneas em fitas $\mathrm{VHS}^{77}$ e, mais tarde, em DVDs e via Internet; em sites de vídeo como Youtube, e, indiretamente, pelas emissoras de TV aberta e a cabo que, via de regra, eram retransmitidas em clubes, raves, discotecas, bares e cafés. Com isso, houve imensa possibilidade de os consumidores assistirem aos vídeos e comprarem mais CDs, financiando mais videoclipes, num círculo que foi se repetindo.

Apesar de serem considerados por muitos estudiosos como rapidamente descartáveis, os videoclipes demonstraram ter um potencial tão grande que, contraditoriamente, muitos grupos musicais ficaram mais conhecidos por eles do que pela presença na lista dos discos mais vendidos. Eles passaram a interessar, assim, às gravadoras fonográficas, que o incluíram em suas estratégias de marketing, incorporaram a tecnologia necessária e criaram departamentos específicos para a sua realização. Já outras tantas perderam a hegemonia da indústria musical,

\footnotetext{
${ }^{76}$ GOODWIN, Andrew. Dancing In The Distraction Factory Music television and popular culture ..., págs. 42 a 48.

77 A gravadora Sony Music fez sucesso com a série de coletâneas Sony 45. Mas a primeira banda a ter uma coletânea em VHS apenas com videoclipes foi o Devo, que, rapidamente, também passou a interagir com eles nos shows.
} 
tornando-se um organismo subsidiário de um conglomerado industrial que abrange várias mídias.

Durante muito tempo, parece ter imperado a ideia de que bom videoclipe é aquele que funciona como ótimo instrumento de publicidade não só de CDs e DVDs, como de outros produtos nele contidos, caso de, além dos filmes aos quais as canções estão inseridas nas trilhas musicais, como carros, cigarros, roupas, cortes de cabelo e até mesmo formas de comportamento. Ou seja, o videoclipe valeu-se de um estilo de vida consagrado pelo rock and roll, a fim de atingir o público jovem com a divulgação publicitária de uma série de bens de consumo. A banda new wave B52 's, por exemplo, marcou seu visual retrô, com as vocalistas esbanjando cortes de cabelo em camadas e roupas de cores brilhantes no videoclipe Legal Tender (1983), com direção de Mick Haggerty \& C.D. Taylor. Já a banda KoRn bastou aparecer no videoclipe A.D.I.D.A.S. (1997), dirigido por Joseph Kahn, com roupas da marca Adidas para que a grife passasse a ser adorada pelos fãs da banda.

Mais uma vez era demonstrada a aproximação entre publicidade e videoclipe. Os dois tipos de produção audiovisual também têm a necessidade de contar uma história, geralmente não-linear e bastante fragmentada, de envolver e encantar a todos em poucos minutos. Para isso, eles se valem de edição rápida, de imagens digitais, de câmera lenta, de cortes frenéticos, de ângulos pouco comuns de câmeras, de mudanças de perspectivas, formatos e de tomadas inusitadas, em sintonia com um telespectador também impaciente que não se interessa mais em ver a mesma imagem por muito tempo. Por isso, como os videoclipes e a MTV demonstraram eficiência comercial, a indústria da propaganda passou a incorporar elementos dos videoclipes nos comerciais.

O princípio de produção de publicidade e videoclipe também é o mesmo, pois ambos se valem de imagens estereotipadas, sendo produzidos em grandes quantidades, resultando numa proliferação de situações intensamente repetidas que se tornam clichês. Foi o que levou o crítico novaiorquino John Pareles, do jornal "The New York Times", a afirmar que, como o videoclipe tem a mesma origem da publicidade, é impossível qualquer análise do videoclipe enquanto arte. Enxergar o videoclipe como algo exclusivamente comercial, realizado para acompanhar a música de trabalho de um determinado disco e, por isso, diferente de todas as outras experiências de se relacionar música e imagem no audiovisual, impede, 
muitas vezes, que se observe o videoclipe como sendo um trabalho artístico, realizado por diretores que buscam imprimir nele suas marcas autorais.

Embora boa parte dos videoclipes, assim como outras produções audiovisuais, tenha fundo comercial, inclusive em função do tipo de música com o qual trabalha, não significa que ele seja um trabalho meramente comercial, sem fundamentação artística. Como afirma José Miguel Wisnik ${ }^{78}$, enquanto a música contemporânea vive num processo circular de autocitação e de autonegação, o mercado consumidor é baseado em ciclos rápidos de posição e reposição da história dos gêneros e dos estilos. Nesse contexto, cria-se um tipo específico de ouvinte: um consumidor que é fetichista em relação às novidades. Contudo, como estas "novidades" não param de surgir, o consumidor precisa estar sempre em dia com seu consumismo ativo e acelerado, o qual não deixa de ser fomentado pelos videoclipes.

Portanto, não podemos ignorar que muitos videoclipes chamam atenção pela qualidade do trabalho artístico desenvolvido pelo realizador, o que é positivo para o sucesso comercial de uma produção como instrumento de marketing. Quanto mais inovador e criativo for um videoclipe, mais facilmente ele ficará na memória do telespectador e mais o fará se identificar com determinado artista e ficar interessado em adquirir os produtos sugeridos no videoclipe, incluindo o próprio disco em questão.

Mas só o fato de haver diferentes opiniões a respeito, já mostra a importância e o impacto causados por essa produção. Assim, é necessário ressaltar a importância dela para a indústria fonográfica e para o desenvolvimento também artístico de profissionais que, no futuro, poderão dar continuidade ao trabalho, em longas-metragens. Esse reconhecimento já foi, em parte, obtido em setembro de 1985, quando um dos museus mais prestigiados do mundo, o Museu de Arte Moderna de Nova lorque (MOMA), abriu as portas para a exibição de videoclipes.

\footnotetext{
${ }^{78}$ WISNIK, José Miguel. O Som e o Sentido Uma outra história das músicas. São Paulo, SP. Cia. das Letras. $2^{\mathrm{a}}$ ed. 2004. págs. 209 a 219.
} 


\subsection{Primeira Geração de Diretores}

Mesmo sem exibir os nomes dos diretores e de outros profissionais envolvidos em cada um dos duzentos videoclipes inéditos que passavam por sua programação a cada mês, o que aconteceu apenas a partir de 1993, a MTV popularizou os realizadores, que se tornaram representantes daquela que é considerada, para alguns estudiosos, a "idade de ouro do videoclipe", que vai de 1982 a 1986. Se, por um lado, essa produção manifestava os escassos recursos técnicos com que era realizada, por outro lado, ela demonstrava o talento dos diretores que, aos poucos, imprimiam suas marcas na tela e conquistavam autonomia para o videoclipe. Mesmo assim, para o grande público, o videoclipe pertence ao intérprete da canção. Poucos são aqueles que reconhecem os traços de um realizador.

Um dos primeiros diretores de videoclipes a se destacar foi Russel Mulcahy, pois, além de ter dirigido o primeiro videoclipe exibido pela MTV, Video Killed The Radio Star, ele criou marca autoral ao trabalhar com a banda britânica Duran Duran. De acordo com o jornalista Marcelo Rezende ${ }^{79}$, foram videoclipes como Planet Earth (lançado em fevereiro de 1981, seis meses antes da MTV entrar no ar), Hungry Like The Wolf (1982), Rio (1982), Save a Prayer (1982) e The Wild Boys (1984), realizados em plena extravagância publicitária, que transformaram quatro jovens em estrelas e ditadores de um novo "modelo pop".

O fato de um único diretor realizar vários videoclipes para determinado artista é forte indicador de que há uma preocupação do primeiro em estabelecer alguns códigos que identifiquem o segundo junto ao público, o que pode ser entendido também como marcas autorais, o que será encontrado nos três realizadores destacados nesta pesquisa. No caso do australiano Russel Mulcahy ${ }^{80}$ com a banda Duran Duran, o que se vê é uma preocupação em situar os jovens rapazes em cenas com muita ação, passadas em ambientes futuristas (principalmente em Planet

79 REZENDE, Marcelo. Ciência do Sonho A imaginação sem fim do diretor Michel Gondry ...

80 Russell Mulcahy trabalhou intensamente com Elton John, em, entre outros, Heels of the Wind (1981), Nobody Wins (1981), I Don't Wanna Go On with You Like That (1986) e The One (1992). Ele também dirigiu produções para outros artistas, como Bette Davis Eyes (1981), de Kim Carnes, Only The Lonely (1982) e Take The L Out of Lover (1982), os dois para Motels; e The Thin Wall (1981), para Ultravox, com referências ao filme Repulsa ao Sexo (1965), de Roman Polanski. 
Earth e The Wild Boys), com várias referências a filmes de ficção científica. Mesmo em Hungry Like the Wolf e Save a Prayer, em que esse tom futurista é trocado pela selva ou por monumentos históricos, encontram-se elementos comuns aos outros videoclipes, como a presença de indígenas, crianças, água e fogo.

Será justamente o aspecto futurista, misturado a referências ao passado, sobretudo à vida primitiva, que colocará Russel Mulcahy como um dos primeiros diretores de videoclipes a migrarem para o longa-metragem, à ficção científica em Highlander - O Guerreiro Imortal (1986). Segundo Marcelo Rezende, o filme obteve resultado tão desastroso que contribuiu para o estigma de que realizadores de videoclipe não se davam bem na hora de filmar histórias maiores e mais consistentes, impressão rapidamente desfeita por realizadores como Sofia Coppola, Michel Gondry e Spike Jonze, para citar apenas alguns.

A dupla britânica de música pop Kevin Godley ${ }^{81}$ e Lol Creme foi outra que criou marca bastante forte nos primeiros anos dos videoclipes, principalmente no que se refere ao aspecto inventivo. Foi ela, por exemplo, que utilizou a técnica do facial-morphing (que transforma a imagem de um rosto com uma transição quase imperceptível) pela primeira vez no videoclipe próprio Cry (1985) ${ }^{82}$. Também se valeu de efeitos produzidos com a utilização de gelo seco (Girls on Film, de 1981, do Duran Duran), fotografia em preto e branco (Every Breath You Take, de 1983, da banda The Police), na utilização de imagens de arquivo (Real Love, de 1996, para o projeto Beatles Anthology) ${ }^{83}$ e na mixagem de som e imagem (Rockit, de 1983, de Herbie Hancock; e Two Tribes, de 1984, de Frankie Goes To Hollywood, que traz trechos sampleados dos discursos dos ex-presidentes dos Estados Unidos, Richard Nixon e John F. Kennedy, em que o planeta Terra explode, em plena Guerra Fria).

Um aspecto importante e que facilita a consagração de um diretor de videoclipes é o domínio musical, que lhe permite relacionar música e imagem de

${ }^{81}$ Sozinho, Kevin Godley dirigiu, entre outros clipes, C'mon People (1993), do Paul McCartney; I've Got You Under My Skin (1993), de Frank Sinatra e Bono Vox; Girls and Boys (1994), do Blur; Hold Me, Thrill Me, Kiss Me, Kill Me (1995), do U2, com cenas do filme Batman Eternamente (1995), dirigido por Joel Schumacher; Dance into the Light (1996) e You'll Be In My Heart (1999), ambos do Phil Collins; My Father's Eyes (1998), do Eric Clapton; The Sweetest Thing (1998), do U2; e Song for the Lonely (2002), da Cher.

82 A mesma técnica seria empregada com maior repercussão em Black Or White (1991), dirigido por John Landis para o Michael Jackson, e no brasileiro Na Rua, Na Chuva, Na Fazenda (1993), dirigido por Luiz Stein para o Kid Abelha.

83 Esse projeto também ganhou o videoclipe em plano-sequência Free as a Bird (1996), dirigido por Joe Pytka, repleto de referências às canções e histórias da banda. 
maneiras extremamente criativas. É o caso, por exemplo, do britânico Julien Temple, que, após acompanhar a banda punk inglesa Sex Pistols, entre 1976 e 1978, dirigiu videoclipes como Do You Really Want To Hurt Me? (1982), do Culture Club, que mostra um julgamento em que o cantor se defende através da música, cujo refrão serve na maioria das vezes para mostrá-lo num tribunal e para introduzir flashbacks para que o espectador compreenda a narrativa; Undercover of the Night (1983), dos Rolling Stones, que conta com vários ruídos sonoros on screen e utiliza alguns sons da canção com função dramática; e Smooth Operator (1984), da Sade, em que a ação se desenrola no interior de uma casa noturna onde a cantora se apresenta.

Facilitar para o espectador a identificação de cada um dos instrumentos, texturas ou mudanças da canção sempre foi uma das maiores preocupações $e$ marcas autorais do diretor norte-americano Dave Meyers, de modo semelhante ao que faz um dos diretores destacados nessa pesquisa, Oscar Rodrigues Alves, como será visto mais adiante. Entre os videoclipes que Meyers realizou, merecem destaque Lose Control (2005), da Missy Elliott, vencedor do Grammy de melhor videoclipe, com vários números de dança em diferentes ambientes; e, para a cantora Pink, Get This Party Started (2002), vencedor do VMA de videoclipe dance e de melhor cantora; Stupid Girl (2006), vencedor de melhor videoclipe pop; e So What (2009), vencedor de melhor videoclipe do ano na MTV Austrália. Todos esses videoclipes também exibem as cantoras dançando em diferentes ambientes e com diferentes figurinos, reafirmando o potencial do videoclipe para lançar tendências de moda e de comportamento.

Portanto, o conhecimento musical é bastante importante na realização de um videoclipe, principalmente em razão de que, na maioria das vezes, as imagens são criadas para uma canção pré-existente. Esse aspecto, de acordo com diretores de videoclipe entrevistados pela revista Variety em $1984^{84}$, limita as possibilidades visuais e aumenta a tensão frequente entre cantores, gravadoras e diretores, que também precisam atrelar sua liberdade de criação às várias limitações financeiras.

Para um dos diretores entrevistados pela revista, a saída para esse impasse é o músico trabalhar com o diretor na conceituação da música, mas outros entrevistados acreditam que tal parceria pode influenciar de forma negativa a

84 Para o resultado e a análise desta pesquisa, ver KAPLAN, E. Ann. Rocking Around the Clock: Music Television, Postmodernism and Popular Culture. Routledge. USA. 1988, págs. 13 e 14. 
música. Arlindo Machado ${ }^{85}$ observa que alguns músicos enfrentam o desafio de realizar os videoclipes de suas canções, encarando-os como formato audiovisual pleno e auto-suficiente, capaz de dar resposta mais moderna à busca de síntese perfeita entre música e imagem, a ponto de alguns artistas já refletirem a respeito das imagens que acompanharão a canção ainda no momento da própria composição $^{86}$.

Essa relação entre diretores e músicos é problematizada por Saul Austerlitz:

A relação artista-diretor, como a dinâmica entre arquiteto e cliente, deve exibir flexibilidade e mente aberta em ambos os lados, de forma a permitir que as idéias fluam. $O$ artista raramente é apático, tendo impressa sua personalidade em vídeos anteriores, e o diretor frequentemente mantém uma estética de vídeo para vídeo. É o vídeo de sucesso que harmoniosamente casa $o$ artista e o videomaker e chega a um produto final que satisfaça as necessidades de ambos. $O$ artista, sendo o primeiro nome associado ao vídeo, sempre exerce um papel maior e mais notável em sua formação do que seu equivalente cinematográfico mais próximo, atores adotando ao menos uma porção da função do autor, tradicionalmente cedida a um diretor de cinema Artistas como Missy Elliot (rapper, MC, compositora e produtora musical norte-americana) podem não dirigir seus próprios clipes, mas seu selo idiossincrático aparece em todos os quadros, invariavelmente. É esta relação que vai servir como guia por, às vezes, obscuras águas da história do videoclipe, e proverá um frame para apropriadamente oferecer crédito ao trabalho videográfico. Neste esforço, grandes clientes devem ser tão considerados (se não mais) que seus capacitadores arquiteturais. Em adição a artistas individuais procurando encontrar certas necessidades em seus trabalhos, videoclipes também tendem a obedecer às regras estabelecidas por gênero. Vídeos de rock, por exemplo, tendem a mostrar um visual semelhante, obedecendo regras de iluminação, movimento de câmera e estilo, especialmente quando colocados em contraste com vídeos de hip hop, que seguem um grupo de padrões totalmente diferentes (apesar de igualmente ligados). ${ }^{87}$

${ }^{85}$ MACHADO, Arlindo. A Televisão Levada a Sério. 2ª ed. São Paulo, SP. Senac. 2001, p. 182.

${ }^{86}$ Esse é o caso do baixista Gerald Casale, que dirigiu os videoclipes de sua banda Devo, como (I Can't Get No) Satisfaction (1978), co-dirigido por Chuck Stlatler, Whip It (1980), e Beautiful World (1981); do andrógino cantor Prince, que dirigiu seus videoclipes When Doves Cry (1984), Raspberry Beret (1985) e Kiss (1986), do cantor George Michael, co-diretor com Andy Morahan, I Want Your Sex (1987), eleito o terceiro videoclipe mais controverso exibido pela MTV, por insinuar sadomasoquismo e tratar a mulher como objeto; e Father Figure (1987); e de David Byrne, compositor e vocalista da banda Talking Heads, para a qual dirigiu Wild Wild Life (1986), e codirigiu Love for Sale (1986), com Melvin Sokolsky, e o nonsense Road to Nowhere (1985), com Stephen R. Johnson.

87 "The performer-director relationship, like the dynamic between architect and client, must exhibit flexibility and open-mindedness on both sides to allow for the free flow of ideas. The performer is rarely a blank slate, having imprinted themselves with the personae of videos past, and the director often has a specific aesthetic that carries over, auteurlike, from video to video. It is the successful video the harmoniously marries performer and videomaker, and crafts a final product that satisfies both their needs. The performer, being the primary name associated with the video, often exerts a larger, more noticeable role in its formation than their closest cinematic equivalent, actors, adopting at least a portion of the auteur function traditionally ceded to a film's director. Artists like Missy Elliot may not direct their own videos, but their idiosyncratic stamp appears in every frame of their clips nonetheless. It is this relation that will serve as a guide through the sometimes murky waters of 
Essa análise de Saul Austerlitz de certa forma resolve o dilema sobre criatividade ou não de um videoclipe e/ou de ser ele obra de arte ou não, uma vez que destaca os diferentes aspectos que envolvem a sua realização.

Outro ponto importante é que a pesquisa de linguagem para a realização dos videoclipes revolucionou o tempo das imagens na televisão e no cinema, em função de sua edição característica. Além de vários filmes adotarem essa estética ${ }^{88}$, muitos diretores de cinema resolveram se arriscar no videoclipe a fim de arejar sua produção, muitas vezes sem se reverter em exercícios audiovisuais audaciosos. Esse foi o caso de Martin Scorsese, diretor de Bad (1987), com Michael Jackson, de duração de 18 minutos e custo de 2,2 milhões de dólares, um dos 10 mais caros da história, que apresenta uma espécie de versão mais moderna do filme musical Amor, Sublime Amor (1961), de Jerome Robbins e Robert Wise ${ }^{89}$.

A diretora brasileira de videoclipes Mini Kerti explica:

Esse tipo de edição educou as novas gerações para ter um olhar mais rápido e atento, que combina com a rapidez da Internet, da comunicação celular, com o ritmo propriamente dito dos dias atuais. Trata-se de um

music-video history, and provide a framework to appropriately parcel out credit for the work of videomaking. In this endeavor, great clients must be saluted as much as (if not more than) their architectural enablers. In addition to individual performers looking to meet certain needs in their work, music videos also tend to abide by the rules established by genre. Rock videos, for example, tend to exhibit a similar look, sticking to a set of guidelines about lighting, camera movement, and style, especially when placed in contrast with the body of hip-hop videos, which follow an entirely different (although equally binding) set of core standards". AUSTERLITZ, Saul. Money for Nothing ..., págs. 8 e 9. Tradução de Inahiá Castro.

${ }_{88}$ '... Entre os filmes, estão A Força do Amor (1983), de Jim McBride; Top Gun - Ases Indomáveis (1986), de Tony Scott; e os trabalhos do diretor Ridley Scott, como Blade Runner - O Caçador de Andróides (1982) e Chuva Negra (1989).

89 Outros cineastas foram Jonathan Demme, que dirigiu Perfect Kiss (1985), do New Order, mero registro da banda tocando em estúdio; David Lynch, que criou o clipe de animação em preto e branco Shot in The Back Of The Head (2009), do Moby, no mesmo estilo do longa-metragem de animação Persépolis (2007), de Marjane Satrapi e Vincent Paronnaud; Brian de Palma, responsável por Dancing in the Dark (1984), do Bruce Springsteen; Spike Lee, diretor de Money Don't Matter 2 Night (1992), do Prince; They Don't Care About Us (1996), do Michael Jackson, que teve duas versões, uma que mostra várias cenas de violência no mundo, com Michael Jackson num presídio, e outra filmada no Morro Dona Marta, no Rio de Janeiro, e no Pelourinho, em Salvador, com a percussão da banda Olodum; e Fight the Power (1989), de Public Enemy, inspirado em seu filme Faça a Coisa Certa (1989); Sam Peckimpah, de Too Late for Goodbyes (1984), do Julian Lennon; Bob Rafelson, de All Night Long (1983), de Lionel Richie; George Lucas, de Rush Rush (1991), de Paula Abdul, estrelado por Keanu Reeves como espécie de antiherói interpretado por James Dean em Juventude Transviada (1955); Gus Van Sant, com o bastante inventivo Under The Bridge (1992), do Red Hot Chili Peppers; e o documentarista Michael Moore, mantendo sua cruzada anti-George Bush, então presidente dos Estados Unidos, em Sleep Now in the Fire (2000), de Rage Against the Machine; e Boom (2003), do System of a Down. Até o artista plástico e videomaker Andy Warhol dirigiu, com Dan Munroe, o videoclipe bem-humorado Hello Again (1984), para a banda Cars. 
tempo mais nervoso, com menos calma, com menos pausa, com menos planos de seqüência. A partir daí, desenvolveu-se uma nova linguagem, uma perspectiva de idéias com imagens que influenciaram a TV e o cinema para sempre. Podemos citar a pesquisa do uso de efeitos especiais, como o morph, por exemplo, no videoclipe do Michael Jackson, Black or White (1991), entre outros (o bullet time ${ }^{90}$, utilizado pela primeira vez no videoclipe Army of Me, dirigido por Michel Gondry para Björk em 1995, e apresentado de forma mais sofisticada e com maior alcance pelo mesmo diretor em Like a Rolling Stone, para os Rolling Stones, em 1995). Os videoclipes foram influenciados pela videoarte e pelas artes plásticas e vice-versa, e ambos, mais uma vez, influenciaram a TV e o cinema. Recursos como o uso do reverse, os efeitos de luz, de supressão de frames, o uso de janelas gráficas, 0 trabalho com texturas nas imagens, uma busca incessante de truques, que proporcionaram um efeito curioso e diferente na imagem, estavam em pauta. A criação de cenários virtuais e surrealistas, como os videoclipes de Björk, tornou-se comum. Muitas vezes são ideias simples, que trabalham o inusitado na imagem e criam uma nova perspectiva no olhar. ${ }^{91}$

Foram justamente essas características que fizeram do videoclipe um dos mais poderosos veículos de divulgação da música para o alto consumo, principalmente dos jovens, para os quais a associação entre música e um referencial imagético já havia se tornado imprescindível antes mesmo da era digital ${ }^{92}$.

\section{6 “Rei e Rainha do Videoclipe”: Michael Jackson e Madonna}

Ninguém parece ter se beneficiado mais dos videoclipes para a identificação do público com suas mudanças de estilos e modos de comportamento ao longo dos anos do que os cantores norte-americanos Michael Jackson e Madonna, justamente

90 Sistema de câmeras ligadas uma à outra e alinhadas horizontalmente para que cada uma captasse um frame do mesmo instante. Essa técnica foi imortalizada na trilogia cinematográfica Matrix, dirigida pelos irmãos Andy e Larry Wachowski, em 1999 e 2003.

91 PEDROSO, Maria Goretti, e MARTINS, Rosana (org). Admirável Mundo MTV Brasil. Editora Saraiva. São Paulo, SP. 2006.

92 O diretor norte-americano Francis Ford Coppola foi o primeiro a captar imagens através de câmeras de filmagem com película 35 milímetros e editá-las com equipamentos eletrônicos no filme O Fundo do Coração, de 1982. Em 1995, foi a última vez que o número de filmes montados mecanicamente se igualou ao dos editados digitalmente. Se até 1996 nenhum filme com edição digital havia ganhado o Oscar de melhor edição, naquele ano todos os vencedores foram editados desse modo, com exceção de $\boldsymbol{O}$ Resgate do Soldado Ryan (1988), de Steven Spielberg. Os sistemas digitais Avid e Lightworks, dois dos mais usados no mercado, aliam o que há de melhor no processo não-linear da Moviola com a possibilidade de manipular e revisar rapidamente uma grande quantidade de material. Isso não implicou, no entanto, no desaparecimento da tira de celulóide perfurada em 35 milímetros. Muito pelo contrário, ela ainda é o meio que capta a imagem em primeiro lugar e pelo qual o filme chega aos cinemas. MURCH, Walter. Num Piscar de Olhos A edição de filmes sob a ótica de um mestre. Editora Jorge Zahar. Rio de Janeiro, RJ. 2004; e LUCA, Luiz Gonzaga Assis de. Cinema Digital Um Novo Cinema?. Imprensa Oficial São Paulo, SP. 2004, p.212. 
denominados por alguns pesquisadores, como Saul Austerlitz, "Rei e Rainha do Videoclipe".

Realizado em 1983, Thriller, dirigido por John Landis, que havia realizado o filme Um Lobisomem Americano em Londres (1981), é considerado, até hoje, um dos melhores videoclipes da história. Foi apontado pela revista Rolling Stone o melhor videoclipe dos anos 80 e pela revista $T V$ Guide \& $M T V$ o melhor do milênio. Produzido por iniciativa da gravadora CBS, ele foi lançado durante a fase de divulgação do disco de Michael Jackson, de mesmo nome, que chegara às lojas em dezembro do ano anterior e tornou-se o de maior êxito de todos os tempos, permanecendo trinta e sete semanas no primeiro lugar da parada de álbuns nos Estados Unidos, vendendo mais de um milhão de cópias apenas em Los Angeles, emplacando sete singles no Top 10 norte-americano e recebendo doze prêmios Grammy. Desse disco, pelo menos mais duas músicas renderam ótimos videoclipes, Beat It (1983), inspirado em filmes de gângsteres e dirigido por Bob Giraldi; e o já citado Billie Jean (1984), dirigido por Steve Barron. Eles fizeram com que Michael Jackson se tornasse o primeiro artista afro-americano a aparecer no horário nobre da MTV.

Com oito minutos (a duração de um curta-metragem), Thriller é considerado um clássico da paródia de filmes de terror e conta com a voz-off aterrorizante do ator Vincent Price, veterano de produções do gênero. As imagens criadas por John Landis para o roteiro feito em parceria com o próprio Michael Jackson, que bancou os custos da obra, amedrontam e emocionam, em função de perfeitos movimentos de câmera, escolha dos figurinos, iluminação, ruídos e coreografia. O videoclipe possui pelo menos uma sequência marcante: a dança dos mortos-vivos ${ }^{93}$. As cenas de bastidores dessa realização renderam um vídeo em VHS que foi o mais vendido da história durante cinco anos, posto perdido em 1988 para outro trabalho de Michael Jackson, Moonwalker.

Ao longo dos anos, Michael Jackson continuaria estrelando produções suntuosas e caríssimas, inovadoras no uso de tecnologias, sempre com longas introduções sem música e com a participação de várias personalidades ${ }^{94}$. Black Or

93 Saul Austerlitz relaciona essa sequência ao número de dança de Fred Astaire e Ginger Rogers no filme $\boldsymbol{O}$ Picolino, dirigido por Mark Sandrich, em 1935.

94 Rapidamente, tornou-se interessante para o videoclipe contar com uma estrela do cinema ou da televisão, ao mesmo tempo em que também para elas era importante aparecer nele como modo de estar na MTV, estabelecendo forte canal de comunicação com o público jovem. A atriz Kim 
White (1991) chamou atenção pela metamorfose de rostos de diferentes etnias e pela presença do astro-mirim Macaulay Culkin. Remember the Time (1992), dirigido por John Singleton, misturava temática egípcia com o ator Eddie Murphy e o jogador de basquete Magic Johnson. No mesmo ano, o sensual In The Closet, dirigido por Herb Ritts e Michael Jackson, foi estrelado pela famosa top model Naomi Campbell $^{95}$. Também de 1992, Jam, dirigido por Michael Jackson e David Kellogg, reuniu os dois maiores astros afro-americanos de então, Jackson e o também jogador de basquete Michael Jordan. Scream (1995), realizado por Mark Romanek em preto-e-branco, marcou o dueto dos irmãos Michael e Janet Jackson, em clima futurista, num dos maiores orçamentos da história, cerca de 7 milhões de dólares. $E$ You Are Not Alone (1995), do diretor Wayne Ishan, que trouxe Jackson cantando sozinho num teatro vazio e no deserto, e na intimidade com a esposa Lisa MariePresley, filha do rei do rock Elvis Presley.

Por meio desses videoclipes, é perceptível como um artista pode se tornar senhor de sua obra e da divulgação que ela terá em todos os meios possíveis, tornando-se muito mais autor deles do que os próprios diretores, uma vez que os escolhe pessoalmente e, muitas vezes, deixa bem claro o que pretende que seja realizado com aquela canção. Além de cantar e dançar muito bem, Michael Jackson demonstrou sempre ter feito questão de apresentar ao público algo realmente inovador, fosse pelo emprego das técnicas e tecnologias mais avançadas do momento, fosse por trabalhar com os melhores profissionais. Outra preocupação era na maneira de transmitir seu estilo e modo de conduta, muitas vezes defendendo a comunidade afro-americana. Um exemplo é a campanha humanitária, divulgada por meio do videoclipe da canção We Are The World, incluída no disco USA For Africa, de 1985, e que reuniu os quarenta e cinco maiores nomes da música de então. Resultado: uma renda de cerca de cinquenta e cinco milhões de dólares para o combate da fome na África.

Basinger fez uma morta em Mary Jane's Last Dance (1993), de Heartbreakers, dirigido por Keir McFarlane. O comediante Chevy Chase estrelou You Can Call Me Al (1986), de Paul Simon, dirigido por Gary Weis. O também ator Danny Ayello encarnou um pai preocupado de Madonna em Papa Don't Preach (1986), dirigido por James Foley. Já o ator Ethan Hawke foi além e dirigiu o clipe Stay (I Missed You) (1994), de Lisa Loed \& Nine Stories. A atriz então adolescente, Alicia Silverstone foi a estrela de dois videoclipes do Aerosmith - Cryin' (1993) e Crazy (1994), ambos dirigidos por Marty Callner e o segundo também com a participação da atriz e filha do vocalista Steven Tyler, e referências ao filme Thelma \& Louise (1991), de Ridley Scott.

95 Outras supermodels estrelaram o videoclipe em preto e branco Love is Strong (1994), dirigido por David Fincher para os Rolling Stones. 
No entanto, para as pretensões da MTV, nenhum videoclipe foi tão importante quanto Thriller, pois, a partir dali, ela teve seu modelo repetido nas mais diversas partes do mundo. A emissora francesa MCM, por exemplo, especializou-se na exibição de videoclipes, apresentando, no começo e no final de cada um, o nome do cantor ou do grupo, do disco, da gravadora e do diretor do videoclipe. Já outras emissoras norte-americanas, como a NBC, criaram programas específicos aos videoclipes como Friday Night Vídeos ${ }^{96}$. O videoclipe estrelado por Michael Jackson foi o grande vencedor da primeira edição do VMA (Video Music Awards), em 1984, nas categorias de escolha da audiência, coreografia e performance.

Se Michael Jackson valeu-se dos videoclipes para tornar-se o maior vendedor de discos da história e o mais badalado artista da música pop de todos os tempos, a "Rainha do Videoclipe" Madonna utilizou-os para provocar discussões, sobretudo em torno dos dogmas religiosos e sexuais, firmando, assim, muito bem sua persona artística. Para Saul Austerlitz, Madonna fez dos videoclipes "álbuns de fotos em movimento". ${ }^{97} \mathrm{E}$, como Michael Jackson, ela sempre procurou escolher os melhores e mais criativos diretores de cada momento para trabalhar e se tornar muito mais a responsável pela autoria dos trabalhos do que eles, uma vez que a polêmica e 0 choque podem ser considerados aspectos que unem toda essa produção.

A carreira de Madonna começou praticamente junto com a MTV e, assim como ela evoluiu, a cantora percebeu que poderia utilizar os videoclipes como plataformas de lançamento de tendências visuais e para atrair críticas e implicâncias, como as do movimento feminista. Porém, uma das grandes pensadoras feministas da época, Camille Paglia, defendeu-a como introdutora do que chamou de "feminismo afirmativo", ou seja: é possível ser forte e sexy ao mesmo tempo. Para a feminista, Madonna "ensinou as moças a serem plenamente femininas e sexuais, mantendo ao mesmo tempo controle sobre suas vidas". ${ }^{98} \mathrm{~A}$ própria popstar comentou a importância do videoclipe e da MTV em sua carreira, à Agência France Press, em 2006: "Nossa carreira começou ao mesmo tempo. O

96 O programa Friday Night Vídeos foi exibido pela primeira vez na emissora norte-americana NBC em 1983.

97 AUSTERLITZ, Saul. Money and for Nothing ...

98 JUNIOR, José Flávio. O Fim da Era Madonna? Revista Bravo!. São Paulo, SP, dezembro de 2008. Em http://bravonline.abril.com.br/conteudo/musica/musicamateria_407201.shtml, acessado em 29 de junho de 2009. 
apoio da MTV me permitiu e ainda me permite, me expressar e partilhar minha visão com o mundo"99.

A norte-americana Mary Lambert, famosa no cinema como diretora do longametragem de terror $\boldsymbol{O}$ Cemitério Maldito (1989), foi uma das profissionais que mais trabalharam com Madonna em videoclipes. Ela dirigiu, entre outros, Borderline (1984), Like a Virgin (1984), Material Girl (1985), no qual Madonna aparece numa revitalização da famosa cena em que a atriz Marilyn Monroe canta e dança, acompanhada de vários homens numa escada, no filme Os Homens Preferem as Loiras (1953), dirigido por Howard Hawks. Havia ali uma clara tentativa de transmitir a mensagem de que, assim como Marilyn Monroe havia se tornado um símbolo sexual ousado na década de 1950, esse posto caberia agora a Madonna.

A citação de outras produções audiovisuais é frequente em videoclipes, numa tentativa dos realizadores dialogarem com os filmes que os marcaram. O compositor e crítico musical Gerard Blanchard ${ }^{100}$ analisa que as imagens oníricas e fantasiosas do videoclipe muitas vezes revitalizam cenas consagradas do cinema, da publicidade, da televisão e até mesmo de outros videoclipes, através da citação, da sátira, da inspiração, da homenagem ou, ainda, do pastiche. Muitas dessas citações não são facilmente reconhecidas pelo público-alvo dos videoclipes, mas, mesmo assim, uma vez que as referências são bastante claras, elas podem despertar o interesse desse público pelo filme mencionado e pela história do audiovisual como um todo. É interessante observar como sequências famosas de filmes, assim como muitas vezes o resumo do enredo completo, são recicladas por muitos videoclipes. Esse é o caso de Watch for the Hook (1998), de Cool Breeze, Outkast \& Goodie Mob, dirigido por David Nelson, com sequência muito parecida com o início do filme Cães de Aluguel (1992), de Quentin Tarantino; La Tortura (2005), de Shakira, dirigido por Michael Haussmann, em que o cantor Alejandro Sanz interpreta personagem parecido com o de James Stewart em Janela Indiscreta (1954), de Alfred Hitchcock; I'm Glad (2003), com direção de David LaChapelle, em que a cantora Jennifer Lopez repete, em forma resumida, a trajetória da protagonista do filme Flashdance (1983), de Adrian Lyne; e We Trying to Stay Alive (1997), do

\footnotetext{
99 Agência France Press. Reprodução em Há 25 anos nascia a revolução MTV. Campinas, SP. 31 de julho de 2006, p. C1.

${ }_{100}$ BLANCHARD, Gerard. Les Videoclips. Communications et Langages. Paris. 72, 2e., trim. 1987, p. 55.
} 
Wyclef Jean, John Forté e Pras, dirigido por Roman Coppola, paródia de Os Embalos de Sábado a Noite (1977), de John Badham, com direito a citação de Stayin'Alive, a canção-tema do filme interpretada pelos Bee Gees. No clipe da regravação de Mrs. Robinson (1992), dirigido por Jesse Peretz, a banda Lemonheads aparece em meio a imagens do filme A Primeira Noite de Um Homem (1967), de Mike Nichols, do qual a canção fizera parte da trilha musical com Simon \& Garfunkel. Jesse Peretz prestou homenagem ao filme Apertem os Cintos ... 0 Piloto Sumiu (1980), de Jim Abrahams e David e Jerry Zucker, no divertido Learn to Fly (1999), do Foo Fighters, em que o vocalista Dave Grohl interpreta passageiros, pilotos e aeromoças. Na década de 1980, a banda norte-americana REM misturou influências da Renascença italiana com filmes de Andrei Tarkovsky e Michelangelo Antonioni, em Losing My Religion (1991), dirigido por Tarsen e que também incomodou a comunidade cristã de vários países por trazer imagens de anjos.

Esse tipo de citação e homenagem aos clássicos do cinema é uma das mais fortes marcas autorais do casal de diretores Jonathan Dayton e Valerie Faries, que também se valem de outros referenciais artísticos. É o caso de Tonight, Tonight (1996), do Smashing Pumpkins, com referências ao clássico Viagem à Lua (1902), de George Méliès; All Around the World (1997), do Oasis, onde aparecem imagens reais da banda tocando em meio a uma animação com referências ao psicodelismo do filme Yellow Submarine, dos Beatles; Californication (2000), do Red Hot Chili Peppers, que simula partida de videogame; e Otherside (2002), também do Red Hot Chili Peppers, com referências ao surrealismo e ao artista gráfico holandês Maurits Cornelis Escher. Em 2006, ao estrear no cinema, a dupla foi indicada ao Oscar pelo filme A Pequena Miss Sunshine.

A principal marca do diretor norte-americano Mark Romanek é a quantidade de referências que leva para os videoclipes que dirige. A fotografia avant-garde do nova-iorquino Joel-Peter Witkin foi utilizada em Closer (1994), do Nine Inch Nails, considerado um dos videoclipes mais caros da história: sete milhões de dólares. $O$ filme do francês Jean-Luc Godard, Alphaville (1965), serviu como base para Little Trouble Girl (1996), do Sonic Youth. Devils Haircut (1996) traz o cantor Beck como um cowboy que caminha com um rádio e é o tempo todo observado, de modo semelhante à primeira sequência do filme A Conversação (1974), de Francis Ford Coppola. E a obra One-Minute Sculptures, do artista plástico austríaco Erwin 
Wurm, foi a inspiração do abstrato e nonsense Can't Stop (2003), do Red Hot Chili Peppers.

As produções com referências a linguagens de outros interesses dos jovens, como videogames, fotografias etc, não são exclusividade de Mark Romanek, nem da dupla Valerie Faris e Jonathan Dayton. Entretanto, poucos videoclipes causaram o mesmo impacto que Material Girl nesse sentido e Madonna continuou estrelando videoclipes com referência a outros filmes, como Open Your Heart (1986), dirigido por Jean-Baptiste Mondino, inspirado em O Anjo Azul (1930), dirigido por Josef von Sternberg, mais uma tentativa de aproximação de Madonna com outro mito do cinema, Marlene Dietrich; Oh Father (1989), dirigido por David Fincher, com heranças de Cidadão Kane (1941), de Orson Welles; e Express Yourself (1989), também dirigido por Fincher com traços do expressionismo alemão de Metrópolis (1927), de Fritz Lang.

Dois anos após dirigir La Isla Bonita (1987), Mary Lambert realizaria um dos mais polêmicos videoclipes estrelados por Madonna - Like a Prayer que, tão logo estreou, em 1989, rendeu inúmeras críticas por parte da comunidade cristã no mundo todo, o que fez com que a artista perdesse um contrato milionário para o anúncio de uma marca de refrigerante. Era chocante demais ver Madonna como se fosse a Virgem Maria, cantando diante de cruzes em chamas, e beijando um Deus negro, mesmo que, no final, ficasse claro tratar-se de um espetáculo teatral. Essa talvez seja a mais contundente prova do interesse de Madonna em utilizar os videoclipes para chocar a sociedade.

A polêmica em torno dos videoclipes estrelados por Madonna continuou com o explicitamente pornográfico Justify My Love (1990), dirigido por Jean-Baptiste Mondino, em que a cantora aparece de espartilho, cinta-liga, calcinha de renda preta e outros acessórios picantes - o que remete ao drama erótico 0 Porteiro da Noite (1974), de Liliane Cavani - e que foi banido da programação da MTV. Mondino também dirigiu, para Madonna, Open Your Heart (1988), em que a popstar interpreta uma cantora de cabaré e beija um menino na boca; Human Nature (1995), com cenas sadomasoquistas, como a em que aparece amarrada numa cadeira; Don't Tell Me (2000), com a cantora num estúdio vestida de cowgirl, dançando como tal diante do painel de uma estrada; e Hollywood (2002), em que ela aparece com diferentes figurinos, como um cor-de-rosa, outro branco e preto, 
outro azul e mais um vermelho, em diferentes cenários, e fazendo aplicação de botox $^{101}$. As referências ao sadomasoquismo e fetiches sexuais reapareceram no escandaloso Erotica (1992), dirigido por Fabien Baron, com a modelo Naomi Campbell e inspirado na atriz Dita Parlo. Também sensual é Vogue, em que a artista aparece com uma roupa preta praticamente transparente numa espécie de ensaio fotográfico, dirigido por David Fincher

Sempre disposta a arriscar novos caminhos, sem medo de errar, Madonna ainda contracenou, no videoclipe Beautiful Stranger (1999), dirigido por Brett Ratner, com o personagem cômico daquele momento, Austin Powers, vivido pelo ator Mike Myers. Foi perseguida por paparazzi em Drowned World (Substitute for Love) (1998), com direção de Walter A. Stern. E, ainda, concordou em ser dirigida pelo então marido e cineasta Guy Ritchie, em What It Feels Like for a Girl (2001), em que aparece defendendo mulheres e roubando, atropelando e dando choque em homens, explodindo um posto de gasolina e se chocando contra um poste. Essa produção foi considerada uma resposta agressiva e masculinizada ao filme de Ritchie, Jogos, trapaças e dois canos fumegantes (1998).

Madonna sempre serviu como modelo, fosse de comparação para as outras cantoras de sua época, fosse de inspiração para as que viriam a seguir na música pop. Na década de 1980, outra cantora de destaque foi Cindy Lauper, famosa pela voz doce e pelos cabelos coloridos, com os videoclipes dirigidos por Edd Griles, Girls Just Wanna Have Fun (1983), com referência aos filmes Uma Noite na Ópera (1935), dos Irmãos Marx, dirigido por Edmund Goulding e Sam Wood; A Bela e a Fera (1946), de Jean Cocteau; e Time After Time (1984), com citação do filme Jardim de Alá (1936), de Richard Boleslawski, que deu o Oscar de melhor atriz à Bette Davis. Paula Abdul também fez bastante sucesso, com os videoclipes dirigidos por David Fincher ${ }^{102}$, Forever Your Girl (1989) e Straight Up (1989).

101 Jean-Baptiste Mondino também dirigiu The Boys of Summer (1984), de Don Henley, em preto e branco, e foi o maior exemplo de fotógrafos de moda que ingressaram com sucesso nos videoclipes, ao trazerem a estética de ensaios de moda como os publicados pela revista Vogue. Outros foram Nick Knight, responsável por, entre outros, o bastante experimental Pagan Poetry (2001), da Björk; Herb Ritts, diretor de Wicked Game (1991), de Chris Isaak, eleito pela MTV o videoclipe mais sexy de todos os tempos; Cherish (1989), da Madonna; e Love Will Never Do (Without You) (1990), de Janet Jackson; e David La Chapelle, diretor de Dirrty (2002), de Christina Aguilera; This Train Don't Stop There Anymore (2001), do Elton John; e It's My Life (2003), do No Doubt, inspirado no filme musical Chicago (2002), de Rob Marshall. 
Ninguém se aproximou mais de Madonna do que a também norte-americana Britney Spears, que começou fazendo caras e bocas de estudante juvenil virginal, em ...Baby One More Time (1998), dirigido por Nigel Dick; até se transformar numa extraterrestre sensual, com a roupa colada ao corpo, em Ooops I Did It Again (2000), também de Nigel Dick; numa aeromoça que assedia os passageiros; numa super-heroína ruiva em Toxic (2004), dirigido por Joseph Kahn; e numa dançarina de pole dance em Gimme More (2007), com direção de Jake Sarfaty. Madonna e Britney Spears apareceram juntas no videoclipe Me Against the Music (2003), dirigido por Paul Hunter, em que se confrontam na dança sensual, separadas por uma parede, até ocuparem o mesmo ambiente.

\subsection{Hip Hop e Heavy Metal Invadem a MTV}

No início da década de 1990, enquanto surgiam vários movimentos musicais provocando uma luta por novos adeptos, na qual o videoclipe era importante instrumento de marketing, aos poucos, a MTV abria espaço para os mais diferentes gêneros musicais, como country, com videoclipes de artistas como Faith Hill e Shania Twain, exibidos na emissora Country Music Television (CMT), criada em 1983; e hip hop, que ganhou um programa próprio, Yo! MTV Raps ${ }^{103}$.

Desde o início, os videoclipes de hip hop desenvolveram uma estética própria, a partir do diálogo entre diretores e artistas, com algumas tendências. A primeira tendência foi a de mostrar imagens do cotidiano, principalmente da periferia das grandes cidades, e da violência a que são submetidos por parte de criminosos, mas, principalmente, em função da ação da polícia. É o que se encontra, por exemplo, no primeiro videoclipe desse gênero musical - The Message (1982), de Grandmaster Flash e Furious Five, dirigido por Sylvia Robinson. Outra tendência importante é mostrar os outros elementos que constituem o hip hop, além da música, caso do grafitti, dos b-boys, como são chamados os dançarinos de hip hop, e do figurino próprio, constituído, sobretudo, de boné, camiseta, bermuda e

'90 (1990), do George Michael. O realizador também desenvolveu uma carreira de sucesso no cinema, com filmes como Seven - Os Sete Pecados Capitais (1995) e O Curioso Caso de Benjamin Button (2008), pelo qual foi indicado ao Oscar de melhor diretor.

103 Yo! MTV Raps estreou na MTV norte-americana em 1989 e tornou-se um dos programas mais populares da emissora. Antes, haviam serviços regionais nos Estados Unidos, como Video Jukebox (The Box), dedicados aos videoclipes de rap. Ver mais em FRIEDLANDER, Paul. Rock and Roll Uma história social. Rio de Janeiro, RJ. Record. 2002, págs. 371 e 372. 
correntes. Esses elementos estão presentes em Planet Rock (1982), de Afrika Bambaataa e Soul Sonic Force; e em Walk This Way (1986) do diretor Jon Small, que marcou o encontro do Run-D.M.C com a banda de rock Aerosmith, como se estivessem numa competição, separados apenas por uma parede, até eles se reunirem durante um show.

O diretor Hype Williams foi o responsável por consagrar, nos videoclipes de hip hop, um modelo que misturava carros esportes e garotas sensuais, deixando de lado os problemas sociais vividos pelas comunidades afro-americanas. Essas são as marcas autorais do realizador, as quais passaram a ser adotadas ou aprimoradas por inúmeros outros realizadores, a ponto de se tornarem praticamente clichês do gênero. Entre os trabalhos mais famosos do diretor estão a animação baseada em movimentos reais do cantor Kanye West, Heartless (2009) e os videoclipes realizados para Busta Rhymes - Woo-ha! Got You All In Check (1996), Tear the Roof Off / Party Goin' On Over Here (1999) e What It Is (2001), experimental nas sobreposições de imagens, incluindo os carrões e as garotas sensuais, clássicos estereótipos do hip hop. O diretor também dividiu a autoria de vários videoclipes com o rapper Busta Rhymes, para suas canções, em que predominam vários efeitos especiais, como a distorção de imagens, caso de What's It Gonna Be (1989), que antecipa tecnologia, simulando seres formados através de líquidos. Tecnologia essa utilizada no filme O Exterminador do Futuro 2 (1991), de James Cameron; Put Your Hand Where My Eyes Can See (1997); Dangerous (1997); Get Out (2000); Fire (2000) e Break Ya Neck (2001). Em 2010, Hype Williams voltou a trabalhar com Kanye West naquele que pode ser considerado o videoclipe mais longo da história - Runaway, com duração de 35 minutos.

Outro realizador importante do estilo hip hop é Paul Hunter, que ficou marcado pelas produções de grandes orçamentos. Ele é o diretor de, entre outros, Vapors (1997), de Snoop Doggy Dogg ${ }^{104}$; Only in California (1997), de Mack 10; Hypnotize (1997), de Ice Cube e Snoop Dogg, co-dirigido com Sean Combs, premiado como melhor videoclipe no VMA daquele ano; Hot Hot Hot (1998), de LL Cool J; Unpretty (1999), com TLC, que custou um milhão e seiscentos mil dólares; Superman (2003), do Eminem; Frontin' (2003), de Pharrell Williams e Jay-Z; Don’t

104 Snoop Doggy Dogg teve o videoclipe Beautiful (2003), dirigido por Chris Robinson, filmado em vários lugares do Rio de Janeiro, como uma escadaria da Lapa, o Parque Lage e a praia de Copacabana. 
Cha (2005), de Pussycat Dolls e Busta Rhymes; e Party Starter (2005), de Will Smith.

Nenhum outro astro do hip hop teve a imagem tão associada aos videoclipes quanto Eminem, a ponto de Saul Austerlitz considerar que era dele o rosto mais familiar da MTV depois de 2000: "Os vídeos de Eminem trabalham com a face de palhaço pintada numa máscara trágica". ${ }^{105}$ Num misto de cartoon com paródias, 0 astro ficou marcado por interpretar diversos personagens em videoclipes como $\mathbf{M y}$ Name Is (1999), com direito a imitação do cantor andrógino Marilyn Manson; The Real Slim Shady (2000), em que aparece como o paciente de um manicômio; Cleanin' Out My Closet (2002), todos dirigidos por Dr. Dre e Philip Atwell; e Without Me (2002), do diretor Joseph Kahn, premiado com o Grammy, em que é apresentado o fictício "The Eminem Show", misto de programa de televisão e história em quadrinhos, com direito a balões com falas e interjeições escritas, legendas aparecendo na tela, Eminem fantasiado de Robin, imitador do Elvis Presley, e paródias das emissoras de televisão CNN e E! Entertainment.

Não é apenas no hip hop que a maneira como determinado diretor se relaciona com as principais referências estéticas do artista do videoclipe pode ser reconhecida como característica autoral. Esse é o caso do trabalho realizado pelo diretor inglês Tim Pope para a banda The Cure, com elementos próprios do gótico, caso do uso intenso de cores escuras, de maquiagens carregadas e da temática pessimista e de vazio existencial. Também é o caso de, entre outros, Love Cats (1983), Close to Me (1985), In Between Days (1985) e Lullaby (1989). Essa relação com o gótico foi mantida nas produções realizadas por Tim Pope para outros artistas, caso de Tainted Love (1981), do Soft Cell; Dazzle (1984), de Siouxsie and the Banshees; Cry Cry Cry (1983), de Neil Young and the Shocking Pinks; Time Will Crawl (1987), de David Bowie; e Eternal Flame (1988), de Bangles. A estética gótica seria levada pelo diretor ao cinema, no qual estreou em 1996, com 0 Corvo: A Cidade dos Anjos, continuação de $\mathbf{O}$ Corvo, dirigido por Alex Proyas e realizado dois anos antes cuja história envolve a vingança de pai e filho que são assassinados e voltam da morte.

O norte-americano Wayne Isham foi um dos responsáveis por fornecer identidade facilmente reconhecível aos videoclipes de heavy metal, com teatralidade

105 AUSTERLITZ, Saul. Money and for Nothing ... p. 184. Tradução do autor. 
exagerada, muitas caras e bocas, várias performances ao vivo no palco, certa rebeldia e muito bom-humor, em meio à mistura de imagens em câmera lenta e acelerada. Essas características caíram rapidamente no agrado dos adolescentes da década de 1980. Entre os trabalhos que realizou, estão Smokin'ln The Boys Room (1985), do Mötley Crüe; Livin' On A Prayer (1986) e I'll Be There For You (1988), ambos do Bon Jovi; Pour Some Sugar on Me (1988), do Def Leppard; e 5 Minutes Alone (1994), do Pantera. Para uma das bandas mais consagradas do estilo, Metallica, ele dirigiu Enter Sandman (1991), Frantic (2003) e a animação futurista Broken, Beat \& Scarred (2009), que mostra cenas dos filmes Gladiador (2000), do Ridley Scott, e Star Wars Episódio VI - O Retorno de Jedi (1983), de George Lucas. Wayne Isham foi eleito, pela MTV dos Estados Unidos, o "melhor diretor de todos os tempos", e, pela revista Entertainment Weekly, um dos cem talentos mais criativos do entretenimento.

Se Wayne Isham foi um dos grandes responsáveis pela criação de uma estética visual para as bandas de heavy metal, ele também exerceu papel semelhante em relação aos principais nomes da música pop dos anos 1990, dos quais filmou coreografias inesquecíveis, principalmente para as boysbands e artistas dançantes. Para Backstreet Boys, ele realizou I Want It That Way, de 1999, em que os rapazes dançam num aeroporto onde há avião com o nome deles e fãs histéricas. Ou seja, o tempo passa e os artifícios pop permanecem os mesmos da época dos Beatles. Com o porto-riquenho Ricky Martin, ele trabalhou no megasucesso Livin'La Vida Loca. Outra boyband para quem produziu videoclipes foi 'N Sync - em 2000, Bye Bye Bye e It's Gonna Be Me; e, em 2001, Pop. Wayne Isham também se valeu de clichês consagrados nos denominados filmes de verão ou de juventude para trabalhar com as cantoras Britney Spears, em I'm Not a Girl, Not Yet a Woman (2002) e Piece of Me, (2007); e Avril Lavigne, em The Best Damn Thing (2008), em que a garota aparece como rebelde e como team leader.

\subsection{Segunda Geração de Diretores}

Na década de 1990, o videoclipe finalmente começou a ser levado mais a sério, em função de ousados realizadores, que firmaram esse formato audiovisual como importante espaço de experimentação e passaram a servir como exemplo e 
parâmetro para a maioria dos jovens diretores ao redor do mundo. A essa altura, a indústria fonográfica mostrava sinais de recuperação, com a troca do disco de vinil pelo CD, e a MTV atingia trezentos e vinte milhões de lares em noventa países e nos cinco continentes ${ }^{106}$. Além disso, a programação da emissora, nos Estados Unidos, tornava-se mais voltada aos programas de variedade.

Segundo Saul Austerlitz, a década de 1980 foi um ponto alto para a experimentação e inovação de diretores de videoclipe. Porém, a maturidade desse formato e o desenvolvimento de trabalhos realmente autorais nele só foram alcançados na década seguinte, sobretudo graças ao trabalho de dois realizadores: Spike Jonze e Michel Gondry, que se valeram do videoclipe para realizar verdadeiros experimentos narrativos e audiovisuais. Desse modo, ficava um pouco para trás a narrativa clássica, a tentativa de transpor literalmente a letra da canção para a tela e a imagem do intérprete da canção quase o tempo todo em cena ${ }^{107}$.

A utilização da edição digital também se tornava marca dessa geração e um grande diferencial com relação à anterior. Afinal, mesmo que a captação fosse realizada em película, todo o processamento passou a ser realizado em ambiente digital, o que tornou possível a criação eletrônica de cenografia, luz, sonorização, efeitos e até mesmo a introdução de novos personagem ou elementos na cena, sem perdas na qualidade da imagem original. A edição não-linear, realizada em computadores, também possibilitou ao realizador interferir na indicação dos efeitos a serem produzidos e na edição da trilha sonora, o que antes era realizado apenas por técnicos especializados. Ou seja, o trabalho realizado na pós-produção computadorizada, na maioria dos casos, tornou-se muito mais importante na realização de um videoclipe do que as próprias filmagens ${ }^{108}$.

Michel Gondry nasceu em Versailles, na França, em 1963, e foi baterista da banda Oui Oui, para a qual dirigiu alguns videoclipes. O destaque do trabalho realizado por ele foi o de recuperar aspectos lúdicos do universo da criança, rompendo com as fronteiras entre fantasia e realidade. Prova disso é que um dos videoclipes mais célebres que dirigiu foi Human Behavior (1993), em que,

\footnotetext{
106 Além da norte-americana, fazem parte da rede as emissoras da Europa (surgida em 1987), Brasil (1990), Ásia (1991), Japão (1992) e América Latina (1995), transmitida para Peru, Equador, Colômbia, Venezuela, Chile, Bolívia, Paraguai e Uruguai..

107 AUSTERLITZ, Saul. Money of Nothing ..., pág, 163. Tradução de Inahiá Castro.

108 LUCA, Luiz Gonzaga Assis de. Cinema Digital. Um Novo Cinema?. Imprensa Oficial. São Paulo, SP, p. 204 a 212.
} 
fantasiada de urso gigante de pelúcia, a cantora islandesa Björk corre por uma floresta e se intriga com o comportamento humano. Também para Björk, Gondry realizou os videoclipes Hyperballad (1996), que se passa num sonho da cantora; e Bachelorette (1998). Outras invencionices marcantes de Michel Gondry foram a realização de um videoclipe inteiro simulando as peças do brinquedo Lego em movimento (Feel In Love With a Girl, de 2002, da dupla White Stripes), a recuperação do universo do diretor de musicais caleidoscópicos Busby Berkeley (Around the World, de 1997, do Daft Punk), a utilização de diferentes luminosos de edifícios comerciais ${ }^{109}$ para formar a letra da canção (La Tour de Pise, de 1993, do cantor francês Jean François Coen) e a técnica do time suspension, que provoca no espectador uma sensação de inversão do cenário, desproporção e movimento em torno de uma cena congelada ou "pausada", que sempre se repete, de modo circular, apenas multiplicando a presença da cantora na tela (Come Into My World, de 2002, de Kylie Minogue)

Marcelo Rezende avalia a proposta de Michel Gondry:

Gondry abole de início a transcrição literal de uma canção, a estrutura que, de alguma maneira, o condicionasse ao tema ou letra propostos pelos cantores, bandas e grupos. Ele toma distância dessa literalidade deixando os músicos com os quais trabalha em segundo plano, a recusa, e mesmo assim se mantém fiel ao espírito do clipe (como mídia), que é a ilustração para o som. Para conseguir mais esse truque ilusionista, Gondry se apoia, essencialmente, no ritmo. A imagem do artista em clipe, para ele, deve estar submetida ao que esse mesmo artista criou, e nesse processo consegue algo surpreendente: prefere a música ao próprio músico, e filma (ele prefere a película ao vídeo) algo que possa ser sentido, imaginado pelo público, transformando-se em um criador de imagens rítmicas baseadas em um "sentimento" do ouvinte diante da música, como se fosse possível ver as notas do ar travestidas de histórias ilógicas e enredos impossíveis. ${ }^{110}$

O universo temático de Spike Jonze, nascido em Rockville, nos Estados Unidos, em 1969, é o das piadas e trucagens audiovisuais, suas principais marcas autorais e que criam uma identidade muito forte entre realizador, artista e espectador. Os trabalhos mais conhecidos que realizou foram: Weapon of Choice (2001), de Fatboy Slim, em, que o ator Christopher Walken, inicialmente

109 Esse mesmo efeito foi utilizado em Killer / Papa Was a Rolling Stone (1993), de George Michael, dirigido por Marcus Nispel, onde trechos e palavras-chave da canção aparecem em diversos produtos num supermercado.

110 REZENDE, Marcelo. Ciência do Sonho A imaginação sem fim do diretor Michel Gondry, págs. $25,26,27,28,39$ e 40. 
desanimado, sai dançando pelos dois primeiros andares de um prédio, realizando verdadeiras acrobacias, até retornar à posição inicial; e Sabotage (1994), da banda Beastie Boys, sátira aos seriados policiais norte-americanos dos anos 1970, com três integrantes da banda de bigodes e vestidos de policiais numa eletrizante perseguição. Em 2002, eles foram considerados, respectivamente, o primeiro e o segundo melhores videoclipes de todos os tempos, pela emissora musical especializada em videoclipes $\mathrm{VH}-1$.

Para It's Oh So Quiet (1995), da cantora Björk, Spike Jonze recriou o ambiente dos musicais do cineasta francês Jacques Demy, como Os GuardaChuvas do Amor (1964) e Duas Garotas Românticas (1967). Ele também colocou Björk para contracenar com um gato "quase humano" e escutar pessoas num bar fazendo barulhos estranhos com a boca, em Triumph of a Heart (2004). O nonsense dá o tom para Da Funk (1997), do Daft Punk, praticamente um curtametragem com diálogos e a música de fundo protagonizado por uma pessoa de muleta, que carrega um rádio e tem cara de cachorro. Em Elektrobank (1997), para os eletrônicos do Chemical Brothers, Spike Jonze utilizou o desempenho acrobático de sua futura esposa, Sofia Coppola, numa competição de solo de ginástica artística.

Filha do cineasta Francis Ford Coppola, Sofia Coppola realizou vários videoclipes até se tornar uma das melhores e mais premiadas diretoras do cinema contemporâneo, com filmes como Virgens Suicidas (1999), Encontros e Desencontros (2003), Maria Antonieta (2006) e Somewhere (2010), vencedor do Leão de Ouro, principal prêmio do Festival de Veneza. Nos videoclipes que dirigiu, ela chamou a atenção por abusar da sensualidade em I Just Don't Know What To Do With Myself (2003), do White Stripes, que mostra a modelo britânica Kate Moss em preto e branco praticando pole dance apenas de lingerie.

O irmão de Sofia Coppola, Roman Coppola também se destacou pela direção de videoclipes, em que prioriza a performance das bandas em diferentes cenários, como All I Wanna Do (1994), de Sheryl Crow, ambientado na frente de um cinema; e Peaches (1996), do The Presidents of the United States of America, que mostra a banda tocando diante de um pé de pêssego. Também merece destaque Last Nite (2001), dos Strokes, que mostra a letra da canção em diferentes tipologias, de modo semelhante a La Tour de Pise, do Michel Gondry. 
Outro filho de cineasta famoso, no caso de Ridley Scott, Jake Scott, que demonstra como é possível repetir um mesmo símbolo em vários videoclipes e, assim, criar uma identidade autoral neles. Esse é o caso das imagens mostradas no interior de um círculo, com as bordas da tela permanecendo pretas. Esse é o caso de Morning Glory (1995), do Oasis, onde a banda toca num apartamento e pessoas que vão reclamar são vistas atravessando o corredor, pelo visor da porta; On Your Own (1995), do Verve, com os músicos aparecendo no interior de um círculo esfumaçado; e Comedown (1995), do Bush.

As produções de Michel Gondry e Spike Jonze influenciaram bastante 0 trabalho de outros diretores do mesmo período, como é o caso de Garth Jennings, cujo codinome é Hammer \& Tones, e que ficou identificado por verdadeiras invencionices audiovisuais, demonstradas não apenas pela utilização de tecnologia de ponta, mas sobretudo pela criatividade e pelo inusitado em mistura de imagens reais e animação. Ele é o responsável por, entre outros, Right Here, Right Now (1999), do Fatboy Slim, que mostra numa animação a evolução da humanidade, desde trezentos e cinquenta bilhões de anos atrás; Pumping On Your Stereo (1999), do Supergrass, em que os músicos aparecem desproporcionais, com braços e pernas imensos, que mais parecem feitos de pano, assim como os instrumentos musicais mostrados; Coffee \& TV (1999), do Blur, em que o espectador rapidamente se envolve com a história de uma caixinha de leite que se perde de seu dono, que é um dos integrantes da banda; e Imitation of Life (2001), do REM, que vai se aproximando e se afastando de convidados de uma festa, parecido com o efeito de uma máquina fotográfica, só que indo e voltando.

$\mathrm{Na}$ mesma linha de trucagens, Jamie Thraves consagrou-se ao dirigir Just (1995), do Radiohead, em que a história de um homem que cai na rua é acompanhada por meio de legendas na tela, com final bem insólito; Charmless Man (1996), do Blur, que apresenta um homem correndo e tentando se livrar da banda, mas encontra-a em todos os lugares; e The Scientist (2002), do Coldplay, que mostra todas as ações do vocalista, Chris Martin, ao inverso. O que chama a atenção nesse diretor é a maneira inventiva e inesperada de como ele consegue contar uma história num videoclipe.

As imagens em preto e branco são bastante frequentes nos videoclipes. Não obstante, poucos a utilizaram com finalidade dramática tão intensa quanto 0 realizador neerlandês Anton Corbijn. Ele é o diretor de entre outros, Strangelove 
(1987), do Depeche Mode, ambientado em Paris, na França; Atmosphere (1988), do Joy Division, que mostra uma espécie de seita religiosa com o mesmo tipo de vestimenta da Ku Klux Klan norte-americana, carregando um imenso pôster do falecido vocalista da banda, lan Curtis, como se estivesse realizando seu enterro; My Friends (1995), do Red Hot Chili Peppers, mostra a banda tocando no estúdio, em meio a velas brancas; Electrical Storm (2002), do U2, com cenas de amor na praia estreladas pela atriz britânica Samantha Morton; e Heart-Shaped Box (1993), do Nirvana, com referências a morte e crucificação, de certo modo antevendo, há menos de um ano, o suicídio do vocalista Kurt Cobain.

A utilização dramática de cores supersaturadas também pode se tornar marca autoral como provou o publicitário e diretor de videoclipes norte-americano Samuel Bayer, que estabeleceu forte identidade visual com novos e populares artistas do rock e da música pop surgidos a partir dos anos 1990. Esse é o caso do Nirvana (Smells Like Teen Spirit, de 1991); Cramberries (Zombie, de 1994); e Green Day (American Idiot, de 2004, e Wake Me Up When September Ends, de 2005). O diretor também trabalhou com artistas veteranos do heavy metal, como Ozzy Osbourne, em Mama, I'm Coming Home (1991); e Iron Maiden, em Wasting Love (1992).

Dos diretores surgidos na primeira década do novo milênio, o norteamericano Marc Webb é um dos que mais recentemente chegaram ao cinema com sucesso, graças ao filme 500 Dias Com Ela, em que é possível observar a estética que desenvolveu nos videoclipes, com uma montagem fragmentada e a atenção toda especial voltada à seleção das canções que conduzem a narrativa. Trabalhando com muitas das novas revelações da música pop, o diretor ficou marcado por produções mais comerciais, nas quais a performance, as coreografias, o estrelato e a riqueza do artista são bastante valorizados. Esse é o caso de American Girls (2002), do Counting Crows; Helena (2005), do My Chemical Romance; Wake Up (2005), da Hillary Duff; London Bridge (2006), da Fergie; Call Me When You're Sober (2006), do Evanescence, que remete ao estilo teatral exagerado dos videoclipes de heavy metal; Goodnight, Goodnight (2008), do Maroon 5; (If You're Wondering If I Want You To) I Want You To (2009), do Weezer; e 21 Guns (2009), do Green Day, premiado como melhor direção em videoclipe no VMA daquele ano. 


\subsection{A Entrada da Internet}

$\mathrm{Na}$ virada do século $\mathrm{XX}$ para o $\mathrm{XXI}$, o videoclipe, assim como a grande maioria dos formatos audiovisuais e dos meios de comunicação, passou por grandes e profundas transformações, em função do surgimento das novas mídias, principalmente a internet. Se, até aquele momento, os realizadores tinham seus trabalhos destacados e reconhecidos graças à televisão, a partir desse momento, com o público, principalmente jovem, tendo acesso à internet. Com o barateamento dos artefatos tecnológicos de captação, armazenamento e edição de som e imagem, os videoclipes passaram a ser realizados não só por profissionais vindos da televisão, da publicidade e/ou do cinema, mas também pelos fãs, de modo muito mais econômico e independente das grandes gravadoras. Eles também passaram a ser vistos principalmente pela rede mundial de computadores, em sites criados para compartilhar vídeos, caso do MySpace, MTV Overdrive e YouTube, nome que pode ser traduzido como "Você Televisão".

Essa mudança tão radical fez com que muitos especialistas decretassem o "fim do videoclipe", o que não ocorreu. Ao contrário. Segundo pesquisa do Instituto Gallup, divulgada pela revista brasileira Época, de 12 de março de 2007, no primeiro ano do YouTube, em 2005, dos cem milhões de vídeos vistos por dia, cerca de 20 milhões eram videoclipes. A diferença é que, além de proporcionar que o espectador veja a produção que deseja quando quer, não dependendo mais dos programadores das emissoras de televisão, o YouTube abriu espaço para quem quiser realizar e disponibilizar um videoclipe no site.

O YouTube foi criado em fevereiro de 2005, em uma garagem de San Francisco, nos Estados Unidos, pelos jovens Chad Hurley e Steve Chen, que, incomodados por não conseguirem enviar vídeos com facilidade a amigos, tiveram a ideia daquele que é hoje o site de compartilhamento de imagens mais conhecido e acessado do mundo. Cerca de vinte meses depois, ele foi comprado por um bilhão e seiscentos e cinquenta milhões de dólares pelo Google, o site de buscas também criado numa garagem da mesma cidade norte-americana, em 1998. Em 10 de outubro de $2006^{111}$, o YouTube, todos os dias, exibia cerca de cem milhões de

\footnotetext{
111 Informação encontrada no portal brasileiro de notícias G1 http://g1.globo.com/Noticias/Tecnologia/0,,AA1306288-6174,00.html
} 
arquivos e os internautas postavam nele cerca de 65 mil novos vídeos. De acordo com a empresa Hitwise, que monitora o tráfego na internet, o site tinha $46 \%$ de participação de mercado de vídeos on-line, contra $23 \%$ do MySpace e $10 \%$ do Google Vídeo.

Diante de tanto sucesso, em 9 de abril de 2009, a Universal Music Group (UMG), líder mundial do segmento musical, lançou, em conjunto com a Google Inc., o serviço de música e vídeo Vevo, que permite aos usuários assistir os videoclipes do catálogo da gravadora. Outro objetivo é servir como espaço para anunciantes. Em junho de 2010, a Viacom, empresa que controla redes como MTV e Nickelodeon, perdeu um processo na justiça em que alegava que o YouTube descumpria leis de direito autoral ao permitir que seus vídeos fossem publicados sem autorização e, por isso, exigia indenização de um bilhão de dólares.

A questão do direito autoral na internet parece ser um problema ainda longe de solução definitiva e afeta diretamente os realizadores de videoclipes, que, até o momento, parecem mais preocupados em se adequar ao tom mais descontraído e despojado exigido pelo novo meio. Além disso, preocupam-se também em valer-se de dispositivos digitais e de plataformas de compartilhamento de vídeos para se transformar nos denominados vídeos virais, adquirindo alto poder de circulação, alcançando grande popularidade e, portanto, tornando-se um fenômeno da internet. Esse nome - vídeo viral - se deve ao fato de os vídeos se espalharem de forma tão rápida quanto um vírus, indo parar em vários sites, blogs, videoblogs, extrapolando os limites da internet, também reprodutores de mp3 com vídeo, Ipods e telefones celulares.

Isso aconteceu com o videoclipe Here It Goes Again, dirigido pela própria banda norte-americana OK Go e por Trish Sie, responsável, ainda, pela coreografia. A produção mostra os músicos dançando em esteiras típicas de academia de ginástica, estreou no YouTube em 31 de julho de 2006 e, até março de 2010, já havia sido visto mais de cinquenta milhões de vezes. Foi premiada pelo YouTube, em 2006, como o vídeo mais criativo do ano e, em 2007, com o Grammy de melhor videoclipe.

Há muita discussão em torno da veracidade do número de acessos calculados pelo YouTube, que está atualmente desenvolvendo medidas de segurança para garantir a confiabilidade das estatísticas. Em 2007, o site 
AvrilBandAids foi acusado de possuir um mecanismo que fazia com que cada vez que o videoclipe Girlfriend, dirigido por Emmett Me Brendon Malloy, fosse acessado no YouTube, de maneira automática, a cada quinze segundos, ele seria autorecarregado, contando uma nova visita. Resultado: em outubro de 2008, ele liderava o ranking do site com cento e cinco milhões de visitas. Com custo superior a um milhão de dólares, a produção mostra Avril Lavigne como duas garotas que disputam o mesmo rapaz, e, em 2010, foi ultrapassada por outro videoclipe, Party in the U.S.A., dirigido por Chris Applebaum, para Miley Cyrus, a protagonista do seriado Hannah Montana, com quase cento e dezessete milhões de acessos. Essa produção faz referência ao filme musical Grease - Nos Tempos da Brilhantina (1978), de Randal Kleiser e mostra a cantora dançando diante da bandeira dos Estados Unidos. Até 25 de outubro de 2010, o videoclipe mais acessado do YouTube era Baby, lançado em fevereiro do mesmo ano, dirigido por Ray Kay, para o cantor adolescente pop Justin Bieber, com 366.549 .549 acessos. Com a participação do rapper Ludacris, o videoclipe mostra o cantor competindo com uma garota numa pista de boliche, dançando e paquerando-a numa mesa de sinuca até que, no final, os dois começam a namorar.

Assim, mesmo com maior espaço para divulgação de produções caseiras, mais baratas e criativas, a internet é dominada principalmente pelo mesmo tipo de videoclipe que antes era realizado para televisão, com o mesmo tipo de desenvolvimento autoral. É o caso do diretor norte-americano Chris Applebaum, responsável por videoclipes em que destaca a sensualidade, a atitude agressiva e poderosa das intérpretes, como em I Love Rock'n'Roll (2002), de Britney Spears, que exibe atitude roqueira nos figurinos, na motocicleta e na destruição de uma guitarra - nada mais clichê. Ele também dirigiu as cantoras Hilary Duff, em So Yesterday (2003); Kelly Osbourne, em One Word (2005); Vanessa Hudgens, em Come Back To Me (2006); e Rihanna, em Umbrella (2007).

Os videoclipes de grandes orçamentos também permanecem sendo realizados e utilizados como importante ferramenta de marketing, agora para serem exibidos pela internet. Caso de Telephone (2010), dirigido pelo escocês Jonas Akerlund, para a cantora norte-americana Lady Gaga e que conta, em cerca de dez minutos, com a participação da também cantora Beyoncé. Recomendado para maiores de 18 anos e proibido de ser exibido na televisão, ele já teve mais de 180 milhões de acessos no YouTube e é uma espécie de continuação de Paparazzi 
(2009), também dirigido por Akerlund e que tem duração de mais de sete minutos. Telephone também tem referências à estética das histórias em quadrinhos, às coreografias de Michael Jackson e aos filmes Thelma \& Louise (1991), de Ridley Scott, e Jackie Brown (1997) e Kill Bill Volumes 1 e 2 (2003 e 2004), de Quentin Tarantino.

Misturando heranças de vários artistas pop do passado, Lady Gaga parece dar continuidade nos videoclipes ao mesmo trabalho desenvolvido durante décadas por Madonna. Ou seja, utilizar essas produções para chamar atenção por meio das mais variadas polêmicas e transmitir modos de comportamento e estilos de figurino. Em 2010, um dos videoclipes que estrelou, Bad Romance, dirigido por Francis Lawrence e em que são valorizados os aspectos bizarros da artista, ganhou o VMA de clipe do ano, melhor clipe feminino, melhor clipe pop, melhor clipe dance, melhor coreografia, melhor edição e melhor direção. Em 24 de outubro de 2010, a cantora atingiu a impressionante marca de um bilhão de visualizações no YouTube.

Não coincidentemente, antes de dirigir videoclipes para Lady Gaga, Jonas Akerlund foi premiado, em 1988, com o Grammy de melhor videoclipe e com sete prêmios no VMA, pela direção de Ray Of Light (1998), da Madonna, em que mostra cenas cotidianas em ritmo extremamente acelerado. Para a mesma cantora realizou ainda Music (2000), em que ela aparece como uma super-heroína; American Life (2003), em que aparece vestida com o uniforme da polícia norte-americana, diante da bandeira de várias nações; e Celebration (2009).

A exposição da contravenção, do chocante, do provocador e do proibido são as marcas autorais de Jonas Akerlund, o que também pode ser reconhecido em videoclipes como Smack My Bitch Up (1997), do Prodigy, que foi banido da MTV por mostrar cenas de sexo explícito e insinuar um rapaz se masturbando, cheirando cocaína, bebendo uísque, roubando, agredindo várias pessoas e tentando violentar mulheres; e My Favourite Game (1998), do Cardigans, em que a vocalista dirige a toda velocidade na contramão de uma estrada, provoca vários acidentes e se suicida no final.

A violência estúpida e inexplicável do mundo moderno é a marca autoral do francês Romain Garvas, filho do cineasta grego Constantinos Costa-Garvas e talvez o realizador de videoclipes mais associados à geração da internet. Em 2010, ele teve o videoclipe Born Free, com a cantora anglo-cingalesa M.I.A., banido pelo 
YouTube. A razão é que a produção mostrava uma divisão do exército norteamericano dando pontapés e coronhadas em moradores de um conjunto habitacional, que eram levados para um campo minado no deserto, virando alvo de diversão para os militares. Há ainda imagens chocantes de um garoto sendo executado com um disparo na cabeça e de corpos explodindo. Antes, Romain havia chamado a atenção com Stress (2008), do duo eletrônico francês Justice, mostrando a brutalidade da ação de gangue de meninos, batendo em pessoas, roubando, pichando paredes e destruindo carros.

Há de se reconhecer, porém, que a maioria dos videoclipes que circula na internet é de baixo orçamento. Afinal, desde 1999, quando foi lançado o Napster, um site eletrônico que operava sem pagar os direitos autorais das músicas, que o público consumidor da indústria fonográfica cada vez mais opta por comprar cópias ilegais de CDs, assim como "baixar" músicas e discos em sites especializados da internet, em vez de adquirir os produtos vendidos legalmente por ela. O resultado é que as principais gravadoras enfrentaram, na primeira década do século XXI, uma crise sem parâmetros e da qual não dá sinais de que conseguirá se recuperar ${ }^{112}$.

Muitos dos videoclipes consagrados na internet rapidamente ganham versões dos próprios fãs, que, descuidadas ou com eficientes recursos de edição, muitas vezes ficam tão famosas quanto às produções originais. Em 2008, o dançarino norte-americano Shane Mercado ficou conhecido por reproduzir a coreografia em preto e branco da cantora Beyoncé, junto com outras duas dançarinas, no videoclipe Single Ladies (Put a Ring On It), dirigido por Jake Nava ${ }^{113}$, eleito o melhor do ano no VMA. Ao mesmo tempo em que o "fanclipe" foi retirado do YouTube a pedido da gravadora Columbia Records, responsável pela distribuição do álbum da cantora, Mercado passou a aparecer nos programas mais populares da televisão dos

112 Em 28 de abril de 2003, foi lançada a iTunes Music Store, serviço online de música e vídeo operado pela Apple Inc., que permite ao usuário baixar a música que quiser por US\$0,99, nos Estados Unidos e no Canadá. Diferentemente do Napster, esse serviço conta com acordos firmados com as principais gravadoras, caso da Warner, EMI, Universal, Sony e BMG. Até setembro de 2006, a loja virtual já havia vendido mais de 1,5 bilhão de músicas e era responsável por mais de $80 \%$ das vendas mundiais de música oline. LUCA, Luiz Gonzaga Assis de. Cinema Digital Um Novo Cinema? Imprensa Oficial. São Paulo, SP, págs. 226 e 227.

113 O britânico Jake Nava é conhecido por reciclar clichês já estabelecidos nos videoclipes em produções como Whatever You Need (2000), da Tina Turner; Holler (2000), das Spice Girls; Stars (2002), do Cramberries; Naughty Girl (2004), da Beyoncé; Streets of Love (2005), dos Rolling Stones; B.Y.O.B. (2005), do System of a Down; Lovelight (2006), do Robbie Williams; e She Wolf / Loba (2009), da Shakira. 
Estados Unidos, caso do Oprah Winfrey Show e transformou em hit da internet o vídeo em que encontra Beyoncé nos Estados Unidos.

O vídeo viral da internet tem se mostrado uma ótima ferramenta de marketing para muitas empresas. Em abril de 2009, a marca de chicletes Trident organizou uma ação para a divulgação do show da cantora Beyoncé em Londres, na Inglaterra, que consistia em um encontro marcado pela própria internet com cem garotas para realizarem a coreografia do videoclipe Single Ladies (Put a Ring On It). A performance coletiva foi filmada e disponibilizada na internet para divulgar tanto 0 show, quanto o produto. O que não é uma novidade em videoclipes, que sempre se mostraram espaço privilegiado para a realização de merchandising de produtos voltados ao público jovem. Mas antes isso não acontecia de modo tão agressivo e eficaz, quanto ocorre agora na rede mundial de computadores. Em 2009, a publicidade de produtos em videoclipes cresceu $8 \%$ em relação a 2008 , enquanto a propaganda paga de produtos em geral caiu 2,8\%, segundo o jornal "O Estado de S. Paulo", de 10 de julho de 2010.

A tática dos "fanclipes" já atraiu o interesse de artistas consagrados, como os integrantes da banda Radiohead, que, em 2008, pediram, aos fãs, por meio do site Aniboom, para realizarem videoclipes para as faixas do álbum In Rainbows. Foi escolhida a animação em 3D, realizada pelo fã francês Clement Picon, como o videoclipe oficial da faixa Reckoner, o que demonstra que os "fanclipes" não são apenas produções baratas e feitas de maneira precária.

Em agosto de 2010, a banda canadense Arcade Fire aproveitou o lançamento do álbum The Suburbs para valer-se de nova estratégia que cada vez atrai mais adeptos na internet: o videoclipe interativo. O diretor Chris Milk e colaboradores anônimos do Google Vídeo criaram imagens para a canção We Used To Wait, que, para serem vistas e completadas, é preciso que o espectador preencha o endereço no qual passou a infância. O programa Google Street View faz montagens com imagens das ruas do local indicado, desde que estejam disponíveis, ao som da canção. No final, é oferecida ao visitante a oportunidade de enviar um cartão postal ao endereço citado. Outro exemplo de videoclipe interativo é Lux Aurumque, produzido por Scott Haines, considerado o primeiro coral virtual da história. Ele mostra o resultado da reunião de 185 vídeos de pessoas de 12 países cantando individualmente em seus respectivos ambientes a mesma canção e agora aparecem 
reunidas num palco virtual, cada uma numa tela diferente, conduzidas por quem as selecionou, o compositor e diretor de orquestra norte-americano Eric Whitacre, que solicitou que elas publicassem os vídeos no YouTube. O resultado já teve mais de 1,2 milhão de acessos no site.

Em plena sociedade globalizada atual, o diretor norte-americano Chris Milk vale-se dos videoclipes para mostrar uma saída dos claustrofóbicos grandes centros urbanos para a natureza idealizada ou relatando grandes tragédias históricas, estabelecendo assim uma marca autoral. É o que se verifica em, entre outros, The Golden Path (2003), de Chemical Brothers e Flaming Lips, em que um executivo foge do escritório para uma comunidade hippie; Mono (2004), de Courtney Love, em que a cantora interpreta uma versão moderna da Bela Adormecida; Doesn't Remind Me (2005), do Audioslave, que, em tom documental, mesmo tratando-se de uma ficção, mostra um garoto, interpretado pelo boxeador norte-americano de seis anos Vinny Intrieri, brincando, treinando e morrendo numa luta (ganhou o Grammy daquele ano como melhor videoclipe); e The Saints Are Coming (2006), de U2 e Green Day, que intercala imagens das bandas no Abbey Road Studio, na Inglaterra, e no estádio Louisiana Superdome, nos Estados Unidos, com fotografias e imagens da ação, das consequências do furacão Katrina, que devastou Nova Orleans, nos Estados Unidos, bem como do socorro prestado às vítimas, em 2005.

Segundo Saul Austerlitz, o videoclipe foi reanimado pela Era da Internet, que o deixou muito mais democrático, ao torná-lo muito mais receptivo para os garotos do que para os superstars ${ }^{114}$. Com isso, a reflexão em torno da questão autoral nesse formato audiovisual, que foi melhor absorvido e se adaptou às novas mídias, é revigorada, uma vez que qualquer pessoa, com uma câmera caseira, pode realizar o seu próprio videoclipe e até interferir na produção de outro. Ao mesmo tempo, as grandes produções permanecem imperando no YouTube e as possibilidades do espectador interferir num determinado videoclipe ainda são bastante limitadas, respeitando os interesses e os traços autorais de um único realizador. Por isso, ainda não há respostas definitivas com relação ao futuro do videoclipe e muito menos a respeito da relação da autoria que se estabelecerá no futuro.

Este capítulo do trabalho dedicou-se à análise e ao destaque de experiências realizadas com o objetivo de explorar a relação música-imagem e que, de algum 
modo, foram muito importantes para o surgimento e produção de videoclipes. Ao mesmo tempo, procurou-se destacar a importância do surgimento de uma cultura voltada aos jovens, vinculada principalmente ao rock and roll, a qual sinalizou para a indústria fonográfica que a imagem e o comportamento de um artista poderiam ser tão importantes quanto à música em si, na divulgação de uma canção e do álbum que integra.

A partir da referência à origem do videoclipe como fruto de experiências artísticas e comerciais, tornou-se importante evidenciar como a questão da autoria foi se manifestando, ao longo do tempo, nesse tipo de produção, nos principais centros mundiais da indústria musical, como Estados Unidos e Grã-Bretanha. Assim, privilegiou-se a observação do modo de trabalhar de alguns diretores que conseguiram imprimir na tela marcas autorais facilmente reconhecíveis ou foram importantes para a criação de uma imagem, com códigos específicos, para determinados artistas, com destaque para Madonna e Michael Jackson, e para estilos musicais, como hip hop e heavy metal.

Muitas vezes, a autoria pode estar não de forma exclusiva nas escolhas de determinado diretor, mas também na maneira dele se relacionar com códigos estabelecidos por alguns estilos musicais. No hip hop, por exemplo, é evidente a necessidade de se retratarem as comunidades carentes de onde são oriundos os artistas ou então valorizar o status que eles obtiveram e que serviram de exemplo para outros membros dessa mesma comunidade, como uma possibilidade de ascensão social. Daí, então, a presença das roupas de marca, sobretudo bonés e camisetas; dos carros suntuosos e dos modelos mais recentes e cobiçados; e da presença de mulheres sensuais. Já no heavy metal o que se procura, na maioria das vezes, é mostrar a performance e o sex appeal dos artistas, em geral de cabelos compridos.

Por sua vez, alguns artistas, como Madonna e Michael Jackson, são tão autores dos videoclipes que estrelam quanto os próprios diretores, inclusive escolhendo-os pessoalmente de acordo com o que pretendem transmitir em determinada produção. Nesses casos, as mudanças de estilos e comportamentos são mais do que valorizadas. Há também o interesse de utilizar o videoclipe como forma de chamar atenção do público em geral, por meio da polêmica sexual e religiosa, no caso de Madonna, ou de mostrar diferentes costumes mundiais, realizar 
majestosas coreografias e contracenar com grandes estrelas, como no caso de Michael Jackson.

Neste capítulo, também foi observado como a autoria no videoclipe pode se manifestar de diferentes maneiras na produção de alguns diretores, que se destacam pela inventividade e pela tentativa de obter uma identidade visual. Uma delas, por exemplo, é a escolha de determinada temática, caso da violência; da relação estabelecida com outras produções artísticas, principalmente cinematográficas; da escolha do tipo de imagens e da fotografia, seja ela colorida ou em preto e branco; da relação estabelecida entre música e imagem; e da valorização de efeitos e trucagens audiovisuais, que muitas vezes se valem do que há de mais moderno em termos tecnológicos.

É verdade que há vários temas recorrentes na maioria dos videoclipes citados aqui capítulo, caso dos números de dança, das cenas interplanetárias, da violência explícita e irracional e da citação ou reprodução de trechos de clássicos do cinema. Outra constatação é que muitas características aqui consideradas autorais, com o passar do tempo, são popularizadas e, de tão repetidas, tornam-se clichês e perdem a eficácia da novidade. No entanto, são justamente elas que fazem com que o videoclipe consiga se reciclar com facilidade e, desse modo, conquiste autonomia a ponto de não depender mais nem mesmo do seu natural espaço de exibição, a televisão.

Reconhecer esse processo e identificar quais os principais realizadores e artistas que mais se beneficiaram do videoclipe é muito importante para se estudar o videoclipe brasileiro, uma vez que essa produção está totalmente atrelada à influência internacional, e observar de que modo ela produção foi se desenvolvendo ao longo dos anos no Brasil. 


\section{CAPÍTULO 3}

\section{HISTÓRIA DO VIDEOCLIPE BRASILEIRO}

A história do videoclipe brasileiro e o modo de trabalhar de seus principais realizadores é muito importante para se compreender o aspecto autoral dos três diretores selecionados para essa pesquisa - Roberto Berliner, Oscar Rodrigues Alves e Maurício Eça. O principal motivo é que foi por influência direta da produção dos Estados Unidos e da Grã-Bretanha, descritos no capítulo anterior, que eles desenvolveram seu trabalho no Brasil.

Conhecendo outros realizadores brasileiros de videoclipe, será possível, nos capítulos seguintes, observar como os três diretores destacados nesta pesquisa se distinguiram dos demais. Também será dado destaque para os artistas que mais se preocuparam com a realização dos videoclipes, caso de Paralamas do Sucesso, Titãs e Skank, entre outros. Não coincidentemente, vários deles trabalharam com esses três realizadores.

Do mesmo modo como descrito no capítulo anterior, é importante analisar os principais exercícios de se relacionar música e imagem em filmes cantantes, animações, números musicais dos programas de auditório da televisão e apresentações nos festivais da música popular, que tornaram possível o surgimento do videoclipe realizado no Brasil.

A observação da consolidação de uma cultura jovem no Brasil, em moldes semelhantes ao das matrizes norte-americana e britânica, também é fundamental para se saber de que modo a indústria fonográfica valorizou o videoclipe brasileiro como importante ferramenta de marketing num país que, ao longo dos anos, se firmou como um dos principais centros mundiais de consumo e produção de música.

Para efeito de estudo, o videoclipe brasileiro foi agrupado em três momentos distintos - a fase do Fantástico, que vai de 1975 a 1980, e é marcada exclusivamente pelos videoclipes do programa de variedades da Rede Globo (uma das maiores produtoras de televisão do mundo); a fase de programas segmentados na televisão e novas produtoras, que vai de 1981 a 1989, quando o rock and roll brasileiro amadurece e surgem outros produtores de videoclipes; e a fase dominada pela MTV Brasil, que começa em 1990, quando os videoclipes são exibidos, sobretudo, em uma emissora totalmente dedicada a eles; e a terceira fase que vem 
até os dias atuais, quando eles parecem migrar para as novas mídias de comunicação, como a Internet, com o site de vídeos YouTube, com o surgimento de novos modelos de produção, como o "fanclipe" e o videoclipe interativo. É importante destacar aqui que muitos dos videoclipes citados neste capítulo não trazem o nome dos diretores.

\subsection{Antecedentes}

A presença da música em filmes praticamente coincide com o surgimento do cinema brasileiro. Em $1908^{115}$, Júlio Ferrez dirigia a comédia em curta-metragem Nhô Anastácio Chegou de Viagem, um dos primeiros exemplos do que foi denominado "filme cantante", caracterizado por colocar cantores escondidos atrás da tela, acompanhando, com a voz, as imagens dos filmes, em geral operetas de prestígio internacional. Muitas vezes, utilizavam-se canudos e funis para melhorar a performance instrumental ${ }^{116}$. Esses filmes apropriavam-se de espetáculos teatrais, como operetas e revistas musicais, e foram realizados devido ao desgaste da película e da impossibilidade de sincronizar de forma razoável, mesmo manualmente, o filme com um disco original.

Em meados de 1911, o ciclo dos cantantes estava encerrado, bastante pela penetração, cada vez maior, da produção importada, nas salas de exibição existentes no país. Devido à Primeira Guerra Mundial, começou a haver um domínio do mercado cinematográfico por parte das grandes companhias norte-americanas, que passaram a dificultar o sucesso financeiro das produções nacionais.

Em 1909, a opereta filmada A Viúva Alegre, dirigida por Eduardo Leite e Américo Colombo, representou um passo adiante em relação aos "cantantes" por ser montado com solos e duetos de três cantores na condução da trama - Ismênia Mateus e os tenores Antônio Cataldi e Angiolini, logo substituído por Santucci. No

115 O nascimento do cinema brasileiro ocorreu em 19 de junho de 1898, quando Afonso Segreto, retornando da Europa, filmou a entrada da baía de Guanabara a bordo do paquete francês Brésil. Em 1907, Paulo Benedetti foi o primeiro produtor de uma película brasileira, chamada Uma transformista original. AUGUSTO, Sérgio. Este mundo é um pandeiro: a chanchada de Getúlio a JK. São Paulo, SP. Cia. das Letras. 1989, p. 85.

116 Também houve "filmes cantantes" na Itália e nos Estados Unidos, onde um dos cantores foi o grande cômico Oliver Hardy, o Gordo, da dupla "O Gordo e o Magro". GOMES, Paulo Emílio Sales. Cinema: Trajetória no Subdesenvolvimento. Paz e Terra. São Paulo, SP. 1996, p. 31 a 34; em AUGUSTO, Sérgio. Este mundo é um pandeiro ..., p. 75 a 84; e em BERNARDET', Jean-Claude. Historiografia Clássica do Cinema Brasileiro. ..., p. 93 a 95. 
total, 180854 espectadores do Rio de Janeiro viram o filme, o equivalente a cerca de dois em cada cinco adultos que havia na cidade na época, o que representou, talvez até hoje, o primeiro recorde de público e de renda do cinema brasileiro ${ }^{117}$. Outra inovação foi introduzida pelo filme Gigolete (1924), dirigido pelo italiano imigrante Vittorio Verga, que contava com a projeção na tela da partitura para a execução da música original, composta para cada cena.

O primeiro filme sonoro brasileiro foi realizado com uma diferença muito pequena de tempo em relação ao internacional. Com os equipamentos necessários para a sonorização importados em 1929, o diretor Luís de Barros lançou o filme Acabaram-se os Otários, que contava com a participação do cantor Paraguaçu, interpretando canções como o choro Carinhoso, de Pixinguinha, cujo som era emitido a partir de um toca-discos estrategicamente posicionado atrás da tela. $O$ filme norte-americano O Cantor de Jazz foi produzido em 1927.

Mesmo com influência dos Estados Unidos, os primeiros musicais realizados no Brasil ficaram conhecidos como "filmusicais carnavalescos" ${ }^{118}$, por documentarem - carnaval brasileiro. O primeiro modelo dessa associação foi o documentário Carnaval Cantado de 1933, que, em pouco menos de uma hora, apresentava números musicais em meio a reportagens jornalísticas. ${ }^{119}$ Também foi realizada na época a comédia musical Coisas Nossas $(1931)^{120}$, dirigida por Wallace Downey, que conta com o Bando de Tangará, formado por Noel Rosa, João de Barro, Alvinho e Henrique Brito, vestidos de sertanejos, cantando Vamos Falá do Norte.

Aos poucos, os "filmusicais carnavalescos" foram substituídos pelas comédias musicais, tanto na modalidade carnavalesca, quanto na que daria origem ao que ficou conhecido como chanchada. Esse tipo de filme foi responsável por aproximar o público do cinema nacional, resgatando elementos do teatro de revista.

As chanchadas conseguiram interagir com o público de maneira mais intensa do que em qualquer outro momento da história do cinema brasileiro. Neles, assim como no teatro de revista, os números musicais facilitavam a construção do roteiro,

\footnotetext{
${ }^{117}$ SOUZA, José Inácio de Melo. Imagens do Passado São Paulo e Rio de Janeiro nos primórdios do cinema. São Paulo, SP. Editora Senac. 2004.

${ }^{118}$ Estima-se que uma centena de fitas curtas tenha documentado o carnaval do Rio de Janeiro entre 1908 e o início dos anos 1930.

119 Mais informações em AUGUSTO, Sérgio. Este mundo é um pandeiro ..., p. 77 a 80.

120 Diferente do que indica o título, Coisas Nossas tinha, entre seus números musicais, uma jovem cantarolando versão de Singin' in the Rain, da dupla Arthur Freed e Naco Herb Brown. Outra curiosidade é que Noel Rosa é que se inspirou no filme para compor seu samba e não o contrário. Ver mais em AUGUSTO, Sérgio. Este mundo é um pandeiro ..., p. 87.
} 
mesmo quebrando a continuidade da narrativa, que, segundo um dos principais diretores do gênero, Carlos Manga, pode ser dividida em quatro estágios bem distintos: 1) herói e heroína se envolvem numa confusão; 2) cômico procura ajudar o casal; 3) vilão vira o jogo; 4) desmascaramento do vilão com um final feliz. Uma das poucas variações possíveis nessa estrutura era o mocinho mostrar-se um grande malandro ${ }^{121}$.

O resultado era infalível e tanta popularidade fez com que tais produções se tornassem fundamentais para promover artistas que já faziam grande sucesso no rádio e que desejavam consagrar-se no Carnaval, época em que os filmes eram lançados.

A ligação com o rádio era grande e muitas chanchadas passaram a adotar, no título, uma saudação comumente usada nesse meio de comunicação, como, por exemplo, o "alô, alô". A primeira delas foi Alô, Alô, Brasil, de 1933, escrita e codirigida pela dupla de compositores João de Barro e Alberto Ribeiro, em parceria com Wallace Downey. O enredo girava em torno de um radiomaníaco que se apaixonava por uma cantora inexistente.

Esses filmes foram fundamentais para o aparecimento das chanchadas nos estúdios da Atlântida, no Rio de Janeiro. Com títulos como Carnaval no Fogo (1949) e Carnaval Atlântida (1952), esse novo gênero do cinema brasileiro era marcado por parodiar grandes clássicos do cinema ou da dramaturgia mundial. Podem-se considerar caricatas as características que apareciam como sendo tipicamente brasileiras nas chanchadas. É o caso das músicas, em que predominavam o samba e as marchinhas carnavalescas.

Nesse primeiro momento do audiovisual brasileiro, porém, nada se aproximou mais do que viria a ser o videoclipe do que parte da obra do cineasta mineiro Humberto Mauro, que, antes, co-dirigira A Voz do Carnaval (1933) e realizara o "filmusical carnavalesco" Favela dos Meus Amores.(1935). O destaque é a série Brasilianas (1945-1956), reunião de músicas do cancioneiro popular, recolhidas pelo maestro e compositor Heitor Villa-Lobos, além de composições dele mesmo, de Noel Rosa e de Ary Barroso. Mas foi o curta-metragem A Velha a Fiar (1964), que mais se aproximou dos videoclipes como tentativa de transformar em imagens a letra da canção, composta por Aldo Taranto e interpretada pelo Trio Irakitã, que

\footnotetext{
${ }^{121}$ MARINHO, Flávio. Oscarito O Riso e o Siso. ..., p. 208.
} 
sempre se repete com a adição de um elemento novo. A produção começa com a parte instrumental acompanhada de imagens que mostram o cotidiano de um sítio.

$\mathrm{Na}$ parte da letra, a mais famosa, há imagens da velha interpretada pelo ator Mateus Colaco fiando, da mosca, da aranha, do rato, do gato, do cachorro, do pau, do fogo, da água, do boi, do homem, da mulher e novamente da mosca. Tudo muito didático, como convinha a uma produção realizada para o Instituto Nacional do Cinema Educativo (INCE). A agilidade do número está na montagem e na inserção posterior de ruídos.

Essa relação entre música e imagem no "primeiro cinema brasileiro" impregnaria a televisão realizada no Brasil desde o início. Acompanhando as novidades tecnológicas internacionais, a primeira emissora de televisão no país Tupi Difusora - estreou no dia 18 de setembro de 1950, com o programa Show na $T_{a b a}{ }^{122}$, que misturava humor com mensagens a respeito da televisão e números musicais estrelados por personalidades das emissoras de rádio de Assis Chateaubriand, que, antes, haviam participado de curtas-metragens exibidos em cidades do interior do país, caso de Chuva de Estrelas (1949), com Lia de Aguiar, que apareceu ainda em Marina Morena (data não-localizada), ao som de canção de mesmo nome, de Dorival Caymmi, autor de Acalanto, música que encerrava a programação da TV Tupi.

No primeiro momento, os programas de televisão brasileiros eram de transmissão local, majoritariamente para São Paulo ou Rio de Janeiro. As transmissões só se tornaram nacionais com a chegada do videotape em 1960, o que permitiu que os erros ao vivo fossem corrigidos antes e que um determinado programa pudesse ser gravado num horário diferente de sua exibição, transmitido em outras localidades fora do eixo Rio-São Paulo e reprisado diversas vezes. A transmissão nacional ao vivo só se tornaria possível, porém, a partir de 1965, com as primeiras transmissões de televisão via satélite no Brasil.

Durante muitos anos, a televisão utilizou a mesma discoteca do rádio para fazer sonoplastia e soube absorver a experiência de locução muito mais cantada do que falada. Vários programas também migraram de um meio para o outro. Esse foi o caso de Calouros em Desfile ${ }^{123}$, apresentado pelo compositor e cantor Ary Barroso,

\footnotetext{
122 Show na Taba foi o programa inaugural da televisão brasileira, comandado por Lolita Rodrigues e Homero Silva, e exibido pela TV Tupi no dia 18 de setembro de 1950.

${ }^{123}$ Calouros em Desfile foi exibido pela TV Tupi nas décadas de 1950 e 1960.
} 
exibido pela TV Tupi. Logo a televisão se tornou um dos mais importantes espaços para que os cantores apresentassem números musicais nos estúdios da emissora. Antes disso, quando a programação se resumia a três horas diárias - das $20 \mathrm{~h}$ às $23 \mathrm{~h}$ - eram exibidos "videoclipes", como denomina a biógrafa da emissora Vida Alves $^{124}$, ou seja, musicais previamente filmados com o elenco da emissora de cantores, corais e conjuntos vocais ou algum visitante estrangeiro em temporada no Brasil, acompanhados pela orquestra ou conjuntos instrumentais. Alguns exemplos são os programas Georges Henry e seu Show Antarctica e Caderno Musical Pirani, que poderiam ser a encenação de operetas, trechos de óperas e comédias musicais $^{125}$.

Além dos programas de auditório, a televisão brasileira herdou do rádio pelo menos outros dois gêneros de programas não-narrativos. O primeiro foi um misto de números musicais com entrevistas, tais como Espetáculos Tonelux e Clube dos Artistas $^{126}$. O segundo foi denominado hit parade, programa com cantores dublando as músicas mais solicitadas no rádio. O diretor de televisão Daniel Filho ${ }^{127}$ lembra que foram realizados, para o hit parade, alguns filmes curtos mostrando intérpretes apresentando suas músicas, o que ele acredita terem dado origem ao videoclipe brasileiro.

Foi também na televisão, em 1955, que artistas de um estilo musical que ficou conhecido como Bossa Nova começaram a se apresentar no programa de variedades Noite de Gala $^{128}$, transmitido pela TV Rio. Geraldo Casé ${ }^{129}$, diretor do programa, recorda que o disco do cantor João Gilberto havia vendido pouquíssimas unidades até ser apresentado no programa. No dia seguinte à apresentação, o estoque do disco que estava nas lojas acabou. Comprovava-se, portanto, a capacidade da televisão em divulgar e popularizar cantores.

O sucesso dos cantores na televisão foi tão expressivo que, já na segunda metade da década de 1960, alguns deles, de grande sucesso e prestígio, foram

\footnotetext{
24 ALVES, Vida. TV Tupi Uma Linda História de Amor. São Paulo, SP. Imprensa Oficial. 2008, p. 74.

${ }^{125}$ FANUCCHI, André. In. BENETON, Rosana, FILHO, André Barbosa, e PIOVESAN, Ângelo. Rádio Sintonia do Futuro. Editora Paulinas. São Paulo, SP. 2004.

126 Espetáculos Tonelux foi exibido pela TV Tupi nas décadas de 1950 e 1960; e Clube dos Artistas esteve na grade da TV Tupi também nas mesmas décadas.

127 FILHO, Daniel. O Circo Eletrônico: Fazendo TV no Brasil. Rio de Janeiro, RJ. Jorge Zahar. 2001. p. 54.

${ }^{128}$ Noite de Gala foi exibido pela TV Rio na década de 1950.

129 CASÉ, Geraldo. In. ESQUENAZI, Rose. No Túnel do Tempo: uma memória afetiva da televisão brasileira. Porto Alegre, RS. Artes e Ofícios. 1993, p. 35.
} 
convidados para comandar seus próprios programas. Elizete Cardoso e Ciro Monteiro, por exemplo, apresentaram o Bossaudade, na TV Record. Elis Regina e Jair Rodrigues comandaram O Fino da Bossa, na mesma Record ${ }^{130}$, a respeito do qual José Ramos Tinhorão comenta:

\begin{abstract}
Foi o sucesso desse programa durante a segunda metade de 1965 que mostrou aos donos de emissoras de TV as amplas possibilidades da recriação dos velhos programas de auditório das rádios na televisão, desde que se compreendesse, afinal, que era preciso um novo produto musical e um novo tipo de apresentação de palco para atender ao gosto das modernas gerações de jovens, voltadas agora para outras expectativas, geralmente ligadas a imagens e modelos projetados pela indústria do som e do show-business internacional. ${ }^{131}$
\end{abstract}

A música foi adotada pelas telenovelas para dar clima a algumas cenas e ajudar na caracterização e rápida identificação do espectador com os personagens, além de servir como tema de abertura, que deve oferecer o clima da telenovela, dizer ao público do que se trata a trama principal, convocar interessados para o início de um novo capítulo e funcionar como alavanca de divulgação. Há também a vinheta, geralmente retirada do tema de abertura e utilizada antes e depois dos intervalos comerciais.

Por muitas vezes, tocar quase na íntegra, para embalar cenas românticas ou lembranças, a música, unida à imagem, é outra precursora do videoclipe, como afirma Nelson Motta, diretor musical de várias telenovelas, como Véu de Noiva, de 1968, cujo disco vendeu mais de 100 mil cópias em poucos dias. De acordo com ele, são montadas imagens, por exemplo, do passado do casal feliz em câmera lenta, correndo na praia e se beijando, só que sem o espírito do videoclipe. ${ }^{132}$

Nesse sentido, a música serviu como importante elo de ligação com 0 telespectador e, segundo Mauro Alencar, ajudou a levar a telenovela para o inconsciente popular e vice-versa. ${ }^{133}$ Afinal, rapidamente, a indústria fonográfica notou que poderia obter lucros do mesmo modo que fazia com o cinema: por meio da gravação das trilhas musicais em disco, cassete e, hoje, em CD. Para maior

\footnotetext{
${ }^{130}$ Bossaudade estreou na TV Record em 1965; e O Fino da Bossa estreou na mesma TV Record naquele mesmo ano.

131 TINHORÃO, José Ramos. Música popular: do gramofone ao rádio e TV. São Paulo, SP. Ática. 1981. p. 180.

${ }^{132}$ Depoimento fornecido ao autor em julho de 2003.

${ }^{133}$ ALENCAR, Mauro. A Hollywood Brasileira: panorama da telenovela no Brasil. Rio de Janeiro, RJ. Senac. 2002, p. 104.
} 
eficiência, não apenas as músicas tocam abundantes nas telenovelas, como a TV Globo veiculava vários comerciais do produto.

O primeiro disco lançado, Salathiel Coelho Apresenta Temas de Novelas, de 1965, é uma coletânea de músicas de telenovelas exibidas pela TV Tupi na época, realizada pelo sonoplasta Salathiel Coelho, que, vindo do rádio, foi um dos primeiros a associar personagens a determinadas canções, criando um vínculo que se tornaria extremamente forte entre a telenovela e a indústria do disco. O primeiro produto a conter músicas de uma única telenovela foi o compacto (disco com apenas duas faixas, uma de cada lado) de $\boldsymbol{A}$ Deusa Vencida, também de 1965. Deu tão certo, que a TV Globo criou a gravadora Som Livre, com o intuito de comercializar discos que tinham sucesso de venda garantido ${ }^{134}$.

A gravadora Som Livre foi criada em julho de 1971, com o lançamento do disco da trilha sonora da telenovela 0 Cafona, que vendeu mais de 200 mil cópias, número expressivo para a época. Em 1975, a trilha internacional da telenovela Carinhoso superou a marca das 500 mil cópias vendidas e, em 1977, essa gravadora tornou-se a de maior vendagem no país, superando, inclusive, as multinacionais líderes do mercado mundial de discos. Até hoje, a primeira trilha sonora nacional lançada na telenovela O Rei do Gado, exibida entre 1996 e 1997, é a campeã do segmento, com mais de 1,5 milhão de cópias vendidas em cerca de um mês, chegando a quase 3 milhões no total.

Se, nos primórdios ${ }^{135}$, as trilhas musicais recebiam canções compostas especialmente para as telenovelas, a partir de 1975 começaram a ganhar força, no mercado fonográfico nacional, as trilhas com seleção de músicas que provocavam impacto junto ao público, proporcionando grandes vendagens. Com isso, perdeu-se o comprometimento de ritmos, gêneros, estilos, tonalidades, timbres, arranjos, temáticas e orquestrações entre as músicas e as situações narrativas. O único objetivo era comercial: juntar num mesmo disco grandes sucessos capazes de alavancar a telenovela e vice-versa.

Cabia ao diretor musical pesquisar, adequar e determinar, com o diretor-geral da telenovela e, em alguns casos, com o autor também, quais seriam as canções utilizadas em determinada telenovela. A partir daí, o produtor musical criava

\footnotetext{
${ }^{134}$ A Som Livre costumava pagar $8 \%$ sobre o número de vendas para as gravadoras pela autorização da utilização de determinada música, sob a forma de "contrato de fonograma".

${ }^{135}$ As primeiras trilhas tinham canções escolhidas aleatoriamente pelo sonoplasta, numa época em que elas não envolviam ainda forte interesse econômico.
} 
variações de cada uma das canções, que foram classificadas em: românticas, para tragédias, suspense, etc., e que deveriam preencher as cenas ${ }^{136}$. Daniel Filho foi ator, produtor e diretor de telenovelas da TV Globo nas décadas de 1970 e 1980, e afirma que:

\begin{abstract}
A música é o apoio da imagem. Sem ela, qualquer produto sofre enorme perda. Grande parte da emoção está embutida no som e na música, que tanto contribuem para o sucesso do produto como podem estragá-lo totalmente. A escolha da música é uma especialidade; afinal, ela tem que completar o aspecto dramático da obra, mas também tem que 'tocar no rádio'. Ou seja, deve-se prever se aquela música fará sucesso e pensar como se fosse a música para um disco ou $C D{ }^{137}$
\end{abstract}

\title{
3.2 Surge o Rock Brasileiro
}

Como nos Estados Unidos e Inglaterra, foi preciso a consolidação do rock and roll e de uma cultura voltada aos jovens para que o videoclipe encontrasse um terreno propício para seu surgimento. A primeira manifestação desse tipo no Brasil foi a gravação da música Rock Around the Clock, pela cantora Nora Ney, famosa por interpretar samba-canção. No entanto, a primeira canção do gênero com letra em português Rock and Roll em Copacabana foi gravado por Cauby Peixoto, cantor muito popular naquele momento, e que, também, não tinha muitos vínculos com o público jovem.

O novo gênero musical chegou ao cinema em 1957, quando Betinho \& Seu Conjunto gravaram o primeiro rock and roll brasileiro com guitarra elétrica Enrolando o Rock -, incluído no filme Absolutamente Certo!, dirigido por Anselmo Duarte. Nesse ano, o sucesso do novo ritmo foi tão grande que o comediante Oscarito parodiou Elvis Presley na chanchada De Vento em Popa, dirigida por Carlos Manga.

$\mathrm{Na}$ televisão, alguns programas musicais também passaram a apresentar exclusivamente números musicais de rock and roll, como Hoje é Dia de Rock, da TV Rio, Os Brotos Comandam, da TV Continental ${ }^{138}$, e Crush em Hi-Fi ${ }^{139}$, da TV

\footnotetext{
${ }^{136}$ Esse é o modelo que ainda direciona as telenovelas.

${ }^{137}$ FILHO, Daniel. O Circo Eletrônico Fazendo TV no Brasil.

${ }^{138}$ Hoje é Dia de Rock, comandado por Jair de Taumaturgo, foi exibido pela TV Rio na década de 1960; e Os Brotos Comandam, apresentado por Carlos Imperial, foi exibido pela TV Continental na década de 1960.

${ }^{139}$ Crush era um famoso refrigerante de laranja e $\mathrm{Hi}$-Fi, termo que, traduzido literalmente do inglês é alta fidelidade (um som perfeito e limpo), mas que também popularizou uma bebida alcoólica que
} 
Record, comandado pelos irmãos Tony e Celly Campello, que estourou com a gravação de Estúpido Cupido, uma versão de Fred Jorge para a música Stupid Cupid, de Neil Sedaka e Howard Greenfield. Também havia o Clube do Rock, um quadro comandado por Carlos Imperial dentro do programa de Jacy Campos exibido pela TV Tupi.

Nada se compara ao sucesso do programa Jovem Guarda ${ }^{140}$, apresentado por três jovens cantores - Roberto Carlos (conhecido como "Rei da Juventude"), Erasmo Carlos (apelidado "Tremendão") e Wanderléa (chamada de "Ternurinha"). Ele estreou nas tardes de domingo de 1965 na TV Record, com músicos tocando ao vivo ou em playback diante de plateia basicamente feminina, que respondia a eles com gritos histéricos. Entre os músicos presentes no primeiro programa, estavam Rosemary, Ronnie Cord, Jet Blacks e Os Incríveis. O auditório da emissora em São Paulo ficou superlotado e estima-se que mais de três milhões de pessoas tenham assistido ao programa pela televisão apenas na capital paulista, número até então nunca registrado.

Em poucos dias, foi-se percebendo o grande potencial de marketing do programa, pois os discos dos artistas que ali se apresentaram simplesmente desapareceram das lojas. Ao mesmo tempo, os jovens adotaram gírias lançadas pelos ídolos e passaram a consumir produtos relacionados a eles. Foi lançada uma grife com a marca Jovem Guarda, com itens de vestuário, bonecos, calçados, chaveiros, bolsas, artigos escolares, etc.

As outras emissoras trataram de criar programas similares à Jovem Guarda. Na TV Bandeirantes, o cantor Ed Carlos ganhou Mini Guarda. O também cantor Márcio Greyck foi para a TV Tupi comandar O Mundo É dos Jovens. Mas nenhum deles fez mais sucesso que $O$ Mundo Encantado de Ronnie Von, apresentado pelo cantor Ronnie Von, apelidado de Príncipe, na mesma TV Record de São Paulo. Após o término da Jovem Guarda, Erasmo Carlos e Wanderléa também apresentaram na emissora, uma vez por semana, durante a noite, Ternurinha e Tremendão. Esses programas transformaram a música num dos artigos mais valorizados pela televisão da época.

misturava o refrigerante com vodka e era bastante comum nas festas dos jovens dos anos $1950 \mathrm{e}$ 1960. O programa Crush em Hi-Fi estreou em 1959, foi exibido pela TV Record até 1962 e contava na equipe de produção com nomes como Zuza Homem de Mello e Solano Ribeiro.

${ }^{140}$ O nome Jovem Guarda foi criado pelo publicitário Carlito Maia, da agência Magaldi, Maia \& Prosperi, para batizar o novo programa musical, sugerido ao então presidente da TV Record, Paulo Machado de Carvalho. 
Roberto Carlos tornou-se o maior ídolo da Jovem Guarda e figurou como astro em três filmes dirigidos por Roberto Farias, influenciados diretamente pelos filmes realizados por Richard Lester, para os Beatles. Essas produções misturavam os gêneros aventura, policial e musical, com a finalidade de agradar seu públicoalvo: os jovens.

Se os filmes estrelados pelos Beatles são considerados precursores do videoclipe mundial, pode-se afirmar que os filmes com Roberto Carlos são os precursores do videoclipe brasileiro, segundo a opinião de José Mario Ortiz Ramos, para quem o filme Roberto Carlos em Ritmo de Aventura (1967) tornou-se o mais famoso dos três dirigidos por Roberto Farias ${ }^{141}$ :

\begin{abstract}
Roberto Carlos em Ritmo de Aventura tentava driblar as dificuldades para se realizar um produto bem confeccionado, devido às deficiências da produção nacional, utilizando a ironia da paródia, caminhando nas pegadas da chanchada, gênero do início da carreira de Roberto Farias. Mas também fugia do registro popular do puro divertimento, recheando a narrativa com o recurso da descontração e pitadas de erudição cinematográfica, como a sequência em que o diretor dentro do filme aparece girando e gritando, numa referência clara a Corisco na clássica sequência de Deus e o Diabo na Terra do Sol (1964). ${ }^{142}$
\end{abstract}

Deus e o Diabo na Terra do Sol, citado no trecho acima, é considerado um marco do movimento cinematográfico brasileiro que ficou conhecido como Cinema Novo. É importante destacar outro filme desse movimento, Macunaíma (1969), dirigido por Joaquim Pedro de Andrade, que utilizou uma canção de Roberto Carlos numa de suas sequências, que se vale de uma montagem rápida e da sucessão de imagens cheias de ação, que levaram Ismail Xavier a denominá-la de "clip de apresentação da garota papo firme" (essa última uma expressão vinda da Jovem Guarda e que era a maneira carinhosa como Roberto Carlos chamava Wanderléa). ${ }^{143}$

No final da década de 1960, um dos mais importantes movimentos da música e da cultura brasileira, o Tropicalismo nasceu com diversas influências, como Jovem Guarda, Cinema Novo, modernas tendências do rock and roll e da contracultura internacional e o que a elite considerava como sendo de mau gosto. Outra

\footnotetext{
${ }^{141}$ Os outros filmes são Roberto Carlos e o Diamante Cor-de-Rosa, de 1969, e Roberto Carlos A 300 Quilômetros Por Hora, de 1971.

142 RAMOS, José Mario Ortiz. Televisão, Publicidade e Cultura de Massa. Petrópolis, RJ. Vozes. 1995, p. 230.

${ }^{143}$ XAVIER, Ismail. Alegorias do Subdesenvolvimento. São Paulo, SP. Brasiliense. 1993, p. 146.
} 
característica desse movimento era se relacionar com o psicodelismo da época, estilo de comportamento que misturava a música pop com as viagens alucinógenas provocadas pela droga LSD, que propiciaram, nos anos 60 , a realização de uma arte bastante colorida e enxuta, o que alguns historiadores consideram fundamental para o aparecimento do videoclipe.

Esses traços de psicodelismo também marcaram a participação de artistas tropicalistas como Caetano Veloso, Gilberto Gil e Gal Costa ${ }^{144}$ nos festivais de música popular, que eram exibidos pela televisão nas décadas de 1960 e 1970: Festival Nacional da Música Popular Brasileira, da TV Excelsior, Festival Internacional da Canção, da TV Globo, e Festival de Música Popular Brasileira, da TV Record ${ }^{145}$.

A respeito do ambiente dos festivais, Zuza Homem de Melo lembra que:

Os quase sonolentos programas em que um grande cantor ou cantora se apresentava durante meia hora num cenário de gosto discutível, mesmo com uma mulher admiravelmente fotogênica como Maysa ${ }^{146}$, chegavam ao fim de uma era. No novo modelo, havia um outro elemento: o público (...) A partir do I Festival da Excelsior, programa musical na televisão brasileira seria outra coisa. Uma coisa única no mundo. E ainda mais: pela primeira vez na história da televisão brasileira, quem estava em casa tinha um contato direto com o que acabava de sair do forno, a nova usina de produção da música popular, a privilegiada geração dos anos 60. Esse público tinha liberdade de avaliar de imediato a nova canção, influenciada ou não pelas platéias. Liberdade de avaliar era um direito de cada cidadão, num país em que a liberdade de pensar vinha sendo tolhida pouco a pouco havia quase um ano. ${ }^{147}$

Os festivais abrigaram a consagração do movimento tropicalista com a classificação das canções Alegria, Alegria, de Caetano Veloso, e Domingo no Parque, de Gilberto Gil, para as finais do III Festival da Música Popular Brasileira, de 1967. As duas canções, que, como as outras, foram apresentadas ao vivo no palco da emissora, traziam características marcantes do tropicalismo: mistura de ritmos tradicionais do país com o rock and roll internacional, marcado pela presença

\footnotetext{
${ }^{144}$ Também não devem ser esquecidos artistas como Tom Zé, Torquato Neto e Capinam.

145 O Festival Nacional da Música Brasileira, da TV Excelsior, foi realizado nos anos de 1965 e 1966; o Festival de Música Popular Brasileira, da TV Record, foi realizado de 1966 a 1969; e o Festival Internacional da Canção, da TV Globo, foi realizado de 1966 a 1972.

${ }^{146}$ Maysa foi uma das primeiras cantoras a aparecer e criar interpretação específica para a televisão do Rio de Janeiro. Ver mais em FILHO, Daniel. O Circo Eletrônico ..., p. 51.

147 MELLO, Zuza Homem de. A Era dos Festivais Uma parábola. São Paulo, SP. Editora 34. 2003, p. 74.
} 
da guitarra elétrica ${ }^{148}$; e letras com temática e construção cinematográfica, o que levava o ouvinte a desenvolver uma espécie de filme na cabeça enquanto a escutava, de modo semelhante ao que fazia o cantor Bob Dylan na música norteamericana. Zuza Homem de Mello descreve Domingo no Parque:

Numa descrição de cenas em cortes rápidos, como em uma seqüência cinematográfica, o estado psicológico de cada um é elaborado em flashbacks até o momento em que José, passeando no parque, avista Juliana com João. Aí, "Foi que ele viu". Há uma modulação reforçando o suspense. Como num movimento de câmera associado ao giro da rodagigante, numa sucessão brilhantemente equilibrada entre letra e música, os versos "uma rosa e um sorvete na mão (...) o espinho da rosa feriu o Zé", são arrematados por um inesperado acorde menor. O sorvete, a rosa, Juliana, a roda gigante girando na mente, "a rosa / é vermelha", o vermelho do sangue na mão de José brotando das facadas cravadas em Juliana e João. A última estrofe, lentamente evocativa, com um José lamuriante, descreve o resto dos corpos inertes na patética cena final, como a de um West Side Story (Amor Sublime Amor, em português, dirigido por Jerome Robbins e Robert Wise, em 1961) ou de uma ópera. Gil havia feito um filme numa canção. ${ }^{149}$

Gilberto Gil e Caetano Veloso também consagraram uma mistura de roupas extravagantes e irreverentes com comportamento ambiguamente sexualizado e com encenações teatrais próximas ao happening. Esse tipo de postura irritou a censura militar que, depois de dois meses, tirou do ar o programa de televisão comandado por eles na TV Tupi e chamado Divino Maravilhoso. O programa dirigido por Fernando Faro ${ }^{150}$ e que inovava a linguagem da televisão, era o ideal para o tipo de postura que desejavam os tropicalistas, mas que desagradava o governo militar,

${ }^{148}$ É curioso observar que o mesmo Gilberto Gil, responsável por chocar a plateia ao convocar uma banda de rock para sua apresentação nos festivais, havia participado, em 18 de julho de 1967, ao lado de nomes como Elis Regina, Jair Rodrigues, Edu Lobo, Geraldo Vandré, MPB-4, Juca Chaves, Ataulfo Alves e Zé Kéti, do que ficou conhecido como "Passeata contra as guitarras elétricas". Evento parecido aconteceria durante a realização do festival Hollywood Rock, em 1988, no Rio de Janeiro e em São Paulo, quando vários nomes importantes do samba se reuniram numa manifestação com discurso bastante similar ao da passeata de 1967: a defesa da música brasileira contra a invasão do rock imperialista internacional.

149 IDEM, págs. 207 e 208.

${ }^{150}$ Fernando Faro realizou o primeiro programa voltado para a Bossa Nova da televisão brasileira, Hora de Bossa, da TV Paulista, e Feira da Música Popular, da TV Tupi. Para a Excelsior, o diretor criou o programa Móbile, que marcou a estreia de Caetano Veloso na televisão e se tornou inovador ao dar espaço para a espontaneidade e a improvisação trazidas pela descontinuidade das imagens convencionais. Sem contornos definidos, sem roteiro prédeterminado e sem forma acabada, como móbile que se modifica, esse programa apresentava desde filmes experimentais canadenses até o cantor Chico Buarque. A consagração de Faro, no entanto, veio com o programa Ensaio, que começou a ser apresentado na Tupi em 1969, mudou de nome para MPB Especial, quando foi ao ar em 1972, na TV Cultura, onde voltou ao ar em 1989 com o nome original. O Ensaio ficou marcado por acabar com o formalismo dos outros 
Após a marcante presença na apresentação de Domingo no Parque no Festival de MPB, da TV Record, a banda Mutantes, formada por Rita Lee e pelos irmãos Arnaldo e Sérgio Baptista, conseguiu se destacar no meio de tantos outros grupos de rock and roll, principalmente os vindos da época da Jovem Guarda, pela postura anarquista e debochada e a grande qualidade musical, que encontrou guarida no Tropicalismo e conquistou diversos fãs pelo mundo.

Para a história do videoclipe brasileiro, talvez o mais importante grupo dos anos 70 seja Secos \& Molhados. Durante apenas dois anos (1973/74), a banda deu, de certa forma, continuidade ao Tropicalismo, misturando a androginia e o glamour do glitter rock com a latinidade brasileira, e também à tentativa de se visualizar a canção nas apresentações da televisão, valendo-se de cenários inovadores.

Lucy Dias descreve a sensação provocada pelos Secos \& Molhados em suas primeiras apresentações:

\begin{abstract}
A primeira aparição pública do grupo reuniu a estranha mistura de dois guerrilheiros e um ser completamente enlouquecido, pintado de dourado, com calça de odalisca, enormes bigodões e grinalda na cabeça. A voz de soprano, o corpo ondulante e sensual "parecia liberar emoções do inconsciente". É homem ou mulher? Fosse o que fosse, ele provocava sobressaltos na libido de todos, e a androginia de cada um saía do armário para brincar com Eros ali encarnado, contestando regras e limites claros, borrando as fronteiras de gênero do "é homem ou é mulher", sem outra possibilidade. $^{151}$
\end{abstract}

Se as vendagens dos discos do Secos \& Molhados conseguiram superar as do "rei" Roberto Carlos, anunciando a existência de mercado promissor para o rock and roll brasileiro, o vocalista Ney Matogrosso deu continuidade a essa postura andrógina, quando começou a se apresentar sozinho. Portanto, não é à toa que muitos consideram América do Sul, dirigido por Nilton Travesso e estrelado por esse cantor, para o programa de variedades da TV Globo, Fantástico, o primeiro videoclipe realizado no Brasil. Outros, no entanto, consideram que foi Gita, dirigido por Cyro Del Nero para Raul Seixas, o célebre roqueiro baiano cujas canções também eram extremamente visuais e contestatória do status quo, caso de, além da

programas e festivais que exigiam a apresentação de smoking, e graças aos grandes closes nos artistas, a iluminação de alto contraste e as perguntas feitas em off. Até os erros eram utilizados.

${ }^{151}$ DIAS, Lucy. Anos 70 Enquanto Corria a Barca. São Paulo, SP. Senac São Paulo. 2001, p. 145. 
que rendeu o videoclipe, Eu Nasci Há Dez Mil Anos Atrás, Al Capone, Sociedade Alternativa e Como Vovó Já Dizia, entre outras ${ }^{152}$.

Não se pode, porém, ignorar as reflexões feitas por Arlindo Machado ${ }^{153}$ a respeito da importância da vídeo-arte para o aparecimento do videoclipe também no Brasil. Sendo assim, pode-se considerar que o vídeo foi utilizado como campo de investigação formal e expressiva, que possibilitou a formação de novo hábito perceptivo no campo do audiovisual. Já no final da década de 1960, cerca de dois ou três anos após o lançamento comercial fora do país, os primeiros modelos de videotape chegaram ao país e foram adotados, majoritariamente, por artistas plásticos que buscavam novos suportes para a produção, que não mais a pintura de cavalete. Muitos encontraram a saída nas tecnologias geradoras de imagens industriais, como fotografia, cinema e vídeo. Entretanto, o primeiro vídeo realizado no Brasil foi $\boldsymbol{M}$ 3×3, registro realizado pela TV Cultura, em 1973, de coreografia da bailarina Analívia Cordeiro, em festival de Edimburgo, na Escócia.

Outro aspecto importante para o surgimento do videoclipe no Brasil foi o fato de que, durante a década de 1970, foram apresentados vários programas de televisão exibindo trechos de shows e também alguns promos realizados pelos artistas internacionais, o que despertou o interesse nos cantores e também nos diretores de televisão brasileiros de trilharem caminho semelhante. Enquanto um dos primeiros VJs da televisão brasileira, Big Boy, codinome de Newton Alvarenga Duarte, apresentou videoclipes importados, primeiro, no Jornal Hoje, da TV Globo, e, depois, no programa Papo Pop, da TV Record, Nelson Motta comandou, nas tardes de sábado da TV Globo, entre 1974 e 1975, o programa Sábado Som, que apresentava gravações de concertos e os promos de artistas como Pink Floyd e Black Sabbath, entre outros.

\subsection{Videoclipes do Fantástico}

Há muita discussão em torno de qual foi o primeiro videoclipe realizado no Brasil, para o programa de variedades da TV Globo, Fantástico. O cenógrafo e

\footnotetext{
${ }^{152} \mathrm{O}$ programa Fantástico é exibido aos domingos, a partir das 20h., pela TV Globo, desde 1973. Um dos primeiros musicais apresentados no programa, em 1974, foi com Secos \& Molhados, com imagens em preto e branco do show no carioca Maracanãzinho, quando Ney Matogrosso interpreta sucessos como $\boldsymbol{O}$ Vira e Rosa de Hiroshima.

${ }^{153}$ MACHADO, Arlindo. A Arte do Vídeo. São Paulo, SP. Brasiliense. 1988, págs. 171 e 172.
} 
diretor de arte Cyro Del Nero ${ }^{154}$ garantia ter sido Gita, que criou e dirigiu para Raul Seixas em 1974. Nessa produção, o cantor aparecia com vários figurinos, como um traje típico da Renascença e uma roupa cor-de-rosa parecendo flutuar diante da projeção em chroma-key de obras de artistas plásticos como o catalão surrealista Salvador Dalí, o suíço Paul Klee, o flamengo Hieronymus Bosch, o pintor e gravador espanhol Francisco de Goya e o artista gráfico francês Odilon Redon, entre outros. Cyro Del Nero comenta a importância do videoclipe Gita:

\begin{abstract}
Augusto César Vannucci ${ }^{155}$ me deu para fazer o que se chamava na época número musical do Gita, de Paulo Coelho e Raul Seixas, e os dois foram bater papo comigo. Eles tinham a ideia de colocar o Raul em cima de um cavalo para atravessar a avenida Rio Branco (no Rio de Janeiro), mas eu disse que não e fiz um storyboard. Raul era um anjo e pouco dizia. Quem falava mais era o Paulo Coelho. Raul só me pediu para ajudá-lo a enfiar a mão e tirar os óculos de dentro da roupa num determinado momento. E, para terminar, eu quis alguma coisa que o celebrasse. Por isso, coloquei uma grande rosa e várias estrelas. É engraçado, porque acho que, entre gravar e colocar no ar, apenas o Vannucci viu. E foi um grande sucesso. $O$ Boni (José Bonifácio de Oliveira Sobrinho, então superintendente de produção e programação da Rede Globo) ficou louco e disse que queria toda vez um número daqueles no Fantástico. Roberto Marinho (fundador e proprietário da TV Globo) pensou que o Boni havia comprado esse material nos Estados Unidos. Havia um clima de que tínhamos entrado numa nova era. E não foi em função da técnica, porque era só chroma-key, com o qual eu já trabalhava. O que eu acho que comoveu foi uma figura como o Raul e uma erudição ao redor, o que na televisão era raríssimo. Eu tenho até hoje um agradecimento escrito por Paulo Coelho, em que ele se refere ao sucesso comercial de Gita, muito graças ao videoclipe. ${ }^{156}$
\end{abstract}

Não há razões para não considerá-lo o primeiro videoclipe realizado para o Fantástico, uma vez que, como define Cyro del Nero, ele se diferencia dos antigos números musicais do programa, que mostravam apenas o cantor no estúdio.

Cyro Del Nero comenta a inovação trazida pelo videoclipe:

${ }^{154}$ Consagrado em 1961 como o melhor cenógrafo nacional na VI Bienal de Artes Plásticas de São Paulo, de 1961, e diretor de arte das TVs Excelsior e Tupi, Cyro Del Nero ficou na TV Globo de 1972 a 1975, quando ganhou o apelido de "Cyro chroma-key", em função das várias aberturas de telenovelas que realizou utilizando essa técnica. Esse foi o caso de Os Ossos do Barão (1973) e Fogo Sobre Terra (1974). Gita era para ter sido o primeiro musical a cores do Fantástico, mas, por atraso na edição, esse papel coube a Bom Tempo (1974), chorinho interpretado por Sônia Santos. Cyro Del Nero também criou e dirigiu os videoclipes Madalena, de Ivan Lins; Marinheiro Só, de Clementina de Jesus; e Voar é Como o Passarinho (1975), de Sá, Rodrix \& Guarabyra. Ele faleceu em 31 de julho de 2010, aos 78 anos.

${ }^{155}$ Augusto César Vannucci foi um ator, diretor, produtor de televisão e criador para a TV Globo de musicais como Globo de Ouro, Alô Brasil, Aquele Abraço, Pirlimpimpim e Plunct Plact Zuummm.

${ }^{156}$ Depoimento ao autor concedido em maio de 2009. O álbum Gita chegou a disco de ouro, com 600 mil cópias vendidas. 
Ao contrário do número musical - em cinema ou televisão -, o videoclipe não é apenas o registro da performance do artista, mas um trabalho criativo, elucidando, comentando, corroborando, ampliando e enaltecendo as qualidades do mesmo. É rico, dependendo da cultura empregada, condizente com o número musical ou como uma ampliação do seu sentido. ${ }^{157}$

Não obstante, o diretor de televisão Nilton Travesso garante que o primeiro videoclipe foi América do Sul, estrelado por Ney Matogrosso e realizado em 1975. A principal razão alegada é que, por ser ele realizado em externas, escapa do modelo dos números de palco tradicionais ou gravados em estúdios e exibidos nos primeiros musicais televisivos, utilizando efeitos especiais, como a solarização e a mudança cromática da imagem, que aparece melhor sincronizada com a música e com maior cuidado na edição.

Nilton Travesso estava insatisfeito com os programas de final de ano do cantor Roberto Carlos, dirigidos por Augusto César Vanucci, em que, enquanto a música tocava de fundo, o cantor aparecia em carros e iates, fazendo olhares distantes e usando cachimbo. Por isso, ele começou a pesquisar a melhor maneira de sincronizar áudio com imagens de um cantor em externas, sem parecer que ele dublava a canção.

Nilton Travesso ${ }^{158}$ descreve como foi dirigir América do Sul:

O que eu imaginei? Se instalar, num gravador, uma corneta e fizer a música sair por ela para o cantor ouvir, e, ao mesmo tempo, colocar o microfone de saída do VT dentro da corneta, como som-guia, eu consigo fazer com que o cantor duble e depois seja possível sincronizar som e imagem na edição. Foi o que fiz. Só que, quando apresentei a ideia para a TV Globo, enquanto alguns consideraram como sendo algo primário, Boni me deixou experimentar. Foi quando comprei um gravadorzinho e uma corneta, e tive a ideia de fazer com Ney Matogrosso. Seria filmado no helicóptero e na terra no meio de um trigal para fazer algo bem primitivo com ele usando uma roupa meio ratazana. Era praticamente um plano fechado com profundidade, mostrando um espaço selvagem, dentro da filosofia da música, e com cornetinha no ouvido dele para que pudesse ouvir e dublar. É claro que tomamos todos os cuidados para amarrá-lo com cinto de segurança, assim como o cameraman e eu, que segurava a corneta e um pequeno projetor de luz, para compensar a luminosidade dentro do helicóptero. Deu tudo certo. A única coisa que me criou problema muito sério foi que, como o gravadorzinho era de pilha, a cada 8 ou 10

${ }^{157}$ NERO, Cyro Del. Videoclipe $X$ Nilton Travesso ou A Travessura de um Sofismo Niltoniano, de 25 de maio de 2009. Esse artigo, distribuído pela internet, foi, de certo modo, motivado pela entrevista concedida a este autor.

158 Nilton Travesso foi diretor, na TV Record, de programas musicais como Show do Dia 7 e os Fesitvais da MPB; e, na TV Globo, ajudou a criar programas como TV Mulher, Som Brasil e Balão Mágico. e dirigiu o Fantástico, de 1974 a 1983, ao lado de Manoel Carlos, Maurício Sherman e José Itamar de Freitas. 
segundos, ele saía totalmente de sincronia e, em função disso, precisamos ficar exatamente 22 horas na edição, eu, Ricardo Leitão, que era o editor do Fantástico, e Roberto Talma (então diretor do programa). Esse videoclipe ganhou até prêmio nos Estados Unidos. ${ }^{159}$

América do Sul mostrava o cantor Ney Matogrosso interpretando a música de Paulo Machado durante três minutos e 38 segundos, em um matagal em Mangaratiba, no interior do Rio de Janeiro. A câmera flagra o artista de frente e de cima, dançando sobre uma pedra ou se misturando com a plantação, como uma espécie ambígua de homem-mulher, selvagem-civilizado, numa "América desabitada", como na época do Descobrimento do Brasil. Acompanhando a tecnologia da época, várias vezes a imagem mudava de tonalidade entre rosa, azul, vermelho e verde.

De acordo com Nilton Travesso, os dois trabalhos são completamente diferentes, pois, enquanto Gita foi gravado em estúdio, América do Sul foi realizado com única câmera portátil, exibindo muita mobilidade e, em determinados momentos, alguns toques de dramaturgia, com aspectos de linguagem cinematográfica. Por isso, não há dúvidas de que a produção de Travesso representou um passo adiante com relação ao trabalho realizado por Cyro Del Nero, não apenas em função do sincronismo labial, mas também pela variação de cenários e pelo trabalho de pós-produção, descolorindo e inserindo outras cores nas imagens.

Em vez de avaliar qual realizador tem ou não razão, o importante é destacar os aspectos que se sobressaem dos argumentos dos dois diretores e que são constituintes da evolução do videoclipe no Brasil. O primeiro deles é o uso como marketing de uma canção e seu artista. É inquestionável que ter um videoclipe exibido no Fantástico num domingo à noite resultava no aumento considerável das vendas do disco, no qual estava inserida a canção, já na segunda-feira e bem como na colocação dela entre os primeiros lugares de execução em rádio. $O$ segundo aspecto é a preocupação com as novidades tecnológicas e a criatividade para suprir as deficiências que essas produções apresentavam. Também há o fato de que o que particularizou o videoclipe brasileiro é ter surgido graças a profissionais que atuavam em uma emissora de televisão e que o realizavam nas ilhas de edição da própria

\footnotetext{
${ }^{159}$ Entrevista dada ao autor em 2006. Esse videoclipe também ganhou o prêmio Ondas, na Espanha, de melhor musical do ano.
} 
emissora, barateando, assim, bastante o custo da produção, utilizando videoteipe e registro em vídeo.

Além de ter dirigido um dos primeiros videoclipes brasileiros e o próprio Fantástico, Nilton Travesso pode ser considerado um dos primeiros realizadores a manifestarem uma identidade autoral, justamente na valorização das cenas em externa e do sincronismo labial. Pertence a ele a direção de, entre outros, Ovelha Negra (1975), com a cantora Rita Lee deitada numa duna; e Sandra Rosa Madalena (1978), com Sidney Magal num acampamento de ciganos. Confirmando que essas produções eram realizadas para atender às necessidades do programa de variedades da TV Globo, ainda durante a exibição deste videoclipe, escuta-se a voz de um locutor anunciando para a próxima semana a exibição de uma reportagem a respeito de como vivem os ciganos no Brasil. Apesar de ter realizado trabalhos importantes, Nilton Travesso declararia, em 2001, que o videoclipe era a "porcaria que se revelaria destruidora para a televisão"160, uma vez que, segundo ele, provocaria a redução da presença do artista musical na TV.

O Fantástico exibia, por domingo, cerca de quatro novos videoclipes, que duravam em média quatro minutos cada, dentro da proposta de misturar entretenimento com informação, seguindo o modelo aplicado com sucesso na imprensa escrita, como, por exemplo, na revista Manchete. Foi atendendo aos objetivos desse gênero, fornecendo uma cara mais gráfica e plástica, com montagem dinâmica, que esses videoclipes foram realizados. Ao mesmo tempo, para que o programa tivesse uma unidade, eles precisavam mostrar uma linguagem que se adequasse à de todas as outras atrações apresentadas e também ao que foi denominado "padrão Globo de qualidade" e que significava bom acabamento, tecnologia de ponta e visualidade agradável.

Percebendo o potencial de marketing desses videoclipes, havia interesse da Rede Globo, que os financiava e possuía os direitos autorais de cada um deles, em divulgar canções utilizadas e comercializadas por sua gravadora, Som Livre, e até em alterar a música de trabalho que merecia videoclipe e havia sido sugerida por outras gravadoras. Ao mesmo tempo, muitas agências de publicidade notaram que poderiam ter ali mais um espaço para merchandising de produtos e de locações, geralmente citadas por escrito em créditos inseridos nas imagens. A audiência da

\footnotetext{
160 JUNIOR, Gonçalo. Pais da TV. Editora Conrad. São Paulo, SP. 2001, p. ...
} 
emissora também seria atraída com os grandes sucessos do momento, inclusive internacionais, caso dos artistas pop Madonna e Michael Jackson, pelos quais a emissora exercia forte pressão nas principais gravadoras multinacionais para ter a exclusividade na primeira exibição do videoclipe no Brasil.

Em geral, os artistas e canções eram selecionados às segundas-feiras em reunião entre representantes das gravadoras e o diretor-geral do programa, José Itamar de Freitas; os roteiros eram aprovados às terças-feiras; e a produção era fechada entre quartas e quintas-feiras, gravada entre quintas e sextas-feiras, editada aos sábados para ir ao ar aos domingos. Muitas vezes, essas etapas eram atropeladas em função de o tempo ser muito mais enxuto. Para serem exibidos, todos os videoclipes precisavam ser aprovados por José Itamar de Freitas. Mesmo que isso não ocorresse, eles eram exclusivos da Rede Globo e, portanto, não poderiam ser exibidos pelas demais emissoras.

Esses videoclipes, na maioria das vezes, trabalhavam com as canções que eram temas das telenovelas exibidas pela TV Globo, com cenas das próprias produções ou estrelados por atrizes e/ou atores do elenco da emissora. Nilton Travesso recorda que existia uma integração muito grande da direção do Fantástico com João Araújo, então presidente da gravadora Som Livre, responsável pelas trilhas sonoras das telenovelas.

Gal Costa, por exemplo, estrelou o videoclipe Modinha para Gabriela, canção-tema da telenovela Gabriela (1975); Baby Consuelo, o de Menino do Rio, da trilha sonora de Água Viva (1980). Rosana foi a estrela de O Amor e o Poder, dirigido por Zé Mario, tema de Mandala (1987). Djavan caminha à beira-mar cantando Oceano, tema romântico da telenovela Top Model (1989). E, em Conquistador Barato (1987), Leo Jaime e Os Miquinhos Amestrados aparecem em meio a imagens da telenovela Bambolê, da qual a canção era tema de abertura. Outro exemplo é Pra Não Mais Voltar (1986), de Fafá de Belém, com imagens da novela Sinhá Moça, da qual era tema de abertura.

Um dos videoclipes mais interessantes na interrelação estabelecida com as telenovelas da TV Globo é Mistérios da Meia-Noite (1985), de Zé Ramalho, dirigido por Paulo Trevisan. Se na telenovela Roque Santeiro ela era tema do professor Astromar, interpretado pelo ator Rui Rezende, que se transformava em lobisomem; no videoclipe, Zé Ramalho se transforma em lobisomem e tenta seduzir a modelo 
Luiza Brunet, a qual, no final, também aparece cheia de pelos insinuando tratar-se de uma mulher-loba.

O diretor Herbert Richers Jr., filho do famoso produtor e empresário de cinema Herbert Richers, acredita ter trazido aos videoclipes do Fantástico, uma nova maneira de se trabalhar, em função da formação cinematográfica:

\begin{abstract}
O que define o videoclipe é a ida para a externa e a maneira de editar, inserindo uma narrativa dramática na música. Antes, levava-se um cantor, por exemplo, para a praia ou para o estúdio, gravava várias vezes a música inteira e chegava à ilha de edição com toneladas de material. Não sabia fazer daquele jeito e não acreditava em gravar a música toda. Precisava decupar com um roteiro. Eu falava: "Na hora em que o cantor estiver cantando esse trecho, ele estará no alto de uma praia, olhando para a montanha, porque tem a ver com a letra. Já nesse outro trecho, imagino nuvens passando". Conforme ia filmando o videoclipe, mais ou menos já sabia que resultado teria. Ao mesmo tempo, nós utilizávamos o que havia no acervo da emissora, inclusive para os cenários, e nos encantávamos com o que chegava de novidades tecnológicas, caso dos softwares novos, que queríamos experimentar. ${ }^{161}$
\end{abstract}

As novidades tecnológicas, os efeitos visuais, a dramaticidade $\mathrm{e}$ as referências cinematográficas são as marcas autorais de Herbert Richers Jr, que acredita ter dirigido, entre 1980 e 1990, cerca de 500 videoclipes. Entre eles, merecem atenção $\mathbf{O}$ Amor Vem Pra Cada Um (1983), da Zizi Possi, em que a cantora aparece envelhecida ${ }^{162}$, com o balé da TV Globo, em meio a muito gelo seco; Baby Suporte (1984), do Barão Vermelho, que mostra o mergulho do baterista Guto Goffi num olho construído artificialmente; Cartão-Postal (1984), de Olivia Hime, inspirado na estética do cineasta italiano Luchino Visconti; e a ficção científica Vírus do Amor (1985), que mostra a cantora Rita Lee e o guitarrista Roberto de Carvalho no interior de um zepelim, simulando uma aeronave, e que descem para a Terra totalmente destruída, com referências ao filme Blade RunnerO Caçador de Andróides (1982), de Ridley Scott.

Quando foi editar o videoclipe Samurai (1982), de Djavan, Herbert Richers Jr. encontrou um plano-sequência realizado pelo câmera José Mário, que registrava a canção do início ao fim. Não teve dúvidas e a transformou na própria produção,

${ }^{161}$ Entrevista concedida ao autor em setembro de 2010.

162 Esse mesmo tipo de maquiagem para envelhecer a cantora seria utilizada em Amor I Love You (2000), da Marisa Monte, dirigido por Breno Silveira e Lula Buarque, vencedor do Video Music Brasil, da MTV Brasil, como melhor videoclipe de MPB; e em Semana Que Vem (2003), da Pitty, dirigido por Maurício Eça, Sérgio Mastrocola e Pablo Nobel, no qual a cantora envelhece enquanto dirige um carro VW Fox, merchandising com função dramática. 
comprovando o imenso talento do colega de trabalho, que tem no registro caprichado de cantores em ambientes externos e nas sobreposições de imagens sua principal marca autoral. O câmera dirigiu, entre outros, Canteiros (sem data precisa), de Fagner, que valoriza a presença do artista na tela em meio à natureza e com várias imagens de arquivo justapostas; Noite do Prazer (1983), do Brylho, que mostra uma festa numa mansão, com direito a banho de piscina e fogos do réveillon estourando $^{163}$; e Portal da Cor (1985), de Milton Nascimento, que caminha e canta em meio a natureza, intercalado com closes aproximados em animais.

Advogado que entrou na TV Globo como operador de videoteipe (VT), Paulo Trevisan também editou vários videoclipes do Fantástico, antes de assumir a direção e realizar cerca de 400 produções, principalmente números de estúdio, com muitos efeitos especiais. Esse é o caso de Chuva de Prata (1984), da Gal Costa, com muito vento, gelo seco e jogo de espelhos e de sombras; Ti Ti Ti (1985), da banda Metrô ${ }^{164}$, com vários recortes na imagem; Amante Profissional (1985), do Herva Doce, clipe bem-humorado a respeito do universo dos homens malhados em academias de ginástica, em que os integrantes da banda aparecem em tamanhos reduzidos; e Eu Sou Terrível (1989), com Erasmo Carlos e Paulo Ricardo, cantando em meio à animação que lembra bonecos de papel.

Trevisan também realizou videoclipes em externa, valorizando a imagem do artista, os detalhes dos bastidores e os cartões-postais de várias cidades. Entre eles, estão Alvorada Voraz (1986), do RPM, que mostra os bastidores da excursão da banda e a apresentação num show, com detalhes da plateia; Deslizes (1987), do Fagner, com várias paisagens, incluindo as dunas da cidade litorânea Jaguaruna (SC); Ouro (1987), de Guilherme Arantes, que segue uma mulher pelas ruas de Nova lorque em meio a vários recortes de imagem e efeitos gráficos; Vou de Táxi (1988), da Angélica, que mostra a cantora com roupa de época num casarão e no

${ }^{163}$ A Noite do Prazer, agora interpretada por um dos compositores e ex-vocalista do Brylho, Cláudio Zoli, recebeu outro videoclipe dirigido, em 2001, por Maurício Eça, um dos diretores destacados nessa pesquisa. É interessante a comparação entre as duas produções, uma vez que, além da diferença de qualidade de acabamento, essa versão é muito mais sensual do que a original, ao mostrar o cantor de olhos vedados e provocado sensitivamente por várias modelos de seios a mostra e insinuando cenas de lesbianismo.

164 Ti Ti Ti foi composta por Rita Lee e Roberto de Carvalho, que a regravaram em 2010 para a abertura do remake da telenovela de mesmo nome e ganhou um videoclipe dirigido pelo próprio Roberto de Carvalho com várias referências de pop art, grafismo de revista, filmes de animação de Norman McLaren e do videoclipe Take Me Out (2004), dirigido por Jonas Odell, para a banda escocesa Franz Ferdinand. 
meio de flores ${ }^{165}$; Caminhoneiro (1984), de Roberto Carlos, incluído no especial de final de ano do cantor, que aparece como motorista de caminhão, com direito aos ruídos ambiente; e Natureza Humana (1986), da Dulce Quental, com imagens registradas na avenida Paulista, na Liberdade e no Anhangabaú, em São Paulo, com direito a muito gelo seco, iluminação estourada e luminosos da cidade.

Paulo Trevisan explica porque gostava tanto de filmar em estúdio, mas muitas vezes recorria às externas, e até misturava os dois ambientes:

\begin{abstract}
Na época, era um privilégio você ter um estúdio para gravar um videoclipe, ainda mais o Teatro Fênix (localizado no Jardim Botânico, no Rio de Janeiro, onde foram realizadas as produções da TV Globo entre 1972 e 1999), onde estavam disponíveis os recursos mais modernos de tecnologia. Então, todo mundo queria gravar ali. Como dificilmente você conseguia uma diária inteira, gravava o videoclipe em duas partes: uma ali, no horário que dava e com os efeitos; e a outra em externa. Porém, era comum o teatro vagar na última hora. Eu cansei de criar um roteiro na sexta-feira, gravar e editar no sábado, para ir ao ar no domingo. Mas, geralmente, eu, como sempre respeitei a opinião do artista, ligava para ele, marcava uma conversa para saber o que pensava a respeito da música e, em cima disso, fazia um roteiro, do qual nunca abri mão, assim como do direito de editar os videoclipes Teve um videoclipe da Blitz, por exemplo, Dali de Salvador (de 1984, que mostra a banda tocando como se estivesse dentro de um aquário com peixes, aos olhos atentos de um gato e muitos efeitos em chroma-key), que o Evandro (Mesquita, vocalista da banda) deu uma ideia tão legal que assinou a direção comigo. Ao mesmo tempo, as gravadoras nos tratavam (os diretores) como semideuses, pois um videoclipe no Fantástico determinava a vida de um disco. Afinal, já na segunda-feira, ele tinha 20 mil cópias vendidas. Então, era business disfarçado de trabalho artístico. ${ }^{166}$
\end{abstract}

A respeito da questão da estética desenvolvida pelos videoclipes do

Fantástico, Herbert Richers Jr., ao ser questionado, emitiu a seguinte posição:

\begin{abstract}
Não acredito que havia uma estética, mas, sim, uma verba fabulosa para que cada um de nós tivesse a sua própria estética. Claro que víamos o que acontecia lá fora com a MTV, que estava inventando toda uma linguagem para a música. Porém, no final, como os videoclipes começaram a ficar muito caros, uma vez que passava uma única vez e chegava a custar o que se gastava num capítulo inteiro de telenovela, ao mesmo tempo em que era óbvio o impacto positivo que eles tinham para as gravadoras, começou-se a querer que elas rachassem a conta. Ou seja, eles se tornaram inviáveis economicamente. Foi o que acabou com toda a liberdade que havia num programa que servia como laboratório de ideias e de novas imagens. ${ }^{167}$
\end{abstract}

\footnotetext{
${ }^{165}$ É interessante observar que, mesmo sendo apresentadora do Clube da Criança e do Milk Shake, ambos da TV Manchete, Angélica estrelou um videoclipe no Fantástico.

${ }^{166}$ Entrevista concedida ao autor em maio de 2010.

${ }^{167}$ Entrevista concedida ao autor em setembro de 2010.
} 


\subsection{O Cenário Pop Rock dos Anos 80}

No início da década de 1980, o Brasil vivia o início da redemocratização política e enfrentava inflação que chegava a $200 \%$ ao ano. O Brasil tornava-se o quinto mercado fonográfico do mundo, graças, principalmente, aos investimentos externos $^{168}$, o que deixou marcas profundas na Indústria Cultural do país. Foi nessa época que começaram a aparecer, nas grandes capitais, várias bandas que misturavam a influência estrangeira com o charme, a simplicidade e até certa inocência da Jovem Guarda, nacionalizando definitivamente o rock and roll. Além disso, as gravadoras encontraram nesses jovens artistas uma nova e importante fonte de renda, no momento em que a crise fonográfica atingia o país, uma vez que eles exigiam menos investimentos e geravam mais lucros do que os nomes consagrados da MPB.

Concorrendo com a produção internacional da música pop, esse novo rock and roll nacional foi incorporado pelas gravadoras e alcançou as paradas de sucesso das rádios $\mathrm{FM}$, graças a canções aceleradas, centradas no refrão, repletas de recorrências melódicas e letras extremamente visuais e, por isso, facilmente adaptáveis aos videoclipes, que eram oferecidos pelo Fantástico às gravadoras como artigo de divulgação dos artistas, em troca de subsídios. Assim, o videoclipe no Brasil surgiu menos vinculado à indústria fonográfica, diferentemente de outros países.

O bom-humor e a presença dos jovens artistas em situações inusitadas e interpretando personagens variados, é uma das marcas autorais desenvolvidas nesses videoclipes. É o que acontece, por exemplo, com a banda Blitz, que foi a primeira a vender quase 1 milhão de cópias de um compacto que incluía o sucesso Você Não Soube Me Amar, abrindo as portas para que outros jovens artistas passassem a ser bem atendidos e assediados pelas gravadoras. O videoclipe dessa música, dirigido por Eid Walesko, em $1982^{169}$, mostra a banda em estúdio, num cenário que imita um bar, vivendo situações parecidas com a da letra da canção; Mais Uma de Amor (Geme Geme) (1982), sem crédito de direção, apresenta os

\footnotetext{
${ }^{168}$ Em 1985, as gravadoras multinacionais CBS, RCA, PolyGram e EMI-Odeon, junto com a brasileira Som Livre, mandavam em mais de $90 \%$ do mercado brasileiro de discos. BRYAN, Guilherme. Quem tem um sonho não dança ..., p. 269.

169 Você Não Soube Me Amar ganhou outro videoclipe, em 35 milímetros - exceção quase absoluta na época - filmado pelo cineasta Murilo Salles, na Praça da Apoteose, no Rio de Janeiro, em 1984, durante show da Blitz.
} 
rapazes como equipe de televisão, filmando a apresentação da própria banda; e $\boldsymbol{A}$ Dois Passos do Paraíso (1984), dirigido e editado por Eid Walesko, que assina o roteiro com Evandro Mesquita, gravado na Marina Barra Club, no Rio de Janeiro, e paródia dos filmes norte-americanos de faroeste, com direito a saloon, tiroteio e muito som ambiente.

Evandro Mesquita comenta como era trabalhar com o diretor Eid Walesko:

Eu fazia roteiro, storyboard e o Walesko dirigia. A música já tocava nas rádios, mas ninguém sabia quem estava cantando. O compacto não tinha fotos. Quando as pessoas viram as caras no clipe e ligaram com o som, arrebentou geral. ${ }^{170}$

Eid Walesko conta como trabalhava no Fantástico e retribui os elogios:

\begin{abstract}
Nosso comandante era o José Itamar de Freitas, mas depois do meu primeiro ano no Fantástico, adquiri um espaço próprio, em que eu mesmo decidia o que rodar, como e onde bem entendesse como sendo o melhor. Havia, entretanto, pedidos esporádicos, do próprio Itamar, do Boni e até mesmo do saudoso Dr. Roberto Marinho. Eu sempre tentava capturar dos intérpretes das músicas o que ia à tela mental deles no momento da concepção das músicas. Esses dados, somados ao que eu entendia como sendo bacana para aquele musical, conformavam o roteiro ideal. Havia, é claro, os que mais se detinham na concepção da coisa em si e, entre eles, Evandro Mesquita, que é super, hiper, mega, ultracriativo. Sempre nos trabalhos em que me envolvo os elementos da natureza são os que de mais impressionante existem. Eu também usava recursos antes inimagináveis, como máquinas de solda elétrica, esmeril, água por sobre objetos, ar comprimido, etc., e, como sempre fui estudioso de ótica, usava, sem que a Rede Globo soubesse, lentes de câmeras fotográficas, $35 \mathrm{~mm}$, usando um adaptador que um amigo desenvolveu para mim. Isso gerava diferencial substancialmente interessante. Também diferente da maioria, eu operava a minha câmera nos musicais que fazia e usava sempre uma só, como linguagem do cinema.
\end{abstract}

Iniciando como operador de câmera na terra-natal Belo Horizonte (MG), Eid Walesko foi um dos mais produtivos diretores de videoclipes do Fantástico e até hoje é reconhecido como um dos melhores realizadores daquela geração e criador de uma estética que misturava câmera invertida com muito gelo seco, nos quase trezentos videoclipes que acredita ter dirigido entre 1980 e 1985 . Além dos videoclipes para a Blitz, ele dirigiu, entre outros, Desculpe o Auê (1983), de Rita Lee e Roberto de Carvalho, filmado em Campos do Jordão (SP) e com merchandising de automóvel, talvez o mais frequente em videoclipes; Mintchura

${ }^{170}$ RODRIGUES, Rodrigo. As Aventuras da Blitz. Ediouro. São Paulo, SP. 2009, p. 136. 
(1983), da Neuzinha Brizola, que é bem-humorado como a música e mostra a cantora no estúdio com vários figurantes, cantando no orelhão e observando imagens em preto-e-branco do interior de um carro e de uma quitinete; e $\boldsymbol{A}$ Mulher Invisível (1984), do Ritchie, que aparece com figurino futurista e os olhos pintados de preto, jogando fliperama e observando uma mulher, da qual só se veem os diferentes sapatos e a sombra num muro pichado e nos contêineres de um porto.

Jodele Larcher, outro diretor do Fantástico, comenta o trabalho de Eid Walesko:

\begin{abstract}
Eid Walesko usava algumas técnicas que a gente não dominava ainda. Ele era cameraman e começou a abrir a câmera e deixar a imagem mais brilhante e com mais contraste. Com luz boa, figurino bom e cenário legal estava ali um videoclipe. Com a descoberta dessa linguagem, ele se aproximou muito da publicidade, que é mais minuciosa. O segredo dele era ter uma fotografia primorosa, com lentes especiais, enquadramentos e a edição do falecido Ivo Alves, que inventou os inserts de quatro frames. ${ }^{171}$
\end{abstract}

Os grafismos e os efeitos especiais são fortes marcas nas produções de Jodele Larcher. Entre elas, destacam-se Meu Erro (1984), co-dirigido com Carlos Magalhães e estrelado pela atriz Cláudia Magno ${ }^{172}$ vendo os integrantes da banda como pilotos de motocross; Múmias (1985), do Bíquini Cavadão, ficção científica com muitos efeitos especiais filmada nas escadarias da Assembleia Legislativa do Rio de Janeiro, com participação da bailarina Cláudia Lecron; Que País É Este (1987), da Legião Urbana, com várias imagens de pontos turísticos e de situações cotidianas do Brasil, e muitos efeitos especiais no registro da banda tocando; Go Back (1988), dos Titãs, co-dirigido por Branco Mello ${ }^{173}$ e que mostra a banda em várias cenas cotidianas e com os filhos ${ }^{174}$; e Automóveis (Atropelamento e Fuga)

${ }^{171}$ Entrevista concedida para a realização do livro Quem tem um sonho não dança, mas cujo trecho não foi utilizado.

172 Claudia Magno também é a protagonista do videoclipe Bete Balanço (1984), do Barão Vermelho, de estética bastante moderna para a época, que começa com a voz de Cazuza em off ao telefone e termina do mesmo modo, e mostra a banda e a atriz num deserto, dentro de automóveis, em estúdio e em fotografias.

${ }^{173}$ Branco Mello é o diretor também de Massacre e Nome aos Bois, realizados para um especial da banda exibido pela TV Manchete, em 1989; Cabeça Dinossauro (1986), filmado na Chapada dos Guimarães (MT), com os integrantes sujos de lama; Vou Duvidar (2003); Porque Eu Sei Que É Amor (2009), co-dirigido com Diana Bouth, que flagra detalhes da fisionomia de várias mulheres; e $\boldsymbol{A}$ Estrada (2009), que mostra a banda em estúdio de modo intercalado com cenas do filme $\boldsymbol{A}$ Estrada da Vida (1954), de Federico Fellini, com a atriz Giulietta Masina.

${ }^{174}$ Esse mesmo recurso seria utilizado por Oscar Rodrigues Alves, em Epitáfio (2001), dos Titãs, um dos videoclipes observados com mais atenção no capítulo 5. Outra coincidência é que as duas produções mostram integrantes da banda em brinquedos de parque de diversões. A principal diferença é que Oscar Rodrigues Alves utiliza diferentes formatos de imagem e também exibe imagens de arquivo de sua própria família. 
(1989), de Skowa e a Máfia, que mistura grafismo de revistas, imagens de arquivo e o mesmo recurso dos dançarinos no fundo branco infinito.

Paralamas do Sucesso foi outra banda que sempre deu muita atenção aos videoclipes, em que aparecem em situações bem-humoradas, por encontrar neles um importante canal de comunicação com o público. Um exemplo é Melô do Marinheiro (1986), dirigido por Maurício Tavares, em que aparecem vestidos de marinheiro cantando num navio, com a participação do ator Alexandre Régis e em meio a imagens de arquivo de pontos turísticos das cidades citadas na letra; Você (1986), realizado pelo mesmo Maurício Tavares.

O mesmo interesse pelos videoclipes bem-humorados foi demonstrado pela banda de rock paulistana Titãs. Entre essas produções, estão Homem Primata (1986), com a banda no centro de São Paulo e dentro de uma jaula em meio a imagens de macacos, no filme A Guerra do Fogo (1981), de Jean-Jacques Annaud; Lugar Nenhum (1989), um dos trabalhos mais famosos da banda, que aparece em diferentes situações num cenário totalmente branco, como jogando pingue-pongue e carregando vaca, aquário e palmeiras; e Comida (1989), dirigido por Paulo Trevisan, filmado em supermercado numa brincadeira com vários gêneros alimentícios e citação das famosas sopas Campbell, imortalizadas pelo artista plástico Andy Warhol. Esse videoclipe provocou bastante discussão na época, em função da desconstrução da canção, que aparece ora tocada ao contrário, ora do modo como foi gravada. Segundo o diretor, algumas emissoras de rádio chegaram até a pedir para tocar a versão "remix" da produção.

Não é à toa, portanto, que dois dos diretores selecionados para terem a obra observada com mais profundidade nessa pesquisa trabalharam com essas duas bandas. Roberto Berliner, por exemplo, trabalhou com os Paralamas do Sucesso em Alagados (1986) e Trac Trac (1991), co-dirigido por Gringo Cardia. Oscar Rodrigues Alves, por sua vez, realizou para os Titãs, entre outros videoclipes, Epitáfio (2001) e Isso (2001). Esses quatro videoclipes serão analisados, respectivamente, nos capítulos quatro e cinco dessa pesquisa. 


\subsection{Programas Segmentados e Produtoras Alternativas}

Talvez o único programa segmentado a fazer frente ao monopólio do videoclipe exercido pelo Fantástico foi o Clip Clip, exibido nas tardes de sábado, entre 1984 e 1987, pela TV Globo, e criado e dirigido por José Bonifácio Brasil de Oliveira, o Boninho. A atração contava com produções próprias, geralmente gravadas ao vivo no estúdio da emissora e exibidos num quadro chamado "Clipe Pirata", e apresentava videoclipes das novas produtoras de vídeo, com financiamento das gravadoras.

Boninho também dirigiu mais de 150 videoclipes, em que desenvolveu como marcas autorais a presença de imagens coloridas e de efeitos óticos. Entre eles, estão Doce Mel (1986), da Xuxa, que interpreta uma boneca que ganha vida e desperta os outros brinquedos; Faz Parte do Meu Show (1988), do Cazuza, em que imagens são inseridas e retiradas, como se flutuassem sobre um fundo preto, incluindo quadro, poltronas e o próprio cantor; Maria (1990), do Dominó, com os rapazes numa estação de trem dançando e paquerando uma garota; e Política Voz (1990), do Barão Vermelho, tocando num quarto com grande variedade de cores e muitos e rápidos movimentos de câmera, em meio a imagens de arquivo de grandes desastres naturais, de lutas de boxe e de soldados em guerra.

O diretor Roberto Berliner, destacado nessa pesquisa, garante que o modo de trabalho de Boninho não era dos mais corretos:

\footnotetext{
Essa é uma acusação que eu tenho quase certeza. Boninho começou a oferecer os serviços dele para as gravadoras. Ou seja, fazia tudo com equipamento e profissionais da TV Globo, cobrava da gravadora provavelmente metade do que nós, que estávamos no mercado, cobrávamos e ainda botava no programa. Então, ao mesmo tempo em que tínhamos a maior dificuldade de entrar no Clip Clip, nossos preços eram maiores do que os dele. Enfim, ele matou a concorrência. ${ }^{175}$
}

Uma das bandas com quem Boninho mais trabalhou foi o Ultraje a Rigor, para quem realizou videoclipes marcados pelo bom-humor, do tipo comédia pastelão, confirmando a tendência das produções estreladas pela maioria das bandas de rock dos anos 80. Entre eles, estão Nós Vamos Invadir Sua Praia (1985), em que os rapazes aparecem fantasiados de recrutas do exército invadindo uma praia carioca;

\footnotetext{
${ }^{175}$ Entrevista dada ao autor em fevereiro de 2009.
} 
Rebelde Sem Causa (1986), com o vocalista Roger Moreira fantasiado de mulher, bebê e criança, e os outros integrantes de bichinhos de pelúcia e de pais; e Pelado (1987), no qual o vocalista Roger Moreira vai, aos poucos, se despindo num estúdio de fundo preto e aparece a animação de uma folha verde colocada nos mais diferentes lugares, numa clara alusão à censura da abertura da telenovela Brega \& Chique, do mesmo ano, ao som justamente dessa canção.

O vocalista do Ultraje a Rigor, Roger Moreira, avalia:

\begin{abstract}
A técnica era pouco evoluída e o videoclipe nem tinha esse nome. Nós íamos gravar um musical para o Fantástico. Então era feito em vídeo, com toda a infraestrutura da TV Globo, sem a intenção de utilizá-lo mais do que uma vez. Também não custava nada para a gente e quem decidia tudo era o Boninho. Nós não podíamos ter a ideia total, a não ser que combinasse com a dele. Uma exceção foi Eu Gosto de Mulher (1987, que começa com vários homens nas ruas de São Paulo falando sobre mulher), que nós fomos fazer um show na Avenida Paulista (em cima da marquise do shoppping Top Center) e perguntamos se ele não queria gravar. Nós nos divertíamos muito fazendo. ${ }^{176}$
\end{abstract}

O cantor Leo Jaime também foi dirigido por Boninho em videoclipes bemhumorados, como $\boldsymbol{O}$ Pobre (1985), no qual pilota um iate e participa de um banquete com os integrantes do João Penca \& Seus Miquinhos Amestrados fantasiados de mendigos; e Nada Mudou (1986), em que canta, caminha e distribui presentes, vestido de Papai Noel, pelas ruas do Rio de Janeiro, e atua como goleiro num Maracanã vazio. Ele tem opinião diferente da manifestada por Roger Moreira:

\begin{abstract}
O Fantástico sempre foi um programa de muito lbope, mas acredito que, nos anos 1980, atingiu o seu auge. Então, o videoclipe do programa era o espaço mais nobre para se lançar uma música nova, uma vez que a repercussão era muito grande. Geralmente, fazia com o Boninho e na maior camaradagem, porque nos divertíamos fazendo. A gente se reunia e decidia o que ia fazer. Era a maior liberdade. ${ }^{177}$
\end{abstract}

Foi nessa época que a linguagem dos videoclipes começou a migrar com mais intensidade para o cinema nacional voltado para o público jovem. Leo Jaime estrelou vários desses filmes, caso de As Sete Vampiras (1986), de Ivan Cardoso, e Rock Estrela (1986), de Lael Rodrigues. Esse diretor já havia realizado, em 1984, Bete Balanço, e faria, em 1987, Rádio Pirata. Outros exemplos são Tropclip (1985), de Luiz Fernando Goulart; e Areias Escaldantes (1985), de Francisco de

\footnotetext{
${ }^{176}$ Entrevista concedida ao autor em outubro de 2009.

${ }^{177}$ Entrevista concedida ao autor em novembro de 2009.
} 
Paula, que lançou várias músicas dos Titãs. José Emílio Rondeau lamentaria ao comentar justamente Rock Estrela: "(...) dá saudades da MTV, cujos videoclipes são melhores em criação e edição do que $90 \%$ desses clipes cinematográficos" ${ }^{\text {"178 }}$.

Além de jornalista, José Emílio Rondeau foi um dos poucos diretores a realizar videoclipes para o Fantástico e numa produtora alternativa à TV Globo, em que prevalece o objetivo de mostrar a banda tocando com vários efeitos na utilização das cores, seja na iluminação das cenas, seja nos efeitos de pósprodução, numa tentativa de soar moderno na televisão. Ele dirigiu, entre outros, Cena de Cinema (1982), do Lobão, com edição de Ivo Alves, em que o cantor aparece em meio a muita fumaça num drive-in e numa estação do metrô carioca; Seu Espião (1984), do Kid Abelha, com a banda tocando em cenário com iluminação de várias cores e a vocalista Paula Toller sendo cortejada no camarim pelos outros integrantes da banda; Pro Dia Nascer Feliz (1984), do Barão Vermelho, cujos integrantes aparecem envolvidos em brigas de gangues com correntes e socos-ingleses, e que conta com a presença da futura jornalista Fátima Bernardes entre as bailarinas; e Carne e Osso (1987), do Picassos Falsos, com a banda tocando em cenário de fundo branco, com a imagem azulada e o rosto do vocalista em meio a chiados.

José Emilio Rondeau destaca o videoclipe preferido que realizou:

O que eu considero o meu melhor videoclipe, na verdade, foi um castigo dado a mim e ao Ivo Alves por termos cometido algum erro em clipes anteriores. Tivemos que fazer juntos um videoclipe. Então eu fiquei quieto durante a criação e filmagem, e Ivo, durante a edição. Ele era o melhor editor que existia. O resultado foi Como Eu Quero (1984), do Kid Abelha (ele mostra a vocalista Paula Toller ao lado da piscina do Parque Lage, no Rio de Janeiro, desenhando e vendo os outros integrantes da banda pelo monitor de um computador, e utiliza vários efeitos de descolorização das imagens). ${ }^{179}$

O trabalho de José Emilio Rondeau marca um período de transição nos videoclipes do Fantástico, que passam a ser realizados também por profissionais com produtoras próprias, sem vínculo empregatício com a TV Globo. Tempo Perdido (1986), por exemplo, ele dirigiu pela produtora Orion, com roteiro da esposa e jornalista Ana Maria Bahiana, para a banda Legião Urbana e para ser exibido inicialmente no programa dominical. $\mathrm{O}$ trabalho, um dos mais bonitos desse período,

\footnotetext{
${ }^{178}$ RONDEAU, José Emílio. In. BRYAN, Guilherme. Quem tem um sonho não dança ..., p. 297.

${ }^{179}$ Entrevista concedida ao autor em 2006.
} 
apresenta, em preto e branco, a banda tocando num cenário em que há apenas televisores que mostram astros do rock, pertencentes ao universo da banda, como Janis Joplin, Jimi Hendrix, John Lennon, Van Morrison e Brian Wilson, em "fotos antiquíssimas, no 'tempo perdido' de quando eles tinham 18, 19 anos apenas, antes que eles mesmos se dessem conta de quem eram", como descreve Ana Maria Bahiana $^{180}$. No final do videoclipe, uma faxineira varre jornais caídos no chão do estúdio.

José Emilio Rondeau relembra essa fase:

Nas produtoras, a gravadora era quem financiava $100 \%$ dos videoclipes, que iam para todos os programas que não eram da TV Globo. Havia a chance de tentar jogar no Fantástico, com a condição de ser exclusivo dele durante algum tempo e só depois passar em qualquer outro lugar. Mas até ali o programa ainda era muito autossuficiente. ${ }^{181}$

Portanto, esses trabalhos eram financiados pelas gravadoras musicais, as quais começaram a desenvolver departamentos específicos para sua realização, estimuladas pela TV Globo, que detinha $80 \%$ dos videoclipes brasileiros. Desde 1981, a gravadora multinacional CBS, por exemplo, priorizava-os como importantes peças promocionais.

Responsável por esse departamento na CBS, Ricardo Silveira analisa:

Antes, você (gravadora) fornecia o artista e o Fantástico produzia (o videoclipe). Mais lá na frente, a TV Globo percebeu que estava gastando uma grana que a indústria fonográfica poderia gastar. Bastava que ela aceitasse que uma produção independente, de preços mais acessíveis, pudesse passear pela programação do Fantástico e aí é que foi abrindo esse leque todo (para novos diretores). Mas, se o Fantástico não abrisse mão de fazer o videoclipe, o rumo poderia ter mudado um pouquinho. ${ }^{182}$

Jodele Larcher tem opinião diferente:

As gravadoras sabiam que os clipes não passariam no Fantástico, então faziam algo com boa qualidade para colocar nos estados todos. Aí fez-se um poder paralelo ao Fantástico, que tinha importância muito grande no mercado, determinando vendagens. ${ }^{183}$

\footnotetext{
${ }^{180}$ BRYAN, Guilherme. Quem Tem Um Sonho Não Dança. Rio de Janeiro, RJ. Editora Record. 2004, p. 326.

${ }^{181}$ Entrevista dada ao autor em 2006.

${ }^{182}$ Entrevista dada ao livro Quem tem um sonho não dança, em meados de 2000.

183 IDEM.
} 
Enquanto os videoclipes do Fantástico apresentavam o "padrão Globo de qualidade" e buscavam se adequar à linguagem internacional, próxima de comerciais, os videoclipes realizados fora da TV Globo adequavam-se mais facilmente ao que pretendia o artista com o qual se trabalhava. Ao mesmo tempo, os limitados investimentos das gravadoras davam certo caráter amador a esses videoclipes mais abertos a experimentações, como destaca o então diretor Eduardo Leite, da produtora Spectrum, ao comentar uma de suas produções: "Em um clip do RPM, Louras Geladas (1985), fizemos coisas dignas de um clip internacional, como acrescentar à música palavras e ruídos que não estavam na gravação original"184. Esse é o caso também das palmas inseridas nessa produção.

Renato Assaf Filho, sócio da produtora Spectrum e que co-dirigiu com Eduardo Leite Insensível (1985), dos Titãs, e Ciúme (1985), do Ultraje a Rigor, opinava a respeito do trabalho realizado fora da TV Globo:

Além do arrocho orçamentário que as gravadoras impõem ao clip, com
suas verbas irreais, enfrentamos uma concorrente imbatível, chamada TV
Globo - que produz clips a um custo bem menor, utilizando para isso sua
estrutura estável, baseada em salários previstos - ao contrário das
produtoras, que funcionam na base de cachês de acordo com a
produção. ${ }^{185}$

A produtora da videomaker Ana Arantes também se destacou nessa época, por misturar diferentes cromaticidades de imagens das mais diversas origens e formatos. Ela é a diretora de, entre outros, Contravenção (1987), do Barão Vermelho, com os garotos dentro de um carro conversível pichando paredes e jogando pedras em janelas, numa mistura de imagens coloridas e em preto e branco, e, no final, com o cenário destruído, aparecendo em ambiente externo no Rio de Janeiro; e Ideologia (1988), do Cazuza, que mostra diferentes símbolos e ídolos como Sigmund Freud, Marilyn Monroe, Jimi Hendrix, Janis Joplin, Bob Marley e Albert Einstein, cenas de programas de televisão e o cantor na contracapa do disco mudando de cor e pilotando um iate; e Burguesia (1989), também de Cazuza, que começa com uma televisão fora do ar e, a partir daí, mostra fotografias e imagens do artista no dia a dia, de pessoas miseráveis na rua, da representação de

\footnotetext{
${ }^{184}$ LEITE, Eduardo. In. MARTINHO, Maria Esther; e PORTO, Gisele. O mundo mágico do videoclip. Video News. № 56, ano 4. São Paulo, SP. Sigla. 1987, p. 77.

${ }_{185}$ Porto, Gisele; e MARTINHO, Maria Esther. O Mundo Mágico do Videoclipe. Vídeo News. São Paulo, SP. ํㅜㄷ. 1987.
} 
uma família burguesa na mesa do jantar e de crianças pedintes num carro com taças de champagne.

Esses videoclipes, na maioria, eram exibidos em programas de televisão dedicados exclusivamente a eles, que assim tinham tratamento mais original e livre, não precisando obedecer à estética de outras atrações. Entre os programas, estava Vídeo Disco, exibido aos sábados pela TV Gazeta; Videorama, apresentado na TV Record; e Clip Trip, exibido na TV Gazeta de 1982 a 1993, com apresentação, primeiro, de Mister Sam e o boneco Capivara, e, depois, de Beto Rivera. No Rio de Janeiro, havia também o Realce, exibido pela TV Record, que misturava videoclipes e esportes como surf, e era comandado por Antônio Ricardo, Ricardo Bocão e Patrícia Barros. Serginho Caffé comandou três programas: Sucessos do Rádio, de segunda a sexta, às 15 horas, na Bandeirantes; Super Especial, que ia ao ar também na TV Bandeirantes, de segunda a sexta na hora do almoço, de 1982 a 1987; e Kliptonita, de 1991 a 1993, na TV Record.

Outros programas bastante famosos foram os comandados pelo músico argentino, radicado no Brasil, e ex-integrante da banda Joelho de Porco, Billy Bond, na TV Record carioca, entre 1983 e 1986, que receberam nomes Videoclipe, Videoroll, Vibração, Metalmania e Rock'n Concert, todos contando com o acervo da produtora dele, BB Vídeo. Entre os cerca de 300 videoclipes que acredita ter dirigido e que são marcados pelo amadorismo e pela vontade de experimentar novas técnicas, estão, entre outros, Fullgás (1984), de Marina Lima, que aparece como se estivesse num ensaio fotográfico, com imagens distorcidas, iluminação estourada e muito gelo seco; e dois para o Biquini Cavadão, No Mundo da Lua (1985), filmado nos estúdios da gravadora Polygram, no Rio de Janeiro; e Tédio (1985), rodado na porta dos estúdios da emissora, com a banda tocando e vários recortes nas imagens.

Billy Bond analisa a importância desse trabalho:

Com a chegada da U-matic, um sistema de vídeo e câmeras mais leves, portáteis com baterias e VT portátil, o truque foi sair do estúdio e fazer na rua com a câmera na mão, como dizia Glauber Rocha. Nós conseguíamos fazer vídeos a baixo custo e em boa qualidade ou razoável qualidade artística. Eu dirigia na época um show mensal na TV Record, chamado Show do Dia Sete. Como não tínhamos verba para levar os artistas até os estúdios em São Paulo, uma vez que os mais famosos artistas moravam no Rio, nós levávamos os 'estúdios' à casa dos artistas e filmávamos take a take, como se fosse um filme, e logo depois editávamos. Chamamos a 
atenção das gravadoras, que começaram a investir em videoclipes nacionais dos seus artistas para incluir na nossa programação. Bingo!!! Mas as gravadoras não dificilmente se intrometiam no script. ${ }^{186}$

O programa Som Pop, exibido entre 1981 e 1983 na TV Cultura, também contou com produções próprias. Uma delas foi dedicada à banda Magazine, pertencente ao segundo apresentador do programa, Kid Vinil, Sou Boy (1983), que começa com imagens do centro de São Paulo e mostra um ator vivenciando as situações da letra da canção e o próprio Kid Vinil cantando e dançando nos estúdios da emissora, em meio a muito gelo seco. Na época, o apresentador do programa era o ator Gerson de Abreu. Essa atração começou, na verdade, em 1973, com o nome TV2 Pop Show, numa época em que exibia praticamente trechos de shows internacionais.

Em 1985, em São Paulo, as emissoras apresentavam uma média de 24 horas semanais de programas dedicados exclusivamente aos videoclipes, tempo dominado majoritariamente pelas produções estrangeiras. Segundo Ana Maria Bahiana $^{187}$, uma das razões para o domínio dos videoclipes internacionais era a falta de produção nacional com um mínimo de qualidade, ou seja, sem domínio de fotografia e edição, resultante da busca pelo material mais barato. $\mathrm{Na}$ opinião da autora, essa situação colocava o Brasil na "pré-história" do videoclipe. No entanto, mesmo girando em torno muitas vezes dos mesmos temas, recursos tecnológicos e efeitos, várias dessas produções já chamavam atenção pela criatividade.

O primeiro programa a exibir videoclipes nacionais competindo com 0 Fantástico foi Mocidade Independente, comandado por Nelson Motta, em 1981. Como faziam parte da equipe técnica do programa, os sócios da produtora paulistana TVDO resolveram realizar videoclipes para bandas novatas do rock and roll brasileiro, como Gang 90 \& As Absurdettes, e exibi-los ali.

Tadeu Jungle, sócio da TVDO na época e futuramente apresentador do programa de auditório A Fábrica do Som, na TV Cultura, lembra que houve choque entre os antigos profissionais da televisão e os jovens videomakers que chegavam ao mercado:

\footnotetext{
${ }^{186}$ Entrevista concedida ao autor em 10 de outubro de 2010.

187 BAHIANA, Ana Maria. In. PEREIRA, Carmem. O Clip Brasileiro Não Presta. Por Quê? Bizz. Ano II. №8. São Paulo, SP. Abril. 03/1986, págs. 57 e 59.
} 
Tentávamos fazer com que algumas apresentações musicais se transformassem em videoclipes, mas isso requeria número muito grande de horas de edição e manipulação de equipamentos. A emissora não entendia o porquê disso. Ela estava acostumada a gravar uma banda com três ou quatro câmeras e colocar aquilo no ar. Quando demoramos oito horas para editar o (vídeo do cantor) Arrigo Barnabé, os caras quase tiveram um chilique e nos qualificaram como incompetentes por "não sabermos editar rápido". Mas fizemos e foi para o ar. ${ }^{188}$

Nessa mesma época, Tadeu Jungle criou, com os companheiros de TVDO, a produtora Videoverso, responsável pelo surpreendente videoclipe Eletricidade (1984), de Kodiak Bachine, dirigido por Alfred Nagib e Jayme Rocco Júnior, e filmado numa usina elétrica e na casa noturna paulistana Carbono 14. A produção de 12 minutos mostra, em clima futurista, o artista como se fosse um robô, em meio a computadores, reproduzindo as imagens que costumavam ser projetadas por estes e em videogames, e que eram consideradas modernas para a época, bem ao estilo da canção eletrônica que the serviu de base. Essa produção pode ser considerada uma tentativa de se criarem imagens que reproduzissem na tela 0 andamento musical. Ela foi um dos destaques do primeiro festival Videobrasil, realizado no Museu da Imagem e do Som, em São Paulo, naquele ano, e que se tornou o principal evento dedicado ao vídeo no Brasil.

Já na fase da MTV Brasil, Tadeu Jungle manteve a valorização dos ruídos e a delicadeza da fotografia em preto e branco, já manifestadas em Mocidade Independente, em videoclipes como O Silêncio (1996), com muitos efeitos de pósprodução, com imagens de várias granulações e cores, sobrepostas ao cantor, sem necessariamente remeter as situações da letra da canção; e Proibida Pra Mim (2000), do Zeca Baleiro, com imagens delicadas de várias mulheres tristes, em preto e branco.

Outra videomaker de destaque naquele período é Malu di Martino. Após estudar cinema e vídeo, entre 1983 e 1984, nos Estados Unidos, ela retornou ao Brasil e começou a realizar vários trabalhos documentais para a televisão, em que as artes plásticas eram foco de atenção. Não à toa, ela dirigiu vídeos a respeito da denominada Geração 80, de artistas como Leda Catunda, Leonilson e Luis Zerbini, e também sobre Flávio de Carvalho, Di Cavalcanti e Tomie Ohtake. Entre os videoclipes que realizou estão Timidez (1985), do Biquini Cavadão, com a banda

\footnotetext{
${ }^{188}$ Entrevista dada ao autor em 06 de junho de 2006.
} 
tocando e cantando em cenário com fundo branco; e Benção Bossa Nova (1989), de Leila Pinheiro e Roberto Menescal.

Para Arlindo Machado, esses novos videomakers vinham com uma proposta completamente diferente daquela apresentada pelos videoartistas das décadas de 1960 e 1970:

No começo dos anos 1980, uma nova vaga de realizadores vai reorientar a trajetória do vídeo brasileiro. Trata-se da geração do vídeo independente, constituída em geral de jovens recém-saídos das universidades, que buscavam explorar as possibilidades da televisão como um sistema expressivo, e transformar a imagem eletrônica num fato da cultura de nosso tempo. O horizonte dessa geração é agora a televisão e não mais o circuito sofisticado dos museus e galerias de arte. Muito sintomaticamente, essa outra vaga se opõe à videoarte dos pioneiros pela tendência ao documentário e à temática social. Com sua entrada barulhenta em cena, $o$ vídeo começa a sair do gueto especializado e conquista seu primeiro público. $^{189}$

Mesmo com interesse em trabalhar para as emissoras comerciais de televisão, essa geração não encontrou, num primeiro momento, abrigo nelas e acabou tendo como saída a publicidade, a produção de vídeos institucionais e de treinamento para empresas, e os videoclipes. Esse foi o caso de outra produtora importante da época, a também paulistana Olhar Eletrônico, que co-produziu videoclipes com o Fantástico, como Será (1985), da Legião Urbana, gravado na danceteria paulistana Rose Bom Bom e que mostra a imagem de um prédio desabando e os rapazes da banda caminhando pelas ruas. A produtora foi responsável ainda pelo programa Crig-Rá, exibido nas tardes de sábado pela TV Gazeta, entre 1984 e 1987, em que misturava música, jornalismo e humor.

Um dos integrantes da produtora era o hoje cineasta consagrado Fernando Meirelles, que comenta o tipo de trabalho que realizavam:

Nunca entramos de fato (no Fantástico), porque, enquanto esses diretores da TV Globo se achavam "reis da cocada", nós os achávamos muito cafonas, principalmente o Eid Walesko. Até hoje se brinca, quando vai fazer a câmera um pouquinho torta: "Faz um Eid Walesko". Além da câmera torta, contraluz e fumaça eram os truques (dele). Então, fazíamos coisas para o Fantástico porque estávamos do lado de fora e, o que é legal, propunhamos com quem (cantores e bandas) queríamos fazer. Era outra turma mesmo. Com Roberto (Berliner), nos identificávamos mais porque é um cara que faz documentários. ${ }^{190}$

${ }^{189}$ MACHADO, Arlindo (org.). Made In Brasil Três décadas do vídeo brasileiro. São Paulo, SP. lluminuras. 2007, p. 18.

${ }^{190}$ Entrevista dada para o livro Quem tem um sonho não dança, em 1999. 
Até então trabalhando no Centro de Documentação da TV Globo, Roberto Berliner começou a dirigir videoclipes em 1985, sendo o primeiro Délica, da Dulce Quental, que mostra a cantora em estúdio em meio a várias imagens de arquivo, e foi exibido pelo Fantástico, que também lançou boa parte dos outros que ele realizou até o final da década. Caso de Drops de Istambul (1986) e Kátia Flávia ${ }^{191}$ (1987), ambos para Fausto Fawcett, sendo que o segundo foi co-dirigido por Sandra Kogut, sua sócia na produtora Antevê, e que mostra várias garotas com o cantor pelas ruas de Copacabana, no Rio de Janeiro, durante a noite. Para os Paralamas do Sucesso, ele realizou Alagados (1986), em que mostra os rapazes tocando em meio a crianças carentes, caminhando por um morro carioca e indo a um baile funk; e A Novidade (1986), que conta com uma abertura fantástica com a atriz Carina Cooper e os rapazes calculando quantas vezes eles fariam, com os discos que já tinham vendido, a travessia na barca Rio-Niterói, onde se passa a produção, com ares de documentário e a participação de anônimos. Este último também foi assinado por Sandra Kogut, que realizou, na mesma época, Manuel (1988), para Ed Motta e Conexão Japeri. Os videoclipes Délica, Alagados e Kátia Flávia serão analisados com mais atenção no próximo capítulo.

Pelo fato de ter sido funcionário da TV Globo, Roberto Berliner se distingue dos demais diretores de videoclipes justamente por ter marcado a transição entre as duas primeiras fases da história dessa produção no Brasil: a do Fantástico e a das produtoras segmentadas, que trabalhavam com financiamento das gravadoras. Essa é uma das razões por que ele foi escolhido como um dos três diretores a ter o trabalho autoral observado com mais profundidade nesta pesquisa.

Também diretor durante três meses do programa FM-TV, exibido pela Rede Manchete, de segunda a sábado, a partir das 19 horas, Roberto Berliner lembra como era a negociação com o Fantástico:

O primeiro clipe que eu e Sandra fizemos juntos foi A Novidade. Um clipe super divertido, porque passamos o dia nas barcas. Na época, eu falei: "Vamos ao Fantástico. Quem é o responsável por isso?". "Oi (Roberto)

${ }^{191}$ Quando Fernanda Abreu regravou Kátia Flávia, a Godiva do Irajá, em 1997, ganhou um videoclipe bem mais estilizado, dirigido por Luiz Stein, com ela fantasiada de "mulher diaba" e interpretando a "louraça beusebu", com cabelo louro e cor de rosa, pilotando um carro a toda velocidade, tendo ao lado Fausto Fawcett, como o "figurão da contravenção", e rapazes fantasiados de lobo. 
Talma, tudo bem? A gente fez um videoclipe e quer te mostrar". Aí ele, mexicanão, fortão: "Mostra aí". Botamos a fita. "O que vocês querem?". "Botar no Fantástico". "Se mudar umas três ou quatro coisas, de repente a gente coloca". "O que você quer que mude?". "Esse cara batendo com o pé na porta". "Vamos ver de novo?". "Está bom desse jeito". Deixou exatamente como estava (...) A partir daí, o Talma começou a nos chamar. Só que tínhamos um poder incrível. Usávamos o equipamento da TV Globo para gravar e as ilhas para editar, e ganhávamos um cachê. E a gravadora ficou super feliz, porque nos pagou e fomos ao Fantástico. ${ }^{192}$

Com relação a precisar seguir ou não os tais "padrões de qualidade" exigidos pela TV Globo, Roberto Berliner ${ }^{193}$ recorda que tinha dificuldades em trabalhar com profissionais da emissora que não estavam familiarizados com a linguagem do videoclipe. Como trabalhava com "defeitos" na imagem, com câmera com muito movimento e com uma edição super picotada, ele começou a ser acusado de querer fazer videoclipe "para ganhar prêmio" e, por isso, despreocupado com a audiência, como conta:

\begin{abstract}
Por mais que tivéssemos referências, de cinema especificamente, pretendíamos era quebrar com a linguagem e com as regras. Tínhamos claras as ideias dos ruídos e de imagens muito pequenas. Quando eu trabalhava na Globo, tinha uma cartilha, onde estava escrito que não podia ter takes com menos de um segundo. Então: "Vou fazer com menos". O pessoal de lá falava: "Vocês só querem fazer clipe para ganhar prêmio e para se relacionar com o público". "Queremos fazer para nos relacionar com o público mesmo". "Mas fazem coisas esquisitas". Continuamos fazendo, o que deu certo algumas vezes. Outras, não. Só que nunca mais nos chamaram. ${ }^{194}$
\end{abstract}

Foi nesse cenário que, em 1986, a equipe da Olhar Eletrônico propôs um projeto em que, inicialmente durante três horas, a Rede Manchete veicularia produção similar a da MTV norte-americana. A negociação entre as duas emissoras, no entanto, foi frustrada. Os jovens videomakers utilizaram, então, o projeto que imaginaram para criar o programa $\boldsymbol{T V} \mathbf{M i x}^{195}$, de onde saiu boa parte dos profissionais que, quatro anos depois, criou a MTV Brasil, por iniciativa do grupo de comunicação Abril. Ao lado da Rede Globo, esse é um dos maiores conglomerados de comunicação do país. Em comum, os dois grupos possuem também o fato de terem participado com sucesso do cenário fonográfico brasileiro, a primeira com a

\footnotetext{
${ }^{192}$ Entrevista dada ao autor em fevereiro de 2009.

193 BRYAN, Guilherme. Videoclipe brasileiro - História, características e internacionalidade. Dissertação de Mestrado. ECA-USP. São Paulo, SP, 2005, p. 92.

${ }^{194}$ Entrevista concedida para este trabalho em fevereiro de 2009.

195 TV Mix ocupou boa parte da programação da TV Gazeta entre 1988 e 1989, e contou com nomes como Serginho Groissman, Astrid Fontenelle, Rogério Gallo e Tadeu Jungle, entre outros.
} 
gravadora Som Livre, e a segunda com a MTV Brasil e com a gravadora Abril Music, criadas na década de 1990.

Para alguns diretores de videoclipe que apareceram durante a década de 1990, como Cláudio Torres e Arthur Fontes, o fato de a Rede Globo ter exclusividade, durante os anos 1970 e 1980, na produção de videoclipes foi um fator limitador, pois ele era concebido não como uma obra, mas como parte de um programa ao qual devia se enquadrar. Prova dos rigores da emissora, que controlava a produção e divulgação dos videoclipes, foi a não-exibição, em 1986, de Toda Forma de Poder, dos Engenheiros do Hawaii, sob alegação de ser uma produção "triste demais" para os padrões do Fantástico. Porém, a produção ainda hoje permanece ágil, com a tela se dividindo em duas partes horizontais e verticais para mostrar a banda tocando num jardim, com a participação do ator Paulo César Pereio. O mesmo aconteceu com Saia de Mim (1991), dos Titãs, que "poderia chocar a tradicional família brasileira", com a banda no centro de São Paulo e tocando em estúdio, misturando imagens coloridas e em preto e branco. $\mathrm{O}$ interessante, portanto, é observar que as restrições se referiam exclusivamente ao conteúdo da letra das canções e não ao que as imagens dos videoclipes mostravam.

Ao mesmo tempo, pelo fato de a MTV Brasil de início ser voltada quase que apenas ao público jovem, os videoclipes dos artistas mais populares do início da década de 1990, caso das duplas sertanejas, permaneceram tendo como único espaço de exibição o Fantástico e os programas segmentados da televisão, que continuaram surgindo na maior parte das emissoras. Entre esses videoclipes, estão Ela Chora Chora (1990), de Chitãozinho \& Xororó, cantando e tocando numa estrada e na boleia de um caminhão; Talismã (1990), com Leandro \& Leonardo, que mostra imagens do centro de São Paulo, com eles cantando em meio as poucas árvores que existem na região; e Coração Está em Pedaços (1992), de Zezé di Camargo \& Luciano, que conta com a participação da atriz Lizandra Souto.

O diretor Paulo Trevisan avalia as diferenças entre os videoclipes exibidos pelo Fantástico e pela MTV Brasil:

Da mesma forma como nós inovamos na década de 1980, a MTV veio com uma linguagem completamente diferente. E tem um detalhe: a MTV começou com videoclipes que custavam 100 mil dólares e que chegaram a um milhão de dólares. O Fantástico não tinha como competir com isso e, como acontece sempre quando entra algo novo, os videclipes feitos por ele começaram a perder a importância para os da MTV. Ao mesmo tempo, a 
MTV só aceitava produções em 16 milímetros e o Fantástico só produzia em vídeo. Então as gravadoras direcionaram todos os seus investimentos para lá. Mesmo sendo uma televisão fechada, vista por poucos, era prestígio ter um artista com videoclipe exibido lá. Portanto, a MTV ajudou a terminar com a era dos videoclipes do Fantástico. ${ }^{196}$

Começava, assim, uma nova fase da história do videoclipe brasileiro, deixando muitos realizadores pelo caminho, os quais migraram sobretudo para a publicidade, também em função de que era um momento em que as portas de entrada para o cinema brasileiro estavam praticamente todas fechadas. Mesmo assim, eles deixaram um legado importante para a história do videoclipe realizado no país, tanto em termos de experimentação da relação imagem-música, quanto do desenvolvimento de estilos pessoais e, portanto, autorais.

\subsection{MTV Brasil}

A MTV Brasil nasceu em 20 de outubro de 1990, quase dez anos após a inauguração da matriz norte-americana, a partir de uma concessão obtida pelo grupo de comunicação Abril, operando em UHF no Rio de Janeiro e em São Paulo, e alcançando 53 cidades e cinco milhões de domicílios. No começo, a emissora, voltada para a faixa etária de 12 a 34 anos, exibia quase exclusivamente a programação norte-americana, mesmo já dando sinais de que pretendia realizar uma partilha cultural com a produção nacional de videoclipes, a qual ajudou no amadurecimento, apesar de só dar os devidos créditos aos seus diretores a partir de 1993.

O primeiro videoclipe exibido pela emissora, e apresentado pela VJ Cuca Lazarotto ao meio-dia, foi Garota de Ipanema $^{197}$, estrelado pela cantora Marina Lima e dirigido por Jon Klein ${ }^{198}$, da MTV britânica, em 35 milímetros, a convite de Rogério Gallo, um dos responsáveis pela implantação da MTV no Brasil. A escolha da canção de Tom Jobim e Vinicius de Moraes, que foi bastante retrabalhada para inaugurar a emissora, não foi aleatória para videoclipe que misturava, em meio a

\footnotetext{
${ }^{196}$ Entrevista concedida ao autor em 2006.

${ }^{197} \mathrm{Na}$ estréia no Rio de Janeiro, esse videoclipe foi ao ar sem áudio até que alguém percebeu e colocou uma música do Dire Straits que não combinava em nada com as imagens no vídeo.

198 Jon Klein também dirigiu videoclipes como The Fly (1991), do U2, co-dirigido por Richie Smyth; Under the Gun (1993), do Sisters of Mercy; Stay Together (1994), do Suede; e Roll With It (1995), do Oasis, registrado num show. Nesses trabalhos, Jon Klein deixa de lado a tentativa de se construir uma narrativa linear, tão comum nesse gênero, e transmiste sensações e experimentações ao espectador.
} 
muitos "ruídos" visuais, algo extremamente moderno com símbolos da cultura brasileira, como um inflável do Abaporu, pintura da artista plástica modernista Tarsila do Amaral para presentear o marido e escritor Oswald de Andrade; bonecas de plástico negras com chupetas de diferentes cores na boca, representando a mestiçagem do país; as belezas naturais do Rio de Janeiro; e a sensualidade da mulher brasileira, representada pela própria cantora, como se estivesse num ensaio fotográfico, com imagens sendo projetadas sobre sua pele. No entanto, de repente, Marina olha para a câmera e fecha os braços apontando arma imaginária para o telespectador.

A futura diretora Mari Stockler, que realizou a direção de arte desse trabalho junto com o artista plástico Paulo Von Poser, lembra:

O diretor John Klein, que estava na implantação da MTV brasileira inventou essa história de nós todos fazermos o primeiro videoclipe da MTV, como espécie de inauguração. Esse diretor inglês co-dirigiu um programa muito interessante na época chamado Buzz. ${ }^{199} 200$

Posteriormente, Mari Stockler desenvolveu importante trabalho em videoclipes em que desenvolveu, como marca autoral, o forte registro documental dos artistas. Primeiro, ela foi diretora de arte de Fora da Ordem (1993), do Caetano Veloso, dirigido por José Henrique Fonseca e Andrucha Waddington. Depois, dirigiu, entre outros, O Coro Vai Comê! (1997), do Charlie Brown Jr., que é apresentado por um letreiro luminoso e mostra a banda num quarto, numa boate e em cima de um carro, e garotas em algumas boates e casas de prostituição de São Paulo; Strani Amori (1995), em preto e branco, para Renato Russo que tem aqui seu último registro em imagem, cantando num fundo branco, enquanto são mostrados anônimos pelas ruas, principalmente casais de diferentes faixas etárias; Firmamento (1996), do Cidade Negra, que mostra fotografias do arquivo pessoal dos músicos e a varanda de uma casa simples com vários familiares da banda e animais, como galinhas, cavalo e cachorro; e No Recreio (2002), produção póstuma de Cássia Eller, co-dirigida por Fábio Soares, com imagens do arquivo pessoal da cantora, a maioria com o filho Chicão e a companheira Maria Eugênia, e outras

\footnotetext{
${ }^{199}$ Programa a respeito dos principais acontecimentos musicais do país.

${ }^{200}$ Entrevista fornecida para esta pesquisa em 12 de junho de 2006.
} 
registradas de forma amadora do interior de um carro em 9 de dezembro de 2000, mostrando paisagens do Rio de Janeiro ${ }^{201}$.

A marca autoral de Mari Stockler permanece nas parcerias desenvolvidas com a diretora Karina Ades, em videoclipes como Quero Ver Você no Baile (2001), de Paula Lima, que prima pela fotografia das imagens coloridas exibidas na tela dividida quase o tempo todo em vários e diferentes retângulos; e Ela Desapareceu (2000), do Skank, que mostra a banda tocando numa sala e uma moça correndo pelos corredores da casa e pela rua, sempre mostrados em ângulos inusitados e muitas vezes com parte do rosto fora da imagem.

Garota de Ipanema foi um dos vinte e um videoclipes brasileiros financiados pela MTV Brasil para o início da programação, com verba advinda de permuta com as gravadoras, por meio de acordo assinado pelo diretor da emissora, Giancarlo Civitta $^{202}$. Entre essas produções, também estavam Pólvora, dos Paralamas do Sucesso, dirigido por Hugo Prata, com direção de arte de Cláudio Torres; O Poeta Está Vivo, do Barão Vermelho, com direção de Arthur Fontes e direção de arte de Cláudio Torres; SLA Radical Dance Disco Club, da Fernanda Abreu, dirigido por Luiz Stein; Todos os Lados, do Capital Inicial; Falar a Verdade, do Cidade Negra, dirigido por Ricardo Van Steen; Me Dê Sua Mão, do Wander Taffo; Deus e o Diabo $^{203}$, dos Titãs, dirigido por Jodele Larcher; Matou a Família e Foi ao Cinema, do Lobão; Perfeição, da Legião Urbana; e No Seu Lugar e Grand' Hotel, ambos dirigidos por Lui Farias e estrelados pelo Kid Abelha. Todos esses videoclipes eram exibidos acompanhados de um selo no canto superior direito da tela, em que aparecia escrito "Exclusivo MTV Brasil" e o símbolo da emissora.

201 Essa mesma ideia de utilizar imagens de arquivo foi muito bem desenvolvida por Oscar Rodrigues Alves, em Epitáfio, dos Titãs, que será observado com mais atenção no capítulo 5; e pelo diretor Marcos Siega, no videoclipe para a canção até então inédita You Know You're Right (2002), do Nirvana, que não tem imagens registradas de modo amador, mas com mais granulação e "ruídos", além de fotografias, e foi lançado oito anos após a morte do vocalista Kurt Cobain junto com a primeira coletânea oficial da banda.

${ }^{202}$ A MTV Brasil também produziu 16 videoclipes ao vivo para artistas de hip hop como Rappin'Hood, MRN, Doctor's MC's e Sistema Negro, gravados em evento no Vale do Anhangabaú, em São Paulo, para os primeiros meses do programa Yo! MTV. A emissora só voltaria a produzir videoclipes em 2001, quando foi realizado o Acústico Roberto Carlos e, como o artista possuía contrato de exclusividade de imagem com a TV Globo, foram produzidos videoclipes de duas canções para divulgarem o trabalho. O primeiro videoclipe foi Todos Estão Surdos, filmado pelo departamento de promoção da própria MTV Brasil; e Eu Te Amo, Te Amo, Te Amo, dirigido por Maurício Eça, Felippe Segall, Kelly Marciano, Max Pochon, Zé Bob Eliezer e F. Sommer, e protagonizado pela VJ Marina Person.

203 Jodele Larcher lembra que o videoclipe da música Deus e o Diabo, dos Titãs, teve duas versões: uma para ser exibida pelo Fantástico e outra pela MTV Brasil. 
Rogério Gallo, que dirigiu o programa Som Pop e trabalhou no programa TV Mix, como "repórter abelha", misto de cinegrafista e jornalista, que ia para as ruas realizar as reportagens e depois as editava nas ilhas da TV Gazeta, recorda que a MTV Brasil filmou vários shows para tirar algumas canções e exibir como videoclipes. Ele comenta a importância dessa produção:

\begin{abstract}
A MTV Brasil foi a única MTV do mundo que se envolveu na produção de videoclipes e isso teve um motivo muito urgente na época para nós: estava às vésperas de estrear e, de fato, não tínhamos acervo nacional que fosse compatível com o padrão de qualidade da MTV, pois internacional tínhamos um de primeiríssima linha. Eu ficava muito frustrado de colocar no ar a música nacional do lado da internacional com padrão de qualidade tão inferior, tanto das produções mais antigas, que eram horríveis, quanto das músicas que faziam sucesso naquele momento. Decidimos, então, que a única maneira de mudar esse quadro era entrarmos na produção dos videoclipes para estabelecer patamar de qualidade diferente do que rolava até então e, a partir daí, incentivar para que o mercado funcionasse sozinho. Ou seja, não tínhamos o objetivo de prosseguir na produção e ter ali um núcleo permanente. Aí eu trouxe o pessoal da publicidade, que já tinha o hábito de trabalhar com película, em $35 \mathrm{~mm}$. Até então, os clipes do Fantástico eram feitos em vídeo e cafonas, com padrão de fotografia muito ruim. Então, a partir desse momento, nós fomos indicando, para as gravadoras, produtoras e diretores como Hugo Prata e Oscar Rodrigues Alves, que já tinham uma linguagem que era a que a MTV gostava, mais moderna e antenada com o que estava acontecendo esteticamente nos clipes internacionais. ${ }^{204}$
\end{abstract}

A MTV Brasil exibiu videoclipes do Fantástico, como explicou a diretora de relações artísticas da emissora, Anna Butler, ao "Jornal do Brasil”, de 1 de junho de 2006: "Tínhamos de reservar $40 \%$ da programação para a produção nacional. Então, passamos a usar o material feito por eles"205. Em 1990, havia 128 videoclipes nacionais em condições de serem exibidos, até porque a MTV Brasil procurava romper com a produção anterior.

Yone Sassa ${ }^{206}$, que trabalhou na produtora Olhar Eletrônico e é gerente de programação musical da MTV Brasil, tem outra opinião:

Esse material pertencia ou pertence à Rede Globo e, portanto, nunca esteve disponível para a MTV Brasil. Depois, os clipes do Fantástico tinham a ver com a proposta deles de fazer um quadro musical no programa.

\footnotetext{
${ }^{204}$ Entrevista fornecida para esta pesquisa em 2006.

${ }^{205}$ GOBBI, Nelson. Videoclipe Cinquentão, Jornal do Brasil. Rio de Janeiro, RJ, 1ํ de junho de 2006, p. B1.

${ }^{206}$ Entrevista fornecida para esta pesquisa em 04 de maio de 2005.
} 
Rogério Gallo lembra que, nessa fase inicial, a relação da MTV com a TV Globo não foi amistosa:

Num primeiro momento, eles bloquearam todos os videoclipes com os quais estávamos contando. Mesmo sendo horríveis os videoclipes que eles tinham, precisávamos de alguns, porque tínhamos que exibir conteúdo nacional e eles não liberaram. Aí algumas gravadoras conseguiram negociar com eles e compraram alguns dos videoclipes para podermos passar. $^{207}$

Criou-se também intensa batalha entre as duas emissoras pela exclusividade de exibição de videoclipes nacionais e estrangeiros, como conta Oscar Rodrigues

Alves:

\begin{abstract}
Uma vez chegou para a gente na MTV - não sei quem é que conseguiu isso - um comunicado interno do Boni, na Globo, proibindo o Fantástico de passar videoclipes filmados em cinema, porque vídeo era para televisão. E também proibindo passar videoclipes em preto e branco, porque os japoneses trabalharam muito para tornar a televisão colorida e que ele achava um retrocesso usar videoclipe preto e branco, e que a audiência não queria ver ${ }^{208}$. Foi meio uma retaliação à MTV, pois o cara viu que ela estava chegando com uma linguagenzinha e quis defender um pouco o que ele acreditava para a televisão brasileira, onde ele fazia e atuava, que era a Globo (...).Logo depois da MTV, eu fui convidado para ir para o Fantástico, como produtor e editor de reportagens especiais (...) $\mathrm{Na}$ minha primeira semana na Globo, o Carlos Alberto Manente (um dos criadores e editor-chefe do programa) (...) me levou para o Rio de Janeiro para assistir ao fechamento do Fantástico e ser apresentado ao José Itamar de Freitas, diretor do programa na época. Eu entrei na sala dele e ele estava desesperado, arrancando os poucos cabelos que ainda sobravam, porque tinha acabado de chegar Justify My Love (dirigido por Jean-Baptiste Mondino, em 1990), um dos clipes mais escandalosos da Madonna e em preto e branco. Só que era um estouro planetário. Existia um lobby fortíssimo entre a MTV e a Globo, junto às gravadoras para estrear os clipes. Então os clipes que estreavam no Fantástico, a MTV botava na geladeira. Tinha uma coisa assim: 'Se estrear na Globo, a gente vai colocar só um mês e meio depois'. Ao mesmo tempo, o Fantástico falava: 'Se estrear na MTV, nós não colocamos no Fantástico'. E, na época, era importantíssimo, como é hoje ainda, o clipe estrear no Fantástico (...) Lembro que o Zé Itamar falava: "Isso é uma loucura, porque vou colocar esse clipe no ar e virá comunicado do Boni e telefonema do Dom Eugênio Sales (arcebispo emérito do Rio de Janeiro). Então eu só vou procurar sarna para me coçar. Mas tenho que colocar, porque todo mundo quer ver. É um sucesso planetário". Ele pensou bastante para tomar a decisão de realmente colocar no ar e colocou. ${ }^{209}$
\end{abstract}

\footnotetext{
${ }^{207}$ Entrevista fornecida para esta pesquisa em 2006.

${ }^{208}$ Reportagem do jornal "Folha de S. Paulo", de 25 de maio de 1993, intitulada "Globo Declara Guerra à Estética do Clipe" e não-assinada, em que era anunciado: "Boni prega contra o excesso de intervenções gráficas em certos programas da Globo, os cortes rápidos entre uma cena e outra, a sobreposição de imagens, o movimento brusco de câmera".

${ }^{209}$ Entrevista dada para esta pesquisa entre 2006 e 2009.
} 
Oscar Rodrigues Alves destaca-se dos demais diretores dessa primeira fase da MTV Brasil, não apenas pela qualidade do trabalho desenvolvido em videoclipes, mas também por ter uma trajetória diferente da maioria. Ele é jornalista de formação, com passagem pelas emissoras de televisão SBT e Bandeirantes, e pelo jornal "Folha de S. Paulo", e ingressou na fase inaugural da MTV Brasil, como diretor de programas e dos VJs. Ele começou a dirigir videoclipes em 1992 e, desde então, realizou mais de trinta produções, das quais sete serão observadas com mais atenção no capítulo cinco.

A mesma origem jornalística tem Hugo Prata, que começou trabalhando na produtora Olhar Eletrônico e foi "repórter abelha" do TV Mix. Ao longo da carreira, ele dirigiu mais de 60 videoclipes, a maioria deles marcada pelo cuidado apurado na fotografia. Entre eles, estão Eu Sei (1997), do Pato Fu, com os músicos fantasiados de espécie de "bobos da corte" tocando em meio a uma ventania, que é bastante valorizada no registro das imagens que mostram também uma espécie de batalha medieval, com fotografia que valoriza os tons de azul escuro; Alma Não Tem Cor (1997), do Karnak, premiado como melhor direção do Video Music Brasil (VMB), que mostra a banda vestida em trajes de época e se apresentando numa feira típica da Idade Média; Enrosca (2000), que mostra a dupla Sandy \& Junior vestida e maquiada de preto tocando e cantando em cenários futuristas; Paciência (2000), do Lenine, que mostra pessoas em cenas cotidianas, bem de acordo com a letra da canção, como uma criança fazendo a lição de casa, um idoso nadando e uma mulher jantando; Como Devia Estar (2003), do Capital Inicial, que utiliza o título da canção como mote para mostrar um médico que transforma pessoas de diferentes idades, origens e religiões em outras pessoas; e Ainda Gosto Dela (2008), do Skank, em preto e branco, com a banda se apresentando e se divertindo num espaço aberto de concreto no meio da cidade, com a participação da cantora Negra Li.

Hugo Prata comenta seu método de trabalho e a relação com os artistas:

Ouço por semanas a música do grupo, converso com o artista, tento tirar dele algum input sobre a letra, sobre a emoção, qual é a intenção daquilo lá. Assim que eu tenho uma ideia, a gente parte para fazer muita pesquisa e referências. Eu fico indo atrás de coisas que são mais ou menos aquilo que eu pensei para ver como fazer, mas principalmente para ter como explicar para a minha equipe. Todos os artistas que trabalham com a gente dão liberdade total. Quase nunca dão ideias. Confiam, gostam, até esperam que a gente acrescente no trabalho deles e desenvolva. O que a gente mais se obriga é a criar uma coisa bem inusitada, que é outra coisa legal de fazer 
videoclipe, um formato de experimentação, sem dúvida. Hoje em dia, eu já não me cobro tanto criar universos fantásticos e coisas tão super produzidas. Não sei se é uma tendência e até quando vai durar, mas hoje acho que as coisas mais simples, mais verdadeiras, mais perto da performance do músico estão mais em pauta. ${ }^{210}$

Retornando ao início da MTV Brasil, o primeiro videoclipe enviado para representar a emissora e o país no Video Music Awards (VMA), nos Estados Unidos, em 1990, foi Flores, dirigido por Jodele Larcher e Gringo Cardia para o Fantástico. A razão era que, ao fundir imagens recortadas sob cenário de pintura de flores, no qual os Titãs tocavam seus instrumentos, cantavam e dançavam, valendo-se de efeitos de chroma-key, essa produção obteve grande destaque, superando os videoclipes inaugurais da MTV Brasil e sucessos exibidos por outras emissoras na época, como $O$ Estrangeiro (1989), de Caetano Veloso, dirigido pelo próprio, com a participação das atrizes Regina Casé e Paula Lavigne, e do diretor teatral José Celso Martinez Correa.

O artista gráfico e cenógrafo Gringo Cardia destacou-se por empregar várias técnicas ousadas nos videoclipes que dirigiu, como a variação de cores e a presença de muitas palavras e desenhos na tela. É dele a direção de, entre outros, A Cerca (1994), que ilustra a letra da canção, a qual remete ao repente nordestino, com pessoas mascaradas e bonecos num estilo bastante comum no Nordeste, com direito a anjos e diabos, e imagens com cores alteradas; Vem Quente Que Eu Estou Fervendo (1996), em que ele filmou vários casais em diferentes situações e a banda Barão Vermelho tocando na frente de um túnel em chroma-key e embaixo d'água ${ }^{211}$; Manguetown (1996), de Chico Science \& Nação Zumbi, onde utilizou a imagem piscando, a presença de vários grafismos na tela, efeitos caleidoscópicos, alteração das cores em pós-produção e presença de um corpo cheio de lâmpadas acesas, remetendo à capa do disco Delicate Sound of Thunder (1988), do Pink Floyd; e O Segundo Sol (1999), videoclipe sensual de Cássia Eller, que caminha de camiseta e calcinha pela casa, em meio à imagem de garotas numa piscina.

O fato de um videoclipe brasileiro, como Flores, ser exibido na MTV norteamericana não era novidade. Desde 1986, vários videoclipes realizados pelas

\footnotetext{
${ }^{210}$ PATARA, Fernanda; e PAIXÃO, Luis. Vídeo-documentário Videoclipe em 3X4. Apresentado como Trabalho de Conclusão de Curso de Rádio e Televisão da Faculdade Belas Artes. São Paulo, SP. 2009.

${ }^{211}$ Esse efeito obtido com a filmagem do artista embaixo d'água foi repetido por Oscar Rodrigues Alves, em Palavras Repetidas (2005), do Gabriel O Pensador.
} 
produtoras alternativas ao Fantástico, como Sopa de Letrinhas, dos Engenheiros do Hawai, que consiste em mostrar a banda tocando em estúdio com a luz estourada, foram exibidos no International Hour, programa da emissora que abrigava produções de outras partes do mundo.

Roberto Berliner, que demorou a ser aceito pela equipe da MTV Brasil, recorda:

Quando a MTV chegou em 1990, aos poucos, o que era um prêmio conseguir botar no Fantástico, passou a ser uma peça de propaganda. Outra diferença é que, nos anos 80, a maioria dos diretores trabalhava com referência: "Vou fazer igualzinho aquele clipe do David Bowie". E eu procurava fazer do meu jeito, à brasileira. Já nos anos 90, alguns diretores começaram a fazer videoclipes para mostrar para as agências de publicidade sua capacidade de fazer coisas bonitas. Havia comprometimento com o mercado, o que nunca tive tanto e nem a pretensão de mostrar para o mercado publicitário. Mas a cobrança era maior. Mesmo eu sendo amigo dos caras das bandas, ficou mais difícil prosseguir no caminho experimental. De certa maneira, consegui fazer com meus amigos, como Pedro Luís (vocalista da banda Pedro Luís e a Parede, para quem dirigiu Rap do Real e Caio no Suingue, ambos em 2004), que é ousado e aberto para experiências (...) Deixou de ser videoclipe para ser só clipe, feito em película. Porém, quando começou a decair, o vídeo voltou. O tempo trouxe também investimentos maiores, comprometimento com o mercado e melhores técnicas. Breno Silveira foi muito marcante na publicidade e no videoclipe. A partir da fotografia dele, acho que o videoclipe passou a ter um pouco mais de brilho. ${ }^{212}$

Breno Silveira começou como fotógrafo de trabalhos da produtora Conspiração Filmes, sediada no Rio de Janeiro, da qual virou sócio em 1996. Essa produtora surgiu em 1991, criada pelos amigos Cláudio Torres, Arthur Fontes, Andrew Waddington (mais conhecido como Andrucha), Lula Buarque de Hollanda e José Henrique Fonseca.

Com experiências na realização de cenários e direção de arte e vídeos de shows de grandes nomes da música brasileira, os membros da Conspiração Filmes tinham como principal objetivo trabalhar com cinema. No entanto, a situação do cinema brasileiro era uma das piores da história, em função do então presidente Fernando Collor de Mello, que, ao tomar posse em 1990, extinguiu órgãos como a Embrafilme, o Concine e a Fundação do Cinema Brasileiro. Com isso, a produção do cinema nacional foi praticamente a zero, o que só começou a ser retomado a partir de cerca de dois anos depois, com a Lei do Audiovisual ${ }^{213}$.

\footnotetext{
${ }^{212}$ Entrevista dada para essa pesquisa em fevereiro de 2009.

${ }^{213}$ Ver mais em ORICCHIO, Luiz Zanin. Cinema de Novo Um balanço crítico da retomada. São Paulo, SP. Estação Liberdade. 2003.
} 
A MTV Brasil era, então, o espaço ideal para que jovens profissionais do audiovisual experimentassem novas possibilidades estéticas, uma vez que as gravadoras não cobravam retorno comercial deles.

Do ponto de vista comercial, mesmo em se tratando de renomadas e premiadas casas de produção, o segmento de videoclipes sempre representou parcela mínima do volume de faturamento, devido aos baixos orçamentos e cachês. A Conspiração Filmes, por exemplo, teve apenas um por cento de seu faturamento nos videoclipes, durante boa parte da década de 1990, e foi deixando de realizá-los quando virou uma das mais premiadas e lucrativas do cinema nacional. Mesmo assim, a Conspiração Filmes aplicou altas quantias no mercado brasileiro de videoclipes, procurando sempre as melhores possibilidades técnicas e encarando-os como espaço privilegiado para exercícios audiovisuais mais ousados. A produtora também institucionalizou o trabalho coletivo, o qual passou a se manifestar, inclusive, na relação do diretor com o compositor e intérprete da canção.

O diretor Cláudio Torres, que havia sido cenógrafo de Marisa Monte, Titãs, Legião Urbana e Paralamas do Sucesso, conta como foi o início da Conspiração Filmes:

\begin{abstract}
Arthur Fontes e Lula Buarque, meus amigos, tinham ido estudar cinema em Nova lorque, e voltaram para o Brasil, em 1991, com a ideia de abrir uma produtora. Aí me chamaram e eu entrei como sócio junto com Zé Henrique Fonseca. A ideia era fazer cinema, mas calhou de ser numa época em que o Collor fechou a Embrafilme e, por ironia do destino, a MTV estava abrindo no Brasil. Achamos um espaço bom para trabalharmos com película, porque, até então, os clipes eram feitos em vídeo, e a MTV, quando produziu clipes para botar na programação, fez questão de ser em película e chamou uma galera de cinema para fazer. Nós estávamos no meio. $^{214}$
\end{abstract}

Com relação às condições técnicas da época, Cláudio Torres analisa:

A MTV transformou o panorama audiovisual brasileiro, mas não foi à toa. $E$ que aconteceu de ela surgir exatamente na hora da virada tecnológica do analógico para o digital. Ou seja, você filma em película, passa para uma fita digital e a possibilidade de manipulação da imagem é muito melhor. Uma edição mais sofisticada transformou a propaganda brasileira, que passou a adotar a mesma linguagem da MTV, de edição mais rápida. ${ }^{215}$

\footnotetext{
${ }^{214}$ Entrevista dada para este trabalho em 2006.

${ }^{215}$ IDEM
} 
O sócio Andrucha Waddington destaca a falta de investimentos em videoclipes:

A exigência na qualidade era norte-americana e europeia, mas com salário paraguaio. Aqui no Brasil, a gente sempre trabalhou com a ideia de colocar na tela muito mais dinheiro do que a gente tinha na verdade para investir. $^{216}$

O diretor Hugo Prata explica porque compensava tanto esforço:

\begin{abstract}
Apesar de não ganhar dinheiro fazendo videoclipe, pois sou diretor de filmes publicitários, produzir videoclipe é para mim uma alternativa para trabalhar o lado artístico da minha profissão, o de film maker. No videoclipe, tenho liberdade total para produzir o trabalho da forma que eu quiser e exercitar a criatividade. ${ }^{217}$
\end{abstract}

Esse lado de film maker foi bastante exercido pelos sócios da Conspiração Filmes, que teve como um dos primeiros videoclipes realizados Haiti (1993), de Caetano Veloso e Gilberto Gil, dirigido por Cláudio Torres e Lula Buarque, misturando obras do artista plástico norte-americano Jean-Michel Basquiat com fotografia em preto e branco dos dois artistas refletidos na água de um poço.

Um tom documental no retrato do cotidiano de diferentes regiões do Brasil é uma das marcas mais importantes dos videoclipes de Lula Buarque, o que se percebe em, entre outros, Kaya N'Gandaya (2002), de Gilberto Gil, gravado em Trench Town, em Kingston, na Jamaica, com o cantor tocando e cantando com músicos locais, e prestando homenagem ao cantor e compositor local Bob Marley; Gentileza (2000), da Marisa Monte, assinado também por André Horta, que retrata o profeta paulista que ficou famoso ao fazer inscrições embaixo de um viaduto no Rio de Janeiro, com um ator interpretando-o pelas ruas da cidade e, no final, aparece uma imagem real do profeta falecido em 1996; e Deixa A Vida Me Levar (2002), de Zeca Pagodinho, co-dirigido por Carolina Jabor, que mostra várias pessoas anônimas do Rio de Janeiro por meio de uma bola de futebol arremessada de um lado para o outro, de uma roda de samba da qual o cantor participa e por meio da câmera que corre horizontalmente para mudar de cena.

Além de Haiti, Cláudio Torres realizou outros videoclipes em que valoriza a qualidade da fotografia e o desenvolvimento de situações narrativas, com motes

\footnotetext{
${ }^{216}$ WADDINGTON, Andrucha. In. PEQUINO, Lívia; GUEDES, Nádia de Moraes Schunck; e LOPES, Tatiane de Oliveira. Piauí_06. Trabalho de Conclusão de Curso de Jornalismo. Faculdade Anhembi Morumbi. São Paulo, SP. Junho/2008, págs. 9 e 10.

${ }^{217}$ PEDROSO, Maria Goretti; e MARTINS, Rosana (org). Admirável Mundo MTV Brasil ..., págs. 12 e
} 
geralmente sugeridos pela letra das canções. Esse é o caso de Pinga (1999), do Pato Fu, co-dirigido com José Henrique Fonseca e Ralph Strelow, o qual participa como caubói que encontra os integrantes da banda sentados diante de uma mesa com vários copos de aguardente, em meio a figurinhas dos jogadores de futebol citados na letra, que piscam na tela e surgem descoloridas, azuis e verdes; Resposta (1998), em branco e preto, para o Skank, co-dirigido por Arthur Fontes, que mostra o encontro e desencontro de pessoas num cruzamento, enquanto 0 semáforo está fechado e onde está parado o carro dirigido pelo vocalista Samuel Rosa; e O Que Me Importa (2000), da Marisa Monte, assinado com Sergio Meckler e Vicente Kubrusly, e baseado exclusivamente em fotografias do cotidiano da cantora, numa montagem bastante dinâmica.

\subsection{Video Music Brasil}

A primeira produção de importância capital para Cláudio Torres e seus companheiros da Conspiração Filmes foi Segue o Seco (1994), dirigida por ele e por José Henrique Fonseca, em 35 milímetros, com orçamento de sessenta e cinco mil cruzeiros (quase o dobro do que se gastava em um videoclipe na época), bancado pela cantora Marisa Monte e pelo empresário dela, Leonardo Netto. A letra da canção é um retrato metafórico da seca nordestina, a qual é a principal referência para as imagens fotografadas delicadamente por Breno Silveira, valorizando os detalhes. Era uma temática cara ao movimento cinematográfico brasileiro, desenvolvido na década de 1960 e denominado Cinema Novo, numa nítida tentativa de se aproximar da realidade brasileira. No videoclipe, há relações literais entre música e imagem - quando se ouve "a boiada seca", vê-se o esqueleto de um boi e o uso frequente de contraste e mistura de cores, com poucas fusões e sobreposições, mas muitas sombras. As rachaduras do chão dialogam com as dos rostos sofridos dos idosos da seca, assim como o amarelo do céu com o da terra, e o reflexo de Marisa Monte na poça d'água com a água refletida no rosto da cantora.

Andrucha Waddington avalia a estética desse videoclipe:

Segue o Seco é um clipe muito legal, feito em um estúdio com uma interpretação do sertão. Eu acho que Central do Brasil (1998), Eu, Tu, Eles (2000), Abril Despedaçado (2001) são filmes sobre o mesmo tema, mas cada um procura sua linguagem. São interpretações do sertão, que foi 
muito filmado pelo Cinema Novo, só que de forma atual, em que cada diretor fez sua interpretação. ${ }^{218}$

Ivana Bentes analisa a relação entre o videoclipe de Marisa Monte e a estética desenvolvida no cinema brasileiro:

Aqui (em Segue o Seco) a proposta é a superestilização e a glamourização do sertão e da paisagem nordestina, que aponta para uma tendência de releitura do moderno cinema brasileiro. Em diferentes níveis e com resultados estéticos e consequências éticas diversas (...) O grupo Conspiração aponta para o que seria uma espécie de "tradução estética", para audiências mais amplas, das questões decisivas colocadas pelo moderno cinema brasileiro e que admitem reciclagens, apropriações, releituras, pastiches e reinvenção. Algumas dessas apropriações caem no mero "visual" ou "estilo", um decalque da forma sem a radicalidade do processo. $^{219}$

O videoclipe Segue o Seco é importante para essa pesquisa pelo fato de que ele aproximou uma temática importante do audiovisual brasileiro ao público jovem da década de 1990, com uma estética totalmente de acordo com os objetivos da então diretora-geral da MTV Brasil, Fátima Ali.

Em 1995, quando a emissora tornou-se a primeira brasileira a transmitir sua programação durante 24 horas ininterruptas para todas as retransmissoras e afiliadas, a diretora resolveu buscar uma característica mais nacional por meio de música feita no país que fosse capaz de agradar ao público-alvo da emissora - os jovens - e seus anunciantes, o que resultou na criação do Video Music Awards Brasil, que, em menos de um ano, mudou de nome para MTV Video Music Brasil (VMB), a versão brasileira do VMA norte-americano ${ }^{220}$, cuja primeira edição foi vencida justamente pelo videoclipe dirigido por Cláudio Torres e José Henrique Fonseca.

José Henrique Fonseca é marcado por realizar videoclipes em que esbanja grande cuidado com a fotografia e com os movimentos de câmera. Ele é o diretor de, entre outros, Malandragem (1994), da Cássia Eller, co-dirigido com Izabel

\footnotetext{
${ }^{218}$ WADDINGTON, Andrucha. In. PEQUINO, Lívia; GUEDES, Nádia de Moraes Schunck; e LOPES, Tatiane de Oliveira. Piauí_06 ..., págs. 17 e 18.

${ }^{219}$ BENTES, Ivana. Videoclipe, Cinema e Política. In. PEDROSO, Maria Goretti; e MARTINS, Rosana (org). Admirável Mundo MTV Brasil ..., págs. 175 e 176.

${ }^{220}$ O Video Music Brasil (VMB) fez parte de acordo global, fechado em 1995, entre a MTV Networks e a Pepsi-Cola a fim de criar evento internacional englobando todas as afiliadas. Na primeira edição, foram inscritos 128 videoclipes, número que subiu para 260 no ano seguinte. As categorias da primeira edição foram Melhor Videoclipe do Ano, Melhor Videoclipe Segundo a Audiência, Melhor Democlipe, Melhor Banda ou Artista Revelação, Melhor Videoclipe de Rock, Pop e MPB e Melhor Edição, Fotografia e Direção.
} 
Jaguaribe, com iluminação que privilegia os tons azuis e com a cantora com a estatura de uma criança, vestida com roupa xadrez que se confunde com o chão de uma casa e uma garotinha brincando, montando armadilhas para outras crianças, correndo pelos corredores, vendo fantoches e destruindo bonecas; A Namorada (1997), de Carlinhos Brown, que conta com a participação da atriz Camila Pitanga, e mostra o cantor como locutor de rádio num estúdio todo estilizado e aberto para os moradores de uma comunidade de Salvador (BA), e Carioca (1999), do Chico Buarque, realizado também por Arthur Fontes e Fábio Fonseca, com linda fotografia em preto e branco, que começa com imagem de um dos cartões postais do Rio de Janeiro e um dos olhos do cantor, sentado num café, escrevendo a letra da canção num bloquinho e acompanhando cenas cotidianas de anônimos, através do vidro, sem ser visto.

Ainda sobre Segue o Seco é importante lembrar os quatro prêmios - direção, edição, fotografia e melhor videoclipe de MPB - que couberam a ele, estrelado por Marisa Monte, que, em entrevista nos bastidores da festa, pedia que as gravadoras entendessem a importância do videoclipe como imagem das músicas e que investissem nele cada vez mais. ${ }^{221}$

As preces de Marisa Monte foram atendidas com o passar dos anos, como explica a diretora de relações artísticas da MTV Brasil, Anna Butler:

\begin{abstract}
A evolução dos clipes foi enorme; primeiro, quase não se fazia videoclipes. Agora (em 2004), todas as bandas, das maiores às menores, fazem clipes como parte fundamental da promoção da sua música. Todas as gravadoras aprovaram o projeto MTV, assim como os artistas. Chegamos a ponto de eles terem uma cláusula em seus contratos com as gravadoras que garante pelo menos um clipe por disco. ${ }^{222}$
\end{abstract}

A partir daí, Marisa Monte demonstrou grande preocupação e interesse em dialogar com o público por meio dos videoclipes, que priorizam sempre fotografias muito bem elaboradas e a preocupação em expor a artista como alguém refinada e ao mesmo tempo comum, diante de importantes temas sociais do país, os quais geralmente não estão explícitos nas letras. Entre as produções estreladas por ela, estão Diariamente (1992), dirigido por Guilherme Ramalho, animação que ilustra os

\footnotetext{
${ }^{221}$ Trecho extraído de programa especial em comemoração aos 15 anos da MTV Brasil, exibido em outubro de 2005.

${ }^{222}$ BUTLER, Anna. In. CHAROUX, Mônica. Estéticas Antropofágicas. About, №766. 10 de maio de 2004, p. 23.
} 
objetos e expressões retratados na canção por meio de traços pretos simples com fundo bege; Beija Eu (1992), que preza a delicadeza das imagens escuras da cantora em ângulos pouco usados e vários objetos religiosos; e Vilarejo (2006), dirigido por Andrucha Waddington, Paulo de Barros e Ricardo Della Rosa, que valoriza fotografias de crianças carentes e de multidões de diferentes origens e religiões, misturadas com a cantora na varanda de uma casa citada na letra da canção.

A escolha da audiência no primeiro Video Music Brasil foi outra produção da Conspiração, que também ganhou como melhor videoclipe pop - Uma Brasileira, dos Paralamas do Sucesso, dirigido por Andrucha Waddington, com a banda tocando, em preto e branco, num banheiro e num quarto, dialogando com polaroides deles mesmos, de uma modelo nos mesmos ambientes e do cantor Djavan sentado numa poltrona. Confirmando o forte interesse nos videoclipes, nessa fase da MTV Brasil, os Paralamas do Sucesso estrelaram outras produções emblemáticas como Lourinha Bombril (1996), dirigida por Andrucha Waddington, Breno Silveira e Toni Vanzolini, em preto e branco, que exibe recorte de imagens da banda e de várias modelos que poucas vezes ocupam a tela inteira e se multiplicam nela, e que ganhou os prêmios de melhor videoclipe do ano, melhor direção e melhor edição; Busca Vida (1997), dirigida por Andrucha Waddington e Breno Silveira, eleito melhor videoclipe do ano, com referências ao romance $\boldsymbol{O}$ Pequeno Príncipe, de Antoine de Saint-Exupéry e ao videoclipe Tonight, Tonight (1996), dirigido por Valerie Faris e Jonathan Dayton para a banda norte-americana Smashing Pumpkins, num exercício de simulação da falta de gravidade ${ }^{223}$, ao mostrar os músicos com diferentes fantasias tocando em cima de planetas feitos em animação 3D. Esse mesmo tipo de animação foi repetido com eles, em 2009, em $\boldsymbol{A}$ Lhe Esperar (2009), dirigido por Eduardo Souza e Rodrigo Lima, em que tocam numa ilha desenhada em computador, em narrativa conduzida por vários ambientes que são alterados por meio de caixas que abrem e fecham, e por onde circulam vários personagens que remetem às dobraduras.

Outro sucesso dos Paralamas do Sucesso foi Ela Disse Adeus (1998), dirigido por Breno Silveira, Toni Vanzolini e Andrucha Waddington, que se tornaria

${ }^{223}$ Esse exercício foi realizado em Virtual Insanity (1996), dirigido por Jonathan Glazer para Jamiroquai; e Todo Universo (2002), do Lulu Santos, dirigido por Jarbas Agnelli, gravado em Moscou, na Rússia, e com vários elementos gráficos inseridos na pós-produção. 
um dos realizadores mais premiados da história do Video Music Brasil (VMB). Esse trabalho é espécie de pastiche dos filmes da época do cinema silencioso, com direito aos fortes ruídos provocados pelo projetor e intertítulos entre as cenas, descrevendo a ação de humor negro, em que a atriz Fernanda Torres interpreta uma mulher que é maltratada pelos três maridos - justamente os integrantes da banda - e chega ao desespero até que resolve se vingar, afogando, envenenando ou estrangulando cada um deles e termina fumando sorridente no quarto. O baterista João Barone chegou a comentar que nunca antes um videoclipe havia sido tão associado com a banda, que se tornou a mais vitoriosa da história do VMB, com quinze prêmios, sendo doze para videoclipes - dois para Uma Brasileira, três para Lourinha Bombril, um para Busca Vida, cinco para Ela Disse Adeus e um para Depois da Queda o Coice $^{224}$.

O mesmo João Barone descreve o trabalho de Andrucha Waddington:

O Andrucha é um cara muito criativo, muito produtivo. Ele junta esses dois aspectos assim de inventar e conseguir fazer, que é uma injeção de ânimo, de criatividade, e o resultado é sempre positivo. ${ }^{225}$

Andrucha Waddington, que considera ter sido o videoclipe sua escola de direção, acrescenta:

Meu processo de clipe é o seguinte: vou fazer o clipe, pego a música, boto em loop e fico jogado na sala ouvindo, vendo que ideias ela sugere para propor para o artista (...) Eu acho difícil identificar um estilo, pois tento fazer trabalho por trabalho muito único. ${ }^{226}$

Para os Paralamas do Sucesso, Andrucha Waddington dirigiu ainda Depois da Queda O Coice (1999), assinado também por Breno Silveira e Toni Vanzolini, com a banda se apresentando num palco circular com iluminação estourada e a câmera realizando movimentos ágeis; Aonde Quer Que Eu Vá (2000), co-dirigido por Gualter Pupo, que mostra apenas a sombra da banda em estúdio e é estrelado também por Débora Bloch e Fernanda Torres, andando pelas ruas com os figurinos do espetáculo teatral Duas Mulheres e Um Cadáver; Seguindo Estrelas (2002), dirigido com Breno Silveira, no qual o baixista Bi Ribeiro caminha pelas ruas do Rio de Janeiro durante a noite e entra em diferentes ambientes, enquanto aparece a imagem do vocalista Herbert Vianna cantando em imagens granuladas exibidas por

\footnotetext{
${ }^{224}$ Depoimento dado em especial exibido pela MTV Brasil, em outubro de 2005, em comeração aos seus 15 anos.

${ }^{225}$ Depoimento dado ao programa Bioclipe, exibido pela MTV Brasil em agosto de 2006.

${ }^{226}$ Depoimento dado ao programa Bioclipe, exibido pela MTV Brasil em agosto de 2006.
} 
televisores; e Na Pista (2005), com a banda dentro de um carro enfeitado com várias luzinhas acesas, circulando pelas ruas do Rio de Janeiro.

Andrucha Waddington pode ser apontado como o diretor brasileiro que melhor mistura imagens coloridas e em preto e branco para, na maioria dos casos, mostrar a performance dos artistas e focalizar anônimos e as diferentes realidades do país ou fazer homenagens e paródias de filmes famosos. Entre outros videoclipes que dirigiu, estão É Proibido Fumar (1994), com a banda sentada numa mesa, tocando num ambiente rodeado de velas acesas, com várias grades como se fosse uma jaula e com garotas e rapazes dançando sensualmente, em imagens mais escuras que valorizam as sombras; Beija-Flor (1995), da Marina Lima, com várias pessoas, incluindo a cantora, dentro de uma casa à beira-mar, em imagens em diferentes tons de marrom; Eu Não Aguento (1996), dos Titãs, que, em imagens descoloridas, insinua que uma garota está sendo torturada, em meio a símbolos religiosos, e faz uma paródia em preto e branco da capa do primeiro e homônimo disco do grupo Secos \& Molhados, lançado em 1973, onde a cabeça dos integrantes aparece dentro de bandejas sobre uma mesa. No início dessa canção, há uma citação da introdução da música Sangue Latino, presente nesse álbum e composta por João Ricardo e Paulinho Mendonça; Música Para Ouvir (1999), do Arnaldo Antunes, assinado com Toni Vanzolini, que mostra o cantor vestido com um figurino formado por várias fitas brancas e pretas, chacoalhando a cabeça e dançando diante de um fundo ora branco, ora preto, valorizando as sombras e os constantes movimentos de câmera; Mr. Scarecrow (2000), co-dirigido por Toni Vanzolini, com Cássia Eller e Herbert Vianna numa belíssima fotografia em preto e branco, com os dois cantores andando e correndo num corredor e numa ponte, com referências ao filme Uma Mulher Para Dois (1962), de François Truffaut, estrelado por Jeanne Moreau; Já É (2004), de Lulu Santos, co-dirigido com Mini Kerti, em que a jornalista Scarlet Moon e as atrizes Fernanda Torres, Mariana Ximenes e Cláudia Abreu participam de paródia do seriado e filme norte-americano As Panteras, filmada na Ilha Fiscal, no Rio de Janeiro.

Poucas bandas conseguem ter a trajetória contada por meio dos videoclipes de maneira tão contundente quanto os Titãs, que se valem deles para mostrar a mudança de estilo em cada álbum, indo da fase grunge e mais pesada até a mais pop e romântica dos discos mais recentes. Não é à toa que foram eles que mais 
vezes representaram o Brasil no VMA, antes do surgimento do VMB, com a indicação de Flores, em 1990, e de Será Que É Isso Que Eu Necessito em $1993^{227}$, que registra em preto e branco a apresentação da banda, com as imagens piscando e frenéticos movimentos de câmera. Essa produção foi dirigida por Beto Brant e Ralph Strelow que, no mesmo ano, realizaram, para a banda, Nem Sempre Se Pode Ser Deus, com ela tocando numa espécie de porão, várias dançarinas de pole dance e iluminação em tons vermelhos; e Taxidermia, bem frenético na mudança de planos que intercalam a imagem de pedaços de carne com o rosto do vocalista Paulo Miklos cantando diante de fundos de diferentes cores e embrulhado em papel alumínio.

Já na fase do VMB, os Titãs foram premiados uma única vez, com Epitáfio (2002), como melhor videoclipe de rock, melhor videoclipe do ano e escolha da audiência (essa produção será analisada com mais atenção no capítulo cinco, dedicado ao trabalho de Oscar Rodrigues Alves, que também trabalhou com a banda em Isso (2001), que mostra o vocalista Paulo Miklos contracenando com a elefanta Bambi e que também merecerá maior destaque no mesmo capítulo; Eu Não Sou Um Bom Lugar (2003), com cada integrante da banda tocando e cantando num lugar diferente e inusitado, como o vocalista Branco Mello embaixo da terra, o também vocalista Sergio Britto no topo de um prédio e o baterista Charles Gavin no meio da rua e na chuva; Enquanto Houver Sol (2003), que começa com um vulcão em erupção e depois mostra os integrantes da banda em imagens escuras com fundo preto e outras projetadas sobre eles; Provas de Amor (2004), com a banda tocando numa estação de metrô e dentro de um vagão, onde há vários casais; e Antes de Você (2009), filmado no centro de São Paulo, com vários anônimos com sacos de papel na cabeça, clara brincadeira com o título do álbum, Sacos Plásticos.

Se os Titãs não foram tão presentes e premiados no Video Music Brasil (VMB), foram um importante incentivo para impulsionar a carreira de várias outras bandas, assim como a produção nacional com o desenvolvimento de equipes especializadas em sua produção e geração de nicho de mercado para ela. $\mathrm{Na}$

${ }^{227}$ Os outros representantes brasileiros no VMA, antes da criação do VMB, foram Sepultura, com Orgasmatron (1991), dirigido por Adriano Goldman, que mostra em preto e branco a banda na estrada, nos bastidores e nos shows; e Territory (1994), que retrata o conflito entre Israel e os países árabes, justamente o tema da canção, mostrando paisagens e costumes, por meio de uma edição bastante ágil e frenética, e em meio aos integrantes da banda tocando em ruínas e sujos de lama; e Nenhum de Nós, com Ao Meu Redor (1992). 
opinião da vice-presidente da MTV norte-americana Rebecca Batties ${ }^{228}$, o resultado foi bastante positivo, pois, já em 1998, os videoclipes realizados no Brasil eram de qualidade equivalente aos da Europa e dos Estados Unidos. Com relação à quantidade, em 1996, foram realizados 1200 videoclipes, contra os 128 do início da MTV Brasil.

Se Ana Maria Bahiana ${ }^{229}$ reclamava, em 1986, da ausência de premiações que estimulassem a competição e, consequentemente, o desenvolvimento do mercado, o VMB abriu espaço para que profissionais da indústria fonográfica e aqueles envolvidos na realização dos videoclipes, além de estudiosos e críticos, pudessem, a convite da emissora, escolher as melhores produções de cada ano em diferentes categorias. Os telespectadores da emissora, no entanto, continuaram escolhendo, em eleição realizada por telefone e via Internet, o representante brasileiro para o VMA norte-americano.

Desse modo, o surgimento da MTV Brasil e a criação do VMB representaram um novo, vasto e importante espaço para a produção de videoclipes brasileiros, em função de que, pela primeira vez, essa produção tinha um espaço na televisão inteiramente voltado a sua exibição e, em consequência, destinado em tempo integral à música. Seus realizadores também passaram a ter o nome exibido nos créditos, o que Ihes deu maior prestígio tanto entre os colegas, quanto entre os outros profissionais de mídia e o público em geral, e a ser premiados e reconhecidos pelo trabalho realizado, o que incentivou com que desenvolvessem várias marcas autorais. Não é à toa, portanto, que alguns estudiosos consideram esse o acontecimento mais importante para a produção musical do Brasil desde os festivais de música popular da década de 1960, uma vez que, como estes, foi responsável por simular o que o público da emissora, considerado jovem, rebelde e irreverente, desejava, concentrando toda a produção musical voltada para ele, aproximando as diferentes tribos e criando um "padrão MTV de imagem".

Uma prova é que o videoclipe Me Beija (1998), dirigido por Roberto Berliner para o cantor e compositor Lobão ${ }^{230}$, hoje VJ da emissora, foi vetado em função de estar fora dos denominados padrões da MTV Brasil. Os profissionais da emissora,

\footnotetext{
${ }^{228}$ BATTIES, Rebecca. In. MASSON, Celso. Pílulas de cinema. In. Veja. Ano 31. №35. São Paulo, SP. Editora Abril. 02/09/1998, págs. 142 e 143.

${ }^{229}$ BAHIANA, Ana Maria. In. PEREIRA, Carmem. O Clip Brasileiro Não Presta. Por Quê? Bizz. Ano II. №8. São Paulo, SP. Abril. 03/1986, págs. 57 e 59.

${ }^{230}$ LOBÃO. In. LEONI. Letra, Música e Outras Conversas. Rio de Janeiro, RJ. Griphus. 1995, p. 147.
} 
no entanto, garantem que ela define a programação por meio da opinião dos diretores e, desde o início da década de 1990, é responsável pelo sucesso de uma música e de um artista ${ }^{231}$.

Outros videoclipes também deixaram de ser exibidos na emissora ou ficaram restritos a exibição após às onze horas da noite, caso de Legalize Já (1995), do Planet Hemp, dirigido por Márcia Leite, por ser considerado apologia às drogas; Don't Let Me Be Misunderstood (2000), do Edson Cordeiro, com direção de Ivy Abujamra e Thays Leite, por ter cena de sexo anal entre um homem e uma mulher; Caio no Suingue (2004), de Pedro Luís e a Parede, dirigido por Roberto Berliner; e Isso Aqui é Uma Guerra (1999), dirigido por Bruno Dragone para o grupo Facção Central, cuja fita foi recolhida na emissora pelo Grupo de Atuação Especial de Repressão ao Crime Organizado (GAECO), pelo fato de os rappers aparecerem como bandidos justiceiros, praticando sequestros relâmpago e assaltos a carros, bancos e residências, finalizados com verdadeiras chacinas. Por mostrar nu frontal da modelo carioca Andréa Guerra, o videoclipe Pedra, Flor e Espinho (1992), do Barão Vermelho, dirigido por Murilo Salles, só seria exibido à exaustão pela MTV Brasil após o sucesso da canção nas rádios.

A gerente de programação musical da emissora, Yone Sassa, conta:

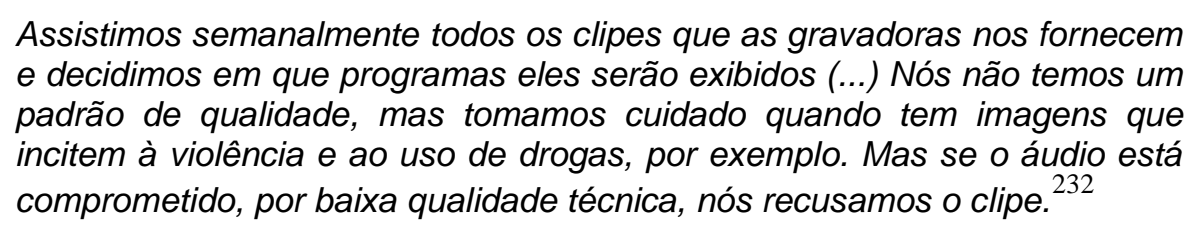

Alê Briganti, do departamento de relações artísticas da emissora, descreve a mesma situação:

Todos os videoclipes que chegam na casa - sem exceção - passam por uma reunião que acontece toda segunda-feira. Os clipes são avaliados por gerentes de todos os departamentos que decidem se estes se encaixam em nossa programação musical e em que programa tocariam. Não existe um cálculo ou porcentagem de clipes nacionais. Sempre damos grande destaque à produção nacional, até porque incentivamos o mercado brasileiro de videoclipes, que está cada vez mais antenado com o mercado

231 A marca MTV Brasil já foi responsável pela vendagem de uma série de produtos próprios, de revista mensal a CDs com as marcas Acústico MTV, MTV Ao Vivo e Balada MTV, entre outros, sendo que a maioria deles figurou na lista dos mais vendidos durante boa parte do ano passado.

${ }^{232}$ BRYAN, Guilherme. Videoclipe Brasileiro História, características e internacionalidade. Dissertação de Mestrado. ECA-USP. São Paulo, SP. 2005, p. 104. 
internacional, tanto em técnica, quanto em estética. Existem novos diretores incriveis. ${ }^{233}$

A sensualidade e o bom-humor em imagens vibrantes são as principais marcas dos videoclipes estrelados pela banda mineira Skank, uma das mais presentes no VMB. Em 1996, por exemplo, Garota Nacional, dirigido por Andrucha Waddington e Arthur Fontes, foi escolhido pela audiência como o melhor videoclipe do ano e premiado como melhor videoclipe pop. A produção contava com a participação das atrizes Carla Marins, Paloma Duarte, Ingra Liberato e Paula Bulamarqui, e de modelos com seios à mostra e em danças sensuais, com a banda tocando entre elas. Na época, citando esse videoclipe e Lourinha Bombril, dos Paralamas do Sucesso, alguns críticos apontaram uma tentativa do videoclipe brasileiro de abusar do aspecto sensual e vulgarizar o corpo feminino.

Outros videoclipes do Skank foram premiados, caso de É Uma Partida de Futebol (1997), como escolha da audiência e melhor videoclipe pop; o bemhumorado Mandrake e os Cubanos (1999), como melhor videoclipe do ano, melhor edição e melhor videoclipe pop, ambos dirigidos por Roberto Berliner; Saideira (1999), dirigido por Roberto Berliner e Raul Mourão, como melhor direção de arte, que mostra a banda tocando num bar de estrada, onde há os mais diferentes tipos de pessoas, que também assumem o microfone; Três Lados (2000), com direção de Roberto Berliner, como melhor videoclipe pop, que apresenta a banda tocando num galpão, intercalada com um casal que se encontra num quarto, onde a câmera adota o ponto de vista do rapaz; Dois Rios (2003), melhor videoclipe pop; Vou Deixar (2004), vencedor da mesma categoria, os dois dirigidos por Oscar Rodrigues Alves; e Sutilmente (2009), dirigido por Conrado Almada, como melhor videoclipe do ano, graças a um efeito visual impressionante provocado por uma câmera que mostra a vista aérea dos músicos tocando grudados em pé em altura bem elevada de uma parede e, abaixo deles, artistas com roupas de diferentes cores fazendo vários exercícios no solo do Ginásio Mineirinho, em Belo Horizonte (MG).

A Conspiração Filmes tornou-se a produtora mais vitoriosa do Video Music Brasil (VMB), com 32 prêmios, incluindo quatro consecutivos de melhor videoclipe do ano segundo o júri - Segue o Seco, Lourinha Bombril, Busca Vida e Ela Disse Adeus. Essa carreira vitoriosa se deve aos altos investimentos realizados nas

${ }^{233}$ Entrevista realizada para esta pesquisa em 23 de outubro de 2006. 
produções e também a um grande cuidado com fotografia, iluminação, edição e direção dos realizadores, que criaram ali diferentes identidades visuais, as quais mais tarde levaram para o cinema, criando um novo padrão de qualidade, baseado não mais no que desejavam as emissoras de televisão, mas, principalmente, o mercado consumidor. Se alguns estudiosos encontram aqui certa estetização de temáticas caras ao audiovisual brasileiro, o mesmo pode ser visto também como uma maior exigência com relação à qualidade necessária para competir de igual para igual com as melhores produções internacionais de videoclipe.

No final da década de 1990, a Conspiração Filmes revelaria novos profissionais, caso de Carolina Jabor e Mini Kerti, duas diretoras que se destacam pela aplicação de novas tecnologias para realizar verdadeiros experimentos audiovisuais em roteiros bastante inusitados, valorizando as figuras femininas. A primeira dirigiu, entre outros, Onda Diferente (2001), de Max de Castro, que mostra o cantor sendo socorrido após ter um ataque cardíaco, por meio de imagens que simulam esse órgão, a ambulância, a linha que registra os bastimentos cardíacos, raios-X e um apartamento pegando fogo, que simula atingir a película no final; $\boldsymbol{A}$ Noite (1999), de MV Bill, assinado com Rafael Dragaud e Mini Kerti, que mostra o rapper saindo de casa, circulando pelas ruas do Rio de Janeiro durante a noite, pregando como um pastor, sofrendo uma blitz da polícia e voltando para casa já durante o dia; e Dentro do Mesmo Time (2003), de Nando Reis, co-dirigido com Toni Vanzolini, em que o cantor aparece caminhando e dirigindo um carro feito em animação, em cenários que parecem maquetes de papelão e que são desmontadas constantemente para ganhar novas formas em seguida. A segunda é a diretora de, entre outros, Garganta (1999), de Ana Carolina, com a cantora tocando e cantando em ambiente externo rodeado de prédios, enquanto uma garota tem o vestido sendo descosturado conforme ela caminha, em função da linha com que era feito - citada na letra da canção - ter ficado presa na porta do quarto.

\subsection{Pop rock nacional dos anos 1990 e 2000}

O rock brasileiro não era mais o mesmo na década de 1990. De início, houve a tendência para se cantar em inglês, graças ao sucesso de bandas metaleiras como Sepultura, que utilizou os videoclipes também para divulgar as coleções de roupas inspiradas no visual dos fãs desse estilo musical e pertencentes à grife 
Cavalera, do baterista Igor Cavalera. As imagens sujas e agressivas, em meio a referências brasileiras reconhecidas internacionalmente, são as marcas das produções estreladas pela banda nessa época e dirigidas pela dupla Ricardo Della Rosa e Larissa Bogan, caso de Bullet The Blue Sky (2003), que apresenta o vocalista Derrick Green fugindo da polícia pedalando uma bicicleta e correndo a pé até saltar do topo de um prédio; e Mind War (2003), que começa com uma terapia em grupo e depois mostra a banda tocando num elevador fechado apenas por grades e uma luta de boxe entre duas garotas. Outras produções do Sepultura com as mesmas marcas são Roots Bloody Roots (1996), dirigido por Thomas Mignone, que começa com citação do poeta e romancista nigeriano Chinua Achebe e a sombra de rapazes jogando capoeira, depois mistura símbolos religiosos com a banda e o Olodum tocando; e Convicted In Life (2006), assinado por Luis Carone e vencedor de edição e direção no VMB, em que a câmera percorre rapidamente uma floresta, onde encontra a banda tocando e cerca de 20 figurantes com os corpos cobertos de lama como se estivessem em estado de putrefação e outros pregados em cruzes, misturados com muito sangue, mutilações, além de porcos sendo sacrificados.

O diretor Luís Carone explica a preferência pelos videoclipes:

Eu sempre tive vontade de fazer uma parada minha. Não curto muito a linguagem de curta. Longa é uma coisa absurda de se fazer, de qualquer jeito, e clipe é uma coisa que você já tem um caminho por seguir. Já tem uma música. Não fica tão complexo para você começar a construir alguma coisa (...) Mas clipe também é uma coisa ingrata, porque no Brasil você não vive disso. Principalmente eu que gasto 3 meses num clipe. Todo orçamento de clipe eu estouro na filmagem. ${ }^{234}$

Luís Carone chama atenção pela criatividade com que cria cenas inusitadas, mexendo nas imagens e inserindo efeitos especiais na pós-produção. Entre os videoclipes que realizou, estão o bem-humorado Fresh Fruit For Rocking Vegetables (2004), do Jumbo Elektro, em que uma cenoura realiza atividades do cotidiano humano, como levantar da cama, ir ao banheiro e pegar ônibus para ir à audição da banda, em que é bem recebida até ser arrastada por um coelho; e Você Sabe (2005), dos Autoramas, pastiche das corridas de autorama, trocadilho com o nome da banda, que aparece pilotando um dos carrinhos até sair da pista e invadir

\footnotetext{
${ }^{234}$ Trecho extraído do programa Bioclipe, exibido pela MTV Brasil em agosto de 2006.
} 
uma estrada. Essa produção fez com que Luís Carone se tornasse o mais jovem vencedor do prêmio de melhor direção no VMB, que também a premiou como melhor videoclipe independente e melhor edição.

Além do heavy metal e do rock and roll, aos poucos, as jovens bandas, sobretudo a partir do início da década de 1990, passaram a misturar forró com rock (caso dos Raimundos), maracatu com rock (como Chico Science \& Nação Zumbi), etc. Assim, foi criada uma música jovem especificamente brasileira, tentando superar a dicotomia entre o que é internacional e o que é nacional, firmando as intenções por meio dos videoclipes.

A banda Chico Science \& Nação Zumbi, por exemplo, encontrou nos videoclipes não apenas um espaço para representar em imagens a mistura do rock and roll com ritmos como maracatu, mas também para apresentar princípios estéticos, em que mostrava a força que tinha nas apresentações ao vivo, defendia as raízes culturais nordestinas e os avanços tecnológicos da cultura cibernética, uma das intenções do denominado movimento manguebeat. Entre as produções que estrelou, estão a já citada Manguetown; A Cidade (1994), dirigida por Guilherme Ramalho, que mistura o "boa noite" do palhaço Velho Faceta com imagens de animais como urubus e caranguejos, também em animação, e da banda no mangue; Maracatu Atômico (1996), dirigida por Raul Machado, em que os músicos aparecem cobertos pela lama do mangue, em cima do palco, durante um show, e com alegorias de maracatu realizadas por Mestre Salustiano; Macô (1996), que mostra a banda em imagens de diferentes formatos, granulações e cores, conta com a participação de Gilberto Gil; e Sangue de Bairro (1996), de Lírio Ferreira e Paulo Caldas, que mistura imagens das apresentações dos rapazes com outras do filme dirigido pela dupla - Baile Perfumado (1997) - do qual a música faz parte da trilha sonora e que mostra a história do bando de Virgulino Ferreira, o Lampião, por meio do fotógrafo e mascate libanês Benjamin Abrahão, famoso por registrar imagens dos cangaceiros.

Lírio Ferreira sempre demonstrou grande preocupação em valorizar as origens nordestinas e retratar as comunidades mais carentes, com qualidade artística e acabamento digno das melhores produções, além de várias referências cinematográficas. Isso pode ser verificado em videoclipes como Pelo Engarrafamento (2001), do cantor Otto, co-dirigido por Sérgio Oliveira, mostrando o cantor correndo pelas ruas do Rio de Janeiro até que, desta vez, é atropelado de fato 
por um ônibus e beijado por um anônimo, interpretado pelo ator Matheus Nachtergaele, numa referência ao filme Beijo no Asfalto (1980), de Bruno Barreto, adaptado da peça teatral homônima de Nelson Rodrigues; Pensar em Você (2000), do Chico César, que começa como um programa de rádio mostrando imagens do acampamento Dom Hélder Câmara, depois imagens em preto e branco do cotidiano das pessoas da comunidade e o artista cantando e tocando violão junto a elas; $\mathbf{E u}$ Não Esqueço Nada (2001), do Kid Abelha, inspirado no filme Asas do Desejo (1987), de Wim Wenders; Capa de Revista (2001), do Afroreggae, que mostra jovens armando revólveres na comunidade carente carioca de Vigário Geral, com Caetano Veloso em off mencionando a chacina de agosto de 1993, que resultou em vinte e uma mortes praticadas pela Polícia Militar, cujos corpos enfileirados são mostrados no vídeo, assim como os cantores caminhando pelo bairro; e Quem De Nós Dois (2001), de Ana Carolina, com um casal se separando e performance da cantora na rua, embaixo de chuva, e termina com citação do personagem G.H., de Clarice Lispector.

Se, em 2001, Lírio Ferreira retratou a morte de vinte e uma pessoas no bairro de Vigário Geral, no Rio de Janeiro, em agosto de 1993, no videoclipe Capa de Revista, do Afroreggae, em 1998, o diretor Maurício Eça, destacado nessa pesquisa, realizou o primeiro registro audiovisual no interior da Casa de Detenção de São Paulo, localizada no bairro do Carandiru - o videoclipe Diário de um Detento, do grupo de hip hop Racionais MC's, co-dirigido por Marcelo Corpani, premiado pela escolha da audiência e como videoclipe de rap no VMB, que será observado com mais atenção no capítulo seis.

Outro marco da preocupação social mostrada em videoclipes é $\boldsymbol{A}$ Minha Alma (A Paz Que Eu Não Quero), do grupo carioca O Rappa, dirigido, em 2000, por Kátia Lund, Breno Silveira e Paulo Lins, autor do romance Cidade de Deus (2002), nome do conjunto habitacional carioca que serve como cenário para aventuras envolvendo o tráfico de drogas, nas décadas de 1960 e 1970. O livro foi adaptado para o cinema em 2002, por Fernando Meirelles e pela própria Kátia Lund, co-diretora do curta-metragem Palace II (2001), piloto do filme Cidade de Deus ${ }^{235}$, e diretora do documentário Notícias de Uma Guerra Particular (1996).

${ }^{235}$ O filme Cidade de Deus rendeu um CD multimídia com videoclipes para remixes eletrônicos da trilha musical criados por VJs, como Alexis e Ernani Pelúcio, a partir de imagens originais disponibilizadas pela própria produtora do filme $\mathrm{O} 2$. 
O vocalista de O Rappa, Falcão, comenta o videoclipe:

\begin{abstract}
Eles estavam muito determinados a tirar daquela música, A Minha Alma, uma coisa em imagem muito perto do que a gente sempre falava que gostaria que tivesse - uma atitude da galera mesmo com um fato de covardia que tivesse acontecido na comunidade. ${ }^{236}$
\end{abstract}

No videoclipe A Minha Alma (A Paz Que Eu Não Quero), o personagem principal e o único com nome da produção, o garoto de óculos Gigante, quer ir à praia com os amigos, que moram no morro. Porém, quando eles chegam ao "asfalto", o que poderia ser interpretado como gesto de educação de um rapaz que apanha uma nota de dinheiro no chão para devolver ao homem que a deixou cair, transforma-se em razão para ele e os companheiros serem tomados como bandidos e agredidos por policiais. Um dos garotos é assassinado, provocando revolta de membros da comunidade que descem o morro praticando saques, destruindo tudo o que encontram pela frente e colocando fogo num carro, com o apoio dos integrantes da banda que, até então, permaneciam olhando tudo incrédulos da mesa de um bar. Com fotografia que parece sufocar o espectador, tudo ganha ainda mais força através dos olhos de uma criança nas imagens em preto e branco. Muitos jovens atores presentes no videoclipe, premiado como escolha da audiência, videoclipe do ano, videoclipe de rock, direção, fotografia e edição no VMB, terão papéis importantes depois no longa-metragem ficcional.

A estética de videoclipes como Diário de um Detento e A Minha Alma é explicada por Ivana Bentes:

\begin{abstract}
Uma música e uma imagem de "protesto" criadas por jovens vindos das favelas e periferias e que funciona hoje como um contradiscurso. Agressividade juvenil, traduzida não apenas nas letras das músicas, na moda - gorros enterrados na cabeça, "manos" e tatuagens no "estilo Carandiru" - mas encarnada num discurso comunitário e coletivo carregado de legítima ira social, que exige e canta mudanças. Da moda ao ativismo, da "atitude" à música e ao discurso políticos, vemos emergir novos sujeitos, que saem dos territórios reais, morros, periferias, guetos, e ascendem à esfera midiática, trazendo o germe de um discurso político renovado, que não se enquadra nas instituições tradicionais - Estado, partido, sindicato, movimento estudantil, está mais próximo da cultura urbana jovem: música, show, TV, internet, moda. ${ }^{237}$
\end{abstract}

${ }^{236}$ Depoimento dado ao especial de 15 anos da MTV Brasil, exibido em outubro de 2005.

237 BENTES, Ivana. Sertões e Favelas no Cinema Brasileiro Contemporâneo. In. BENTES, Ivana (org.). Ecos do Cinema de Lumière ao digital. Editora UFRJ. Rio de Janeiro, RJ. 2007, págs. 222 e 223. 
Ao longo da carreira, a banda carioca O Rappa provaria estar preocupada em utilizar os videoclipes não apenas para apresentar ao público novas canções e álbuns, mas também manifestar forte preocupação social para jovens que se unem mais em torno dos interesses culturais do que pelas antigas formas de organizações sociais. Não à toa, a banda é a segunda mais premiada na história do VMB, com 13 estatuetas. Outras produções premiadas foram O Que Sobrou do Céu (2001), filmada em Belford Roxo, no Rio de Janeiro, e dirigido por André Horta e Kátia Lund $^{238}$, como videoclipe do ano, direção e fotografia, ao mostrar o sequestro de um possível empresário, que é colocado num cativeiro instalado na casa de uma família carente, cujo chefe é envolvido de modo forçado e, no final, quando a polícia estoura o cativeiro, é salvo pelo sequestrado; Instinto Coletivo (2002), do diretor Jarbas Agnelli, animação feita em computador com a letra da canção escrita na tela e vários ruídos nos desenhos do boneco, presente na arte gráfica do disco de mesmo nome e ao vivo, jogando capoeira e sambando, premiada como melhor direção e direção de arte; e O Salto (2004), realizado por Bruno Murtinho e Sérgio Schmid, que mostra um homem prejudicado pelo congelamento da caderneta de poupança praticado pelo então presidente Fernando Collor de Mello e que acaba cometendo suicídio. Foi premiado como melhor direção e edição.

A banda brasiliense Raimundos, marcada pelo denominado forrock (mistura de rock com forró), também ganhou destaque com videoclipes sempre marcados pelo bom-humor de estilo pastelão, abusando dos pastiches e retomando um pouco a estética desenvolvida para as bandas de rock dos anos 1980. Esse é o caso de, entre outros, A Mais Pedida (1999), dirigido por José Eduardo Belmonte, vencedor da escolha da audiência no VMB, em que os garotos fingem ser uma banda de pagode e brincam com todos os clichês do estilo. São enganados por um empresário inescrupuloso, caindo nas graças de uma fã, interpretada pela cantora Érika, que faz com que eles sejam tocados na rádio, apresentem-se em programa de auditório bem popular e estampem a capa das principais revistas e jornais do país, com nomes ligeiramente modificados. No final, eles imitam a banda norte-

\footnotetext{
${ }^{238}$ Kátia Lund também dirigiu o videoclipe Traficando Informação (1992), de MV Bill, que começa com as imagens de cartão-postal do Rio de Janeiro até a câmera fazer um grande plano aéreo na Cidade de Deus e serem mostradas imagens de uma briga entre jovens moradores, como se tivessem sido registradas de maneira amadora, em meio a desenhos e artista interpretando a canção e caminhando pela comunidade.
} 
americana de punk rock Ramones, como fizeram no início da carreira. E Mulher de Fases (1999), também dirigido por José Eduardo Belmonte, que foi escolhido o melhor do ano pela audiência e melhor videoclipe de rock. Brinca com o estilo country dos rodeios e dos peões de boiadeiro com os cenários de espetáculos teatrais para o público infantil.

Esse bom humor e a valorização da caracterização dos integrantes dos Raimundos em personagens permaneceram nos videoclipes que Raul Machado realizou para eles. Esse é o caso de Eu Quero Ver o Oco (1995), que destaca, em diferentes formatos, iluminação e granulações, a banda em vários cenários, como um ferro-velho e uma parede com grafitti, na qual tomam uma geral da polícia; e Me Lambe (1999), assinado também pelo consagrado fotógrafo de revistas J.R. Duran, que começa com o guitarrista Digão enganando crianças ao levantar peso falso e, depois, mostra os rapazes numa festa rodeados de garotas, o vocalista Rodolfo com uma delas na roda-gigante, como citado na letra da canção, e termina com todos eles presos, fazendo trabalho forçado.

No entanto, as marcas autorais mais fortes de Raul Machado são a utilização de recursos como a tela dividida em várias partes e a câmera girando em torno dos músicos. Tais características são encontradas em videoclipes como Malungo (1998), da Nação Zumbi, com a tela dividida em diferentes partes e cores, em imagens que valorizam sombras e distorções; Apostas e Certezas (2005), do CPM 22, com a banda tocando na chuva em imagens em preto e branco até que o sol sai e as imagens ficam coloridas; e Não Vou Ficar (2005), do Forgotten Boys, também assinado por Cadu Porto, com a tela dividida em quatro partes, ora horizontais, ora verticais, sendo que cada uma focaliza um ângulo diferente da banda tocando em estúdio com fundo preto.

Para a banda carioca Planet Hemp, Raul Machado realizou três videoclipes Dig Dig Dig (Hempa) (1995), com a câmera focalizando os integrantes da banda, sobretudo o vocalista Marcelo D2, de baixo para cima ou em closes extremamente aproximados; Queimando Tudo (1997), que começa com animações do desenhista Speto de pessoas num bar e, depois, mostra Marcelo D2 sentado num guindaste e caminhando pelas ruas do Rio de Janeiro; e Ex-Quadrilha da Fumaça (2000), codirigido por Kátia Lund e Eduardo Kurt, que faz uma brincadeira com a Esquadrilha 
da Fumaça, nome popular do Esquadrão de Demonstração Aérea (EDA) ${ }^{239}$ (um grupo de pilotos e mecânicos da Força Aérea Brasileira que realizam demonstrações de acrobacias aéreas), ao colocar macacos para pilotar aeronaves e saltar de páraquedas, e também com os figurinos típicos do hip hop utilizados pelos integrantes da banda, perseguidos por macacos-policiais.

Marcelo D2 comenta o trabalho com Raul Machado: "É sempre legal fazer clipe com o Raul (...) Você fala: 'Vamos fazer clipe tipo Janete Clair de ácido'. Ele: 'Boa ideia. Todo mundo de roupa assim'. 'Caramba, o diretor levou a parada para cima (risos)". Os dois voltaram a trabalhar juntos quando o diretor realizou um videoclipe para cada uma das 13 faixas do disco solo de D2, Eu Tiro É Onda (1998), com destaque para 1967, com a letra da canção na tela e várias imagens sobrepostas do cantor em diferentes cenários do Rio de Janeiro; e Samba de Primeira, que começa com imagens do carnaval carioca exibidas no filme Orfeu Negro (1959), do francês Marcel Camus, e depois mostra o cantor em estúdio com fundo branco cantando e junto com DJs e mulatas, simbolizando a mistura de samba e funk, justamente o que preconizava no álbum.

A realidade da cidade do Rio de Janeiro e as referências à estética hip hop e ao cinema são a tônica dos videoclipes dirigidos pelo paulista Johnny Araújo para o carioca Marcelo D2 - Qual É? (2003), que mostra o cantor saindo de casa no bairro onde mora, em meio à imagem de vários moradores, cantando no meio da rua, cortando o cabelo e participando de roda de samba com Bezerra da Silva, Arlindo Cruz e Falcão, do Rappa. A inspiração é o filme Faça a Coisa Certa (1989), de Spike Lee. O trabalho foi premiado no VMB como melhor direção, melhor videoclipe de rap e melhor videoclipe segundo os jurados; Loadeando (2004), que marca um desafio de dança entre a turma do cantor e a turma do filho Stephan, formadas por b-boys, dançarinos de rap, da mesma faixa etária, num prédio abandonado e numa pista de dança e que levou os prêmios de fotografia, melhor videoclipe de rap e melhor videoclipe do ano; e Dor de Verdade (2007), assinado também por Jacques Cheviche, que começa com imagens em preto e branco da baía de Guanabara, mostra o cantor e vários dançarinos no estúdio com fundo ora branco, ora preto, e

\footnotetext{
${ }^{239}$ A Esquadrilha da Fumaça foi citada também no videoclipe Todo Errado (2002), dirigido por Mauro Lima, para Caetano Veloso e Jorge Mautner, com este dentro de um avião que a produção leva a crer estar fazendo acrobacias, junto com outras aeronaves, e o outro cantor numa torre de controle de vôo.
} 
presta homenagem ao mesmo sambista Bezerra da Silva, falecido dois anos antes, com a participação de Arlindo Cruz e Zeca Pagodinho e partes da letra da canção escritas na tela.

Johnny Araújo explica seu método de trabalho:

Todos os videoclipes que eu faço são roteirizados. A maioria pelo diretor que está realizando o trabalho e, algumas vezes, em parceria com o artista, o que é bem legal. Para mim, é fundamental o roteiro, como num curta ou longa-metragem. Eu sempre faço um layout do clipe. Você pensa num roteiro, ouve a música muitas vezes e busca referências visuais para $o$ trabalho. Depois, vem a parte do orçamento. Você viabiliza a ideia com o custo do vídeo e, nesse momento, o roteiro sofre algumas alterações para se adequar à verba disponível. ${ }^{240}$

Cuidado especial ao trabalho de câmera e a valorização das cores das imagens são as marcas autorais de Johnny Araújo em videoclipes como Zóio de Lula (1999), do Charlie Brown Jr., que mostra os integrantes da banda andando de skate em diferentes ambientes, tocando à beira-mar, tomando sol e paquerando uma garota; Tamo Aí Na Atividade (2004), também do Charlie Brown Jr., no qual a câmera adota o ponto de vista dos pés de um skatista, enquanto os integrantes da banda comentam em off a relação entre o esporte e a música; Um Minuto Para 0 Fim do Mundo (2005), do CPM 22, que começa com dois jovens com asas de anjo e depois trata da história desse casal, com referências ao filme Asas do Desejo (1987), de Wim Wenders; e Fly (2009), da Wanessa Camargo, assinado também por Gustavo Bonafé, que conta com a participação do rapper norte-americano Ja Rule, cantando diante de prédios durante o dia, enquanto Wanessa ocupa o mesmo cenário durante a noite, até os dois dançarem juntos na boate Club Royal, em São Paulo.

A proximidade entre cinema e videoclipe no Brasil não se restringe apenas às citações, uma vez que muitos cineastas também se exercitaram nesse formato audiovisual, até como modo de arejar suas produções. Esse é o caso de Monique Gardenberg, diretora de Jenipapo (1996), Benjamin (2003) e Ó Paí, Ó (2007), que adotou, nos videoclipes, recursos tipicamente cinematográficos e o ponto de vista do intérprete das canções. Entre eles, estão Amor, Meu Grande Amor (1996), do Barão Vermelho, que intercala imagens da banda em dois ambientes diferentes

\footnotetext{
${ }^{240}$ Trecho não utilizado de entrevista para dissertação de mestrado Videoclipe brasileiro - História, características e internacionalidade. ECA-USP. São Paulo, SP. 2005
} 
entre as paredes de uma sala, onde um casal se relaciona amorosamente e depois corta o cabelo e o descolore; Não Enche (1998), do Caetano Veloso, em que a câmera assume o papel da amante do cantor, que aparece deitado numa cama e começa a "reclamar" a letra da música, olhando para ela e caminhando pelos ambientes do lugar até sair de uma grande caixa metálica; e Consumado (2004), para Arnaldo Antunes, plano-sequência que começa com o cantor sentado na janela de um casarão, depois caminhando e dançando com figuras inusitadas, como bailarinas e gêmeas cantoras, até chegar ao filho Brás, que simula tocar guitarra.

Monique Gardenberg comenta a importância da relação entre cinema e videoclipe: "No Brasil, é saudável que o cineasta tenha uma segunda profissão, porque é muito difícil fazer cinema. Como não quero mudar de país, procuro outras atividades, como fazer videoclipes"241. Já Arnaldo Antunes, que trabalhou com ela e para quem videoclipe é o jeito mais moderno de se ouvir música, analisa a relação com os diretores: "Gosto de participar da elaboração do roteiro, dou muita ideia. Sempre escolho diretores que me dão liberdade para opinar. Tanto o clipe quanto a gravação têm de ser divertidos, prazerosos". 242

Outra cineasta que trabalhou com Arnaldo Antunes foi Laís Bodanzky, diretora dos longas-metragens Bicho de Sete Cabeças (2001), Chega de Saudade (2008) e As Melhores Coisas do Mundo (2010). Para o cantor, ela dirigiu as duas versões do videoclipe Essa Mulher (2002), sendo que a escolhida pelo público para ser a oficial também recebeu o Prêmio Multishow de melhor videoclipe do ano. Nas duas versões, Arnaldo Antunes espalha pelo apartamento onde está a atriz Vanessa Gerbelli, objetos com a sua cara, criados pela fã Cássia Macieira e aos quais a atriz não dá importância. Ele dialoga com uma marionete com as suas feições feitas pelo bonequeiro Cláudio Santini e dança vestido de boneco. A principal diferença entre as duas versões é que, em uma, Vanessa sai de casa sozinha e, na outra, Arnaldo Antunes chega para buscá-la.

Portanto, assim como na produção internacional, muitos cineastas brasileiros encontraram no videoclipe um espaço para arejar o trabalho e experimentar novas linguagens, técnicas e tecnologias. No entanto, para Rogério Gallo, um dos

${ }^{241}$ NAGIB, Lúcia. O Cinema da Retomada Depoimentos de 90 cineastas dos anos 90 . Editora 34. São Paulo, SP. 2002, p. 219.

242 MARCHETTI, Paulo; e GOMYDE, Heloisa. Bonecos de Cena. Revista da MTV. São Paulo, SP. no7, 12/2001, p. 53. 
responsáveis pela implantação da MTV no Brasil, esses diretores criativos e de reconhecíveis trabalhos autorais são exceções no videoclipe brasileiro:

Existem diretores, sem dúvida, que fizeram trabalhos muito interessantes. Mas acho que são bastante pontuais. Como conjunto, falta experimentação, ousadia e criatividade. A grande maioria dos clipes é apoiada numa fórmula bastante repetitiva, recorrendo mais ou menos aos mesmos truques e, nesse tipo de conduta, perde a oportunidade de fazer experimentações radicais, que é para isso que o videoclipe pode servir. Acho que é um tipo de mídia onde se pode experimentar como, às vezes, na publicidade e na própria televisão não se pode. Então, acho que é uma perda e, no conjunto, encontro uma produção bastante conservadora. ${ }^{243}$

A vocalista da banda mineira Pato Fu, Fernanda Takai, explica o que costuma ser mais comum na relação entre esses diretores e os intérpretes das canções com os quais trabalham:

Às vezes, temos uma ideia e a desenvolvemos com os diretores escolhidos por nós; outras vezes, deixamos totalmente em aberto, apenas dizendo o que a gente não gostaria que fosse o caminho tomado, por exemplo. ${ }^{244}$

Prova é que a banda Pato Fu trabalhou com os mais diferentes diretores, demonstrando estar sempre aberta aos experimentalismos e invencionices que eles propusessem, desenvolvendo, assim, intensa relação autoral com eles. Ao mesmo tempo, também se tornou uma das bandas que soube melhor aproveitar o videoclipe para criar identidade visual com o público, sempre associada a algo bem-humorado e, ao mesmo tempo, inventivo e inusitado. É justamente o que se encontra no democlipe O Processo de Criação Vai de 10 Até 100 Mil (1993), com temas que retornariam nas produções seguintes da banda, caso das sobreposições, transparências e interesse por imagens relacionadas ao corpo humano, apesar de aqui o tema mais recorrente ser notas de dinheiro. Outros videoclipes marcantes na trajetória da banda foram Sobre o Tempo (1994), dirigido por Eduardo de Jesus e Rodolfo Magalhães, com várias imagens sobrepostas da banda em diferentes ambientes, como um sofá e um pneu num lago, e que venceu o VMB de banda revelação; Qualquer Bobagem (1994), de Eduardo Climachavska, em que os rapazes aparecem dentro de um carro e interpretam mecânicos que confundem a madame interpretada por Fernanda Takai com uma cangaceira; Made in Japan

${ }^{243}$ Entrevista dada para esta pesquisa em 2006.

244 TAKAI, Fernanda. In. LIMA, Vanessa. Entrevista: Fernanda Takai. São Paulo, SP. Ainda? Fanzine Oficial. n-4. Quanta. Maio/2003, p. 11. 
(1999), vencedor do VMB de melhor direção de arte, que começa com imagem de explosão e velocidade acelerada nas ruas de uma cidade até chegar numa fábrica onde está sendo construído um robô gigante no estilo do brinquedo Transformers, no interior do qual aparece a vocalista Fernanda Takai cantando em japonês ${ }^{245}$, vestida de astronauta e controlando as estrepolias que o robô faz em ambiente externo, até lutar contra outro robô, controlado pelos outros integrantes da banda; e Eu (2001), assinado por Luiz Ferre, que conta com a participação de André Abujamra como ator e mostra o que poderia ter sido a primeira apresentação secreta do teremim, um dos primeiros instrumentos musicais completamente eletrônicos, que produz som sem qualquer contato físico e foi inventado em 1919 pelo russo Lev Sergeivitch Termen, raptado, em 1938, pela KGB, principal agência de informação e segurança da antiga União Soviética,

Em 2005, o Pato Fu tomou uma atitude praticamente inédita ao convidar diferentes diretores para dirigir um videoclipe para cada uma das 13 faixas do disco Toda Cura Para Todo Mal, de 2005. Entre eles, estavam Roberto Berliner e Duda Pessoa, com Sorte e Azar, em que são exibidas imagens de arquivo da banda e outras gravuras, envelhecidas digitalmente e nas quais foram inseridos ruídos e desenhos; o cartunista Laerte, diretor da animação Uh Uh Uh La La La La lé lé!, que retrata grande congestionamento com vários animais nos carros e em locais próximos, como a calçada e um bar; e Jarbas Agnelli, com Anormal, que simula imagens de raios- $X$ animadas dos mais diferentes objetos, animais e até mesmo dos integrantes da banda tocando e cantando, e que foi eleito melhor direção de arte no VMB daquele ano.

${ }^{245}$ Em carreira-solo, Fernanda Takai fez sucesso com a versão em japonês de $\boldsymbol{O}$ Barquinho, clássico da Bossa Nova, chamada Kobune, que ganhou, em 2007, um videoclipe dirigido por Giuliano Chiaradia e Paula Padilha, que mostra a cantora em preto e branco caminhando numa praia e folheando um livro que a mostra no mesmo lugar, com a imagem recebendo várias interferências visuais e gráficas, como desenhos, e iluminação que remete a filmes da primeira metade do século XX. 


\subsection{Abril Music e Outros Ritmos e Estilos Musicais}

No início da década de 1990, o rock and roll perdeu a hegemonia quase completa que havia conquistado na década anterior nos meios de comunicação para cantores sertanejos e bandas de axé music. Coube, então, às gravadoras acreditar no potencial mais amplo de artistas já plenamente testados em seus próprios ambientes, fosse num rodeio ou em cima de um trio elétrico.

No caso específico da axé music, as performances que artistas e bandas criavam para suas músicas vinham ao encontro da nova realidade exigida pelos grandes meios de comunicação, especialmente pela MTV Brasil. O desafio da indústria fonográfica era criar um espetáculo televisivo com o mesmo poder de magnetismo exibido pelos cantores-dançarinos dos Estados Unidos, como os ídolos pop Madonna e Michael Jackson. Daí, então, torna-se fácil explicar a rápida popularidade na emissora de artistas como Daniela Mercury que, ao longo da carreira, vendeu mais de 12 milhões de discos no mundo todo e estrelou videoclipes como O Canto da Cidade (1992), dirigido por Patricia Prata, com a cantora andando pelas ruas de uma cidade e dançando em cenário, em imagens com diferentes cores e granulações; Nobre Vagabundo (1997), dirigido por Gringo Cardia e premiado como melhor fotografia no VMB, com a artista cantando e dançando num banheiro, num matagal e no meio de pessoas sujas de lama; e llê Pérola Negra (2000), eleito melhor videoclipe de axé no VMB, com produção bastante plástica da cantora dançando com panos, em dunas, à beira-mar com figurantes e numa cabana.

Com a popularidade desses novos ritmos e movimentos musicais, a MTV Brasil entrou num dilema do qual nunca conseguiu sair de maneira plenamente satisfatória: videoclipes mais populares devem ou não ser exibidos pela emissora? Em março de 1999, a emissora, que atingia mais de 16 milhões de residências de 200 municípios do país, resolveu, então, abrir espaço na programação para outros ritmos, como axé, samba, pagode e MPB, com categorias específicas no VMB, que seguiram por três anos. E obteve resultados muito positivos - segundo a própria emissora, apenas em 1999, a audiência e o faturamento cresceram $62 \%$ e $35 \%$, respectivamente. No primeiro ano, o já comentado Carioca, de Chico Buarque, foi premiado como melhor videoclipe de MPB; Vai Vadiar, de Zeca Pagodinho, com direção de João Elias Junior, melhor videoclipe de pagode; e Carro Veho, da Banda Eva, dirigido por Monique Gardenberg, espécie de cartoon com a cantora pilotando 
um carro na estrada e passando por várias situações citadas na letra como flertar com vários rapazes, melhor videoclipe de axé.

Em 2006, o diretor geral da MTV Brasil, André Mantovani, explicava:

\begin{abstract}
A gente não tem restrições quanto à exibição de videoclipes dentro da nossa linha editorial, dentro daquilo que a gente se propõe exibir ou não, e não tem nada que ver com democracia. É um canal de televisão que exibe o que acha que tem que exibir. Eu não passo música sertaneja, por exemplo, porque eu acho que não cabe aqui, ou música gospel. ${ }^{246}$
\end{abstract}

Por sua vez, a diretora de marketing Márcia Santos explica a estratégia da maioria das gravadoras:

\begin{abstract}
Um videoclipe hoje (2004), no Brasil, tem maior ou menor importância, dentro do trabalho de promoção, de acordo com o segmento do artista. Como os principais canais para rotação de um videoclipe são hoje a MTV e o Multishow, os clipes nos estilos pop, rock, hip hop e orientados para o público jovem são uma grande ferramenta para o trabalho da música e imagem do artista. Já os artistas mais populares, como os românticos, sertanejos e, em alguns casos, até os de MPB, acabam tendo uma forma mais restrita de divulgação através do videoclipe ${ }^{247}$.
\end{abstract}

A abertura da MTV Brasil para novos estilos e ritmos tinha uma finalidade também comercial para o grupo Abril, que administrava a emissora, e criou, em julho de 1998, a gravadora Abril Music, a qual passou a contar com artistas dos mais diferentes segmentos musicais. O objetivo era competir num mercado que, em 1997, tinha o sexto maior faturamento do mundo e crescia mais de $30 \%$ ao ano. Quando encerrou as atividades, em 2003, a gravadora ocupava a sétima posição no mercado nacional, controlando 4,7\% do mercado, segundo a Associação Brasileira dos Produtores de Discos (ABPD).

Nesse período, a gravadora Abril Music lançou mais de 800 títulos, entre CDs e DVDs, de 38 artistas, como Gal Costa, Rita Lee, Titãs, Capital Inicial e Ultraje a Rigor, duas bandas que, na época, tiveram a carreira recuperada. Todos eles venderam milhões de cópias dos álbuns resultantes do projeto Acústico, da MTV Brasil, e estrelaram vários videoclipes de sucesso, como já observado neste capítulo. A gravadora também revelou, entre outros, a dupla sertaneja Bruno \&

\footnotetext{
${ }^{246}$ MANTOVANI, André. In. PEDROSO, Maria Goretti; e MARTINS, Rosana (org). Admirável Mundo MTV Brasil ..., p. 7.

${ }^{247}$ BRYAN, Guilherme. Videoclipe Brasileiro História, características e internacionalidade. Dissertação de Mestrado. ECA-USP. São Paulo, SP. 2005, p. 102.
} 
Marrone, o grupo de rock Los Hermanos, o cantor de forró Frank Aguiar, o cantor de pop romântico Maurício Manieri e a banda de forró universitário Falamansa, que vendeu mais de 1 milhão de cópias, também graças ao sucesso do videoclipe Rindo A Toa / Xote dos Milagres (2000), de João Elias Junior, que faz referências à internet e mostra os integrantes tocando e cantando em barraca de praia, com jovens dançando e se divertindo.

A Abril Music saiu de cena em 2003, quando as vendagens de discos sofriam uma queda vertiginosa, principalmente em função dos downloads não-pagos da internet e da pirataria. Segundo pesquisa da Federação do Comércio do Estado de São Paulo (Fecomercio-SP), em 2002, o comércio varejista de CDs faturara 39\% menos do que em 2001. Ao mesmo tempo, em 2002, a MTV era vista por cerca de 3,5 milhões de jovens, de 15 a 29 anos, das classes A e B, segundo o Instituto Brasileiro de Opinião Pública e Estatística (Ibope).

Antes disso, entre 1999 e 2003, a Abril Music teve o selo musical Deckdisc, que depois se tornaria uma das primeiras gravadoras independentes do país. Além dessa relação comercial que o aproximava da MTV Brasil, o selo teve laços muito mais estreitos com a emissora, em função de ter sido fundado e administrado por João Augusto, pai do VJ Rafael Ramos, que fez parte da banda Baba Cósmica e que se tornaria produtor da maior parte dos novos artistas de rock lançados por ali, caso de, entre outros, Dead Fish, Cachorro Grande, Matanza e a cantora Pitty. Não à toa, muitos deles foram premiados ou pelo menos indicados nas principais categorias do VMB.

A cantora baiana Pitty é a campeã de prêmios no VMB, quinze no total, empatada com os Paralamas do Sucesso, e sempre faz questão de aparecer em situações inusitadas nos videoclipes. É o caso de Teto de Vidro (2003), dirigido por Mauício Eça, que mostra a cantora em ação no estúdio e andando pela rua, desenrolando novelo de lã e passando por pessoas que andam para trás com o rosto desconfigurado; Admirável Chip Novo (2003), também com direção de Maurício Eça e escolhido pela audiência como melhor videoclipe do ano de 2004, em que a cantora aparece com vestido de época, agindo como robô, de acordo com o que é mencionado na letra, com roupa preta curta, dançando como faz nos shows; Memórias (2005), de Ricardo Spencer e Alexandre Guena, vencedor do Prêmio Multishow de melhor videoclipe e escolha da audiência no VMB, com ares de filme de terror, com a cantora e os músicos que a acompanham num casarão 
abandonado, fazendo o "jogo do copo" e encontrando fantasmas, como mencionado na letra da canção; Déjà Vu (2006), melhor videoclipe de rock no VMB, dirigido por Ricardo Spencer, que mostra a cantora caminhando pelo centro de São Paulo em câmera lenta e em imagens em preto e branco, acompanhada por vários figurantes, até chover e as imagens ficarem coloridas; Na Sua Estante (2006), animação dirigida por Sérgio Guilherme Filho e Thalita Galvani, eleito melhor videoclipe tanto no VMB, quanto no Prêmio Multishow, e que mostra um homem de lata correndo com um coração dependurado no pescoço, sofrendo uma desilusão amorosa, parando no ferro velho e se transformando numa bicicleta; De Você (2008), melhor videoclipe no $\mathrm{VMB}$, dirigido por André Moraes e paródia de filmes de terror como $\boldsymbol{A}$ Noite dos Mortos Vivos (1968), de George A. Romero, que mostra a criatura se rebelando contra o criador e libertando outras iguais, como a própria cantora; e Me Adora (2009), dirigido por Ricardo Spencer, eleito melhor videoclipe no Prêmio Multishow e que apresenta a cantora na sala de uma casa rodeada e adorada por vários jovens.

Maurício Eça explica quais são as vantagens de se trabalhar com bandas e artistas iniciantes, como a Pitty, e fazer democlipes:

\begin{abstract}
A gente tem tanta necessidade de vender um disco de uma banda que já é famosa, como de lançar ou de dar uma cara para uma banda que ninguém conhece. Às vezes é até muito mais importante fazer um clipe de uma banda demo do que de uma banda consagrada, porque aquilo pode matar ou ajudar a carreira de alguém. Também é muito mais legal, às vezes, fazer um clipe demo, porque são pessoas que não têm vícios, nem problemas. Estão ali confiando muito em você, botando uma responsabilidade bacana, porque te admiram e respeitam. Tem frescor e paixão muito maiores. ${ }^{248}$
\end{abstract}

\title{
3.10 O Fim do Videoclipe?
}

Em dezembro de 2006, o diretor de programação da MTV Brasil, Zico Góes, tomou uma decisão bastante polêmica: dedicar atenção total aos programas de variedades, como os de auditório, entrevistas, debates, documentários e reality shows, e excluir da programação diurna da emissora os videoclipes, que, segundo ele, tinham se mudado para a Internet. Por isso, ele resolveu investir também num local exclusivo para essas produções, o portal MTV Overdrive, que entrou no ar em

\footnotetext{
${ }^{248}$ Entrevista fornecida para essa pesquisa entre 2006 e 2009.
} 
25 de agosto de 2006, com videoteca de seis mil títulos, para concorrer com o Youtube, apontado como responsável por transmitir produtos da emissora ilegalmente. Por sua vez, as emissoras Multishow, MixTV e PlayTV foram ampliando o espaço dado aos videoclipes, assim como VH1, transmitido pelo sistema Sky de TV por assinatura via satélite.

André Mantovani, diretor-geral da MTV Brasil, comentava na época ${ }^{249}$ que não era mais papel social da emissora exibir videoclipes, mas, sim, comentá-los, assim como o trabalho dos artistas. Zico Góes acrescentava:

\begin{abstract}
A gente vai ter mais espaço para músicos no ar, vamos deixar de rodar videoclipes. Alguns programas vão morrer, como o ícone da MTV, o Disk. $O$ consumo de clipes, as listas são muito mais imediatas nesse mundo digital do que no ar. O jovem não quer ver três minutos de clipe, depois mais três. Ele quer ver televisão, uma história bem contada. Clipe tem no YouTube, no Overdrive também. O programa de clipe, com VJ apresentando, esse morreu. Eles estarão na madrugada, porque preciso manter a programação 24 horas no ar. Na programação, só estarão a serviço do formato dos programas. Só clipe não dá audiência. ${ }^{250}$
\end{abstract}

Zico Góes não deixa de ter razão, uma vez que, hoje, muitos videoclipes fazem sucesso primeiro na internet, principalmente em sites como Youtube. Um exemplo é o videoclipe não oficial da música Music Is My Hot Hot Sex, da banda brasileira Cansei de Ser Sexy, que mostra os músicos em estúdio com imagens que mudam de cor e granulação o tempo todo, e que, em março de 2008, gerou uma das maiores polêmicas da história do site. A razão é que ele contava então com inexplicáveis mais de 114 milhões de acessos. Foi o suficiente para surgir a desconfiança de uso de sistemas automáticos para aumentar o número de visitas de modo automático e ilegal. O videoclipe, então, foi removido temporariamente.

As produções caseiras são uma tendência importante na internet, em que qualquer pessoa com uma câmera portátil pode se tornar realizadora de um videoclipe. Desse modo, torna-se mais importante o talento do que o acesso a tecnologias muito sofisticadas e caras. Um dos melhores exemplos no país é o do realizador Vras 77 , que dirige videoclipes com os equipamentos que fabrica na garagem de casa para artistas do hip hop paulistano, caso do Mister-M, para quem realizou, entre outros, Inquérito (2010), que mostra o artista interpretando a canção

\footnotetext{
${ }^{249}$ RÉ, Adriana Del. O Videoclipe Perde a Vez. Caderno TV \& Lazer. O Estado de S. Paulo. São Paulo, SP. 10 de dezembro de 2006, págs. 4 e 5. ${ }^{250}$ IDEM.
} 
diante de um microfone e tendo ao fundo diferentes paisagens de São Paulo, em meio a fotografias em preto e branco de ídolos como Michael Jackson e Nelson Mandela.

A forrozeira piauiense Stephany, de 18 anos, conseguiu gravar dois discos a partir dos fanclipes que disponibilizou no Youtube. Um exemplo é Eu Sou Stefhany (No Meu Cross Fox) que, apenas nos dois primeiros meses de 2009, teve mais de 265 mil acessos, graças a uma versão da balada romântica $\boldsymbol{A}$ Thousand Miles, da cantora norte-americana Vanessa Carlton, com a mesma coreografia sexy do videoclipe Single Ladies, da também norte-americana Beyoncé e o explícito merchandising do carro de luxo.

Ao mesmo tempo, novas experiências começaram a ser realizadas nos videoclipes brasileiros exibidos na internet. Um exemplo é o site Música de Bolso, que, como está explicado na própria página da internet, "quer produzir uma apresentação 'ao vivo' onde ela provavelmente não aconteceria - ou se acontecesse - onde não haveria uma câmera para registrá-la. Que quer a descontração e o acaso. Que não quer ser um clipe e quer, antes, simplicar e dinamizar a experiência do vídeo musical". A iniciativa deu tão certo que hoje há mais de 250 vídeos de 128 artistas, que já foram acessados mais de 1,2 milhão de vezes, inclusive no Youtube. Graças a eles, a cantora paulistana Tiê foi convidada para se apresentar fora do Brasil e a assinar um contrato com a gravadora Warner, pela qual lançou seu primeiro disco em 2009, Sweet Jardim. O videoclipe da faixa-título mostra, com ares de filmagem amadora, a cantora interpretando a música num estacionamento, junto com os músicos. Outra produção do site é Pela Madrugada (2008), da paulista Tulipa Ruiz, que aparece numa cozinha rodeada de figurantes mascarados e/ou fantasiados, filmada pelo próprio pai e compositor, Luiz Chagas.

No final de maio de 2010, a dupla sertaneja Zezé di Camargo \& Luciano lançou, no Fantástico, o primeiro videoclipe interativo do Brasil, o que fez com que milhões de pessoas descobrissem a possibilidade de inserir a própria imagem na produção dedicada à música Tapa na Cara, que mostra a dupla cantando em estúdio e um rapaz deitado na cama com a esposa e olhando na carteira a foto da amante, no caso a internauta, que aparece também na capa de uma revista e na televisão de um bar. A mecânica funciona a partir de um hotsite hospedado na página eletrônica da dupla e que pode ser acessado em 
www.zezedicamargoeluciano.com.br/clipe. Ali, o internauta pode fazer o upload de uma foto ou tirá-la na hora com a webcam. O resultado aparecerá em determinadas cenas do vídeo e poderá ser enviado por meio de convites aos amigos em sites de relacionamento como Twitter, Orkut e Facebook.

Outra iniciativa desse tipo foi realizada em novembro de 2010 pelo Skank, que através do site www.skankplay.com.br, permite que os internautas enviem vídeos tocando algum instrumento ou cantando uma das músicas da banda e depois as misturem com as imagens de outros fãs ou dos próprios artistas, que gravaram suas performances separadamente. No entanto, a interatividade apenas engatinha no videoclipe brasileiro e ainda tem muito a evoluir, sobretudo no sentido de tornar o espector muito mais participativo.

Se o videoclipe é um gênero audiovisual bastante privilegiado e requisitado na internet, isso não significa, porém, que ele perdeu a importância para as emissoras de televisão e não interessa mais ao público do veículo. Muito pelo contrário. Em 2009, com a saída de Zico Góes, a MTV Brasil aumentou a exibição de videoclipes em 30\% com relação ao ano anterior e abriu a possibilidade para que os telespectadores escolhessem o que pretendiam ver e recebessem informações dos artistas preferidos por meio de torpedo SMS (enviado por telefone celular) ou votação na internet. Também foram criadas faixas matutinas de videoclipes com o nome $\boldsymbol{L A B}$, divididas em "clássico", "now”, "BR”, "Lista”, "Rádio" e "Toca Aí”.

A mudança ocorreu principalmente com a ida de Cris Lobo para a direção de programação da MTV Brasil, no final de 2008. Na emissora desde o início, como apresentadora do programa $\boldsymbol{M T V}$ no $\boldsymbol{A r}$, Cris Lobo explica a importância do videoclipe:

\begin{abstract}
O videoclipe já mostrou ser o produto a se adequar da melhor maneira a diferentes focos de exibição, pois se dá muito com a internet, por ter um formato de curta duração. Ele já foi exibido no cinema, ajuda a vender DVD e se adequa a todos esses sites. Então, é um formato muito maleável e muito forte para o jovem ainda hoje (...) Eu voltei a passar videoclipe por dois motivos: um, percebi que essa ainda é a melhor maneira de apresentar à audiência o artista novo. E a outra coisa foi um projeto que a gente criou para ter uma interatividade maior. Então agora, se você está assistindo a um clipe, você pode mandar um torpedão via celular e receber informação de um artista. Isso foi uma maneira que a gente viu pra essa audiência que pensa em várias coisas ao mesmo tempo ter mais um motivo que não seja só o videoclipe pra ficar ligado. ${ }^{251}$
\end{abstract}

${ }^{251}$ PLAZA, Mônica. Rolling Stone - A Morte do Videoclipe? Trabalho de Conclusão de Curso de Pós-Graduação. Pontifícia Universidade Católica de Brasília. Brasília, DF. Junho de 2009, p. 28. 
Essa capacidade dos videoclipes se adequarem a diferentes meios de exibição chegou ao extremo de se realizarem produções ao vivo por video-jockeys (VJs) em raves e outras festas, principalmente envolvendo música eletrônica.

A VJ Bete Rum é uma das profissionais mais conhecidas dessa área e explica o trabalho que realiza:

O VJ é responsável por colocar as imagens no telão, mas não qualquer imagem, nem de qualquer jeito. As fontes são cuidadosamente preparadas e concatenadas ao vivo, para construir, com o áudio, um ambiente capaz de envolver a visão, a audição e o tato. ${ }^{252}$

A indefinição com relação ao futuro do videoclipe brasileiro e a quais veículos ele será destinado é que torna relevante o trabalho realizado pelos mais diferentes diretores desse formato audiovisual, e que será mais aprofundado e analisado nos próximos três capítulos, destinados ao trabalho de Roberto Berliner, Oscar Rodrigues Alves e Maurício Eça.

Neste capítulo, buscou-se traçar um amplo painel a respeito da origem e da história do videoclipe no Brasil, por meio de seus principais realizadores e dos artistas que melhor souberam se valer dele para transmitir mensagens e estilos de comportamento ao público, nos três diferentes momentos - do Fantástico, das produções para programas segmentados, da MTV Brasil e agora para a internet.

O cantor e compositor Djavan, que foi dirigido por Oscar Rodrigues Alves em Acelerou (1999), que merecerá mais atenção no capítulo cinco, analisa a diferença das três fases do videoclipe brasileiro:

Na época, videoclipe para o Fantástico era uma grande novidade. $A$ música transformada em imagens. Mas era uma coisa embrionária que, se você colocar para ver hoje, é uma piada. Não tinha todas as novidades que o videoclipe adquiriu quando saiu dos estúdios da televisão e foi para os estúdios independentes. Agora a internet mudou absolutamente tudo, por ser um canal independente para cada indivíduo, e o videoclipe perdeu a força que tinha quando era só a televisão que podia expor. A MTV também perdeu o poder de canal exclusivo. ${ }^{253}$

${ }^{252}$ BRYAN, Guilherme. Cultura Eltrônica Traz Gírias da Gíria. Revista Língua Portuguesa nํ⒒ São Paulo, SP. Editora Segmento.2006, p. 18.

${ }^{253}$ Entrevista concedida para essa pesquisa em outubro de 2010. 
Portanto, a questão autoral nessas diferentes fases da história do videoclipe brasileiro se apresentou de modos distintos. Na fase do Fantástico, por exemplo, vários diretores de destacaram por valorizar e experimentar os vários recursos tecnológicos disponíveis na época e que hoje aparentam estar datados, principalmente em números realizados nos estúdios da TV Globo. Ao mesmo tempo, as jovens bandas de rock dos anos 1980 ficaram resgistradas por estrelar videoclipes marcados pela tentativa de associá-las com esportes radicais e o que era considerado moderno, ou então com um humor bastante próximo da comédia pastelão. Nos dois casos, os videoclipes também se adequaram aos padrões de qualidade da emissora.

$\mathrm{Na}$ fase seguinte, dos videoclipes realizados por produtoras independentes à TV Globo para exibição em outros programas segmentados da televisão que não o Fantástico, verifica-se uma maior liberdade criativa por parte dos realizadores, na maneira de retratar as letras das canções, seja por meio de exercícios audiovisuais mais ousados, seja por deixar mais de lado o aspecto comercial e procurar retratar com mais intensidade a realidade social do país.

O período da entrada da MTV Brasil coincide com um dos piores momentos do cinema brasileiro, o que leva muitos jovens realizadores a se arriscarem primeiro no videoclipe antes de partirem para a publicidade ou para o longa-metragem. É o caso dos sócios da produtora carioca Conspiração Filmes, que trazem para o videoclipe uma qualidade tanto técnica quanto imagética dignas das melhores produções internacionais, valendo-se de grandes investimentos e grande cuidado principalmente com a fotografia e os cortes e movimentos de câmera. Eles também dão maior atenção para temas caros à cinematografia brasileira, como o sertão, a fome e as favelas.

Nesse momento, muitas jovens bandas musicais passaram a misturar o rock and roll com ritmos mais tradicionais do Brasil, como o forró e o maracatu. Desse modo, os videoclipes estrelados por esses artistas contaram com elementos dessa cultura. Ao mesmo tempo, outros fenômenos internacionais, caso do heavy metal e do hip hop, renderam seus frutos por aqui e os videoclipes misturaram os elementos trazidos mais dos Estados Unidos com a realidade social sobretudo da periferia das grandes metrópoles brasileiras.

O bom-humor em estilo pastelão também estar presente, principalmente em bandas como Raimundos e Charlie Brown Jr. Outros artistas, como Marisa Monte e 
Pato Fu, contaram com produções mais requintadas, em que os experimentos audiovisuais são mais valorizados do que a transmissão de uma mensagem social e política. Já bandas como Pavilhão 9, Racionais MC's e O Rappa utilizaram os videoclipes para registrar momentos políticos do país que consideravam relevantes e transmitir ideias e posições sócio-políticas bastante claras e explícitas.

É nesse cenário que também se procurou localizar e ressaltar a importância dos três diretores selecionados para a presente pesquisa, uma vez que cada um deles realizou videoclipes que podem ser considerados peças-chaves para a compreensão do que foi feito de mais importante no país nesse gênero audiovisual, que revolucionou o modo de se relacionar música e imagem e soube absorver, como poucos, mais rapidamente, as novidades técnicas e tecnológicas.

Nós próximos três capítulos, além de se conhecer a história de Roberto Berliner, Oscar Rodrigues Alves e Maurício Eça, procurar-se-á observar a produção deles como um todo, destacando-se sete videoclipes especialmente selecionados pelos autores. Um dos principais objetivos é localizar de que modo eles conseguiram ou não desenvolver marcas autorais que superaram a simples questão de estilo para se tornarem importantes no relacionamento com os artistas musicais com os quais trabalharam, assim como com os outros profissionais envolvidos nas produções, com as gravadoras que os contrataram, num exercício de liberdade e experimentação audiovisual.

Não se pretende, porém, emitir qualquer juízo de valor e nem apontar esses três diretores de videoclipes brasileiros como sendo os que realizaram as melhores produções e, portanto, mais se destacaram e se distinguiram dos demais, mas sim demonstrar como eles são importantes num tipo de desenvolvimento autoral identificado em outros diretores, o que se procurou descrever neste capítulo. 



\section{CAPÍTULO 4}

\section{O DIRETOR DOCUMENTAL}

\section{ESTUDO DE CASO - ROBERTO BERLINER}

Este capítulo é dedicado à observação do aspecto autoral dos videoclipes dirigidos por Roberto Berliner, dando maior ênfase a sete produções. Seis delas foram indicadas pelo próprio diretor como as mais representativas de sua obra e o primeiro videoclipe dirigido por ele, pois, de acordo com Paulo Emílio Salles Gomes $^{254}$, é ali que se encontra a virtualidade do conjunto da obra de um realizador. Pode-se, assim, utilizar o método da leitura retrospectiva, com as obras recentes iluminando as anteriores.

Em vez de fazer uma análise técnica aprimorada de cada uma das produções, o que se procurou destacar foi a maneira como Roberto Berliner relacionou-se com a canção escolhida para desenvolver um determinado videoclipe, com seus intérpretes e com os outros profissionais envolvidos na produção. Também foram observados elementos presentes na maioria dos videoclipes selecionados e que, desse modo, podem ser indicadores do trabalho autoral, no sentido da ideia de "câmera-stylo", termo criado pelo crítico e diretor francês Alexandre Astruc para representar o fato de um cineasta se expressar através de um filme ${ }^{255}$. Pode-se afirmar, então, que um diretor é capaz de se expressar por meio dos videoclipes que realiza.

Porém, como foi afirmado em capítulo anterior, não se pretende aqui demonstrar que Roberto Berliner é mais autoral, eficiente e/ou mais inovador do que outros realizadores de videoclipes no Brasil. Mas, sim, que a seleção pautou-se por ser ele um diretor presente numa lista de produções gravadas aleatoriamente da televisão, sobretudo da MTV Brasil. A escolha também se deve ao fato de ser ele um dos poucos profissionais com passagem importante por duas das três fases da história do videoclipe brasileiro: a das produções realizadas por produtoras independentes da TV Globo para serem exibidas em programas segmentados da televisão; e da MTV Brasil. Um fator importante é que ele teve três videoclipes

\footnotetext{
254 Ver nota nำ.

${ }^{255}$ Ver nota nำ12.
} 
premiados no Vídeo Music Brasil, todos do Skank - É Uma Partida de Futebol, melhor edição, melhor videoclipe pop e escolha da audiência; Mandrake e os Cubanos (1997), vencedor de melhor direção de arte, melhor videoclipe pop e melhor videoclipe do ano; e Três Lados (2000), melhor videoclipe pop. Antes, em 1986, Alagados foi premiado pela Associação Brasileira dos Produtores de Discos (ABPD) e pelo Rio Cine Festival.

Como na produção cinematográfica, o diretor é quem geralmente assume várias funções no videoclipe, o que é motivo para associar-se a autoria com este profissional, segundo o ensaísta e realizador francês Jean Epstein. É importante observar que, no caso de Roberto Berliner, ele partilhou o trabalho com profissionais que assumiram o posto de co-diretores em videoclipes que dirigiu.

\subsection{Biografia}

Roberto Berliner nasceu no Rio de Janeiro, em 1957, e, com 19 anos, entrou no curso de Jornalismo da Escola de Comunicação da Universidade Federal do Rio de Janeiro (UFRJ). No lugar da redação de textos, o que mais o atraiu ali foi um cineclube e uma câmera de Super-8, com a qual filmou movimentos operários e 0 congresso de reabertura da União Nacional dos Estudantes (UNE), em 1979.

No início da década de 1980, Roberto Berliner passou a frequentar assiduamente dois locais que se tornaram fundamentais para seu futuro profissional: o Centro de Documentação (CEDOC), da TV Globo, onde ficou de 1980 a 1983 e descobriu uma paixão por imagens de arquivo; e o Circo Voador, emblemático espaço cultural da zona sul carioca, do qual foi um dos fundadores e em que a maior parte dos artistas do rock nacional daquela época começou, como Blitz, Paralamas do Sucesso, Barão Vermelho e Kid Abelha e os Abóboras Selvagens, entre outros. Boa parte desses shows foi devidamente registrada pelo jovem realizador, por meio de uma câmera VHS, novidade para a época. O resultado foi o documentário Circo Voador no Arpoador, ainda inédito.

Armado no verão de 1982, na Praia do Arpoador, o Circo Voador foi demolido por ordem da prefeitura. Sem um espaço físico adequado, os responsáveis pelo projeto, entre eles Roberto Berliner, criaram o Circo Sem Lona, em que um grupo de teatro e outro de vídeo levavam seu trabalho para comunidades carentes do Rio de 
Janeiro. O resultado foi um curso com o importante cineasta Joaquim Pedro de Andrade e a realização de um vídeo, Ovídio (1983), do qual Berliner foi editor.

Nesse momento, surgiam na vida de Roberto Berliner mais duas paixões - os documentários e o registro de pessoas que vivem à margem da sociedade -, o que passa a ser a tônica de seu trabalho nos videoclipes e também em dois dos três filmes em longa-metragem realizados até agora: $\boldsymbol{A}$ Pessoa É Para $\boldsymbol{O}$ Que Nasce (1998, o curta, e 2005, o longa-metragem), a respeito de três irmãs cegas e cantoras; e Pindorama - O Circo do Futuro (2007), co-dirigido com Lula Queiroga e Leo Crivellare, a respeito de uma trupe de sete irmãos anões. O terceiro é Herbert De Perto (2006), co-dirigido por Pedro Bronz, que mostra a trajetória do vocalista e guitarrista dos Paralamas do Sucesso, Herbert Vianna, e originário de curtametragem de mesmo nome.

O primeiro contato com videoclipes veio em 1985, quando Roberto Berliner tornou-se diretor, mesmo sem receber os devidos créditos, do programa segmentado da TV Manchete, FM-TV, que tinha o futuro escritor best-seller Paulo Coelho como redator. Para apresentar o programa, Berliner escalou os atores Patrícia Pillar e Tim Rescala.

Roberto Berliner descreve:

\begin{abstract}
Foi uma experiência muito legal, porque trabalhava com cinco câmeras ao mesmo tempo e resolvi fazer tudo aberto, com elas aparecendo. Às vezes, até uma câmera apresentava o videoclipe. Como acho que o Eid Walesko gostava muito de câmera torta, resolvemos fazer tudo torto, com os apresentadores meio que escorregando ou tentando subir em algum lugar. Ali passava de tudo, desde videoclipes internacionais até brasileiros.
\end{abstract}

O curioso é que, mesmo sendo logo demitido do cargo de diretor do programa FM-TV, Roberto Berliner manteve a relação com os então relativamente recentes vídeos criados para determinada canção. A amiga videomaker e cantora Dulce Quental, recém-saída do grupo Sempre Livre, convidou-o para dirigir o videoclipe Délica, a ser exibido no programa dominical da TV Globo, Fantástico.

Como Roberto Berliner gosta de afirmar que, na sua carreira, sempre um trabalho leva ao outro, Délica (1985) foi lançado num bar, onde compareceram o baixista e o baterista da banda Paralamas do Sucesso, respectivamente Bi Ribeiro e João Barone, que o levaram para conhecer o vocalista, Herbert Vianna, e o convidaram para dirigir o videoclipe Alagados, considerado, por ele, um marco na 
carreira. Na mesma época, Berliner criava com Sandra Kogut a produtora Antevê, cujo nome fazia referência ao fato deles tentarem realizar uma espécie de "antitelevisão". "Nossa formação era muito hippie e meus ideais eram, e acho que ainda são, os de uma coisa coletiva, de estar todo mundo junto, ganhando igual e tentando melhorar o mundo", garante.

Sandra Kogut relembra essa fase:

Naquela época, pouquíssimas pessoas trabalhavam com vídeo. Era uma coisa muito nova e naturalmente o Roberto e eu nos aproximamos, porque éramos os dois interessados nisso. Eu era mais nova e vinha das artes plásticas, usando o vídeo de uma forma mais experimental, enquanto o Roberto já tinha trabalhado em televisão e tinha mais experiência, uma abordagem já mais profissional. Na volta de uma viagem ao México, com o Circo Voador, em 1986, resolvemos comprar um equipamento de edição, na época o formato era U-matic, e tudo isso era uma aventura, porque custava muito caro. Não era acessível como é hoje. Enfim, investimos nisso juntos e abrimos uma produtora, chamada Antevê. ${ }^{256}$

A parceria com Paralamas do Sucesso seria uma das mais duradouras na carreira de Roberto Berliner, pois, além do filme Herbert De Perto, e de oito videoclipes - Alagados (1986); A Novidade (1987), co-dirigido com Sandra Kogut, Trac Trac (1991), Tendo a Lua (1991), Essa Tarde (1996), Vital e Sua Moto (2003), co-dirigido por Pedro Bronz e Rogério Boechat, De Perto (2003), também assinado por Leo Domingues, e Lanterna dos Afogados (2003) -, renderia três vídeos em longa-metragem - V, O Vídeo (1987), Vamo Batê Lata (1995), Hoje (2006); e Sossego (1999), espécie de videoclipe para a abertura da telenovela da TV Globo, Vila Madalena, que mostra uma banda tocando e os integrantes dos Paralamas sentados em poltronas, bem de acordo com a letra da canção.

Embora não tenha sido selecionado para esta pesquisa, o videoclipe $\boldsymbol{A}$ Novidade tem papel bastante importante na obra de Roberto Berliner. Primeira parceria dele com Sandra Kogut, a produção chama atenção pelas filmagens realizadas da banda Paralamas do Sucesso na barca Rio-Niterói, que funciona como espécie de micro-documentário e conta com cenas dos bastidores da própria gravação, com vários ruídos ambientes, fala de anônimos e de Herbert Vianna: "Alô, pessoal, aqui os Paralamas do Sucesso. Meu nome é Herbert. A gente está gravando um videoclipe nessa barca, atrapalhando um pouquinho a viagem de vocês". A ideia era fazer algo semelhante ao documentário Let It Be (1970), dos

${ }^{256}$ Entrevista concedida ao autor em outubro de 2010. 
Beatles, em que a banda aparece tocando no topo de um prédio. Outro destaque é a apresentação do videoclipe realizada especialmente para a exibição no Fantástico, com a atriz Carina Cooper. Apresenta os integrantes da banda e amigos deles nos estúdios e na sala de edição da emissora, questionando a quantidade de vezes em que seria possível fazer a travessia realizada pela barca, se todos os discos vendidos pela banda fossem colocados em fila.

Porém, no início da década de 1990, a Antevê chegou ao fim e, poucos anos depois, a relação entre Roberto Berliner e Paralamas do Sucesso ficou um pouco estremecida. Durante vários anos, eles não trabalharam juntos, como explica o próprio Berliner:

\begin{abstract}
Nos anos 80, tinha liberdade de fazer videoclipe como queria. Com o surgimento da MTV (Brasil), surgiu também um pouco da vontade de fazer do videoclipe um comercial do artista, tanto por parte dos diretores, que queriam entrar ou se manter na publicidade, quanto por parte das bandas, que queriam vender mais. O que era uma expressão artística da música passou a ser propaganda da banda. Aos poucos, fui perdendo o interesse. Só continuei fazendo com as bandas com que conseguia interagir, como Paralamas e Skank. O engraçado é que as duas tinham muito a ver e, no mesmo momento em que a Conspiração começou a fazer clipes dos Paralamas, o Skank começou a me chamar. Foi um acaso e acho que continuei fazendo mais ou menos a mesma bagunça. ${ }^{257}$
\end{abstract}

Em 1993, Roberto Berliner fundou a produtora TV Zero, cujo nome foi dado pelo cantor e compositor Chico Science. Por ali, ele realizou, além de seus longasmetragens, o projeto Free Jazz, a respeito das mais variadas tendências musicais do mundo. Em 1997, Berliner iniciou a série Som da Rua, que reuniu 50 minidocumentários a respeito de músicos de rua, apresentando uma faceta pouco mostrada no vídeo dos artistas brasileiros, e também realizou o curta-metragem Afinação da Interioridade (2001), estrelado por Gilberto Gil.

Mais polêmico do que Caio no Suingue, em que vários figurantes aparecem nus, foi Me Beija (1998), do Lobão, vetado para ser exibido na MTV Brasil, em função de não cumprir os denominados padrões da emissora. A produção em preto e branco mostra o cantor, compositor e hoje VJ da MTV Brasil deitado numa mesa como se estivesse morto e aos poucos readquirindo vida. Em meio a muitas distorções e sobreposições de imagens, Lobão também é mostrado em close, falando outras palavras que não as que estão sendo cantadas na música.

257 IDEM 
Atualmente, Roberto Berliner só voltaria a dirigir videoclipes em condições especiais:

\begin{abstract}
Se um amigo falar: 'Vamos fazer' e tiver tempo, eu não falo não. $O$ videoclipe me deu a possibilidade de fazer o que queria. Enquanto isso foi possível, continuei fazendo. Quando começou a se tornar cada vez menos possível, deixei de me interessar tanto. Então, se for nessas condições, é possível que volte sim, entre um filme e outro, porque estou focado nisso. O problema é saber onde isso acontecerá. Nos anos 80 , se o videoclipe passasse uma vez no Fantástico, estava pago várias vezes, porque a mídia lá era caríssima. Hoje, se vai para o Youtube e passa 50 mil vezes, não fala com milhões, mas com um público específico, o que pode ser muito bom também. ${ }^{258}$
\end{abstract}

\title{
4.2 Videoclipes Selecionados
}

Roberto Berliner não considera que o cerne de sua obra esteja no primeiro videoclipe que dirigiu, Délica (1985), da Dulce Quental, realizado para o programa Fantástico, da TV Globo, e, portanto, obedecendo de certo modo aos padrões de qualidade da emissora. A razão é que toda a produção é baseada inteiramente em imagens da cantora, em estúdio, justapostas e misturadas com imagens de arquivo, o que ele já vinha realizando com certa frequência em experiências anteriores. Entre essas imagens, estão as do guitarrista Jimi Hendrix; do robô C3PO, da série de filmes Guerra nas Estrelas, dirigida por George Lucas; do filme O Picolino (1935), dirigido por Mark Sandrich e estrelado por Fred Astaire e Ginger Rogers; e outras capturadas do documentário Japão, Uma Viagem no Tempo: Kurosawa, pintor de imagens, dirigido por Walter Salles Jr., em 1986. Seria possível dizer, então, que esse videoclipe representa uma ruptura no trabalho de Roberto Berliner, espécie de divisor de águas.

Mesmo assim é possível reconhecer ali alguns elementos que se tornaram marcas autorais do realizador. Por exemplo a utilização do que o próprio Berliner denomina "edição com alguns defeitos". Ou seja, o que não era comum se fazer até então, caso da tela dividida em três partes, todas ocupadas com imagens da cantora em diferentes ângulos e vários áudios dela sobrepostos, de modo já presente na canção original; uma tentativa de se inserirem imagens de acordo com o ritmo da música e de algumas delas traduzirem literalmente o que é dito na letra, como na imagem de um avião a toda velocidade associado a "alucinadamente veloz". Há 
também grande cuidado na fotografia, assinada por Walter Carvalho, um dos mais importantes fotógrafos do cinema brasileiro.

A presença de ruídos nas imagens é uma tônica do trabalho de Roberto Berliner em videoclipes, muito em função dele em geral também assumir o posto de editor, como explica:

Os ruídos são as imagens de arquivo, que vem cada uma de um lugar, sujas e limpas. O clipe era calcado na letra, como sempre, seja pela afirmação ou pela negação. E não sei por que achava que tinha uma coisa globalizada. E, além da conexão verbal mais clara, eu trabalhei muito com o movimento dos objetos ou das pessoas dentro da cena, em relação à música. E com uma coisa orgânica de como a câmera se movimentaria em relação ao cenário. Eu também tratei a imagem como se fosse a própria música, em harmonia ou impacto com a batida. Às vezes, dá certo. Às vezes, não. Nesse caso, foi legal.

De acordo com Dulce Quental, esse trabalho foi fruto de muito diálogo e troca entre ela e Roberto Berliner:

\begin{abstract}
Quando gravei o Délica e surgiu a oportunidade de fazer o videoclipe, pensei logo no Roberto. Eu sabia bem o que queria e achei que ele sabia traduzir o que estava na minha cabeça. Ele nunca tinha feito um videoclipe. Esse foi o primeiro. Deu super certo, porque a gente tinha as mesmas referências, e ele foi super fiel à ideia original (...) O Délica foi exibido num festival no antigo Hotel Nacional (no Rio de Janeiro), mas ficou mais restrito ao underground. Eu não sei dizer se o Délica tem a marca do Roberto. Talvez seja uma mistura de nós dois. A colagem do início, por exemplo, foi ideia minha. Mas acho que o escolhi por achar que ele tinha uma veia documental forte e saberia editar bem as imagens e ideias. Então acho que foi mais um trabalho coletivo que tem a marca de nós dois.
\end{abstract}

Para Roberto Berliner, a principal herança de Délica foi possibilitar a realização de vários trabalhos com a banda Paralamas do Sucesso, que se encantou com o resultado da produção e resolveu convidá-lo para realizar Alagados. No entanto, há de se reconhecer que mais uma vez o diretor se vale de imagens de arquivo em alguns trechos desse videoclipe, caso das que mostram a favela da Maré e foram cedidas pela produtora Olhar Eletrônico.

O próprio Roberto Berliner conta o que pretendia realizar nessa produção:

Era uma época que tinha muita tecnologia, luzes, fumaça e a minha ideia era fazer um videoclipe brasileiro, bem típico do que se fazia no cinema daqui e que a música deles estava querendo. Eu pensava que rock era uma coisa meio elitista, da garotada, e queria botar a música para falar com todo mundo. Filmamos no Morro de São Carlos, no Estácio, num baile funk na Vila Mimosa, e em ruas e lugares mais pobres do Rio de Janeiro. Foram 
dois dias de filmagens e havia uma coisa planejada e outra ao acaso. Aliás, até hoje, faço muito isso. Deixo a planejada se não surgir nada, mas sempre acaba surgindo. Eu também sempre gostei de trabalhar de uma maneira coletiva.

O vocalista dos Paralamas do Sucesso, Herbert Vianna, tem opinião parecida a respeito dos propósitos desse videoclipe:

Quando começamos a fazer videoclipe no primeiro e segundo discos era para o Fantástico, que, em cem por cento dos casos, eram péssimos. Submetíamo-nos aquilo e tomamos um bode que, quando fomos na direção contrária, na época do Selvagem (terceiro disco), queríamos clipe que não nos mostrasse maquiados, bonitos e saltando de motocicleta. Era a barca, a favela, o baile funk, gente desdentada na lama. Isso para nós era muito importante - espécie de afirmação de um ponto de vista e de uma estética. $^{259}$

Nesse videoclipe, portanto, a noção de autoria surge do encontro de interesses do diretor e dos artistas com quem está trabalhando a tal ponto que fica difícil determinar de que modo surgiu a ideia original. Trata-se de uma autoria coletiva, como destacou acima o próprio Roberto Berliner que, para realizar o roteiro, partiu dos lugares mencionados na letra da canção, caso da favela da Maré, no Rio de Janeiro, dos alagados de Itapagipe, em Minas Gerais, e da cidade de Trenchtown, na Jamaica. Já a inserção do baile funk pode ter partido de um interesse da banda sobre o assunto, despertado pelo antropólogo Hermano Vianna, irmão do Herbert Vianna que, na época, realizava sua pesquisa de mestrado, a qual originou o livro O Mundo Funk Carioca, de 1988.

Roberto Berliner também considera um aspecto importante desse videoclipe, além das imagens serem editadas de acordo com o ritmo da canção, a interrupção dela para a inserção de ruídos externos, situação do anônimo que aparece no final gritando: "Bra-bra-bra-Brasil!!!", no canal da avenida Francisco Bicalho, no Rio de Janeiro, o que pode ser apontado como mais uma marca autoral do realizador:

Nós fazíamos algumas interrupções na música, o que comecei em Alagados e chocava um pouco. A televisão era muito limpinha, sem erros. Hoje, acho que relaxaram um pouco. Como trabalhei no CEDOC (da TV Globo), muito perto do estúdio do jornalismo, via como eles se incomodavam se alguém gaguejasse ou errasse o texto. Passei, então, a me interessar por trabalhar justamente com os defeitos, o que talvez tenha permeado meu trabalho e, certamente, influenciado os filmes também.

${ }^{259}$ BRYAN, Guilherme. Quem tem um sonho não dança ..., p. 339. 
A ideia de se filmar na rua, com a constante presença de anônimos das classes menos favorecidas, é outra forte marca autoral do diretor e que se sobressai nesse videoclipe. Ele mostra, basicamente, pessoas das favelas, algumas delas deitadas no esgoto, e os integrantes dos Paralamas do Sucesso tocando acompanhados de crianças e frequentando um baile funk, com direito até à revista real por parte da segurança do local. Esse retrato contundente do Brasil se tornaria importante cartão de visitas para o diretor, a ponto de lhe render o convite para dirigir o documentário Angola (1989), premiado no festival do Centre International de Création Vídeo Montbeliard Belford, na França.

As gravações foram marcadas por clima de festa, de acordo com Roberto Berliner:

\begin{abstract}
Queria botá-los naquele ambiente do qual estavam falando e fazer com que tivessem voz e comportamento ativos. Se não misturasse, ficaria falso. Foram dois dias de filmagem com eles e um terceiro sem eles, documental. Filmamos também o samba no Morro do Estácio, em São Carlos, onde havia duas facções e era preciso pedir autorização para elas para ir lá com os Paralamas. Estávamos filmando e, de repente, os garotinhos começaram a dançar. Herbert também. E eu estimulei um pouco. Daí as coisas foram surgindo naturalmente através dos nossos movimentos, inclusive de câmera. Eu sabia em que locação iria, para qual pedaço da música, e o que faria: 'Aqui vou botar os Paralamas com a favela ao fundo'. Amigos apareceram na filmagem nesse dia, por acaso, e também foram se juntando e dando ideias. O clipe foi muito aberto. Filmar é uma festa para mim. Um momento lúdico, maravilhoso. É como um carro descendo a ladeira e você guiando, meio sem freio, e precisando chegar ao final com festa.
\end{abstract}

As filmagens nas ruas, com a presença constante de pessoas de classes de baixa renda na tela e o forte caráter documental permaneceram no videoclipe seguinte, Kátia Flávia (1987), de Fausto Fawcett. As imagens foram filmadas na rua Prado Júnior, tradicional ponto das prostitutas cariocas, bem de acordo com o universo retratado pelo artista em suas canções.

Roberto Berliner conta o que pretendia com esse videoclipe:

Havia uma coisa documental e algo meio ficcional. O plano inicial era começar numa televisão, com a câmera presa numa grua. Alugamos um apartamento na rua Prado Júnior. A câmera viria e faria zoom out. Com o afastamento da grua, desceria e encontraria os pés de uma garota de programa, loira, andando. Lembro que gravei muita gente falando 'Kátia Flávia' e 'Calcinha', mas não sei se há essas interferências no videoclipe (Essas interferências existem de fato). Fomos pelas ruas mais importantes de Copacabana, com a câmera suja e tudo meio borrado. 
Kátia Flávia, que termina com imagens do televisor saindo do ar e intercaladas com as imagens de loiras correndo, também marcou a parceria de Roberto Berliner com Sandra Kogut, tanto na direção, quanto na edição, o que ambos dividiram igualmente, como explica Roberto Berliner:

A Sandra fazia uma coisa e eu outra, e só nos juntávamos na hora de fazer as cenas mais específicas e complexas. Era uma divisão de trabalho muito igual. Criávamos juntos, o que era muito legal. Um completava o outro. Eu tinha um pouco mais de experiência e ela ajudava muito criativamente. Fausto, acho, obedeceu mais do que deu ideia, até porque a música já falava tudo. De qualquer maneira, ele era espetacular. Imitava Mick Jagger nas caras que fazia. Então o personagem era muito forte.

Sandra Kogut completa:

\begin{abstract}
Fizemos todas as etapas juntos, da concepção até a finalização. Estávamos em sintonia absoluta. A gente queria as mesmas coisas, e concordava. Essa é a minha lembrança.Tinha aquela sensação de estar vencendo uma barreira, fazendo uma coisa nova, de um jeito mais próximo da gente, sem o peso todo daquele modo de produção global da época. Aquelas equipes enormes, com um equipamento pesado. A gente queria filmar na rua, com a câmera em movimento, sem muita luz, com gente da rua. Tinha uma vontade documental muito grande já naquilo tudo. Havia uma ousadia e a gente se sentia fortalecido por isso. O videoclipe era o lugar onde existia menos formatação, onde mais experiências eram possíveis. E, ao mesmo tempo, o Fausto era nosso amigo, e a gente se identificava com a música e com a estética dele.
\end{abstract}

As principais referências vieram do filme Esse Obscuro Objeto do Desejo (1977), de Luis Buñuel, que mostra um homem rico e sofisticado, recém-entrado na terceira idade, o qual tenta obsessivamente ganhar os afetos de uma jovem de 18 anos, que manipula o desejo carnal dele. Já a canção retrata uma loira deslumbrante e arrasadora do submundo carioca, que, no videoclipe, é interpretada por três atrizes, sendo uma delas Paula Bulamarqui. Mais uma vez, houve a utilização de imagens de arquivo, no caso do seriado norte-americano Dama de Ouro e de duas das mais famosas loiras do universo pop - a atriz Marilyn Monroe e a cantora Madonna, que aparece no videoclipe Borderliner (1984), dirigido por Mary Lambert.

Kátia Flávia foi realizado para ser exibido no Fantástico, com a equipe de profissionais da TV Globo, mas sem obedecer muito aos padrões de qualidade exigidos pela emissora, o que gerou certas dificuldades para Roberto Berliner, como explica: 
Por mais que tivéssemos referências de cinema, especificamente, nossa ideia era quebrar com a linguagem e com as regras. Tínhamos claras as ideias dos ruídos e de cenas muito curtas. Quando eu trabalhava na TV Globo, havia uma cartilha, onde estava escrito que não podia ter takes com menos de um segundo. Então: 'Vou fazer com menos'. O pessoal de lá falava: 'Vocês só querem fazer clipe para ganhar prêmio e para se relacionar com o público'. 'Queremos fazer para nos relacionar com o público mesmo'. 'Mas fazem coisas esquisitas'. Essas coisas nós continuamos fazendo, o que deu certo algumas vezes. Outras, não. Só que nunca mais nos chamaram.

Sandra Kogut tem opinião parecida:

Era muito difícil produzir fora da Globo alguma coisa que seria exibida lá, porque o processo de produção tinha que acontecer dentro da empresa. No Kátia Flávia, a gente conseguiu subverter um pouco isso, trazendo outra maneira de fazer, mais livre, mais próxima do videoclipe, que era um espaço aberto a experimentações, e mais longe do musical, que era o que a Globo fazia.

Com relação aos aspectos autorais de Roberto Berliner nesse videoclipe, Sandra Kogut garante:

Acho que ali você já identifica uma intenção documental, uma vontade de filmar na rua, com gente, de interagir, que acho que permaneceram presentes no trabalho dele. Uma estética mais viva, usando o impulso e a intuição. Nada muito arrumadinho.

O cuidado com a edição das imagens no ritmo da canção e algumas brincadeiras sonoras, como, por exemplo, uma das loiras cantando no lugar do Fausto Fawcett, com o áudio original; e outras brincadeiras visuais, como a iluminação estourada e imagem piscando em alguns momentos, são aspectos que se repetem nos videoclipes dirigidos por Roberto Berliner. Graças a esse trabalho, ele foi convidado para estrear na publicidade, realizando os comerciais da Casa das Calcinhas, utilizando a mesma canção de Fausto Fawcett.

As experimentações entre música e imagem atingem um dos pontos altos na produção de Roberto Berliner, com o videoclipe Trac Trac, para o qual foi convidado pela banda Paralamas do Sucesso para dividir a direção com o artista gráfico e diretor audiovisual Gringo Cardia. No final, enquanto Berliner cuidou mais da direção e da edição, Cardia se envolveu mais com a direção de arte. 
A ideia principal de Trac Trac, realizado em 16 milímetros, uma novidade na carreira de Roberto Berliner, acostumado até então a trabalhar exclusivamente com vídeo, surge a partir da letra da canção composta pelo argentino Fito Paez, como explica:

\begin{abstract}
Fui em cima da sensação de correria desgraçada do verso 'não, não passa o tempo, ao mesmo para mim. Tomo comprimidos e sigo sem dormir'. As coisas vão acontecendo uma atrás da outra. Tive a ideia, então, de fazer o videoclipe em plano-sequência e em 16 milímetros, e rodar em menos quadros. Desse modo, você só pega um fotograma a cada um segundo, a cada cinco frames, e, quando projeta, tudo fica mais rápido. Escolhemos um percurso e o fizemos com alguns pontos de corte, porque não dava para fazer tudo seguido. Há um corte quando o Bi (Ribeiro, baixista) pega a moto. Deixamos essa cena pendente. Chegamos, com a câmera que ficava numa traquitana, até a moto, cortamos e, depois, como ela tinha que chegar a algum lugar, fizemos a continuação, até com alguns erros de continuidade, quando um cara entra no ônibus (...) Na edição, tentamos fazer mais ou menos o desenho da música. Sempre que possível eu diminuía ou acelerava um pouquinho, até porque tinha que fazer as imagens caberem no tempo da canção. Para isso, precisei fazer muitas gerações, porque só acelerava 200\%. Tinha que ser 200, 400, 800. Cada vez sempre um múltiplo de 200 (...) Mas não tive tempo para fazer isso e o editor, que estava comigo, não teve a manha de fazer. Infelizmente, o videoclipe perdeu qualidade da imagem.
\end{abstract}

Sem a presença de imagens de arquivo e o aspecto documental, tão fortes nos videoclipes realizados por Roberto Berliner, Trac Trac possui outras características que se repetem na obra do diretor. Esse é o caso dos inúmeros ruídos e interferências na imagem, seja por meio da câmera tremida, que se movimenta aceleradamente pelas ruas do centro do Rio de Janeiro num dia de pouco movimento, seja por meio de uma trucagem visual em que a câmera encontra quase o tempo todo os integrantes dos Paralamas do Sucesso em diferentes lugares.

Roberto Berliner reconhece estes ruídos como sendo importantes marcas autorais de seu trabalho e destaca a constante presença do lixo nas imagens:

Talvez o que preze muito seja câmera em movimento, interferências no videoclipe - através de ruídos na própria imagem - e o sujo. Nunca busco o belo pelo belo. Acho que o belo está em outros lugares que não o que estamos acostumados a ver como tal. Meu tipo de beleza está mais na lama, no esgoto. Sempre procuro a sujeira para interferir num mundo tão limpinho (...) Também trabalhei quase sempre com artistas plásticos. Nos meus videoclipes, os cenários nem sempre eram uma coisa bela, brilhante, mas traziam informações de outras áreas (...) Na minha filosofia, estou muito mais próximo do povo do que das celebridades, do sujo do que do limpo, do feio do que do belo, conceitos que a publicidade e o cinema 
impregnaram. É o branco e o preto (...) Falava: 'Televisão é assim? A minha vai ser antevê, antitevê e, ao mesmo tempo, antever, porque acho que um dia será desse jeito".

Para Roberto Berliner, Trac Trac foi um dos videoclipes mais difíceis de ser dirigido, em função da complexidade de se encontrar pontos de corte que ficassem praticamente imperceptíveis. Ao todo, eram sete ou oito cortes e houve até concurso da MTV Brasil para identificá-los. Foi preciso, então, tomar-se uma série de cuidados nas filmagens, como lembra:

\begin{abstract}
Foram dois dias de filmagem, um no domingo, quando filmamos um trecho movimentado do centro da cidade, Rio antigo, que não daria para fazer durante a semana, porque haveria muita gente passando, e facilitava, uma vez que teríamos mais controle e poderíamos botar os figurantes, meu cunhado, sobrinho e amigos, e abrir uma barbearia, um bar e uma igreja. Era uma época mais amadora. Aliás, o videoclipe continuou sendo amador. As pessoas gostavam da banda e da gente também. Então arte e profissionalismo misturavam-se muito. Havia tesão e desejo das pessoas de estarem do lado dos Paralamas, participando do glamour da filmagem (...) Para Gringo, cheguei à referência de uma vídeoarte, que juntei com a ideia de ser um plano-sequência, por essa coisa nervosa do dia a dia, quando ficamos com milhares de coisas na nossa cabeça, pegamos ônibus, moto, andamos para lá e para cá, e acabamos nas barcas. E aí tem as alegorias, que o Gringo cuidou mais e são nossas fantasias (caso do dragão, recuperado de um espetáculo da Intrépida Trupe).
\end{abstract}

O baterista João Barone tem lembrança parecida e destaca a importância de se trabalhar com Roberto Berliner:

\begin{abstract}
Esse videoclipe foi idealizado para ser rodado no famoso "plano-sequencia" e deu um trabalho danado... Foi uma loucura. Ensaiávamos o movimento para não errar na hora da gravação... Se pobre gosta de luxo, como dizia Joãozinho 30, Robertinho faz clipes para os "intelectuais"... No bom sentido, claro! Suas produções são de estética realista, de certa rudeza, que dá personalidade ao trabalho. Não é um cara que ia atrás de receitas mais apelativas, do tipo fazer clipe com cara de comercial de loja de roupa, de carro, etc.
\end{abstract}

Portanto, Trac Trac pode ser considerado um videoclipe bastante autoral, uma vez que ele apresenta vários elementos pouco comuns nesse gênero audioviosual, fruto de um realizador que se permite o experimentalismo e a fuga das regras e convenções. Não é à toa que o então diretor artístico da gravadora EMI, Jorge Davidson, declarou a Roberto Berliner: "Dessa vez você foi onde ninguém foi. 
Dessa vez, você ultrapassou todas as barreiras. Esse seu videoclipe é um horror. As pessoas vão passar mal”.

O videoclipe mais premiado de Roberto Berliner, que ganhou como melhor edição, melhor videoclipe pop e escolha da audiência no VMB, e, certamente, o mais conhecido é a mega produção É Uma Partida de Futebol (1997). Ela aliou a paixão da banda e do realizador pelo futebol, com a herança imagética do cinejornal Canal 100, criado por Carlos Niemeyer em 1959 e exibido nos cinemas, entre 1959 e 1986, antes do filme principal. As imagens dos jogos de futebol privilegiavam a câmera fechada, no nível do gramado, e o foco mais aproximado dos lançamentos e gols. Some-se a isso a experiência de Berliner como um dos diretores do longa-metragem Todos os Corações do Mundo, de Murilo Salles, a respeito da Copa do Mundo de 1994, disputada nos Estados Unidos e vencida pelo Brasil. Foi também a primeira produção do diretor a contar com merchandising indireto - uma das maiores empresas de material esportivo do mundo, Umbro, financiou os uniformes das equipes de artistas e ex-jogadores que aparecem no videoclipe.

Muitas marcas autorais de Roberto Berliner aparecem nessa produção, a começar pelo forte aspecto documental, tanto que o videoclipe poderia ser chamado de "um dia no estádio do Mineirão", em Belo Horizonte. Ele começa com o porteiro abrindo o portão do local e a multidão chegando para o clássico entre Cruzeiro e Atlético Mineiro e termina justamente com ele fechando o mesmo portão.

A presença de sons externos à canção é outra marca autoral de Roberto Berliner. Nesse caso, escutam-se desde as chaves e o portão no início, até o final do videoclipe, quanto os pés dos jogadores pisando na água no vestiário, a animação da torcida, com seus gritos de guerra, e a voz de locutores de rádios locais. Logo no início, escuta-se o seguinte texto de João Saldanha, jornalista e treinador de futebol brasileiro: "O futebol é um ramo da arte. Eu chamaria de arte popular". A música também foi bastante editada para abarcar essas interferências sonoras e para que as imagens fossem totalmente sincronizadas com ela, com o claro intuito de criar mais emoção.

Entretanto, a ideia desse videoclipe demorou a surgir, como explica Roberto Berliner:

Fernando Furtado (empresário do Skank), um cara muito inteligente e que sempre dá ideias, algumas boas, outras não, como todo mundo, queria fazer, em estúdio, um menino que sonhava em jogar futebol. Eu até 
comecei fazendo o que ele queria - essa história meio melosa, com o garoto no quarto sonhando. Não lembro se era estúdio e depois teria um corte para o Maracanã ou se construiríamos uma casa no estádio. Com aquela música, o videoclipe não poderia ser meloso e piegas. Então falei: "Vamos fazer futebol, futebol. Pegar um clássico no Mineirão, porque vocês são de Minas e não tem sentido fazer no Maracanã". De cara, sabia que dois (o vocalista Samuel Rosa e o tecladista Henrique Portugal) eram cruzeirenses e dois (o baixista Lelo Zaneti e.o baterista Haroldo Ferreti) atleticanos. Samuel comprou a minha ideia. Só que, por algum motivo, Haroldo não poderia estar no Mineirão. Então o filmei no Maracanã, com a bateria no centro do gramado. Algo que não dá nem para perceber. Filmamos também eles tocando em um dos vestiários, com o túnel para o gramado todo alagado de água da chuva, o que deu um brilho.

O vocalista do Skank, Samuel Rosa, descreve a importância do trabalho:

Num certo sentido, Roberto Berliner foi felizardo, pois pegou o auge da indústria fonográfica, quando tínhamos orçamentos muito bons. Eu não imaginaria para esse videoclipe um diretor que não fosse ele, que adora futebol e entende aquele clima e atmosfera. É Uma Partida de Futebol nunca foi uma música radiofônica. Claro que é um tema de apelo enorme, ainda mais tratando do Brasil, mas ela não era para ser música de rádio como se tornou depois, muito por causa do videoclipe e da ideia de ir para a arquibancada do Mineirão em pleno jogo Cruzeiro e Atlético, um clássico mineiro. Eu me lembro da gente na mixagem da música comentar que poderia fazer um videoclipe, que pegasse um pouco das torcidas. Nós, como uma banda mineira, queríamos mostrar um pouquinho da festa, da rivalidade e da guerra entre cruzeirenses e atleticanos num dia de clássico. Temos cenas no Maracanã, mas o contexto não é lá. Então as duas torcidas ficaram muito satisfeitas e ficou esse casamento eterno da banda com o futebol. O jogo do Mineirão ali é impressionante e o Berliner conseguiu colocar no ritmo da música até o momento em que o juiz tira um cartão amarelo do bolso para dar ao jogador.

O fato de, diferente dos videoclipes dirigidos por Roberto Berliner e observados anteriormente, É Uma Partida de Futebol ter contado com grande orçamento, possibilitou que ele trabalhasse com várias câmeras e quatro equipes de filmagem. Também tornou possível o registro de grande quantidade de imagens, que aparecem em cortes secos e rápidos para dar ainda mais emoção ao videoclipe, em edição calcada principalmente na batida da bateria e na letra da canção. $O$ diretor conta:

Como não foi uma partida muito emocionante, tivemos de botar emoção. Se houvesse planos longos de grandes jogadas, faltas, gols incríveis, acho que os teria deixado. Mas tinha apenas uma quantidade de planos bem pensados, fechados de pés, de fúria da torcida. Essa coisa nervosa do futebol, meio coliseu, e de identificação de jogadores, que achávamos que daria mais clima, mesmo com a autorização de todos. Por um acaso, o jogo foi 1 a 1, o que foi muito bom, porque tinha gol de um lado e de outro. Mas, na edição, durante muito tempo, não tinha gol, até que falei: "Isso é quase sexo sem gozo. Tem que ter bola na rede". Botamos e foi espetacular. 
É Uma Partida de Futebol, portanto, tornou-se um clássico obrigatório do videoclipe brasileiro e confirmou várias marcas autorais de Roberto Berliner, mais ainda no que se refere ao aspecto documental. Afinal, esse videoclipe é quase um documentário musical em curta-metragem, bastante dinâmico e movimentado, do universo do futebol, registrando desde os bastidores da torcida chegando ao estádio e se animando nas arquibancadas até as jogadas propriamente ditas.

Se É Uma Partida de Futebol marcou o contato de Roberto Berliner com uma super produção, o videoclipe seguinte destacado nessa pesquisa, Caio no Suingue, ficou marcado pela polêmica, uma vez que nele todas as pessoas aparecem nuas, o que indica que o diretor optou pela leitura mais sexual para 0 título de duplo sentido da canção. Antes, porém, um dos roteiristas, o artista visual e performático Michel Grossman, chegou a pensar em colocar a banda vestida de galinha, de cócoras, batendo as asas, o que foi rapidamente vetado por Berliner, cuja ideia prevaleceu:

Como o videoclipe não tinha dinheiro (o orçamento foi de apenas $10 \mathrm{mil}$ reais), resolvi: 'Vou pegar o que tem e usar em negativo, câmera e luz Vou ver uma locação barata e botar todo mundo pelado, com planos interessantes de gente bonita, feia, simples'. Chamei pessoas de todos os tipos e usei muito a plasticidade delas, quase como fotografias. A ideia é muito simples: usar os corpos, o que talvez a palavra suingue tenha me levado a fazer. Mas as pessoas nuas não representavam um suingue. Certamente, tive outras motivações também (...) O clipe teve vários figurantes, muito felizes, pois deixaram de aparecer no fundo. A banda topou na hora (...) E o ruído foi o próprio nu, que a MTV, por bobagem ou sei lá o quê, passou pouquíssimo e sempre depois da meia-noite.

São justamente os ruídos e a liberdade de criação que podem ser apontados como as principais marcas autorais de Roberto Berliner nesse videoclipe. Há, novamente, a forte presença da edição calcada no ritmo da música e uma maneira mais criativa e inusitada de se representar a temática da letra. As artes plásticas e visuais aparecem por meio da referência à capa do álbum Eletric Ladyland (1968), do guitarrista Jimi Hendrix, nas cenas em que a câmera mostra de cima para baixo o corpo de várias pessoas misturadas.

Para Roberto Berliner, o que mais define sua marca autoral nesse trabalho é a valorização do que denomina como sendo "a beleza da feiúra e a feiúra da beleza”, o que também aparece nos videoclipes Alagados, Kátia Flávia e É Uma 
Partida de Futebol, em que há forte presença de populares e anônimos em meio aos artistas e pessoas famosas.

O próprio Roberto Berliner explica:

\begin{abstract}
A estética sempre está presente. Eu trabalhei com gente mais suja, misturada com gente mais limpa. O clipe começa com as pessoas vestidas tirando a roupa e a figurinista resolveu tirar também. Levei um susto. De repente, ela apareceu no set pelada. Um cara começou a ter ereção no meio da filmagem. Uma menina não quis tirar o sutiã. Acabou usando, mas ficou chato (...) Havia crianças também, filhos da galera, que hoje estão grandes. A coisa da família, da mistura de classes, da geometria do corpo, da beleza da feiúra e da feiúra da beleza ficou marcada.
\end{abstract}

O líder da banda, Pedro Luís, que também aparece sem roupa, avalia o resultado do videoclipe:

A princípio, o convite foi para fazer Tudo Vale a Pena, mas a ideia era tão surreal que, quando mudou para Caio no Suingue, todo mundo nu ficou até fácil! (...) Considerando o que tínhamos de orçamento, Roberto conseguiu operar milagres, com seu bom gosto e boas relações. Bom gosto, ousadia e originalidade são um bom trinômio de qualidades que Roberto,hoje em dia meu amigo, merece.

Portanto, em Caio no Suingue, Roberto Berliner leva ao extremo o aspecto documental, enquanto registro dos corpos nus dos seres humanos; a edição acompanhando a batida da música; e a valorização de encontrar beleza onde geralmente ela não é mostrada enquanto tal. Estão aí, então, suas principais marcas autorais.

Assim como em Caio no Suingue, em Mandrake e os Cubanos (1999), a pesquisa de referências também foi muito importante para o resultado final do videoclipe e pode ser considerada uma marca autoral de Roberto Berliner, que explica os propósitos do trabalho:

Nós queríamos fazer um anticlipe, bem-humorado, já que eu tinha feito videoclipes de todos os jeitos e achávamos que a linguagem estava esgotada e que a música demandava mágica. O Mandrake, das histórias em quadrinhos, era capaz de fazer as pessoas terem a sensação de que, de repente, ele estava diante de um leão e não existia leão ali. Era uma época em que eu estava fazendo muita propaganda. Então pedia referências de todos os lados. Então tem Mr. Bean, Jerry Lewis, Peter Sellers. Uma cena que achássemos interessante, nós transformávamos. Outras fazíamos iguais. Algumas coisas nem tinham referência. Nós inventamos. 
Mais uma vez, há a presença das artes plásticas que, aqui, aparecem pela co-direção do artista plástico Raul Mourão, que também participou do roteiro e da edição de É Uma Partida de Futebol. Ele tem opinião parecida:

\begin{abstract}
Para Mandrake, fizemos uma pesquisa extensa de filmes e programas de televisão de humor. Uma fita com duas horas repleta de gags visuais (Monty Python, Mr. Bean, Três Patetas, etc.). Várias gags que estão no clipe foram chupadas dali. Havia também um desejo de subverter a ordem normal, que coloca o vocalista/líder/guitarrista em primeiro plano nos clipes e o baterista ao fundo. Nossa ideia era colocar o baterista em destaque por pura piada/provocação/nonsense.
\end{abstract}

Roberto Berliner considera que a escolha do baterista Haroldo Ferreti para protagonizar o videoclipe se deve ao fato de, além do vocalista Samuel Rosa, os outros integrantes do Skank serem muito tímidos:

\begin{abstract}
Haroldo também é meio antiestrela, antibandleader. É aquele cara meio bobo. Gente como a gente. Por isso, achava que conseguiria quebrar a coisa do ídolo e conseguimos. Ele foi exatamente o que pensávamos e entrou na viagem total. Talvez tenha dado um palpite ou outro: 'Vou fazer uma cara mais assim'. Sabíamos que ele não era um ator, mas um antiator. Uma coisa meio dura, estranha, espetacular. A banda também comprou a ideia de que não precisava, naquela época, se vender enquanto imagem.
\end{abstract}

Muito da naturalidade e da espontaneidade de Haroldo Ferreti no videoclipe se deve ao trabalho da coreógrafa Dani Lima, ex-integrante do grupo de dança Intrépida Trupe. Outros destaques são os figurinos criados pela esposa de Roberto Berliner, Ana Amélia Macedo, e a maquiagem propositalmente exagerada realizada por Marlene, que transformaram o baterista em mágico, cafetão, hippie, gueixa, velhinha e cangaceiro, muitos deles mencionados na letra.

$O$ videoclipe começa mostrando os outros integrantes da banda em ambiente externo para apresentar o baterista em estúdio com uma linguagem típica das comédias pastelão, incluindo a maneira com que a câmera se aproxima do rosto dele. Há também uma edição bastante calcada no ritmo da música e a presença de vários ruídos, visando a provocar o riso e a acentuar o aspecto lúdico - outra marca na direção de Roberto Berliner. Outro destaque é a utilização de algumas trucagens, como, por exemplo, a brincadeira com o nome da artista plástica e viúva de John Lennon, Yoko Ono, e a cena em que Haroldo Ferreti parece segurar um charuto, mas descobre-se que ele está sendo segurado por outra pessoa, quando o baterista, fantasiado de malandro, esbofeteia uma garota. 
Samuel Rosa destaca o resultado eficiente desse videoclipe:

\begin{abstract}
Nós achamos engraçado esse apelo que tem sempre para o vocalista ser 0 protagonista. A gente sempre brincou um pouco com isso. Até chegar ao Cosmotron, que é o nosso sétimo álbum, a banda nunca tinha aparecido na capa de um disco, a exceção do Lelo (baixista) com uma fantasia de calango e virou a imagem da capa do disco Calango. O Haroldo sempre teve uma veia artística boa, não de ter feito teatro, mas é um cara muito expressivo, até mais com o movimento de músculos da face. A gente sempre achou isso muito legal nele, do olhar, das caras que faz, etc. Apostando nisso, nós o colocamos para ser o cara que vai mudando de cenário, dançando e fazendo caras e bocas. Deu super certo. Até hoje, às vezes, as pessoas se aproximam chamando-o de Mandrake. A ideia ali é um pouco tirada das coisas do Austin Powers (personagem interpretado no cinema pelo ator Mike Myers).
\end{abstract}

\begin{abstract}
Roberto Bertliner também encontra nesse videoclipe referências ao importante grupo teatral carioca dos anos 1970, Asdrúbal Trouxe o Trombone, e lamenta o fato de sentir que, no final, o videoclipe perde um pouco de qualidade, em função de ele não ter tido mais tempo para realizar o que gostaria.

O próprio Roberto Berliner enumera as marcas autorais que encontra em

\section{Mandrake e os Cubanos:}

\begin{abstract}
Certamente me marcou, porque é um videoclipe de que gosto muito. A ficção, que uso nos meus documentários, já usava ali. O tosco e a brincadeira também talvez tenham se acentuado. O bom-humor foi especialmente marcante. E era para ser meu último videoclipe, porque queria me dedicar mais a outras coisas. Percebi que dedicava tempo imenso para fazer o que não dava dinheiro e não era o meu foco principal cinema. Se era para não ganhar dinheiro, preferia investir mais nos documentários.
\end{abstract}

Raul Mourão tece vários elogios ao parceiro e amigo:

Roberto é um autor transgressor. Tem obsessão por encontrar caminhos diferentes e inusitados. Tem uma paixão pelo incomum, pelo improvável e pelo insólito. É um cara inquieto, sempre fugindo do óbvio, do comum, do previsível. Sempre teve uma postura autoral mesmo em projetos comerciais como os videoclipes que fazíamos para as gravadoras. E uma grande honra ter podido trabalhar com ele e funcionou como uma grande escola para mim, tanto profissional, como de vida.

\title{
4.3 Considerações Gerais
}

Por meio da observação de sete videoclipes dirigidos por Roberto Berliner, tornou-se possível identificar como ele utilizou esse gênero audiovisual para 
experimentar novas linguagens e recursos e, assim, desenvolver fortes marcas autorais, sobretudo no que se refere ao aspecto documental e à tentativa de fugir das convenções. Outros aspectos importantes são a utilização de ruídos externos e o que denomina sujeira e interferências nas imagens, muitas vezes com finalidade dramática; a edição caprichada, em geral calcada no ritmo da música, adotando como referência a bateria, na maioria dos casos; e a utilização de diferentes referências, principalmente do cinema e das artes plásticas.

O próprio Roberto Berliner explica o que pretendia:

O que talvez tenha sido minha preocupação inicial é fazer com que a música, não a letra, esteja muito retratada na forma ou no movimento como eu filmava. Sempre tentei fazer com que melodia, câmera e edição tivessem sempre alguma coisa a ver, em geral pela afirmação, mas muitas vezes pela negação.

A valorização do que costuma ser considerado feio, sujo ou lixo na sociedade, é outra marca importante de Roberto Berliner, que ele garante ter levado para os documentários que realizou:

\begin{abstract}
A Pessoa É Para O Que Nasce, tanto o curta, quanto o longa, tem muito a ver com videoclipe. Primeiro, sempre que vou fazer um documentário, tenho vontade de enaltecer personagens à margem, usando linguagem de videoclipe e da propaganda. Talvez até mais da propaganda do que do videoclipe. Se bem que minha propaganda tem muito a ver com videoclipe. Também tento fazer coisas experimentais e trabalhar com movimentos de câmera e símbolos nos documentários, o que nem sempre é aceito pelos documentaristas.
\end{abstract}

Para chegar a tal resultado, Roberto Berliner explica como costuma ser seu método de trabalho, sempre com o objetivo de criar uma identidade visual para o artista que dirige:

A primeira coisa que eu fazia era ouvir a música um monte de vezes para ter ideias. Em nenhum momento, eu falava não. Escrevia e ficava com um monte de ideias, incríveis e mirabolantes. Nos anos 80 , eu batia a máquina e depois tirava cópia em xerox ou carbono. Deixava um ou dois dias. 'Já tenho ideias suficientes para limar'. Chegava a duas ou três ideias e as desenvolvia, tentando perceber a simples, a complexa e a que custaria muito dinheiro. Então, em geral, ia à gravadora e conversava: 'Tenho três ideias. Como está a verba?'. Nesse começo, era média ou pequena. Então fazia o que era possível (...) Fazia um roteiro, em que sabia o que seria feito em cada segundo da música, e um plano de filmagem. Mas chegava na hora e achava que outro plano era mais interessante. Então fazia os dois (...) Na maior parte das vezes, não dá certo mesmo, mas, em outras, o erro 
leva ao acerto (...) Então eu prezo muito o acaso, assim como ouvir as pessoas em volta.

Outra característica importante do trabalho autoral de Roberto Berliner é o diálogo estabelecido com os artistas com quem trabalha. Não é à toa que ele dirigiu vários videoclipes para as bandas Paralamas do Sucesso e Skank, por exemplo. O diálogo, em muitas ocasiões, é determinante para a criação de uma estética ou de uma proposta visual muito definida. Um dos exemplos mais claros nesse sentido é o videoclipe Alagados.

Roberto Berliner garante que muitas vezes leva em consideração a opinião dos artistas, mas que a sua ideia acaba prevalecendo:

\begin{abstract}
Em geral, tem uma reunião inicial, na gravadora, onde contam como foi a composição da música, o que pensaram e, às vezes, a tradução que tem em imagem. Em geral, anoto, levo em consideração a ideia deles e até faço um roteiro, quando tenho tempo. Também levo a minha ou as minhas ideias. Às vezes, eu misturo um pouquinho. Nenhuma vez, porém, deixei de fazer a minha, porque sempre respeitaram meu trabalho e os convenci de que a ideia deles não era tão boa (risos), por ser piegas, impossível, grande demais, ou custar uma fortuna. Muitas vezes, isso foi determinante para que a ideia da banda não fosse adiante. A segunda reunião, quando tem, é para mostrar o roteiro. Pedro (Luís), por exemplo, o que eu fizesse ele achava legal e faria. Com Skank e Paralamas, também é assim.
\end{abstract}

É importante frisar também o contexto histórico em que Roberto Berliner dirigiu esses videoclipes, uma vez que ele é um dos principais exemplos de profissionais que começaram trabalhando com vídeo, na década de 1980, e chegaram a trabalhar com película, já na fase da MTV Brasil. Ele foi também um dos primeiros realizadores a ter sua própria produtora, inicialmente a Antevê e depois a TV Zero e a realizar produções para o programa Fantástico, da TV Globo. Ou seja, há o interessante contrassenso, presente principalmente nos videoclipes Alagados e Kátia Flávia, de desafiar as convenções, na tentativa de realizar uma antitelevisão, para ser exibido na emissora de maior audiência do país. A observação dessas produções também é importante para se notar a mudança também estética na maneira de trabalhar com a edição analógica e digital, uma vez que o diretor também assume o posto de editor na maioria dos videoclipes selecionados.

Portanto, a autonomia e total controle sobre o trabalho que realiza é que faz de Roberto Berliner um autor com propriedade para desenvolver características 
próprias e arriscar-se em caminhos inusitados, que vão agregando novos valores ao conjunto de sua obra. Tais características serão levadas, inclusive, para os documentários que realizará em seguida, e, graças a elas, é que, em muitos casos, tornar-se-á possível identificar um videoclipe dirigido por ele, antes mesmo de se lerem os créditos. 


\section{CAPÍTULO 5}

\section{UM AUTOR A SERVIÇO DA MÚSICA}

\section{ESTUDO DE CASO - OSCAR RODRIGUES ALVES}

Este capítulo é destinado à observação do trabalho autoral desenvolvido pelo paulistano Oscar Rodrigues Alves nos videoclipes, destacando sete produções, sendo seis selecionadas por ele e a primeira, por acreditar-se conter o cerne de sua obra. Antes disso, porém, é preciso conhecer a trajetória do realizador, de que modo ele chegou a esse formato audiovisual e que lições levou dele para o cinema e para a publicidade.

Jornalista de formação e um dos profissionais envolvidos com a instalação da MTV Brasil, Oscar Rodrigues Alves é um exemplo importante de realizador que foi se desenvolvendo e amadurecendo sua obra simultaneamente com a história dessa emissora de televisão voltada de forma exclusiva aos videoclipes. Não é à toa que ele foi um dos realizadores mais premiados no VMB - Até Quando?, do Marcelo D2, melhor edição em 2001; Epitáfio, dos Titãs, melhor videoclipe de rock, melhor videoclipe do ano e escolha da audiência em 2002; Dois Rios, do Skank, melhor videoclipe pop em 2003; Vou Deixar, do Skank, melhor videoclipe pop em 2004; e Fracasso, da Pitty, premiado como melhor videoclipe de rock em 2010.

Reconhecer os diferenciais dos videoclipes dirigidos por ele é muito importante para identificar e compreender suas principais marcas autorais. Assim, é preciso destacar o papel preponderante desempenhado pelas mudanças tecnológicas em sua obra. Afinal, começou trabalhando com película mais edição linear e precisou se adaptar rapidamente à edição digital e não-linear, e ao trabalho com os mais modernos softwares de computadores.

\subsection{Biografia}

O audiovisual e a música sempre estiveram muito presentes na vida de Oscar Rodrigues Alves. Seu pai havia sido filmado na infância e fez o mesmo com os filhos, através de câmeras de 16 milímetros e Super-8. Ao mesmo tempo, na casa 
onde morava, eram realizadas rodas de samba e Oscar, imbuído pela música, aprendeu a tocar bateria. Mesmo assim, o futuro diretor acreditava que sua vocação estava na política, como a do bisavô Francisco de Paula Rodrigues Alves (presidente do Brasil de 1902 a 1906), tanto que foi presidente do grêmio do Colégio Palmares, em São Paulo. Desistiu quando participou de um congresso da União Brasileira dos Estudantes Secundaristas (UBES). "Teria que engolir muito sapo. Então eu percebi que talvez o jeito mais legal de continuar nesse meio era ser jornalista", lembra.

Foi, então, estudar Jornalismo na Escola de Comunicações e Artes (ECA), da Universidade de São Paulo (USP), onde se formou em 1990. Já no segundo ano da faculdade, em 1987, ele assumiu o posto de assistente de direção do Jornal de Vanguarda, da TV Bandeirantes, em que conviveu com personalidades como o poeta Paulo Leminski, o político e escritor Fernando Gabeira e o economista Delfim Neto. O programa teve dupla importância para Oscar: realizar reportagens musicais e pegar imagens jornalísticas do dia aliadas a uma música e fazer uma espécie de videoclipe com elas; e assumir muitas vezes a direção, sem ter feito curso para tal função. Ou seja, foi algo que aprendeu na prática e que se tornou determinante na sua carreira.

No mesmo ano em que se formou, Oscar Rodrigues Alves foi convidado para ser um dos fundadores da MTV Brasil, como Diretor de Programas:

\begin{abstract}
Em 1990, é a fundação da MTV e as pessoas que foram trabalhar nela, entre eles Rogério Gallo, eu já conhecia um pouco. Elas faziam TV Mix, na Gazeta, e tinham ligação entre quem conseguia fazer algumas coisas pop na TV. Quer dizer, elas na Gazeta e eu na Bandeirantes. Começamos a ficar amigos nessa época. Daí chamaram-me para ser diretor de programas da MTV e dos VJs (video jockeys, que apresentavam os videoclipes). Foi o primeiro lugar onde eu tive o cargo mesmo de diretor. Hugo Prata era diretor de atores, digamos assim. Ele escolheu os VJs e cuidou da performance deles. A MTV queria que eu cuidasse do conteúdo dos textos. Enfim, compúnhamos uma dupla. Dirigimos juntos as primeiras gravações dos VJs da MTV, dois meses antes da estreia. Nós formamos os VJs e fazíamos meio um conselho lá dentro, capitaneados pelo Victor Civita Neto (...) Vieram alguns caras ensinar para a gente como fazer a MTV. Entre eles, Alex Coletti, que ainda é produtor e diretor dos Unplugged, e Ivano Del Caballo, producer também. Os dois vieram para ensinar a gente a fórmula de como gravar os VJs e quantos por dia. Enfim, rolava um McDonaldzinho da MTV. Tinha uma formulinha de como acertar o bloco da programação.
\end{abstract}

curioso na carreira de Oscar é que, logo em seguida, ele se mudou para a primeira casa de exibição dos videoclipes brasileiros, o programa Fantástico, da TV 
Globo, onde entrou como produtor e editor de reportagens especiais. Logo em seguida, em 1992, estreou na publicidade, como ele mesmo relata:

Nessa época, eu decidi não voltar para a TV. Tinha vários amigos que começavam a fazer publicidade e também me enveredei um pouco por ela, muito levado por eles e um pouco pela vontade de filmar e trabalhar com película e cinema. Enfim, outra experiência.

Também em 1992, Oscar Rodrigues Alves dirigiu o primeiro videoclipe, Quitambô, para a banda Batakotô, a convite de Vitor Martins, sócio da gravadora Velas. O realizador destaca as principais diferenças entre trabalhar com videoclipe e publicidade, no início da década de 1990:

\begin{abstract}
A diferença entre publicidade e videoclipe é clara para nós que éramos jovens diretores na época, ligados em música. Gostávamos muito de trabalhar com música e estávamos à procura de uma imagem mais legal, por isso acabamos trabalhando com película. A geração que veio junto com a MTV começava a receber videoclipes de fora, feitos em filme, e queria atingir aquele padrão de qualidade (...) Não por coincidência, os diretores que foram fazer videoclipe também estavam fazendo publicidade, até porque videoclipe nunca deu muito dinheiro. Trabalhar com filme precisa ter mais dinheiro dedicado à produção do que a televisão sempre teve. Nas produtoras que a gente trabalhava, havia câmeras, luz e cultura da película, que, na televisão, não havia. Pelo contrário, havia uma grande ignorância sobre a película. Apesar de o primeiro jornalismo da TV ser feito em 16 milímetros, com o vídeo isso logo foi embora, porque era muito mais barato.
\end{abstract}

Como profissional da produtora 5.6 Filmes, Oscar Rodrigues Alves dirigiu o videoclipe Flor do Futuro (1995) para o amigo João Marcelo Bôscoli, com o qual havia trabalhado no programa Companhia da Música, exibido pela CNT. O orçamento de Flor do Futuro foi financiado pela gravadora Sony Music, onde trabalhava Adriana Pena, que cuidava do departamento de marketing e o levou a dirigir Realidade Virtual (1997), do Cidade Negra, ambientado num futuro próximo com uma cidade cheia de antenas. Esse grupo carioca era empresariado por Leninha Brandão, que cuidava também da carreira de Gabriel O Pensador. Assim surgiu a direção de Até Quando? (2001). Em seguida, o realizador passou pelas produtoras Ilustrada Filmes, Academia de Filmes e Nuclear, em que se encontra atualmente, pelas quais dirigiu todos os videoclipes que fez até hoje. 
Oscar Rodrigues Alves considera o diretor Roberto Berliner uma influência importante nos videoclipes que realiza e acredita pertencer a uma geração que assistiu ao maior salto tecnológico na televisão:

\begin{abstract}
Quando eu comecei, em 1987, era U-matic, analógico. Se a fita amassava, você tinha que refazer tudo, porque copiar de U-matic para U-matic perdia muita qualidade. Era uma loucura. De certa maneira, foi interessante, porque o raciocínio linear de montagem requer mais trabalho do que o nãolinear, no sentido de preparação. Eu preparava muito mais as minhas edições no papel. Cronometrava mais o tempo das coisas (...) Hoje em dia, você pode mover uma coisa de trás para frente, mexer, tirar, cortar. Lá não. Você editava o que estava na fita. Vai para frente, para trás. Já era. Então me ajudou a pensar mais na montagem, numa época em que acho que a estava descobrindo ainda. A montagem não-linear, você pode, a qualquer instante, rever, trocar, virar. A montagem linear requer mais preparação. Então, acho que foi bom ter uma base onde precisava me preocupar mais e depois a tecnologia me deixar mais solto. Isso foi bem legal. Foi gostosa essa transição.
\end{abstract}

O diretor acrescenta o que essa geração de profissionais do audiovisual trouxe de diferente, em relação às anteriores, para o videoclipe e para a publicidade:

Acho que a questão de a gente ter trabalhado bastante com película e o envolvimento de pessoas do mercado de cinema e de publicidade nos videoclipes melhorou. Quer dizer, é difícil colocar juízo de valor. Mas trouxe clipes mais bem acabados, digamos assim. $O$ fato de se trabalhar com cinema requer profissionais diferentes da televisão. O cinema trabalha com negativo, que tem que ser exposto perfeitamente e, depois da revelação, é que verá como ficou. Quer dizer, necessita de um rigor técnico maior do que o vídeo (...) O ramp de cores, de saturação e de luminância que a película dá é muito maior do que o vídeo. Então, nos permitiu trabalhar com nuances técnicas de contraste, brilho, cor, muito maior do que o vídeo.

\title{
5.2 Videoclipes Selecionados
}

\author{
Oscar Rodrigues Alves consegue identificar algumas marcas autorais \\ importantes no primeiro videoclipe que realizou, Quitambô (1992), para a banda \\ Batacotô:
}

Eu acho que tento ser bastante fiel ao que os músicos estão tocando, no jeito de mostrá-los tocando e sincronizado com o áudio, algo bem presente nesse videoclipe e que permeia a minha obra toda. Ou seja, tornar a música bem visível ao espectador. Na hora em que você mostra os instrumentos que estão sendo tocados, faz com que o espectador conecte o som ao instrumento e ao músico que o está gerando. Conceitualmente, o que tem importante ali, que passa por tudo, além disso, é a preocupação com a edição e com o contraponto entre os músicos tocando e alguma imagem artística, nesse caso figurinos, a praia, a areia (...) Sempre tive fissura de 
sincar os cortes com a música, o que fui refinando e até hoje faço. Não é que a cada acorde da música ou a cada virada de batera, eu picote de acordo com o tanto de notas que os caras emitem. Mas alguma ligação intrínseca com a dinâmica da música você sempre vai encontrar nos meus clipes. Eu acho isso importantíssimo. Sempre os meus clipes, inclusive o do Batakotô, vão ajudar, entre aspas, a pessoa a ouvir a música de uma maneira mais legal, seja fazendo cortes que te levam para o instrumento, seja mudando a dinâmica da música. Não são poucas as pessoas que falam: "Consigo ouvir instrumentos que eu não conseguia ouvindo a música, na hora em que vejo seu clipe. Você mostra o que está acontecendo musicalmente muito melhor para mim do que conseguiria identificar ao apenas ouvir a música".

O diretor aponta que ali ele foi fisgado pelo videoclipe e que também identifica alguns efeitos óticos que se tornariam característicos na sua carreira:

\begin{abstract}
Já tinha algumas jogadas de transições óticas, fotografia, silhueta, que funcionaram. A transição de um special de percussão e teclado foi feita numa poça d'água na areia da praia, onde Jorge Barreto, vocalista, havia aparecido cantando contra ela e dava uma turvada. A água mexia e embaralhava um pouco a imagem. Isso resultou super bem. Logo no primeiro clipe também já tem câmera subaquática. Meu pai, como mergulhador, tinha um blimp para câmera Hi8, que me emprestou. Então, apesar de ser o primeiro clipe, ele é bem trabalhado e cheio de elementos interessantes, que depois eu carreguei mais adiante na minha carreira (...) Tinha um monte de brinquedinhos para usar e a gente abusou deles. Mas era um esquema totalmente amador. Editamos e eu vi que tinha ficado bom tudo o que pensei, as fusões, transições e mistura do preto e branco com cor. Inventei uma formulazinha para o clipe, que eu percebi que deu certo e deu muito prazer de fazer.
\end{abstract}

Financiado pela gravadora Velas, Quitambô é um videoclipe marcado sobretudo pelos movimentos tanto de câmera, que muitas vezes distorcem propositalmente as imagens, quanto do registro das ondas do mar com a garrafa boiando e o nome da música escrito nela. Ou seja, Oscar Rodrigues Alves consegue imprimir na tela quase um balé de imagens no ritmo da canção. Também há a mistura de imagens em preto e branco no estúdio, valorizando a execução dos instrumentos musicais, e coloridas na praia de Arraial do Cabo, no Rio de Janeiro, destacando a paisagem, o que se tornará outra marca importante do realizador.

Num videoclipe de baixo orçamento, o que chama a atenção é a criatividade do realizador, que utilizou o clima do título da canção, que significa festa africana, para filmar a banda na areia, interagindo com uma garrafa de areia desenhada, trabalho artesanal típico do litoral brasileiro, além de imagens de uma senhora trabalhando na tal garrafa. 
Os efeitos visuais e a tentativa de mostrar ao espectador os detalhes e requintes da música, por meio da edição, nesse caso bastante literal, são, portanto, as marcas autorais de Oscar Rodrigues Alves. Aparecem em Quitambô e são levadas para o videoclipe seguinte, Realidade Virtual (1997), do Cidade Negra, primeira produção do realizador como profissional contratado por uma grande gravadora, Sony Music. Contava com bom orçamento e tempo disponível (a única a contar com quatro diárias), e foi indicada a sete categorias do VMB de 1997, embora não tenha ganho nenhum prêmio.

Se, em Quitambô, as imagens servem para criar um clima para a música, ressaltar a presença dos instrumentos musicais e acompanhar o movimento, em Realidade Virtual, Oscar Rodrigues Alves desenvolveu uma narrativa mais clássica. A banda de reggae Cidade Negra aparece numa espécie de futuro próximo, tocando e cantando entre várias antenas de televisão, algumas reais, filmadas em Alphaville e na Torre da TV Bandeirantes, ambos em São Paulo, e outras desenvolvidas em computador com tecnologia 3D. O som é hackeado por um emissário que o transmite para uma garota por meio de um laptop. No entanto, o diretor acredita que essa narrativa não foi muito bem explicada no videoclipe e, muitas vezes, serviu apenas de pretexto para mostrar equipamentos tecnológicos e transmitir um clima futurista, sugerido pelo assistente de direção Pietro Sargentelli. Ele que viria a ser co-diretor de Amor Pra Recomeçar (2001), do Frejat, e diretor de, entre outros, Dias Melhores (2000), Só Hoje (2002) e O Que Eu Também Não Entendo (2001), todos do Jota Quest; e Ela Não Está Aqui (2001), do KLB, dividido com Adrian Teijido.

Em Realidade Virtual, Oscar Rodrigues Alves chama atenção para os figurinos desenvolvidos por Cris Didália e Ana Morelli, que criaram texturas e jaquetas com sagu e resina de borracha. Outros aspectos destacados pelo realizador são a fotografia requintada e moderna, em tons de azul e verde, e o cenário com referências do pôster original do filme Alien, o 8 Passageiro (1979), de Ridley Scott, trazidas pelo diretor de arte Marcos Sachs.

Outro aspecto interessante da produção é a inserção de ruídos sonoros, criados para indicar a presença das antenas e dos computadores, como explica o diretor: 


\begin{abstract}
A Sony me mandou os másteres da música, com bateria, teclado, tudo separado. Eu estava próximo ao Bernardo Vilhena (poeta carioca, que aparece recitando um poema em off no início de videoclipe) (...) Fiz uma aberturinha e, no meio do clipe, na hora em que nosso hacker vai armar o equipamento, eu também abria a música e deixava só a bateria. Ele abre o computador, acha o sinal dos caras e daí a gente volta para o estúdio deles tocando. Cidade Negra só ficou sabendo na hora em que viu o clipe e adorou. A letra era sobre uma paixãozinha distante e platônica: "Pois quando você passa e eu vou atrás / O mal do dia a dia já nem lembro mais". Não tem um momento em que os caras estão com a gata. Enfim, a coisa da realidade virtual ficou muito mais pelo ambiente futurista que a gente fez. Não tem nada muito ligado só a letra. A música tem uma coisa legal que é a participação especial da Patra, cantora jamaicana que não podia participar do clipe. Mas, de alguma maneira, ela tinha que estar presente. Eu queria que ela estivesse. Então pegamos uma lâmpada de refletor de cinema gigantesca e a Sony me mandou a voz dela separada. Eu passei por um osciloscópio, equipamento que lê áudio e transforma em imagens, em ondas, e depois elas foram aplicadas dentro da lâmpada. A banda ficou meio dançando em volta e adorando a voz da Patra. Virou um máster legal pra caramba. A gente também conseguiu criar uma dinâmica que fosse sustentando e dando gás para cada um dos climas da música, evitando que o clipe ficasse enfadonho. Criamos várias situações e tiramos proveito disso. Esse foi um clipe bastante planejado.
\end{abstract}

Realidade Virtual começa com os músicos caminhando numa rua, em imagens em preto e branco, ao som de Bernardo Vilhena recitando o poema: "Há sete mil anos, a mesma cultura. Nenhuma censura vai evitar. A gente cultua a eterna mistura. O jeito mais perto de se encontrar". Em seguida, começam as imagens coloridas, com destaque para os tons mais escuros. Assim como a mistura de preto e branco com colorido, a valorização da sensualidade de uma modelo no videoclipe é uma marca importante no trabalho de Oscar Rodrigues Alves. Há também muitos efeitos visuais, como nas cenas onde os músicos aparecem se equilibrando sobre algumas antenas.

A valorização das imagens de uma mulher e da paisagem é a tônica do videoclipe Acelerou, que Oscar Rodrigues Alves dirigiu para o cantor e compositor Djavan, em 1990. A ideia original era filmar as imagens em Barcelona, na Espanha, em função da paixão, tanto do realizador quanto do artista, pelo arquiteto catalão Antoni Gaudí. Porém, em função da agenda lotada do cantor, eles optaram por realizar a produção em Paraty, no litoral do Rio de Janeiro.

Oscar Rodrigues Alves destaca a importância da seleção da bailarina e coreógrafa gaúcha Luciana Brites para o videoclipe:

Fizemos casting e descobrimos uma garota espetacular. Ela é atriz, bailarina, fez ginástica olímpica. Não era só um rosto bonito. Esse é um clipe que cresceu muito da concepção para a realização, porque a gente 
começou a rodar numa manhã bem cedo, no amanhecer numa praia de Paraty, numa maré baixa. A ideia era fazer algumas cenas bonitas dela andando na maré baixa. Só que ela começou a fazer algumas acrobacias, dançar, se jogar na água e virou algo incrível. Ela deu um gás espetacular ao clipe. De tudo que fez ali, a gente foi atrás, numa situação muito perigosa até para a câmera, porque é muito difícil você correr com ela na água (...) Então ali teve uma precisão de movimentos muito grande (...) Depois fomos para um barco em construção, também uma situação perigosa para a steadicam (sistema onde a câmera é acoplada ao corpo do operador através de um colete onde é instalado um braço dotado de molas), e para as ruas de Paraty. É muito difícil andar com steadicam, porque a rua é de pedra e toda tarde chovia no verão. Havia desníveis muito grandes entre pedras altas e buracos. Era muito difícil de trabalhar. Outra cena que a gente fez super legal foi aquela em que a Luciana se pendura numa corda e se joga no rio. Não é qualquer um que faz aquela cena. Ali teve muito dos treinos de circo e ginástica olímpica dela. E a falta de medo também.

O diretor destaca ainda o encontro ao acaso do Country Bar, que entrou no videoclipe em função do nome e do desenho de uma espécie de mariachi exibido na entrada que foi destacado pelo diretor de fotografia Adrian Teijido, o qual, pela participação tão acentuada, levou o crédito de co-direção.

Segundo Oscar Rodrigues Alves, Djavan solicitou mais imagens dele, uma vez que acreditava haver certa desigualdade de exposição dele e de Luciana Brites. O próprio cantor comenta como foi a experiência de trabalhar com o realizador:

O Oscar é muito inventivo e uma pessoa que tem uma animação e um entusiasmo contagiantes. Eu acho muito bom isso. A pessoa que tem inventividade e entusiasmo tem tudo praticamente (...) Paraty foi um lugar que a gente escolheu pela sua beleza natural e acaba que a música tinha uma atmosfera que poderia ser adequada com aquele cenário. Eu achei ótimo. Não me lembro se fui eu que sugeri ou se foi ele mesmo. Só sei que fomos bater em Paraty e vivemos momentos maravilhosos ali. Quer dizer, a cidade é linda e, para mim, que amo arquitetura e, sobretudo, a arquitetura imperial do Brasil, adorei. Foi uma experiência importante. Eu acho que o Oscar deu uma visibilidade bacana à música, que ganhou com o clipe dele.

A valorização da paisagem, da fotografia que mistura imagens em preto e branco a cores mais neutras de Djavan, caminhando pelas ruas da cidade, e do azul mais estourado da atriz, fazendo coreografias sensuais no mar, são marcas autorais do diretor em Acelerou. No entanto, o que ele mais destaca é a maneira diferenciada de trabalhar com a música, por meio da edição, dos movimentos de câmera com imagens desfocadas e com interferências, de finalidade declaradamente dramática, como explica: 


\begin{abstract}
A letra fala da paixão de um homem por uma mulher, que acelerou e depois tirou o corpo fora. Então eles não estão nunca juntos (...) Usei mesmo a mulher onírica em situações reais, mas que pudessem ser lembranças especiais dele, e tem um special, que é aquele "Muito mais perdido, quase um cara vencido", em que a gente ralentou a música no Pro Tools (estação de trabalho em áudio digital que integra hardware e software, muito utilizada na produção de música). Então ficou "Muito mais perdido", bem mais lento. Ele cantou mais lento e a gente rodou a câmera mais lentamente, para que tivesse a imagem na velocidade normal dela, 24 quadros por segundo. $A$ gente rodou a 12 para que, quando estivesse a 24, ele estivesse sincado com a velocidade original da música, mas acelerado. Nessa hora, a gente pegou o que a Lu Brites tinha feito de mais incrível na praia e editamos num ritmo mais acelerado do que o do clipe e fizemos esse special, que é bem legal e que vai gerar uma herança no Até Quando?, do Gabriel O Pensador.
\end{abstract}

Oscar Rodrigues Alves acrescenta, a respeito da semelhança entre os videoclipes Acelerou e Até Quando?, do rapper Gabriel O Pensador, co-dirigido com Nando Cohen, em 2001, o seguinte:

\begin{abstract}
Tem uma herança dos meus clipes anteriores que é a alteração da velocidade. Esse também é acelerado na hora que ele fala: "Acordo, não tenho trabalho, procuro trabalho, quero trabalhar". Usamos a mesma técnica do Djavan, Acelerou. Reduzimos a velocidade da música, rodamos com ele cantando mais lento e a câmera rodando mais lenta para que, na hora que tudo fosse acelerado, ele ficasse rapidinho e sincado com a música original do $C D$.
\end{abstract}

Está aí, portanto, uma das principais marcas autorais de Oscar Rodrigues Alves. O resultado teria sido ainda mais surpreendente, caso Gabriel O Pensador não tivesse impedido que houvesse mais alterações na música original e vetado o sound design desenvolvido por Paulo Beto, cujo codinome artístico é Anvil FX. Ele é um dos pioneiros da música eletrônica em Minas Gerais. A mistura de imagens coloridas com outras em preto e branco também volta a aparecer.

Em Até Quando?, Oscar Rodrigues Alves partiu de uma ideia bem simples: posicionar Gabriel O Pensador sentado numa cadeira e projetar animações sobre as imagens, realizando uma transposição quase literal da letra, através do comportamento do cantor e pautando a edição na batida nervosa da música, como observa:

Nós fomos vendo a letra e criamos cenas específicas para cada coisa que ela dizia. Fomos decupando e tentando ter leituras interessantes para cada um dos versos que nos indicavam que ali merecia uma animação. Não são relações óbvias. São leituras que sempre acrescentam outra dimensão à 
letra. Reforçam, mas sem obviedade. A águia, por exemplo, fala de repressão e compressão econômica.

Muito do resultado final desse videoclipe surgiu durante as próprias filmagens, o que fez com ele se tornasse algo completamente diferente do que era visto até então na produção brasileira, conforme esclarece o diretor:

\begin{abstract}
Quando a gente roda, já tem a ideia muito discutida com o artista. Mas tem muita coisa que aparece na hora e que dá um sabor especial ao clipe. Em Até Quando?, por exemplo, não tinha a ideia de fazer a sobreposição de dois personagens. A ideia era o Gabriel e a intervenção da animação por cima, mas, quando a gente posicionou a câmera, colocou a lente grande angular e enquadrou o Gabriel, eu falei: 'Encosta na lente'. Ficava super legal. Aí falava: 'Se joga na cadeira'. Ele se jogava. Ficou super legal também. Ali, naquela hora, falei: 'Vou rodar os dois e sobrepor. Vou ver o que acontece'. E deu super certo, porque virou uma coisa importante, conceitual ali, de ter um cara ativo, que dá o esporro, e um passivo, que toma o esporro (...) Era um clipe no qual nós estávamos muito entusiasmados com a simplicidade e com a diferença para tudo que estava no ar. As pessoas falam da linguagem videoclipe, termo que eu abomino, porque imagino vários cortes rápidos, o que não é o caso. Eu ambicionava bastante fazer um clipe com um formato bem diferente. Essa é uma coisa muito difícil que eu nem sempre consigo, mas sempre procuro. Já tinha uma simplicidade pretensiosa, digamos assim, que acabou sendo ainda mais enriquecida.
\end{abstract}

Originalmente, a ideia do Gabriel $O$ Pensador era ter um videoclipe bem jornalístico, com imagens de violência desde o Brasil até a Faixa de Gaza, no Oriente Médio, uma vez que a letra questiona até quando o cidadão continuará levando "porrada" e sendo "saco de pancada". Não obstante, Oscar Rodrigues Alves o convenceu a ir para outra direção, numa mistura de imagens reais com animação. No final, a própria atuação do cantor foi muito importante para o resultado, segundo o próprio diretor:

A gente tinha a ideia de fazer uma coisa dele de braço cruzado e desenhar uma roupa de hospício. Na hora que vinha uma águia no clipe e falava: "Escola, esmola / Favela, cadeia", por exemplo, ele mesmo pôs a cabeça entre as pernas e a abraçou, uma coisa da performance na hora. Nando falou: "Genial. Vamos pôr uma águia que vem e ataca o cara". Não foi uma coisa que a gente pré-concebeu. Depois que ele fez isso e que Nando teve a ideia de colocar essa águia, a gente também sentiu que havia poucas animações no clipe. A dinâmica pedia mais animações, que estavam um pouco diluídas.

O co-diretor de Até Quando?, Nando Cohen avalia a importância desse videoclipe: 
O que eu gosto muito do Até Quando? é que ele é muito simples. Apesar de ser uma técnica mista da animação com o Gabriel, é uma câmera travada no estúdio e o cara numa cadeira o clipe inteiro. O Gabriel é um senhor ator, até porque acredita no que escreve. A parte da animação também é legal e fizemos com o Anderson, um cara muito autoral, quase um grafiteito, com trabalho único. Esse clipe, eu e o Oscar fizemos bem a quatro mãos. Eu acho que, mesmo juntando imagens da banda com animação, Até Quando? tem um formato menos convencional de videoclipe.

Os figurinos foram escolhidos pelo próprio Gabriel O Pensador, que aparece como dois personagens na tela. $O$ personagem contestador de cabelo preso e camiseta preta regata, e o personagem passivo que usa uma camiseta cinza e o cabelo solto. Por sua vez, as animações foram realizadas à mão, diretamente na tela do computador, por um desenhista chamado Anderson, apresentado ao Oscar Rodrigues Alves por Nando Cohen. O que chamou atenção foram os traços fortes e agressivos em desenhos que chocam também, pela brutalidade, como, por exemplo, a cena da águia atacando o cantor, outra de canibalismo e mais uma em que um revólver atira no rosto para acompanhar o verso "Ou aceita ser um saco de pancada ou vai para o saco". As animações também aparecem em cores muito fortes, em contraste com os tons praticamente neutros do cantor sentado na poltrona.

O editor Daniel Rezende, indicado ao Oscar em 2004, pelo filme Cidade de Deus, foi convidado a participar da edição final do videoclipe e ganhou os créditos, tal a importância das interferências que realizou e que Oscar considera como sendo "muito inteligentes e sutis". Resultado: a edição, dividida por Oscar, Daniel Rezende e Rogério Ferreira Alves, foi premiada no VMB de 2001. O diretor acredita que o prêmio se deve mais pela pós-produção como um todo, incluindo a inserção das animações, do que pela edição propriamente dita. Ele destaca também que, graças a esse videoclipe, foi convidado para dirigir o primeiro comercial para a Coca-Cola e que sempre que o apresenta em palestras em universidades, é aplaudido antes mesmo do término da exibição.

O videoclipe mais premiado dentre os realizados por Oscar Rodrigues Alves é Epitáfio, dos Titãs, que, no VMB de 2002, levou as estatuetas de melhor videoclipe de rock, melhor videoclipe do ano e escolha da audiência. Esse trabalho é tão marcante para o diretor que ele resolveu utilizar os créditos de direção para homenagear o pai, Francisco Rodrigues Alves, e o avô, Oscar Rodrigues Alves.

A realização do videoclipe aconteceu praticamente por acaso. Oscar Rodrigues Alves já estava trabalhando na ideia de Isso, que viria a realizar alguns 
meses mais tarde, quando a canção Epitáfio estourou nas rádios, muito em função da morte do guitarrista Marcelo Frommer, em 11 de junho de 2001, atropelado por um motoqueiro na avenida Europa, em São Paulo.

O diretor descreve como pensou rapidamente numa ideia para o videoclipe Epitáfio:

\begin{abstract}
A letra de Epitáfio sempre remeteu à poesia de Jorge Luis Borges: "Poderia ter comido menos lentilha e tomado mais cerveja". Enfim, é uma série de imagens de uma pessoa no final da vida que achava que devia ter aproveitado melhor. Então achei que era possível fazer um layout, como a gente chama, pegar a música, digitalizar para o computador e começar a juntar imagens da minha família, fossem as que meu avô filmou do meu pai em 1928 ou as que eu filmei da minha casa e da minha mulher. Eu não tinha filho na época ainda. As coisas do meu pai filmadas pelo meu avô eram em 16 milímetros com dupla perfuração, com a câmera Ison Kodak, que, quando meu pai nasceu, meu avô comprou para filmá-lo. Depois, meu pai, ainda com essa mesma câmera, filmou minhas irmãs em 16 milímetros e me filmou muito em Super-8. Eu roubei essa câmera dele, Canon 1014, e filmei bastante minha mulher e minha casa. Um material totalmente caseiro. Achei que aquilo estava muito adequado para depois o que Sérgio Britto, compositor da música, veio a chamar de "espirito da canção".
\end{abstract}

A aprovação dos integrantes dos Titãs foi imediata, com a ressalva de que gostariam de ser filmados em alguns lugares especiais. O guitarrista Tony Bellotto escolheu um passeio de bicicleta; o tecladista Sérgio Britto preferiu tocar piano na sala de casa, na companhia do filho; o vocalista Nando Reis optou por ir ao estádio ver um jogo de seu time do coração, São Paulo; o baterista Charles Gavin sugeriu assistir a um episódio do seriado National Kid; Paulo Miklos apareceu passeando com o cachorro; e o vocalista Branco Mello foi registrado andando por entre os graffitti espalhados pelo bairro paulistano Vila Madalena.

Sérgio Britto comenta como foi trabalhar com Oscar Rodrigues Alves nesse videoclipe:

Foi muito legal, porque o Oscar é um cara muito talentoso e muito musical. A gente um dia fez um almoço e estava falando de não fazer uma leitura muito óbvia da música e nem uma coisa ilustrativa. A ideia é dele. Então o mérito dele foi total nesse clipe e ele teve uma sensibilidade muito grande de fazer essa leitura com imagens da música, porque foi um casamento perfeito e não óbvio. Eu acho que ficou muito bacana essa história de ele filmar cada um de nós fazendo coisas que gostava (...) Isso junto com os arquivos da família dele, aquela coisa do dia a dia, da simplicidade e a beleza que a vida pode ter. Combinou muito bem ali com essa coisa lírica que a música tem. Então acho que ele acertou, tanto é que foi um clipe também premiadíssimo e que ajudou a propagar a música (...) A gente fez talvez algumas sugestões de edição, de um trechinho ou de outro que não 
estava satisfeito. Mas, nesse caso, a ideia partiu dele e, imediatamente, a gente gostou. Então não teve muita discussão.

A respeito da importância desse trabalho, Oscar Rodrigues Alves destaca:

\begin{abstract}
A verdade nua e crua é que esse videoclipe, para mim, é um elo perdido ou um elo achado. Ele amarra muito da minha vida, da minha ligação familiar com meu pai e com meu avô, do meu ofício, do meu encontro com os Titãs. Esse videoclipe é muito mais do que um videoclipe para mim. Ele é um filminho da minha vida. Acho que ele salvou provavelmente umas 250 horas de análise para descobrir quem eu sou (risos) (...) A música já era muito forte e eu não queria que as imagens a estragassem. Pelo contrário. Se há uma coisa que eu busco no videoclipe é que as imagens deixem a música ainda mais legal. Então acho que os objetivos foram mais do que plenamente concretizados.
\end{abstract}

O pai do diretor, Francisco Rodrigues Alves, foi até reconhecido em açougue após o videoclipe ser premiado no VMB. Comenta a ligação da família com o cinema e a importância de ter suas imagens recuperadas pelo filho, inicialmente para o vídeo comemorativo doméstico Chico 70, para as comemorações de seus 70 anos, e depois no videoclipe Epitáfio:

\begin{abstract}
Ele faz isso e não consulta nenhum médico para ver se meu coração agüenta (...) Estava filmando para mim. Não estava fazendo para ele. A gente é meio egoísta nessas coisas. Nunca pensa nos outros. Você pensa: "Eu vou filmar e guardar essas imagens para mim". E ele roubou (...) Meu pai me ensinou (a filmar), porque eu pegava a câmera e não sabia fazer nada. Ele é quem me mostrou como era. Tinha aquela caixinha e o rolo, abria, punha depressa lá dentro, fechava e passava.
\end{abstract}

\title{
Algumas marcas autorais de Oscar Rodrigues Alves aparecem em Epitáfio.
}

Caso da mistura de imagens de diferentes formatos e coloridas com preto e branco, da valorização dos artistas no vídeo e de uma preocupação com a tradução do sentido da letra em imagens,além da edição calcada na estrutura musical, procurando valorizá-la. $O$ próprio diretor afirma a respeito da dinâmica da música:

Ele tem um pouquinho de sinc musical em uma viradinha de bateria que $o$ Charles pega uma micro do $A C / D C$, que ele tem, e dá uma batucadinha. Eu a fiz encaixar numa virada que ele faz na música. Depois também fiz casar com essa virada de bateria a imagem do José, filho do Britto, tocando uma bateriazinha e dando duas pratadas. Tem uma procura pela musicalidade, pelo sinc, até numa situação onde supostamente não poderia ter. Achei um sinc impossível do menino tocando bateria com Charles Gavin. Uma coisa legal também é que, nas imagens do meu avô, tinha um colorbar verde e todo riscado, com aquelas faixas verticais, que vai do branco ao preto, passando por ciam, yellow, magenta. Eu achei numa ponta de filme mesmo, 
que casou muito bem com o final da música, em que tem um loop de bateria eletrônica do Charles, que continua como se fosse um disco riscado. Acho que foi uma sacada legal.

Creditando o ofício que escolheu profissionalmente ao pai, Oscar Rodrigues Alves destaca a coincidência de haver imagens dele num parque de diversões na avenida Santo Amaro, em São Paulo, e que também aparece no videoclipe Go Back, dirigido por Branco Mello e Jodele Larcher para os Titãs em 1988. Mostra os integrantes da banda com os filhos e em cenas cotidianas. Também recorda que há imagens em Epitáfio que vieram não apenas dos registros familiares, mas também do arquivo de imagens que costuma organizar por conta própria:

\begin{abstract}
Por exemplo, tem um moleque que corre de cueca, que é um cara genial que filmei quando estava fazendo um documentário para a HBO. Em 1998, fiz um segundo documentário do Brazilian Music Festival, um festival brasileiro que aconteceu em Nova lorque. Só que, antes de ir para Nova lorque, a gente viajou ao Brasil atrás dos artistas e da casa dos que estavam indo viajar. Ou seja, a gente foi na casa do Hermeto Paschoal, em Bangu; a Caruaru, fazer a Banda de Pífanos; a Recife, fazer o Cascabulho. Vi um moleque de cueca correndo, se divertindo, e, na hora, falei: "Vou gravar esse moleque". Ainda era Super-8. Não era nem vídeo. E filmei. "Um dia eu uso isso". No Epitáfio, lembrei dessa cena e usei.
\end{abstract}

Após o grande sucesso de Epitáfio, Oscar Rodrigues Alves foi convidado a retomar a ideia original do videoclipe Isso (2001), dos Titãs, no qual considera ter desenvolvido uma narrativa que escapava do que se via habitualmente na televisão:

Isso abre meu repertório e acho que não há outro igual. Não é uma ideia copiada de nenhum clipe. Modéstia à parte, acho que é um trabalho de direção super legal, que me orgulha, pois é completo, tem ideia e realização legais, fotografia e edição muito boas, figurino legal pra caramba do Marcelo Sommer e (Paulo) Miklos arrebentando. Sou muito feliz com ele e não ganhou prêmio (...) O clipe é sensacional, mas é bom notar que a gente (Academia de Filmes) pagou para fazer esse clipe. Eu coloquei dinheiro, uns 10, 12 paus nesse clipe. Ele não tinha dinheiro para todos os equipamentos e também não quisemos e não tivemos patrocínio. Quis apostar, porque era uma ideia que eu queria muito realizar e ter na minha filmografia. Achava que seria um clipe muito chocante. Fui realmente indicado a melhor diretor no VMB desse ano (...) Talvez se eu tivesse de pinçar um clipe até hoje, o mais completo seria esse. A começar pela grande ideia. Acho que o grande clipe começa por uma grande ideia. Talvez essa tenha sido a ideia mais legal que eu tive até hoje para videoclipe.

A ideia desse videoclipe surgiu a partir de um filme publicitário que Oscar Rodrigues Alves estava realizando na época: 
Eu tinha acabado de fazer uma campanha de lançamento de novos sabores de (refrigerante) Fanta, onde um dos filmes tinha rodado com uma elefanta - Bambi - e foi engraçado, porque bem depressa achei que não tem nada mais isso do que uma elefanta na minha cabeça naquela hora. Então peguei as imagens brutas rapidamente no arquivo, comecei a olhar e, como era (Paulo) Miklos quem cantava a música, tive a ideia de fazer um encontro entre um macho e uma fêmea que não conseguem se adaptar e se beijar, não falam a mesma língua e estão totalmente desencontrados. Pensei numa estradona, num ambiente que interferisse menos nos personagens. Peguei uma imagem do filme de Fanta, tirei a cor, passei para sepia, que era uma ideia que eu tinha da cor, e achei que a música cabia perfeitamente na imagem da elefanta (...) Aí desenvolvi e cheguei no Rio de Janeiro já com uma ideia de locação, que era arrozal em Tremembé, que fica perto de Campos do Jordão, cerca de 180 quilômetros de São Paulo, e uma leitura de imagens bem em cima da música.

Apesar de ter saído para o set de filmagem com a ideia muito bem desenvolvida, o diretor garante que se valeu bastante de um olhar atento para os improvisos e imprevistos, característica muito específica dele:

\begin{abstract}
Cheguei numa estrada reta e a elefanta ficou louca com o cenário, começou a brincar com a areia, a correr e tal. Trombeteava. Você, então, tira proveito da loucura que acontece na hora. Tem que estar esperto e aproveitar essas coisas que enriquecem o clipe. Eu preciso chegar ao set sabendo que dali tiro um clipe do qual vou me orgulhar. Não saio para filmar sem saber que os componentes que levantei vão me dar um clipe legal. Mas muitas vezes as coisas mais legais acontecem por acaso, por sorte, enfim. Tem que ficar ligado, porque o clipe vai se transformando ao longo do tempo. Não é um roteiro fechado, que você roda os diálogos ali e pimba (...) Havia muitas cenas preparadas: as tentativas de conquista, um anelzão com uma pedra azul que o Sommer me emprestou, e ele (Paulo Miklos) tenta ganhar a elefanta de todas as maneiras possíveis. Ele oferece esse anel. Ela não quer saber. A gente tinha levado uma rosa de açúcar também, daquelas de enfeitar bolo, que ele oferece. Ela vai e come a rosa. Ele encosta a cabeça na tromba dela. Uma cena que foi muito legal é ele andando de costas e ela de frente. Ele falando e a gente enquadrando o perfil dos dois. Foi genial.
\end{abstract}

\footnotetext{
Oscar Rodrigues Alves chama a atenção para os figurinos criados pelo estilista Marcelo Sommer, que remetem a algo meio circense e com ares de fábula, para mostrar a imagem da banda tocando em estúdio, em cima de um giratório. Os movimentos de câmera nessas cenas acompanham exatamente o ritmo da música, ficando mais frenéticos nos instantes em que a canção é mais roqueira. Outros destaques são a pintura da elefanta numa tela posicionada num cavalete, fruto do trabalho do diretor de arte Marcos Sachs, e a atuação de Paulo Miklos, contracenando com a elefanta Bambi:
} 
A gente esteve duas vezes no Circo Stankowich com Paulo Miklos para ele se acostumar um pouco com a elefanta e a gente ver se ia dar certo. $O$ elefante é um bicho muito difícil de a gente se relacionar, muito por causa do tamanho e do peso. Quer dizer, ele é controlado, domado, domesticado, mas não é empurrável. Se ele vier andando em sua direção, você não tem o que fazer. E tem a questão da tromba. Não é como pata de cachorro ou rabo de rato. É um aspirador peludo, gigantesco, que dá volta no pescoço, faz carinho, joga água, cheira. Um negócio muito doido. Miklos começou com muito medo dessa dificuldade de se relacionar fisicamente com a base da história que ele viveria ali. Essa dificuldade de relacionamento era importantíssima. No dia da filmagem, ele deu uma talagada num uísque e relaxou. Ele é um ator de primeira. Na hora em que abre a câmera e o bicho tem que desempenhar, não tem para ninguém. É com o cara mesmo.

Como marcas autorais nesse videoclipe, identificam-se a dinâmica da montagem, de acordo com as viradas da música; a inserção de ruídos, como o som de um elefante, e outras transformações na música; leitura inusitada para a letra da canção; a utilização de maquinarias como steadicam; e utilização de uma abertura, de modo semelhante à de Realidade Virtual, mas nesse caso com o vocalista Branco Mello recitando um trecho da música Qualquer Negócio: "O pior cego é aquele que não quer ver / Sem conservantes, cem por cento natural / Cada um é seu próprio animal / Você pode ser a namorada do Brasil / De novo para você o que você nunca viu".

Oscar Rodrigues Alves identifica outras marcas autorais ali, ao observar que:

Busca incansável pela originalidade e não ter medo de propor alguma coisa para os artistas - fosse propor ao Miklos que contracenasse com um elefante, que era difícil para ele, fosse convencer os Titãs a permitirem que Paulo tivesse papel preponderante, principal, digamos assim, dentro dessa história. Eu vinha de trabalhos com Cidade Negra, banda que fazia questão de certo equilíbrio da participação de todos os músicos. Achava que os Titãs fossem assim também e que teria um pouco de trabalho ao tentar convencê-los. Mas foi bem tranquilo, talvez pela história tão legal que a gente criou. Em nenhum instante, eles se opuseram a que isso acontecesse. Planejamento bem feito te deixando tranquilo para improvisar muito na hora. A gente planejou muito. "Vamos viajar às quatro da manhã para chegar à locação às seis, junto com o sol, e começar pelo dib dib, que é o equipamento mais demorado para se montar, e começar a rodar com a primeira luz. E foi isso o que aconteceu (...) Na hora da luz mais linda, o equipamento estava montado, como tinha sido planejado. A partir daí, a gente estava livre para aproveitar os improvisos que a Bambi nos proporcionou.

Portanto, originalidade, planejamento, dinamismo, criatividade, sensibilidade e muito ânimo, além de, é claro, improvisação criativa constituem alguns pilares que sustentam o diferencial do trabalho desse autor. 
Se o videoclipe Isso merece destaque especial na obra de Oscar Rodrigues Alves pelo ineditismo, Dois Rios, dirigido para o Skank, em 2003, e premiado como melhor videoclipe pop no VMB 2005 e melhor fotografia em videoclipe pela Associação Brasileira de Cinematografia, pode ser considerado um dos videoclipes do diretor que mais emocionaram as pessoas, como ele mesmo relata:

Ele foi o primeiro videoclipe que tirou lágrimas das pessoas. (...) Eu, particularmente, tenho dificuldade em chorar. Então, se alguém chega para mim e fala: "Faz um clipe para as pessoas chorarem". Eu já digo: "Não sei fazer isso". Eu fiz um clipe com sensibilidade, claro. Acho que a sensibilidade está sempre presente nos meus clipes, mas jamais pensei que fosse levar as pessoas a chorarem, ainda mais num videoclipe. Tudo bem que a carga dramática da música ajuda muito e já encaminha, mas é um negócio que é muito curtinho. É difícil você fazer uma pessoa se emocionar, chegar às lágrimas, com um videoclipe. Foi a primeira vez que aconteceu e não era esperado, nem planejado (...) Samuel (Rosa, vocalista da banda) gastou bastante tempo comigo falando do clipe, incluindo uma coisa que tomei como elogio, um padrão de qualidade do meu trabalho: "Véio, quando a gente deixou de ser uma banda independente e foi contratado pela Sony Music, falou: "Puxa, agora nós vamos virar uma banda. Sempre quisemos ser filmados desse jeito". Engraçado. Eu acho que ele quis dizer que aquilo está muito bem feito, que a banda estava muito bem filmada musicalmente. Aquele vídeo tinha uma cara de clipe gringo, digamos assim.

O contato para trabalhar com o Skank surgiu por meio do empresário da banda, Fernando Furtado, que gostou da maneira com que Oscar Rodrigues Alves filmou os Titãs em cima de um sistema giratório. Tanto que o mesmo efeito foi repetido em Dois Rios, o que pode ser apontado como marca autoral do realizador, assim como a mistura de imagens reais com animações, que é a principal tônica do videoclipe. No entanto, o realizador aponta haver aí um avanço em sua obra, uma vez que, mesmo mantendo o fundo preto, desta vez ele foi pintado com flairs, trazidos pelo fotógrafo Adriano Goldman e que define como sendo distorções óticas. Elas geram uma bola e podem ser utilizadas como efeito ou defeito especial, e cuja inspiração veio do videoclipe Staring at the Sun, dirigido por Jake Scott para a banda irlandesa U2, em 1997. Outro acréscimo na imagem da banda é mostrar um piano de parede aberto, sugestão dada pelo falecido produtor musical Tom Capone.

Oscar Rodrigues Alves comenta a nova parceria com Nando Cohen:

A gente criou uma coisa legal: fizemos a banda e, num telecine, escolha de cores. Isso é uma coisa legal da minha parceria com o Nando e começou no 
Até Quando?, do Gabriel O Pensador. A gente sempre filma antes e, às vezes, a animação vai correndo na paralela ou rola depois. Mas eu sempre monto uma base filmada e mostro ao Nando e ele fala: "Essa banda está muito boa". Aí chama a equipe dele (da qual no caso de Dois Rios fazia parte o futuro diretor de videoclipes Luis Carone) e começa a melhorar a animação. Ele pegou a parte filmada e usou cores da parte filmada na animação. A gente tentou integrar um pouco as coisas através das cores das distorções que o flair causou. Então, tem sempre uma instigadinha que dou no Nando a partir de imagens filmadas (...) A parte filmada é muito simples, intencionalmente simples, porque sabíamos que haveria pósprodução bastante rebuscada. Então a concepção foi feita com as bases muito simples, com fundos pretos e roupas em tons de cinza, para deixar que a animação tivesse bastante espaço para atuar. Ali você identifica minha preocupação com sincronismo, musicalidade, fotografia apurada, servindo como base para que a pós-produção pudesse pintar e bordar, fosse em cima das imagens, como em Até Quando?, fosse criando outro universo, no caso de Dois Rios.

\section{Entretanto, a principal referência de Dois Rios é o filme Pink Floyd - The}

Wall, dirigido por Alan Parker em 1982, para a banda britânica Pink Floyd, tendo como enredo todas as canções do álbum de mesmo nome e que mistura animação com imagens reais. Oscar Rodrigues Alves explica como essa influência surgiu após viagem à Belo Horizonte (MG), para conhecer os integrantes do Skank:

Eu voltei de BH com The Wall na cabeça, com aquela cena lindérrima do pássaro e de duas flores, se não me engano - uma orquídea ou um lírio - e rola uma cópula e depois uma mordida. Voltei com isso e montei para Nando, que, obviamente, já conhecia. Partimos dali. Tinha os rios e a água. O Nando (Cohen, co-diretor do videoclipe) começou a mostrar algumas técnicas que ele estava começando a utilizar para trabalhar com água. Animação tem sempre que levar em conta o prazo. É um processo bastante trabalhoso e que requer você planejar muito bem, porque despende muito tempo. Então a gente ouviu a música várias vezes e fez uma decupagem muito objetiva do que precisava fazer para contar a história. Aí Nando veio com a ideia de transformar as flores na história de uma flor e de um pássaro. $O$ encontro que eu via no The Wall gostaria que acontecesse também em animação. Então, o pássaro sobrevoa o rio, a flor vem nadando $e$ eles se encontram numa pororoca qualquer, digamos assim (...) Paralelamente, eu desenvolvi, com Adriano Goldman, a pegada que teria. Nando desenvolveu uma estética muito interessante, meio japonesa, para a animação, e eu não queria que a parte filmada brigasse esteticamente com ela. Eu sabia que descarregaria uma boa parte do orçamento e, com isso, boa parte das possibilidades estéticas, em cima da animação e que não poderia fazer, por exemplo, um cenário que, de alguma maneira, grudasse ou compusesse com ela. Fui pelo outro lado.

Nando Cohen também avalia a importância desse videoclipe:

Esse é um videoclipe bem mais poético e feito totalmente em cima da letra. A ideia de fazer um encontro desses dois rios e criar os personagens que são a flor e o passarinho, numa animação $3 D$ de estilo nem um pouco convencional. Eu lembro que o Oscar queria uma coisa mais The Wall $2 D$ 
assim, meio lisérgico. A co-direção foi bem dividida, porque eu interferi muito pouco na parte filmada e fiquei mais cuidando da parte da animação. Havia umas coisas de um flair, com umas luzes contra, que veio para a animação também. Os caras do Skank foram totalmente na cega, porque confiaram muito no Oscar, aprenderam a confiar também no meu trabalho e ficaram super emocionados.

O vocalista do Skank, Samuel Rosa, considera esse um dos videoclipes mais sofisticados já realizados para a banda:

\begin{abstract}
Nós não demos palpite algum. Foi a primeira vez que trabalhamos com o Oscar e ele veio com essa ideia da animação da ave que beija uma flor na água, conjugada com imagens num clima meio anos 70 , com a luz mais escura. Tudo alinhado com a proposta da música. Daí você vê a importância que tem o diretor ter um conhecimento prévio da música, das referências que ela tem, da história da banda e do contexto em que está sendo lançado aquele álbum. Acabou que Dois Rios tornou-se um dos videoclipes mais requintados e sofisticados que o Skank tem, assim como a música. Então esse clipe tem toda a assinatura do Oscar.
\end{abstract}

As marcas autorais de Oscar Rodrigues Alves se manifestam, então, em Dois Rios pela mistura de imagens reais com animação, pelas imagens mais neutras, que mostram a banda tocando, com outras mais coloridas, advindas da animação; pela maneira de filmar a banda em estúdio e pelo modo de relacionar as imagens com a música, o que, neste caso, acontece de modo bastante literal com relação à letra. $O$ realizador comenta $o$ aspecto:

Esse foi um clipe totalmente criado em cima da letra e da música. "O céu está no chão". Daí nós falamos: "Vamos fazer uma poça d'água e o pássaro e o céu refletidos no chão". Fomos exatamente em cima da letra, criando imagens poéticas que contassem histórias e as traduzissem. Não há edição de som. Foi o fonograma tal qual ele é no disco. Ele já tem dinâmica muito louca. Tem solo de guitarra. Começa só com piano e voz, aí entra baixo, depois batera. Respeitamos na filmagem essa dinâmica.

\title{
5.3 Considerações Gerais
}

A análise de sete videoclipes dirigidos por Oscar Rodrigues Alves tornou possível identificar algumas das principais marcas autorais desenvolvidas e aprimoradas por esse realizador ao longo do seu trabalho. A principal delas é a tentativa de tornar a música ainda mais atraente ao espectador, identificando para ele a presença dos instrumentos musicais e do ritmo musical adotado, mas sempre procurando escapar da tradução óbvia. Ele opta por realizar efeitos especiais, no 
caso de Quitambô e Realidade Virtual, ou sincronismos inusitados, como em Epitáfio. A transformação da música original e a inserção de ruídos é outra tônica do trabalho do realizador. Ele se preocupa também com a qualidade do registro dos músicos na tela, seja como atores principais, caso de Paulo Miklos em Isso e de Gabriel O Pensador em Até Quando?; seja em meio a natureza, como em Acelerou, com Djavan, em Paraty, e com a banda em sistemas circulares, como em Isso e Dois Rios. Ou seja, é algo próximo do que o crítico francês Serge Daney identifica no videoclipe como sendo "ver com os ouvidos".

O próprio Oscar Rodrigues Alves explica o padrão de qualidade que gosta de adotar:

Sabe o que é um bom videoclipe? É o que faz a música ficar mais legal ao seu ouvido por algum motivo, porque a montagem respeitou a dinâmica da música e o cara soube transportar a dinâmica dela para uma dinâmica legal de imagem; ou a leitura da letra da música ficou super legal. Então bom clipe, para mim, é aquele que você assiste e fala: "Vou ouvir essa música e ela vai bater mais legal depois de ter visto esse clipe". Ele pode ter uma fotografia completamente suja e detonada, mas a ideia ser muito boa.

Outras marcas autorais importantes de Oscar Rodrigues Alves são a mistura de imagens em preto e branco ou em cores neutras com outras imagens coloridas, usualmente de cores saturadas; a mistura de imagens reais, em geral dos intérpretes das canções, com animações; a utilização de diferentes maquinarias e efeitos de iluminação; a valorização de belas modelos e paisagens; e o grande interesse em figurinos, direção de arte e pós-produção. Também chama atenção a influência das referências cinematográficas, como em Dois Rios, e a busca por soluções simples e originais, como em Até Quando? e Isso.

Ele mesmo acrescenta a respeito de onde se manifestam suas marcas autorais:

Em algumas coisas básicas, como preocupação com o sincronismo entre imagem e som; musicalidade; respeito à dinâmica da música; cuidado com a adequação de todos os elementos (fotografia, direção de arte, edição) ao que a música está pedindo. Por mais que eu tenha clipes embaixo da água (Palavras Repetidas, do Gabriel O Pensador, de 2005, co-dirigido por Nando Cohen) ou na Lua (A Estrada, do Cidade Negra, de 1998), filmado em 35 milímetros ou em Super-8, com elementos muito distintos uns dos outros, muita gente fala: "Vi um clipe no ar e achei que era a cara do Oscar. Esperei os créditos e era mesmo". Não é que eu repita sempre a mesma fórmula, mas quem vê um clipe, vai notando um pouco de todas as preocupações que eu tenho. Então, pelo que as pessoas falam, acho que dá para identificar um DNAzinho nos meus clipes. 
Com relação aos métodos de trabalho que costuma adotar, o realizador explica:

\begin{abstract}
Primeiro, o artista me manda a música. Eu, então, ouço várias, várias e várias vezes. Ali já penso em quem vão ser meus parceiros, principalmente o diretor de fotografia, e volto para ele com uma ideia do clipe (...) A partir da hora que a gente (ele e o artista) se afinou, eu volto e dou uma orçada. Aí vem um estica e puxa com a agência e com a gravadora ou, às vezes, com a gravadora e o empresário do artista, envolvendo o orçamento do clipe. Aprovado o orçamento, vem a produção de fato. Dependendo da ideia do clipe, uma ou duas semanas de pré-produção - levantar cenário, procurar locação e tudo mais (...) Acho que mais do que know-how de efetivamente como fazer cada coisa, um diretor precisa seguir uma linha e extrair da equipe e dos artistas o que ele tem em mente. Também me considero muito autor, porque as possibilidades de interpretar uma música são infinitas, e o resultado do clipe é uma interpretação encomendada pelos autores da música.
\end{abstract}

A co-direção também é algo importante nos videoclipes realizados por Oscar Rodrigues Alves e destacados nesta pesquisa, principalmente no caso de Até Quando? e Dois Rios, ambos co-dirigidos por Nando Cohen. O realizador avalia seu peso no resultado dos seus videoclipes:

\begin{abstract}
Quando eu chamo alguém para co-dirigir comigo, é porque tenho certeza de que essa pessoa vai agregar muito e dar outra dimensão à obra que está sendo feita. E acho que sempre que co-dirijo tem uma base ali do meu trabalho muito clara, que quem vem, aproveita essa base e sobe alguns degraus. Seja Nando Cohen, Luciano Cury, Marcelo Presotto, Hugo Prata, os meus parceiros sempre partem da base do que eu faço de melhor para desenvolver a partir disso. As co-direções trazem outros temperos para minha cozinha, que são importantes. Ficar usando aquele temperinho do arroz e feijão todo dia, uma hora enche. Então precisa vir alguém que tire um pouco daquele trivial da cozinha de todo dia. Por isso, em algumas horas, eu apelo, no bom sentido, para esses meus parceiros. Também é sempre um trabalho de parceria com a equipe toda.
\end{abstract}

A questão dos direitos autorais também preocupa Oscar Rodrigues Alves, quando ele afirma que:

Antes do DVD, as gravadoras tinham o pretexto de que os videoclipes promoviam o álbum. Não eram comerciais do álbum. A partir do DVD na prateleira de uma loja, isso caiu por terra. Ficou muito clara a possibilidade 
comercial do DVD e do videoclipe também. Então, a partir disso, e respaldado pela lei, comecei a cobrar direitos autorais pelos videoclipes e pelos DVDs também (...) Talvez eu seja um dos poucos diretores no Brasil que cobram e recebem porcentagem de videoclipes. Ganho uma porcentagem por cópia vendida de DVD, de $2 \%$ a $5 \%$, variando de projeto para projeto (...) Tem projeto que abro mão do direito autoral. Troco por um advantage, digamos assim. Ele me dá uma grana e eu deixo de cobrar o direito autoral.

Com relação á nova fase do videoclipe no Brasil, sobretudo após o advento da internet, o diretor destaca:

O videoclipe hoje mudou bastante de característica. Ele tem muito pouco ou nada de dinheiro. São muito pontuais realmente os artistas que ainda tem uma grana vinda do departamento de marketing da gravadora. Talvez dê para contar nos dedos de uma mão quais são os artistas que ainda trabalham nos moldes antigos, digamos assim, de quando havia a indústria fonográfica. Então ele é uma plataforma para ainda mais experimentação e sem compromisso. É feito com celulares e câmeras de vídeo, e tem que ser, forçosamente, algo muito barato e que depende da dedicação total da equipe envolvida, que com certeza ganhará muito pouco ou nada de dinheiro. Já ganhava muito pouco antigamente. Hoje em dia, tende a zero, quando as pessoas não têm que pôr dinheiro.

Para Oscar Rodrigues Alves, assim como para tantos outros, incluindo Roberto Berliner e Maurício Eça, a saída passou a ser a publicidade e o cinema. Não é à toa que, em 2008, ele co-dirigiu, com Branco Mello, o filme Titãs - $\boldsymbol{A}$ Vida Até Parece Uma Festa (2008), para onde acredita ter levado, curiosamente, mais heranças da experiência como jornalista, do que como diretor de videoclipes e comerciais:

Sincronismo, organização, musicalidade, planejamento, dedicação, respeito à obra do artista. Mas acho que esse filme tem muito a ver com a minha bagagem como jornalista, mais do que como diretor de videoclipes. Eu já vejo na minha produção como jornalista a preocupação com o sincronismo e com a musicalidade. No caso dos clipes, eles me proporcionaram muita expressão artística - "vamos para a Lua, vamos para debaixo d'água" - que não é uma coisa que esse filme carecia. Ele carecia de uma pessoa que trabalhasse com os Titãs na melhor maneira de contar essa história. Então aí minha bagagem como jornalista foi mais importante. Claro que em todos os clipes que a gente teve que fazer dentro desse filme, o fato de eu ter dirigido muitos clipes me ajudou, facilitou, abriu a cabeça para isso e me deu ferramentas técnicas que ajudaram muito o filme. Mas dentro dessa obra eu me vejo muito mais como um jornalista do que como um diretor de videoclipes (...) Fico muito contente de ter conseguido, com o Branco, desenvolver esse roteiro sem perder a carga pop que o videoclipe tem e que o filme precisava. Acho que ele tirou de mim o que tenho de melhor. Por isso, me dediquei tanto a um projeto que me deixou trabalhar em tudo o que mais gosto. 
Sem dúvida alguma, a partir dos depoimentos feitos por Oscar Rodrigues Alves, pode-se traçar a trajetória de um profissional que se propõe a fazer com seriedade um videoclipe e, assim, desenvolver um trabalho bastante autoral.

Desde a preparação e realização até a finalização do videoclipe, exige-se uma grande dedicação do autor (e/ou autores) e demais participantes, demonstrando o trabalho que uma produção dessa demanda. Daí a importância em destacar a sua validade.

Não se trata, pois, de uma produção simples e superficial, mas, sim, de uma produção artística em que todos os elementos precisam estar completamente sincronizados para que o resultado seja reconhecido e a grandiosidade do trabalho respeitada, uma vez que não se trata de um trabalho amador ou de uma mera diversão. 



\section{CAPÍTULO 6}

\section{A BUSCA PELA ESSÊNCIA DO ARTISTA}

\section{ESTUDO DE CASO - MAURÍCIO EÇA}

Neste capítulo, será dado destaque ao trabalho autoral desenvolvido pelo paulistano Maurício Eça como um dos mais produtivos diretores de videoclipes no Brasil. Desde 1994, ele já dirigiu mais de 100 videoclipes, muitos deles realizados para artistas estreantes e com orçamentos bem pequenos. Foram selecionadas, no entanto, sete produções que foram consideradas as mais relevantes para a identificação dos principais aspectos da obra do autor. Antes disso, porém, é importante conhecer a trajetória desse realizador, tanto no videoclipe, como na publicidade, na televisão e no cinema.

Formado em cinema, Maurício Eça tem seu trabalho associado aos principais nomes da música pop rock nacional surgidos nas décadas de 1990 e na primeira década do século XXI. Mesmo realizando muitas produções quase a "toque de caixa" e simultaneamente, o realizador foi bastante premiado no VMB - Diário de Um Detento, dos Racionais MC's, ganhou escolha de audiência e melhor videoclipe de rap em 1998; Melissa, do Bidê ou Balde, levou melhor videoclipe de artista revelação em 2001; e Admirável Chip Novo, da Pitty, ganhou escolha da audiência em 2003.

Identificar os traços comuns nos videoclipes dirigidos por Maurício Eça é fundamental para compreender como foram sendo desenvolvidas suas principais marcas autorais, assim como observar como uma estética é capaz de se desenvolver, inclusive quando os rigores excessivos de qualidade são deixados de lado em função da criatividade e da originalidade. É justamente o que se identifica de mais forte no trabalho desse realizador.

\subsection{Biografia}

A paixão pelas câmeras e pelo set de filmagem começou quando Maurício Eça era ainda garoto. "Meu pai é redator publicitário, que lê e escreve muito. Desde 
pequeno, eu fui influenciado para ler e ir ao cinema. Talvez tenha entrado num set de filmagem quando era moleque, para ser figurante de comercial que meu pai fazia para o Unibanco, com o Pelé”, lembra.

Formado em Cinema pela Faculdade Armando Álvares Penteado (FAAP), em São Paulo (SP), Maurício Eça fez estágio durante a faculdade na produtora de cinema e publicidade Mix Som, como assistente de produção no programa de televisão Cadeira do Barbeiro, estrelado por Cacá Rosset e Lucinha Lins, e exibido pela TV Manchete. Na mesma época, trabalhou como contra-regra do filme Perfume de Gardênia (1992), do Guilherme de Almeida Prado, na produção de Sábado (1995), do Ugo Giorgetti, e realizou alguns filmes de 1 minuto de duração.

Como muitos colegas de sua geração, Maurício Eça partiu para a publicidade e para o videoclipe, em função da situação em que se encontrava o cinema nacional:

No começo dos anos 90, quando me formei, era a época do (então presidente Fernando) Collor, que acabou com a Embrafilme. Não tinha como fazer cinema no Brasil. Passamos de um período em que se fazia mais de 100 filmes por ano para outro em que se faziam cinco. Então, quem se formava em cinema, não tinha outra opção, senão se sentir obrigado a entrar no mundo da publicidade. Não que isso seja um problema, até porque fazer publicidade é uma forma de você conviver com profissionais, ter grana e experimentar. Você realiza com condições e exercita uma narrativa que pode vir a usar depois no cinema. Eu comecei a ver isso no videoclipe também. Já que tinha baixo orçamento, você estava a fim de fazer e tinha tesão. Para mim, essa sempre foi a essência um pouco de fazer videoclipe no Brasil. É você ser um apaixonado, que se entrega para essa parada e faz. Além disso, é uma vitrine e uma forma de você experimentar linguagens e, mais do que isso, começar a realizar.

Foi como assistente do diretor Odorico Mendes, na produtora Croma, que mais aprendeu e se aproximou dos videoclipes, como conta:

Fui assistente de direção dele durante anos. Esse cara me ensinou muito, porque, além de ser diretor, tinha diversas empresas. Então começou a jogar na minha mão muita responsabilidade. Para aprender, foi ótimo. E, como tinha experiência de produção, eu acho que consegui segurar essa onda. Isso mais ou menos em 1994 e 1995. A Croma virou Adrenalina Filmes, produtora que, com o estouro da MTV, destacou-se como grande realizadora de videoclipes, um pouco antes do que a Conspiração. Então eu vivia numa produtora que tinha diversos diretores e todo mundo queria fazer videoclipe, mercado que começamos a conquistar de certa forma. Odorico era enlouquecido por hip hop, adorava Racionais MC's e era um megalômano total. Investia grana no que ele curtia e fez alguns videoclipes praticamente de graça. Dentre eles, alguns de hip hop, como Fórmula Dinamental, para DMN, banda do Xis. O clipe tinha exatamente orçamento 
zero e foi de primeiro mundo - quatro diárias de filmagem. Super produção. Acho que foi o primeiro em que trabalhei como assistente.

Maurício Eça aponta as principais diferenças entre trabalhar com publicidade, cinema e videoclipe:

O que a publicidade me ensinou é que cada trabalho tem que ter a sua cara e ser direcionado para um público ou para um tipo de estética. Você não pode fazer um clipe da Pitty que se adeque só para um cara de 80 anos de idade ou botá-la absolutamente estetizada, lindinha, tudo perfeitinho. A publicidade me ensinou a entender cada movimento, cada artista, e traduzilo em imagem. Ela me direciona o foco. O cinema é como eu conto a história e vejo o que é importante - a crueza e a realidade. Talvez o cinema, o documentário e a fotografia sejam muito mais referência (...) Normalmente, quem faz os roteiros nos videoclipes do Brasil são os próprios diretores, muitas vezes com a ajuda da banda ou do cantor. Então é diferente de um cara que é diretor e trabalha com publicidade, em que 0 roteiro vem da agência e só é preciso realizar e dar o seu olhar. Então, eu, já há algum tempo assistente do Odorico, em pelo menos 10 videoclipes, de artistas como Jorge Benjor, Gabriel O Pensador, Cidade Negra, Sublimes, DMN e Sistema Negro, estava querendo começar a dirigir. Assistente é um caminho para aprender e chegar lá. Eu ainda não podia ser diretor de publicidade, porque não tinha nome e as pessoas não me conheciam. Então, fazer videoclipe era uma forma de eu começar a criar um nome, ser visto e, mais do que isso, praticar, acertar, errar e contar uma história.

O primeiro videoclipe que Maurício Eça dirigiu foi o da banda feminina de heavy metal Volkanas, When 2R1 (1994), pela produtora Croma Filmes. A partir daí, ele passou por várias produtoras, caso de Side By Side, Cinema Centro, Open Filmes e Mixer, pelas quais realizou mais de 100 videoclipes.

O realizador explica qual é a essência de se realizar videoclipes no Brasil:

Na verdade, clipe no Brasil é muito amor à vontade de fazer uma imagem em movimento com música, que dará visibilidade e aparecerá na tevê. Mas ganhar dinheiro com clipe, eu ganhei muito pouco na minha vida. Além disso, você tem que assinar um contrato cedendo essas imagens para fazerem o que quiserem com elas. Não há respeito pelos diretores (...) Durante certa época, eu tinha até medo das pessoas falarem em diretores clipeiros, criando um rótulo, um estigma. Meio que dei um tempo de fazer videoclipe para entrar fundo na publicidade e não ficar com esse estigma. Hoje, não temo esse clichê, porque sou um diretor que faço e gosto de fazer videoclipes, com minha linguagem, que é a mesma para publicidade e cinema. O videoclipe te dá visibilidade para o meio publicitário te ver como um cara moderno. 


\title{
6.2 Videoclipes Selecionados
}

Maurício Eça reconhece grande importância no primeiro videoclipe que dirigiu - When 2R1 (1994), da banda de heavy metal feminina Volkanas, na época em que artistas desse estilo geralmente cantavam em inglês, para o trabalho que viria a realizar posteriormente, como explica:

\begin{abstract}
Acho que tinha minha preocupação em contar a história da melhor forma possível. É a eterna briga de forma e conteúdo. Talvez ali já tenha sujeira, crueza e necessidade de identificar aquele público e tipo de som. Apesar de ser o primeiro clipe, ingênuo, inseguro e ansioso, eu tentei mostrar um pouco daquele universo do heavy metal. Até então, ainda não era diretor, mas assistente de direção. Foi uma oportunidade. Ali eu queria mostrar serviço e, ao mesmo tempo, tinha tesão em fazer aquele primeiro trabalho.
\end{abstract}

Ao mostrar a vocalista tendo alucinações num quarto do hotel, imagens de uma estrada e a banda em ambientes externos e tocando em estúdio, Maurício Eça se valeu muito da utilização de sobreposições, diferentes granulações, sombras, distorções, efeitos de descoloração e mistura de imagens coloridas e em preto e branco. Ele garante que muitos desses aspectos são influências diretas da estética heavy metal, presente nas capas dos discos e nas fotografias de artistas do estilo musical. Por isso, em sua opinião, esse é um videoclipe bem atípico em sua obra:

\begin{abstract}
Você vê que não teve um enfoque. Era só uma mistura de linguagem, em prol da estética heavy metal. Também tem algumas coisas que não é que estejam no lugar errado, mas, sim, numa quantidade absurda de elementos, o que, com o tempo, fui aprendendo a dosar. Tem ainda o fato de que as ilhas de edição estavam mudando do analógico para o digital. Então havia efeitos digitais que você punha meio a torto e a direito, sem dosar. (...) Por ser o primeiro clipe, eu fiquei bem feliz com o resultado, porque a qualidade estética ficou bacana, bem editadinho e vendeu bem a imagem da banda. Lembro até que alguém falou: "Está gringo". Não é um tipo de elogio que levo em conta, mas achei que ficou honesto. Não me envergonhou. Tinham imagens bem ingênuas e outras bem bonitas.
\end{abstract}

Como o orçamento era muito baixo, Maurício Eça contou com o apoio e a infraestrutura da produtora Adrenalina e aceitou inserir um merchandising da pizzaria paulistana 1900, numa cena em que a cantora aparece num quarto bagunçado, pensando na vida, com uma pilha de pizzas perto. $O$ diretor garante que esse tipo de propaganda no interior do videoclipe é uma solução válida, desde que não esteja fora de contexto e tenha a ver com a produção. 
A constante falta de verba nos videoclipes dirigidos pelo realizador, desde 0 primeiro, fez com que ele desenvolvesse o que considera uma de suas mais fortes marcas autorais, como explica:

Pela falta de grana, é inerente ao meu trabalho de criação de videoclipe descobrir coisas na hora da produção e da edição. Aprendi, desde o início, fazendo orçamento de clipe, a trabalhar com muito pouco e ser rápido e criativo. $\mathrm{O}$ que é ser rápido em videoclipe? Eu acho que um clipe tem que ter quantidade e qualidade de imagens - quanto mais melhor-para ser rico e não ter repetição. Mudar a câmera e já fazer mais coisas. Não perder muito tempo com elucubração. Óbvio que tem momentos em que a gente precisa ter tempo até a cena ficar o ideal, mas nem sempre o ideal é o necessário. Ideal talvez seja passar um vigor, uma quantidade de coisas que contem melhor a história.

Para a realização de Bagulho no Bumba (1997), da banda paulistana Virgulóides, foi oferecido a Maurício Eça um orçamento bem melhor. A concepção do videoclipe foi dividida com o cenógrafo e grafiteiro Zé Carratu e com o fotógrafo Rui Mendes, que o apelidou de "David Lynch ${ }^{260}$ brasileiro", em função da busca pelo inusitado.

Rui Mendes avalia o trabalho com Maurício Eça nesse videoclipe da seguinte forma:

Bagulho no Bumba foi idealizado, roteirizado e fotografado por mim. Como estava trabalhando na mesma produtora onde Maurício era assistente, convidei-o para me ajudar a co-dirigir o vídeo dos Virgulóides. Maurício colaborou com as ideias mais "a la David Lynch", como o anãozinho e coisas do tipo... É muito esquisito este Maurício (risos) e, não é que eu queira me gabar, mas ele é cria minha (risos). Ele vai negar até o fim do mundo. Gostei bastante desse clipe, apesar das cenas em chroma-key serem muito feias.

Maurício Eça explica como surgiu a concepção desse videoclipe:

O que buscamos foi entender um pouco da estética desses caras, que vinham da periferia, de bairros mais afastados de São Paulo, e eram mais populares. Era muito fácil fazer deles um grupo absolutamente pop. Mas não era isso o que queríamos, mas manter o que eles tinham de mais essencial. Trouxemos também as coisas divertidas e loucas que eles faziam e que a música falava.

260 David Lynch é um cineasta norte-americano famoso por filmes como Veludo Azul (1986) e Cidade dos Sonhos (2001). 
A presença de Zé Carratu também foi fundamental em Bagulho no Bumba, como relata Maurício Eça:

\begin{abstract}
Lembro que estávamos montando o cenário do ônibus - feito com restos de outros ônibus e várias outras coisas, como um banco de várias cores -, e sofrendo para imaginar como filmaríamos. A ideia era filmá-lo no estúdio, passando, na janela, vários cenários pintados pelo Zé Carratu, como no teatro, com aquele ciclorama, que mexe só a roldana. Só que a gente começou a bater a cabeça, porque não tinha grana para isso e não ia dar certo. Quando estávamos no estúdio, com o cenário quase pronto, passou um marceneiro, pirotécnico, e falou: "Por que vocês não botam esse ônibus numa caçamba de caminhão?". Aí Zé Carratu, cuja família tem caminhões, conseguiu um aberto para o dia seguinte, botamos o casco do ônibus no caminhão e saímos filmando pelas ruas de São Paulo, com pessoas interagindo. Ficou muito mais louco. No ônibus, estava o tio Dedé, o anão, mais alguma figura bizarra e a banda cantando atrás. Outra ideia era que, na real, o ônibus era uma lata de sardinha. Então tem a parte de fora do ônibus, que a gente filmou em estúdio, como uma lata de sardinha, e a cena final com a banda dentro dela literalmente, vem alguém e fecha. Tem também um momento em que a letra menciona delegacia, porque descobriram que tinha bagulho no ônibus e os Virgulóides vão presos. No clipe, a delegacia é o inferno, com o anão vestido de diabo, umas gostosas e um cenário pegando fogo. É um clipe super divertido e com estética real e descompromissada.
\end{abstract}

Segundo Maurício Eça, os integrantes dos Virgulóides deram várias sugestões, principalmente de cenas que já tinham visto e gostado, e de amigos que desejavam que participassem do videoclipe, caso do anão Líder, que faz o cobrador do ônibus; de uma pessoa do estúdio Bebop que tira a dentadura; e do tio do baixista Beto, que interpreta o motorista. Há também uma mulata que está dentro do ônibus, os policiais e os figurantes que aparecem no inferno.

A presença de participantes curiosos e inusitados passará a ser, a partir daí, uma marca autoral muito importante nos videoclipes desse realizador. Outras características que Maurício considera importantes, no que veio a realizar posteriormente, são o bom-humor e a vontade e o respeito de transmitir a essência do artista com o qual trabalha no videoclipe. Outras marcas são a mistura de imagens registradas em ambientes externos e em estúdio, com diferentes granulações coloridas e em preto e branco, e a leitura inusitada, mas, ao mesmo tempo, quase literal da letra da canção.

Bagulho no Bumba tornou-se um dos videoclipes mais populares realizados por Maurício Eça, atrás apenas talvez de Diário de um Detento, dirigido por ele, Marcelo Corpani e Tony Tiger, para os Racionais MC's, com roteiro do próprio Maurício e do vocalista e letrista da banda, Mano Brown. Esse trabalho, vencedor do 
VMB 1998 nas categorias de melhor videoclipe de rap e escolha da audiência, só foi realizado por ele em função da banda estar devendo um show para o Odorico Mendes e, em troca, oferecer a ele a direção de dois videoclipes. Um deles coube a Maurício Eça.

Para Maurício Eça, Diário de Um Detento foi um avanço na sua obra, conforme conta:

\begin{abstract}
Quando eu tinha que mostrar quem eram os Virgulóides, no que eles acreditavam e na simplicidade deles, eu mostrei. Quando passei, a partir dos Racionais, a ter que mostrar a realidade da periferia e o que eles vivem, sofrem e sonham, foi um avanço absurdo, na busca da verdade do outro. $A$ partir dali também, eu comecei a fazer muito mais videoclipes. Tive uma temporada de clipes de hip hop. Por quê? Por eu ter feito o clipe dos Racionais, ter ficado bom e as pessoas terem visto: "O cara conseguiu trabalhar com os caras e fazer uma coisa do caralho, entendendo a nossa linguagem da periferia, com narração do nosso cotidiano, sem filtrar tanto, e sendo um grande porta-voz dessa estética".
\end{abstract}

Maurício Eça lembra que a primeira reunião com Mano Brown foi bastante tensa e que ele fez questão absoluta da realização na Casa de Detenção de São Paulo, localizada no bairro do Carandiru. A respeito da realização do videoclipe, ele conta:

\begin{abstract}
Por uma série de sortes, a gente conseguiu autorização, na época do (governador Mário) Covas, para filmar no Carandiru. Eu não tinha a menor ideia do que fazer e de como era lá dentro. Os caras não deixaram a gente ir antes para ver. No dia da filmagem, toda a equipe chegou de manhã no Carandiru, umas dez e pouco, assim como o Brown, que levou alguns amigos dele para fazerem o papel de presos. Os moleques com calça bege. Foi quando o diretor (da casa de detenção) falou: "Vocês estão loucos? Não vai entrar ninguém com calça bege. Os equipamentos que vocês estão trazendo. Luz? Nada entra". Em suma, entramos com uma equipe minúscula, quase sem luz, e sabendo que tínhamos que sair até, sei lá, quatro da tarde. Não tinha segurança e entramos no meio dos presos, só que autorizados, porque os Racionais eram alter-ego dos caras e estavam contando a realidade deles. Eram tão admirados que todos queriam participar do clipe. Ao mesmo tempo, eu, pelo menos, tive medo no começo por estar no meio daquela galera que não tinha a menor ideia de quem eu era. Nesse dia, lembro que não fiz xixi, não bebi água, não fiz porra nenhuma. Só queria filmar. Tudo para mim era novo e forte. Também queria ir embora dali o mais rápido possível.
\end{abstract}

Pelo fato da ingenuidade que possuíam para realizar aquele trabalho com tanta dedicação e com um olhar próprio, Maurício Eça acredita que eles conseguiram imprimir ali uma linguagem própria e ter desenvolvido algumas técnicas 
que se tornariam marcantes em seu trabalho, caso do uso de câmera lenta, que já aparecera em When 2R1:

Câmera lenta foi um pouco a tônica do clipe nas filmagens. Por quê? Ao mesmo tempo em que podia filmar muito, não podia, porque tinha que seguir o tempo das autorizações e dos Racionais. Brown não é um cara que você fala: "Ficou bom aqui. Agora vai ali". "Espera aí. Será que ficou bom? Depois a gente vai fazer ali, porque agora preciso conversar com três ou quatro manos". Ele era cheio de ideias do que tinha que ser filmado e participou da edição. Ainda negociamos com o diretor um segundo dia e conseguimos. Fizemos algumas cenas em estúdio e no Capão Redondo, porque tínhamos filmado pouco lá dentro. Também consegui imagens de alguns fotógrafos que registraram o massacre. Foi a conjunção de um monte de coisas que fui conseguindo e resultou num trabalho muito legal. Documental demais. Essa é a grande força de Diário de Um Detento. Nós ficamos com a coisa do "tem que ser de verdade e real", dita pelo Brown, e acho que o clipe imprimiu isso e entrou num momento muito forte, porque as pessoas viviam marasmo no Brasil.

Em 2 de outubro de 1992, uma rebelião na Casa de Detenção de São Paulo resultou na morte de 111 detentos pela Polícia Militar do Estado de São Paulo. Esse episódio foi registrado primeiro no videoclipe Diário de Um Detento, cuja letra é inspirada no livro de mesmo nome do ex-detento Jocenir, e depois no livro Estação Carandiru, do médico Dráuzio Varella, lançado em 1999 e adaptado para o cinema por Hector Babenco, em 2002. Portanto, o videoclipe de Maurício Eça tornou-se um documento histórico dos mais relevantes, tanto que foi premiado em vários festivais de curta-metragem.

O próprio Maurício Eça comenta essa importância histórica:

\begin{abstract}
Essa foi a primeira grande filmagem no Carandiru, antes do filme Carandiru. E, mais do que tudo, tem essa linguagem de documental super forte, com uma estética suja e fotográfica, tipo Sebastião Salgado, que a gente buscou. Não sei como a molecada começou a pedir, pedir, pedir o clipe e ele entrou no Disk MTV (programa exibido na época pela MTV Brasil e que era a parada diária dos videoclipes mais pedidos pelos telespectadores), às seis da tarde, tendo oito minutos. Então rompeu um padrão, ocupando o espaço de dois clipes e com palavrões e cenas de violência. Foi impossível não passar. Diário de Um Detento foi mais forte do que qualquer coisa e admirado por outros meios. Foi para Los Angeles e, depois, participou do festival Rio Cine e do É Tudo Verdade, como documentário. Também foi considerado o videoclipe brasileiro mais importante da história da MTV e entrou na mostra Made in Brasil, do Itaú Cultural, com os vídeos mais importantes do Brasil. Até hoje, ele é uma referência e, durante muito tempo, as pessoas falavam de mim e remetiam a ele. Virou um pouco estigma, mas pelas pessoas admirarem e respeitarem. Para mim, foi muito legal.
\end{abstract}

O editor Tony Tiger relembra como foi realizado esse videoclipe: 
Ele tem uma cara meio documental, meio de curta-metragem, e conta a história realmente. É mais descritivo. O Maurício foi lá e meio que contou a história que o Mano Brown contava na letra. Então ele teve esse diferencial, assim como ser bem longo. Como ele foi filmar num lugar em que não podia ficar muito tempo, não filmou muita coisa e foi direto ao assunto. Então a edição foi tranquila, pois o que se estava falando era o que se tinha para mostrar. Além disso, tem as marcas do Maurício de câmera na mão e a objetividade, de ir direto ao que ele quer.

Diário de Um Detento começa com a imagem de crianças em preto e branco jogando dominó e o som ambiente. Em seguida, em imagem colorida, aparecem presidiários, entre eles Mano Brown, praticando o mesmo jogo na Casa de Detenção. Esse aspecto confirma a marca autoral de Maurício Eça, de misturar imagens de diferentes origens, granulações e cores, tanto que ainda seriam utilizadas imagens de arquivo da TV Bandeirantes, fotografias de época e imagens registradas em beta e em 16 milímetros, que misturam cenas no Carandiru com imagens do extermínio dos judeus pelo nazismo.

Os contrastes de iluminação e as imagens piscando são importantes nesse trabalho e voltarão a aparecer na obra do realizador. As imagens também são totalmente calcadas no que diz a letra da canção, aspecto que o diretor mantém em outros videoclipes de hip hop que realizou. O videoclipe termina com crianças brincando de tiroteio e o trecho do "Salmo 23 cap. 4" exibido na tela: "... e mesmo que eu ande no Vale / da sombra e da morte / não temerei mal algum / porque tu estás comigo".

O videoclipe seguinte, Regina Let's Go (2001), da banda CPM 22, co-dirigido por Maurício Eça com Felipe Segall, é mais próximo das marcas autorais mais fortes do realizador. Essa produção é considerada por muitos, incluindo o próprio diretor, o melhor videoclipe já feito para a banda que, até aquele momento, só estrelara um videoclipe independente.

Maurício Eça recorda o primeiro contato com a banda até o desenvolvimento da idéia do videoclipe:

Eles tinham acabado de assinar com uma gravadora, estavam ainda meio confusos e falaram: "A única ideia que a gente tem é indo de carro para a praia". Olhamos (Maurício e o co-diretor Felipe Segall) e falamos: "Indo de carro para a praia ... Que legal, hein?! Ideia boa. Volta daqui uma semana" (risos). Puta bosta. Mais clichê impossível. A gente, então, começou a ter uma ideia que, teoricamente, não tinha nada a ver com a letra, mas, depois de pronto, parece que tem algum sentido que, no meio do processo, fomos 
buscar. Acho que foi o Felipe que sugeriu fazer um clipe japonês legal. Fomos atrás de referências e vimos algumas fotos meio de máfia, que achamos divertidas. Pensamos, a partir daí, numa história em que a banda estivesse inserida meio ao acaso e que deixasse o clipe com uma cara meio de trailer de cinema, meio filminho. Mais do que mostrar o que a banda faz, a gente iria apresentá-la por meio de uma história. Foi essa viagem com as referências nipônicas. Quando eles voltaram, contamos um pouco da história com máfia japonesa e meio cíclica. Ela começa no final, com o cara fugindo de uma máfia, que quer a grana de uma aposta. Daí a gente resolveu botar luta no meio e Regina, causa da briga e da aposta, seria a assassina no final. Os caras do CPM 22 adoraram. Disseram que não tinham entendido nada e que não tinha nada a ver com a música, mas chaparam. Era uma ideia que eles nunca tinham pensado, mas infinitas vezes melhor que a deles, o que sacaram na hora.

Regina Let's Go tem tudo a ver com a estética inusitada desenvolvida por Maurício Eça nos videoclipes, com a valorização de elementos que caracterizassem a máfia japonesa, no que se refere à direção de arte, maquiagem e figurinos, assim como ao trabalho da escolha do elenco. Os personagens diferentes e, de certo modo, bizarros, também estão presentes, assim como a utilização de diferentes formatos e tonalidades de imagens, registradas em 16 milímetros e Super 8 milímetros.

A escolha dos cenários também foi determinante:

Por sorte, um dia a gente foi à Liberdade (bairro paulistano) e estava tendo uma festividade chinesa, com fitinhas da sorte. Tinha uma coisa meio Tóquio mesmo. Levamos o ator para correr, numa perseguição. Ele corria no meio da multidão real, que estava na festa, e a gente ia de Super-8 atrás dele. Não víamos a cara das pessoas, mas uma multidão. Foi mais uma coisa, sem planejar, sem proteção e sem polícia. Fomos na louca, como fiz muitas vezes (risos). A primeira diária foi em Super-8 para buscar uma sujeira diferente, uma coisa meio de filme antigo. A segunda diária foi com a banda, quando falamos: "Vamos botá-la tocando num bar com cara meio de karaokê japonês, meio Yakuza". Então, tem uma mesa com um velho, sem dedo, com aquela coisa da Yakuza de cortar o dedo, e uma menina mais nova. A gente caracterizou o bar do Cambridge (hotel paulistano) e filmou cenas de ação, de brigas e do cara com a Regina, no começo e no fim do clipe. Também fomos atrás de lutadores. As cenas de perseguição no hotel e na rua têm muita coisa super crua de câmera na mão. Tem uma cena em que eu pego a câmera na mão e corro atrás do cara. A gente virou uma rua e vieram em cheio em cima de mim. Fui para o chão, a câmera voou e eu ainda consegui pegá-la, sem quebrar.

O videoclipe apresenta uma narrativa que começa com um trecho da cena final e depois mostra cenas de amor, de perseguições e da banda tocando em meio a um local de decoração oriental. Essa narrativa é mais calcada na crueza da música, do que no sentido da letra e conta, no início e no final, com a inserção de ruídos ambientes, como o som de um tiro, diálogos e de uma música japonesa, de 
um CD comprado aleatoriamente na Liberdade, girada ao contrário. Há também uma edição toda calcada no ritmo da canção, com cortes secos rápidos, movimentos acelerados, adiantamento e retorno das imagens e o que o diretor chama de "pipocos". Outra marca autoral é a utilização de câmera na mão.

O editor Tony Tiger destaca a importância da edição nesse videoclipe:

\begin{abstract}
Apesar de esse videoclipe ter sido feito em película, tem certa velocidade e narrativa diferente... A ideia era como se a música tivesse sido feita para um longa-metragem e nós fôssemos fazer um videoclipe da música com o assunto do filme. E, na edição, eu meio que aproveitei umas narrativas de filmes de ficção até meio recentes, que estavam marcando a época, como Snatch - Porcos e Diamantes (Snatch, 2000, do diretor Guy Ritchie) e Clube da Luta (Fight Club, 1999, do diretor David Fincher). Por isso, os cortes são rápidos, com algumas alterações de velocidade. Coisas imperceptíveis mesmo, não só para se entender a história, mas para sentir aquela ação.Assim, a edição só veio a colaborar em como contar a história de um jeito atrativo.
\end{abstract}

Segundo Maurício Eça, o resultado foi surpreendente:

Teve aceitação bacana, porque tem essa cara de filminho e uma crueza,
uma sujeira, de apresentá-los de uma forma: "Esses caras tem a ver com
isso. Eles fazem coisa boa e não se preocuparam apenas em mostrar ao
mundo como tocam bem" (...) Havia a preocupação em ter uma cara para o
CPM 22. Eu acho que a gente vendeu e os apresentou muito bem para o
Brasil. O original desse clipe talvez sejam a edição e a estética. Acredito
que, a partir dele, comecei a me preocupar um pouco mais com a minha
estética, crua, suja e diferente a cada trabalho, e não com a estética
publicitária. Talvez esse clipe tenha sido realmente um pouco menos de
conteúdo e um pouquinho mais de estética, até em função do momento
tecnológico que estávamos vivendo, de telecines; e também do meu
trabalho na publicidade já buscar uma coisa diferente de estética. Pode ser
que esse clipe tenha sido o pulo do gato. Virgulóides era sujo e feio;
Racionais, apesar de ter uma estética, é de documentário, de cinema (...)
Apesar de ter certa estética e a gente procurar uma caracterização japa,
sem requinte, esse clipe vai mais pelo lado do submundo. Talvez tenha a
ver com hip hop e coisas esquisitas e pobres. Não somos bonitinhos e
ordinários. Era uma banda de hardcore. Acho que CPM 22 é muito mais
pop hoje do que era naquela época, em que ainda não tinha o conceito de
emo e de hardcore melódico, que, teoricamente, veio do independente e
estava se lançando. Havia preocupação de apresentá-los de maneira
interessante, de mostrar que não eram popzinhos e acreditavam numa
coisa mais poderosa e com atitude. A sujeira e a crueza tinham uma razão.
Se fosse uma banda mais pasteurizada, talvez fosse diferente a parada.

A sujeira e a crueza das imagens, bem como a utilização de cenas aparentemente despropositadas e personagens estranhos e bizarros, permanece em Melissa (2001), dirigido por Maurício Eça, para a banda gaúcha Bidê ou Balde, que estava sendo lançada. $O$ vocalista Carlinhos também sugeriu algumas 
referências ao cineasta norte-americano David Lynch, grande fonte de inspiração do diretor e, portanto, mais uma marca autoral.

O objetivo de realizar algo impactante com poucos recursos também esteve presente nesse videoclipe e é outra marca autoral, como descreve Maurício Eça:

\begin{abstract}
Como tinha pouquíssima grana, era preciso filmar tudo num só lugar. $A$ locação foi muito importante para editar as cenas. Através dela, fiz o roteiro com outras cenas e ideias. Achamos o (Restaurante e Cervejaria) DaDo Bier, uma cervejaria louca, meio tecnológica com banheiros esquisitos e um lugar de vidro com algumas cortinas. Levamos um piso quadriculado para o lugar onde a banda tocaria. Essa música o Carlinhos fez para Melissa, colega de faculdade de quem era a fim, mas ela não dava bola. Então, tem algumas autoreferências no clipe. Por exemplo, na cena final, a menina que aparece ao lado deles é a própria Melissa. Há outra cena em que um anão fala ao contrário um trecho de Twin Peaks, de David Lynch (série de televisão exibida pela rede norte-americana ABC, entre abril de 1989 e junho de 1991). Foi uma homenagem que a gente quis prestar (...) Carlinhos queria a banda tocando numa festa. A música era absolutamente descontraída e pop. A estética tinha a ver com o som meio Weezer (banda norte-americana de rock alternativo), pop, desencanado. Construímos a locação e a estética em conjunto com o que a canção divertida trazia. "Vamos botar um cara esquisito num banheiro". Daí tinha um ator com quem já tinha trabalhado e que gostava.Botamos um nariz estranho para uma cena totalmente nonsense dele, no banheiro. "Ah, vamos botar duas meninas lindas se beijando". Por quê? A música tinha uma coisa de proibido. Aí botamos. Tem uma menina que tinha feito um comercial que passa desfilando. Havia ainda uma parte da letra engraçada, que eu falei: "Vamos botar uma menina sem sal". Como é uma menina sem sal? "Acharemos uma menina sem peito". "Ah, legal". Daí uma menina da equipe falou: "Eu tenho umas estrelinhas tatuadas no meu peito". "Ah, você mostra?". "Mostro". Tem uma cena na cozinha, ela levanta a camisa e bota sal no peito (risos).
\end{abstract}

Melissa mostra a banda tocando, cantando e pulando na cervejaria, em meio a crianças e outras pessoas, com a câmera balançando ao ritmo da música. Essas imagens são intercaladas com outras de uma modelo sentada numa cadeira e abraçada a uma boneca de plástico, de um homem segurando um porta-retratos, mulheres num banheiro se beijando, outra garota jogando sal no seio e um anão dublando o áudio modificado de Twin Peaks e acompanhado da legenda "Essa aqui é minha prima. De onde ela vem, há música no ar. Se tu quiser que eu te leve, eu aprendo a dirigir". E, no final, há uma simulação de como se o filme estivesse se queimando.

O vocalista e compositor do Bidê ou Balde, Carlos Carneiro, comenta essa produção e a participação da banda:

O Maurício é um cara muito aberto a ideias e deixava a gente opinar bastante sobre o videoclipe, principalmente na última cena, inspirada no 
Twin Peaks, que tem o anãozinho (Vagner) e a própria Melissa que inspirou a música (...) Nessa cena, ele deixou a gente se meter bastante - e nas ideias de roteiro, antes da execução, também. Nós opinamos bastante também no roteiro, em ideias estéticas, de misturar glamour com a coisa de mistério nonsense, que fazem parte da identidade visual e artística da Bidê, que o Maurício (e o Marcelo Nunes, que fez a fotografia) sacou muito bem! Acho que participamos desde a escolha da locação até as cores e o elenco. Gostamos muito do resultado, até porque foi um videoclipe premiado revelação no VMB 2001 - e nosso cartão de visitas. Até hoje todo mundo fala bem do clipe. Eu até achei que ficaria datado, mas não, acho que continua atual e divertido! Depois, quando vi alguns outros trabalhos dele, como o primeiro videoclipe da Pitty, achei aquilo muito parecido com o que tínhamos feito em Melissa. Muito "Maurício Eça". Parecia que ele tinha continuado com aquela ideia estética e desenvolvido outras com a Pitty, em cima da letra.

Mais uma vez um videoclipe dirigido por Maurício Eça é calcado não em cima do que diz a letra, mas nas sensações que ela sugere, com o objetivo de transmitir para o espectador, da melhor maneira possível, o que pensa e como é a banda, no caso, totalmente "desencanada e divertida", como qualifica o realizador. Outras marcas autorais de Maurício Eça nesse videoclipe são a utilização de imagens com diferentes cores e granulações e outras com ruídos, piscando na tela.

O realizador avalia o resultado final:

\begin{abstract}
Foi um clipe totalmente no espírito de gincana e feito com raça. Não tem nada de muito trabalhado e, por conta disso, muita alma. Foi uma grande festa fazer, com pessoas com muito tesão. Numa filmagem, tudo o que você está vivendo naquele momento imprime na imagem. Esse clipe imprimiu muito o que vivíamos naquele momento. Foi engraçado, porque ele concorreu ao VMB de clipe de banda revelação e, naquele ano, estavam estourados Falamansa e KLB. Era barbada um dos dois ganhar e ganhou Bidê ou Balde. Os caras fizeram uma puta festa. Anos depois, eu fui fazer clipe dos dois e eles falavam a mesma coisa: "Como é que aquela bosta do Bidê ou Balde foi ganhar?". Eu falei: "Fui eu que fiz". Lembro que eles olharam feio: "Pô!" (risos). É engraçado, mas eu acho que é um clipe que passa alegria. As pessoas vêem e dão risada.
\end{abstract}

Poucos recursos também foram destinados à realização do videoclipe Garota de Berlim, que Maurício Eça dirigiu para o Supla em 2001. Como a música havia sido gravada em 1985, com a participação da cantora alemã Nina Hagen, ele convenceu o cantor a realizarem a produção em Berlim (capital da Alemanha), em vez de fazerem num castelo medieval da família Suplicy em Petrópolis (RJ).

Nesse videoclipe, Maurício Eça procurou aproveitar a grandiosidade da cidade histórica e grande, com alguns cartões-postais, como a torre da televisão e a praça com a escultura de Alice no País das Maravilhas, mas sem criar algo com 
cara de vídeo turístico. Ele considera ter realizado algo documental, na mesma linha de Diário de Um Detento, e complementa a respeito da ideia da produção:

\begin{abstract}
A ideia do clipe, com um quê documental, era o Supla caminhando pela cidade, vendo a foto de uma mulher, pela qual se apaixona e fica o clipe inteiro atrás dela, procurando e nunca encontrando, conseguindo beijá-la apenas em sonho. Na verdade, não se sabe se era sonho ou se realmente ele a conheceu, temática da música. A garota deveria ser a filha da Nina Hagen, Cosma Shiva, atriz alemã super famosa. Na véspera da filmagem, a gente ficou sabendo que a Cosma estava doente em Hamburgo e não poderia ir a Berlim. Fizemos casting e arranjamos uma modelo alemã, filha de português. Por coincidência, super bonita, que fez e foi ótimo. Com Nina Hagen não podendo mais ser a "garota" por ter passado alguns punhados de anos, a gente entrou em contato com ela, que fez participação super afetiva, com três personagens - policial que dá geral no Supla, cigana num sasquatch, lugar meio abandonado transformado em centro cultural, e mulher super elegante no cinema, onde dois gêmeos, amigos dela, contorcionistas de circo, fazem umas acrobacias (...) Foi legal, porque a luz na Europa é contínua, não varia muito no dia e é muito baixa. Estava super nublado e tem cenas embaixo de chuva. A fotografia é o máximo. Ao mesmo tempo, tinha um mistério e as ruas não estavam tão cheias. Também tem edição absolutamente louca e inspirada do Tiger, com acelerações, e procuramos estética que tivesse a ver com o Supla - uma coisa meio urbana. O clipe foi indicado à escolha da audiência no VMB.
\end{abstract}

A preocupação com a estética do artista, a utilização de câmera na mão, a utilização de ruído ambiente - no caso, o som de Supla caminhando por uma estação de metrô - e de imagens de diferentes tons de cores, além da edição bastante calcada no ritmo da música, são características específicas das produções de Maurício Eça, encontradas nesse videoclipe. Também são utilizadas figuras inusitadas, como a própria cantora Nina Hagen, interpretando três personagens diferentes. O próprio realizador acrescenta:

A gente procurou criar uma estética em cima da música, que é super forte e tem batida que vem dos anos 80 , misturada com rock and roll mais de hoje. A edição é bem alucinada, como tem de ser em muitos momentos da música e era a cara do Supla, principalmente nesse momento da carreira, em que tinha uma coisa super forte. Não sei se popular é a palavra.

O editor Tony Tiger destaca a grande quantidade de cortes utilizada nessa produção:

O Maurício foi para a Alemanha com o fotógrafo e, como na Europa você não pode sair filmando à vontade, ele fingiu que fazia um filme infantil, com a câmera na mão. E, de novo, entrou o lado dele de mostrar como vê as coisas. Algo legal nesse videoclipe foi o ressurgimento do rock do Supla e que fizemos uma edição muito picotada e rápida, para não dar tempo do 
telespectador respirar e se envolver com aquilo. Para ter uma ideia, há mais ou menos uns 400 cortes, quando geralmente num videoclipe de três minutos há entre 40 e 50 cortes.

Mais uma artista iniciante que Maurício Eça ajudou a se consagrar através dos videoclipes foi a roqueira baiana Pitty, com quem trabalhou a primeira vez em 2003, quando realizou Máscara, que confirma várias marcas autorais do realizador. Entre elas, estão a utilização de figuras bizarras, nesse caso bem de acordo com o refrão da canção, e as referências ao cineasta David Lynch, de acordo com os interesses da artista.

Indicado para essa empreitada pelo produtor Rafael Ramos, da gravadora Deckdisc, Maurício Eça lembra como foi o primeiro contato com a artista e com a música:

\begin{abstract}
Eu ouvi a música e achei divertida aquela voz baiana, de uma mulher cantando rock, com aquele "bizarro, bizarro, bizarro". Depois conversei com a Pitty por telefone e ela foi super simpática e humilde, no sentido de querer ouvir as minhas ideias. Acho que ela estava muito aberta por ser seu primeiro trabalho e por ainda estar meio se posicionando, com muitas outras coisas para decidir - disco, divulgação, etc. Ela deixou na minha mão e confiou muito mim. Deu uns inputs, umas ideias do que gostava e do que não gostava. Conversamos muito a respeito de cinema, que ela gostava de Stanley Kubrick e David Lynch. Acho que escrevi algumas ideias para ela, que gostou de algumas e não gostou de outras. Começamos meio a pensar juntos e fomos misturando soluções. Ela sugeriu um reality show e pensei na gaiola. Pensei também nos jurados que estão ali vendo pessoas bizarras, e a banda tocando atrás, como se fosse um ambiente s, que, na câmera, seria dividido. Às vezes, teria só os jurados ou os jurados com a banda atrás. E outras vezes só a banda, os jurados com os bizarros ou só os bizarros. Com isso, meio que criamos uma espécie de narrativa desse freak show. É mistureba: de tudo um pouco. Tinha um livro de um fotógrafo tcheco chamado Jand Salbeck, que eu gosto bastante e é maluquíssimo. A Pitty adorou todos esses tipos loucos, que tiveram caracterização super forte. Também privilegiamos as cores verde, amarelo e azul na direção de arte, no cenário e na fotografia. Lembro também de um filme de que usei um pedaço como referência, cuja história é de um menino que fica preso num porão até sei lá que idade e um dia sai, pira no mundo e vira meio popstar e meio monstro. Uma coisa meio maluca. No clipe, tem um carinha que é criado pela mãe e é meio lixo.
\end{abstract}

A cantora Pitty tem outra versão para a criação de Máscara:

Quando a gente estava gravando essa música, começaram a aparecer as imagens, mesmo sem supor que seria um clipe. Quando a gente decidiu que ela seria o single, a gente falou: "Pô, já temos o clipe!". Pintou essa ideia de fazer um freak show, cada um com a sua personalidade, e a gente tocando. É um clipe doido, só tem maluco. ${ }^{261}$

${ }^{261}$ MENOTTI, Alex. Fazendo Clipe. Revista da MTV, nํ24. São Paulo, SP. Abril de 2003, pág. 36. 
Além das várias referências audiovisuais, que podem ser consideradas marcas autorais de Maurício Eça, Máscara possui a relação entre música e imagem estabelecidas através do que a letra sugere e na edição calcada no ritmo da música. Outros pontos importantes são a direção de arte, edição e fotografia mais sujas, a utilização de um único cenário e a presença de vários participantes fora dos padrões convencionais. Nesse caso como jurados e concorrentes de um freak show, caso de uma garotinha fantasiada de miss, um senhor vestido de mulher, um anão com fantasia de macaco, duas garotas vestidas de anjo, um lutador de sumô, um tocador de flauta e o rapaz sendo cuidado pela mãe.

Maurício Eça explica de que modo esse videoclipe teve desdobramentos no trabalho posterior que realizou com Pitty:

O clipe tinha que ter sintonia com todo o trabalho de divulgação e lançamento dela. A ideia era impressionar. E impressionava, porque era sujo na medida certa, sempre respeitando a artista (...) Algo que sempre fiz nos clipes da Pitty foi ter um monte de histórias e de referências misturadas, além de coisas que só a gente entende e as outras pessoas entendem em alguns sentidos. Eles são muito sensoriais. Aqui fomos descobrindo uma máscara que depois usei em Teto de Vidro (2003), Admirável Chip Novo (2003) e menos em Semana Que Vem (2003). Então, são misturas de referências e de sensações que a gente bota e não parecem ter mais sentido, mas que tem essa coisa sensorial muito forte. Até depois que a gente fez Admirável Chip Novo, a Pitty falou: "Tem um monte de coisa nesse clipe que ninguém vai entender, mas é do caralho". É o encontro de um monte de sensações que fazem uma coisa mais forte. É loucura, sonho. Deixa você pensando muito mais no que aquilo quer dizer. A Pitty permitia, eu pirava e ela ia junto.

O editor Tony Tiger tem opinião semelhante:

Uma coisa interessante no Maurício Eça é lançar ou relançar artistas. Ninguém conhecia a Pitty. Foi a partir dali que ela começou a estourar. Há também a inserção de elementos estranhos, mensagens subliminares e metalinguagens. Em Máscara, ele mostra uma pessoa querendo ser outra ou alguém que não é, sempre com aquela batida rock and roll.

\subsection{Considerações Gerais}

Através da observação dos sete videoclipes selecionados na obra de Maurício Eça, foi possível identificar algumas especificidades no seu trabalho. A principal delas é a constante tentativa de realizar uma produção que sinalize para o telespectador quais são os desejos e aspirações de um determinado artista, geralmente valorizando seu aspecto inusitado, irreverente e grotesco. O aspecto 
documental não é uma tônica tão forte, uma vez que aparece apenas em duas produções, Diário de Um Detento e Garota de Berlim.

Considerando-se influenciado por diretores de videoclipe como Oscar Rodrigues Alves, Maurício Eça avalia essa constante busca pela essência do artista como sua principal marca autoral:

\begin{abstract}
Considero-me autor a partir do momento em que faço o roteiro, penso na ideia e na criação do clipe, absolutamente junto com a banda. Não sei se em 100\%, mas em muitos dos meus videoclipes, a banda é muito importante no que ela pensa e sonha. Tem muitos artistas que não têm a menor ideia e deixam totalmente aberto. Outros dão sugestões que acho uma bobagem, e acabo convencendo-os a fazer algo bem diferente. Mas muitos artistas, já no primeiro bate-papo, dizem como pensaram a música quando a compuseram ou até como imaginaram o clipe, e me ajudam a criar. Há um limite entre criação e autoria. Muitos trabalhos ainda têm a gravadora por trás, às vezes impedindo um arroubo de criatividade ou loucura. Então, há muitos artistas com quem falava: "Isso é legal, mas vamos tentar focar numa coisa que venda um pouco mais, no sentido do que você representa e que imagem quer passar". Não é que fosse empecilho ou entrave, mas algo que a gente tinha que levar em conta com alguns artistas. Muitos deles queriam chocar e ser de verdade e totalmente diferentes. Não fazer nada que fosse comercial. Acho que o grande barato do videoclipe sempre foi provocar ou causar algum tipo de reação no espectador e, para isso, tinha que ter imagem interessante, que atraísse (...) Talvez você olhe um clipe do KLB, um do D2 e outro do Virgulóides e diga: "Os três foram você quem fez". Mas eles são absolutamente diferentes. Você entende que é por conta da minha preocupação na estética de cada artista e não minha. Aquilo é do D2. Tem a ver com a música, com a estética, com as roupas, com o movimento, com o estilo musical dele e com o que ele acredita. Era muito fácil, por exemplo, pegar os Virgulóides e fazer deles um grupo absolutamente pop. Não era o que a gente queria, mas, sim, manter o que eles tinham de mais essencial. Sempre busquei a verdade do artista, porque, se você acredita naquilo, está vendida a obra.
\end{abstract}

Com relação aos aspectos mais técnicos, podem ser consideradas marcas autorais de Maurício Eça: a constante utilização de câmera na mão; a edição calcada no ritmo da música, com imagens de diferentes formatos e cores, muitas vezes tremidas e pulsantes; e a temática baseada no tema da letra, mas sem ser literal. As referências cinematográficas, principalmente do cineasta David Lynch, também são constantes e levaram o diretor a se aproximar de muitos artistas com o mesmo gosto, caso de Bidê ou Balde e Pitty.

Maurício Eça explica seu método de trabalho, mesmo quando realiza até quatro videoclipes ao mesmo tempo: 
Normalmente, eu recebo a música, troco uma ideia com a banda ou com o cantor, para ver se eles têm alguma sugestão e se a canção tem algum significado. Em cima do que falam - ou se não falam nada - busco minhas referências. Pesquiso, leio, assisto alguma coisa e crio, a partir de algumas ideias. A banda fala: "Gosto dessas". A gravadora: "Gosto dessas". Daí chega-se a um consenso. Faço um roteiro, pesquiso locações, atores, etc., e filmo. Mais ou menos esse é o meu processo criativo. Sou um débil mental que chamam para fazer videoclipe com o prazo de uma semana, dez dias, porque sabem que vou lá e faço normalmente em uma diária. É difícil fazer em duas diárias. Só quando o orçamento é maior ou há a necessidade de filmar mais cenas em lugares diferentes. Então, tudo precisa ser muito bem pensado para chegar pronto na filmagem, seguro e com o que preciso para realizar e sair um pouco do que pensei. Pode demorar um, três, cinco ou dez dias, dependendo do caso. A complexidade do trabalho requer isso. Quando é um trabalho que tem cenário ou não sei o quê, precisa de um pouco mais. Mas eu improviso muito na hora de filmar, até por conta dos orçamentos baixos. Já a edição é botar tudo que a gente realizou para frente. Normalmente, é durante a edição que a gente, muitas vezes, desfragmenta ou busca coisas muito diferentes do imaginado, mas sempre partindo do que foi pensado de início. Quando tem computação ou muito efeito, pode demorar um pouco mais. Se não, eu me interno com o meu editor, em geral Tony Tiger, e editamos muito rápido. Até porque já filmei um pouco com olho de editor. Sei mais ou menos os cortes que preciso, o que vem da experiência de já ter feito bastante coisa.

\section{Tony Tiger comenta a forte parceria estabelecida com Maurício Eça:}

Trabalhamos juntos há 16 anos, desde o videoclipe das Volkanas, de 1994. Temos uma sintonia muito grande que começa na primeira ideia. Inclusive, eu participo da parte de roteiro, porque o Maurício sempre achou interessante ter mais gente tendo propostas e, às vezes, gosta de me dar o roteiro para ler. Então virou uma parceria bem legal.

\footnotetext{
A falta de grandes orçamentos e os prazos sempre apertados fizeram de Maurício Eça um diretor extremamente criativo, que valoriza a espontaneidade, a preparação prévia e a falta de perfeccionismo exagerado. Ele garante ter encontrado no videoclipe um grande laboratório para experiências audiovisuais:
}

Para mim, como diretor, hoje, ter feito e fazer videoclipe foi uma grande escola. Muitas vezes eu entrava num set de filmagem de um videoclipe e tinha que experimentar e ser criativo em todos os aspectos, principalmente na dificuldade. Eu concebia a coisa de um jeito e, na hora, via que não dava para ser daquele jeito por falta de grana ou por alguma coisa do gênero. Então, precisava, naquele momento, ser criativo, mudar e continuar feliz (...) Tinha que ter desprendimento e desapego, e ser rápido. Saber que, muitas vezes, em cima da coisa que não deu certo, ter outra ideia criativa, que depois funcionava mais (...) Assim, acho que minha velocidade e, muitas vezes, clareza, são legais para o videoclipe, no sentido de ter certeza do que quero fazer. Também sinto falta de, em alguns trabalhos, ter suado um pouco mais. É válido você, de repente, sofrer um pouco mais e pensar em outras formas. Ao mesmo tempo, também acho que para esse tipo de trabalho que você muitas vezes não tem muita grana ou condições técnicas, é legal criar em cima do que você quer e tentar fazer o maior número de imagens diferentes e possíveis para aquele clipe. Ou seja, apesar de ser 
barato fazer, ele parece um pouco mais caro, em função de ter muitas cenas diferentes.

A co-direção também está bastante presente na obra de Maurício Eça. Para ele, esse tipo de divisão precisa significar a união de forças entre as pessoas, conforme explica:

O processo de co-direção, nos meus videoclipes, é realmente a união de forças de pessoas que fazem muitas vezes coisas diferentes. Cada parceiro é diferente. Às vezes, você divide o que cada um vai fazer. Um vai cuidar mais dos artistas e o outro vai cuidar mais da câmera, da técnica. É um modo de dividir essa autoria. Um diretor e um fotógrafo que co-dirigem, mas cada um cuida mais especificamente de certas coisas. Não que não possa dar palpite um no trabalho do outro. Foi algo que aprendi a trabalhar com parceiros fortes que dividiam problemas e as ideias artísticas.

Bastante premiado na publicidade ${ }^{262}$, Maurício Eça é diretor do curtametragem O Pecado Mora em Casa (1992), e co-diretor do documentário Universo Paralelo (1994). Mesmo confirmando que o videoclipe brasileiro atravessa um momento de transição, ele continua na busca do que considera o videoclipe ideal:

\begin{abstract}
O videoclipe é a junção de várias linguagens e formas de expressão. Bom videoclipe é o que traduz de alguma forma a música, o artista, traz uma linguagem nova ou com certa qualidade estética ou, ainda, conta uma boa história. É meio subjetivo. Já me perguntaram: "O que é melhor - boa ideia com pouca grana ou péssima ideia com muita grana?". Acho que o melhor é uma boa ideia com muita grana (risos), mas ainda acho que uma boa ideia muitas vezes é melhor do que uma má ideia bem custeada. Óbvio que uma boa ideia que necessite de um mínimo é importante. Às vezes, podemos matar uma boa ideia por uma má realização. Mas, se for bem realizada, com pouco ou muito dinheiro, é muito melhor do que uma má ideia realizada com um milhão de dólares. Para mim, videoclipe tem que ter alguma coisa que chame atenção e faça seus olhos brilharem.
\end{abstract}

Portanto, a busca pela essência do artista com o qual trabalha, procurando apresentá-lo ao espectador de modo inusitado e diferente é o que faz Maurício Eça ser um diretor tão singular. Para atingir esse objetivo, a estranheza, os movimentos rápidos de câmera e a adoção do ponto de vista de quem assiste a história narrada, e que não consegue desgrudar os olhos da tela, são os instrumentos mais eficazes encontrados pelo realizador.

${ }^{262}$ Com a campanha Hot Power, para a produtora JWT de Buenos Aires, Maurício Eça ganhou a medalha de prata no festival de Nova York, medalha de ouro no Eagles Awards, no México, e bronze no festival de Londres, na Inglaterra, todos em 2004. 



\section{CONCLUSÃO}

Como foi visto ao longo deste trabalho, o videoclipe é um formato audiovisual que contribuiu para o desenvolvimento de novas linguagens e técnicas na área. Afinal, desde o surgimento, ele mostrou ser um excelente espaço para experimentações e exercícios audiovisuais mais ousados e foi o que melhor soube adequar-se a diferentes mídias e tecnologias. Além disso, é inegável que foi se inserindo na formação das gerações surgidas a partir do último quarto do século XX e que foram também influenciando sua trajetória.

Sendo assim, esta pesquisa teve como principal objetivo refletir sobre como a questão da autoria se manifestou e se manifesta na sua modalidade de produção, principalmente a realizada no Brasil, através da análise da obra de três de seus principais realizadores: Roberto Berliner, Oscar Rodrigues Alves e Maurício Eça.

Nas abordagens sobre a autoria e a produção de videoclipes, foram tomadas como referências as teorias desenvolvidas também para o cinema e para a telenovela. Afinal, as duas fontes audiovisuais foram de importância capital para o desenvolvimento do videoclipe no mundo e no Brasil. Por isso, nos dois primeiros capítulos, foi apresentado um amplo painel histórico a respeito das experiências que tornaram possível o surgimento desse formato audiovisual.

Como boa parte da produção televisiva, o videoclipe herdou igualmente profissionais, linguagens e técnicas desenvolvidas no cinema, sendo que se pode afirmar que o processo inverso também foi e é bastante intenso. Ou seja, muitos realizadores audiovisuais começaram trabalhando com videoclipes, até como uma espécie de laboratório para novos exercícios, muitas vezes baseados na utilização de novas técnicas e ferramentas, que, mais tarde, levariam para o cinema, para a publicidade e para outras produções audiovisuais.

É fato ainda que, como nos outros gêneros e formatos audiovisuais, foram poucos, até agora, os realizadores que souberam aproveitar as possibilidades oferecidas pelo videoclipe para desenvolver produções realmente artísticas e criativas. A grande maioria sempre se submeteu aos clichês e às facilidades necessárias para vender um produto de interesse da indústria fonográfica.

No que se refere à escolha do diretor dos videoclipes, como seu autor, foi observado que este, muitas vezes, assume junto a função de roteirista. Assim, o 
caso do realizador é contemplado pelas duas principais correntes teóricas relacionadas à autoria no cinema. Enquanto alguns teóricos, principalmente os responsáveis pela "política do autor", atribuem esse papel ao diretor, uma vez que é ele quem capitaneia o trabalho de dezenas de profissionais, outros pensadores, como Henri-Diamant Berger, acreditam que o autor é o roteirista, uma vez que é no roteiro que se encontra escrito o filme do modo como ele será impresso em película. Esse tipo de raciocínio é o mesmo que prevalece quanto às telenovelas.

Para analisar com mais profundidade a questão autoral na produção de Roberto Berliner, Oscar Rodrigues Alves e Maurício Eça, tomaram-se como referência textos de Paulo Emílio Salles Gomes, nos quais ele considera que a obra de um realizador audiovisual é um conjunto de ações que contêm temas recorrentes. Desse modo, procurou-se confirmar, na pesquisa, a eficácia da utilização do método da leitura retrospectiva, com as obras recentes iluminando as anteriores e estas anunciando as posteriores, em busca de uma unidade a ser encontrada. Não se desprezou, porém, o fato de que muitas vezes há rupturas, além de contradições internas à obra como um todo.

O presente estudo também levou em conta as três principais premissas da "política do autor", que se adequa tanto ao cinema como ao videoclipe, destacadas por Jean-Claude Bernardet no Capítulo 1, que são: a competência técnica do diretor; o conjunto de estilos recorrentes, que constituirão sua assinatura; e a denominada "mise en scéne", ou seja, os aspectos que fazem do cinema definitivamente uma arte.

Outro aspecto considerado na reflexão a respeito da autoria foi o fato de que uma determinada produção audiovisual sempre envolve dezenas de profissionais e, portanto, o conceito romântico de autoria como original e exclusiva foi relativizada. $O$ motivo, como destacado por Cecília Sayad, é o fato de que o diretor depende da colaboração de outros profissionais, como atores, fotógrafos e editores, tão fundamentais para o resultado final de uma obra. Por isso, foram realizadas entrevistas, não só com cada um dos três realizadores, mas também com alguns dos profissionais e artistas com os quais eles trabalharam.

Procurou-se, então, demonstrar que a autoria no videoclipe pode se manifestar na relação estabelecida com os códigos encontrados em alguns estilos musicais, caso do hip hop e do heavy metal, por exemplo. Por sua vez, alguns artistas, como Michael Jackson e Madonna, são tão autores dos videoclipes que 
estrelam quanto seus próprios diretores, inclusive pelo fato de os escolherem pessoalmente de acordo com o que pretendem transmitir em determinada produção.

É fácil identificar também que muitas das marcas autorais destacadas neste trabalho, com o passar do tempo, de tão repetidas por outros profissionais, tornamse clichês e perdem a eficácia da novidade. Basta observar alguns recursos muito presentes em alguns dos videoclipes citados na pesquisa, no que se refere, por exemplo, aos números de dança, à violência explícita e irracional, à citação ou reprodução de trechos de clássicos do cinema e às cenas interplanetárias.

O momento histórico em que determinada produção é realizada é outro fator fundamental para a observação do aspecto autoral, sobretudo no que se refere às referências utilizadas. Por isso, no caso do videoclipe brasileiro, a produção foi agrupada em três fases distintas, que não obedecem à uma rigidez cronológica, mas mesclam-se em diferentes momentos. A primeira delas é a da produção realizada para o programa Fantástico, da TV Globo, quando os diretores precisavam se encaixar no padrão estético exigido pela emissora, mas, ao mesmo tempo, podiam experimentar novas linguagens e recursos, muitos dos quais hoje soam extremamente datados. A fase seguinte foi a dos videoclipes realizados por produtoras independentes à TV Globo e, geralmente, por profissionais vindos de escolas de cinema, rádio e televisão, além da videoarte, que se permitiram realizar exercícios audiovisuais mais ousados, deixando mais de lado o aspecto comercial e procurando retratar com mais intensidade a realidade social do país. A terceira fase é a da entrada da MTV no Brasil, justamente num momento crítico da história do cinema brasileiro. Acontece quando muitos jovens realizadores encontram no videoclipe um espaço que não tinham mais no curta e no longa-metragem, trazendo para ele uma maior preocupação tanto estética quanto técnica, a fim de realizar produções em condições de igualdade com as internacionais, valendo-se de grandes investimentos e cuidado apurado com a fotografia, os movimentos de câmera e os cortes.

O momento da entrada da MTV no Brasil também coincidiu com uma das mais importantes mudanças tecnológicas para os realizadores audiovisuais: quando, principalmente a montagem/moviola ou edição, foi deixando de ser analógica para passar a ser realizada de modo digital. A mudança trouxe aos realizadores uma nova maneira de encarar seu ofício e realizar as atividades exigidas por ele. As 
possibilidades de exercícios audiovisuais tornaram-se muito mais vastas com a tecnologia digital.

Nos capítulos destinados a cada um dos três realizadores, foram analisadas com mais profundidade sete produções de cada um deles. Destas, seis foram escolhidas pelos próprios realizadores, em função da relevância em sua obra como um todo, pela qualidade estética e experiências realizadas, assim como pelo grau de prestígio e premiação. A outra produção foi a primeira realizada por eles, considerando-se a premissa de que ela poderia conter o cerne da obra de determinado diretor de videoclipes.

Foi possível, então, identificar as principais marcas autorais dos três diretores. No caso de Roberto Berliner, elas se manifestam com mais ênfase no aspecto documental e na tentativa de fugir das convenções, valorizando o que chama de sujeira e interferências nas imagens, além da presença de populares na tela, aspectos que o diretor levou para os documentários em longa-metragem que realizou até agora. Por sua vez, Oscar Rodrigues Alves tem como principal tônica em sua obra a tentativa de tornar a música ainda mais atraente para o espectador, identificando para ele a presença dos instrumentos musicais e do ritmo adotado, sempre procurando escapar das traduções óbvias e literais das letras, realizando narrativas mais ousadas e com mistura de diferentes técnicas e linguagens, caso da mistura de animação com imagens reais. O terceiro realizador, Maurício Eça, caracteriza-se mais por identificar na sua obra quais são os desejos e aspirações dos artistas com os quais trabalha, geralmente em início de carreira, valorizando o aspecto inusitado, irreverente e até mesmo grotesco, o que o aproxima, por exemplo, do cineasta norte-americano David Lynch.

São esses alguns dos aspectos importantes que tornam a obra de Roberto Berliner, Oscar Rodrigues Alves e Maurício Eça singulares e diferentes entre si, o que comprova a forte presença da questão autoral no que eles realizam e também no videoclipe brasileiro como um todo. Afinal, não è a toa que esse formato audiovisual tem se mostrado o mais receptivo a novas experiências técnicas e de linguagem, e que mais rapidamente se adequa aos diferentes meios de comunicação. Basta observar o grande sucesso que ele faz hoje na internet, sobretudo no site de vídeos YouTube.

A observação de alguns videoclipes produzidos no Brasil, no decorrer do trabalho, teve como objetivo dar uma ideia do que foi essa produção, mais exaustiva 
para alguns diretores no início, mais favorável para outros, mas, sem dúvida, uma luta para sua colocação tanto no mercado como no processo de conhecimento, incorporação, reconhecimento e apreciação pelo público, num espaço muitas vezes adverso ao videoclipe.

A apresentação e exploração dos videoclipes mostram a preocupação de seus autores em retratar de maneira diversificada a realidade de uma sociedade em rápida transformação. Cenas que abordam temas sociais como pobreza, discriminação, conflitos de geração e avanços tecnológicos versus padrões consolidados, cristalizados, retratam a preocupação - explícita ou não - com o cotidiano marcado pelos vários tipos de desigualdades em um mundo em acelerada transformação.

A "simples" (não tão simples, mas complexa, artística e rica) contraposição e sobreposição de cores vivas com cenas em preto e branco, por exemplo, chamam a atenção para essas diversidades, para essas contradições, para esses diferentes mundos e universos da vida moderna. Outros detalhes que compõem as cenas dos videoclipes, ricas em imagens e movimentos, reforçam a necessidade que o artista tem em registrar também a dinâmica da transformação da realidade nas letras de suas canções.

Os autores e/ou diretores a se lançarem nessa empreitada contam, em seus depoimentos, as dificuldades encontradas no início do trabalho, mescladas com o prazer de produzir algo diferente, contestador, que pudesse retratar os anseios de liberdade, de mudança, sem deixar de retratar, ao mesmo tempo, os problemas e contradições desses mesmos momentos que englobam valores, perspectivas, padrões de comportamento, tecnologias diversificadas etc.

Portanto, espera-se que este trabalho de retratar a história do videoclipe no Brasil e no mundo, e de analisar os videoclipes dos três realizadores destacados na pesquisa contribuam para um maior conhecimento a respeito de videoclipe: sua produção, sua autoria, aceitação e incorporação, e também possa constituir-se em material de referência para uma área ainda pouco explorada em trabalhos acadêmicos. Ao mesmo tempo, esse formato audiovisual tem demonstrado ser um espaço importante para o exercício formal estético, muitas vezes obrigando o seu realizador a ser criativo e a experimentar novas técnicas e softwares, 
desenvolvendo, assim, um trabalho artístico de importância capital para a produção audiovisual como um todo. 
FONTES CONSULTADAS

1. DEPOIMENTOS

\begin{tabular}{|c|c|}
\hline Entrevistado & Ano \\
\hline Alê Briganti & 2006 \\
\hline Billy Bond & 2010 \\
\hline Carlos Carneiro & 2010 \\
\hline Claudio Torres & 2006 \\
\hline Cyro Del Nero & 2009 \\
\hline Djavan & 2010 \\
\hline Dulce Quental & 2010 \\
\hline Eid Walesko & 2010 \\
\hline Fernando Meirelles & 1999 \\
\hline Francisco Rodrigues Alves & 2006 \\
\hline Herbert Richers Jr. & 2010 \\
\hline Herbert Vianna & 1999 \\
\hline João Barone & 2010 \\
\hline Jodele Larcher & 1999 \\
\hline Johnny Araújo & 2006 \\
\hline José Emilio Rondeau & 2006 \\
\hline Leo Jaime & 2010 \\
\hline Márcia Santos & 2006 \\
\hline Mari Stockler & 2006 \\
\hline Nando Cohen & 2010 \\
\hline Nelson Motta & 2003 \\
\hline Nilton Travesso & 2006 \\
\hline Paulo Trevisan & 2010 \\
\hline Pedro Luís & 2010 \\
\hline Raul Mourão & 2010 \\
\hline Ricardo Silveira & 1999 \\
\hline Rogério Gallo & 2006 \\
\hline Roger Moreira & 2010 \\
\hline Rui Mendes & 2010 \\
\hline Samuel Rosa & 2010 \\
\hline Sandra Kogut & 2010 \\
\hline Sergio Britto & 2010 \\
\hline Tadeu Jungle & 2006 \\
\hline Tony Tiger & 2010 \\
\hline Yone Sassa & 2006 \\
\hline
\end{tabular}

\section{LIVROS E PERIÓDICOS}

ALENCAR, Mauro. A Hollywood Brasileira: panorama da telenovela no Brasil. Rio de Janeiro, RJ. Senac. 2002

ALVES, Vida. TV Tupi Uma Linda História de Amor. São Paulo, SP. Imprensa Oficial. 2008 
AUGUSTO, Sérgio. Este mundo é um pandeiro: a chanchada de Getúlio a JK. São Paulo, SP. Cia. das Letras. 1989

AUMONT, Jacques et al. A Estética do Filme. Campinas, SP. Papirus. 1995

AUSTERLITZ, Saul. Money For Nothing. Continuum. Londres, Grã-Bretanha. 2007

BAHIANA, Ana Maria. A Eficiente Máquina de Sonhar. Video News, no 43, ano 4. Sigla Editora. São Paulo, SP. 1984

Vídeo News, no41, ano 4. Sigla Editora. São Paulo, SP. 1984.

BENETON, Rosana; FILHO, André Barbosa; e PIOVESAN, Ângelo. Rádio Sintonia do Futuro. São Paulo, SP. Editora Paulinas. 2004.

BENTES, Ivana (org.). Ecos do Cinema de Lumière ao digital. Editora UFRJ. Rio de Janeiro, RJ. 2007

BERCHMANS, Tony. A Música do Filme - Tudo o que você gostaria de saber sobre a música de cinema.

BERNARDET, Jean-Claude. O Autor no Cinema. Editora Brasiliense. São Paulo, SP, 1994

. Historiografia Clássica do Cinema Brasileiro

BLANCHARD, Gerard. Les Videoclips. Communications et Langages. Paris. 72, 2e., trim. 1987

BRANDÃO, Antonio Carlos; e DUARTE, Milton Fernandes. Movimentos culturais de juventude. São Paulo, SP. Moderna. 2004

BRANDINI, Valéria. Cenários do Rock Mercado, produção e tendências no Brasil. São Paulo, SP. Editora Olho D'Água. 2004

BRYAN, Guilherme. Quem Tem Um Sonho Não Dança - Cultura jovem brasileira nos anos 80. Ed. Record, Rio de Janeiro, RJ. 2004

Videoclipe Brasileiro - História, características e internacionalidadde. Dissertação de Mestrado. Escola de Comunicação e Artes da USP. São Paulo, SP. 2005

30 Anos Num Clipe. Folhateen. Folha de S. Paulo. São Paulo, SP. 31 de outubro de 2005

CARRASCO, Ney. Sygkhronos A Formação da Poética Musical do Cinema. São Paulo/SP. Via Lettera:Fapesp. 2003

CHAROUX, Mônica. Estéticas Antropofágicas. About, nำ766. 10 de maio de 2004

COSTA, Cristina. Questões de Arte. Editora Moderna. São Paulo, SP. 1999

DIAS, Lucy. Anos 70 Enquanto Corria a Barca. São Paulo, SP. Senac São Paulo. 2001

ESQUENAZI, Rose. No Túnel do Tempo: uma memória afetiva da televisão brasileira. Porto Alegre, RS. Artes e Ofícios. 1993

FERNANDES, Vagner. Clara Nunes Guerreira da Utopia. Ediouro. Rio de Janeiro, RJ. 2007

FILHO, Daniel. O Circo Eletrônico: Fazendo TV no Brasil. Rio de Janeiro, RJ. Jorge Zahar. 2001

FRANCE PRESS. In. Há 25 anos nascia a revolução MTV. Campinas, SP. 31 de julho de 2006, pág. C1.

FRIEDLANDER, Paul. Rock and Roll Uma história social. Rio de Janeiro, RJ. Record. 2002

GOBBI, Nelson. Videoclipe Cinquentão, Jornal do Brasil. Rio de Janeiro, RJ, 1ำ de junho de 2006, pág. B1

GOMES, Paulo Emílio Sales. Cinema: Trajetória no Subdesenvolvimento. Paz e Terra. São Paulo, SP. 1996 
GOODWIN, Andrew. Dancing In The Distraction Factory Music television and popular culture. Minnesota, USA. University of Minnesota Press. 1992

HOINEFF, Nelson. A Nova Televisão - desmassificação e o impasse das grandes redes. Rio de Janeiro, RJ. Relume Dumará. 1996

JACKSON, Arthur; e TAYLOR, John Russell. The Hollywood Musical. Grã-Bretanha. MCGraw-Hill Book. 1971

JUNIOR, Gonçalo. Pais da TV. São Paulo, SP. Editora Conrad. 2001

KAPLAN, E. Ann. Rocking Around the Clock: Music Television, Postmodernism and Popular Culture. Routledge. USA. 1988

LEITÃO, Denise Marques. O Autor na Telenovela Brasileira. Trabalho de Conclusão de Curso. Escola de Comunicação e Artes da USP. São Paulo, SP. 2004

LEONI. Letra, Música e Outras Conversas. Rio de Janeiro, RJ. Griphus. 1995

LIMA, Vanessa. Entrevista: Fernanda Takai. São Paulo, SP. Ainda? Fanzine Oficial. no4. Quanta. Maio/2003

LOIOLA, Thompson. Revista da MTV. Ano 1, no 5. São Paulo, SP. ZMA3. Julho/2001

LUCA, Luiz Gonzaga Assis de. Cinema Digital Um Novo Cinema? Imprensa Oficial. São Paulo, SP. 2004.

LUSVARGHI, Luiza Cristina. A MTV no Brasil - a padronização da cultura na mídia eletrônica mundial. Dissertação de Mestrado. ECA/USP. 2002

MACHADO, Arlindo. A Arte do Vídeo. São Paulo, SP. Brasiliense, 1988

A Televisão Levada a Sério. $2^{\underline{a}} e d$. São Paulo, SP. SENAC.

2001

Máquina e Imaginário. 3a ed. São Paulo, SP. Edusp. 2001

Made in Brasil Três décadas do vídeo brasileiro. São Paulo, SP. Iluminuras. 2007

MACHADO, Marcelo. In. A Imagem da Música. São Paulo, SP. Veja. Editora Abril. 21/05/1986

MARCHETTI, Paulo; e GOMYDE, Heloisa. Bonecos de Cena. Revista da MTV. São Paulo, SP. no7, 12/2001

MARCONDES, Pyr. Uma História da Propaganda Brasileira. Rio de Janeiro, RJ. Ediouro. 2001

MARINHO, Flávio. Oscarito O Riso e o Siso. Rio de Janeiro, RJ. Editora Record. 2008

MÁRQUEZ, Gabriel García. La Bendita Mania de Contar. Editorial Sudamericana. Buenos Aires, Argentina. 2008

MARTINHO, Maria Esther; e PORTO, Gisele. O mundo mágico do videoclip. Video News. № 56, ano 4. São Paulo, SP. Sigla. 1987

MARTINS, Rosana; e PEDROSO, Maria Goretti (orgs). Admirável Mundo MTV Brasil. São Paulo, SP. Saraiva Editora. 2006

MASSON, Celso. Pílulas de cinema. In. Veja. Ano 31. №35. São Paulo, SP. Editora Abril. 02/09/1998

MÁXIMO, João. A Música do Cinema Volume 1. Rio de Janeiro, RJ. Editora Rocco. 2003

MELLO, Zuza Homem de. A Era dos Festivais Uma parábola. São Paulo, SP. Editora 34. 2003

MEMÓRIA GLOBO. Autores Histórias da Teledramaturgia Vol. 1. Editora Globo. São Paulo, SP, 2008

MENOTTI, Alex. Fazendo Clipe. Revista da MTV, №24. São Paulo, SP. Abril de 2003 MILLER, Gustavo. Do Fantástico ao Youtube A História do Videoclipe Musical no Brasil. Projeto Experimental (TCC). PUC-SP. São Paulo, SP. 2007 
MOTTA, Nelson. Noites Tropicais. Editora Objetiva. Rio de Janeiro, RJ. 2000

MURCH, Walter. Num Piscar de Olhos A edição de filmes sob a ótica de um mestre. Editora Jorge Zahar. Rio de Janeiro, RJ. 2004

NAGIB, Lúcia. O Cinema da Retomada Depoimentos de 90 cineastas dos anos 90. Editora 34. São Paulo, SP. 2002

NÃO-IDENTIFICADO. Globo Declara Guerra à Estética do Clipe. Folha de São Paulo. São Paulo, SP. 25/1/993

NERO, Cyro Del. Videoclipe $X$ Nilton Travesso ou A Travessura de um Sofismo Niltoniano. Texto distribuído pela internet em 25 de maio de 2009.

ORICCHIO, Luiz Zanin. Cinema de Novo Um balanço crítico da retomada. São Paulo, SP. Estação Liberdade. 2003

PEDROSO, Maria Goretti, e MARTINS, Rosana (org). Admirável Mundo MTV Brasil. Editora Saraiva. São Paulo, SP. 2006

PEQUINO, Lívia; GUEDES, Nádia de Moraes Schunck; e LOPES, Tatiane de Oliveira. Piauí_06. Trabalho de Conclusão de Curso de Jornalismo. Faculdade Anhembi Morumbi. São Paulo, SP. Junho/2008

PEREIRA, Carmem. O Clip Brasileiro Não Presta. Por Quê? Bizz. Ano II. №8. São Paulo, SP. Abril. 03/1986

PLAZA, Mônica. Rolling Stone - A Morte do Videoclipe?. Trabalho de Conclusão de Curso de Pós-Graduação. Pontifícia Universidade Católica de Brasília. Brasília, DF. 2009.

PORTO, Gisele; e MARTINHO, Maria Esther. O Mundo Mágico do Videoclipe. Vídeo News. São Paulo, SP. no56. 1987

PUGGIALI, Ricardo. Beatlemania. Ediouro. São Paulo, SP. 2008

RAMOS, Fernão Pessoa (org.). Teoria Contemporânea do Cinema Pósestruturalismo e filosofia analítica Volume 1. Editora Senac. São Paulo, SP, 2005

RAMOS, José Mario Ortiz. Televisão, Publicidade e Cultura de Massa. Petrópolis, RJ. Vozes. 1995

RÉ, Adriana Del. O Videoclipe Perde a Vez. Caderno TV \& Lazer. O Estado de S. Paulo. São Paulo, SP. 10 de dezembro de 2006, págs. 4 e 5.

REZENDE, Marcelo. Ciência do Sonho A imaginação sem fim do diretor Michel Gondry. Editora Alameda. São Paulo, SP. 2005

RODRIGUES, Rodrigo. As Aventuras da Blitz. Ediouro. São Paulo, SP. 2009

RODRIGUES, Rodrigo Fonseca e. Música Eletrônica A Textura da Máquina. Annablume. São Paulo, SP. 2005.

SAYAD, Cecília. O Jogo da Reinvenção Charlie Kaufman e o Lugar do Autor no Cinema. São Paulo, SP. Alameda. 2008

SCHWARZMAN, Sheila. Humberto Mauro e as imagens do Brasil. São Paulo, SP. Editora UNESP. 2004

SOARES, Thiago. Videoclipe, o elogio da desarmonia. Olinda, PE. Editora do Autor. 2004

SOUZA, José Inácio de Melo. Imagens do Passado São Paulo e Rio de Janeiro nos primórdios do cinema. São Paulo, SP. Editora Senac. 2004.

TINHORÃO, José Ramos. Música popular: do gramofone ao rádio e TV. São Paulo, SP. Ática. 1981

TOMAZI, Nelson Dacio (coord). Iniciação à Sociologia. 2aㅡ Ed. São Paulo, SP. Editora Atual. 2000

VICENTE, Eduardo. Música e Disco no Brasil: A trajetória da indústria fonográfica nas décadas de 80 e 90. Tese de doutoramento. ECA/USP. 2001. 
WISNIK, José Miguel. O Som e o Sentido Uma outra história das músicas. São Paulo, SP. Cia. das Letras. $2^{\underline{a}}$ ed. 2004

XAVIER, Ismail. Alegorias do Subdesenvolvimento. São Paulo, SP. Brasiliense. 1993

\section{REFERÊNCIAS ELETRÔNICAS}

BENTES, Ivana. Documentário digital, publicidade, videoclipe e cinema. In. www.uerj.br/ labore/pole_imagem_cinema_main_p9.htm.

JUNIOR, José Flávio. O Fim da Era Madonna? Revista Bravo!. São Paulo, SP, dezembro de 2008. Em

http://bravonline.abril.com.br/conteudo/musica/musicamateria_407 201.shtml

MACHADO, Arlindo. Linhas de força do vídeo brasileiro. In.

www.itaucutlural.org.br/madeinbrasil/ curadorintegra.htm

NERO, Cyro Del. In. MAIA, Carla. Site Tele História, em 13 de novembro de 2008 http://www.telehistoria.com.br/thnews/colunas_integra.asp?id=388 1

VÁRIOS. http://www.mvdbase.com/artist.php?last=Strokes\&first=the

VÁRIOS, http://g1.globo.com/Noticias/Tecnologia/0,,AA1306288-6174,00.html

ZANINI, Mariana. Músicas em imagens e movimento. Sobrecarga. 17 de fevereiro de 2005. In. http://www.sobrecarga.com.br/node/view/4796

\section{OUTROS}

- "Especial 15 Anos MTV Brasil" (14 episódios) - Exibido em outubro de 2005 pela MTV Brasil.

- "Bioclipe" (3 episódios) - Exibido em agosto de 2006 pela MTV Brasil.

- PATARA, Fernanda; e PAIXÃO, Laís. Vídeo-documentário "Videoclipe em 3x4". Trabalho de Conclusão de Curso de Rádio e Televisão na Faculdade Belas Artes. São Paulo, SP. 2008. 
BIBLIOCLIPE

(Lista de Todos os Videoclipes Citados no Trabalho)

Videoclipes Internacionais

\begin{tabular}{|c|c|c|c|}
\hline INTÉRPRETE & MÚSICA & DIRETOR & ANO \\
\hline Aerosmith & Crazy & Marty Callner & 1994 \\
\hline Aerosmith & Cryin' & Marty Callner & 1993 \\
\hline Aerosmith & Janie's Got a Gun & David Fincher & 1987 \\
\hline $\begin{array}{l}\text { Afrika Bambaataa e } \\
\text { Soul Sonic Force }\end{array}$ & Planet Rock & & 1982 \\
\hline $\mathrm{A}-\mathrm{Ha}$ & Crying in the Rain & Steve Barron & 1990 \\
\hline $\mathrm{A}-\mathrm{Ha}$ & Cry Wolf & Steve Barron & 1986 \\
\hline $\mathrm{A}-\mathrm{Ha}$ & Hunting High and Low & Steve Barron & 1986 \\
\hline $\mathrm{A}-\mathrm{Ha}$ & Take On Me & Steve Barron & 1985 \\
\hline Arcade Fire & We Used To Want & Chris Milk & 2010 \\
\hline Audioslave & Doesn't Remind Me & Chris Milk & 2005 \\
\hline AvrilBandAids & Girlfriend & $\begin{array}{l}\text { Emmett Me Brendon } \\
\text { Malloy }\end{array}$ & 2007 \\
\hline Avril Lavigne & The Best Damn Thing & Wayne Isham & 2008 \\
\hline Backstreet Boys & I Want It That Way & Wayne Isham & 1999 \\
\hline Bangles & Eternal Flame & Tim Pope & 1988 \\
\hline Beastie Boys & Sabotage & Spike Jonze & 1994 \\
\hline Beatles & Free as a Bird & Joe Pytka & 1996 \\
\hline Beatles & Real Love & Godley \& Creme & 1996 \\
\hline Beck & Devills Haircut & Mark Romanek & 1996 \\
\hline Bee Gees & Stayin' Alive & Bruce Gowers & 1977 \\
\hline Beyoncé & Check On It & Hype Williams & 2005 \\
\hline Beyoncé & Naughty Girl & Jake Nava & 2004 \\
\hline Beyoncé & $\begin{array}{l}\text { Single Ladies (Put a Ring } \\
\text { On It) }\end{array}$ & Jake Nava & 2008 \\
\hline B-52's & Legal Tender & $\begin{array}{l}\text { Mick Haggarty \& C.D. } \\
\text { Taylor }\end{array}$ & 1983 \\
\hline Billy Idol & Eyes Without a Face & David Mallet & 1982 \\
\hline Billy Idol & White Wedding & David Mallet & 1982 \\
\hline Björk & Army of Me & Michel Gondry & 1995 \\
\hline Björk & Bachelorette & Michel Gondry & 1998 \\
\hline Björk & Hyperballad & Michel Gondry & 1996 \\
\hline Björk & Human Behavior & Michel Gondry & 1993 \\
\hline Björk & It's Oh So Quiet & Spike Jonze & 1995 \\
\hline Björk & Pagan Poetry & Nick Knight & 2001 \\
\hline Bjöirk & Triumph of a Heart & Spike Jonze & 2004 \\
\hline Blondie & Hanging On The Telephone & David Mallet & 1978 \\
\hline Blur & Charmless Man & Jamie Thraves & 1996 \\
\hline Blur & Coffee \& TV & Hammer \& Tones & 1999 \\
\hline Blur & Girls and Boys & Kevin Godley & 1994 \\
\hline Blur & Just & Jamie Thraves & 1995 \\
\hline Bon Jovi & l'll Be There For You & Wayne Isham & 1988 \\
\hline
\end{tabular}




\begin{tabular}{|c|c|c|c|}
\hline Bon Jovi & Livin'On A Prayer & Wayne Isham & 1986 \\
\hline Britney Spears & ... Baby One More Time & Nigel Dick & 1998 \\
\hline Britney Spears & Gimme More & Jake Sarfaty & 2007 \\
\hline Britney Spears & I Love Rock'n'Roll & Chris Applebaum & 2002 \\
\hline Britney Spears & $\begin{array}{l}\text { I'm Not a Girl, Not Yet a } \\
\text { Woman }\end{array}$ & Wayne Isham & 2002 \\
\hline Britney Spears & Ooops I Did It Again & Nigel Dick & 2000 \\
\hline Britney Spears & Piece of $\mathrm{Me}$ & Wayne Isham & 2007 \\
\hline Britney Spears & Toxic & Joseph Kahn & 2004 \\
\hline Bruce Springsteen & Dancing in the Dark & Brian de Palma & 1984 \\
\hline Bryan Adams & $\begin{array}{l}\text { (Everything I Do) I Do It For } \\
\text { You }\end{array}$ & Julien Temple & 1991 \\
\hline Bryan Adams & Heaven & Steve Barron & 1984 \\
\hline Buggles & Video Killed The Radio Star & Russell Mulcahy & 1981 \\
\hline Bush & Comedown & Jake Scott & 1995 \\
\hline Busta Rhymes & Break Ya Neck & $\begin{array}{l}\text { Busta Rhymes e } \\
\text { Hype Williams }\end{array}$ & 2001 \\
\hline Busta Rhymes & Dangerous & $\begin{array}{l}\text { Busta Rhymes e } \\
\text { Hype Williams }\end{array}$ & 1997 \\
\hline Busta Rhymes & Fire & $\begin{array}{l}\text { Busta Rhymes e } \\
\text { Hype Williams }\end{array}$ & 2000 \\
\hline Busta Rhymes & Get Out & $\begin{array}{l}\text { Busta Rhymes e } \\
\text { Hype Williams }\end{array}$ & 2000 \\
\hline Busta Rhymes & $\begin{array}{l}\text { Put Your Hand Where My } \\
\text { Eyes Can See }\end{array}$ & $\begin{array}{l}\text { Busta Rhymes e } \\
\text { Rype Williams }\end{array}$ & 1997 \\
\hline Busta Rhymes & $\begin{array}{l}\text { Tear Roof Off / Party } \\
\text { Goin'On Over Here }\end{array}$ & Hype Williams & 1999 \\
\hline Busta Rhymes & What It Is & Hype Williams & 2001 \\
\hline Busta Rhymes & What's It Gonna Be & $\begin{array}{l}\text { Busta Rhymes e } \\
\text { Hype Williams }\end{array}$ & 1989 \\
\hline Busta Rhymes & $\begin{array}{l}\text { Woo-La! Get You All In } \\
\text { Check }\end{array}$ & Hype Williams & 1996 \\
\hline Cardigans & My Favourite Game & Jonas Akerlund & 1998 \\
\hline Cars & Hello Again & Andy Warhol & 1984 \\
\hline Cars & You Might Think & Jeff Stein \& Chalex & 1984 \\
\hline Celine Dion & My Heart Will Go On & Bille Woodruff & 1997 \\
\hline Chemical Brothers & Eletrobank & Spike Jonze & 1997 \\
\hline $\begin{array}{l}\text { Chemical Brothers e } \\
\text { Flaming Lips }\end{array}$ & Golden Path & Chris Milk & 2003 \\
\hline Cher & Song for the Lonely & Kevin Godley & 2000 \\
\hline Chris Isaak & Wicked Game & Herb Ritts & 1991 \\
\hline Christina Aguilera & Dirrty & $\begin{array}{l}\text { Jean-Baptiste } \\
\text { Mondino }\end{array}$ & 2002 \\
\hline $\begin{array}{l}\text { Christina Aguilera, } \\
\text { Mya, Pink e Lil'Kim }\end{array}$ & Lady Marmalade & Paul Hunter & 2001 \\
\hline Cindy Lauper & Girls Just Wanna Have Fun & Edd Griles & 1983 \\
\hline Cindy Lauper & Time After Time & Edd Griles & 1984 \\
\hline Coldplay & Scientist & Jamie Thraves & 2002 \\
\hline
\end{tabular}




\begin{tabular}{|c|c|c|c|}
\hline $\begin{array}{l}\text { Cool Breeze, Outkast } \\
\& \text { Goodie Mob }\end{array}$ & Watch for the Hook & David Nelson & 1998 \\
\hline Counting Crows & American Girls & Marc Webb & 2002 \\
\hline Courtney Love & Mono & Chris Milk & 2004 \\
\hline Cramberries & Stars & Jake Nava & 2002 \\
\hline Cramberries & Zombie & Samuel Bayer & 1994 \\
\hline Culture Club & A View To a Kill & Godley \& Crème & 1985 \\
\hline Culture Club & $\begin{array}{l}\text { Do You Really Want To Hurt } \\
\text { Me }\end{array}$ & Steve Barron & 1982 \\
\hline Culture Club & It's a Miracle & Steve Barron & 1984 \\
\hline Culture Club & Karma Chameleon & Steve Barron & 1983 \\
\hline Culture Club & Love Is Love & Steve Barron & 1984 \\
\hline Culture Club & Miss Me Blind & Steve Barron & 1984 \\
\hline Cure & Close To Me & Tim Pope & 1985 \\
\hline Cure & In Between Days & Tim Pope & 1985 \\
\hline Cure & Love Cats & Tim Pope & 1983 \\
\hline Cure & Lullaby & Tim Pope & 1989 \\
\hline Daft Punk & Around the World & Michel Gondry & 1997 \\
\hline Daft Punk & Da Funk & Spike Jonze & 1997 \\
\hline David Bowie & Ashes to Ashes & $\begin{array}{l}\text { David Mallet e David } \\
\text { Bowie }\end{array}$ & 1980 \\
\hline David Bowie & Boys Keep Swinging & David Mallet & 1979 \\
\hline David Bowie & China Girl & David Mallet & 1983 \\
\hline David Bowie & D.J. & David Mallet & 1979 \\
\hline David Bowie & Let's Dance & David Mallet & 1983 \\
\hline David Bowie & Time Will Crawl & Tim Pope & 1987 \\
\hline Def Leppard & Pour Some Sugar On Me & Wayne Isham & 1988 \\
\hline Depeche Mode & Strangelove & Anton Corbijn & 1987 \\
\hline Devo & Beautiful World & Gerald Casale & 1981 \\
\hline Devo & (I Can't Get No) Satisfaction & $\begin{array}{l}\text { Gerald Casale e } \\
\text { Chuck Statler }\end{array}$ & 1978 \\
\hline Devo & Whip It & Gerald Casale & 1980 \\
\hline Dire Straits & Money For Nothing & Steve Barron & 1985 \\
\hline Don Henley & The Boys of Summer & $\begin{array}{l}\text { Jean-Baptiste } \\
\text { Mondino }\end{array}$ & 1984 \\
\hline Duran Duran & Girls On Film & Godley \& Crème & 1981 \\
\hline Duran Duran & Hungry High and Low & Russel Mulcahy & 1982 \\
\hline Duran Duran & Planet Earth & Russel Mulcahy & 1981 \\
\hline Duran Duran & Rio & Russel Mulcahy & 1982 \\
\hline Duran Duran & Save a Prayer & Russel Mulcahy & 1982 \\
\hline Duran Duran & The Wild Boys & Russel Mulcahy & 1984 \\
\hline Elton John & Heels of the Wind & Russel Mulcahy & 1981 \\
\hline Elton John & $\begin{array}{l}\text { I Don't Wanna Go On With } \\
\text { You Like That }\end{array}$ & Russel Mulcahy & 1986 \\
\hline Elton John & Nobody Wins & Russel Mulcahy & 1981 \\
\hline Elton John & The One & Russel Mulcahy & 1992 \\
\hline Elton John & $\begin{array}{l}\text { This Train Don't Stop There } \\
\text { Anymore }\end{array}$ & $\begin{array}{l}\text { Jean-Baptiste } \\
\text { Mondino }\end{array}$ & 2001 \\
\hline Eminem & Cleanin'Out My Closet & Dr. Dre e Philip Atwell & 2002 \\
\hline
\end{tabular}




\begin{tabular}{|c|c|c|c|}
\hline Eminem & My Name Is & Dr. Dre e Philip Atwell & 1999 \\
\hline Eminem & Superman & Paul Hunter & 2003 \\
\hline Eminem & The Real Slim Shady & Dr. Dre e Philip Atwell & 2000 \\
\hline Eminem & Without Me & Joseph Kahn & 2002 \\
\hline Eric Clapton & My Father's Eyes & Kevin Godley & 1998 \\
\hline $\begin{array}{ll}\text { Eric } & \text { Whitrace } \\
\text { Orchestra } & \\
\end{array}$ & Lux Aurrunque & Scott Haines & 2010 \\
\hline Evanescence & Call Me When You're Sober & Marc Webb & 2006 \\
\hline Fatboy Slim & Right Here, Right Now & Hammer \& Tones & 1999 \\
\hline Fatboy Slim & Weapon of Choice & Spike Jonze & 2001 \\
\hline Fergie & London Bridge & Marc Webb & 2006 \\
\hline Foo Fighters & Learn to Fly & Jesse Peretz & 1999 \\
\hline $\begin{array}{l}\text { Frankie Goes To } \\
\text { Hollywood }\end{array}$ & Two Tribes & Godley \& Creme & 1984 \\
\hline $\begin{array}{l}\text { Frank Sinatra e Bono } \\
\text { Vox }\end{array}$ & I've Got You Under My Skin & Kevin Godley & 1993 \\
\hline Franz Ferdinand & Take Me Out & Jonas Odell & 2004 \\
\hline Freddie Mercury & Made In Heaven & David Mallet & 1985 \\
\hline Genesis & Ripples & Bruce Gowers & 1976 \\
\hline George Michael & Father Figure & $\begin{array}{l}\text { George Michael e } \\
\text { Andy Morahan }\end{array}$ & 1987 \\
\hline George Michael & Freedom ‘90 & David Fincher & 1990 \\
\hline George Michael & I Want Your Sex & $\begin{array}{l}\text { George Michael e } \\
\text { Andy Morahan }\end{array}$ & 1987 \\
\hline George Michael & $\begin{array}{l}\text { Killer / Papa Was a Rolling } \\
\text { Stone }\end{array}$ & Marcus Nigel & 1993 \\
\hline George Michael & Kiss & $\begin{array}{l}\text { George Michael e } \\
\text { Andy Morahan }\end{array}$ & 1986 \\
\hline Godley \& Crème & Cry & Godley \& Creme & 1985 \\
\hline $\begin{array}{l}\text { Grandmaster Flash e } \\
\text { Furious Five }\end{array}$ & The Message & Sylvia Robinson & 1982 \\
\hline Green Day & American Idiot & Samuel Bayer & 2004 \\
\hline Green Day & 21 Guns & Marc Webb & 2009 \\
\hline Green Day & $\begin{array}{l}\text { Wake Me Up When } \\
\text { September Ends }\end{array}$ & Samuel Bayer & 2005 \\
\hline Heartbreakers & Mary Jane's Last Dance & Keir McFarlane & 1993 \\
\hline Herbie Hancock & Rockit & Godley \& Creme & 1983 \\
\hline Hilary Duff & So Yesterday & Chris Applebaum & 2003 \\
\hline Hilary Duff & Wake Up & Marc Webb & 2005 \\
\hline Human League & Don't You Want Me & Steve Barron & 1981 \\
\hline $\begin{array}{l}\text { Ice Cube e Snoop } \\
\text { Dogg }\end{array}$ & Hypnotize & $\begin{array}{l}\text { Paul Hunter e Sean } \\
\text { Combs }\end{array}$ & 1997 \\
\hline Iron Maiden & Wasting Love & Samuel Bayer & 1992 \\
\hline Jamiroquai & Virtual Insanity & Jonathan Glazer & 1996 \\
\hline Janet Jackson & $\begin{array}{l}\text { Love Will Never Do (Without } \\
\text { You) }\end{array}$ & Herb Ritts & 1990 \\
\hline Jean-François Coen & La Tour de Pise & Michel Gondry & 1993 \\
\hline Jefferson Starship & Light The Sky On Fire & George Lucas & 1978 \\
\hline
\end{tabular}




\begin{tabular}{|c|c|c|c|}
\hline Jennifer Lopez & I'm Glad & David La Chapelle & 2003 \\
\hline Joy Division & Atmosphere & Anton Corbijn & 1988 \\
\hline Julian Lennon & Too Late for Goodbyes & Sam Peckimpah & 1984 \\
\hline Justice & Stress & Romain Gravas & 2008 \\
\hline Justin Bieber & Baby & Ray Kay & 2010 \\
\hline Kanye West & Heartless & Hype Williams & 2009 \\
\hline Kanye West & Runaway & Hype Williams & 2010 \\
\hline Kelly Osbourne & One Word & Chris Applebaum & 2005 \\
\hline Kim Carnes & Bette Davis Eyes & Russel Mulcahy & 1981 \\
\hline Korn & A.D.I.D.A.S. & Joseph Kahn & 1997 \\
\hline Kylie Minogue & Come Into The World & Michel Gondry & 2002 \\
\hline Lady Gaga & Bad Romance & Francis Lawrence & 2010 \\
\hline Lady Gaga & Paparazzi & Jonas Akerlund & 2009 \\
\hline Lady Gaga & Telephone & Jonas Akerlund & 2010 \\
\hline Lemonheads & Mrs. Robinson & Jesse Peretz & 1992 \\
\hline Lionel Richie & All Night Long & Bob Rafelson & 1983 \\
\hline $\begin{array}{l}\text { Lisa Loed \& Nine } \\
\text { Stories }\end{array}$ & Stay (I Missed You) & Ethan Hawke & 1994 \\
\hline LL Cool J & Hot Hot Hot & Paul Hunter & 1998 \\
\hline Mack 10 & Only in California & Paul Hunter & 1997 \\
\hline Madonna & American Life & Jonas Akerlund & 2003 \\
\hline Madonna & Bad Girl & David Fincher & 1993 \\
\hline Madonna & Beautiful Stranger & Brett Ratner & 1999 \\
\hline Madonna & Borderline & Mary Lambert & 1984 \\
\hline Madonna & Burning Up & Steve Barron & 2006 \\
\hline Madonna & Celebration & Jonas Akerlund & 2009 \\
\hline Madonna & Cherish & Herb Ritts & 1989 \\
\hline Madonna & Don't Tell Me & $\begin{array}{l}\text { Jean-Baptiste } \\
\text { Mondino }\end{array}$ & 2000 \\
\hline Madonna & $\begin{array}{l}\text { Drowned World (Substitute } \\
\text { for Love) }\end{array}$ & Walter A. Stern & 1998 \\
\hline Madonna & Erotica & Fabien Baron & 1992 \\
\hline Madonna & Express Yourself & David Fincher & 1989 \\
\hline Madonna & Hollywood & $\begin{array}{l}\text { Jean-Baptiste } \\
\text { Mondino }\end{array}$ & 2002 \\
\hline Madonna & Human Nature & $\begin{array}{l}\text { Jean-Baptiste } \\
\text { Mondino }\end{array}$ & 1995 \\
\hline Madonna & Justify My Love & $\begin{array}{l}\text { Jean-Baptiste } \\
\text { Mondino }\end{array}$ & 1990 \\
\hline Madonna & La Isla Bonita & Mary Lambert & 1987 \\
\hline Madonna & Like a Prayer & Mary Lambert & 1989 \\
\hline Madonna & Like a Virgin & Mary Lambert & 1984 \\
\hline Madonna & Material Girl & Mary Lambert & 1985 \\
\hline Madonna & Music & Jonas Akerlund & 2000 \\
\hline Madonna & Oh Father & David Fincher & 1989 \\
\hline Madonna & Open Your Eyes & $\begin{array}{l}\text { Jean-Baptiste } \\
\text { Mondino }\end{array}$ & 1986 \\
\hline Madonna & Papa Don't Preach & James Foley & 1986 \\
\hline Madonna & Ray of Light & Jonas Akerlund & 1998 \\
\hline
\end{tabular}




\begin{tabular}{|c|c|c|c|}
\hline Madonna & Vogue & David Fincher & 1990 \\
\hline Madonna & What It Feels Like for a Girl & Guy Ritchie & 2001 \\
\hline $\begin{array}{l}\text { Madonna e Britney } \\
\text { Spears }\end{array}$ & Me Against the Music & Paul Hunter & 2003 \\
\hline Maroon 5 & Goodnight, Goodnight & Marc Webb & 2008 \\
\hline Metallica & Broken, Beat \& Scarred & Wayne Isham & 2009 \\
\hline Metallica & Enter Sandman & Wayne Isham & 1991 \\
\hline Metallica & Frentic & Wayne Isham & 2003 \\
\hline M.I.A. & Born Free & Roman Gravas & 2010 \\
\hline Michael Jackson & $\mathrm{Bad}$ & Martin Scorsese & 1987 \\
\hline Michael Jackson & Beat It & Bob Giraldi & 1983 \\
\hline Michael Jackson & Billie Jean & Steve Barron & 1983 \\
\hline Michael Jackson & Black Or White & John Landis & 1991 \\
\hline Michael Jackson & In The Closet & $\begin{array}{l}\text { Herb Ritts e Michael } \\
\text { Jackson }\end{array}$ & 1992 \\
\hline Michael Jackson & Jam & $\begin{array}{lr}\text { David Kellogg } & \text { e } \\
\text { Michael Jackson } & \end{array}$ & 1992 \\
\hline Michael Jackson & Remember the Time & John Singleton & 1992 \\
\hline $\begin{array}{l}\text { Michael Jackson e } \\
\text { Janet Jackson }\end{array}$ & Scream & Mark Romanek & 1995 \\
\hline Michael Jackson & They Don't Care About Us & Spike Lee & 1996 \\
\hline Michael Jackson & Thriller & John Landis & 1983 \\
\hline Michael Jackson & You Are Not Alone & Wayne Isham & 1995 \\
\hline Miley Cyrus & Party In The USA & Chris Applebaum & 2010 \\
\hline Missy Elliott & Lose Control & Julien Temple & 2005 \\
\hline Moby & $\begin{array}{l}\text { Shot In The Back of the } \\
\text { Head }\end{array}$ & David Lynch & 2009 \\
\hline Motels & Only The Lonely & Russel Mulcahy & 1981 \\
\hline Mötley Crüe & Smokin'In The Boys Room & Wayne Isham & 1985 \\
\hline $\begin{array}{ll}\text { My } & \text { Chemical } \\
\text { Romance } & \\
\end{array}$ & Helena & Marc Webb & 2005 \\
\hline $\begin{array}{l}\text { Neil Young and the } \\
\text { Shocking Pinks }\end{array}$ & Cry Cry Cry & Tim Pope & 1983 \\
\hline New Order & Perfect Kiss & Jonathan Demme & 1985 \\
\hline Nine Inch Nails & Closer & Mark Romanek & 1994 \\
\hline Nirvana & Heart-Shaped Box & Anton Corbijn & 1993 \\
\hline Nirvana & Smells Like Teen Spirit & Samuel Bayer & 1991 \\
\hline No Doubt & It's My Life & $\begin{array}{l}\text { Jean-Baptiste } \\
\text { Mondino }\end{array}$ & 2003 \\
\hline 'NSync & Bye Bye Bye & Wayne Isham & 2000 \\
\hline 'NSync & It's Gonna Be Me & Wayne Isham & 2000 \\
\hline 'NSync & Pop & Wayne Isham & 2001 \\
\hline Oasis & All Around the World & $\begin{array}{l}\text { Jonathan Dayton \& } \\
\text { Valerie Faries }\end{array}$ & 1997 \\
\hline Oasis & Morning Glory & Jake Scott & 1995 \\
\hline Oasis & Roll With It & Jon Klein & 1995 \\
\hline OK Go & Here It Goes Again & OK Go & 2006 \\
\hline Ozzy Osbourne & Mama, I'm Coming Home & Samuel Bayer & 1991 \\
\hline
\end{tabular}




\begin{tabular}{|c|c|c|c|}
\hline Pantera & 5 Minutes Alone & Wayne Isham & 1994 \\
\hline Paula Abdul & Forever Your Girl & David Fincher & 1989 \\
\hline Paula Abdul & Rush Rush & George Lucas & 1991 \\
\hline Paula Abdul & Straight Up & David Fincher & 1989 \\
\hline Paul McCartney & C'mon People & Kevin Godley & 1993 \\
\hline Paul Simon & You Can Call Me Al & Gary Weis & 1986 \\
\hline Peter Gabriel & Sledgehammer & Stephen Johnson & 1986 \\
\hline $\begin{array}{l}\text { Pharell Williams } \\
\text { Jay-Z }\end{array}$ & Frontin' & Paul Hunter & 2003 \\
\hline Phil Collins & Dance Into The Light & Kevin Godley & 1996 \\
\hline Phil Collins & You'll Be In My Heart & Kevin Godley & 1989 \\
\hline Pink & So What & Julien Temple & 2009 \\
\hline Pink & Stupid Girl & Julien Temple & 2006 \\
\hline Police & Every Breath You Take & Godley \& Crème & 1983 \\
\hline $\begin{array}{l}\text { Presidents of the } \\
\text { United States }\end{array}$ & Peaches & Roman Coppola & 1996 \\
\hline Prince & Automatic & Bruce Gowers & 1982 \\
\hline Prince & Money Don't Matter 2 Night & Spike Lee & 1992 \\
\hline Prince & Raspberry Beret & Prince & 1985 \\
\hline Prince & Sexuality & Bruce Gowers & 1981 \\
\hline Prince & When Doves Cry & Prince & 1984 \\
\hline Prodigy & Smack My Bitch Up & Jonas Akerlund & 1997 \\
\hline Public Enemy & Fight The Power & Spike Lee & 1989 \\
\hline $\begin{array}{l}\text { Pussycat Dolls e } \\
\text { Busta Rhymes }\end{array}$ & Don't Cha & Paul Hunter & 2005 \\
\hline Queen & Body Language & David Mallet & 1982 \\
\hline Queen & Bohemian Rhapsody & Bruce Gowers & 1975 \\
\hline Queen & Bycicle Race & David Mallet & 1978 \\
\hline Queen & I Want Break Free & Davd Mallet & 1984 \\
\hline Queen & Radio Ga Ga & David Mallet & 1984 \\
\hline Radiohead & Just & Jamie Thraves & 1995 \\
\hline Radiohead & Reckoner & Clement Picon & 2008 \\
\hline $\begin{array}{l}\text { Rage Against the } \\
\text { Machine }\end{array}$ & Sleep Now in the Fire & Michael Moore & 2000 \\
\hline $\begin{array}{l}\text { Red Hot Chili } \\
\text { Peppers }\end{array}$ & Californication & $\begin{array}{l}\text { Jonathan Dayton e } \\
\text { Valerie Faries }\end{array}$ & 2000 \\
\hline $\begin{array}{l}\text { Red Hot Chili } \\
\text { Peppers }\end{array}$ & Can't Stop & Mark Romanek & 2005 \\
\hline $\begin{array}{ll}\text { Red Hot Chili } \\
\text { Peppers }\end{array}$ & My Friends & Anton Corbijn & 1995 \\
\hline $\begin{array}{l}\text { Red Hot Chili } \\
\text { Peppers }\end{array}$ & Otherside & $\begin{array}{l}\text { Jonathan Dayton e } \\
\text { Valerie Faries }\end{array}$ & 2002 \\
\hline $\begin{array}{l}\text { Red Hot Chili } \\
\text { Peppers }\end{array}$ & Under The Bridge & Gus Van Sant & 1992 \\
\hline REM & Imitation of Life & Hammer \& Tones & 2001 \\
\hline REM & Losing My Religion & Tarsen & 1991 \\
\hline Ricky Martin & Livin' La Vida Loca & Wayne Isham & 1999 \\
\hline Rihanna & Umbrella & Chris Applebaum & 2007 \\
\hline Robbie Williams & Lovelight & Jake Nava & 2006 \\
\hline
\end{tabular}




\begin{tabular}{|c|c|c|c|}
\hline Rod Stewart & Baby Jane & Steve Barron & 1983 \\
\hline Rolling Stones & Like a Rolling Stone & Michel Gondry & 1995 \\
\hline Rolling Stones & Love Is Strong & David Fincher & 1994 \\
\hline Rolling Stones & Streets of Love & Jake Nava & 2005 \\
\hline Rolling Stones & Undercover of the Night & Julien Temple & 1983 \\
\hline $\begin{array}{l}\text { Run DMC e } \\
\text { Aerosmith }\end{array}$ & Walk This Way & Jon Small & 1986 \\
\hline Rush & Tom Sawyer & Bruce Gowers & 1981 \\
\hline Sade & Smooth Operator & Julien Temple & 1984 \\
\hline Shakira & La Tortura & Michael Haussmann & 2005 \\
\hline Shakira & She Wolf / Loba & Jake Nava & 2009 \\
\hline Sheryl Crow & All I Wanna Do & Roman Coppola & 1994 \\
\hline Sinéad O'Connor & Nothing Compares U2 & John Mayburry & 1990 \\
\hline $\begin{array}{l}\text { Siouxsie and the } \\
\text { Banshees }\end{array}$ & Dazzle & Tim Pope & 1984 \\
\hline Sisters of Mercy & Under The Gun & Jon Klein & 1993 \\
\hline Smashing Pumpkins & Tonight, Tonight & $\begin{array}{l}\text { Jonathan Dayton \& } \\
\text { Valerie Faries }\end{array}$ & 1996 \\
\hline Snoop Doggy Dogg & Beautiful & Chris Robinson & 2003 \\
\hline Snow Patrol & Open Your Eyes & Robert Hales & 2007 \\
\hline Soft Cell & Tainted Love & Tim Pope & 1981 \\
\hline Sonic Youth & Little Trouble Girl & Mark Romanek & 1996 \\
\hline Spice Girls & Holler & Jake Nava & 2000 \\
\hline Strokes & Last Nite & Roman Coppola & 2001 \\
\hline Suede & Stay Together & Jon Klein & 1994 \\
\hline Supergrass & Pumping On Your Stereo & Hammer \& Tones & 1999 \\
\hline System of a Down & Boom & Michael Moore & 2003 \\
\hline System of a Down & B.Y.O.B. & Jake Nava & 2005 \\
\hline Talking Heads & Love for Sale & $\begin{array}{l}\text { David Byrne e Melvin } \\
\text { Sokolsky }\end{array}$ & 1986 \\
\hline Talking Heads & Road to Nowhere & $\begin{array}{l}\text { David Byrne e } \\
\text { Stephen R. Johnson }\end{array}$ & 1985 \\
\hline Talking Heads & Wild Wild Life & David Byrne & 1986 \\
\hline Tears for Fears & Pale Shelter & Steve Barron & 1983 \\
\hline Tina Turner & Whatever You Need & Jake Nava & 2000 \\
\hline TLC & Unpretty & Paul Hunter & 1999 \\
\hline Toto & Africa & Steve Barron & 1982 \\
\hline Ultravox & The Thin Wall & Russel Mulcahy & 1981 \\
\hline USA for Africa & We Are The World & & 1985 \\
\hline U2 & Electrical Storm & Anton Corbijn & 2002 \\
\hline $\mathrm{U} 2$ & $\begin{array}{l}\text { Hold Me, Thrill Me, Kiss Me, } \\
\text { Kill Me }\end{array}$ & Kevin Godley & 1995 \\
\hline $\mathrm{U} 2$ & Staring At The Sun & Jake Scott & 1997 \\
\hline U2 & The Fly & $\begin{array}{l}\text { Jon Klein e Richie } \\
\text { Smyth }\end{array}$ & 1991 \\
\hline U2 & The Sweetest Thing & Kevin Godley & 1998 \\
\hline U2 e Green Day & The Saints Are Coming & Chris Milk & 2006 \\
\hline Vanessa Hudgens & Come Back To Me & Chris Applebaum & 2007 \\
\hline
\end{tabular}




\begin{tabular}{|l|l|l|l|}
\hline Verve & On Your Own & Jake Scott & 1995 \\
\hline Weezer & $\begin{array}{l}\text { (If You're Wondering If I } \\
\text { Want You To) I Want You } \\
\text { To }\end{array}$ & Marc Webb & 2009 \\
\hline White Stripes & Feel In Love With a Girl & Michel Gondry & 2002 \\
\hline White Stripes & $\begin{array}{l}\text { I Just Don't Know What To } \\
\text { Do With Myself }\end{array}$ & Sofia Coppola & 2003 \\
\hline Whitney Houston & I Have Nothing & S. A. Baron & 1992 \\
\hline Whitney Houston & I Will Always Love You & Alan Smithee & 1992 \\
\hline Will Smith & Party Starter & Paul Hunter & 2005 \\
\hline $\begin{array}{l}\text { Wyclef Jean, John } \\
\text { Forté e Pras }\end{array}$ & We Trying to Stay Alive & Roman Coppola & 1997 \\
\hline ZZ Top & Sharp Dressed Man & Tim Newman & 1983 \\
\hline
\end{tabular}

Videoclipes Nacionais

\begin{tabular}{|c|c|c|c|}
\hline INTÉRPRETE & MÚSICA & DIRETOR & ANO \\
\hline Adriana Calcanhoto & Devolva-me & $\begin{array}{lr}\text { Palito, } & \text { Suzana } \\
\text { Moraes } & \text { e } \\
\text { Ferreiririo }\end{array}$ & 2000 \\
\hline Afroreggae & Capa de Revista & Lírio Ferreira & 2001 \\
\hline Ana Carolina & Garganta & Mini Kerti & 1999 \\
\hline Ana Carolina & Quem de Nós Dois & Lírio Ferreira & 2001 \\
\hline Angélica & Vou de Táxi & Paulo Trevisan & 1988 \\
\hline Arnaldo Antunes & Consumado & Monique Gardenberg & 2004 \\
\hline Arnaldo Antunes & Essa Mulher & Laís Bodanzky & 2002 \\
\hline Arnaldo Antunes & Música Para Ouvir & $\begin{array}{l}\text { Andrucha } \\
\text { Waddington e Toni } \\
\text { Vanzolini }\end{array}$ & 1999 \\
\hline Arnaldo Antunes & O Silêncio & Tadeu Jungle & 1996 \\
\hline Autoramas & Você Sabe & Luis Carone & 2005 \\
\hline Baby Consuelo & Menino do Rio & & 1980 \\
\hline Banda Eva & Carro Velho & Monique Gardenberg & 1999 \\
\hline Barão Vermelho & Amor, Meu Grande Amor & Monique Gardenberg & 1996 \\
\hline Barão Vermelho & Baby Suporte & Herbert Richers Jr. & 1983 \\
\hline Barão Vermelho & Bete Balanço & & 1984 \\
\hline Barão Vermelho & Contravenção & Ana Arantes & 1987 \\
\hline Barão Vermelho & O Poeta Está Vivo & Arthur Fontes & 1990 \\
\hline Barão Vermelho & Pedra, Flor e Espinho & Murilo Salles & 1992 \\
\hline Barão Vermelho & Política Voz & Boninho & 1990 \\
\hline Barão Vermelho & Pro Dia Nascer Feliz & José Emilio Rondeau & 1984 \\
\hline Barão Vermelho & $\begin{array}{l}\text { Vem Quente Que Eu Estou } \\
\text { Fervendo }\end{array}$ & Gringo Cardia & 1996 \\
\hline Batakotô & Quitambô & $\begin{array}{ll}\text { Oscar } & \text { Rodrigues } \\
\text { Alves } & \\
\end{array}$ & 1992 \\
\hline Bidê ou Balde & Melissa & Mauricio Eça & 2001 \\
\hline Biquini Cavadão & Múmias & Jodele Larcher & 1985 \\
\hline Biquini Cavadão & No Mundo da Lua & Billy Bond & 1985 \\
\hline
\end{tabular}




\begin{tabular}{|c|c|c|c|}
\hline Biquini Cavadão & Tédio & Billy Bond & 1985 \\
\hline Biquini Cavadão & Timidez & Malu di Martino & 1985 \\
\hline Blitz & A Dois Passos do Paraíso & Eid Walesko & 1984 \\
\hline Blitz & Dali de Salvador & Paulo Trevisan & 1984 \\
\hline Blitz & $\begin{array}{l}\text { Mais Uma de Amor (Geme } \\
\text { Geme) }\end{array}$ & & 1982 \\
\hline Blitz & Você Não Soube Me Amar & Eid Walesko & 1982 \\
\hline Blitz & Você Não Soube Me Amar & Murilo Salles & 1984 \\
\hline Brylho & Noite do Prazer & José Mario & 1983 \\
\hline Caetano Veloso & Fora da Ordem & $\begin{array}{l}\text { José } \quad \text { Henrique } \\
\text { Fonseca e Andrucha } \\
\text { Waddington }\end{array}$ & 1993 \\
\hline $\begin{array}{l}\text { Caetano Veloso e } \\
\text { Gilberto Gil }\end{array}$ & Haiti & $\begin{array}{l}\text { Cláudio Torres e Lula } \\
\text { Buarque }\end{array}$ & 1993 \\
\hline Caetano Veloso & Não Enche & Monique Gardenberg & 1998 \\
\hline Caetano Veloso & O Estrangeiro & Caetano Veloso & 1989 \\
\hline $\begin{array}{l}\text { Caetano Veloso e } \\
\text { Jorge Mautner }\end{array}$ & Todo Errado & Mauro Lima & 2002 \\
\hline Cansei de Ser Sexy & Music Is My Hot Hot Sex & & 2008 \\
\hline Capital Inicial & Como Devia Estar & Hugo Prata & 2003 \\
\hline Capital Inicial & Todos os Lados & & 1990 \\
\hline Carlinhos Brown & A Namorada & $\begin{array}{ll}\text { José } & \text { Henrique } \\
\text { Fonseca } & \\
\end{array}$ & 1997 \\
\hline Cássia Eller & Malandragem & $\begin{array}{lr}\text { José } & \text { Henrique } \\
\text { Fonseca e } & \text { Izabel } \\
\text { Jaguaribe } & \\
\end{array}$ & 1994 \\
\hline Cássia Eller & No Recreio & $\begin{array}{l}\text { Mari Stockler e Fábio } \\
\text { Soares }\end{array}$ & 2002 \\
\hline $\begin{array}{lll}\text { Cássia } & \text { Eller } & \text { e } \\
\text { Herbert Vianna } & \end{array}$ & Mr. Scarecrow & $\begin{array}{l}\text { Andrucha } \\
\text { Waddington e Toni } \\
\text { Vanzolini }\end{array}$ & 2000 \\
\hline Cazuza & Burguesia & Ana Arantes & 1989 \\
\hline Cazuza & Faz Parte do Meu Show & Boninho & 1988 \\
\hline Cazuza & Ideologia & Ana Arantes & 1988 \\
\hline Charlie Brown Jr. & O Coro Vai Comê! & Mari Stockler & 1997 \\
\hline Charlie Brown Jr. & Tamo Aí Na Atividade & Johnny Araújo & 2004 \\
\hline Charlie Brown Jr. & Zóio de Lula & Johnny Araújo & 1999 \\
\hline Chico Buarque & Carioca & $\begin{array}{lr}\text { José } & \text { Henrique } \\
\text { Fonseca, } & \text { Arthur } \\
\text { Fontes e } & \text { Fábio } \\
\text { Soares } & \\
\end{array}$ & 1999 \\
\hline Chico César & Pensar em Você & Lírio Ferreira & 2000 \\
\hline $\begin{array}{l}\text { Chico Science \& } \\
\text { Nação Zumbi }\end{array}$ & A Cidade & Guilherme Ramalho & 1994 \\
\hline $\begin{array}{l}\text { Chico Science \& } \\
\text { Nação Zumbi }\end{array}$ & Macô & & 1996 \\
\hline $\begin{array}{l}\text { Chico Science \& } \\
\text { Nação Zumbi }\end{array}$ & Manguetown & Gringo Cardia & 1996 \\
\hline Chico Science & Maracatu Atômico & Raul Machado & 1996 \\
\hline
\end{tabular}




\begin{tabular}{|c|c|c|c|}
\hline Nação Zumbi & & & \\
\hline $\begin{array}{l}\text { Chico Science \& } \\
\text { Nação Zumbi }\end{array}$ & Sangue de Bairro & $\begin{array}{l}\text { Lírio Ferreira e Paulo } \\
\text { Caldas }\end{array}$ & 1996 \\
\hline Chitãozinho \& Xororó & Ela Chora Chora & & 1990 \\
\hline Cidade Negra & Falar a Verdade & Ricardo Van Steen & 1990 \\
\hline Cidade Negra & Firmamento & Mari Stockler & 1996 \\
\hline Cidade Negra & Realidade Virtual & $\begin{array}{l}\text { Oscar Rodrigues } \\
\text { Alves }\end{array}$ & 1997 \\
\hline Cláudio Zoli & A Noite do Prazer & Mauricio Eça & 2001 \\
\hline Clementina de Jesus & Marinheiro Só & Cyro Del Nero & $s / d$ \\
\hline CPM 22 & Apostas e Certezas & Raul Machado & 2005 \\
\hline CPM 22 & Regina Let's Go & $\begin{array}{l}\text { Mauricio Eça e Felipe } \\
\text { Segall }\end{array}$ & 2001 \\
\hline CPM 22 & $\begin{array}{l}\text { Um Minuto Para o Fim do } \\
\text { Mundo }\end{array}$ & Johnny Araújo & 2005 \\
\hline Daniela Mercury & Ilê Pérola Negra & & 2000 \\
\hline Daniela Mercury & Nobre Vagabundo & Gringo Cardia & 1997 \\
\hline Daniela Mercury & O Canto da Cidade & Patricia Prata & 1992 \\
\hline Djavan & Acelerou & $\begin{array}{ll}\text { Oscar } & \text { Rodrigues } \\
\text { Alves } & \\
\end{array}$ & 1999 \\
\hline Djavan & Oceano & & 1989 \\
\hline Djavan & Samurai & José Mario & 1982 \\
\hline Dominó & Maria & Boninho & 1990 \\
\hline Dulce Quental & Délica & Roberto Berliner & 1985 \\
\hline Dulce Quental & Natureza Humana & Paulo Trevisan & 1986 \\
\hline $\begin{array}{l}\text { Ed Motta e Conexão } \\
\text { Japeri }\end{array}$ & Manuel & Sandra Kogut & 1988 \\
\hline Edson Cordeiro & $\begin{array}{llll}\text { Don't } & \text { Let } & \text { Me } & \text { Be } \\
\text { Misunderstood } & & \\
\end{array}$ & Ivy Abujamra & 2000 \\
\hline $\begin{array}{l}\text { Engenheiros do } \\
\text { Hawaii }\end{array}$ & Sopa de Letrinhas & & 1986 \\
\hline $\begin{array}{l}\text { Engenheiros do } \\
\text { Hawaii }\end{array}$ & Toda Forma de Poder & & 1986 \\
\hline $\begin{array}{ll}\text { Erasmo Carlos } & \mathrm{e} \\
\text { Paulo Ricardo } & \\
\end{array}$ & Eu Sou Terrível & Paulo Trevisan & 1989 \\
\hline Facção Central & Isso Aqui É Uma Guerra & Bruno Dragone & 1999 \\
\hline Fafá de Belém & Pra Não Mais Voltar & & 1986 \\
\hline Fagner & Canteiros & José Mario & $s / d$ \\
\hline Fagner & Deslizes & Paulo Trevisan & 1987 \\
\hline Falamansa & $\begin{array}{l}\text { Rindo A Toa / Xote dos } \\
\text { Milagres }\end{array}$ & João Elias Junior & 2000 \\
\hline Fausto Fawcett & Drops de Istambul & Roberto Berliner & 1986 \\
\hline Fausto Fawcett & Kátia Flávia & $\begin{array}{l}\text { Roberto Berliner e } \\
\text { Sandra Kogut }\end{array}$ & 1987 \\
\hline Fernanda Abreu & $\begin{array}{l}\text { Kátia Flávia, a Godiva do } \\
\text { Irajá }\end{array}$ & Luiz Stein & 1997 \\
\hline Fernanda Abreu & $\begin{array}{l}\text { SLA Radical Dance Disco } \\
\text { Club }\end{array}$ & Luiz Stein & 1990 \\
\hline Fernanda Takai & Kobune & Giuliano Chiarada e & 2007 \\
\hline
\end{tabular}




\begin{tabular}{|c|c|c|c|}
\hline & & Paula Padilha & \\
\hline Forgotten Boys & Não Vou Ficar & Raul Machado & 2005 \\
\hline Frejat & Amor Pra Recomeçar & $\begin{array}{ll}\text { Oscar } & \text { Rodrigues } \\
\text { Alves } & \end{array}$ & 2001 \\
\hline Gabriel O Pensador & Até Quando? & $\begin{array}{ll}\text { Oscar } & \text { Rodrigues } \\
\text { Alves } & \end{array}$ & 2001 \\
\hline Gabriel O Pensador & Palavras Repetidas & $\begin{array}{l}\text { Oscar Rodrigues } \\
\text { Alves }\end{array}$ & 2005 \\
\hline Gal Costa & Chuva de Prata & Paulo Trevisan & 1984 \\
\hline Gal Costa & Modinha Para Gabriela & & 1975 \\
\hline Gilberto Gil & Esperando na Janela & & 2000 \\
\hline Gilberto Gil & Kaya N'Gandaya & Lula Buarque & 2002 \\
\hline Guilherme Arantes & Ouro & Paulo Trevisan & 1987 \\
\hline Herva Doce & Amante Profissional & Paulo Trevisan & 1985 \\
\hline Ivan Lins & Madalena & Cyro Del Nero & $s / d$ \\
\hline João Marcelo Bóscoli & Flor do Futuro & $\begin{array}{l}\text { Oscar } \quad \text { Rodrigues } \\
\text { Alves }\end{array}$ & 1995 \\
\hline Jota Quest & Dias Melhores & Pietro Sargentelli & 2000 \\
\hline Jota Quest & $\begin{array}{l}\text { O Que Eu Também Não } \\
\text { Entendo }\end{array}$ & Pietro Sargentelli & 2001 \\
\hline Jota Quest & Só Hoje & Pietro Sargentelli & 2002 \\
\hline Jumbo Elektro & $\begin{array}{l}\text { Fresh Fruit For Rocking } \\
\text { Vegetables }\end{array}$ & Luis Carone & 2004 \\
\hline Karnak & Alma Não Tem Cor & Hugo Prata & 1997 \\
\hline Kid Abelha & Como Eu Quero & José Emilio Rondeau & 1984 \\
\hline Kid Abelha & Eu Não Esqueço Nada & Lírio Ferreira & 2001 \\
\hline Kid Abelha & Grand'Hotel & Lui Farias & 1990 \\
\hline Kid Abelha & $\begin{array}{l}\mathrm{Na} \text { Rua, Na Chuva, Na } \\
\text { Fazenda }\end{array}$ & Luiz Stein & 1993 \\
\hline Kid Abelha & No Seu Lugar & Lui Farias & 1990 \\
\hline Kid Abelha & Seu Espião & José Emilio Rondeau & 1984 \\
\hline KLB & Ela Não Está Aqui & $\begin{array}{lrl}\text { Adrian } & \text { Teijido } & \mathrm{e} \\
\text { Pietro Sargentelli } & \end{array}$ & 2001 \\
\hline Kodiak Bachine & Eletricidade & $\begin{array}{l}\text { Alfred Nagib e Jayme } \\
\text { Rocco Junior }\end{array}$ & 1984 \\
\hline Leandro \& Leonardo & Talismã & & 1990 \\
\hline Legião Urbana & Perfeição & & 1990 \\
\hline Legião Urbana & Que País É Este & Jodele Larcher & 1987 \\
\hline Legião Urbana & Será & Olhar Eletrônico & 1985 \\
\hline Legião Urbana & Tempo Perdido & José Emilio Rondeau & 1986 \\
\hline $\begin{array}{l}\text { Leila Pinheiro e } \\
\text { Roberto Menescal }\end{array}$ & Benção Bossa Nova & Malu di Martino & 1989 \\
\hline Lenine & Paciência & Hugo Prata & 2000 \\
\hline Leo Jaime & Nada Mudou & Boninho & 1986 \\
\hline Leo Jaime & O Pobre & Boninho & 1985 \\
\hline 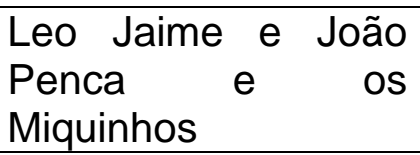 & Conquistador Barato & & 1987 \\
\hline
\end{tabular}




\begin{tabular}{|c|c|c|c|}
\hline Amestrados & & & \\
\hline Lobão & Cena de Cinema & José Emilio Rondeau & 1982 \\
\hline Lobão & $\begin{array}{l}\text { Matou a Família e Foi ao } \\
\text { Cinema }\end{array}$ & & 1990 \\
\hline Lobão & Me Beija & Roberto Berliner & 1998 \\
\hline Lulu Santos & Já É & $\begin{array}{l}\text { Andrucha } \\
\text { Waddington e Mini } \\
\text { Kerti }\end{array}$ & 2004 \\
\hline Lulu Santos & Todo Universo & Jarbas Agnelli & 2002 \\
\hline Magazine & Sou Boy & & 1983 \\
\hline Marcelo D2 & Dor de Verdade & Johnny Araújo & 2007 \\
\hline Marcelo D2 & Loadeando & Johnny Araújo & 2004 \\
\hline Marcelo D2 & 1967 & Raul Machado & 1998 \\
\hline Marcelo D2 & Qual É? & Johnny Araújo & 2003 \\
\hline Marcelo D2 & Samba de Primeira & Raul Machado & 1998 \\
\hline Marina Lima & Beija-Flor & $\begin{array}{l}\text { Andrucha } \\
\text { Waddington }\end{array}$ & 1995 \\
\hline Marina Lima & Fullgás & Billy Bond & 1984 \\
\hline Marina Lima & Garota de Ipanema & Jon Klein & 1990 \\
\hline Marisa Monte & Amor I Love You & $\begin{array}{l}\text { Breno Silveira e Lula } \\
\text { Buarque }\end{array}$ & 2000 \\
\hline Marisa Monte & Beija Eu & & 1992 \\
\hline Marisa Monte & Diariamente & Guilherme Ramalho & 1992 \\
\hline Marisa Monte & Gentileza & $\begin{array}{l}\text { André Horta e Lula } \\
\text { Buarque }\end{array}$ & 2000 \\
\hline Marisa Monte & O Que Me Importa & $\begin{array}{l}\text { Claudio Torres, } \\
\text { Sergio Meckler e } \\
\text { Vicente Kubrusly }\end{array}$ & 2000 \\
\hline Marisa Monte & Segue o Seco & $\begin{array}{lc}\text { Claudio } & \text { Torres e } \\
\text { José } & \text { Henrique } \\
\text { Fonseca } & \end{array}$ & 1994 \\
\hline Marisa Monte & Vilarejo & $\begin{array}{l}\text { Andrucha } \\
\text { Waddington, Paulo } \\
\text { de Barros e Ricardo } \\
\text { Della Rosa }\end{array}$ & 2006 \\
\hline Max de Castro & Onda Diferente & Carolina Jabor & 2001 \\
\hline Metrô & $\mathrm{TiTi} \mathrm{Ti}$ & Paulo Trevisan & 1985 \\
\hline Milton Nascimento & Portal da Cor & José Mario & 1985 \\
\hline Mister-M & Inquérito & Vras 77 & 2010 \\
\hline MV Bill & A Noite & $\begin{array}{l}\text { Rafael Dragaud, Mini } \\
\text { Kerti e Carolina Jabor }\end{array}$ & 1999 \\
\hline MV Bill & Traficando Informação & Kátia Lund & 1992 \\
\hline Nação Zumbi & Malungo & Raul Machado & 1998 \\
\hline Nando Reis & Dentro do Mesmo Time & $\begin{array}{l}\text { Toni Vanzolini } \mathrm{e} \\
\text { Carolina Jabor }\end{array}$ & 2003 \\
\hline Nenhum de Nós & Ao Meu Redor & & 1992 \\
\hline Neuzinha Brizola & Mintchura & Eid Walesko & 1983 \\
\hline Ney Matogrosso & América do Sul & Nilton Travesso & 1975 \\
\hline Nirvana & You Know You're Right & Marcos Siega & 2002 \\
\hline
\end{tabular}




\begin{tabular}{|c|c|c|c|}
\hline Olivia Hime & Cartão-Postal & Herbert Richers Jr. & 1984 \\
\hline O Rappa & $\begin{array}{l}\text { A Minha Alma (A Paz Que } \\
\text { Eu Não Quero) }\end{array}$ & $\begin{array}{l}\text { Kátia Lund, Breno } \\
\text { Silveira e Paulo Lins }\end{array}$ & 2000 \\
\hline O Rappa & Instinto Coletivo & Jarbas Agnelli & 2002 \\
\hline O Rappa & O Que Sobrou do Céu & $\begin{array}{l}\text { André Horta e Kátia } \\
\text { Lund }\end{array}$ & 2001 \\
\hline O Rappa & O Salto & $\begin{array}{l}\text { Bruno Murtinho e } \\
\text { Sérgio Schmid }\end{array}$ & 2004 \\
\hline Otto & Pelo Engarrafamento & $\begin{array}{l}\text { Lírio Ferreira e Sérgio } \\
\text { Oliveira }\end{array}$ & 2001 \\
\hline $\begin{array}{l}\text { Paralamas do } \\
\text { Sucesso }\end{array}$ & Alagados & Roberto Berliner & 1986 \\
\hline $\begin{array}{l}\text { Paralamas do } \\
\text { Sucesso }\end{array}$ & A Lhe Esperar & $\begin{array}{l}\text { Eduardo Souza e } \\
\text { Rodrigo Lima }\end{array}$ & 2009 \\
\hline $\begin{array}{l}\text { Paralamas } \\
\text { Sucesso }\end{array}$ & A Novidade & $\begin{array}{l}\text { Roberto Berliner e } \\
\text { Sandra Kogut }\end{array}$ & 1986 \\
\hline $\begin{array}{l}\text { Paralamas } \\
\text { Sucesso }\end{array}$ & Aonde Quer Que Eu Vá & $\begin{array}{l}\text { Andrucha } \\
\text { Waddington e Gualter } \\
\text { Pupo }\end{array}$ & 2000 \\
\hline $\begin{array}{l}\text { Paralamas } \\
\text { Sucesso }\end{array}$ & Busca Vida & $\begin{array}{l}\text { Andrucha } \\
\text { Waddington e Breno } \\
\text { Silveira }\end{array}$ & 1997 \\
\hline $\begin{array}{l}\text { Paralamas } \\
\text { Sucesso }\end{array}$ & De Perto & $\begin{array}{l}\text { Roberto Berliner e } \\
\text { Leo Domingues }\end{array}$ & 2003 \\
\hline $\begin{array}{l}\text { Paralamas } \\
\text { Sucesso }\end{array}$ & Depois da Queda O Coice & $\begin{array}{lr}\text { Andrucha } & \\
\text { Waddington, } & \text { Breno } \\
\text { Silveira e } \\
\text { Vanzolini }\end{array}$ & 1999 \\
\hline $\begin{array}{l}\text { Paralamas } \\
\text { Sucesso }\end{array}$ & Ela Disse Adeus & $\begin{array}{l}\text { Breno Silveira, Toni } \\
\text { Vanzolini e Andrucha } \\
\text { Waddinaton }\end{array}$ & 1998 \\
\hline $\begin{array}{l}\text { Paralamas } \\
\text { Sucesso }\end{array}$ & Essa Tarde & Roberto Berliner & 1996 \\
\hline $\begin{array}{l}\text { Paralamas } \\
\text { Sucesso }\end{array}$ & Lanterna dos Afogados & Roberto Berliner & 2003 \\
\hline $\begin{array}{l}\text { Paralamas } \\
\text { Sucesso }\end{array}$ & Lourinha Bombril & $\begin{array}{ll}\text { Andrucha } & \\
\text { Waddington, } & \text { Breno } \\
\text { Silveira e } & \text { Toni } \\
\text { Vanzolini } & \\
\end{array}$ & 1996 \\
\hline $\begin{array}{l}\text { Paralamas } \\
\text { Sucesso }\end{array}$ & Melô do Marinheiro & Maurício Tavares & 1986 \\
\hline $\begin{array}{l}\text { Paralamas } \\
\text { Sucesso }\end{array}$ & Meu Erro & Jodele Larcher & 1984 \\
\hline $\begin{array}{l}\text { Paralamas } \\
\text { Sucesso }\end{array}$ & Na Pista & & 2005 \\
\hline $\begin{array}{l}\text { Paralamas } \\
\text { Sucesso }\end{array}$ & Pólvora & Hugo Prata & 1990 \\
\hline $\begin{array}{l}\text { Paralamas } \\
\text { Sucesso }\end{array}$ & Seguindo Estrelas & $\begin{array}{l}\text { Andrucha } \\
\text { Waddington e Breno }\end{array}$ & 2002 \\
\hline
\end{tabular}




\begin{tabular}{|c|c|c|c|}
\hline & & Silveira & \\
\hline $\begin{array}{ll}\text { Paralamas } & \text { do } \\
\text { Sucesso } & \end{array}$ & Sossego & Roberto Berliner & 1999 \\
\hline $\begin{array}{l}\begin{array}{l}\text { Paralamas } \\
\text { Sucesso }\end{array} \\
\end{array}$ & Tendo a Lua & Roberto Berliner & 1991 \\
\hline $\begin{array}{ll}\text { Paralamas } & \text { do } \\
\text { Sucesso } & \end{array}$ & Trac Trac & $\begin{array}{l}\text { Roberto Berliner e } \\
\text { Gringo Cardia }\end{array}$ & 1991 \\
\hline $\begin{array}{l}\text { Paralamas } \\
\text { Sucesso }\end{array}$ & Uma Brasileira & $\begin{array}{l}\text { Andrucha } \\
\text { Waddington }\end{array}$ & 1995 \\
\hline $\begin{array}{ll}\text { Paralamas } & \text { do } \\
\text { Sucesso } & \end{array}$ & Vital e Sua Moto & 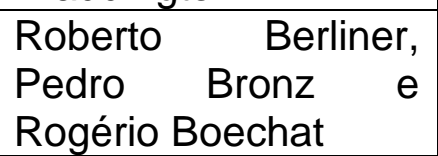 & 2003 \\
\hline $\begin{array}{l}\text { Paralamas } \\
\text { Sucesso }\end{array}$ & Você & Maurício Tavares & 1986 \\
\hline Pato Fu & Anormal & Jarbas Agnelli & 2007 \\
\hline Pato Fu & Eu & Luis Ferre & 2001 \\
\hline Pato Fu & Eu Sei & Hugo Prata & 1997 \\
\hline Pato Fu & $\begin{array}{l}\text { O Processo da Criação Vai } \\
\text { de } 10 \text { Até } 100\end{array}$ & & 1993 \\
\hline Pato Fu & Made in Japan & Jarbas Agnelli & 1999 \\
\hline Pato Fu & Pinga & $\begin{array}{l}\text { Claudio Torres, José } \\
\text { Henrique Fonseca e } \\
\text { Ralph Strelow }\end{array}$ & 1999 \\
\hline Pato Fu & Qualquer Bobagem & $\begin{array}{l}\text { Eduardo } \\
\text { Climachavska }\end{array}$ & 1994 \\
\hline Pato Fu & Sobre o Tempo & $\begin{array}{l}\text { Eduardo de Jesus e } \\
\text { Rodolfo Magalhães }\end{array}$ & 1994 \\
\hline Pato Fu & Sorte e Azar & $\begin{array}{l}\text { Roberto Berliner e } \\
\text { Duda Pessoa }\end{array}$ & 2005 \\
\hline Pato Fu & Uh Uh Uh La La La La lé lé! & Laerte & 2007 \\
\hline Paula Lima & Quero Ver Você no Baile & $\begin{array}{ll}\text { Mari Stockler } & \text { e } \\
\text { Karina Ades } & \end{array}$ & 2001 \\
\hline $\begin{array}{l}\text { Pedro Luís e } \\
\text { Parede }\end{array}$ & Caio no Suingue & Roberto Berliner & 2004 \\
\hline $\begin{array}{l}\text { Pedro Luís e a } \\
\text { Parede }\end{array}$ & Rap do Real & Roberto Berliner & 2004 \\
\hline Picassos Falsos & Carne e Osso & José Emilio Rondeau & 1987 \\
\hline Pitty & Admirável Chip Novo & Mauricio Eça & 2003 \\
\hline Pitty & Déjà Vu & Ricardo Spencer & 2006 \\
\hline Pitty & De Você & André Moraes & 2008 \\
\hline Pitty & Fracasso & $\begin{array}{l}\text { Oscar } \quad \text { Rodrigues } \\
\text { Alves }\end{array}$ & 2010 \\
\hline Pitty & Máscara & Mauricio Eça & 2003 \\
\hline Pitty & Me Adora & Ricardo Spencer & 2009 \\
\hline Pitty & Memórias & $\begin{array}{l}\text { Ricardo Spencer e } \\
\text { Alexandre Guena }\end{array}$ & 2005 \\
\hline Pitty & Na Sua Estante & $\begin{array}{lr}\text { Sérgio } & \text { Guilherme } \\
\text { Filho } \\
\text { Galvani }\end{array}$ & 2006 \\
\hline
\end{tabular}




\begin{tabular}{|c|c|c|c|}
\hline Pitty & Semana Que Vem & $\begin{array}{l}\text { Mauricio Eça, Sérgio } \\
\text { Mastrocola e Pablo } \\
\text { Nobel }\end{array}$ & 2003 \\
\hline Pitty & Teto de Vidro & Mauricio Eça & 2003 \\
\hline Planet Hemp & Dig Dig Dig (Hempa) & Raul Machado & 1995 \\
\hline Planet Hemp & Ex-Quadrilha da Fumaça & $\begin{array}{l}\text { Raul Machado, Kátia } \\
\text { Lund e Eduardo Kurt }\end{array}$ & 2000 \\
\hline Planet Hemp & Legalize Já & Márcia Leite & 1995 \\
\hline Planet Hemp & Queimando Tudo & Raul Machado & 1997 \\
\hline Racionais MC's & Diário de Um Detento & $\begin{array}{lr}\text { Mauricio Eça } & \text { e } \\
\text { Marcelo Corpani }\end{array}$ & 1998 \\
\hline Raimundos & A Mais Pedida & $\begin{array}{ll}\text { José } & \text { Eduardo } \\
\text { Belmonte } & \\
\end{array}$ & 1999 \\
\hline Raimundos & Eu Quero Ver o Oco & Raul Machado & 1995 \\
\hline Raimundos & Me Lambe & J.R. Duran & 1999 \\
\hline Raimundos & Mulher de Fases & $\begin{array}{ll}\text { José } & \text { Eduardo } \\
\text { Belmonte } & \\
\end{array}$ & 1999 \\
\hline Raul Seixas & Gita & Cyro Del Nero & 1974 \\
\hline Renato Russo & Strani Amori & Mari Stockler & 1995 \\
\hline Rita Lee & Ovelha Negra & Nilton Travesso & 1975 \\
\hline $\begin{array}{l}\text { Rita Lee e Roberto } \\
\text { de Carvalho }\end{array}$ & Desculpe o Auê & Eid Walesko & 1983 \\
\hline $\begin{array}{l}\text { Rita Lee e Roberto } \\
\text { de Carvalho }\end{array}$ & $\mathrm{TiTi} \mathrm{Ti}$ & Roberto de Carvalho & 2010 \\
\hline $\begin{array}{l}\text { Rita Lee e Roberto } \\
\text { de Carvalho }\end{array}$ & Vírus do Amor & Herbert Richers Jr. & 1985 \\
\hline Ritchie & A Mulher Invisível & Eid Walesko & 1984 \\
\hline Roberto Carlos & Caminhoneiro & Paulo Trevisan & 1984 \\
\hline Roberto Carlos & $\begin{array}{l}\text { Eu Te Amo, Te Amo, Te } \\
\text { Amo }\end{array}$ & $\begin{array}{lr}\text { Mauricio Eça, } & \text { Felippe } \\
\text { Segall, } & \text { Kelly } \\
\text { Marciano, } & \text { Max } \\
\text { Pochon, Zér Bob } & \text { Eliezer e F. Sommer } \\
\end{array}$ & 2001 \\
\hline Roberto Carlos & Todos Estão Surdos & MTV Brasil & 2001 \\
\hline Rosana & O Amor e o Poder & José Mario & 1987 \\
\hline RPM & Alvorada Voraz & Paulo Trevisan & 1986 \\
\hline RPM & Louras Geladas & Eduardo Leite & 1985 \\
\hline Sandy \& Junior & Enrosca & Hugo Prata & 2000 \\
\hline $\begin{array}{l}\text { Sá, Rodrix } \\
\text { Guarabyra }\end{array}$ & Voar é Como o Passarinho & Cyro Del Nero & $\mathrm{s} / \mathrm{d}$ \\
\hline Sepultura & Bullet the Blue Sky & $\begin{array}{l}\text { Ricardo Della Rosa e } \\
\text { Larissa Bogan }\end{array}$ & 2003 \\
\hline Sepultura & Convicted in Life & Luis Carone & 2006 \\
\hline Sepultura & Mind War & $\begin{array}{l}\text { Ricardo Della Rosa e } \\
\text { Larissa Bogan }\end{array}$ & 2003 \\
\hline Sepultura & Orgasmatron & Adriano Goldman & 1991 \\
\hline Sepultura & Roots Bloody Roots & Thomas Mignone & 1996 \\
\hline Sepultura & Territory & & 1994 \\
\hline Sidney Magal & Sandra Rosa Madalena & Nilton Travesso & 1978 \\
\hline
\end{tabular}




\begin{tabular}{|c|c|c|c|}
\hline Skank & A Cerca & Gringo Cardia & 1994 \\
\hline Skank & Ainda Gosto Dela & Hugo Prata & 2008 \\
\hline Skank & Dois Rios & $\begin{array}{lr}\text { Oscar } & \text { Rodrigues } \\
\text { Alves e Nando Cohen }\end{array}$ & 2003 \\
\hline Skank & Ela Desapareceu & Mari Stockler & 2000 \\
\hline Skank & É Proibido Fumar & $\begin{array}{l}\text { Andrucha } \\
\text { Waddington }\end{array}$ & 1994 \\
\hline Skank & É Uma Partida de Futebol & Roberto Berliner & 1997 \\
\hline Skank & Garota Nacional & $\begin{array}{l}\text { Andrucha } \\
\text { Waddington e Arthur } \\
\text { Fontes }\end{array}$ & 1996 \\
\hline Skank & Mandrake e os Cubanos & Roberto Berliner & 1999 \\
\hline Skank & Resposta & $\begin{array}{l}\text { Lula Buarque e } \\
\text { Arthur Fontes }\end{array}$ & 1998 \\
\hline Skank & Saideira & $\begin{array}{l}\text { Roberto Berliner e } \\
\text { Raul Mourão }\end{array}$ & 1999 \\
\hline Skank & Sutilmente & Conrado Almada & 2009 \\
\hline Skank & Três Lados & Roberto Berliner & 2000 \\
\hline Skank & Vou Deixar & $\begin{array}{l}\text { Oscar Rodrigues } \\
\text { Alves }\end{array}$ & 2004 \\
\hline Skowa e a Máfia & $\begin{array}{l}\text { Automóveis (Atropelamento } \\
\text { e Fuga) }\end{array}$ & Skowa e a Máfia & 1989 \\
\hline Stephany & $\begin{array}{l}\text { Eu Sou Stephany (No Meu } \\
\text { Cross Fox) }\end{array}$ & Stephany & 2009 \\
\hline Supla & Garota de Berlim & Mauricio Eça & 2001 \\
\hline Tiề & Sweet Jardim & & 2009 \\
\hline Titãs & A Estrada & Branco Mello & 2009 \\
\hline Titãs & Antes de Você & $\begin{array}{ll}\text { Oscar } & \text { Rodrigues } \\
\text { Alves } & \end{array}$ & 2009 \\
\hline Titãs & Cabeça Dinossauro & Branco Mello & 1986 \\
\hline Titãs & Comida & Paulo Trevisan & 1989 \\
\hline Titãs & Epitáfio & $\begin{array}{lr}\text { Oscar } & \text { Rodrigues } \\
\text { Alves e Francisco } \\
\text { Rodrigues Alves }\end{array}$ & 2001 \\
\hline Titãs & Eu Não Aguento & $\begin{array}{l}\text { Andrucha } \\
\text { Waddington }\end{array}$ & 1996 \\
\hline Titãs & Flores & $\begin{array}{ll}\text { Jodele Larcher e } \\
\text { Gringo Cardia }\end{array}$ & 1989 \\
\hline Titãs & Go Back & $\begin{array}{l}\text { Jodele Larcher e } \\
\text { Branco Mello }\end{array}$ & 1988 \\
\hline Titãs & Deus e o Diabo & Jodele Larcher & 1990 \\
\hline Titãs & Enquanto Houver Sol & $\begin{array}{ll}\text { Oscar } & \text { Rodrigues } \\
\text { Alves } & \\
\end{array}$ & 2003 \\
\hline Titãs & Eu Não Sou Um Bom Lugar & $\begin{array}{ll}\text { Oscar } & \text { Rodrigues } \\
\text { Alves } & \\
\end{array}$ & 2003 \\
\hline Titãs & Homem Primata & & 1986 \\
\hline Titãs & Insensível & $\begin{array}{l}\text { Renato Assaf Filho e } \\
\text { Eduardo Leite }\end{array}$ & 1985 \\
\hline Titãs & Isso & Oscar $\quad$ Rodrigues & 2001 \\
\hline
\end{tabular}




\begin{tabular}{|c|c|c|c|}
\hline & & Alves & \\
\hline Titãs & Lugar Nenhum & & 1989 \\
\hline Titãs & Massacre & Branco Mello & 1989 \\
\hline Titãs & $\begin{array}{l}\text { Nem Sempre Se Pode Ser } \\
\text { Deus }\end{array}$ & $\begin{array}{l}\text { Beto Brant e Ralph } \\
\text { Strelow }\end{array}$ & 1993 \\
\hline Titãs & Nome aos Bois & Branco Mello & 1989 \\
\hline Titãs & Por Que Eu Sei Que é Amor & $\begin{array}{l}\text { Branco Mello e Diana } \\
\text { Bouth }\end{array}$ & 2009 \\
\hline Titãs & Provas de Amor & $\begin{array}{ll}\text { Oscar } & \text { Rodrigues } \\
\text { Alves } & \end{array}$ & 2004 \\
\hline Titãs & Saia de Mim & & 1991 \\
\hline Titãs & $\begin{array}{l}\text { Será Que É Isso Que Eu } \\
\text { Necessito }\end{array}$ & $\begin{array}{l}\text { Beto Brant e Ralph } \\
\text { Strelow }\end{array}$ & 1993 \\
\hline Titãs & Taxidermia & $\begin{array}{l}\text { Beto Brant e Ralph } \\
\text { Strelow }\end{array}$ & 1993 \\
\hline Titãs & Vou Duvidar & Branco Mello & 2003 \\
\hline Tulipa Ruiz & Pela Madrugada & Luiz Chagas & 2008 \\
\hline Ultraje a Rigor & Ciúme & $\begin{array}{l}\text { Renato Assaf Filho e } \\
\text { Eduardo Leite }\end{array}$ & 1985 \\
\hline Ultraje a Rigor & Eu Gosto de Mulher & Boninho & 1986 \\
\hline Ultraje a Rigor & $\begin{array}{l}\text { Nós Vamos Invadir Sua } \\
\text { Praia }\end{array}$ & Boninho & 1985 \\
\hline Ultraje a Rigor & Pelado & Boninho & 1987 \\
\hline Ultraje a Rigor & Rebelde Sem Causa & Boninho & 1986 \\
\hline Virgulóides & Bagulho no Bumba & $\begin{array}{l}\text { Mauricio Eça, Rui } \\
\text { Mendes e Zé Carratu }\end{array}$ & 1997 \\
\hline Volkanas & When 2R1 & Mauricio Eça & 1994 \\
\hline Wander Taffo & Me Dê Sua Mão & & 1990 \\
\hline Wanessa Camargo & Fly & $\begin{array}{l}\text { Gustavo Bonfé e } \\
\text { Johnny Araújo }\end{array}$ & 2009 \\
\hline Xuxa & Doce Mel & Boninho & 1986 \\
\hline Zeca Baleiro & Proibida Pra Mim & Tadeu Jungle & 2000 \\
\hline Zeca Pagodinho & Deixa A Vida Me Levar & $\begin{array}{l}\text { Carolina Jabor e Lula } \\
\text { Buarque }\end{array}$ & 2002 \\
\hline Zeca Pagodinho & Vai Vadiar & João Elias Junior & 1999 \\
\hline Zé Ramalho & Mistérios da Meia-Noite & Paulo Trevisan & 1985 \\
\hline $\begin{array}{l}\text { Zezé di Camargo \& } \\
\text { Luciano }\end{array}$ & Coração Está em Pedaços & & 1992 \\
\hline $\begin{array}{l}\text { Zezé di Camargo \& } \\
\text { Luciano }\end{array}$ & Tapa na Cara & & 2010 \\
\hline Zizi Possi & O Amor Vem Pra Cada Um & Herbert Richers Jr. & 1983 \\
\hline
\end{tabular}





\section{ANEXOS}

\section{Clipeografia (de acordo com memória de Roberto Berliner)}

\begin{tabular}{|c|c|c|c|}
\hline ANO & INTÉRPRETE & MÚSICA & DIREÇÃO \\
\hline 1985 & Dulce Quental & Délica & Roberto Berliner \\
\hline 1986 & Fausto Fawcett & Drops de Istambul & Roberto Berliner \\
\hline 1986 & Paralamas do Sucesso & Alagados & $\begin{array}{l}\text { Roberto Berliner e } \\
\text { Sandra Kogut }\end{array}$ \\
\hline 1987 & Paralamas do Sucesso & A Novidade & Roberto Berliner \\
\hline 1987 & Chacal e Ricardo Barreto & Andréia Andróide & Roberto Berliner \\
\hline 1987 & Fausto Fawcett & Kátia Flávia & $\begin{array}{l}\text { Roberto Berliner e } \\
\text { Sandra Kogut }\end{array}$ \\
\hline 1991 & $\begin{array}{l}\text { Chico Buarque, Gilberto } \\
\text { Gil, Caetano Veloso e } \\
\text { outros }\end{array}$ & A Luz do Mundo & Roberto Berliner \\
\hline 1991 & Paralamas do Sucesso & Tendo a Lua & Roberto Berliner \\
\hline 1991 & Paralamas do Sucesso & Trac Trac & $\begin{array}{l}\text { Roberto Berliner e } \\
\text { Gringo Cardia }\end{array}$ \\
\hline 1994 & O Rappa & Caô-Caô & Roberto Berliner \\
\hline 1995 & Gabriel O Pensador & Rabo de Saia & Roberto Berliner \\
\hline 1995 & MC Junior e MC Leonardo & Rap das Armas & Roberto Berliner \\
\hline 1996 & Lulu Santos & Aviso aos Navegantes & Roberto Berliner \\
\hline 1996 & Paralamas do Sucesso & Esta Tarde & Roberto Berliner \\
\hline 1997 & Skank & $\begin{array}{l}\text { É Uma Partida de } \\
\text { Futebol }\end{array}$ & Roberto Berliner \\
\hline 1997 & Lenine & Hoje Eu Quero Sair Só & $\begin{array}{l}\text { Roberto Berliner, } \\
\text { Joshua Callaghan } \\
\text { e Leonardo } \\
\text { Domingues }\end{array}$ \\
\hline 1997 & Gabriel O Pensador & Cachimbo da Paz & Roberto Berliner \\
\hline 1998 & Verônica Sabino & As Vezes Nunca & Roberto Berliner \\
\hline 1998 & Lobão & Me Beija & Roberto Berliner \\
\hline 1998 & Pedro Luis e a Parede & Caio no Suingue & Roberto Berliner \\
\hline 1998 & Ney Matogrosso & Miséria no Japão & $\begin{array}{l}\text { Roberto Berliner e } \\
\text { Ronaldo Soares }\end{array}$ \\
\hline 1998 & Skank & Saideira & $\begin{array}{l}\text { Roberto Berliner e } \\
\text { Raul Mourão }\end{array}$ \\
\hline 1998 & Ney Matogrosso & Poema & Roberto Berliner \\
\hline 1999 & Skank & Mandrake e os Cubanos & $\begin{array}{l}\text { Roberto Berliner e } \\
\text { Raul Mourão }\end{array}$ \\
\hline 1999 & Pedro Luis e a Parede & Rap do Real & Roberto Berliner \\
\hline 1999 & Paralamas do Sucesso & Sossego & Roberto Berliner \\
\hline 2000 & Skank & Três Lados & Roberto Berliner \\
\hline 2003 & Paralamas do Sucesso & Vital e Sua Moto & $\begin{array}{l}\text { Roberto Berliner, } \\
\text { Pedro Bronz e } \\
\text { Rogério Boechat }\end{array}$ \\
\hline$\cdots$ & Paralamas do Sucesso & De Perto & $\begin{array}{l}\text { Roberto Berliner e } \\
\text { Leo Domingues }\end{array}$ \\
\hline & Paralamas do Sucesso & Lanterna dos Afogados & Roberto Berliner \\
\hline 2005 & Pato Fu & Sorte e Azar & $\begin{array}{l}\text { Roberto Berliner e } \\
\text { Duda Pessoa }\end{array}$ \\
\hline
\end{tabular}




\section{Entrevista Completa de Roberto Berliner}

\section{Como você, formado em Jornalismo, chegou ao videoclipe?}

Em 1974, eu organizei um grupo de teatro com amigos e participei de duas peças, como ator - uma infantil e outra adulta. Em 1976, entrei na faculdade, Escola de Comunicação da Universidade Federal do Rio de Janeiro (UFRJ), e para um cineclube, onde escolhíamos filmes para serem passados em $16 \mathrm{~mm}$. Um dos caras do cineclube tinha uma câmera, mas não sabia mexer. Nós compramos, então, alguns rolinhos de Super-8 e saímos filmando. Rapidamente, eu me dei muito bem com a câmera. Foi algo que me fisgou de cara. Entre 1976 e 1980, no final da ditadura, fizemos alguns filmes sobre greves - de estudantes, de motoristas de ônibus, $1^{\circ}$ de maio - e do congresso de reabertura da União Nacional dos Estudantes (UNE), em 1979, na Bahia. Eu fui para lá sozinho, com a câmera Super-8 e um gravadorzinho, que colocava a tiracolo. Foi maravilhoso. Logo em seguida, fiz a mesma coisa em vídeo com filmes que eram exibidos na escola. Montávamos em alguns varais, onde dependurávamos os filmes e depois escolhíamos as imagens. Eu fui o único do cineclube que continuou filmando.

Em 1980, eu entrei no CEDOC (Centro de Documentação da TV Globo), arquivo de imagens e de textos que, na época, estava sendo informatizado. No dia em que cheguei, fui direto para um seminário onde se discutia como seriam catalogadas as coisas. Recémformado, comecei a dar muitas idéias. Para mim, foi muito legal, porque precisávamos encontrar uma maneira de catalogar. Eu fiquei 3 anos e meio lá e, durante esse período, comecei a editar, o que me interessava, além da pesquisa. Havia um monte de ilhas a disposição. Às vezes, acabava meu horário, ficava pegando imagens de arquivo e editando de onda. Foi quando descobri a câmera de vídeo e comecei a filmar em VHS, passar para U-Matic, que era o que havia na Globo, e editar lá. Foi me dando prática e, então, eles começaram a me pedir para fazer algumas edições, de coisas do Roberto Marinho, especiais a respeito do Brasil para ser enviado ao Japão e retrospectivas de pessoas que poderiam morrer em breve. Mas nunca achei que seria diretor.

No verão de 1982, eu fiz parte do grupo que fundou o Circo Voador, porque era de um grupo de teatro do Hamilton Vaz Pereira, chamado Vivo Muito Vivo e Bem Disposto, que tinha Fausto Fawcett, Sérgio Meckler, Karen Accioly, Carlos Laufer. Era demais, no meio do Arpoador. Às vezes eu saía da Globo, com short debaixo, e ia direto para lá. Ou fazia o inverso: ia salgado mesmo para a Globo. Espero que isso um dia vire filme. Depois de três meses, que para a gente foi uma eternidade, tiveram que demolir o Circo no Arpoador, que era um lugar completamente esquecido, pois os moradores começaram a reclamar. No finalzinho desse período, comecei a filmar em vídeo, com uma câmera emprestada. Buza Ferraz, diretor de teatro e cinema, falou: "Acho que tenho um negócio desses lá em casa". Vídeo era uma coisa recente e encontrei no porão da casa dele uma câmera VHS, com a qual comecei a gravar as coisas do Circo. Gravei, gravei, gravei e editei esse material na Globo. Fiz um documentariozinho chamado "Circo Voador no Arpoador", que serviu para irmos atrás de patrocínio e continuarmos vivos. Encontramos o Ponto Frio, uma loja de eletrodomésticos. Cheguei também a fazer edições para passar no telão antes dos shows. Pegava Jimi Hendrix, Nelson Gonçalves, fazia umas misturas e passava lá. Antes disso, fazia fitinhas de festa, porque gostava muito de editar e no arquivo também, pegava uma música, botava depoimentos e voltava para ela. Eu brinquei muito com isso, mas fazendo coisas que só levaram a ter experiência um pouco maior.

Entre março e setembro, ficamos sem o Circo e fizemos o Circo Sem Lona, em que um grupo de teatro e outro de vídeo iam para comunidades carentes. Íamos com um teatrinho, fazíamos uma animação e, vestidos de palhaço, jogávamos bola contra a comunidade local. Como eu já não era mais muito ator, ia com vídeo, que era o que me interessava, e gravava. Numa Kombi, botava duas televisões em cima e passava para eles o que tinham falado sem editar. Era uma loucura, porque eles não imaginavam que era possível reproduzir tão rápido uma imagem. Eu falava: "No final da tarde, passaremos o vídeo que estou filmando aqui". Até me lembro que uma mulher falou: "Como vai dar tempo 
de colorir isso tudo?" (risos). Acabei fazendo outro documentário. Foi quando surgiu a Antevê, nome relacionado ao que eu queria fazer, meio uma antitevê.

Logo em seguida, entre final de 1982 e início de 1983, participei de um curso do Joaquim Pedro (de Andrade) no Circo Voador, que me marcou muito. Eu cuidava da parte de edição, o Waltinho Carvalho, da parte de câmera, e o Joaquim, da direção geral. Aprendi muito com o Joaquim, um cara sensacional, ligado na juventude. Eu e Alice (filha dele) tínhamos uma relação muito próxima, mas muito conflituosa. Ele ria à beça das nossas brigas. Para o curso, fizemos o vídeo "Ovídio", completamente bagunçado. Valia tudo. Qualquer idéia de gente de todas as áreas: teatro, circo, artes plásticas.

Ao mesmo tempo, eu continuava na Globo e dava aulas de teatro, o que fiz de 1978 a 1983 e que era algo que gostava muito, lidar com crianças e adolescentes. Foi quando deixei de ser ator para começar a pensar na direção. Comecei a perceber que mandar e tentar fazer algo com os outros era mais legal do que eu mesmo atuar. Esses três vídeos em 1982 foram muito importantes também, porque comecei a fazer as coisas e ganhar segurança. Gravei tudo o que acontecia no Circo Voador, principalmente de rock. Foi uma escola, porque estava no palco, na cara dos caras, com liberdade total e câmera em movimento, que gosto muito. Tinha também um negócio chamado Creche Apareche e a Domingueira Voadora, com dança de salão. Eu cheguei a morar no escritório do Circo com o Perfeito (Fortuna, criador do Circo e ator do Asdrúbal), quando pedi demissão da Globo. Para mim, era quase como tocar ou jogar bola. Por isso, no início da minha carreira, tive muita dificuldade de mandar câmera, diretor de fotografia ou editor fazer as coisas, pois, antes, fazia tudo sozinho.

Naquela época, eu dei a idéia de fazer uma coisa parecida com Video Show, só que muito mais interessante: pegar imagens fabulosas de arquivo que foram ou não ao ar, e fazer especiais específicos sobre determinados temas. Eles até fazem, mas é muito pouco. Não rolou e pedi demissão. Deixei de ganhar um salário decente, que pagava aluguel e carro, para entrar no Circo Voador de cabeça. Ali foi um momento muito importante e eu participava praticamente de tudo. Nossa formação era muito hippie e meus ideais eram, e acho que ainda são, os de uma coisa coletiva, de estar todo mundo junto, ganhando igual e tentando melhorar o mundo. Só que nós éramos muito ativos. O negócio era brincar. O que documentávamos também era para ser coletivo, mas eu acabei centralizando, por causa do tempo. Às vezes, acordávamos no fim de semana às seis da manhã para ir a uma comunidade de algum lugar e muitos não acordavam, porque realmente ficávamos até às quatro da manhã no Circo dançando. Algumas pessoas não seguravam a onda. Tanto que saí do Circo porque achava que esse espírito estava só dentro de alguns. Outros estavam se beneficiando daquilo para ganhar dinheiro para eles próprios.

Assim que saí do Circo, no final de 1984, começo de 1985, me chamaram para editar uma minissérie na TV Manchete. Nessa época, havia um programa lá chamado $\boldsymbol{F M}$-TV, de videoclipe, comandado por João Kleber e Marcão, um cara da Rádio Manchete. Minha primeira atitude foi demitir João Kleber, porque achava que não tinha nada a ver com aquilo e, como não podia demitir o Marcão, um cara legal, botei Patrícia Pillar e Tim Rescala para apresentar com ele. O redator do programa era um cara chamado Paulo Coelho, que acho que não tinha o menor saco para fazer aquilo. Ele devia estar duro e redigia uma coisa muito parecida sempre: "Ugadundu, que na Uganda significa boa noite". Cada dia ele trazia um e era sempre igual. Não dava para fazer sempre igual, então acabava mexendo no texto dele. Fiquei dois, três meses na direção e nem cheguei a assinar. Acho que quem assinava era o Mario Marcio Bandarra, que me colocou na Manchete. Mas, para mim, foi uma experiência muito legal, porque trabalhava com cinco câmeras ao mesmo tempo e resolvi fazer tudo aberto, com elas aparecendo. Às vezes até um câmera apresentava o clipe que vinha. Como acho que o Eidi Walesko gostava muito de câmera torta, resolvemos fazer tudo torto, com os apresentadores meio que escorregando ou tentando subir em algum lugar. Ali passava de tudo, desde clipes internacionais até brasileiros, do Nilton Travesso, Jodele (Larcher), Eidi, que era a grande estrela. 
Acho que o Boninho começou a fazer por ali e com ele aconteceu um negócio matador, chamado Clip Clip, programa de videoclipes de tarde na TV Globo. Cerca de seis meses depois, o que ele fez? Essa é uma acusação que eu tenho quase certeza. Começou a oferecer os serviços dele para as gravadoras. Ou seja, fazia tudo com equipamento e profissionais da TV Globo, cobrava da gravadora provavelmente metade do que nós, que estávamos no mercado, cobrávamos e ainda botava no programa. Então, ao mesmo tempo em que tínhamos a maior dificuldade de entrar no Clip Clip, nossos preços eram maiores do que os dele. Enfim, ele matou a concorrência.

Fui demitido do FM-TV e a Dulce (Quental), que era videomaker também e me conhecia de festivais de vídeo, me chamou para fazer o clipe Délica, onde usei muitas imagens de arquivo, um monte roubadas, algumas delas, sem saber, do Walter Salles, que ficou louco comigo. Eram caras dançando no Japão, imagens inéditas do programa Japão. Como é que eu ia adivinhar? Expliquei a situação. Mas, como era um mundo menos controlado, esse clipe foi ao ar diversas vezes e ninguém mais reclamou.

Em seguida, surgiu Paralamas, porque $\mathrm{Bi}$ (Ribeiro, baixista) e João Barone (baterista) foram ao lançamento do clipe num barzinho em Botafogo e me chamaram: "A gente gostou do clipe. Está a fim de fazer o nosso também?". Trocamos telefones e combinamos de ir à casa do Herbert (Vianna, vocalista), na Gávea, para ele me conhecer e fazer um teste. Foi muito engraçado, porque passava o vídeo e o cara: "Deixa eu ver de novo" (risos). Ele gostou também. Eu já tinha filmado eles no Circo Voador, mas não éramos muito próximos.

O primeiro clipe que fiz para eles foi Alagados. Era uma época que tinha muita tecnologia, luzes, fumaça e a minha idéia era fazer um videoclipe brasileiro, bem típico do que se fazia no cinema daqui e que a música deles estava querendo. Eu pensava que rock era uma coisa meio elitista, da garotada, e queria botar a música para falar com todo mundo. Filmamos no Morro de São Carlos, no Estácio, num baile funk na Vila Mimosa, e em ruas e lugares mais pobres do Rio. Foram dois dias de filmagens e havia uma coisa planejada e outra ao acaso. Aliás, até hoje faço muito isso. Deixo a planejada se não surgir nada, mas sempre acaba surgindo. Eu também sempre gostei de trabalhar de uma maneira coletiva.

Em 1986, o Perfeito resolveu me chamar para que a Sandra não fosse sozinha ao México, fazendo a cobertura do Circo Voador (na Copa do Mundo). Foi uma loucura. Era um bando de malucos. Circo Volador. Fomos num Hércules abarrotado de coisas, num espaço entre o teto e o equipamento que estávamos levando. Mal dava para beber, torto, uma Coca-Cola. E rolava de tudo - sexo, drogas e rock and roll. Não acabou em tragédia por pura sorte. Foi quando eu e Sandra começamos a trabalhar juntos, resolvemos virar sócios e fizemos um vídeo que editamos e passou na televisão mexicana. Trabalhávamos com VHS ainda e o sistema do México era Betamax, da Sony, que acho até que era melhor. Então não tinha como comprar nem fita. Acho que tivemos problema de bateria, pois nenhuma encaixava na nossa câmera.

A idéia era tentar passar do México para os Estados Unidos, onde tenho parentes, e estudar lá. No meio do caminho, porém, resolvemos comprar uma ilha de edição, no Panamá, e formalizar a Antevê como empresa. A Sandra voltou ao Brasil para conseguir dinheiro com minha mãe e meu irmão, e com o pai dela, e mandou. Só que, naquela época, demorava muito para o dinheiro chegar. Tudo demorava. Então fiquei no México e depois fui para o Panamá, praticamente duro. Cheguei num sábado, paguei o equipamento, fiquei numa espelunca e fui ao aeroporto na quarta para ir embora. Só que o vôo estava lotado, overbooking, e tive que voltar, mas não tinha mais dinheiro. Foi quando vi um cara completamente desesperado e arrasado, que falava mal o português. "Você é brasileiro?". "Sim". "Como é o seu nome?". "Gilberto". Ele era um ex-jogador de futebol, um negão, que tinha jogado de seis a oito anos na América Central e economizado um dinheirinho para voltar ao Brasil e abrir um bar. Sugeri, então, de a gente rachar um quarto. Ele estava super desconfiado.

Entre quarta-feira e sábado ou domingo, data do outro vôo, nós passeamos pelo Panamá. Eu teria um arranjo com alguém que liberaria o excesso de peso. Só que não 
liberaram e eu não tinha dinheiro, nem cartão de crédito, e cheque não servia. "Gilberto, você tem que me ajudar". "Eu não tenho dinheiro". E me deixou lá com o equipamento, desesperado, tentando falar com o pessoal da Varig. Quarenta minutos depois, volta o Gilberto: "Toma la plata". Puto, mas com remorso. Aí entrei. "Valeu Gilberto!". Ao chegar ao Brasil, com o equipamento pesadão, me pegam na alfândega. Teria que pagar 500 dólares. Eu já tinha avisado no Brasil e falei para o meu irmão: "É ele". Aí meu irmão pagou e nunca mais vi o Gilberto, infelizmente.

No Brasil, eu e a Sandra fomos para uma casa, chamada Cidadela, que abrigava, ao mesmo tempo, uma empresa de eventos, Soldout; o ateliê do Barrão, um artista plástico; a Antevê, ocupando duas salas; e Luiz Antônio, dono da casa, que articulava patrocínios e fazia projetos especiais, como um livro sobre Santos Dumont, e com quem eu fui para Angola, porque ele conseguiu um patrocínio da Petrobrás. Acabamos ficando na Cidadela durante uns dois anos e depois nos mudamos para outra produtora, do Tom Job Azulay, que marca o início da minha história como produtor.

O primeiro clipe que eu e Sandra fizemos juntos foi $\boldsymbol{A}$ Novidade. Um clipe super divertido, porque passamos o dia nas barcas. Na época, eu falei: "Vamos ao Fantástico. Quem é o responsável por isso?". "Oi (Roberto) Talma, tudo bem? A gente fez um clipe e quer te mostrar". Aí ele, mexicanão, fortão: "Mostra aí". Botamos a fita. "O que vocês querem?". "Botar no 'Fantástico'”. "Se mudar umas três ou quatro coisas, de repente a gente coloca". "O que você quer que mude?". "Esse cara batendo com o pé na porta". "Vamos ver de novo?". "Está bom desse jeito". Deixou exatamente como estava. Mas falou: "Quero que vocês façam uma cabeça, a chamada de apresentação do clipe". Fizemos uma cabeça sensacional, meio esquisita. Pegamos uma amiga atriz, Carina Cooper, e fizemos uma bagunça, como se ela se enganasse e os Paralamas, então, voltassem para a ilha de edição. A partir daí, o Talma começou a nos chamar. Só que tínhamos um poder incrível. Usávamos o equipamento da TV Globo para gravar e as ilhas para editar, e ganhávamos um cachê. E a gravadora ficou super feliz, porque nos pagou e fomos ao Fantástico.

Logo depois, a Globo nos chamou para fazer Kátia Flávia. Éramos muito amigos do Fausto (Fawcett), fechamos a (rua) Prado Júnior e foi super legal ter tudo o que queríamos atrizes, equipamentos -, mantendo um caráter documental. Em seguida, fizemos para o Fantástico também, Andrea Andróide (de Chacal e Ricardo Barreto), trabalhando com efeitos e com o Éder Santos. Nós fazíamos algumas interrupções na música, o que comecei em Alagados e chocava um pouco. A televisão era muito limpinha, sem erros. Hoje acho que relaxaram um pouco. Como trabalhei no CEDOC, muito perto do estúdio do jornalismo, via como eles se incomodavam se alguém gaguejasse ou errasse o texto. Passei, então, a me interessar por trabalhar justamente com os defeitos, o que talvez tenha permeado meu trabalho e, certamente, influenciado os filmes que fiz.

No final de 1989, voltei à TV Globo para fazer o programa Juba \& Lula, que era muito ruim. Peguei um editor que não editava e um roteirista que não roteirizava. Então eu roteirizava, filmava e editava, até que falei para o Talma: "Chega. Não consigo mais". Ele respondeu: "Vai para casa, ganha o salariozinho e, daqui a seis meses, te chamo para fazer outro trabalho". Era um salário muito bom. Ali eu viraria um funcionário da Globo ou seguiria meu caminho. Resolvi seguir. Só que, logo depois, entrou o (Fernando) Collor na presidência e fiquei fodido.

No início dos anos 1990, eu tive um desentendimento com a Sandra, que saiu da Antevê, e eu fiquei com outros dois sócios. Como estava na era Collor, foi uma tragédia. Reuni com os dois e falei: "Quando entrar um dinheiro, eu dou para vocês. Mas se não entrar, não dará para pagar salário". Já no final do ano, nos desentendemos e me chamaram para trabalhar numa produtora em São Paulo. Não sabia quanto cobraria, mas resolvi cobrar o dobro do que tinha pensado e o cara achou barato e fechou na hora. Passei lá só dois meses, porque a produtora era estranha e eu não conseguia trabalhar direito. Se fosse uma produtora mais legal, acho que teria ficado. Foi quando assisti Asas do Desejo (de 1987, dirigido por Wim Wenders), que mexeu comigo profundamente. Saí torto do 
cinema: "Tenho que sair fora desse lugar". Não foi uma época muito boa. Aí voltei para o Rio e fiquei sozinho em casa com a Antevê.

Como fazia publicidade desde 1987, uma produtora, Iser, que fazia documentário e pertencia ao Instituto de Estudos da Religião, criado na época da ditadura e que tinha a ver com movimentos sociais, onde trabalhavam dois amigos, me chamou para ser diretor da casa e deixar a produtora auto-sustentável, pois, como vivia de doações, estava quebrando e não tinha mais como sobreviver. Eu, então, falei: "Só vou se a Antevê for junto". Foi quando começou a Antevê Iser, um nome esquisito e feio. Começamos a procurar outros nomes, até que, em 1993, fui apresentado, acho que no estúdio do Liminha, ao Chico Science, que perguntou o nome da produtora e, como não entendeu, disse: "Como? TV Zero?". Aí falei: "Não, mas pode ser". Nosso padrinho foi Chico Science. A partir daí, virou TV Zero.

Em 1998, fiz o primeiro documentário, o curta das ceguinhas. Antes, em 1996, 1997, viajei o mundo atrás dos músicos do Free Jazz. Depois, em 2000, fiz o curta-metragem do (Gilberto) Gil (Afinação da Interioridade, de 2001) e algumas coisas para a exposição $\boldsymbol{A}$ Imagem do Som. Em 2000, comecei a filmar o longa das ceguinhas, no qual fiquei três ou quatro anos. Nesse período, decidi parar aos poucos com a propaganda, mas ainda faço comercial que tenha a ver comigo, que o cachê seja bom ou que seja interessante para a produtora.

\section{Qual é a diferença entre fazer videoclipe para Fantástico e MTV?}

Quando a MTV chegou em 1990, aos poucos, os trabalhos, que era um prêmio conseguir botar no Fantástico, passaram a ser uma peça de propaganda. Outra diferença é que, nos anos 80, a maioria dos diretores trabalhava com referência: "Vou fazer igualzinho aquele clipe do David Bowie". E eu procurava fazer do meu jeito, a brasileira. Já nos anos 90, alguns diretores começaram a fazer videoclipes para mostrar para as agências sua capacidade de fazer coisas bonitas. Havia um comprometimento com o mercado, o que eu nunca tive tanto e nem a pretensão de mostrar para o mercado publicitário, mas a cobrança era maior. Mesmo eu sendo amigo dos caras das bandas, ficou mais difícil prosseguir no caminho experimental. De certa maneira, consegui fazer com meus amigos, como Pedro Luis, que é ousado e aberto para experiências.

Tendo a Lua e Trac Trac eu realizei ao mesmo tempo, já anos 90. Tendo a Lua era um clipe cheio de ruídos, onde só usei câmeras ultrapassadas, não havia alguma que valesse mesmo a pena. Já Trac Trac fiz em $16 \mathrm{~mm}$, com um pouquinho mais de grana. Dividi com o Gringo Cardia. O último clipe que fiz para eles foi em 1995, Essa Tarde. Nós éramos muito amigos. Eu e Herbert tínhamos uma relação muito próxima e minha mulher era muito amiga da Lucy. Mas acho que os Paralamas tinham um pouco a vontade de fazer algo mais chique, tanto que foram trabalhar com a Conspiração (Filmes), que deu uma roupagem mais brilhante e chique para eles, e que achei que talvez fosse bom para nossa relação. Mas, por acaso, fui me afastando dos Paralamas, até que, em 2005, fiz um especial com eles, Hoje. Antes, tinha feito, nos anos 1980, V, O Vídeo, e, nos anos 1990, Vamô Batê Lata.

$\mathrm{Na}$ Conspiração, estavam os caras que faziam em película, o que os levou a explodirem na propaganda. Não só eles. Oscar (Rodrigues Alves) mesmo, eu acho que começou na propaganda através disso. Já eu sempre tive uma relação próxima e distante com a propaganda. Nunca fiz clipe para falar: "Eu sei fazer propaganda". O objetivo sempre foi vender um produto. Era para fazer assim? Eu ia lá e fazia. Um trabalho contratado. Tentava fazer o melhor possível a idéia deles. Já, no clipe, podia fazer a minha idéia, do jeito que fosse, com menos grana. Era liberdade total e tentava desligar totalmente da propaganda. Em geral, fazia o oposto. Agora, nunca foi o meu fim estar apenas num lugar. O meu negócio era fazer documentário, videoclipe e propaganda, e levar coisas do videoclipe para o documentário, da propaganda para o videoclipe e da propaganda para 0 cinema. 


\section{Como você vê a relação entre videoclipe e publicidade?}

Nos primórdios, o videoclipe vinha da vídeoarte e estava mais interessado nas artes plásticas. Com o tempo, foi se aproximando da propaganda, o que se acentuou a partir do momento em que a banda virou um produto de verdade - talvez tenha sempre sido, mas nunca tratei dessa maneira. O que eu queria mesmo quando fazia um clipe era criar uma identidade para a banda. Mas teve momento na música brasileira, que acho que começa com Marisa Monte, que tudo ficou organizado, limpo e ensaiado demais, com cenário perfeito. A partir dali, todo mundo começou a se cuidar mais e a fazer uma coisa mais chique. Antigamente, ia a um show de rock and roll, era rock and roll. Com o tempo, profissionalizou demais e deu uma engessada tanto quanto a publicidade, onde fazemos um trabalho em muito pouco tempo, de 30 segundos, em que não se pode errar e há um formato certinho. Às vezes, sobrava um tempinho, eu ia lá e tentava fazer as minhas coisas.

Nos anos 80, tinha mais liberdade de fazer videoclipe como queria. Com o surgimento da MTV, porém, surgiu também um pouco da vontade de fazer do videoclipe um comercial do artista, tanto por parte dos diretores, que queriam entrar ou se manter na publicidade; quanto por parte das bandas, que queriam vender mais. O que era uma expressão artística da música passou a ser propaganda da banda. Aos poucos, fui perdendo o interesse. Só continuei fazendo com as bandas que conseguia interagir, como Paralamas e Skank. O engraçado é que as duas tinham muito a ver e, no mesmo momento em que a Conspiração começou a fazer clipes dos Paralamas, o Skank começou a me chamar. Foi um acaso e acho que continuei fazendo mais ou menos a mesma bagunça. A minha história com o Skank foi super bem-sucedida e muito agradável, porque eles são pessoas abertas, engraçadas e relaxadas, que me davam liberdade total.

Lembro que, quando fiz Trac Trac, para os Paralamas, Jorge Davidson, que era da EMI, me ligou: "Roberto, dessa vez você foi onde ninguém foi. Dessa vez, você ultrapassou todas as barreiras. Esse seu clipe é um horror. Como vai ser? As pessoas vão passar mal". Era um clipe todo rápido. Quando começou, eu achei que estava me elogiando, mas detonou o meu trabalho. Com o clipe Hoje Eu Quero Sair Só, na rua e bem simples, com uma verba relativamente pequena, que fiz para o Lenine, outro amigo do Circo Voador, Jorge Davidson também me ligou detonando: "Você fez mal ao seu amigo. Vai estragar a carreira dele". Logo depois, eu o encontrei no show do Lenine e falei: "Pelo amor de Deus, quando eu fizer uma coisa boa, você me elogie também, porque só me liga para detonar". Já havia essa preocupação com o mercado.

\section{O fato de o videoclipe apresentar os créditos, e a publicidade não, fez com que você ficasse mais associado a ele?}

$\mathrm{Na}$ verdade, era mais um nome ali. Ninguém sabia quem eu era. Na publicidade, quando você faz um filme, é mais ou menos a mesma coisa. Se estão interessados, rapidamente descobrem quem foi que fez. E tem 0 atendimento nas produtoras que vai mostrar o seu trabalho. "Ah, esse clipe é do Berliner". Era legal, mas os amigos é que identificavam. Ou então, depois, quando as pessoas te conhecem: "Ah, você é o Berliner que fez aquele negócio?". É uma assinatura. Como diretor, acho que não é muito bom ficar famoso. Se a imagem de um documentarista ficar muito célebre, na hora em que for fazer o documentário, passará a ser mais importante do que o sujeito do filme. Sei que o crédito leva trabalho aos diretores, mas nunca foi meu foco. 


\section{Como é seu método de trabalho e como escolhe a equipe?}

A primeira coisa que eu fazia era ouvir a música um monte de vezes para ter idéias. Em nenhum momento, eu falava não. Escrevia e ficava com um monte de idéias, incríveis e mirabolantes. Nos anos 80 , eu batia a máquina e depois tirava cópia em xerox ou carbono. Deixava um ou dois dias. "Já tenho idéias suficientes para limar". Chegava a duas ou três idéias e as desenvolvia, tentando perceber a simples, a complexa e a que custaria muito dinheiro. Então, em geral, ia à gravadora e conversava: "Tenho três idéias. Como está a verba?". Nesse começo, era média ou pequena. Então fazia o que era possível.

Por exemplo, a idéia inicial de $\boldsymbol{A}$ Novidade era começar na Praia de Botafogo, com a câmera subindo. Era um clipe grandioso, uma loucura. Ela, então, passava e fechava na avenida Copacabana. Como não toparam, fomos para as barcas e botamos uma grua em cima dela, o que nunca ninguém havia feito. Durante uma viagem normal, os Paralamas tocavam no teto e a gente botou umas caixas de som imensas embaixo. A idéia surgiu do

Let It Be (vídeo dos Beatles tocando no topo de um prédio em Londres), só que, no nosso caso, começava no alto com a banda, enquanto embaixo tinha o som, mas ninguém entendia muito e, de repente, eles apareciam tocando no meio da galera. Foi tudo bem planejado. Éramos eu e a Sandra dirigindo, com dois câmeras. E tinha um terceiro câmera fazendo planos gerais. Mas ficamos preocupados que, apesar de Alagados ter sido um sucesso, Paralamas ainda não era uma banda tão conhecida. Por isso, colocamos atores camuflados no meio da galera, como se fossem passageiros, para dar uma animada. Foi uma delícia, porque chegou um momento em que eles não precisavam mais animar nada. Era um dia de sol e depois choveu. Aconteceu de tudo.

Fazia um roteiro, em que sabia o que seria feito em cada segundo da música, e um plano de filmagem. Mas chegava na hora e achava que outro plano era mais interessante. Então fazia os dois. Acontecia também de o boy do set me dar uma idéia. Tirando alguns clipes em que o roteiro era muito preciso, caso de Mandrake e os Cubanos, quando as idéias foram surgindo e se incorporando na edição, tento o que não vai dar certo primeiro, pois, o que vai dar, eu já sei. Na maior parte das vezes, não dá certo mesmo, mas, em outras, o erro me leva ao acerto. Tem várias cenas famosas de cinema que foram feitas ao acaso. Então eu prezo muito o acaso, assim como ouvir as pessoas em volta.

Sempre tive parceiros também porque eu ouvia a música, escrevia e, em alguns momentos, precisava debater minhas idéias com alguém. No caso, meus interlocutores sempre foram Leo ou Raul Mourão, artista plástico muito amigo, mesmo quando não codirigiam. Como são pessoas em quem confio, minhas inseguranças eram filtradas por eles. Fiz todos meus trabalhos de forma coletiva. Até 1987, eu trabalhei muito com o Flávio Ferreira. Tivemos um desentendimento e entrou o Gustavo Ádila, que trabalhou comigo até o início dos anos 1990. Foi quando entrou o José Tadeu, que ficou até 1996 e com quem não me desentendi (risos). Em 1996, entrou o Jacque Cheuiche, que é meu parceiro até hoje, que fez Som da Rua, cuja idéia era trabalhar com o som das pessoas que se expressam de maneira maravilhosa e estão no lixo. Adoro lixo. Gosto de olhar e várias coisas que encontro pelo caminho pego, como computadores e câmeras velhas.

Além do Jacque, nesse período, comecei a trabalhar com André Horta e hoje, basicamente, trabalho com os dois. Paulinho Violeta foi outro grande parceiro. De vez em quando, experimento trabalhar com outros fotógrafos. Mas a parceria com pessoas que ficam muito perto é importante para mim. Talvez eu diversifique menos as idéias e amplie menos meus horizontes, mas, ao mesmo tempo, consolido coisas com eles, que já me conhecem, sabem o que quero e entendem minhas deficiências e qualidades.

\section{O que determina se o videoclipe será filmado em película, vídeo ou Super-8?}

O orçamento influencia muito, assim como a gravadora. Muitas vezes, quando quis fazer em vídeo, a gravadora quis uma coisa mais limpinha. Então ia para o $16 \mathrm{~mm}$. Acho que nunca usei $35 \mathrm{~mm}$ em videoclipe, até em função da verba. Houve um período, nos anos 1990, em que vídeo ficou de fora. Lembro que saiu uma matéria, acho que em "O Globo", 
mostrando a importância do $16 \mathrm{~mm}$, e eu falava: "Meu negócio é vídeo, por conta da leveza". Saiu o contrário no jornal. No Som da Rua, quis usar $16 \mathrm{~mm}$, porque achava importante dar destaque para aqueles músicos. Porém, com músicos já conhecidos, achava o vídeo bom, porque podia usar a minha linguagem, tanto do documentário, quanto dos defeitos. Agora, imagem para mim é importante em qualquer formato.

\section{Você dialoga com o intérprete da canção para fazer um videoclipe?}

Quem chama a gente, em geral, são os artistas, pelo menos os mais importantes. Com os artistas menos importantes, a gravadora impõe. Em geral, tem uma reunião inicial, na gravadora, onde contam como foi a composição da música, o que pensaram e, às vezes, a tradução que têm em imagem. Em geral, anoto, levo em consideração a idéia deles e até faço um roteiro, quando tenho tempo. Também levo a minha ou as minhas idéias. Às vezes eu misturo um pouquinho. Nenhuma vez, porém, deixei de fazer a minha, porque sempre respeitaram meu trabalho e convenci que a idéia deles não era tão boa (risos), por ser piegas, impossível, grande demais, ou custar uma fortuna. Muitas vezes, isso foi determinante para que a idéia da banda não fosse adiante. A segunda reunião, quando tem, é para mostrar o roteiro. Pedro (Luís), por exemplo, o que eu fizesse, ele acharia legal e faria. Com Skank e Paralamas, também é assim.

Recentemente, fiz o DVD Hoje, com Paralamas. A idéia surgiu do Zé Fortes (empresário da banda) de colocar o grupo tocando em círculo, sem cenário, um virado para o outro em estúdio bem grande, onde Raul Mourão botou algumas escadas. Aconteceu o que chamei de "liberdade vigiada". Botei os melhores câmeras: Waltinho Carvalho, Gustavo Habda, Jacque Cheuiche, André Horta e Lula Carvalho, filho do Waltinho. Todos tinham comunicação comigo e podiam fazer o que quisessem até eu mandá-los fazer determinadas coisas. A equipe apareceria à vontade. Entre uma música e outra, eu falava: "Atenção, Waltinho, você vai ficar com Herbert e João Barone nessa. Jacque, você ficará com Bi". Eu ficava girando em torno e tentando corrigir o que faziam. Foi uma diversão total, porque eles ficavam muito soltos e eu tinha confiança total neles.

\section{Os clipes que dirigiu para o Fantástico foram exibidos pela MTV?}

Foram exibidos, mas bem pouco. Délica foi e Kátia Flávia talvez também tenha passado. Acho que $\boldsymbol{A}$ Novidade não passou, mas não tenho certeza. Não sei se a Globo cedia. Talvez tenha havido um problema entre as emissoras.

\section{Você é contra ou a favor da inclusão de merchandising em videoclipe?}

Sou a favor do merchandising, desde que não atrapalhe o clipe e seja incluído de maneira esperta e inteligente. Porém, quando o merchandising começa a entrar em conflito com a música e/ou tira a sua liberdade, acho grave, porque é uma interferência. Por exemplo, vou fazer um filme sobre esquizofrênicos. Se um cara da indústria farmacêutica falar: "Quero botar dinheiro no seu filme"; certamente interferirá na minha liberdade de mostrar o que penso dessa indústria. Por isso, há determinados momentos em que é nocivo.

Em É Uma Partida de Futebol, a Umbro deu os uniformes da pelada entre artistas e ex-jogadores. Nem sei se ela patrocinava também Cruzeiro ou Atlético. Mas a produção não ganhou nenhum tostão, que me lembre. Talvez a gravadora ou o Skank tenham ganhado. Havia uma verba boa para fazer esse videoclipe e pude trabalhar com vários câmeras.

\section{Você se considera autor dos seus videoclipes?}

Com certeza, considero-me autor, porque são idéias que, em geral, vieram da minha cabeça. Escrevo o roteiro, planejo, dirijo e edito, com outros. Mesmo quando não assino com alguém, os colaboradores exercem muita interferência. Mas sempre os coloco como 
co-diretores, porque acho que são mesmo e me lembro quando fazia tudo e não assinava. Então considero que somos realmente autores desses trabalhos, porque fizemos todo o processo, do início ao final. Em alguns casos, sofremos interferências da gravadora, mas muito pouca. Na verdade, lembro-me de um caso em que não era eu dirigindo, mas entrei para dar um jeito, porque a gravadora recusou o clipe da TV Zero.

\section{Você consegue encontrar a sua autoria quando co-dirige os clipes?}

Quase sempre a palavra final é minha. Sou super democrático, mas alguém tem de ter essa função. Com a Sandra não. Realmente dividíamos. Depois disso, o Gringo é um cara espetacular, mas, na hora de mandar na equipe, ele tinha menos experiência. Então, enquanto eu comandava mais a filmagem, ele fazia mais a parte da arte e participou menos da edição. Com Raul Mourão, Leo Domingues e Joshua, a palavra final era minha. Se o projeto tinha que ser abortado, eu abortava. Mas, muitas vezes, eu deixava a idéia ir adiante, mesmo sem gostar. É autoria coletiva, mas, quase sempre, encontro ali o que pensei.

\section{É fácil identificar suas marcas autorais?}

Não sei se sei dizer. Nunca pensei sobre isso. Talvez o que preze muito seja câmera em movimento, interferências no clipe - através de ruídos na própria imagem - e o sujo. Nunca busco o belo como belo. Acho que o belo está em outros lugares que não o que estamos acostumados a ver como tal. Meu tipo de beleza está mais na lama, no esgoto. Sempre procuro a sujeira para interferir num mundo tão limpinho. Por isso, acho que meus clipes não me levavam à propaganda e vice-versa. Outra coisa muito ligada ao meu trabalho é a edição. Como fui editor e trabalho há muitos anos com Leo Domingues, vou à ilha e fico muito tempo lá. Também trabalhei quase sempre com artistas plásticos. Nos meus clipes, os cenários nem sempre eram uma coisa bela, brilhante, mas traziam informações de outras áreas. Vários clipes ainda vem do documentário e há humor neles. Talvez tenha esquecido algo comum a todos, mas o mais importante neles é a emoção, depois o ritmo e, por fim, a informação.

Sempre tento experimentar alguma coisa nova nos clipes. Nem sempre acho que consigo, mas tento fazer com que eles me levem a algum lugar. Acho que o clipe foi vanguarda para o cinema e para a publicidade, que, dificilmente, se renova por si própria e, por isso, bebe em outras fontes. Porém, a partir do momento em que clipes viraram propagandas, deixaram de ser vanguarda.

\section{O videoclipe, então, deixou de ser espaço de experimentação?}

Foi deixando aos poucos, por parte dos diretores. Por exemplo, quando Jorge Davidson reclamou do clipe que fiz com Lenine, logo em seguida, ele fez um clipe com Hugo Prata, chique, com brilhos. Por isso, foi me interessando menos. Na minha filosofia, estou muito mais próximo do povo do que das celebridades, do sujo do que do limpo, do feio do que do belo, conceitos que a publicidade e o cinema impregnaram. E o branco e o preto. $\mathrm{Na}$ publicidade dos anos 1980 e 1990, para você botar um negro era uma discussão de semanas, pois o belo é o europeu, o americano. E eu sempre tentei trabalhar com o oposto. Falava: "Televisão é assim? A minha vai ser antevê, antitevê e, ao mesmo tempo, antever, porque acho que um dia será desse jeito".

\section{Em Délica, há o cerne do Roberto Berliner, diretor de videoclipe?}

Acho que não. Aquele é um clipe muito simples e barato, com imagens de arquivo, que não volto a usar em videoclipe. Mas a edição tinha alguns defeitos. Botei três Dulces. Nesse clipe e em Alagados, eu fiz tudo sozinho. A produtora era na minha casa e, embora tivesse uma equipe para filmar, era eu sozinho editando, porque não tinha grana. Mas talvez 
em Alagados estivesse mais claro o caminho que eu seguiria, pois tem a coisa de documentário, que me interessava muito e achei que, para o clipe, seria legal. A Novidade tem a ver com isso. Kátia Flávia e É Uma Partida de Futebol, de certa forma, também.

\section{O que é um bom videoclipe para você?}

Um bom produto audiovisual te instiga a fazer alguma coisa. Quando saio de um filme bom, falo: "Tenho que me mexer". Talvez o videoclipe tenha menos essa capacidade, por ser um produto menor, mas, de qualquer maneira, tem que mexer contigo, sendo alegre, triste ou encontrando novas soluções. O que talvez tenha sido minha preocupação inicial é fazer com que a música, não a letra, esteja muito retratada na forma ou no movimento como eu filmava. Sempre tentei fazer com que melodia, câmera e edição tivessem sempre alguma coisa a ver, em geral pela afirmação, mas muitas vezes pela negação, como no clipe do Lobão, em que ele canta uma coisa e aparece outra. Aquele é um clipe ao contrário. E algo que acho fundamental.

\section{O que você levou dos videoclipes para os documentários?}

A Pessoa É Para O Que Nasce, tanto o curta, quanto o longa, tem muito a ver com videoclipe. Primeiro, sempre que vou fazer um documentário, tenho vontade de enaltecer personagens à margem, usando linguagem do videoclipe e da propaganda. Talvez até mais da propaganda do que do videoclipe. Se bem que minha propaganda tem muito a ver com clipe. Também tento fazer coisas experimentais e trabalhar com movimentos de câmera e símbolos nos documentários, o que nem sempre é aceito pelos documentaristas. Muita gente faz restrição ao meu trabalho por causa disso. Mas talvez tenha ultrapassado fronteiras.

Em Pindorama, eu pedi para Lula (Queiroga) compor músicas para levar nas filmagens, pois queria que o filme tivesse cara pop. Cada personagem teria sua música, mas acabou não tendo. Mesmo assim, há um trabalho para colocar os caras em lugar mais elevado. Talvez eu os trate e queira botá-los como artistas como outros quaisquer, de primeira linha. A diferença é que ninguém olhou para eles, pois categoria suficiente eles possuem. A minha idéia é mostrar que, ao invés de ter Caetano Veloso e Chico Buarque, pode ter as três ceguinhas ou os anões.

\section{Teoricamente, o cinema tem muito a ver com videoclipe e vice-versa?}

Nos anos 1980, o cinema foi totalmente influenciado pelo videoclipe, mas logo depois ele foi beber no cinema em geral. Houve essa troca. Também acho que qualquer diretor se interessa em fazer qualquer coisa, seja uma bobagem para o fundo de uma peça ou de um desfile até um filme em $35 \mathrm{~mm}$, em longa-metragem. Gosto de fazer tudo que me desafie. Talvez, por isso, quando me desafiam menos, perco um pouco o interesse. Aí procuro as coisas mais simples e banais, pois, se você não se coloca desafios até nelas, corre o risco de cair do cavalo. Nas vezes em que isso aconteceu, achei que já sabia tudo e percebi que não era nada disso (risos). É preciso trabalhar duro para chegar ao resultado.

\section{Quais são suas principais referências quando faz um videoclipe?}

Varia de caso para caso. Em Mandrake e os Cubanos, queríamos fazer uma espécie de anticlipe e um clipe engraçado, por isso olhamos todos os filmes de comédia. Não destacamos o Samuel (Rosa, vocalista), que aparece no fundo, mas trabalhamos direto com Haroldo (baterista), que ensaiou com uma coreógrafa. Tivemos tempo, porque Samuel estava jogando Rock Gol (competição de futebol realizada pela MTV Brasil). Esse seria meu último clipe e realmente foi. Então queria outra linguagem, meio cafona, cheia de referências. Depois dele, Rap do Real, eu não ia dirigir, mas Raul e Leo, que dirigiriam, me 
chamaram porque não estavam segurando a onda. O roteiro era todo deles. Sossego era abertura de novela. Não era bem um clipe. Três Lados também seria do Raul e do André, mas não deu muito certo e a gravadora Sony me chamou para fazer. Fiz uma espécie de direção de criação para Pato Fu com o Duda, que trabalha com animação. Dei motivação para ele trabalhar. Também fiz Fernanda Takai cantando uma das músicas das ceguinhas.

Minhas referências vem dos documentários e do cinema francês, italiano e independente americano, principalmente das décadas de 1950, 1960 e 1970, quando eu era freqüentador assíduo de cinema. Sempre que podia, estava no cinema. Nos anos 1980, aparece o vídeo VHS. Antes, você tinha que ir ao cinema para ver um filme ou ao cineclube para ver um $16 \mathrm{~mm}$. Não tinha outra forma.

Asdrúbal (Trouxe o Trombone, grupo teatral) também tem muito a ver com tudo que fui fazendo. Acho que me formei muito com eles. Outra coisa é a rua. Eu olho muito a rua e estou ligado no que as pessoas fazem. Esse é meu principal objetivo: olhar para as pessoas.

$\mathrm{Na}$ publicidade, havia a indústria da referência. Você ia fazer um cara comendo sanduíche em filme de MacDonald's, pegava referências de como filmaram a mordida, etc. Dizia: "Quero ver como todo mundo filmou alguém jogando bola". Aí olhava: "Isso me interessa. O cara filma assim, assado". É um estudo.

\section{Você costuma ver videoclipes e utilizá-los como referência?}

Eu adorava ver videoclipe, e achava super legal, mas não vejo mais MTV. Desde que fiz $\boldsymbol{F M}-\boldsymbol{T V}$, na TV Manchete, tive a idéia de fazer $\boldsymbol{A M}-\boldsymbol{T V}$, de música brega, brasileira, e que acho que daria super certo, com Fabio Jr. conversando com donas-de-casa e porteiros, dando dicas de pequenas coisas, como tirar manchas, e botando videoclipes de Altemar Dutra e essa galera que a gente nem conhece. Eu apresentei à Globo, mas queriam fazer com Luiz Fernando Guimarães. Falei que era legal também, mas que seria meio de sacanagem. Espero que um dia ainda faça.

\section{Desde que você começou, o videoclipe brasileiro teve evoluções?}

Hoje em dia, eu não conheço mais. Mas teve evolução, como a de que deixou de ser videoclipe para ser só clipe, feito em película. Porém, quando começou a decair, o vídeo voltou. O tempo trouxe também investimentos maiores, comprometimento com o mercado e melhoras técnicas. Breno Silveira foi muito marcante na publicidade e no videoclipe. A partir da fotografia dele, acho que o videoclipe passou a ter um pouco mais de brilho. Ele trouxe essa cara para o trabalho da Conspiração. Esteticamente, eu nunca cheguei perto, talvez por falta de interesse.

\section{Como foi a mudança do analógico para o digital?}

Na montagem cinematográfica, você pode mexer nos planos sem alterar a estrutura. $\mathrm{Na}$ fita de vídeo, espaço e tempo estavam juntos. Por isso, não era possível mexer no meio, porque sobraria um pedaço da fita e, ainda mais com Umatic, perderia uma geração, ao não ser que pegasse de novo o original. Então, na hora em que queria recolocar um plano, ficava um rabinho de outro ou, quando refazia, perdia mais um pedaço. Geralmente, no videoclipe, você coloca a música e vai colando imagens em cima. Eu costumava abrir a música e inserir coisas. Outra diferença é que já chegávamos, na ilha, sabendo mais ou menos onde começar. Hoje em dia, na edição não-linear, consegue-se mudar tudo o tempo todo e mexer a vontade, tira o início e põe no meio, o meio no final.

Em 1996, 1997, já estávamos com o não-linear funcionando e, no início, todo mundo apanhou à beça. Era muito engraçado. Determinadas coisas que queríamos fazer, os editores falavam: "É impossível". E sabíamos que era possível. Foi um período de descobertas, em que todo mundo apanhou muito. Mas, como os cineastas mais velhos nem pensavam na edição em vídeo, não conseguiam entender, eu sei claramente como funciona 
a edição não-linear, só que não quis aprender. Naquela época, eu ainda tinha uma ilha Umatic. Então o que fazia era editar um off-line, com o que queria e, mesmo se gerasse muitas vezes, depois eu recolocava os planos, porque era mais fácil. Uma coisa que me dava o maior pavor era o tempo que levava para renderizar um videoclipe, às vezes vinte $e$ quatro horas, e, se depois descobria que não era nada daquilo, precisava esperar mais vinte e quatro horas. Algo absurdo, ainda mais para o mercado publicitário.

\section{Que tipo de visibilidade o videoclipe te deu?}

É difícil perceber, mas o retorno era muito bacana. Um trabalho sempre me levou ao outro, o que significava que as pessoas estavam gostando do que eu fazia. Mas não fui logo de cara para a MTV. Demorei um pouquinho. Talvez tenham achado que eu já estava meio passado. Aos poucos, porém, o negócio foi retomando. As pessoas da publicidade viam muito MTV e começaram a me chamar por ter essa fama do moderninho, embora não sei se era. Jamais me preocupei com isso. Quando não sabiam exatamente o que fazer, diziam: "Quero uma coisa moderna, um clipe". Então me chamavam e, muitas vezes, eu resolvia. Nesse sentido, me ajudou muito no mercado publicitário, assim como os documentários.

\section{Qual era a importância de ter um videoclipe premiado?}

Nos anos 80, Alagados ganhou dois prêmios - um da Associação Brasileira dos Produtores de Disco (ABPD) e outro no (festival) Riocine, de melhor videoclipe. No ano seguinte, com $\boldsymbol{A}$ Novidade, eu também ganhei. Devo ter ganhado também prêmios em outros festivais. Depois só ganhei prêmio com É Uma Partida de Futebol, melhor clipe pelo júri oficial e melhor montagem no VMB. Mandrake acho que ganhou só no júri popular. No júri oficial, quem ganhou foi (André) Abujamra, com (a banda dele) Karnak. Mas, nem sempre, o seu trabalho de maior projeção ou o que você acha melhor irá, necessariamente, ganhar prêmios. Depende muito da composição do júri e, no caso de prêmio popular, há pessoas que botam os fãs para votar, o que acontece também em festivais de cinema. Então prêmio é um reconhecimento. Mas, no final das contas, para nós, diretores, se não ganhamos é uma decepção, e, se ganhamos, entendemos que arranjaram três caras no júri, que, por acaso, gostaram do nosso filme. Já, no outro festival, o cara achou horrível. Participei de júri em que um intelectual ou um crítico importante ficava: "Eu gosto muito desse filme". "Mas é uma porcaria, porque você gosta?". "Esse personagem foi muito importante na minha infância". Então fico meio ressabiado em levar prêmio muito a sério. $\mathrm{O}$ importante é o namoro do filme com o público. Isso, sim, me interessa. Penso no meu público como se fosse eu e fico tentando surpreendê-lo.

\section{Você tem controle da circulação e repercussão de cada videoclipe?}

Não tenho. O clipe é vendido para a gravadora. Você é contratado e vende por um preço. Acho até que não é uma coisa muito legal e nem muito justa. A vida inteira nós não podemos reclamar direitos autorais. Talvez se entrássemos com algum recurso, fosse possível reverter. Também não se ganha dinheiro com videoclipe. Em nenhum caso, me lembro de ter ganhado. Havia um cachê simbólico, porque a grana era pequena ou, quando tinha muita grana, queríamos fazer algo legal. Afinal de contas, era uma diversão e algo meio autoral que estaria no ar. Como eu fazia publicidade para ganhar dinheiro, no clipe, ganhava um pouquinho. Já, no documentário, botava dinheiro. 


\title{
Você tem algum sistema de arquivo e catalogação do seu trabalho?
}

Tenho (uma sala imensa com todas as fitas organizadas e arquivadas).

\author{
Você filma para arquivo de imagens, que podem ser usadas no futuro, em \\ algum trabalho?
}

Eu filmo e fotografo muito, tanto na produtora, como com a minha família. Muitas vezes usei imagens de arquivo, que descubro por aí. Fiz um videoclipe inteiro em cima de imagens lindas de arquivo, do final dos anos 40. Elas eram de um casal que se separou numa briga horrorosa e não as cedeu. Era o clipe Três Lados, do Skank, que ficou pronto. A filha deles havia me dado essas imagens.

\section{Com a saída do videoclipe da televisão para as novas mídias, você vislumbra algum caminho para ele ou estamos em um momento de ruptura?}

Os DVDs ainda vendem relativamente bem. O Youtube é excelente para o videoclipe. Mas estamos num momento de transição, onde quem perceber qual é a saída mais rápido se dará bem. Como estou fora desse mercado atualmente, vejo de longe e acompanho muito pouco, percebo que toda a indústria do entretenimento está num momento de mudança. A indústria fonográfica foi a primeira a ser atingida, pois tinha lucros absurdos e, de repente, os piratas surgiram e perdeu-se o controle. Mas a pirataria só existe porque os donos do poder também estão explorando. Se os preços fossem mais justos, a diferença com a pirataria não seria tão grande e as gravadoras teriam conseguido sobreviver. Esse negócio da pirataria tem um lado horroroso de botar bandidos no poder, embora os que estejam no poder não sejam menos bandidos, e tem uma ligação com a produção de armas. Mas há também a democratização da informação. Hoje em dia, quem sabe ler e tem um computador acessa qualquer informação do mundo.

\section{Para você pode ser ainda interessante fazer videoclipe?}

Claro que sim. Se um amigo falar: "Vamos fazer" e tiver tempo, eu não falo, não. O videoclipe me deu a possibilidade de fazer o que quiser. Enquanto isso foi possível, continuei fazendo. Quando começou a se tornar cada vez menos possível, deixei de me interessar tanto. Então, se for nessas condições, é possível que volte sim, entre um filme e outro, porque estou focado nisso. O problema é saber onde isso acontecerá. Nos anos 80 , se o videoclipe passasse uma vez no Fantástico, estava pago várias vezes, porque a mídia lá era caríssima. Hoje, se vai para o Youtube e passa 50 mil vezes, não fala com milhões, mas, com um público específico, o que pode ser muito bom também. O problema é que esse público encontra músicas piratas na Internet ou na rua, o que reverte em shows, grande saída dos músicos. Os shows vão ficar valorizados e, como haverá menos dinheiro, talvez voltem os shows mais espontâneos e orgânicos. 


\section{Videoclipes Comentados de Roberto Berliner}

\section{DÉLICA - DULCE QUENTAL}

Data: 1984

Roteiro: Roberto Berliner

Direção: Roberto Berliner

Assistente: ...

Produção: ....

Fotografia: Walter Carvalho

Operador de Câmera (VT): Paulinho Violeta

Direção de Arte: ...

Figurino ...

Edição e Montagem: Roberto Berliner

Edição de Som: ...

Figurantes: ...

Orçamento: ...

Contratante/Financiador: Fantástico - Rede Globo

Premiação: ...

Materiais Utilizados: Umatic.

\section{$\underline{\text { História do Videoclipe }}$}

Eu conheci a Dulce Quental no I Festival Vídeo Rio, em 1983, quando ganhei prêmio de melhor edição por Ovídio. Ficamos amigos e ela fez uma poesia em que me citava e, no ano seguinte, me chamou para fazer o videoclipe Délica, que tinha muito pouco dinheiro e cuja música tratava de várias coisas. O que fiz foi aproveitar o dinheiro com uma diária bem filmada e fotografada, com Walter Carvalho e Paulinho Violeta, que tinha feito Ovídio, como operador de VT. Também havia um maquiador caríssimo, trazido por ela, que fez uma maquiagem de três horas. A gravação foi feita em estúdio, muito simples, porque eu estava preparadinho para usar imagens de arquivo, quase todas roubadas, daqui e dali. Além de Walter Salles, ninguém reclamou até agora (risos). Ela cantou em posições diferentes e, em determinado momento, botei três Dulces - uma no meio e não lembro se as outras duas estavam inteiras.

Nossa relação era muito aberta e fácil. Na hora de fazer o roteiro, ela certamente me ajudou, porque entendia do assunto. Então trabalhamos um pouco juntos, mas não muito. Foi muito bacana. Ela é uma pessoa ótima e mantemos contato, mas não muito próximo. Foi um bom primeiro clipe, que fiz praticamente sozinho, incluindo a edição, e foi super aprovado por ela.

\section{Heranças e Avanços}

Eu já editava muitas imagens de arquivo e fazia brincadeiras de misturar, nas horas vagas. Sempre pensei em fazer algo assim - pegar imagens de arquivo, o que foi feito até pelo custo do clipe.

\section{Relação Imagem-Música}

Os ruídos são as imagens de arquivo, que vem cada uma de um lugar, sujas e limpas. O clipe era calcado na letra, como sempre, seja pela afirmação ou pela negação, e não sei por que achava que tinha uma coisa globalizada. $E$, além da conexão verbal mais clara, que acho que havia, eu trabalhei muito com o movimento dos objetos ou das pessoas dentro da cena em relação à música, e com uma coisa orgânica de como a câmera se movimentaria em relação ao cenário. Eu também tratei a imagem como se fosse a própria 
música, em harmonia ou em impacto com a batida ou a harmonia. Às vezes, dá certo. Às vezes, não. Nesse caso, foi legal.

\section{$\underline{\text { Marcas }}$}

Edição é algo em que estou sempre muito ligado. Já vinha, de certa maneira, do trabalho com arquivo. Inscrevi Délica atrasado no Fest Rio, mas passou hors-concours e foi um grande sucesso. O clipe me trouxe, principalmente, a longa relação com os Paralamas, através de Bi (Ribeiro, baixista) e João (Barone, baterista). 
ALAGADOS - PARALAMAS DO SUCESSO

Data: 1986

Roteiro: Roberto Berliner

Direção: Roberto Berliner

Assistente: ...

Produção: Sacha

Fotografia: ...

Operador de Câmera (VT): ...

Direção de Arte: ...

Figurino ...

Edição e Montagem: Roberto Berliner

Edição de Som: ...

Figurantes: ...

Orçamento: ...

Contratante/Financiador: Fantástico - Rede Globo

Premiação: ...

Materiais Utilizados: Umatic.

História do Videoclipe

Em Alagados, tinha vontade de fazer documentário pobre, Terceiro Mundo. A letra da música, fala de Alagados, Favela de Maré e Trenchtown, na Jamaica, onde nasceu Jimi Cliff e não sei se Bob Marley também. Eu tinha morado em Alagados, quando fui fazer o Congresso de Abertura da UNE, em 1979, e caí num barraco, que uma menina superpobre da mesma facção, Ação Popular (AP), abriu. Ela abrigou uns sete, que dormiram enfileirados na sala. Todo dia, acordava e tinha que passar pelas palafitas. Sete anos depois, estava fazendo o clipe cuja idéia era juntar a música, que falava desse tipo de gente e do que eu via no dia-a-dia, como o pessoal que morava na Lagoa Rodrigo de Freitas e vivia no esgoto, ou os ambulantes que ficavam atrás da Central. Ou seja, um mundo de onde vem nossa cultura, que é samba, baile funk, etc. Também peguei imagem de arquivo e outra emprestada de um vídeo da Favela da Maré, cedida pela (produtora) Olhar Eletrônico.

Filmar no baile funk foi um pouquinho estranho, mas não se compara a hoje em dia. Até mostro uma revista totalmente real e consegui colocar o João Barone para tocar. Queria botá-los naquele ambiente do qual estavam falando e fazer com que tivessem voz e comportamento ativos. Se não misturasse, ficaria falso. Foram dois dias de filmagem com eles e um terceiro sem eles, documental. Filmamos também o samba no Morro do Estácio, São Carlos, onde havia duas facções e era preciso pedir autorização para elas para ir com Paralamas. Estávamos filmando e, de repente, os garotinhos começaram a dançar, Herbert também e eu estimulei um pouco. Daí as coisas foram surgindo naturalmente através dos nossos movimentos, inclusive de câmera. Eu sabia em que locação iria, para qual pedaço da música, e o que faria: "Aqui vou botar os Paralamas com a favela ao fundo". Amigos apareceram na filmagem nesse dia, por acaso, e também foram se juntando e dando idéias. O clipe foi muito aberto. Filmar é uma festa para mim. Um momento lúdico, maravilhoso. É como um carro descendo a ladeira e você guiando, meio sem freio e precisando chegar ao final com festa.

A relação com Paralamas não era tão consolidada. Então apresentei o roteiro para eles e não sei se a informação de baile funk veio do Hermano (Vianna, irmão de Herbert), que começava a se interessar pelo assunto. A equipe era pequenininha. Eu era um pouco produtor. Ficava na minha casa, com minha máquina de escrever, ouvindo a música várias vezes num paraibão (rádio microsystem) e imaginando milhares de coisas que não sabia se dariam certo. Também gostava muito, e ainda gosto, de olhar em volta e do descontrole de filmar na rua. De repente, por que vou para lá e você para cá? Acho que o roteiro é um pouco isso. Já, na edição, tem que corrigir todos os problemas da filmagem. É um momento decisivo: estraga ou conserta o filme. Em geral, conserto, mas tem o lado angustiante de 
perceber o quanto errei. Nesse caso, fiquei sozinho na edição, operando, mas havia material suficiente.

Heranças e Avanços

De herança, o clipe trazia o documental, que vinha do Super-8, do Circo Voador em vídeo, talvez do próprio arquivo e dos documentários que fazia. De avanços, a confiança talvez de que sabia fazer e a sensação de que era produtor também. Tenho interesse em continuar trabalhando em equipe, pois quero ouvir outras pessoas o tempo inteiro e influenciar alguém. Produzir um monte de trabalhos prejudica bastante a minha carreira de diretor, mas avança no lado de produtor. Então trouxe o lado de diretor, produtor e editor. Ficou mais claro que era capaz de fazer tudo.

\section{Relação Imagem-Música}

Acho que só entra captação de som no final, com o cara falando: "Bra-bra-bra Brasil", ajoelhado na beira do Francisco Bicalho, um canal horroroso (do Rio de Janeiro). O cara estava ali, chegamos com a câmera e ele falou. O clipe tinha essa liberdade e o que me interessou foi tentar fazer com que a música se aproximasse do nosso cotidiano, trazer os Paralamas da Europa, onde eles estavam, para cá. Eles tinham uma influência forte européia, de UB40 e Police, onde conheceram o som da Jamaica e falaram: "Porra, Jamaica é igual a Brasil". Alagados tem uma mistura muito legal de tudo. É rock? É reggae? É samba? Tem tudo ali e queria que tivesse também no clipe. Seguramente, através da música, também fui fazendo os movimentos de câmera e dos personagens dentro do quadro.

\section{$\underline{\text { Marcas }}$}

Esse clipe foi um grande avanço, fez sucesso e se tornou um cartão de visitas. Onde ele passava, era uma referência de Brasil. Logo depois, viajei para o México e ele foi um sucesso lá também. As pessoas começaram a ver que meu negócio era documentário. Ele também me levou a fazer outro clipe com Paralamas, A Novidade, dividindo a direção com Sandra (Kogut, videomaker), e, logo em seguida, me levou também ao Luiz Antonio Silveira, que me convidou para fazer, com ele, o documentário Angola, que tem muito da linguagem de videoclipe, como câmera dançando. 


\section{KÁTIA FLÁVIA - FAUSTO FAWCETT}

Data: 1987

Roteiro: Roberto Berliner e Sandra Kogut

Direção: Roberto Berliner e Sandra Kogut

Assistente: ...

Produção: ...

Fotografia: ...

Operador de Câmera (VT): Renato Laranjeiras (grua)

Direção de Arte: ...

Figurino ...

Edição e Montagem: Roberto Berliner e Sandra Kogut

Edição de Som: ...

Figurantes: Paula Bulamarqui, Vicky.

Orçamento: ...

Contratante/Financiador: Fantástico - Rede Globo

Premiação: ....

Materiais Utilizados: Umatic.

História do Videoclipe

Conheci Fausto (Fawcett) no Circo Voador, em 1981, quando fazíamos parte de um grupo que se encontrava no Parque Lage, depois na casa do Hamilton (Vaz Pereira, diretor). Ele é talvez a figura mais importante da minha geração no Rio, comparável ao Arnaldo Antunes em São Paulo. Só que, embora seja fundamental, continua um pouco à margem, talvez por escolha própria. Tinha grande admiração por ele, para quem já tinha feito Drops de Istambul, clipe-ruído, filmado em teatrinho.

Quando surgiu Kátia Flávia, não me lembro se oferecemos ao Fantástico ou se eles se interessaram e Fausto falou para nós. Certo é que a música, espetacular, começava a explodir. Aí eu e Sandra fizemos o roteiro, com o universo da Rua Prado Júnior, de Copacabana, que é o do Fausto, e três loiras ao mesmo tempo, três Kátias Flávias, que representam todas as que conhecemos. A referência veio do filme Esse Obscuro Objeto do Desejo (1977), de Luis Buñuel, que tem duas atrizes. Uma loira era a Paula Bulamarqui, a outra uma modelo, Vicky. Mais uma vez, era o submundo, do qual Fausto fala tão bem.

Havia uma coisa documental e algo meio ficcional. O plano inicial do filme era começar numa televisão, com a câmera presa numa grua. Alugamos um apartamento na Rua Prado Junior. A câmera viria, faria zoom out. Com o afastamento da grua, desceria e encontraria os pés de uma garota de programa, loira, andando. Lembro que gravei muita gente falando "Kátia Flávia" e "Calcinha", mas não sei se há essas interferências no clipe. Fomos pela Avenida Copacabana, Atlântica e Barata Ribeiro, as três ruas mais importantes de Copacabana, com a câmera suja e tudo meio borrado, e precisávamos trabalhar com uma equipe que não conhecíamos, o que foi um pouco esquisito.

$\mathrm{Na}$ televisão, há um horário e uma estrutura burocrática que, certamente, influencia no resultado. A grua, por exemplo, como foi a primeira coisa que filmamos, não ensaiamos, era difícil de se fazer e estava errado. Mas o cara da TV Globo, marrento, falou: "Deu minha hora. Vou sair para entrar outro". Eu não usava nem crachá. Era o Renato Laranjeiras, que acho que faz Domingão do Faustão hoje em dia, muito bom, gordão. Tive que implorar para ele fazer e aí fez em 15 minutos e ficou bom para caramba. Resolveu, foi embora e entrou outro, que nem me lembro mais quem era.

Talvez tenhamos utilizado duas câmeras, o que pode ter agilizado. A Sandra fazia uma coisa e eu outra, e só nos juntávamos na hora de fazer as cenas mais específicas e complexas. Era uma divisão de trabalho muito igual. Criávamos juntos, o que era muito legal. Um completava o outro. Eu tinha um pouco mais de experiência e ela ajudava muito criativamente. Fausto, acho, obedeceu mais do que deu idéia, até porque a música já falava 
tudo. De qualquer maneira, ele era espetacular. Imitava Mick Jagger nas caras que fazia. Então o personagem era muito forte.

Por mais que tivéssemos referências, de cinema especificamente, nossa idéia era quebrar com a linguagem e com as regras. Tínhamos claras as idéias dos ruídos e de imagens muito pequenas. Quando eu trabalhava na TV Globo, tinha uma cartilha, onde estava escrito que não podia ter takes com menos de 1 segundo. Então: "Vou fazer com menos". O pessoal de lá falava: "Vocês só querem fazer clipe para ganhar prêmio e para se relacionar com o público". "Queremos fazer para nos relacionar com o público mesmo". "Mas fazem coisas esquisitas". Essas coisas nós continuamos fazendo, o que deu certo algumas vezes. Outras, não. Só que nunca mais nos chamaram.

\section{$\underline{\text { Heranças e Avanços }}$}

Foi mais um trabalho que trouxe o lado documental, a edição e talvez um estreitamento na relação com Fausto. Tínhamos planos de fazer um curta-metragem na época. Um avanço foi aprender a me relacionar com equipe grande, diferente do que estávamos acostumados, e aprender a mandar, principalmente em quem não queria obedecer, e a gritar e me fazer respeitar. Tem também o lado autoral, de tentar reforçar o que queríamos. Editamos a dois, Sandra e eu. Então já começava a ser uma coisa mais partilhada. Eu dava uma idéia, ela dava outra. Às vezes, eu saía da ilha, ela mexia; outras vezes, ela saía e eu mexia. Fizemos do jeito que quisemos. Não houve concessões e foi muito bom. Acho que foi o que levou a TV Globo a me chamar para fazer o programa Juba \& Lula, um fracasso. Fiz a parte documental e quem dirigia a outra parte era Jodele (Larcher) e (Nilton) Travesso.

\section{Relação Imagem-Música}

Não me lembro de ter editado a música e nunca consideramos a idéia de traduzir a letra claramente. Falou "óleo", apareceu óleo, "água", água. Tentamos fazer o clima total da música e a coisa orgânica do movimento de câmera, o que fazia parte do meu universo. Não sei nem se pensava nisso ou se era meu lado intuitivo.

\section{$\underline{\text { Marcas }}$}

Essa música virou um sucesso que me levou a fazer não sei se meu primeiro comercial, mas acho que sim, da Casa das Calcinhas, muito mais pela música do Fausto, do que pela nossa competência com clipes. Ligaram-me de São Paulo, da agência pequena que atendia essa loja, e falaram: "Vimos o clipe no Fantástico e queremos fazer um comercial". O cara tinha verba bem pequena. Tivemos que editar a música para ficar dentro do tempo de 30 segundos e fizemos barbaridades, como pegar um guarda-chuva, botar umas linhas e pendurar várias calcinhas. Aquele negócio girava e as calcinhas rodavam em volta da mulher. Criamos também skylines de prédios para botar atrás da janela, como se ela fosse de um apartamento. Era uma coisa totalmente horrorosa.

Às vezes pensamos em coisas que não se realizam ou realizamos coisas que não pensamos. Então, muitas vezes, se emocionam ou riem do que não percebemos. Na hora em que botamos a câmera ali, principalmente na rua, vimos uma vitrine que é boa ou aquele lugar está esquisito ou chega um bêbado, o que gosto muito de usar. 
TRAC TRAC - PARALAMAS DO SUCESSO

Data: 1991

Roteiro: Roberto Berliner e Gringo Cardia

Direção: Roberto Berliner e Gringo Cardia

Assistente: ...

Produção: ...

Fotografia: ...

Operador de Câmera (VT): ...

Direção de Arte: ...

Figurino ...

Edição e Montagem: Roberto Berliner

Edição de Som: ...

Figurantes: Márcia Cabrita

Orçamento: ...

Contratante/Financiador: ...

Premiação: ....

Materiais Utilizados: $16 \mathrm{~mm}$ e Umatic.

História do Videoclipe

No início de 1990, exatamente na posse do Collor, Herbert (Vianna) começou a namorar Lucy e nos encontramos em São Paulo, no hotel Hilton, onde, de repente, entra a Zélia (Cardoso, então Ministra da Economia) e foi aquela correria e desespero. Eu era júri do prêmio Fiat e teria show dos Paralamas, que acabei não podendo ir. Mas, num dia de folga, levei a Lucy na Liberdade e ficamos muito amigos.

Em julho, fui para um festival na França. Voltei em setembro. Fui para São Paulo, passei dois meses e chamaram-me para fazer Tendo a Lua, na casa de Herbert, com várias câmeras de vídeo, todas fora de uso profissional; e Trac Trac, que deveria ser dividido com Gringo Cardia, de quem gosto muito, acho um cara espetacular, conheço desde os tempos do Circo Voador e que, junto com o (artista plástico) Barrão, é autor do logotipo da Antevê. Mas, antes, deixei-os a vontade para fazer só com Gringo.

Trac Trac é uma música do Fito Paez, sucesso na Argentina, e fui em cima da sensação de correria desgraçada do verso "não, não passa o tempo, ao menos para mim". As coisas vão acontecendo, uma atrás da outra. Tive a idéia, então, de fazer o clipe em plano-sequência e em $16 \mathrm{~mm}$, e rodar em menos quadros. Desse modo, você só pega um fotograma a cada um segundo, a cada cinco frames, e, quando projeta, tudo fica mais rápido. Escolhemos um percurso e o fizemos com alguns pontos de corte, porque não dava para fazer tudo seguido. Há um corte quando Bi pega a moto e muda para um dia de semana. Deixamos essa cena pendente. Chegamos, com a câmera que ficava numa traquitana, até a moto, cortamos e, depois, como ela tinha que chegar a algum lugar, fizemos a continuação, até com alguns erros de continuidade, quando o cara entra no ônibus.

No dia da filmagem, por acaso, tinha uma greve de lixeiros e lixo por todos os lados. Já tinha a idéia de colocar mendigos e Gringo aproveitou um dragão de um espetáculo que tinha feito com a Intrépida Trupe. Nas filmagens, eu comandava o que estava sendo filmado e Gringo o que aconteceria à frente. Discutíamos tudo. Por isso, o trabalho ficou muito bem articulado e todo mundo se divertiu. Eu havia chamado Márcia Cabrita, excelente atriz, para fazer uma mendiga, e outro ator, que não apareceu. Como tinha um mendigo ali, falei: "Por favor, dá um empurrão naquela mulher". Eu precisava desse empurrão. Ele deu, continuei a cena e foi ótimo. No começo, a Márcia ficou grilada comigo, mas, logo depois, ficou tudo bem. Coisa que só a rua traz.

Foram dois dias de filmagem, um no domingo, quando filmamos um trecho movimentado do centro da cidade, Rio antigo, que não daria para fazer durante a semana, porque haveria muita gente passando, e facilitava, uma vez que teríamos mais controle e 
poderíamos botar os figurantes, meu cunhado, sobrinho e amigos, e abrir uma barbearia, um bar e uma igreja. Era uma época mais amadora. Aliás, o videoclipe continuou sendo amador. As pessoas gostavam da banda e da gente também. Então arte e profissionalismo misturavam-se muito. Havia tesão e desejo das pessoas de estarem do lado dos Paralamas, participando do glamour da filmagem. Era muito fácil chamar gente para participar. Para os Paralamas, eu falei das idéias e eles gostaram. Já para Gringo, cheguei com a referência de uma vídeoarte, que juntei com a idéia de ser um plano-seqüência, por essa coisa nervosa do dia-a-dia, quando ficamos com milhares de coisas na nossa cabeça, pegamos ônibus, moto, andamos para lá e para cá, e acabamos nas barcas. E aí tem as alegorias, que o Gringo cuidou mais e são nossas fantasias.

\section{$\underline{\text { Heranças e Avanços }}$}

Talvez Trac Trac tenha sido meu primeiro clipe em $16 \mathrm{~mm}$, um avanço, porque o orçamento cresceu um pouquinho. Na verdade, deram-me orçamento um pouco maior para fazer um clipe barato e outro mais caro. Eu tive que me virar com esse orçamento para fazer os dois, Tendo a Lua e Trac Trac. Há a rua e as barcas, referência a $\boldsymbol{A}$ Novidade, assim como atores misturados com o dia-a-dia e a presença da própria Márcia Cabrita.

\section{$\underline{\text { Relação Imagem-Música }}$}

O clipe é acelerado porque achava que a música era acelerada. "Não passa o tempo, ao menos para mim. Tomo comprimidos e sigo sem dormir". Os cortes são imperceptíveis, em princípio. Na edição, tentamos fazer mais ou menos o desenho da música. Sempre que possível eu diminuía ou acelerava um pouquinho, até porque tinha que fazer as imagens caberem no tempo da canção. Para isso, precisei fazer muitas gerações, porque só acelerava $200 \%$. Tinha que ser $200,400,800$. Cada vez sempre um múltiplo de 200. Então queria suprimir frames. A cada 5 frames ficava 1. Mas não tive tempo para fazer isso e o editor, que estava comigo, não teve a manha de fazer. Infelizmente, o clipe perdeu qualidade de imagem.

\section{$\underline{\text { Marcas }}$}

Era um clipe mais difícil de dirigir, pois uma coisa tinha que encaixar na outra, como plano-sequência. Precisava encontrar os melhores pontos de corte para não denunciar muito que não era. Às vezes, foi bem-sucedido. Outras, nem tanto. A MTV fez um concurso para saber onde estavam os cortes. Acho que tinha uns 7 ou 8 cortes. Para minha vivência, foi muito bom, assim como foi muito bom trabalhar com Gringo.

Depois de Trac Trac, fiquei um tempão sem fazer clipe para Paralamas, que talvez já estivessem começando a relação com a Conspiração. Até me chamaram para fazer um clipe, para o qual tive a idéia de utilizar uma casa muito antiga, de madeira, onde faria outro plano-sequência, só com steadicam suave, o oposto de Trac Trac. Tive um probleminha com João Barone e a Conspiração acabou fazendo exatamente a mesma coisa. Com certeza, fiquei na bronca. 


\section{É UMA PARTIDA DE FUTEBOL - SKANK}

Data: 1997

Roteiro: Roberto Berliner

Direção: Roberto Berliner

Assistente: ...

Produção: ...

Fotografia: Victor Lopes, Jacques Cheuiche e Guru

Operador de Câmera (VT): ...

Direção de Arte: ...

Figurino ...

Edição e Montagem: Roberto Berliner e Leo Domingues

Edição de Som: ...

Figurantes: ...

Orçamento: ...

Contratante/Financiador: Sony Music

Premiação: ...

Materiais Utilizados: Duas câmeras de $16 \mathrm{~mm}$.

\section{História do Videoclipe}

Adoro futebol. É uma paixão. Existem coisas que são intuitivas. A música é uma delas. O drible é outra. $E$ a filmagem às vezes também, como nesse caso. Os Skanks estavam na Sony e me chamaram para jogar uma pelada na fábrica de CDs da gravadora. Começamos a jogar e, enquanto eu escorregava para cá e para lá, o time deles deu um banho, 4 a 0 . De repente, meu time começou 4 a 1, 4 a 2, 4 a 3, 4 a 4 e, no finalzinho, 5 a 4 (risos). Como eles são fissurados por futebol, essa pelada esfriou o negócio. Mas passou um tempinho e eles me chamaram para fazer o clipe e para ir a Belo Horizonte. Por acaso, eu, flamenguista doente e eterno rival do Atlético Mineiro, levei duas camisas, uma azul e outra verde. Falei: "Azul Cruzeiro e uma verde qualquer". Mas tinha jogo entre Atlético e Portuguesa, a qual usava camisa verde e ganhou.

Fernando Furtado, um cara muito inteligente e que sempre dá idéias, algumas boas, outras não, como todo mundo, queria fazer, em estúdio, um menino que sonhava em jogar futebol. Eu até comecei fazendo o que ele queria - essa história meio melosa, com o garoto no quarto sonhando com futebol. Não lembro se era estúdio e depois teria um corte para o Maracanã ou se construiríamos uma casa no estádio.

Com aquela música, o clipe não poderia ser meloso e piegas, e falei: "Vamos fazer futebol, futebol. Pegar um clássico no Mineirão, porque vocês são de Minas e não tem sentido fazer no Maracanã". De cara, sabia que dois eram cruzeirenses e dois atleticanos. Então precisava ser Cruzeiro e Atlético, e teríamos que aguardar até que eles jogassem. Samuel (Rosa, vocalista do Skank) comprou a minha idéia. Só que, por algum motivo, Haroldo não poderia estar no Mineirão. Então o filmei no Maracanã, com a bateria no centro do gramado, algo que não dá nem para perceber. Filmamos também eles tocando em um dos vestiários, com o túnel para o gramado todo alagado de água da chuva, o que deu um brilho.

Eu estava fazendo Som da Rua na Bahia e cheguei a uma da manhã de viagem. Walter Carvalho fotografaria. Chequei com a produção: "Tudo certo para amanhã? Vamos buscar Waltinho?". "Ele vai por meios próprios". Então liguei para ele: "Waltinho, tudo certo?". "Rapaz, não vou poder ir". "Como assim?! Não tem isso. Você vai". Tive uma discussão com ele e chamei Guru, assistente de câmera que não sei se já fotografava. No meio da manhã, chegou também Jacques Cheuiche, que fazia Som da Rua e terminou de fotografar. Ficamos com duas câmeras $16 \mathrm{~mm}$, o que facilitou o trabalho.

No Mineirão, foi um dia intenso, porque esse foi um clipe caro, com várias câmeras e quatro equipes de filmagem. Houve um jogo entre artistas e ex-jogadores. Não sei como eles separaram. E, logo depois, Cruzeiro e Atlético, partida que não tinha muito valor no 
Campeonato Mineiro, tanto que acho que o Cruzeiro botou o time reserva. Então, uma semana antes, comecei a ir aos programas esportivos de lá, incendiar as torcidas. Num deles, me perguntaram qual era meu time e falei. "E em Minas?". "O Atlético sempre nos ajudou muito. É freguês do Flamengo". E aí os caras no estádio me hostilizaram. Eu não podia ir para a torcida do Atlético de jeito algum. Então fiquei na torcida do Cruzeiro, como estava planejado.

Nossa idéia era, enquanto começávamos na sede da torcida do Atlético, também haveria uma câmera pela cidade, com Vitor Lopes, co-diretor com missões estabelecidas, pegando situações que remetessem a futebol. Só que ele desobedeceu totalmente. Ao invés das situações documentais que eu precisava, com nenhuma situação armada, ele pegou uma bola e começou a armar situações com ela. Chegou, inclusive, a, no final do jogo, filmar uma mulher pelada com o campo sendo regado. Ou seja, ele rodou, em $16 \mathrm{~mm}$, coisas que não entraram no clipe. Mais cedo, havíamos feito também cenas de bola entrando no gol e detalhes. Também filmamos o cara realmente abrindo e fechando o portão do estádio.

Nós tivemos um trabalho imenso de edição. Leo até ganhou prêmio. Como não foi uma partida muito emocionante, tivemos de botar emoção. Se houvesse planos longos de grandes jogadas, faltas, gols incríveis, acho que os teria deixado. Mas tinha apenas uma quantidade de planos bem pensados, fechados de pés, de fúria da torcida, essa coisa nervosa do futebol, meio coliseu, e de identificação de jogadores, que achávamos que daria mais clima, mesmo com autorização de todos. Por um acaso, o jogo foi 1 a 1 , o que foi muito bom, porque tinha gol de um lado e do outro. Mas, na edição, durante muito tempo, não tinha gol, até que falei: "Isso é quase sexo sem gozo. Tem que ter bola na rede". Botamos e foi espetacular.

\section{Heranças e Avanços}

Acho que trago experiências do filme da Copa de 94, onde eu não filmava futebol, mas fazia documentário. Na minha equipe, o diretor de fotografia era Walter Carvalho, por isso o chamei para fazer a fotografia do clipe. Eu ficava observando o jogo e, quando começava a chegar perto da área, tínhamos que filmar e saber pegar os melhores momentos de torcedores e técnicos.

Nos anos 90, a indústria da referência foi muito importante para mim, por causa da publicidade. Eu olhava muito tudo e sou muito próximo do Alexandre Niemeyer, herdeiro do Canal 100, que é um tesouro. Eu quero transformar aquilo em um museu. A edição era mais focada nos lances, lançamentos, gols. Uma marca registrada era a câmera mais fechada possível, no nível do gramado. Por isso, como herança, colocamos uma das câmeras no gramado, só perseguindo a bola e os pés.

Tinha avanços no sentido de eu fazer reuniões com uma equipe com quatro técnicos de som, quatro fotógrafos, quatro assistentes de câmera e quatro produtores.

\section{$\underline{\text { Relação Imagem-Música }}$}

Infelizmente, a MTV suprimiu, mas eu começava com uma frase do João Saldanha, o comentarista que o Brasil consagrou, talvez um dos mais importantes nomes do futebol brasileiro e que fez parte da minha vida inteira: "Futebol é um ramo da arte". Procurei várias frases e até nem achei a melhor. Há também a locução de rádios locais, que é sempre muito bacana e que eu gosto muito. Pedimos autorização e pegamos as fitas. A música, que tem tudo a ver com futebol, é totalmente editada, porque corto e boto a interferência das torcidas. Cada equipe tinha seu técnico de som. Queríamos que as imagens tivessem o ritmo da música e a emoção e o ritmo do futebol. Acho que o clipe foi muito bem sucedido. 
Marcas

Tem os cortes rápidos que eu já fazia e todo mundo começou a fazer. O videoclipe é associado a cortes rápidos de imagens. Tem também a coisa de querer que a edição seja orgânica e que o movimento traduza o sopro dos metais ou uma batida da bateria. Eu e Leo nos dedicamos muito à edição. Nosso trabalho tem muito a ver com tempo de dedicação. Nunca resolvemos uma edição de uma hora para outra, a não ser quando fomos obrigados a fazer isso em propaganda. E, nesse clipe, trabalhamos muito. 


\section{CAIO NO SUINGUE - PEDRO LUIS E A PAREDE}

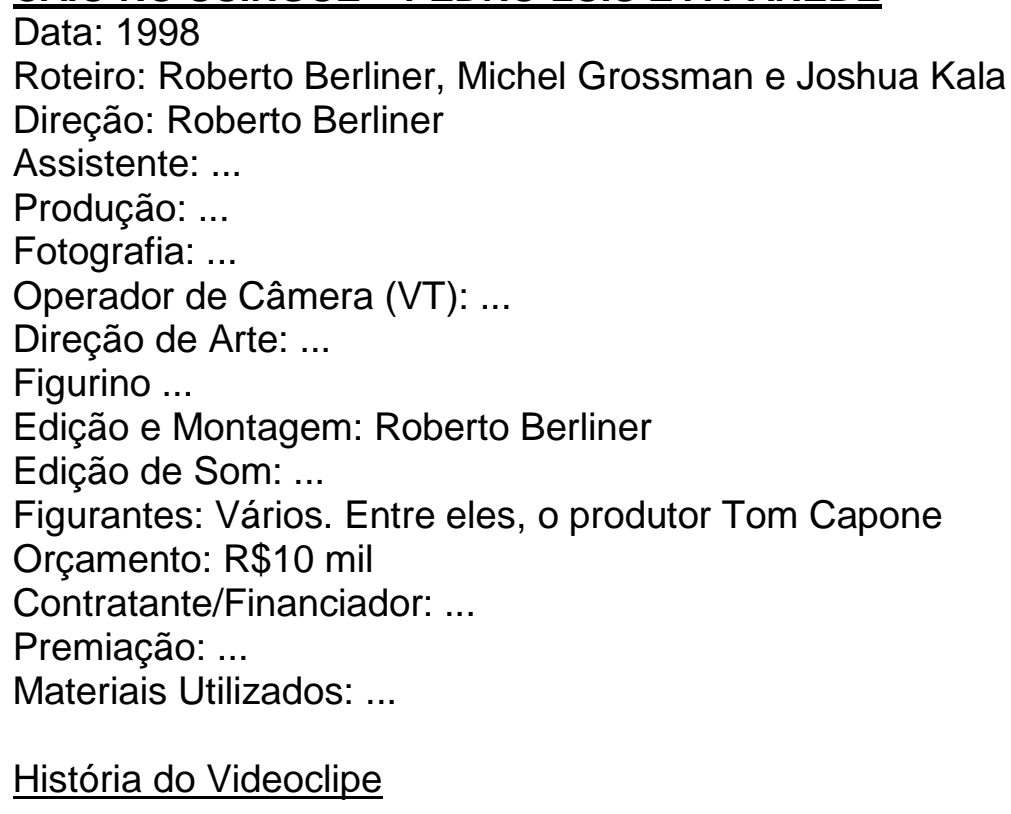

Minha memória apagou Pedro Luis, um cara muito especial, do Circo Voador, quando o filmei em VHS. Então o conheci mesmo em 1996 e ficamos muito amigos, com outros amigos em comum, como Lula Queiroga e Lenine. Ele falou: "Faça o que quiser, estou na tua". Eu estava muito encantado com um cara chamado Michel Grossman, artista plástico que fazia performances. Como estava fazendo outros trabalhos de publicidade, Michel e Joshua Kala, americano artista plástico, muito amigo, que já voltou para os Estados Unidos, desenvolveram a idéia e conversaram com a banda. Falei: "Se ela topar, eu topo". Michel teve a brilhante idéia de botar a banda vestida de galinha, de cócoras, batendo as asas. Eu cheguei de viagem, na TV Zero, e estavam todos ensaiando: "Cocorocó". Olhei aquela cena e pensei: "Isso não vai dar certo". Fiquei apavorado e chamei o Pedro: "Está tudo bem?". "Estou na tua. Se achar isso legal, eu entro". "Não acho que isso é legal". Na verdade, tinha falado que, se a banda topasse, eu topava, mas ela topou porque achava que era idéia minha. Então tive desavença com Michel, que não entendeu e ficou super triste.

Como o clipe não tinha dinheiro, resolvi: "Vou pegar o que tem e usar em negativo, câmera e luz. Vou ver uma locação barata e botar todo mundo pelado, com planos interessantes de gente bonita, feia, simples". Chamei pessoas de todos os tipos e usei muito a plasticidade delas, quase como fotografias. A idéia é muito simples: usar os corpos, o que talvez a palavra suingue tenha me levado a fazer. Mas as pessoas nuas não representavam um suingue. Certamente, tive outras motivações também. Joshua, que dirigiu comigo, me disse que o mandei ir embora do set. Não me lembro, pois minha memória é muito ruim. Provavelmente, ele estava atrapalhando. São coisas que acontecem. Achei que o ambiente tinha sido harmônico.

O clipe teve vários figurantes, muito felizes, pois deixaram de aparecer no fundo. A banda topou na hora. Aliás, teria topado o negócio da galinha também. E tem a participação especialíssima do querido e falecido produtor Tom Capone, que falou: "Tiro tudo, mas não tiro a minha bota". E o ruído foi o próprio nu, que a MTV, por bobagem ou sei lá o quê, passou pouquíssimo e sempre depois da meia-noite.

\section{$\underline{\text { Heranças e Avanços }}$}

Herança, eu acho que é a liberdade de criação, muito legal e vinda dos clipes anteriores. Ali, talvez tenha ido ao extremo de botar todo mundo pelado. Hoje em dia, tem artista que faz isso, mas acho que não se fazia. 
De avanço, tem a plástica do nu, do belo e do feio, da mistura. Eu lembro de ter me baseado muito em fotografias, de todos os tipos e décadas. A geometria me interessou muito, mas sem perder a emoção.

\section{$\underline{\text { Relação Imagem-Música }}$}

Repetem-se os meus caminhos anteriores, como os movimentos de câmera.

\section{Marcas}

A estética sempre está presente. Eu trabalhei com gente mais suja, misturada com gente mais limpa. O clipe começa com as pessoas vestidas tirando a roupa e a figurinista resolveu tirar também. Levei um susto. De repente, ela apareceu no set pelada. Um cara começou a ter ereção no meio da filmagem. Uma menina não quis tirar o sutiã. Acabou usando, mas ficou chato. A equipe falou: "Por que estamos pelados e vocês não?". Mas, como estávamos carregando equipamentos, acabamos não ficando. Seria esquisito. $\mathrm{Na}$ verdade, o que queríamos era imagem e não uma performance da equipe. Havia crianças também, filhos da galera, que hoje estão grandes. A coisa da família, da mistura de classes, da geometria do corpo, da beleza da feiúra, e da feiúra da beleza, ficaram marcadas. Há também algo meio hippie e um momento que homenageia a capa do disco do Jimi Hendrix (Electric Ladyland). 


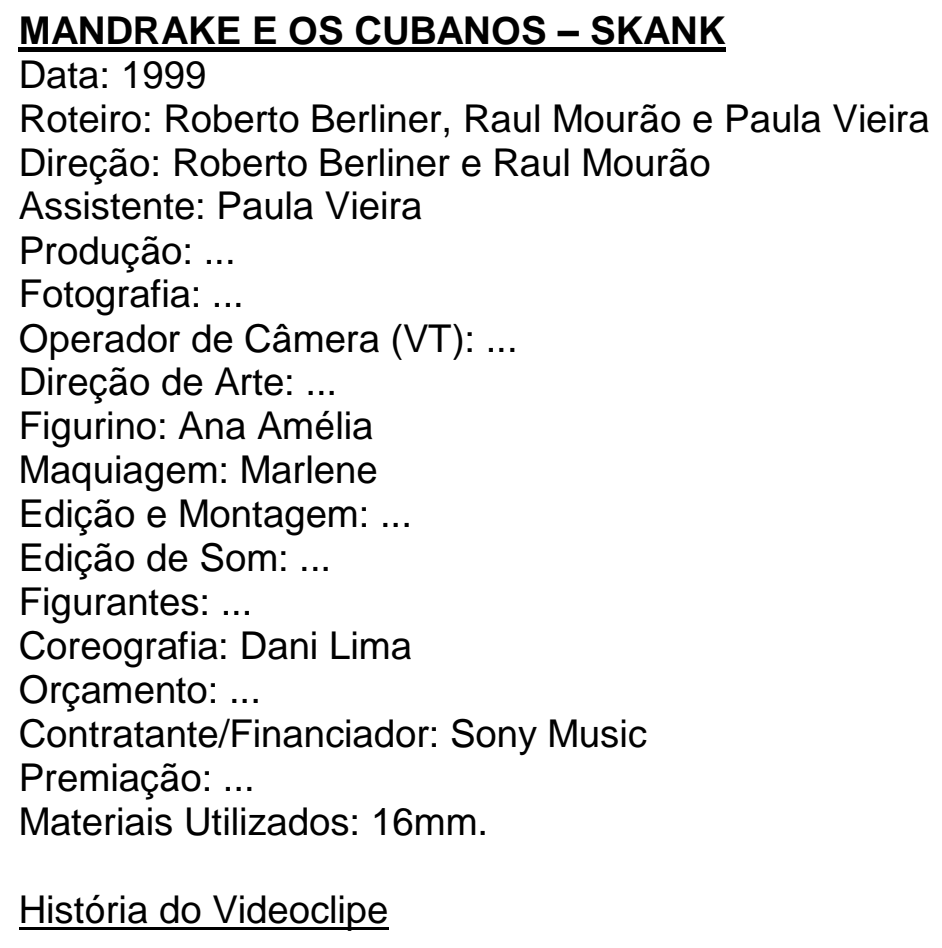

A idéia é minha, do Raul Mourão e da Paula Vieira, assistente de direção, roteirista e que, apesar de não ter assinado a direção, teve importância muito grande. Deveria ter assinado. Nós queríamos fazer um anticlipe, bem-humorado, já que eu tinha feito clipes de todos os jeitos e achávamos que a linguagem estava esgotada e que a música demandava mágica. O Mandrake, das histórias em quadrinhos, era capaz de fazer as pessoas terem a sensação de que, de repente, ele estava diante de um leão e não existia leão ali. Era uma época em que eu estava fazendo muita propaganda, então pedia referências de todos os lados e, principalmente, Raul e Paula foram atrás. Então tem muitas referências de Mr. Bean, Jerry Lewis, Peter Sellers. Uma cena, que achássemos interessante, nós transformávamos. Outras fazíamos igual. Algumas coisas nem tinham referência. Nós inventamos.

Samuel seria coadjuvante e Haroldo, que é muito engraçado, transformado em estrela. O conceito é esse. Lelo é muito tímido. Henrique ainda consegue disfarçar a timidez. Mas nenhum dos dois toparia fazer. Haroldo também é meio antiestrela, anti-bandleader. É aquele cara meio bobo, gente como a gente. Por isso, achava que conseguiria quebrar a coisa do ídolo e conseguimos. Ele foi exatamente o que pensávamos e entrou na viagem total. Talvez tenha dado um palpite ou outro: "Vou fazer uma cara mais assim". Sabíamos que ele não era um ator, mas um antiator. Uma coisa meio dura, estranha, espetacular. A banda também comprou a idéia de que não precisava, naquela época, se vender enquanto imagem. A imagem do Samuel já estava consolidada. E eu sempre achei chatas poses e roupinhas imitando isso e aquilo. Por isso, resolvemos fazer um esculacho geral. Nem sei se isso passa, mas ficamos muito satisfeitos com o resultado.

Tem um trabalho de direção de ator e de coreografia muito grande da Dani Lima, coreógrafa, que tem um grupo de dança, era da Intrépida Trupe e que eu conhecia desde o Circo Voador no México, em 1986. Ela dançava, fazia circo e criou uma coreografia espetacular. O papel dela foi fundamental, claro que com a minha orientação. Ajudou muito com idéias e know-how. Minha mulher, Ana Amélia, também teve um papel importante como figurinista. A maquiagem foi da Marlene, maquiadora espetacular. A maquiagem é exagerada, como figurino e coreografia, até pela bagunça e efeitos meio toscos.

Foram dois dias de filmagem puxadíssimos. Teve diversão e estresse. Trabalhávamos com dois cenários, se não me engano. Enquanto um era feito, filmávamos no outro. Aí mudava, desmanchava um, que começava novamente a ser preparado. Como Raul Mourão é artista plástico e Paula é assistente de direção e me ajudou bastante, na 
hora, quem dirigia era eu mesmo, com Raul em volta, dando uma idéia ou outra. Esse clipe fez muito sucesso com as crianças. Elas viam muito. Meus sobrinhos e filhos pedem até hoje: "Bote o chame chamê"

\section{Heranças e Avanços}

Ali, sim, eu fiz um clipe diferente de tudo que tinha feito. Talvez tenha influência do Asdrúbal (Trouxe o Trombone, grupo de teatro dos anos 1970), com a coisa teatral e bemhumorada. Havia uma representação muito simples e simbólica, e talvez também a vontade de querer quebrar com o que está acontecendo e fazer uma coisa esculhambada, que não se faz.

O que eu trago de todos os trabalhos são os erros. Eu sou muito ligado nos erros e sei exatamente onde errei em cada um deles. Isso é uma coisa que vai ficar para o resto da vida. "Poderia ter mexido nisso e naquilo". Umas bobagens, tipo uma recuada do Haroldo, que ficou muito junto com as pessoas que o perseguem. Ou que deveria ter insistido em fechar o clipe como queríamos e, no final, ele virou meio um resumo de tudo e não uma obra fechada. Acho que o salvamos, mas ele dá uma esculhambadinha no final, pois não tive tempo de filmar tudo.

De avanço, teve estúdio e controle total do que faria e do que aconteceria em cada minuto. O clipe foi quase todo assim.

\section{Relação Imagem-Música}

Tem o desenho da música, mas sem seguir o que a letra diz. Tem ruído de som, algo proposital e sempre presente nos meus clipes. Acredito que o som potencializa a imagem. Você vê a música. Bota a mesma cena com ou sem música e saem significados completamente diferentes. Nesse clipe, achava que tinha que ter som ambiente, porque não gosto quando a imagem fica muito limpa do som, como se visse as coisas acontecendo e só houvesse uma música atrás. Fica falso. Às vezes, gosto muito de música quando ela está no cinema. Só que, quando boto numa cena, tão alegre ou triste quanto ela, não cabe.

\section{Marcas}

Certamente me marcou, porque é um clipe que gosto muito. A ficção, que uso nos meus documentários, já usava. O tosco e a brincadeira, também talvez tenham se acentuado. O bom-humor foi especialmente marcante. $\mathrm{E}$ era para ser meu último clipe, porque queria me dedicar mais a outras coisas. Percebi que dedicava tempo imenso para fazer o que não dava dinheiro e não era o meu foco principal - cinema. Se era para não ganhar dinheiro, preferia investir mais nos documentários. 
Clipeografia (de acordo com memória de Oscar Rodrigues Alves)

\begin{tabular}{|c|c|c|c|}
\hline ANO & INTÉRPRETE & MÚSICA & DIREÇÃO \\
\hline 1992 & Batakotô & Quitambô & Oscar Rodrigues Alves \\
\hline 1995 & João Marcelo Bôscoli & Flor do Futuro & Oscar Rodrigues Alves \\
\hline 1997 & Cidade Negra & Realidade Virtual & Oscar Rodrigues Alves \\
\hline 1998 & Cidade Negra & Já Foi & Oscar Rodrigues Alves \\
\hline 1998 & Djavan & Eu Te Devoro & Oscar Rodrigues Alves \\
\hline 1998 & Cidade Negra & A Estrada & Oscar Rodrigues Alves \\
\hline 1998 & Cidade Negra & A Cor do Sol & Oscar Rodrigues Alves \\
\hline 1999 & Djavan & Acelerou & Oscar Rodrigues Alves \\
\hline 2000 & Djavan & Esquinas & Oscar Rodrigues Alves \\
\hline 2001 & Gabriel O Pensador & Astronauta & Oscar Rodrigues Alves \\
\hline 2001 & Gabriel O Pensador & Até Quando? & $\begin{array}{l}\text { Oscar Rodrigues Alves e } \\
\text { Nando Cohen }\end{array}$ \\
\hline 2001 & Frejat & Amor Pra Recomeçar & $\begin{array}{l}\text { Oscar Rodrigues Alves, } \\
\text { Pietro Sargentelli e } \\
\text { Marcelo Trotta }\end{array}$ \\
\hline 2001 & Djavan & Cair em Si & Oscar Rodrigues Alves \\
\hline 2001 & Simoninha & É Isso Que Dá & Oscar Rodrigues Alves \\
\hline 2001 & Gabriel O Pensador & Tem Alguém Aí? & Oscar Rodrigues Alves \\
\hline 2001 & Zélia Duncan & Alma & Oscar Rodrigues Alves \\
\hline 2001 & Titãs & Epitáfio & $\begin{array}{lll}\text { Francisco e } & \text { Oscar } \\
\text { Rodrigues Alves } & \end{array}$ \\
\hline 2001 & Cidade Negra & A Flecha e o Vulcão & Oscar Rodrigues Alves \\
\hline 2001 & Capital Inicial & Quatro Vezes Você & $\begin{array}{l}\text { Oscar Rodrigues Alves e } \\
\text { Hugo Prata }\end{array}$ \\
\hline 2001 & Titãs & Isso & Oscar Rodrigues Alves \\
\hline 2003 & Skank & Dois Rios & Oscar Rodrigues Alves \\
\hline 2003 & Bro'z & A Prometida & Oscar Rodrigues Alves \\
\hline 2003 & Skank & Vou Deixar & $\begin{array}{l}\text { Oscar Rodrigues Alves, } \\
\text { Marcelo Presotto, Luciano } \\
\text { Cury e Adriano Goldman }\end{array}$ \\
\hline 2003 & Titãs & $\begin{array}{l}\text { Eu Não Sou Um Bom } \\
\text { Lugar }\end{array}$ & Oscar Rodrigues Alves \\
\hline 2003 & Titãs & Enquanto Houver Sol & Oscar Rodrigues Alves \\
\hline 2004 & Cidade Negra & Perto de Deus & Oscar Rodrigues Alves \\
\hline 2004 & Titãs & Provas de Amor & Oscar Rodrigues Alves \\
\hline 2005 & Gabriel O Pensador & Palavras Repetidas & $\begin{array}{l}\text { Oscar Rodrigues Alves e } \\
\text { Nando Cohen }\end{array}$ \\
\hline 2005 & Jota Quest & Além do Horizonte & Oscar Rodrigues Alves \\
\hline 2006 & Skank & $\begin{array}{l}\text { Uma Canção É Pra } \\
\text { Isso }\end{array}$ & $\begin{array}{l}\text { Oscar Rodrigues Alves, } \\
\text { Alexandre Cruz e Nando } \\
\text { Cohen }\end{array}$ \\
\hline
\end{tabular}




\section{Entrevista Completa de Oscar Rodrigues Alves}

\section{Como você, formado em Jornalismo, chegou ao audiovisual e ao videoclipe?}

Jamais pensei em fazer videoclipe, mas sempre estive muito perto da música por tocar bateria. Sempre teve roda de samba na minha casa. Minhas irmãs tocam e cantam. Minha mãe também é uma pessoa super musical. Ao mesmo tempo, meu pai sempre teve câmera e tenho tio documentarista, que já morreu. Meu avô comprou uma câmera para filmar meu pai, que depois nos filmou em 16, Super-8 e VHS. Ou seja, ele sempre foi ligado em tecnologia. Foi rádio-amador também. Válvula, botão e transistores foram muito presentes na minha infância.

Eu queria ser político. Sempre gostei muito de política e de História, mas fui ser presidente do grêmio do (Colégio) Palmares, onde eu estudava, e, na primeira reunião da Ubes (União Brasileira dos Estudantes Secundaristas), já percebi que não conseguiria fazer política, a qual me chatearia bastante. Teria que engolir muito sapo. Então eu percebi que talvez o jeito mais legal de continuar nesse meio era ser jornalista. Ou seja, fazer política de um lado onde achei que poderia ser mais útil e ia me divertir mais e engolir menos sapo do que sendo político. la observá-los e criticá-los.

Minha irmã foi repórter da Bandeirantes e conseguiu um estágio para mim. No segundo semestre de faculdade, eu comecei a trabalhar. Era estagiário do Jornal da Bandeirantes e fui contratado para ser assistente de direção do Jornal de Vanguarda, apresentado por Doris Giesse, em 1987. A Bandeirantes tinha uma coisa que é muito ruim e legal: ser solta. Esse horário da noite, hoje em dia, é nobre e muito bom de jornal, mas, na época, era meio largado. O jornal tinha um formato bastante experimental. Havia os comentaristas Fernando Gabeira, Washington Novaes, Delfim Neto, que falava de Economia, Mario Simonsen, que falava de ópera. (Paulo) Leminski era o redator-chefe. Durante um ano e meio, eu convivi com Leminski diariamente, o que foi riquíssimo para minha formação.

Aprendi muito também com Alberto Villa, que hoje é chefe de redação do Fantástico e um dos criadores do "Caderno 2", e morou muito tempo na França. Um cara fissurado pelo jornalismo francês. $E$ aí havia alguns quadros, como "A Mulher Mistério de Brasília", que era a Christiane Tricerri, parceira do Cacá Rosset, com texto que Fernando Mitri escrevia sobre política.

Ainda no Jornal da Bandeirantes, eu cuidava muito de internacional. Sempre gostei muito de política internacional, mas, no Jornal de Vanguarda, com Leminski e Gabeira, comecei a fazer muita matéria de música. Villa sempre gostou muito de música. Era um cara que dava muita atenção para as matérias culturais. O jornal em si tinha mais espaço para isso do que os hard news das 20 horas. Então ali eu falei: "Vou me divertir muito mais indo para esse lado". Foi aí que comecei a ir um pouco mais para o lado da cultura e menos para o da política.

Eu comecei a dirigir alguns desses quadros e a fazer algumas matérias, como produtor e editor. Era assistente de direção, mas não sabia dirigir. Ninguém me ensinou. Não fiz curso. Lá eles perceberam que eu tinha jeito para a coisa. Quer dizer, muitas vezes eu tinha que dirigir porque o diretor estava preocupado com outros projetos. Sobrou bastante espaço para eu trabalhar. Sempre gostei muito de câmera e ali realmente fui mordido pela televisão e pela ligação da imagem com o som. Vamos dizer que foi ali que eu comecei a descambar um pouco do impresso, que era a minha intenção primeira, de ser repórter de jornal.

Logo depois do Jornal de Vanguarda, eu fiz algumas matérias especiais e, como o SBT fez aquele projeto de jornalismo com Boris (Casoy), a gente deu uma namoradinha. (Luiz Fernando) Emediato, que era um dos diretores de jornalismo do SBT, via o Jornal de Vanguarda, era amigo do Villa do "Estadão" e me pediu algumas matérias especiais. Fiz uma matéria meio como freela para ele com o Caetano (Veloso) e os Ambitious Lovers, Arto Lindsay e Peter Scherer. Mas eu tinha aula na ECA com o Carlos Eduardo Lins da Silva, 
que, na época, era diretor de redação da "Folha" e me fez um convite para ser repórter e eu aceitei. Sempre foi um sonho meu ser repórter de jornal. Falei: "Quer saber? Vou ser até para ser uma vez e não precisar mais voltar para isso". Entrei em "Cidades" - na época não era "Cotidiano" -, fiquei seis meses e caí fora. Aí, sim, eu fui para o SBT, junto com o Villa, que foi contratado como editor-chefe do jornal. Eu fui editor de cultura dele. Fiquei um tempo e fui demitido do SBT no Plano Collor. O jornal acabou do dia para a noite e entrou Pica-Pau no horário.

Nessa mesma época, a MTV estava começando a se formar. Em 1990 é a fundação da MTV e o pessoal, entre eles Rogério Gallo, que estava montando a MTV, eu já conhecia um pouco. Eles faziam TV Mix, na Gazeta, e tinha uma ligação meio entre quem estava conseguindo fazer algumas coisas pop na TV. Quer dizer, eles na Gazeta e eu na Bandeirantes. A gente começou a ficar amigo nessa época. Daí me chamaram para ser diretor de programas da MTV e dos VJs. Foi o primeiro lugar onde eu tive o cargo mesmo de diretor. Hugo Prata era diretor de atores, digamos assim. Ele escolheu os VJs e cuidou da performance deles. A MTV queria que eu cuidasse do conteúdo dos textos. Enfim, compúnhamos uma dupla. Dirigimos juntos as primeiras gravações dos VJs da MTV, dois meses antes da estréia. Nós formamos os VJs e fazíamos meio um conselho lá dentro, capitaneados pelo Cici, Victor Civita Neto. Quando a Abril falou: "Vamos fazer a TV". Ele falou: "Vamos trazer a MTV para o Brasil". Foi o capitão.

\section{O que passava de videoclipe nessa época em que você cuidava dos textos dos VJs? E você lembra quais foram os clipes que inauguraram a MTV?}

Dos gringos, Deee-Lite, Groove Is In The Heart, foi um clássico lá. Era um clipe que a gente ouvia muito antes de estrear. Era meio um hinozinho nosso dos clipes gringos. INXS (Suicide Blonde). Erasure (Blue Savannah), MC Hammer (Can't Touch This), A-Ha (acho que Take On Me), Prince (acho que Get Off). Dos brasileiros, o primeiro foi Paralamas do Sucesso, Pólvora, gravado ao vivo e dirigido pelo Hugo Prata, pós-produzido pelo Eduardo Xocante, que era um cara bem talentoso na época. Depois teve Fernanda Abreu, SLA Radical Dance Disco Club, que acho que é do Luiz Stein. E Barão Vermelho, $\boldsymbol{O}$ Poeta Está Vivo, se não me engano do Arthur Fontes. Marina Lima, que a direção de arte é da Mari Stockler.

Vieram alguns caras ensinar para a gente como fazer a MTV. Entre eles, Alex Coletti, que ainda é produtor e diretor dos Unplugged, e Ivano Del Caballo, producer também. Os dois vieram para ensinar à gente a fórmula de como gravar os VJs e quantos por dia. Enfim, rolava um McDonaldszinho na MTV. Tinha uma formulinha de como acertar o bloco da programação.

Uma vez chegou para a gente na MTV - não sei quem é que conseguiu isso - um comunicado interno do Boni, na Globo, proibindo o Fantástico de passar videoclipes filmados em cinema, porque vídeo era o formato ideal para televisão. Película era para cinema e vídeo era para televisão. E também proibindo passar videoclipes preto e branco, porque os japoneses trabalharam muito para tornar a televisão colorida e ele achava retrocesso usar videoclipe preto e branco, que a audiência não queria ver. Foi meio uma retaliação à MTV, pois o cara viu que ela estava chegando com uma linguagenzinha e quis defender um pouco o que ele acreditava para a televisão brasileira, onde ele fazia e atuava, que era a Globo.

\section{A MTV não passava os clipes do Fantástico?}

A gente passava Titãs, por exemplo. A gente fazia, mas passava. Eu lembro que a MTV estreou bancando ela mesma os primeiros clipes, o que não fez depois. O Poeta Está Vivo, Fernanda Abreu, Marina Lima. A MTV chamou alguns diretores para fazer a sua primeira leva de videoclipes brasileiros. Todo mundo achava super bregas e beirando o ridículo os clipes da Globo. A moçada que fez MTV não gostava deles. Então havia um, não é nem pré-conceito, era um pós-conceito aos clipes da Globo. Mas alguns eu lembro que 
passavam. Flores foi indicado, digamos, primeiro representante brasileiro no VMA. Não havia votação como existe hoje e é um clipe muito legal de Jodele (Larcher) e Gringo Cardia. Lembro que achei super legal na época. Para mim, ele destoava em termos qualitativos do que a Globo vinha fazendo em videoclipes.

Logo depois da MTV, eu fui convidado para ir para o Fantástico, como produtor e editor de reportagens especiais. Também na ECA eu tinha aula com o Carlos Manente, que era editor-chefe em São Paulo e o Fantástico queria dar uma modernizada. Os caras me chamaram e eu também queria ver qual era a da Globo. Enfim, me ofereceram um salário que era o dobro. Na minha primeira semana na Globo, o Manente me levou para o Rio de Janeiro para assistir ao fechamento do Fantástico e ser apresentado ao José Itamar de Freitas, diretor do programa na época. Eu entrei na sala dele e ele estava desesperado, arrancando os poucos cabelos que ainda sobravam, porque tinha acabado de chegar Justify My Love, um dos clipes mais escandalosos da Madonna e em preto e branco. Só que era um estouro planetário.

Existia um lobby fortíssimo entre a MTV e a Globo junto às gravadoras para estrear os clipes. Então os clipes que estreavam no Fantástico, a MTV botava meio na geladeira. Tinha uma coisa assim: "Ah, se estrear na Globo, a gente vai colocar só um mês e meio depois". Ao mesmo tempo, o Fantástico falava: "Se estrear na MTV, nós não colocamos no Fantástico.". E, na época, era importantíssimo, como é hoje ainda, o clipe estrear no Fantástico. Hoje menos, porque eles não colocam mais o clipe inteiro. Lembro que o Zé Itamar falava: "Manente, isso é uma loucura, porque eu vou colocar esse clipe no ar e virá comunicado do Boni e telefonema do Dom Eugênio Salles. Então eu só vou procurar sarna para me coçar. Mas tenho que colocar, porque todo mundo quer ver. $E$ um sucesso planetário". Ele pensou bastante para tomar a decisão de realmente colocar no ar e colocou. Então eu vivenciei bastante os dois lados dessa briga Globo - MTV, com relação aos videoclipes.

Depois, eu, que já tinha inaugurado a MTV, voltei para o grupo Abril para montar o departamento de produção da TVA. Fiquei lá um ano e pouco, quando a TVA teve problemas de entregar o sinal. Houve uma revolução no Brasil nessa época, porque o telefone era via cabo e a televisão era pelo ar. Todo mundo achava, eles da TV pelo menos, que foram pioneiros, que seria uma loucura entrar na cabeação da Telesp e resolveram fazer as transmissões por via aérea, em MPS. São Paulo tinha que ter contato visual das antenas receptoras com os transmissores, o que é impossível numa cidade tão montanhosa como essa. A TVA começou a vender e não entregar e ir muito mal. A certa altura do produto deles, resolveram cortar o departamento de produção, porque achavam, com razão, que as pessoas assinavam a TVA por causa dos filmes, não por causa dos programas, e acabaram com o meu departamento.

Nessa época, eu, então, decidi não voltar para TV. Tinha vários amigos que começavam a fazer publicidade e comecei também a me enveredar um pouco por ela, muito levado por eles e um pouco pela vontade de filmar e trabalhar com película e cinema. Enfim, outra experiência. Em meados de 1992, eu comecei a fazer publicidade.

\section{Por quais produtoras você passou? Qual era a sua função em cada uma delas e porque elas fecharam ou você as deixou?}

A primeira produtora pela qual eu fui contratado como diretor exclusivo foi a 5.6 Filmes, produtora importantíssima do Brasil. Quando eu estava lá, era a primeira produtora do Brasil, fundada pelo Wellington Amaral. Fui para lá em 1994. Era uma produtora bastante voltada para publicidade, que começou a fazer clipes, eu acho, mais constantemente quando fui para lá, onde fiz Realidade Virtual e Flor do Futuro, do João Marcelo Bôscoli. Fiquei até 1998, quando fui convidado pelo Ricardo Carvalho para ser sócio de uma produtora chamada llustrada Filmes.

O Ricardo Carvalho, mais conhecido como Gordo, é uma pessoa bem importante da publicidade brasileira. Ele é do Rio Grande do Sul, mas radicado em São Paulo há muito 
tempo. Fez, por exemplo, os bichinhos da Parmalat. Ele teve uma passagem rápida pela 5.6, nos conhecemos lá e houve um momento em que eu estava percebendo que não havia muito mais por onde crescer, porque era uma produtora de um diretor bastante espaçoso, digamos assim, que me deu muito espaço, mas chegou uma hora que eu precisava de mais espaço do que ele estava a fim de me dar. Tive esse convite de ser sócio de um cara que eu acho bem talentoso.

Na llustrada, fiz alguns clipes também importantes: Já Foi e $\boldsymbol{A}$ Estrada, do Cidade Negra; Acelerou e Eu Te Devoro, do Djavan. Eu fiquei na llustrada um pouco menos de um ano. Também me desentendi com o Ricardo. Fiquei freelancer por alguns meses e logo fui contratado pela Academia de Filmes. Fui diretor exclusivo lá também. Dois ou três meses depois, eles me ofereceram sociedade.

Fui sócio da Academia até o começo de 2006, quando também por uma questão de achar que eu precisava de mais espaço do que estava tendo, saí e montei a minha própria produtora, Nuclear, pela qual fiz Uma Canção É Pra Isso (2006), do Skank. Todos os clipes que eu não citei na llustrada e na 5.6, eu fiz na Academia.

Batakotô, eu tinha, como tenho até hoje, uma empresa, Pró-4, que é só para eu dar nota, enfim. É na minha casa o endereço. Eu tinha uma câmera HI8 e estava começando a fazer publicidade. Mas mais do que publicidade eram uns institucionais, como se faz uma geladeira na fábrica da Prosdócimo, em Curitiba. Estava almejando chegar ao mercado de 30 segundos e eu tinha HI8. Tinha uma assistente super legal, Drica de Lima Barbosa, que hoje é diretora da produtora do Instituto Criar, do Luciano Huck, e um grande amigo, Adriano Melo, que era escoteiro e eu achava que tinha um jeito para produção. Era um cara que sempre que precisava colocar uma faixa na frente da casa da minha namorada, ele ia lá comigo, comprava o tecido, as cordas, tinta spray, e pichava no tecido a frase: "Meu amor, eu te amo". A gente pegava a escada e punha no boogie dele. Enfim, era um cara que tinha esse jeito produtor assim e eu queria colocá-lo na produção. Então eu tinha uma Parati. Fomos nós três para Arraial do Cabo, no Rio de Janeiro. A mulher do empresário da banda era figurinista também e fez o figurino. A gente foi para o estúdio. A banda já estava gravando. E fizemos uns másteres preto e branco com os caras tocando e, depois, fomos para Arraial do Cabo. A equipe na minha Parati e a banda alugou um microônibus. Eu tinha voltado de Los Angeles com um steadicamzinho para HI8 e meu pai, como é mergulhador, tinha blimp para gravar debaixo d'água. Então foi um esquema meio guerrilha, mas armado até os dentes. Tinha um monte de brinquedinhos para usar e a gente abusou deles. Mas era um esquema totalmente amador. Editamos e eu vi que tinha ficado bom tudo o que pensei, as fusões, transições e mistura do preto e branco com cor. Inventei uma formulazinha para o clipe, que eu percebi que deu certo e deu muito prazer de fazer. Daí eu tomei gosto.

\section{Qual é a relação entre publicidade e videoclipe, e quais são as diferenças de produção? Porque você resolveu enveredar pelo caminho do clipe?}

A diferença entre publicidade e videoclipe é clara para nós que éramos jovens diretores na época, ligados em música. Gostávamos muito de trabalhar com música e estávamos à procura de uma imagem mais legal, por isso acabamos trabalhando com película. A geração que veio junto com a MTV começava a receber videoclipes de fora, feitos em filme, e queria atingir aquele padrão de qualidade. A maioria dos diretores até hoje que trabalha com publicidade não se interessa por videoclipe. Não por coincidência, os diretores que foram fazer videoclipe também estavam fazendo publicidade, até porque videoclipe nunca deu muito dinheiro. Trabalhar com filme precisa ter mais dinheiro dedicado à produção do que a televisão sempre teve. Nas produtoras que a gente trabalhava, havia câmeras, luz e cultura da película, que, na televisão, não havia. Pelo contrário, havia grande ignorância sobre a película, apesar de o primeiro jornalismo da TV ser feito em $16 \mathrm{~mm}$. Mas com o vídeo isso logo foi embora, porque era muito mais barato.

Vitor Martins tinha acabado de montar a gravadora Velas, junto com Ivan Lins. O primeiro lançamento deles acho que foi Lenine \& Suzano, Olho de Peixe, espetacular álbum. E um dos lançamentos pop que ele apostava era uma banda chamada Batakotô, 
formada por excelentes músicos de estúdio, Téo Lima e Cidão Machado, que tocavam com Djavan e (Gilberto) Gil. Ele queria fazer um clipe para esses caras e me chamou. Eu o conheci através do César Camargo Mariano, de quem sou cunhado. No final da TVA, eu comprei uma câmera HI8 e comecei a fazer várias filmagens de gravações de estúdio do César. Por exemplo, ele fez um disco com Leni Andrade, eu fui lá com a minha câmera HI8 fazer umas imagens que foram ficando super legais. César foi para Los Angeles e fui com ele fazer um documentário da gravação de um disco de piano solo, chamado Solo Brasileiro, que ficou, modéstia à parte, bem bonito, porque era um estúdio muito legal. Eu tentei vender para a Polygram, que não se interessou. Na verdade, eu tenho até hoje o projeto de fazer um documentário do César. Tenho muita coisa dele que fui guardando ao longo dos anos, meio para deixar envelhecer e algum dia fazer alguma coisa. Mas mostrei para o Vitor e ele chapou ao me ver fazer algumas coisas legais, só com uma câmera.

Apesar de ter montado a MTV, eu gostava muito mais de programas onde dirigia e cuidava do texto. Eu não tinha pegada, digamos, artística. Não achava que fosse fazer videoclipe. Achava que ia fazer programas de TV, muito mais do que videoclipes, que já têm naturezas diferentes. Mas aí ele me pediu para fazer o clipe do Batakotô.

Publicidade para mim ainda estava bem no começo. Estava fazendo institucionais, mas nada que chamasse a atenção. Logo na seqüência, também Vitor Martins apresentou, a mim e ao João Marcelo Bôscoli, Petrônio Correa Filho, filho do Petrônio Correa, dono da MPM, uma das grandes agências de publicidade do Brasil, e que estava começando a fazer produção independente. Tinha uma produtora chamada Intermeios, e um programa, Companhia da Música, de música ao vivo. Ele me chamou para dirigir, João Marcelo para apresentar, e Bernardo Vilhena para ser o redator. Comprou um horário na CNT, que tinha acordo com a Gazeta, e então fizemos o programa juntos. Eu já tinha uma ligação familiar com João Marcelo, porque minha irmã casou com o César, que é meio pai torto dele, então sempre convivemos muito e tivemos uma banda. Nessa época, João e seu irmão, Pedro Mariano, tinham um contrato com a Sony Music e João fez um álbum chamado João Marcelo Bôscoli e Companhia. Eu fiz um vídeo-release para esse projeto. Captei toda a gravação do álbum, concomitantemente ao Companhia da Música.

Fiz o primeiro clipe dele, segundo meu, que foi Flor do Futuro, o primeiro para a Sony Music. Eu já estava na 5.6, que, na época, era a maior produtora de publicidade do Brasil, super equipada. Logo depois, a Adriana Pena, que cuidava do departamento de marketing da Sony (e hoje é mulher do Nelson Motta) e da Predileta Produções, no Rio de Janeiro, uma produtora bem, bem, bem esperta, me apresentou ao Cidade Negra, que me chamou para fazer Realidade Virtual, clipe do qual eu gosto bastante. Então aí entrei realmente na Sony e foi o primeiro clipe com um bom orçamento, indicado a todas as categorias que podia ter sido indicado no VMB - diretor, clipe pop, edição, fotografia, clipe do ano. Não levou nada, mas foi super indicado.

Antes, só Fantástico fazia videoclipe. Então os caras levavam o disco novo dos Titãs para a Globo e ela falava: "Ah, esse é do Boninho. Esse é do Zé Mario. Esse é do Jodele". Eles se dividiam sei lá como e faziam os clipes. Naquela época, as gravadoras começaram a ter que prestar atenção em outros diretores, na Conspiração, depois em mim, no (Roberto) Berliner, enfim, em gente que estava começando a fazer videoclipe.

Cidade Negra tinha como empresária Leninha Brandão, que me convidou pra dirigir Gabriel O Pensador e assim foi indo. Fui convidado pela gravadora, pela empresária e pelo próprio artista. Um dia tocou o celular, era Zélia Duncan falando: "Vou fazer um videoclipe e um DVD para a Universal, vi o seu clipe Até Quando?, do Gabriel, chapei e gostaria muito de te conhecer e de trabalhar com você". Então varia muito.

A MTV bancou uma leva inicial e depois parou. Daí as gravadoras começaram a bancar. No primeiro clipe que fiz do Gabriel, ele tinha o de Astronauta para fazer e eu tinha acabado de fazer $\boldsymbol{A}$ Estrada, de Cidade Negra, que tem algumas cenas "na Lua". Um amigo dele, Michel Pachá, diretor de arte do clipe, conheceu uma sucata no Rio de Janeiro e ele me pagou uma passagem para irmos até a sucata juntos. O Pachá tinha visto umas roupas de escafandrista para vender na entrada e a associou à de astronauta. Quando eu entrei no 
lugar, era incrível e vi um cilindro gigante e umas sucatas de uns foguetinhos. Até hoje não sei o que podia ser aquilo. Olhei e o Pachá tinha um amigo que mantinha uma equipe de soldadores. Eles faziam decoração de casas noturnas. Eu olhei e falei: "Gente, estou doido ou construímos um foguete aqui com essas sucatas?". Os caras olharam: "Se tiver uma equipe, a gente constrói". A partir daí, a gente ficou encantado com o clipe. Só que o orçamento estava em 78 mil reais e o orçamento da gravadora era de 60 mil reais. Ficava faltando 18 mil, bastante importantes para o clipe ficar direito. Daí eu fiquei num estica e puxa com Cristina Dória, que cuidava desse departamento na gravadora, até que ela me ligou e falou: "Oscar, sinto muito. Não temos mesmo 78. Temos 60 e essa é a nossa palavra final". Falei: "Cris, então muito obrigado. Prefiro não fazer, porque eu quero trabalhar direito com o Gabriel e, por essa grana, não vou conseguir fazer o que tenho em mente. É uma pena, porque é um super clipe, legal para caramba, mas prefiro não fazer". Isso foi de manhã. Durante a tarde, Leninha Brandão me ligou e falou: "Oscar, o Gabriel está encantado com a idéia e quer continuar com você. Ele vai pôr do bolso dele esses 18 mil reais". Aí eu falei: "Porra". Tirei o chapéu para o cara e fizemos um clipe muito legal, do qual me orgulho bastante até hoje. Então aí foi o primeiro clipe bancado pelo artista. Palavras Repetidas também teve um bom dinheiro que veio do bolso dele.

Digamos que, para A Flecha e o Vulcão, clipe que fiz para o Cidade Negra na Jamaica, eu consegui um patrocínio do SuperClubs, que são os resorts de alto padrão. A gente tinha feito vários clipes, Realidade Virtual, A Estrada, A Cor do Sol, e falamos: "Já fomos para Lua, fizemos um meio futurista e agora temos que fazer um roots e ir para a Jamaica". Mas precisava de uma grana, que a gente sabia que a gravadora não conseguiria dar. Eu fui fuçando, fuçando, fuçando e arrumei o patrocínio do SuperClubs, que na época estava inaugurando resort na Bahia e precisava fazer uma jogada de marketing no Brasil. Eles trocaram toda a estadia, transporte e uma grana para a gente se virar na Jamaica por show dos caras no resort deles na Bahia. Então eles não puseram grana, mas trocaram por um show, o que é grana para um artista.

Mais recentemente eu fiz um DVD para Zélia Duncan, Eu Me Transformo em Outras, que foi totalmente bancado por ela, através do selo Duncan Discos, com distribuição da Universal. Ela gastou uma boa grana para fazer esse DVD. O que eu também reputo assim como bancado por um artista, porque a gravadora dela é ela e Denise Colker, advogada dela.

\section{No videoclipe do Batacotô, você já encontra o cerne do Oscar Rodrigues Alves, diretor de videoclipes?}

Certamente. Eu acho que tento ser bastante fiel ao que os músicos estão tocando, no jeito de mostrá-los tocando e sincronizado com o áudio, algo bem presente nesse clipe e que permeia a minha obra toda. Ou seja, tornar a música bem visível ao espectador. $\mathrm{Na}$ hora em que você mostra os instrumentos que estão sendo tocados naquele momento, faz com que o espectador conecte o som ao instrumento e ao músico que o está gerando. Conceitualmente, o que tem importante ali que passa por tudo, além disso, é a preocupação com a edição e com o contraponto entre os músicos tocando e alguma imagem artística, nesse caso figurinos, a praia, a areia. Quitambô é uma festa.

No Batacotô, há uma interpretação bem literal, em cima do que a letra dizia, o que fui cada vez mais querendo quebrar na minha maneira de trabalhar e me expressar. Eu sempre ouço uma coisa óbvia, dou um giro de 180 graus e vou para o outro lado procurando 0 oposto do óbvio. Esse também foi um clipe bem guerreiro e que tinha muito pouca grana.

Depois você vai pegando a manha e entendendo do quanto de material você precisa para fazer um videoclipe interessante. Mas o grande barato desse clipe foi poder falar: "Acho que vou conseguir ser um diretor de videoclipe". Ele já tinha algumas jogadas de transições óticas, fotografia, silhueta, que funcionaram. A transição de um especial de percussão e teclado foi feita numa poça d'água na areia da praia, onde Jorgão Barreto, vocalista, havia aparecido cantando contra ela, dava uma turvada. A água mexia e embaralhava um pouco a imagem. Isso resultou super bem. Logo no primeiro clipe também 
já tem câmera subaquática. Meu pai, como mergulhador, tinha um blimp para câmera HI8, que me emprestou. Então, apesar de ser o primeiro clipe, ele é bem trabalhado e cheio de elementos interessantes, que depois eu carreguei mais adiante na minha carreira.

\section{Você se considera autor dos seus videoclipes? Por quê?}

Muito, porque acho que, mais do que know-how de efetivamente como fazer cada coisa, um diretor precisa seguir uma linha e extrair da equipe e dos artistas o que ele tem em mente. Também considero-me muito autor, porque as possibilidades de interpretar uma música são infinitas, e o resultado do clipe é uma interpretação encomendada pelos autores da música. Eu nunca sou o autor único e exclusivo, mas o fato de imprimir visão à música que $o$ artista te entregou e o fato de ficar alguns dias pensando e comandar uma equipe em torno do que pensou é claramente muito autoral. Eu olho para todos os meus clipes e me identifico. Acho que isso me faz ter certeza de que tem autoria minha naquelas produções.

\section{É fácil identificar a sua autoria num videoclipe?}

Em algumas coisas básicas, como preocupação com o sincronismo entre imagem e som; musicalidade, respeito à dinâmica da música, cuidado com a adequação de todos os elementos (fotografia, direção de arte, edição) ao que a música está pedindo. Por mais que eu tenha clipes embaixo da água ou na Lua, filmado em $35 \mathrm{~mm}$ ou em Super-8, com elementos muito distintos uns dos outros, muita gente me fala: "Vi um clipe no ar e achei que era do Oscar. Esperei os créditos e era mesmo". Não é que eu repita sempre a mesma fórmula, mas quem vê um clipe, vai notando um pouco de todas as preocupações que eu tenho. Então, pelo que as pessoas falam, acho que dá para identificar um DNAzinho nos meus clipes.

\section{A autoria se mantém quando você co-dirige um videoclipe?}

Eu acho que ela permanece e se multiplica. Quando eu chamo alguém para co-dirigir comigo, é porque tenho certeza que essa pessoa vai agregar muito e dar uma outra dimensão a essa obra que está sendo feita. $E$ acho que sempre que co-dirijo tem uma base ali do meu trabalho muito clara, que quem vem, aproveita essa base e sobe alguns degraus. Seja Nando Cohen, Luciano Cury, (Marcelo) Pressoto, Hugo Prata, os meus parceiros sempre partem da base do que eu faço de melhor para desenvolver a partir disso. As codireções trazem outros temperos para minha cozinha, que são importantes. Ficar usando aquele temperinho do arroz e feijão todo dia, uma hora enche. Então precisa vir alguém que tire um pouco daquele trivial da cozinha de todo dia. Por isso, em algumas horas, eu apelo, no bom sentido, para esses meus parceiros. Também é sempre um trabalho de parceria com a equipe toda.

Em Acelerou, foi o contrário - Adrian Teijido não seria co-diretor, mas ele contribuiu tanto na feitura do clipe que achei que devia o crédito de co-direção a ele. A gente foi para Paraty e fez uma cena num boteco que foi ele que chamou atenção por ter um "caubói" meio louco escrito. Ele deu tantas idéias para uma estrutura tão simples que era locação, luz do dia, Djavan e Luciana Britis, que achei que ele tinha contribuído mais do que apenas como diretor de fotografia.

Até Quando? é um trabalho bem de co-direção. Eu já tinha trabalhado com Nando Cohen, com Cidade Negra. Já tinha feito Astronauta, com Gabriel, o Pensador, quando ele me chamou para fazer Até Quando?, no qual fiquei viajando muito com o Nando e fomos chegando, realmente juntos, na fórmula de misturar a imagem filmada do Gabriel sentado numa poltrona com a animação em cima. Essa foi uma idéia bastante dividida entre mim e Nando. Foi uma co-direção bem clara. Depois, na hora, os dois personagens ficaram muito legais - Gabriel para frente ativo e Gabriel largado na poltrona, passivo. Em Dois Rios, também. Nos dois casos, a parte filmada é muito simples, intencionalmente simples, porque 
sabíamos que haveria pós-produção bastante rebuscada. Então a concepção foi feita com as bases muito simples, com fundos pretos e roupas em tons de cinza, para deixar que a animação tivesse bastante espaço para atuar. Ali você identifica minha preocupação com sincronismo, musicalidade, fotografia apurada, servindo como base para que a pósprodução pudesse pintar e bordar, fosse em cima das imagens, como em Até Quando?, fosse criando outro universo, no caso de Dois Rios.

Exceto talvez Hugo Prata em Quatro Vezes Você, porque Capital Inicial já era parceiro dele, nunca me convidaram. Já no caso do clipe do Simoninha ele nos convidou. Então, em 98\% das minhas co-direções, a música chegou para mim e eu falei: "Esse clipe seria legal fazer com fulano". As parcerias renovam a sua maneira de pensar e trabalhar.

\section{Você é contra ou a favor da inclusão de merchandising no clipe?}

Sou a favor de conseguir filmar bem e de fazer coisas legais. Não sou purista nesse sentido. Quero ter as melhores condições para poder filmar e, se precisar fazer merchandising, vou tentar fazer do jeito mais legal possível para se encaixar no roteiro. É legal para todo mundo, para a banda, para mim e para o espectador. A Estrada era um clipe que eu não tinha grana para fazer como queria e, na época, estava fazendo comercial de sorvete para a Yopa. Pedi para a agência, Thompson na época, e achei que poderia colocar a Yopa no clipe de alguma maneira, pois ele se passava na Lua e na praia. No meu modo de trabalhar, eu sempre ouço a música, penso na coisa mais óbvia e depois faço o exercício de pensar totalmente o oposto ao que a música propõe. Então a canção dizia: "Quando bate a saudade, eu vou para o mar". Claro que ele estava falando do mar, mas comecei a pensar no mar da tranqüilidade, na Lua, e a criar esses dois másteres. A banda me pediu que usasse as crianças. Eles já tinham filmado com os filhos em Firmamento, que foi o último clipe que fizeram antes dos cinco seguidos comigo. É da Mari Stockler. Um clipe que eles adoram e que é todo voltado à família. As crianças eram meio bebês ainda. Eles me pediram para usá-las de novo num clipe, um pouco mais crescidas. Os dois másteres eram, então, eles na Lua, olhando para a Terra com saudade das crianças, e as crianças na praia olhando a Lua com saudade dos pais. Eu achava que elas podiam estar tomando sorvete na praia, tranqüilamente. Na reunião de produção, entre a produtora, a agência e o cliente para decidir tudo o que aconteceria no comercial, falei: "Gostaria rapidamente de apresentar um negócio para vocês. Eu dirijo videoclipes e estou fazendo esse para o Cidade Negra". Foi minha primeira parceria com Nando Cohen, dono da Adolfo Filmes, e com animação tradicional envolvida.

O Nando fez um pedacinho de animação, um layoutzinho, para eu levar para eles. 0 mesmo que eu usava com publicidade, em reuniões bem minuciosas, onde se mostra cenário e casting. Fiz um pouco isso para vender o projeto para a Yopa e precisava do que eles chamam de pocket money, uns quinze paus. Sugeri aparecer uma embalagem de um sorvete, com as crianças chupando-o. Na hora, o diretor de marketing da Yopa falou: "Não sei se uma embalagem. Um carrinho de sorvete pode ser?". Eu falei: "Claro. Pode". Eles, na hora, me deram quinze paus e, durante a filmagem, mandaram eles mesmos um carrinho de sorvete para a praia. O logo Yopa aparece durante três segundos, num décimo do quadro. Quer dizer, não é nem uma coisa gritante, mas viabilizou um clipe que, modéstia à parte, acho super bem realizado e que, sem esse merchandising, não teria conseguido fazer. Então sou totalmente a favor, desde que viabilize a idéia e a faça ser bem realizada.

\section{Você consulta o intérprete e o compositor para realizar um videoclipe?}

Sempre os artistas pedem que a gente crie os roteiros. Alguns artistas - Gabriel, entre eles - ocupam-se muito de discutir a idéia com o diretor. O processo criativo meu com Gabriel é muito rico de discussão. Ele é um cara que se envolve bastante. Tem idéias. Outros artistas confiam totalmente. Não têm nem muita idéia de como vai ser realizado, mas confiam na gente. Mas todos, de uma maneira ou de outra, me confiam a tarefa de criar e fazer o roteiro. Fora alguns clássicos como Roberto Carlos - Além do Horizonte, do Jota 
Quest -, com quem nunca conversei, nos clipes que fiz, os compositores eram componentes da banda. Eu converso muito mais com os componentes da banda e com os cantores, no caso de artistas solos como Gabriel, do que com os compositores. Mas, no caso dos Titãs, sempre o compositor da música é o cara que se ocupa mais do clipe e quem cuida da idéia e do caminho que o projeto vai ter. Então o primeiro clipe dos Titãs, para o qual eu fui convidado a dirigir, Isso, foi (Tony) Bellotto, compositor da música, quem me ligou. Principalmente depois da morte do Marcelo (Fromer), que era o cara que organizava um pouco a banda.

\section{Você vai para a gravação com o roteiro pré-determinado ou ele vai acontecendo ao longo das filmagens?}

Quando a gente roda, já tem a idéia muito discutida com o artista. Mas tem muita coisa que aparece na hora e que dá um sabor especial ao clipe. Até Quando?, por exemplo, não tinha a idéia de fazer a sobreposição dos dois personagens. A idéia era o Gabriel e a intervenção da animação por cima, mas, quando a gente posicionou a câmera, colocou a lente grande angular e enquadrou o Gabriel, eu falei: "Encosta na lente". Ficava super legal. Aí falava: "Se joga na cadeira". Ele se jogava. Ficou super legal também. Ali, naquela hora, falei: "Vou rodar os dois e sobrepor. Vou ver o que acontece". E deu super certo, porque virou uma coisa importante, conceitual ali, de ter um cara ativo, que dá o esporro, e um passivo, que toma o esporro. Isso, dos Titãs, é uma história de amor de um casal em que o homem não consegue mais se relacionar com a mulher, abraçá-la e beijá-la. Ele oferece uma flor. Ela não quer mais. Ele oferece jóias. Ela não quer mais. Eles não falam a mesma língua. Quer dizer, é uma metáfora de um casamento em crise. Daí você chega numa estrada reta e a elefanta fica louca com o cenário, começa a brincar com a areia, a correr e tal. Trombeteava. Você, então, tira proveito da loucura que acontece na hora. Tem que estar esperto e aproveitar essas coisas que enriquecem o clipe.

Eu preciso chegar ao set sabendo que dali tiro um clipe do qual vou me orgulhar. Não saio para filmar sem saber que os componentes que levantei vão me dar um clipe legal. Mas muitas vezes as coisas mais legais acontecem por acaso, por sorte, enfim. Tem que ficar bem ligado, porque o clipe vai se transformando ao longo do tempo. Não é um roteiro fechado, que você roda os diálogos ali e pimba. E é o grande barato. A publicidade tem um método muito fechado, digamos assim. Você se compromete muito com a agência e com o cliente a respeito do que vai filmar. Faz shoot board, que mostra aqui vou fazer um close up e ali plano americano. Compromete-se muito a contar a história que o cliente quer ipsis litteris. Eu não faço shoot board de clipe. Só quando é uma coisa que tem um efeito, que todo mundo tem que olhar muito tecnicamente para aquilo - eu, o diretor de fotografia, o pessoal de efeitos visuais, enfim. Aí, sim, a gente desenha alguma coisa. Mas eu conto nos dedos os clipes em que fiz. E nunca fiz shoot board de clipe inteiro. O grande barato do videoclipe, para mim, é essa liberdade de chegar na hora e enquadrar do jeito mais legal.

\section{equipe? \\ Quais são as etapas de realização de um videoclipe e como você determina a}

Primeiro, o artista me manda a música. Eu, então, ouço várias, várias e várias vezes. Ali já penso talvez em quem vão ser meus parceiros, principalmente o diretor de fotografia, e volto para o artista com uma idéia do clipe. Depois que comecei a trabalhar com Nando Cohen, muitas vezes eu mando a música para ele ver se tem alguma idéia boa também. A gente bate uma bola assim. Mas já mandei músicas para ele que eu tive uma idéia antes que pudesse voltar com alguma e toquei o clipe sozinho. Então, antes de voltar para o artista decidir alguma coisa, eu me reúno com essas pessoas que elegi. Realidade Virtual, por exemplo, a idéia de fazer a cidade com as torres, um futurinho como a gente chamava, é 
do Pietro Sargentelli, meu assistente durante muito tempo e hoje também diretor de clipe ${ }^{263}$. Isso foi uma idéia só minha, até porque não deu tempo de conversar com alguém. Os caras me mandaram a música numa sexta-feira e precisava ter uma idéia até domingo. Então foi daí que, rapidamente, eu tive essa idéia e me satisfiz com ela do jeito que a concebi no prazo que eles me deram. O diretor de arte Marcos Sachs é um grande parceiro que também gosto de envolver cedo como parceiro. Fez Realidade Virtual, Isso e Tem Alguém Aí?. Então é assim: ouço a música, começo a encaminhar para um lado, vou chamando a equipe, faço uma ou duas reuniões, e daí volto com essa idéia para o artista e discuto um pouco com ele. "Ah, gostei". Ou "Não gostei". Acrescenta ou tira alguma coisa. É meio assim que funciona. A partir da hora que a gente se afinou, eu volto e dou uma orçada. Aí vem um estica e puxa com a agência e com a gravadora ou, às vezes, com a gravadora e o empresário do artista, envolvendo o orçamento do clipe. Aprovado o orçamento, vem a produção propriamente dita. Dependendo da idéia do clipe, uma ou duas semanas de préprodução - levantar cenário, procurar locação e tudo mais. Eu acho que nunca fiz um clipe com mais de quatro diárias. Realidade Virtual acho que foram quatro diárias. A Flecha e o Vulcão teve cinco dias, mas era uma viagem. Preferi gastar o dinheiro indo para a Jamaica e fiz um clipe em Super-8. Gastei menos na película. Fiz uma produção mais barata. Então é muito difícil você ter cinco diárias em $16 \mathrm{~mm}$. É bastante caro. Depois vem a pós-produção, que engloba telecinagem do material filmado, edição, efeito de pós-produção, se tiver, enfim, sonorização e a entrega.

\section{Como você determina o formato que utilizará, película, Super-8 ou vídeo?}

São dois vetores que trabalham nisso: o que a idéia pede e o orçamento que tem para realizá-la. Gabriel O Pensador, Até Quando?, poderia ter sido feito em vídeo, mas, como era fácil de captação, foi feito em 16, até porque tinha um efeito ali de alteração de velocidade que eu queria realmente fazer em filme. Tinha o chabel, que era uma coisa que eu queria também usar. Palavras Repetidas, grande parte do dinheiro eu tive que pedir ao Gabriel, porque achava que tinha que ser feito em $16 \mathrm{~mm}$. Era um clipe que precisava de definição, porque trabalhava com bolhas pequenas de ar. Então insisti muito para que a gente tivesse o orçamento que teve, o que forçou o Gabriel a pôr dinheiro do bolso dele. E acabou sendo premiado como melhor videoclipe pop e pela fotografia. Isso justificou minha batalha pela grana. Foi ótimo. Agora, eu sabia que, em A Flecha e o Vulcão, por exemplo, o mais importante era ir para a Jamaica. Podia fazer em vídeo. Levei até algumas câmeras de vídeo, mas a gente acabou fazendo em Super-8 para ter uma textura até mais suja, granulada, que tinha a ver com esse clima roots que a gente queria dar. Então é sempre uma batalha da idéia com o orçamento. Fico equilibrando esses dois vetores.

\section{$\mathrm{O}$ que um bom videoclipe precisa ter?}

Eu gosto de clipes que tenham coisas que nunca vi, como Isso tem. Mas é difícil. O bom clipe para mim pode ser muita coisa. Um clipe onde eu vejo: "Esse cara fez uma puta montagem. A fotografia está meio bomba, mas o clipe ficou bom porque a montagem é boa". Sabe o que é um bom videoclipe? É o que faz a música ficar mais legal ao seu ouvido por algum motivo, porque a montagem respeitou a dinâmica da música e o cara soube transportar a dinâmica dela para uma dinâmica legal de imagem; ou a leitura da letra da música ficou super legal. Então bom clipe, para mim, é aquele que você assiste e fala: "Vou ouvir essa música e ela vai bater mais legal depois de ter visto esse clipe". Ele pode ter uma fotografia completamente suja e detonada, mas a idéia ser muito boa. Poderia ter feito Miklos e o elefante com uma fotografia trash, ainda haveria uma boa idéia e um bom clipe

263 Pietro Sargentelli dirigiu videoclipes como Dias Melhores (2000), Só Hoje (2002), cheio de referências de filmes italianos dos anos 60; e O Que Eu Também Não Entendo (2001), ambos do Jota Quest; e Ela Não Está Aqui (2001), do KLB, dividido com Adrian Teijido. 
ali. Quer dizer, não dá para dizer que um bom clipe é o que é bem fotografado e editado. Bom clipe é aquele que a música fica mais legal depois de você assistir.

\section{Quando você vai fazer um videoclipe, quais são as principais referências, outros clipes, filmes?}

Tudo. Lembro que, no começo da MTV, e depois na minha carreira publicitária, muitas pessoas chegavam para a gente e falavam: "Eu quero uma linguagem meio videoclipe". Aí, para você, que é um estudioso disso, nada mais ridículo do que falar numa "linguagem videoclipe", porque um clipe pode ser Sinéad O'Connor, Nothing Compares U2, que é quase plano-seqüência com um fundo preto, não tem quase cortes; ou Tem Alguém Aí?, que é totalmente cortado, recortado, sujo. Pode ter uma animação. Quer dizer, na hora em que te pedem isso, você engole seco e fala: "Deixa eu tentar traduzir o que esse cara está querendo dizer. Acho que são muitos cortes e câmera na mão". Mas acho que é o que vier na cabeça. Você pode falar: "Quero uma fotografia em preto e branco, cinema noir". Ou: "Quero fazer um clipe com fogos de artifício, como o Mark Romanek". Então é tudo o que faz parte da sua cultura visual.

Já Foi, a idéia do trailer, é do Adriano Goldman, diretor de fotografia. A gente foi para o Rio fazer um EPK (electronic press kit) do Quanto Mais Curtido Melhor, álbum do Cidade Negra, e ali eles mostraram a música para a gente. Voltamos no avião tendo idéias. Daí ele falou: "Então vamos fazer um roadie movie, né? Ali tem uma cobra meio Oliver Stone, Assassinos Por Natureza". "Já tem 360 roadie movies, mas vamos fazer o nosso também". Não precisa ser original e genial a todo instante. "Ah, vamos filmar de carro e helicóptero?". "Animal. Tesão. Tem condições?". "Tem". Então junta tudo o que tem na cultura visual. Marcos Sachs, por exemplo, é um cara que sempre traz muitas referências de livro. Ele tem uma biblioteca incrível. Então, em Realidade Virtual, ele trazia muita coisa de (HR) Giger (autor do pôster de Aliens), para o cenário. Então as referências vêm a todo instante, de todos os lugares.

Isso, por exemplo, não tem referências. Foi composto totalmente da nossa cabeça. Eu sabia que queria um figurino diferente. Pedi para a figurinista pesquisar um pouquinho e ela veio com uma coleção do Marcelo Sommer, que tinha uma coisa meio circense, meio fábula. Quando ela veio com o termo fábula, eu falei: "Perfeito. É isso que eu quero. Uma coisa meio fábula". Então fomos levantando. Mas não é que a gente chegou em alguma coisa, e eu pedi para ele: "Faz uma roupa de acordo com Alice no País das Maravilhas.

\section{Você gosta de ver videoclipes e quais referências bacanas você tem?}

Adoro. Ainda assisto MTV. Video 1 Soul, Video 1 Hits. Referências posso tratar como ídolos meus, mesmo que não tenham me influenciado? Mark Romanek, Stephane Sednaoui, Jonathan Glazer, Paul Hunter. Michel Gondry, por exemplo, eu admiro, mas não gosto de fazer o que ele faz. Ele é absolutamente genial, tem uma mente completamente ligada à pós-produção e desenho. Eu desenho muito mal, então não tenho os mesmos atributos que ele. Admiro o trabalho, mas não me influenciou. Penso muito diferente dele o jeito de trabalhar. Não tenho a pegada dele. Tem uma mulher que adoro, Sophie Muller, que filma bastante com a Sade. As coisas da Sade eu acho lindas. E com a Annie Lennox. Tem alguns clipes daquele álbum, Diva, que são incríveis.

Do Brasil? Roberto Berliner. É um cara de quem sou bastante fã do trabalho. É Uma Partida de Futebol eu acho um clipe muito legal. Quando ouvi a música, tinha uma idéia diferente para o clipe, mas acho a idéia super legal. Ele fez um negócio incrível. Gosto muito dele e o acho bem talentoso. 


\section{Quais foram as evoluções que você notou no videoclipe brasileiro entre o momento em que começou e agora?}

Acho que a questão da gente ter trabalhado bastante com película e o envolvimento de pessoas do mercado de cinema e de publicidade nos clipes melhorou. Quer dizer, é difícil colocar juízo de valor. Mas trouxe clipes melhor acabados, digamos assim. O fato de se trabalhar com cinema requer profissionais diferentes da televisão. O vídeo, você põe o olho de alguma maneira e está vendo a imagem. O profissional do cinema trabalha com negativo, que tem que ser exposto perfeitamente e, depois da revelação, é que vai ver como é que ficou. Quer dizer, necessita de um rigor técnico maior do que o vídeo. E deu possibilidades técnicas também, além do vídeo. O ramp de cores e de saturação e de luminância que a película dá é muito maior do que o vídeo. Então nos permitiu trabalhar com nuances técnicas de contraste, brilho, cor, muito maior do que o vídeo.

Em termos de concepção, os clipes cresceram muito. Eles eram bastante ingênuos, quando começaram a ser feitos no Brasil, e hoje acho que há um requinte muito grande de criação. Tem clipe que é debaixo d'água ou na Lua. Clipe de animação $3 d$, $2 d$. Edições de áudio. Mas é engraçado, porque eu ficaria muito mais na evolução cronológica do que na evolução de qualidade, porque você pega, por exemplo, Comida. O clipe dos Titãs, feito na Globo, tem uma edição de áudio e uma coisa que é super ousada para a época. Não se faz nem hoje em dia. No Realidade Virtual, dei uma enlouquecida também. Bernardo Vilhena foi o primeiro cara que levou uma fita cassete do Cidade Negra para a Sony e, nessa época, eu estava bem próximo dele por conta do Companhia da Música. Então, ele criou uma introdução para o clipe. Eu peguei as masters de áudio da música e separei em canais. Separei os efeitos e os usei numa introdução que eu criei com a voz do Bernardo Vilhena, que tem uma locução muito legal. No meio da música, eu editei e deixei só a bateria com um pouquinho de teclado para fazer uma cena em que tem um cara que, teoricamente, vai captar o som que vem do ensaio do Cidade Negra em cima de uma torre para a menina que está no outro prédio ouvir. Então tem uma edição de áudio bem trabalhada. Eu não falaria em uma evolução qualitativa, estética. Você pega as coisas que David Cunningham fazia no European Film Festival, no Canadá, que a gente assistiu, na Cultura, há cinco anos, tem coisas que são modernas hoje em dia.

Agora o fato de a gente viajar mais nos clipes, criar mais, ter mais condições técnicas, poder trabalhar em cinema um pouco, permitiram alguns arroubos do que poderia chamar de evolução técnica. Isso é bem relativo. Acho que houve evolução de criatividade. Pensar em fazer um clipe inteiro debaixo d'água ou num avião em queda livre, que deixa a pessoa sem gravidade dentro. Ou seja, abriu-se a mente para possibilidades que se tem de interpretar a letra de uma música.

\section{Como foi a mudança para o digital?}

Isso realmente foi um grande barato, principalmente, não na captação, mas na pósprodução, pelo fato de você poder trabalhar com vários layers, várias camadas de imagem. A começar pelos equipamentos mais rústicos, entre aspas, apesar de super inovadores. Caso do ADO (ActiveX Data Objects), da Ampeg, o primeiro equipamento que fazia a imagem voar, virar página e já trabalhava com camadas de imagens, e nos proporcionou dar umas viajadas, depois de todos os Paint Brushes, até o AVID, a edição não-linear. Isso certamente trouxe para a montagem um dinamismo, porque o equipamento também transforma o jeito de você trabalhar.

Eu agora estou experimentando um negócio novo que se chama Multicam, uma função do Final Cut Pro 5. Ele trabalha como se estivesse em um switcher ao vivo de gravação e pega a tela do play, divide em 9 ou em 16, e você consegue ver todas as câmeras que usou num show, por exemplo, porque está gravado, como eu gravei o Cidade Negra, e pode botar na hora, refazendo o clima do show e depois ainda acertar com precisão os cortes. Esse é o primeiro projeto de DVD ao vivo que eu faço assim. Antes eu colocava todos em layer, e ia vendo um por um. Uma tela no máximo por vez. Então, eu 
percebi que o próprio jeito diferente de você trabalhar altera o resultado final. Quando eu dei play nas primeiras edições que fiz, olhei e falei: "Esse corte não é a minha cara. Mas legal, gostei do jeito que ficou". Então, mesmo depois de tanto tempo trabalhando com isso, você ainda toma algumas surpresas. É a tecnologia efetivamente influenciando o artístico, o produto final, mesmo em casos simples, como um corte seco de um show. Então mudou bastante e propiciou que a gente pudesse fazer virtualmente tudo o que quisesse. Ir para a Lua de um jeito diferente, mais real, entre aspas, menos fabuloso que (Georges) Méliès.

\section{Você chegou a pegar a fase sem o digital?}

Peguei. Eu talvez seja da geração que viu o maior salto tecnológico na televisão. Quando eu comecei, em 1987, era U-matic, analógico. Se a fita amassava, você tinha que refazer tudo, porque copiar de U-matic para U-matic perdia muita qualidade. Era uma loucura. De certa maneira, foi interessante, porque o raciocínio linear de montagem requer mais trabalho do que o não linear, no sentido de preparação. Eu preparava muito mais as minhas edições no papel. Cronometrava mais o tempo das coisas. Programas especiais que fazia, com blocos com durações, eu planejava bastante no papel antes de começar a editar.

Hoje em dia, você pode mover uma coisa de trás para frente, mexer, tirar, cortar. Lá não. Você editava o que estava na fita. Vai para frente. Para trás, já era. Então, me ajudou a pensar mais na montagem, numa época em que acho que a estava descobrindo ainda. $A$ montagem não-linear, você pode a qualquer instante rever, trocar, virar. A montagem linear requer mais preparação. Então acho que foi bom ter uma base onde precisava me preocupar mais e depois a tecnologia me deixar mais solto. Isso foi bem legal. Foi gostosa essa transição. digital?

Essa prática faz falta, por exemplo, em quem já começou trabalhando com o

Não sei se faz falta, porque Daniel Rezende, por exemplo, editor de Cidade de Deus, que editou alguns videoclipes - ganhamos o prêmio da MTV juntos com Até Quando?, do Gabriel, onde ele deu alguns pitacos -, não pegou isso. Quer dizer, já entrou no não-linear. $\mathrm{Na}$ palestra que ele deu quando foi indicado ao Oscar, ao lado de Walter Murch, todo mundo falando da moviola e ele: "Não sei de nada disso, não, hein?! O meu negócio é 0 e 1". Muito engraçado. E eu o acho um grande editor. Não acho que faça falta para ele. Para mim, eu achei bom. Gosto de ter passado por isso na minha formação.

Agora nos Titãs (no documentário co-dirigido com Branco Mello), por exemplo, eu estou me valendo muito da montagem não-linear, porque o material vem chegando para mim. Não é um projeto que vi todo o material e, a partir disso, pude traçar um roteiro e o filme se apresentou a minha frente. Não. A cada dia, chegam coisas novas. Então é excelente você poder pegar o negócio pronto. "Isso aqui é para o começo do filme". E isso não gerar um transtorno demoníaco na sua vida. Mas gosto muito de ter a base do raciocínio de montagem antigo, digamos assim.

\section{O videoclipe dá visibilidade para o seu trabalho e te traz retornos?}

Traz retorno mais com os artistas e um pouquinho no mercado publicitário, mas nada significativo. Por exemplo, logo depois de ganhar os prêmios de Epitáfio, veio uma maré de seca na publicidade. Até o final do ano, trabalhei pouco. Então não é que, se você fizer um clipe genial, na sequência, chovem trabalhos. É verdade que no meio musical dá moral, mas nada que faça ficar tranqüilo como ser indicado ao Oscar.

\section{Mas cria uma marca "Oscar, o diretor de clipes"?}


Posso dizer que sim. Não uma marca, mas as pessoas me conhecem muito pelo meu trabalho musical, digamos assim. Eu acho que sou mais respeitado pelo meu trabalho com a música do que como diretor de atores, por exemplo. Até porque é mais forte mesmo e é no que estou mais interessado.

\section{Dá uma visibilidade maior para o seu trabalho do que a publicidade?}

Dá, simplesmente por causa do crédito no clipe. Os comerciais as pessoas vêem, mas não sabem que é seu. Os clipes, as pessoas sabem, porque elas lêem o seu nome ali no rodapé nos programas da MTV. Minha tia, por exemplo, vê meu nome lá e vem falar: "Ah, os Titãs". Mas não vê o comercial. Não sabe o que é meu. Não lê as publicações especializadas. Dá mais visibilidade nesse sentido.

\section{Você pegou a fase quando a MTV começou, que não tinha créditos?}

Eu não dirigia videoclipes nessa época. O primeiro que dirigi já tinha crédito. Então não sei te responder.

\section{Qual é a importância de ganhar prêmios e que visibilidade dá ao seu trabalho?}

É claro que dá visibilidade. Meu pai, no dia seguinte em que a gente ganhou com Epitáfio, foi reconhecido no açougue. Tem uma visibilidade maior do que a gente pode pensar, mas, ao mesmo tempo, não é tanto assim. O fato de ter ganhado vários prêmios não me fez, por exemplo, fazer muito mais publicidade. Não é como na América, onde o cara ganha um prêmio e nunca mais falta trabalho. Não é o Oscar e te confesso que alguns dos clipes pelos quais sou mais apaixonado não foram premiados.

Isso, por exemplo, abre meu repertório e acho que é um que não há outro igual. Não é uma idéia copiada de nenhum clipe. Modéstia à parte, acho que é um trabalho de direção super legal, que me orgulha, pois é completo, tem idéia e realização legais, fotografia e edição muito boas, figurino legal para caramba do Marcelo Sommer, e (Paulo) Miklos arrebentando. Sou muito feliz com ele e não ganhou prêmio.

\section{Você tem controle da circulação e repercussão de cada clipe seu?}

Zero. Absolutamente descontrolado. Preocupo-me totalmente com a cópia que sai da minha produtora para a gravadora. A partir daí, algumas vezes eu vejo clipes fora de synch no ar. Aí ligo para a gravadora, para a MTV, para o Multishow, quem quer que esteja passando, porque, depois da cópia master que eu envio, cada TV faz a sua cópia. Enfim, vira uma loucura.

\section{Como funciona a questão de direito autoral?}

Com o advento do DVD, os clipes passaram a ter um valor comercial muito claro para mim. Antes do DVD, até para manter os orçamentos baixos, as gravadoras tinham o pretexto de que os clipes eram promocionais, promoviam o álbum. Não eram comerciais do álbum. A partir do DVD na prateleira de uma loja, isso caiu por terra. Ficou muito clara a possibilidade comercial do DVD e do videoclipe também. Então, a partir disso e respaldado pela lei, comecei a cobrar direitos autorais pelos videoclipes e pelos DVDs também, que variam muito de caso a caso. Talvez eu seja um dos poucos diretores no Brasil que cobram e recebem porcentagem de videoclipes. Ganho uma porcentagem por cópia vendida de DVD, de $2 \%$ a $5 \%$, variando de projeto para projeto. Tem projeto que você ganha uma porcentagem mais alta, $5 \%$, mas, a partir de 30 mil cópias, quando a gravadora conseguiu pagar o investimento, digamos assim, ficamos sócios no lucro. Ou não. Você ganha $2 \%$ a partir da primeira cópia. 
Tem projeto que abro mão do direito autoral. Troco por um advantage, digamos assim. Ele me dá uma grana e eu deixo de cobrar o direito autoral. Existe essa possibilidade também, porque sei lá o que vai acontecer com esse mercado das gravadoras. Então, às vezes, é outro acordo bom não precisar ficar acompanhando a cada trimestre como é que vão as vendas e tudo mais. Então às vezes pode ser um bom deal para ambos os lados.

\section{Você arquiva e cataloga seus trabalhos?}

Arquivo em DVCAM. Claro que todas as produtoras têm. Depende de como o clipe é feito também. Todas as produtoras pelas quais eu passei ou fui sócio têm másteres em beta digital e beta analógica também. Eu na minha casa tenho masters DVCAM para eu poder assistir e mexer na hora que quiser.

Você costuma filmar para arquivo pessoal e, de repente, sente necessidade de usar aquilo em algum clipe?

Cada vez mais eu faço isso. Sempre que estou com uma câmera à mão, no meio da produção de um filme, de um clipe ou só porque a câmera está no carro, porque voltei de um lugar ou fui com meu filho no parque, fico esperto para coisas legais que possam me inspirar.

Em Epitáfio, por exemplo, eu usei muito material. Não só material que filmei objetivamente da minha família, dos meus amigos, da minha casa, mas disso. Por exemplo, tem um moleque que corre de cueca, que é um cara genial que filmei quando estava fazendo um documentário para a HBO. Em 1998, fiz um segundo documentário do Brazilian Music Festival, um festival brasileiro que aconteceu em Nova lorque. Só que, antes de ir para Nova lorque, a gente viajou ao Brasil atrás dos artistas e da casa dos que estavam indo viajar. Ou seja, a gente foi à casa do Hermeto Paschoal, em Bangu; a Caruaru, fazer a Banda de Pífanos; a Recife, fazer o Cascabulho. Vi um moleque de cueca correndo, se divertindo, e, na hora, falei: "Vou gravar esse moleque". Ainda era Super-8. Não era nem vídeo. E filmei. "Um dia eu uso". No Epitáfio, lembrei dessa cena e usei.

Agora com o digital é ainda mais fácil. Você não queima negativo. É bem mais barato do que fazer em filme. Então, sim, eu fiz bastante, tanto filme quanto imagem em still e foto.

\section{Com a pulverização de sair da tevê e ir para outras mídias, como está o videoclipe brasileiro hoje?}

O mercado mudou muito. Há mais ou menos dois anos eu não faço um videoclipe. Não há mais encomendas e orçamentos das gravadoras como havia, mesmo que fosse para se fazer um clipe decente com condições de viajar, construir cenário ou fazer em película. O videoclipe hoje mudou bastante de característica. Ele tem muito pouco ou nada de dinheiro. São muito pontuais realmente os artistas que ainda têm uma grana vinda do departamento de marketing da gravadora. Talvez dê para contar nos dedos de uma mão quais são os artistas que ainda trabalham nos moldes antigos, digamos assim, de quando havia a indústria fonográfica. Então ele é uma plataforma para ainda mais experimentação e sem compromisso. É feito com celulares e câmeras de vídeo, e tem que ser, forçosamente, algo muito barato e que depende da dedicação total da equipe envolvida, que certamente ganhará muito pouco ou nada de dinheiro. Já ganhava muito pouco antigamente. Hoje em dia, tende a zero, quando as pessoas não tem que por dinheiro.

Então mudou bastante em pouco tempo, muito por causa da derrocada final da indústria fonográfica, que, há algum tempo, ainda dava um pouquinho de dinheiro para a gente produzir com um pouco mais de cuidado e de possibilidades. Alguns artistas até estão começando a bancar do seu próprio bolso, pelo simples fato do clipe ter sido pulverizado para a Internet, da MTV não ter mais a mesma força que tinha há 4,5 anos. A MTV estimulou muito os artistas e as gravadoras a colocarem dinheiro e expandirem as possibilidades artísticas dos clipes. 


\section{Para você, ainda é interessante fazer videoclipe?}

É sempre muito interessante, mas confesso que estou meio órfão e vivendo a tristeza de um formato e de uma fórmula que havia até há pouco tempo e que não há mais. Muita gente não me chama, porque acha que vou precisar de um orçamento " $x$ " para fazer os clipes como eu fazia. Muita gente também prefere trabalhar com molecada que está a fim de fazer os clipes com esse formato de trabalho que existe hoje. Confesso que ainda não consegui me adaptar. Até porque estive muito ocupado, ultimamente, principalmente por causa da minha agenda e do filme dos Titãs, para o qual eu tive que doar bastante do meu tempo, e recusei alguns trabalhos.

Mas eu sinto que a minha produção, mesmo na publicidade, está órfã de todos os experimentos que fazia nos videoclipes. Isso tem me deixado bastante triste e, ao mesmo tempo, instigado a voltar a pesquisar, não sei se para videoclipe, mas a ligação da imagem com o som, talvez seja num trabalho com longa-metragem. Ou seja, usar tudo que aprendi com os videoclipes no longa-metragem. Um dos meus próximos projetos é fazer um filme de ficção que me deixe extravasar toda essa criatividade que os videoclipes me deixavam e já não deixam mais.

\section{Qual é a relação que há entre videoclipe e cinema?}

O clipe é tão aberto que pode ser tudo. Já Foi, por exemplo, é um rodie movie, mas não tem uma história. Não tem começo, meio e fim. Não tem roteiro. Já Isso tem mais ou menos. Não claramente. Tem intro do Branco (Mello). Apresentam-se os atores. Vem os conflitos e eles terminam juntos. É um roteirinho, enfim. Agora tem clipes, Tem Alguém Aí?, do Gabriel, que não tem nada de roteiro. Tem dissertações, diálogos, edição. Tem uma coisa que vai linkando com a letra. Quer dizer, o rato é meio o jovem ao qual o Gabriel fala: "Não vai se detonar". O clipe, na verdade, é bem porrada, meio anti-drogas e moralista. Acho legal dar um se liguetes na rapaziada. Ele fala: "Atenção, não sai por aí detonando". Então acho que há clipes que têm historinha. Paralamas (do Sucesso), Ela Disse Adeus, tem historinha e uma coisa com cinema mudo muito forte. Para usar a linguagem no sentido mais estético, acho que também com relação ao conteúdo é uma coisa completamente aberta. Tem clipes que são apenas viagens estéticas ou que pontuam a letra um pouquinho. Cabe tudo.

\section{O que você levou da experiência com videoclipes para o filme dos Titãs?}

Sincronismo, organização, musicalidade, planejamento, dedicação, respeito à obra do artista. Mas acho que esse filme tem muito a ver com a minha bagagem como jornalista, mais do que como diretor de videoclipe. Eu já vejo na minha produção como jornalista a preocupação com o sincronismo e com a musicalidade. No caso dos clipes, eles me proporcionaram muita expressão artística - "vamos para a Lua, vamos para debaixo d'água" - que não é uma coisa que esse filme carecia. Ele carecia de uma pessoa que trabalhasse com os Titãs na melhor maneira de contar a história. Então aí minha bagagem como jornalista foi mais importante.

Claro que em todos os clipes que a gente teve que fazer dentro desse filme, o fato de eu ter dirigido muitos clipes me ajudou, facilitou, abriu a cabeça e me deu ferramentas técnicas que ajudaram muito o filme. Mas dentro dessa obra eu me vejo muito mais como um jornalista do que como um diretor de videoclipes. Apesar de a maioria das matérias colocar "o diretor de videoclipes, Oscar Rodrigues Alves", que é como apareci muito mais na mídia nesses últimos tempos, eu sou jornalista, profissão da qual, como diria o nosso exMinistro do Trabalho, "sou, mas não estou" (risos). Foi uma boa combinação dessas duas profissões em que atuo.

Muita gente me falou: "Comecei a ver o filme dos Titãs e achei que era uma sucessão de videoclipezinhos ou eventinhos U2, entre aspas, e, ao longo do filme, percebi que você estava me contando uma história". Há roteiro muito claro nas entranhas daquela 
colagem maluca de eventos, o que atribuo muito ao meu background como jornalista. Mas fico muito contente de ter conseguido, com o Branco, desenvolver esse roteiro sem perder a carga pop que o videoclipe tem e que esse filme precisava. Acho que ele tirou de mim o que tenho de melhor, por isso me dediquei tanto a um projeto que me deixou trabalhar em tudo o que mais gosto. 


\title{
Videoclipes Comentados de Oscar Rodrigues Alves
}

\author{
"QUITAMBÔ" - BATOCOTÔ \\ Data: 1992 \\ Roteiro: Oscar Rodrigues Alves \\ Direção: Oscar Rodrigues Alves \\ Assistente: Adriana de Lima Barbosa \\ Produção: Adriano Melo \\ Fotografia: ... \\ Operador de Câmera (VT): ... \\ Direção de Arte: ... \\ Figurinos: Tita \\ Edição e Montagem: Oscar Rodrigues Alves \\ Edição de som: ... \\ Figurantes: ... \\ Contratante/Financiador: ... \\ Premiação: .... \\ Materiais Utilizados: Blimp, tripé e steadicam. Câmera K. \\ História do Videoclipe
}

Foi exibido na MTV, teve zero de impacto e a banda também não deu certo. Mas eu fui mordido pela mosca do videoclipe. Teve dinheiro da (gravadora) Velas. Eu acho que era 7 mil moedas brasileiras da época. Era bem pouco. Recebi a música e ouvi à exaustão, como sempre. Ela falava de areia. "Qui tambô tambô". "Tambô" é uma festa africana. "Na areia, na areia". Esse meu amigo tinha uma casa em Iguaba, na região dos Lagos, no Rio, e eu tinha ido de férias para lá, quando ouvimos e falamos: "Vamos para Arraial (do Cabo) fazer esse clipe". Tinha uma noção do que precisava - a banda tocando e outras imagens que fossem dando dinâmica ao clipe. A certa altura, o Jorjão Barreto, cantor da música, acha a garrafa no chão e a joga no mar. Tivemos também a idéia de trabalhar com uma senhora que faz desenhos em garrafas de areia. Então, quando viajamos, sabíamos o que iríamos fazer.

Houve essas três etapas: em São Paulo, a gente captou essa senhora fazendo a garrafa; depois, no Rio de Janeiro, fizemos a banda no estúdio; e, em Arraial do Cabo, fizemos os músicos dançando e cantando na areia. A gente enterrou uma câmera na areia e colocamos a garrafa grudada na lente. Então fazia fade out numa imagem e o fade in era óptico, digamos assim. Não era eletrônico. Quando a garrafa estava encostada na câmera, tapava a entrada de luz e deixava tudo escuro. Quando ele tirava a garrafa, revelava se tratar de uma garrafa grudada ali. Isso funcionou super bem. Eu falei: "Acho que perigas de eu fazer esse negócio bem-feito". Depois usamos a garrafa debaixo d'água também com esse blimp. O Jorjão joga a garrafa na água e daí a gente termina o clipe com essa imagem subaquática, da garrafa boiando com o nome da música, Quitambô.

A gente improvisou uma câmera k com o meu carro. Então meu amigo ia dirigindo e eu ia sentado para fora da janela com o steadicam simulando uma câmera k. Então era uma câmera k brazuca, digamos assim. Esse clipe também foi editado linearmente, na extinta Frame, produtora que ficava em Cotia. Editamos em beta no que a gente chamava de Abbey Road, duas máquinas players e uma rec.

Lembro que depois o Téo, um dos líderes da banda, baterista de quem eu já era bastante fã, por conta dos discos do Djavan, viu o clipe e falou: "Oscar, nunca vi um clipe tão legal". Claro, o Téo não via muitos videoclipes e acho que ele ficou bastante entusiasmado com o jeito que mostrava a música, com o baixo no lugar certo e sincado. Foi um elogio legal que me deu um gás. 


\section{Heranças e avanços}

Os objetivos iniciais eram fazer um clipe dinâmico, colorido e musical. Ao longo das filmagens, como sempre acontece, arrumamos um saco de lixo preto, fizemos um espelho d'água na praia, uma pequena poça, e gravamos o Jorjão cantando através do reflexo na poça. Na hora em que rola um solo de baixo, e, antes de rolar um special da música, ele dá um grito e, na hora do grito, dá uma balançada na água e a imagem dele dá uma deformada. Isso virou uma passagem para o special. Pintou na hora e foi uma coisa totalmente, entre aspas, linguagem videoclipe. Foi mais um elemento que me fez perceber que eu sabia criar e executar, o que me deu vontade de fazer o segundo.

\section{Relação Imagem-Música}

Lembro de videoclipezinhos que eu fazia na época da faculdade. Meu pai comprou uma ilha VHS. Então eu pegava Earth, Wind and Fire, In The Stomp, uma música que gosto para caramba. la para a praia, levava a câmera e gravava. Depois voltava para a ilhazinha e editava. Sempre tive fissura de sincar os cortes com a música, o que fui refinando e até hoje faço. Não é que, a cada acorde da música ou a cada virada de batera, eu picote de acordo com o tanto de notas que os caras emitem. Mas alguma ligação intrínseca com a dinâmica da música você sempre vai encontrar nos meus clipes. Eu acho isso importantíssimo. Sempre os meus clipes, inclusive Batakotô, vão ajudar, entre aspas, a pessoa a ouvir a música de uma maneira mais legal, seja fazendo cortes que te levam para o instrumento, seja mudando a dinâmica da música. Não são poucas as pessoas que falam: "Consigo ouvir instrumentos que eu não conseguia ouvindo a música, na hora em que vejo seu clipe. Você mostra o que está acontecendo musicalmente muito melhor para mim do que conseguiria identificar ao apenas ouvir a música". Acho que videoclipe legal é o que faz a música ficar mais legal.

No caso do "Batakotô", como é uma banda de músicos, todas as viradas, solos e "specialzinhos" estão registrados, até de um jeito um pouco careta, digamos assim. Como foi o primeiro, eu fui meio óbvio no que estava acontecendo. Depois fui refinando esse jeito de editar. Mas não tomo qualquer instrumento como base. Vou de acordo com o que a música está me sugerindo.

\section{Marcas}

A única marca bem visível é a montagem a serviço do áudio. Também tem a utilização de vários suportes de câmera - blimp, steadicam - e instrumentos de maquinarias diferentes, como gruas. Se você analisar, eu acho que tem mais clipes que usam diversos maquinários do que os que vão à simplicidade. Mas já fiz clipes tão diferentes que não dá para tirar uma marca. 


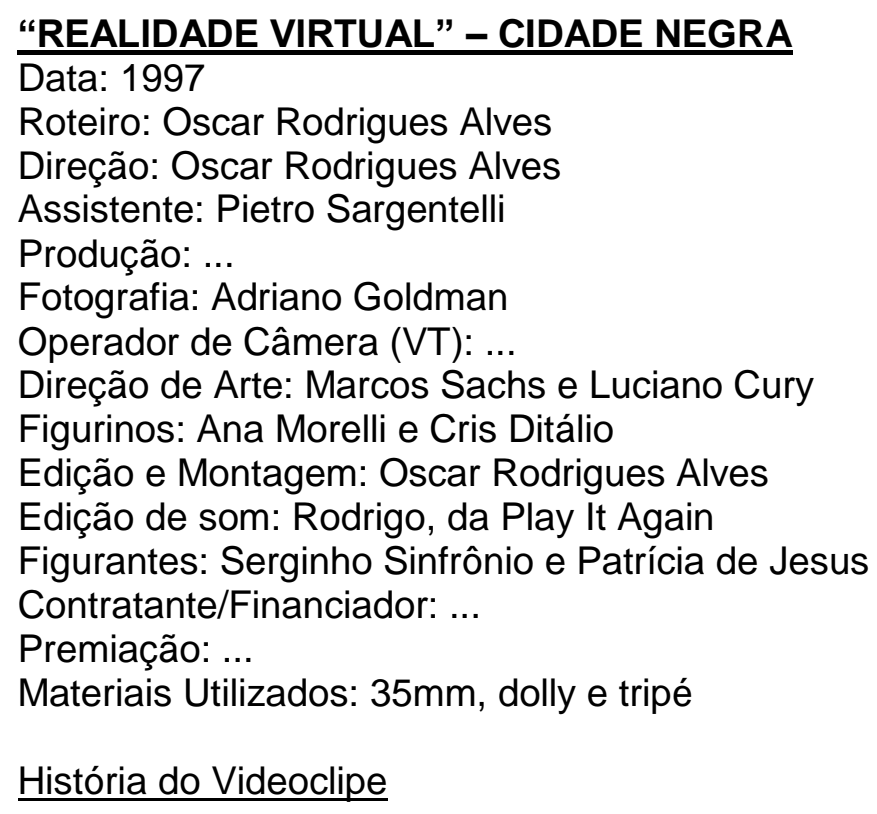

Foi o primeiro clipe que fiz para a Sony. Tinha uma graninha e Cidade Negra estava num momento bem poderoso. Pietro (Sargentelli) deu uma idéia muito legal que era fazer um futuro próximo, com uma cidade lotada de antenas. Achei que tinha equipamento para fazer essa cidade bem legal. Alexandre Cruz, que tinha montado comigo o João Marcelo (Bôscoli, Flor do Amanhã), já estava bombado, operando o frame, equipamento de efeitos visuais e composição. Também havia umas antenas legais em São Paulo, que conseguiríamos captar, assim como fazer algumas em 3D e em animação, se quisesse. Era uma música difícil, que não levava para muito para algum caminho a partir da letra. Então essa idéia foi muito bem vinda.

Luciano Cury, que também cuidou da direção de arte na parte eletrônica, conseguiu uma liberação para a gente filmar na torre da (TV) Bandeirantes. Então estabelecemos vários masters. A banda teria um estúdio cenográfico no topo de uma torre. A gente 0 construiu no estúdio da 5.6. A parte de fora do estúdio foi feita em 3D, pela Vetor Zero, e aplicada digitalmente no topo da torre da Bandeirantes, na (avenida) Doutor Arnaldo, em frente ao (hospital) Emilio Ribas. Também fizemos uns masters em antenas que tinham em Alphaville. E fiz travelling giratório de 360 graus, debaixo das antenas e coloquei os caras em cima.

Daí, claro, tinha que ter a gata. Inventamos uma historinha, que acho que não fica clara no clipe, mas também não precisava, de uma menina que tenta ouvir o som dos caras no estúdio. Ela manda um emissário, que é um negão amigo meu - Serginho Sinfrônio -, gente fina que dança para caramba. Ele pára embaixo da torre, abre o laptop, põe o fone e transmite o som que consegue hackear dos caras tocando na torre para ela. Mas é tudo meio pretexto para usar um laptop, um pouco de tecnologia num clipe chamado Realidade Virtual. Virtual também por ser um futurinho. Ainda tem a casa da gata numa janela, através da qual ela vê a torre onde os caras estão tocando. É um clipe ousado e acho que nunca tive tanto trabalho de reuniões com a equipe. Também havia bastante prazo para fazê-lo uns dois meses.

Foram quatro diárias, mas uma choveu e tivemos que refazer. Acabou sendo quase cinco diárias. Foi um clipe muito trabalhado. Para o figurino, Cris Didália e Ana Morelli desenvolveram texturas e fizeram jaquetas com sagu, aquela bolinha branca, e uma resina de borracha. Trabalho super cuidadoso. A gente tinha transporte e câmera sempre à mão. Adriano Goldman e eu saíamos pela cidade fazendo imagens de todas as torres para depois compor. Eu usei e abusei das condições que tinha. É um clipe que não ganhou prêmio, mas foi indicado a sete categorias da MTV. Clipe do qual eu gosto bastante e, certamente, elevou o padrão técnico e estético dos meus clipes. 
O clipe tem composição, flame em flame, na cidade com as torres. Teve um pouquinho de 3D, que a Vetor Zero fez, no estúdio visto do lado de fora da torre. Não usei grua, nem steadicam, mas, sim, dolly e tripé. Foi editado em AVID e pós-produzido em flame.

A parceria com Cidade Negra tornou-se tão forte, porque fiz apresentação como se fosse de filme publicitário para eles, que sentiram que eu os estava tratando com atenção. Isso foi muito legal. Nunca fiz isso para outro videoclipe. Fizemos fotos e compusemos a cidade. Era um material que não serviu exatamente só de apresentação para eles, mas também para enxergarmos o clipe inteiro. Isso gerou uma amizade entre a gente. Fizemos várias reuniões e fui mostrando tudo para eles passo a passo.

\section{Heranças e Avanços}

Atingimos uma qualidade de imagem e de fotografia power. Acho que para todos nós que trabalhamos no clipe, ele foi um passinho à frente nas nossas carreiras e trabalhos. Foi uma fotografia incrível do Adriano Goldman; e uma cenografia muito chocante, assim como todo o acompanhamento com relação ao filme, do Mário Sachs. Acho que foi muito legal, à custa de bastante trabalho. Tivemos muitas reuniões para chegar ao resultado final. Queríamos fazer clipe de rigor técnico e estético, e fizemos.

O clipe poderia ter contado de modo mais claro a história da menina que quer ouvir o som dos caras. Mas não era algo que a letra e eu pedíssemos muito forte. Isso é o efeito a posteriori. Em todo clipe, alguma hora, seja uma semana ou dez anos depois que você entrega, fala: "Podia ter feito uma cena assim, se tivesse conseguido filmar quando não deu, porque o sol se pôs". Então não é algo que tire meu sono.

Teve avanço em todos os sentidos, na fotografia super cuidada, diferente da de vídeo externazinha do Batakotô e bem diferente do estúdio do João Marcelo. Enfim, uma fotografia requintada, moderna, nos seus tons de verde e azul. Um cuidado com a pele negra dos caras. Casting 90\% negro. Cenografia requintadérrima. Composições digitais, 3D. Enfim, um clipe que usou muitos elementos e forçamos a barra em todas as áreas que podíamos.

Talvez também mostre mais segurança minha de ter feito dois (videoclipes) e já ter mais na mão a questão de como separar os másteres e que tipo de coisa eu teria que filmar para conseguir um clipe com uma dinâmica legal. Enfim, experiências de trabalho mesmo, de vida. Nada claramente herdado.

\section{Relação Imagem-Música}

Tem uma edição requintada de áudio. Quem fez foi o Rodrigo, da produtora de áudio Play It Again. A Sony me mandou os másteres da música, com bateria, teclado, tudo separado. Eu estava próximo ao Bernardo Vilhena, fazíamos Companhia da Música, e foi ele quem levou Cidade Negra para a Sony. Depois eles se desentenderam. Mas, nessa época, Vilhena era bem amigo da banda. Então usei uma poesia dele, que não me lembro o nome, e ele faz uma locução: "Há sete mil anos, a mesma ...". Fiz uma aberturinha e, no meio do clipe, na hora em que nosso hacker vai armar o equipamento, eu também abria a música e deixava só a bateria. Ele abre o computador, acha o sinal dos caras e daí a gente volta para o estúdio deles tocando. Cidade Negra só ficou sabendo na hora em que viu o clipe e adorou.

A letra era sobre uma paixãozinha platônica e distante: "Mas quando você passa / e eu vou atrás / do nosso dia-a-dia / eu já não me lembro mais". Não tem um momento em que os caras estão com a gata. Enfim, a coisa da realidade virtual ficou muito mais pelo ambiente futurista que a gente fez. Não tem nada muito ligado só a letra, não.

A música tem uma coisa legal que é a participação especial da Patra, cantora jamaicana que não podia participar do clipe. Mas, de alguma maneira, ela tinha que estar presente. Eu queria que ela estivesse. Então pegamos uma lâmpada de refletor de cinema 
gigantesca e a Sony me mandou a voz dela separada. Eu passei por um osciloscópio, equipamento que lê áudio e transforma em imagem, em ondas, e depois o Alexandre as aplicou dentro da lâmpada. A banda fica meio dançando em volta e adorando a voz da Patra. Virou um máster legal para caramba. Está dentro dessa riqueza de coisas que acontecem no clipe.

A gente também conseguiu criar uma dinâmica que fosse sustentando e dando gás para cada um dos climas da música, evitando que o clipe ficasse enfadonho. Criamos várias situações e tiramos proveito disso. Esse foi um clipe bastante planejado.

\section{$\underline{\text { Marcas }}$}

Não saberia dizer, porque, deixando a modéstia de lado, sempre tenho em mente fazer um clipe legal. Faço clipes de maneiras tão diferentes que é difícil colocar uma marca. É difícil ver um clipe meu e falar: "Esse eu achei meia-bomba, chato, mal feito". Então, vontade de fazer as coisas bem feitas. É um clipe bem diferente dos dois anteriores, mas, assim como eles, é bom para a música. 


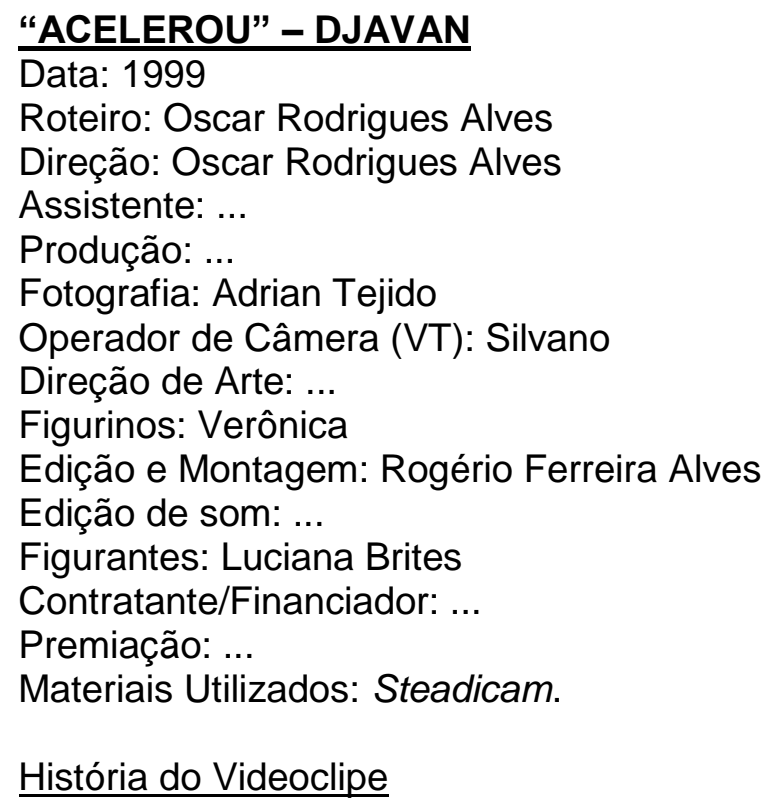

Eu queria filmar esse clipe em Barcelona e levei um livro para o Djavan ver. Na hora que o tirei da mochila, ele falou: "Não precisa nem abrir esse livro. Eu sou fascinado por Barcelona e fã número 1 do Galdí. Nós vamos fazer alguma coisa em Barcelona, mas não vai ser agora, porque não tenho data para viajar. Vamos fazer em Paraty". Conheço muito bem Paraty. Passei as minhas férias de juventude todas lá. Meu pai tinha um terreno na praia. É uma cidade bastante inspiradora. Achei que a gente podia fazer um clipe legal. Saímos filmando nas locações.

Fizemos casting e descobrimos uma garota espetacular. Ela é atriz, bailarina, fez ginástica olímpica. Não era só um rosto bonito. Esse é um clipe que cresceu muito da concepção para a realização, porque a gente começou a rodar numa manhã bem cedo, no amanhecer numa praia de Paraty, numa maré baixa. A idéia era fazer algumas cenas bonitas dela andando na maré baixa. Só que ela começou a fazer algumas acrobacias, dançar, se jogar na água e virou algo incrível. Ela deu um gás no clipe espetacular. De tudo que fez ali, a gente foi atrás, numa situação muito perigosa até para a câmera, porque é muito difícil você correr com ela na água. Um tombo na água salgada inutiliza uma câmera muito cara. Então ali realmente teve uma precisão de movimentos muito grande do Silvano, o Leão Mole, que é operador de steadicam de todos os meus clipes.

Depois fomos para um barco em construção, também uma situação bem perigosa para a steadicam, e para as ruas de Paraty. É muito difícil andar com steadicam, porque a rua é de pedra e toda tarde chovia no verão. Havia desníveis muito grandes entre pedras altas e buracos. Era muito difícil de trabalhar.

Outra cena que a gente fez super legal foi aquela em que a Luciana se pendura numa corda e se joga no rio. Não é qualquer um que faz aquela cena. Ali teve muito dos treinos de circo e ginástica olímpica dela. $\mathrm{E}$ a falta de medo também.

O objetivo inicial era fazer cenas legais em Paraty, que eu sabia que havia vários fundos e situações legais. A gente chegou um dia antes e a cidade nos ofereceu coisas muito legais. À procura de um rio, achamos um barzinho, que foi até o Adrian (Tejido) que notou, e que tem um negócio muito engraçado escrito e um índio desenhado. Parece um bar perdido num deserto americano.

Depois, na montagem, Djavan pediu para que eu tirasse um pouco de cenas da menina e colocasse mais dele. Ele achou que estava muito em cima dela. Mexi um pouco na montagem por conta desse pedido. Não era nada sério e a montagem que acabou ficando eu gosto mais. Na parte A da música, ele pediu que deixasse um plano-sequência comprido dele andando no cais de Paraty, que destoa um pouco do ritmo da montagem, 
mas que acho bonito. Na verdade, ele pediu e achei que ficaria até mais bonito. Atendi sem discussões.

\section{Heranças e avanços}

Não identifico heranças, não.

Relação Imagem-Música

A letra fala da paixão de um homem por uma mulher, que acelerou e depois tirou o corpo fora. Então eles não estão nunca juntos. "Ando ...". Aparece ele andando no cais do porto e cortando para cenas incríveis dela, super sensuais. Então aí, sim, bem em cima da letra.

Usei mesmo a mulher onírica em situações reais, mas que pudessem ser lembranças especiais dele, e tem um special, que é aquele "muito mais perdido, quase um cara vencido" (canta alto), em que a gente "ralitou" a música no Pro Tools, que é um programa de áudio. Então ficou "muito mais perdido" (canta bem lento e grave), bem mais lento. Ele cantou mais lento e a gente rodou a câmera mais lentamente, para que tivesse a imagem na velocidade normal dela, 24 quadros (por segundo). A gente rodou a 12 para que, quando estivesse a 24 quadros por segundo, ele estivesse sincado com a velocidade normal, original da música, mas acelerado.

Nessa hora, a gente pegou o que a Lú Brites tinha feito de mais incrível na praia e editamos num ritmo mais acelerado do que o do clipe e fizemos esse special, que é bem legal e que vai gerar uma herança no Até Quando?, do Gabriel O Pensador.

\section{$\underline{\text { Marcas }}$}

Para falar de uma maneira mais técnica e ampla, o respeito à dinâmica da música. Nessa hora, a música é completamente diferente do que na intro, na parte $\mathrm{A}$ e na parte $\mathrm{B}$. 


\section{“ATÉ QUANDO?" - GABRIEL O PENSADOR}

Data: 2001

Roteiro: Oscar Rodrigues Alves e Nando Cohen

Direção: Oscar Rodrigues Alves e Nando Cohen

Assistente: ...

Produção: ...

Fotografia: Adrian Tejido

Operador de Câmera (VT): ...

Direção de Arte: Nando Cohen

Figurinos: Gabriel O Pensador

Edição e Montagem: Oscar Rodrigues Alves, Rogério Ferreira Alves e Daniel Rezende

Edição de som: Paulo Beto

Animação: Anderson

Figurantes: ...

Contratante/Financiador: Sony Music.

Premiação: Vencedor do prêmio de melhor montagem no VMB 2001.

Materiais Utilizados: $16 \mathrm{~mm}$, animação tradicional feita a mão no red bass.

História do Videoclipe

A letra dessa música é muito forte e incita as pessoas a deixarem uma situação passiva, tomarem atitudes e tirarem as vidas do marasmo. O Gabriel tinha leitura muito jornalística dessa música e queria usar imagens de porradas mesmo, fosse da época da repressão no Brasil ou da Faixa de Gaza, com palestinos e israelenses brigando.

Eu argumentei que fazia muito isso na época em que era editor do Jornal de Vanguarda. Toda noite pegava as imagens jornalísticas do dia, $\boldsymbol{A A U U}$, dos Titãs, e fazia um clipe com essa pegada. Não queria fazer isso de novo. Liguei para Nando (Cohen) e tivemos a idéia de fazer um clipe de uma forma muito simples: Gabriel sentado numa cadeira, com interferências.

Nando me apresentou o Anderson, um dos animadores que trabalhavam com ele, de traço genial, tosco, fortíssimo. Criações incríveis. Eu topei na hora. Houve até outros animadores, mas a base são os traços do Anderson. Gabriel tinha receio, porque já tinha usado animação em outro clipe, mas, quando viu os traços do cara, também se amarrou. Fomos nós três para o Rio - eu, Adrian e Nando - e a gente posicionou a câmera e colocou a lente, acho que era uma 5.5, e o Gabriel sentou na poltrona. Não houve figurinista. Ele mesmo levou as roupas. Nessa hora, ele ficava muito legal largado para trás e quando vinha para frente e grudava o rosto na câmera. Deu-nos a idéia de filmar dos dois jeitos e fazer os dois personagens - um passivo, o cara largado na cadeira, e um ativo, que dá o texto e tem a performance espetacular do Gabriel, que claro que eu, como diretor, ficava espetando.

A gente tinha a idéia de fazer uma coisa dele de braço cruzado e desenhar uma roupa de hospício. Na hora que vinha uma águia no clipe e falava: "Escola, esmola, favela, cadeia"; por exemplo, ele mesmo pôs a cabeça entre as pernas e a abraçou, uma coisa da performance na hora. Nando falou: "Genial. Vamos pôr uma águia que vem e ataca o cara". Não foi uma coisa que a gente pré-concebeu. Depois que ele fez isso é que Nando teve a idéia de colocar essa águia e a gente também sentiu que havia poucas animações no clipe. A dinâmica pedia mais animações, que estavam um pouco diluídas.

Um grande barato foi essa sobreposição do Gabriel com ele mesmo. Ele tinha levado, sei lá, duas camisas diferentes, cinzas. Acho que a calça é a mesma. A gente usou uma para o passivo e uma para o ativo. Daí eu montei o clipe sozinho. Não sabia como fazer essa sobreposição no art, tecnicamente, e pedi para o Rogério. Depois, eu propus a ele que, em cima da minha primeira edição, que já estava quase pronta, sentasse uma tarde e desse uns pitacos, o que ele fez.

Daí nós mostramos para o Daniel, que estava montando outro clipe e falou: "Nossa, que legal!". "Então, Dani, senta aí uma tarde e enfia a mão um pouquinho também". Ele sentou uma tarde, enfiou a mão um pouquinho e eu dei co-edição para o Rogério e o Daniel. 
Era um clipe no qual nós estávamos muito entusiasmado com a simplicidade e com a diferença para tudo que estava no ar. Quando as pessoas falam da linguagem videoclipe, que é um termo que eu abomino, porque imagino muitos cortes rápidos, o que não é o caso; eu ambicionava bastante fazer um clipe com um formato bem diferente dela. Essa é uma coisa muito difícil que eu nem sempre consigo, mas sempre procuro. Já tinha uma simplicidade pretensiosa, digamos assim, que acabou sendo ainda mais enriquecida.

Eu faço várias palestras em faculdades, ou mesmo semanas de criação publicitária, e muita gente me pede para falar um pouco da relação entre videoclipe e publicidade, já que eu trafego bastante nos dois. Em todos os lugares em que dou play nesse clipe, ele é aplaudido antes do final da exibição. É o clipe meu que as pessoas mais admiram. $O$ primeiro comercial de Coca-Cola me foi dado claramente porque o cliente viu o clipe e falou: "É genial". Eu ouvi na MacCan Ericsson também. Quer dizer, ele apresentou uma linguagem. Foi um marco na minha carreira fortemente e na do Nando também, com certeza.

\section{Heranças e avanços}

Tem uma herança dos meus clipes anteriores que é a alteração da velocidade. Esse também é acelerado na hora que ele fala: "Acorda, não tenho trabalho, procuro trabalho, quero trabalhar". Usamos a mesma técnica do Djavan, Acelerou. Reduzimos a velocidade da música, rodamos com ele cantando mais lento e a câmera rodando mais lenta para que, na hora em que tudo fosse acelerado, ele ficasse rapidinho e "sincado" com a música original do CD.

De avanços, há procura de linguagem e de montagem. A montagem foi premiada, apesar de eu achá-la muito simples, de poucos cortes. Acho que ele é premiado mais pela pós-produção inteira do que especificamente pela montagem, apesar de ser uma honra ter sido premiado ao lado do Rogério, que é um grande parceiro, e do Dani, que é um montador que eu admiro muito. O que o Daniel Resende fez, por exemplo, foram sutilezas de esconder um personagem e entrar com outro sincado com a música. Eu acho bonito que ela tenha sido premiada, pois é muito inteligente e sutil.

\section{$\underline{\text { Marcas }}$}

Uma pegada nervosa de direção. Eu acho que consegui tirar do Gabriel o melhor da performance dele, apesar da restrição de estar sentado numa poltrona. Ou seja, tem uma pegada de direção com coisas muito simples e com uma performance que você nunca viu do Gabriel. Algo muito gratificante para um diretor.

\section{Relação Imagem-Música}

Houve uma edição de som brilhantemente feita por um cara que faz áudio na Logo Filmes, Paulo Beto, cujo codinome artístico é anvil fx. Fez sound design brilhante, mas não foi para o clipe porque Gabriel não quis alterar a música original. Foi uma pena. Continuo discutindo com ele até hoje, mas ele não quis. Eu acho que acrescenta muito na carga dramática do clipe.

Nós fomos vendo a letra e criamos cenas específicas para cada coisa que ela dizia. Fomos decupando e tentando ter leituras interessantes para cada um dos versos que nos indicavam que ali merecia uma animação. Não são relações óbvias. São leituras que sempre acrescentam outra dimensão à letra. Reforçam, mas sem obviedade. A águia, por exemplo, fala de repressão e compressão econômica. 


\section{"EPITÁFIO" - TITÃS}

Data: 2001

Roteiro: Oscar Rodrigues Alves

Direção: Francisco e Oscar Rodrigues Alves

Assistente: ...

Produção: ...

Fotografia: Marcelo Trotta

Operador de Câmera (VT): ...

Direção de Arte: ...

Figurinos: ...

Edição e Montagem: Oscar Rodrigues Alves

Edição de som: ...

Figurantes: ...

Contratante/Financiador: Abril Music

Premiação: Melhor videoclipe rock, Melhor videoclipe do ano segundo os jurados, Melhor videoclipe do ano segundo a audiência no VMB 2002.

Materiais Utilizados: Material de arquivo em Super-8 e 16mm

\section{História do Videoclipe}

Estava na minha sala um dia e tocou o celular. Era da MTV. Eu acho que era a Alê Briganti falando: "Estou aqui com (Tony) Bellotto e ele queria falar com você, pode ser?". "Claro". Eu não conhecia o Tony. Tinha feito uma entrevista com ele em 1988-89, na época de Õ Blésq Blóm, quando trabalhava no SBT, no Jornal da Noite. Não o conhecia, portanto. Ele chegou e falou: "E aí, Oscar, tudo certo? O negócio é o seguinte: estou aqui na MTV e a gente vai lançar um clipe novo de Isso, que é a música de trabalho agora. $\mathrm{Na}$ verdade, a gente ia tirar um clipe do Luau MTV, mas acabei de assistir e não gostei. Achei que não é o caso de soltar isso como um clipe". Só parênteses: nos Titãs, principalmente depois da morte do Marcelo Frommer, que organizava bastante a banda, geralmente o compositor da música de trabalho é quem encaminha o clipe e cuida um pouco da vida dela. Isso era do Bellotto, letra e música. Era uma sexta-feira. "Eu gostaria de saber se você não quer fazer um clipe nosso. Tem quase nada de dinheiro, porque a gente ia tirar do Luau $M T V$ e precisa ter uma idéia boa até domingo de manhã" (risos).

Eu não ia deixar escapar jamais a chance de trabalhar com Titãs. Então falei: "Claro que topo". Desliguei o telefone, fechei os olhos e falei: "Puta que o pariu. O que eu faço agora?". Comecei a viajar em cima da letra, que falava de uma situação de ruptura de um casal e tal. Poderia ser "just another love song", que fala de um amor que vai acabando, mas, ao mesmo tempo, encontra forças em algum lugar e sobrevive.

Eu tinha acabado de fazer uma campanha de lançamento de novos sabores de Fanta, onde um dos filmes tinha rodado com uma elefanta - Bambi - e foi engraçado, porque rapidamente achei que não tem nada mais "isso" do que uma elefanta na minha cabeça naquela hora. Então peguei as imagens brutas rapidamente no arquivo, comecei a olhar e, como era (Paulo) Miklos que cantava a música, tive a idéia de fazer um encontro entre um macho e uma fêmea que não conseguem se adaptar e se beijar, não falam a mesma língua e estão totalmente desencontrados. Pensei numa estradona, num ambiente que interferisse menos nos personagens. Peguei uma imagem do filme de Fanta, tirei a cor, passei para "ceca", que era uma idéia que eu tinha da cor, e achei que a música cabia perfeitamente na imagem da elefanta. Pus no meu laptop.

Jamais poderia imaginar que os Titãs fossem capazes de fazer uma reunião domingo de manhã numa padaria. Mas lá estava eu na Galeria dos Pães, na rua Estados Unidos, em São Paulo, e nos encontramos. Foram Bellotto, (Paulo) Miklos, a empresária deles na época, Connie Lopes, e eu. Sentamos e pedimos suco de laranja e pão de queijo. Eu pedi um sanduíche de mortadela, abri o laptop e, como já tinha trabalhado bastante com banda, sabia que todas elas prezam por um equilíbrio da participação de cada um no clipe. 
Para Isso, eu tinha sonhado que Miklos pudesse ter um papel um pouco mais especial por causa da questão desse master dele contracenando com a elefoa Bambi e não sabia como o resto da banda iria reagir. Na hora em que falei a idéia, mostrei a imagem e disse que era possível filmar com a elefanta, Bellotto e Miklos chaparam com a idéia.

$\mathrm{Na}$ reunião, eu já tinha conseguido desenvolver um pouco mais do enredo do clipe e deu tempo de falar: "Miklos e a elefanta na longa estrada da vida. Esse é o mote". "Ah, legal". Aí desenvolvi e cheguei no Rio de Janeiro já com uma idéia de locação, que era arrozal em Tremembé, que fica perto de Campos do Jordão, cerca de 180 quilômetros de São Paulo, e uma leitura de imagens bem em cima da música. Quer dizer, o mote era a impossibilidade de encontro entre esse macho e essa fêmea e tudo o que o macho estava tentando fazer para reconciliar com sua fêmea.

Os Titãs, na época, eram seis ainda - Arnaldo (Antunes) tinha saído e Frommer tinha morrido, mas Nando (Reis) ainda estava na banda. Então sempre havia muitas questões com todos eles e uma dificuldade em marcar o dia da filmagem. Mais do que isso: Charles (Gavin) estava à beira de ser pai. Na verdade, eu queria levar todo mundo para Tremembé, mas Charles falou: "Para Tremembé, não vou, porque minha filha está para nascer a qualquer instante. O máximo que eu faço é ir para São Paulo". O estúdio era bem perto do aeroporto. Se a Mariana começasse a ter contrações, ele voava para o aeroporto e pegava a ponte-aérea.

Dois dias antes de a gente filmar, Nando teve que cancelar, porque tinha coletiva do álbum solo. Daí marcamos para dali a uma semana. Só que três dias antes dessa nova data, Epitáfio bombou nas rádios, sem a banda e a gravadora imaginar. Não era a música de trabalho. Na verdade, alguém de uma rádio começou a pôr e as pessoas começaram a pedir a música. Ela ficou emocionante, porque a morte do Frommer aumentou muito a carga dramática dela, apesar dela não ter sido, de maneira alguma, composta por causa disso. A música calou fundo no Brasil inteiro.

Ouço pouco rádio, mas é fácil perceber quando uma música pega. Então eu mesmo lia nos jornais e revistas as músicas mais tocadas nas rádios. Durante meses, Epitáfio foi líder. Então você vê que ali é uma coisa que se sobrepõe ao jabá e ao trabalho de divulgadores de rádio e televisão. Foi uma música que você recebia Power Point de pessoas que pegavam imagens lindas e colocavam a trilha em cima delas e mandavam para outras pessoas. Enfim, estourou.

Nesse momento, a gravadora falou: "Pára com Isso. Vamos trabalhar Epitáfio agora". Eu fiquei desalentado, porque achava que era o clipe mais chocante que já tinha criado. Essa coisa da elefanta e tudo mais. Fiquei muito, muito, muito chateado e com um pepino para resolver que era responder a uma urgência de lançar um clipe e começar a criação do zero.

A letra de Epitáfio sempre remeteu à poesia do Jorge Luis Borges: "poderia ter comido menos lentilha e tomado mais cerveja". Enfim, é uma série de imagens de uma pessoa no final da vida que achava que devia ter aproveitado melhor. Então achei que era possível fazer um layout, como a gente chama, pegar a música, digitalizar para o computador e começar a juntar imagens da minha família, fossem as que meu avô filmou do meu pai em 1928 ou as que eu filmei da minha casa e da minha mulher. Eu não tinha filho na época ainda. As coisas do meu pai filmadas pelo meu avô eram em $16 \mathrm{~mm}$ com dupla perfuração, com a câmera Ison Kodak, que, quando meu pai nasceu, meu avô comprou para filmá-lo. Depois meu pai, ainda com essa mesma câmera, filmou minhas irmãs, em 16, e me filmou muito em Super-8. Eu roubei essa câmera dele, Canon 1014, e filmei bastante minha mulher, minha casa. Um material totalmente caseiro. Achei que aquilo estava muito adequado para depois o que (Sérgio) Britto, compositor da música, veio a chamar de "espírito da canção". Mostrei para o Tim Tim, fotógrafo, Marcelo Trotta, que falou: "O clipe está aí. Não temos mais nada para filmar".

Fizemos uma reunião no escritório dos Titãs, do Nelson (Damacena), que organiza a vida deles, e eles falaram: "Não tem o que mexer. Vamos só criar algumas situações para a gente ser inserido. Já está aí, mas pode usar essas cenas?". Falei: "Claro que pode. Cenas minhas. Está na mão". Na mosca. 
Então cada um escolheu como gostaria de ser filmado. Bellotto falou: "Vamos dar uma banda de bike por aí". Nando falou: "Vamos ao jogo do São Paulo". Meu amigo Mariano Boni, que trabalha na Rede Globo, conseguiu uma liberação para filmar no Morumbi. Branco (Mello): "Vamos à Vila Madalena, nos grafites que eu gosto para caramba". Charles queria ver National Kid. E Britto queria tocar piano na sala da casa dele, com o filho. Acho que são essas situações.

Meu pai entra como co-diretor porque filmou muitas das imagens que eu usei no clipe e que me alertou para a origem da minha profissão, do meu ofício. Certamente eu virei um diretor pelo contato que sempre tive com câmeras, pelo fato de meu pai me filmar desde moleque. Meu pai foi influenciado pelo meu avô, que filmava numa época, 1928, em que era muito difícil. Não se revelava filme no Brasil e você tinha que mandar para fora. Então quis prestar uma homenagem ao meu pai e ao meu avô.

Meu pai é cinéfilo, mas jamais pensou em levar isso mais a frente do que filmar os filhos. Na verdade, o cinema dele tem a ver com a paixão pelos filhos. E meu avô era médico e político, que comprou a câmera para filmar o amor dele, o filho. E eu sou Oscar Rodrigues Alves Neto. Não uso Neto. Meu nome já é grande o suficiente. Eu tirei o Neto, quando comecei a trabalhar. Mas na hora de colocar, coloquei diretores Francisco e Oscar Rodrigues Alves, porque esse Oscar Rodrigues Alves contemplava também ao meu avô. Então ficava todo mundo contemplado - meu pai, meu avô e eu. Meu bisavô chamava-se Francisco, meu avô Oscar, meu pai Francisco e eu Oscar. Então meu pai é Francisco de Paula Rodrigues Alves Neto, que é o mesmo nome do meu bisavô. E eu sou Oscar Rodrigues Alves Neto, mesmo nome do meu avô. Meu filho se chama Tomás para acabar com essa palhaçada (risos).

Tem umas cenas que meu pai fez no parquinho, na avenida Santo Amaro, quando eu era moleque, e, por coincidência, cada um pode chamar de um nome, foi onde o Branco fez o clipe de Go Back. Inacreditavelmente no mesmo parquinho que não existe mais. É onde passa a avenida Jornalista Roberto Marinho. Ele fez umas imagens subjetivas de um brinquedo chamado Disco Voador, que montava e subia com uma grua hidráulica. Meu pai fez uma subjetiva dele dentro do brinquedo voando e vendo os arredores do parque, uns trailers de hot dog. Então essa imagem acabou sendo muito moderna. Achei muito legal ele ter tido a presença de espírito de não só ficar filmando filho, mas registrar um pouco a sensação do parquinho.

O clipe bombou tanto quanto a música e fomos premiados como Melhor Videoclipe Rock, Melhor Videoclipe do Ano segundo os jurados e Melhor Videoclipe do Ano segundo a audiência em 2002. Achei muito legal o clipe ter sido premiado como melhor Videoclipe Rock com imagens feitas em 1928, quando o rock nem existia.

Depois a MTV até tirou um sarro do meu discurso de agradecimento. Mas a verdade nua e crua é que esse videoclipe, para mim, é um elo perdido ou um elo achado. Ele amarra muito da minha vida, da minha ligação familiar com meu pai e com meu avô, do meu ofício, do meu encontro com os Titãs. Esse videoclipe é muito mais do que um videoclipe para $\mathrm{mim}$. Ele é um filminho da minha vida. Acho que ele salvou provavelmente umas $\mathbf{2 5 0}$ horas de análise para descobrir quem eu sou (risos).

\section{$\underline{\text { Heranças e avanços }}$}

Se há uma coisa que esse clipe tem é herança (risos). Eu o herdei do meu avô e do meu pai. Britto, no discurso pelo Melhor Videoclipe Rock, fez um agradecimento especial a mim, "que soube traduzir em imagens o espírito da canção". Quando o compositor da música fala isso, ali então está o gol.

Não teve nada que a gente não alcançou. Eu não faço clipe para ganhar prêmio. Então alcançou muito mais coisas do que imaginava. A música já era muito forte e eu não queria que as imagens a estragassem. Pelo contrário. Se é uma coisa que eu busco no videoclipe é que as imagens deixem a música ainda mais legal. Então acho que objetivos mais do que plenamente concretizados. Agora não tem avanço, não. 


\section{Relação Imagem-Música}

No sentido do respeito à dinâmica da música. Ele tem um pouquinho de sinc musical em uma viradinha de bateria que o Charles pega uma micro do AC/DC que ele tem e dá uma batucadinha. Eu a fiz encaixar numa virada que ele faz na música. Depois também fiz casar com essa virada de bateria a imagem do José, filho do Britto, tocando uma bateriazinha e dando duas pratadas no mesmo prato. Tem uma procura pela musicalidade, pelo sinc, até numa situação onde supostamente não poderia ter. Achei um sinc impossível do menino tocando bateria com Charles Gavin.

Uma coisa legal também é que nas imagens do meu avô tinha um colorbar verde e todo riscado, com aquelas faixas verticais, que vai do branco ao preto passando por ciam, yellow, magenta. Eu achei numa ponta de filme mesmo, que casou muito bem com o final da música, onde tem um loop de bateria eletrônica do Charles, que continua como se fosse um disco riscado. Acho que foi uma sacada legal.

\section{$\underline{\text { Marcas }}$}

Uso do Super-8. Puxa, esse é um clipe muito sui generis em que filmei pouco na verdade. Então respeito à dinâmica da música e interpretação legal da letra. 


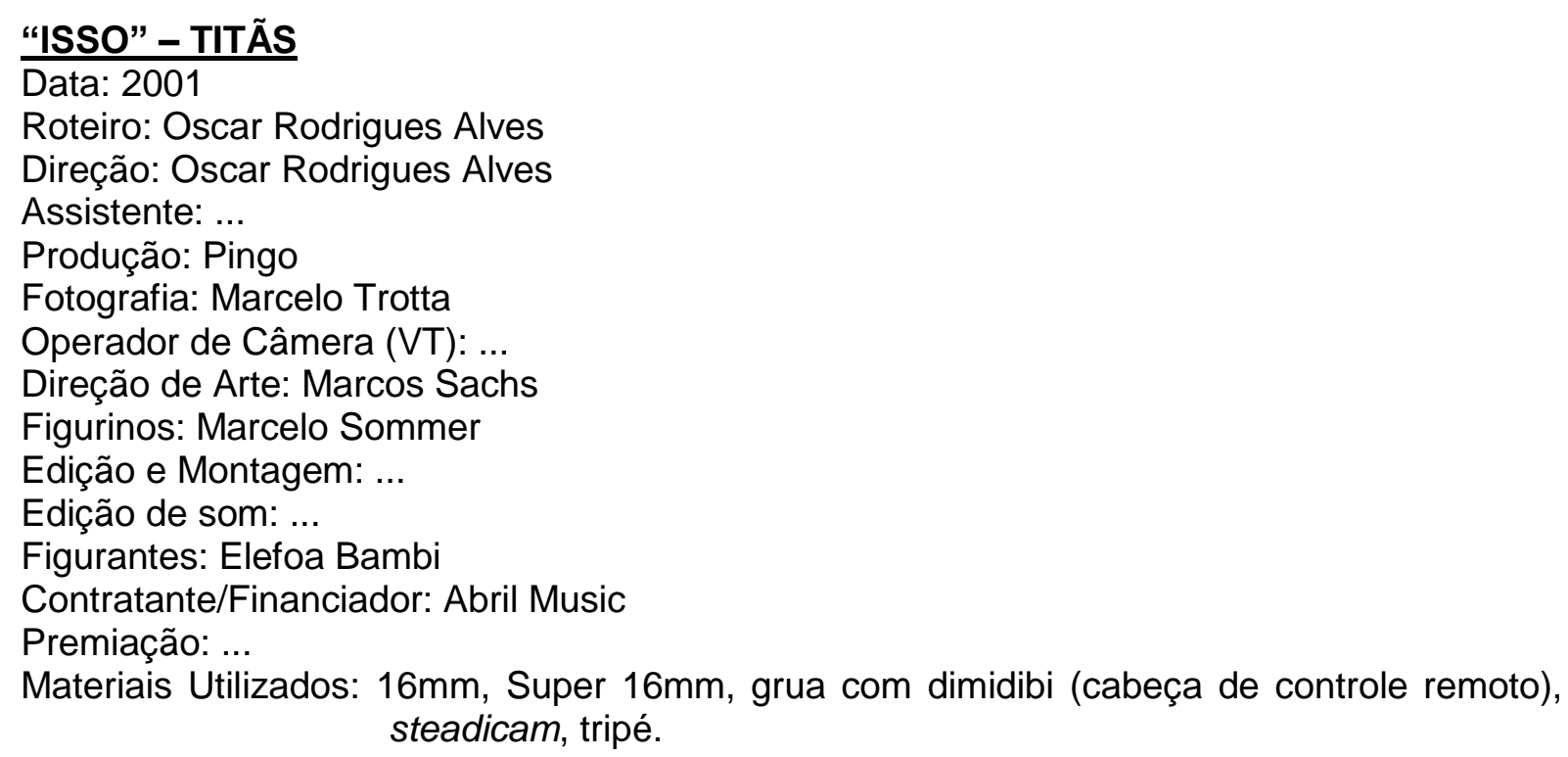

História do Videoclipe

Epitáfio veio, bombou, ganhou todos os prêmios e, depois, Isso entrou numa outra novela da Globo e, automaticamente, por causa disso virou música de trabalho. Duas novelas diferentes da Globo fizeram a gravadora ir atrás, aproveitar o marketing de graça, e, por conta disso, eu salvei uma idéia pela qual tinha ficado apaixonado e que infelizmente não tinha filmado por causa de Epitáfio. Ainda conseguimos fazer Isso com mais dinheiro do que a gente teria.

Quando a gente foi filmar, Charles, por exemplo, estava na beira de ser pai. Então a minha idéia inicial era uma locação árida numa estrada retona e ela foi encontrada em Tremembé, perto de Taubaté, que fica a cerca de 150 quilômetros de São Paulo, num arrozal. Mas Charles não queria viajar 150 quilômetros, porque realmente a Dora nasceu por ali. Então ele falou: "O máximo que vou fazer é ir para São Paulo e filmar no estúdio da Academia de Filmes, que está há dez minutos do aeroporto". Se a mulher dele entrasse em trabalho de parto, ele podia cair fora e voltar rapidamente para o Rio de Janeiro.

Antes, eu tinha programado usar a diária da melhor maneira possível. Ir cedinho para Tremembé e filmar um dia inteiro lá. Um deslocamento desses no meio do dia é um tiro no pé para uma filmagem, porque você estoura, cansa a equipe para caramba e perde muito tempo de filmagem. A gente saiu de São Paulo às quatro da manhã e era um deslocamento radical e lento para caramba, que tinha elefante, grua, steadicam. Ou seja, não é que você vai lá com uma vanzinha rapidinho, chega e roda. Com um desvio errado da elefanta, você perde a melhor luz. Enfim, foi uma produção muito bem armada pelo Pingo, diretor de produção.

O clipe não foi filmado na primeira vez, porque Nando (Reis) decidiu cancelar, porque tinha entrevista de divulgação do segundo álbum solo. Aí depois a gravadora cancelou. Então era para Nando estar nesse clipe e não esteve, porque saiu da banda antes de a gente filmar. Também era para a gente fazer tudo em externa e acabou sendo um cruzamento de externa e estúdio, por causa do Charles, o que não foi mal. Esse é um dos clipes que eu mais gosto. Ele abre meu repertório de clipes. Acho que ele é criativo e que nunca vi nem parecido em termos de idéia e realização.

A gente esteve duas vezes no Circo de Stankovishi com Paulo Miklos para ele se acostumar um pouco com a elefanta e a gente ver se ia dar certo. O elefante é um bicho muito difícil da gente se relacionar, muito por causa do tamanho e do peso. Quer dizer, ele é controlado, domado, domesticado, mas não é empurrável. Se ele vier andando em sua direção, você não tem o que fazer. E tem a questão da tromba. Não é como pata de 
cachorro ou rabo de rato. É um aspirador peludo gigantesco que dá volta no pescoço, faz carinho, joga água, cheira. Um negócio muito doido.

Miklos começou com muito medo dessa dificuldade de se relacionar fisicamente, a base da história que ele viveria ali. Essa dificuldade de relacionamento era importantíssima. No dia da filmagem, ele deu uma talagada num uísque e relaxou. Ele é um ator de primeira. $\mathrm{Na}$ hora em que abre câmera e o bicho tem que desempenhar, não tem para ninguém. É com o cara mesmo.

O elefante é um bicho incontrolável. Então a gente foi muito esperto de preparar a câmera antes de trazer a Bambi para o set. A primeira cena que a gente faria, com uma grua subindo e o Paulo e a elefanta seguindo juntos pela longa estrada da vida, por causa da luz, foi a última cena do clipe. De manhã cedo e no final do dia, o sol está bem baixo. Então como a gente só estaria na locação no começo do dia, eu queria fingir que era o final do dia, que tem uma luz muito parecida. A gente montou a grua, colocou a câmera e, daí, chamou a elefanta.

Quando a elefanta chegou à estrada, ela começou a brincar com a areia que estava lá e isso rendeu cenas incríveis, porque a luz estava bem baixinha e a areia jogada ao vento e no contra-luz funcionou lindamente. Ela juntava areia e jogava por cima do corpo, meio para coçar e limpar também. Não estava planejado. E, dali, vieram cenas incríveis dela.

Paulo e eu já tínhamos conversado muito sobre esse clipe, não só nas vezes em que fomos efetivamente trabalhar no circo, mas durante a viagem. A gente foi falando bastante. "Olha, é você discutindo a relação com a elefanta, gesticulando bastante (que é característica boa do Paulo também)". Na hora em que vimos a elefanta fazendo aquelas coisas, começamos a rodar e eu falei: "Vai lá, Paulo, vai lá". Tem até um making of muito legal, em que eu apareço pedindo umas reações para o Paulo. À medida que ia vendo as imagens, ia meio pilotando. "Põe a mão na cabeça. Você não acredita nisso". Então teve coisas que ele foi fazendo junto. Pelo fato de estar num lugar que curtiu pacas, ela também saía correndo, se divertia com a liberdade de ir e vir. A cena que ela sai correndo e ele sai correndo atrás e fica puto, é totalmente da cabeça dela. Paulo ia atrás e eu: "Vai, vai, vai. Corre, Paulo". Com a câmera junto.

Depois falei: "Já tem um monte de recheio aqui, vamos contar a história". Pedimos para o treinador deixá-la mais num canto e rodamos ali todas coisas que precisavam para contar a história. Havia muitas cenas preparadas: as tentativas de conquista, um anelzão com uma pedra azul que Sommer me emprestou, e ele tenta ganhar a elefanta de todas as maneiras possíveis. Ele oferece esse anel. Ela não quer saber. A gente tinha levado uma rosa de açúcar também, daquelas de enfeitar bolo, que ele oferece. Ela vai e come a rosa. Ele encosta a cabeça na tromba dela. Uma cena que foi muito legal é ele andando de costas e ela de frente. Ele falando e a gente enquadrando de perfil os dois. Foi genial.

A gente teve de sete e meia até meio-dia, quatro horas e meia de trabalho muito proveitosas. Rendeu muito. Tudo que a gente filmou, usou. Inclusive os acidentes. Tem uma cena em que ela vem em direção à câmera e bate nela. Era uma girafona enorme, mas para ela deveria parecer um dinossauro de ferro, sei lá o quê. Graças a Deus não aconteceu nada.

O clipe é sensacional, mas é bom notar que a gente (a Academia de Filmes) pagou para fazer esse clipe. Eu coloquei dinheiro, uns 10, 12 paus. Ele não tinha dinheiro para todos os equipamentos e também não quisemos e não tivemos patrocínio. Quis apostar, porque era uma idéia que eu queria muito realizar e ter na minha filmografia. Achava que ia ser um clipe muito chocante. Fui realmente indicado a melhor diretor no VMB desse ano.

Teve um trabalho de pesquisa de figurino da Nicole Nativa e ela me indicou as peças do Sommer. Ela saiu entre a primeira e a segunda vez de Isso. A gente não tinha nem dinheiro para pagar o cachê dela. Então falei: "Vou chamar o Sommer direto. Estou colocando dinheiro nesse clipe". O figurino é todo dele, que também foi muito gentil e cobrou nada pelo uso da coleção.

Como Miklos foi protagonista do clipe e também na parte do estúdio, e era o cantor, eu quis que cada um tivesse um "specialzinho". Charles acho que tem um master só dele e também filmou pouco, porque queria voltar para o Rio o quanto antes. Bellotto também tem 
um master sozinho, com calça com boca de sino gigantesca. Também tem um "specialzinho" do Bellotto. No estúdio, a gente colocou a banda em cima de um giratório de carro de metros e meio de diâmetro, de uma plataforma circular. Com fundo preto, a banda girava com a câmera parada e a banda girava em cima desse giratório. Criamos um balé, um negócio muito interessante que eu viria a usar depois no Skank.

$\mathrm{Na}$ cena final, a elefanta andando na estrada, com o treinador a frente dela, que vai andando e chamando: "Vem Bambi"; a gente apagou digitalmente frame a frame esse treinador. Não é efeito que apareça como efeito digital, mas que foi bem usado ali. Foi usar os efeitos digitais para o bem. Não é nada de pirotecnia, mas é bem importante, porque essa cena não existiria com a carga dramática dela se você visse o treinador, e também não seria tão bela se tivesse que enquadrar menor para não ver o treinador.

Tem outra cena, em que Miklos está pintando um quadro num cavalete com carvão. Ele foi efetivamente pintado pelo Marcos Sachs, que é um grande pintor. Ele pegou uma foto da Bambi e pintou de próprio punho aquele quadro. Então é uma direção de arte que eu acho bem, bem bonita.

Acho que talvez se eu devesse pinçar um clipe até hoje, o mais completo seria esse. A começar pela grande idéia. Acho que o grande clipe começa por uma grande idéia. Talvez essa tenha sido a idéia mais legal que eu tive até hoje para videoclipe.

\section{Heranças e Avanços}

De herança, tem dinâmica de montagem, edição de áudio e câmera tremida e balançada do Capital Inicial. Também há uso de maquinarias, steadicam e grua. Tem introdução que não tem nada a ver com a música, que é herança de Realidade Virtual. Nesse caso ainda mais, porque ela é bem teatral, fabulosa. Avanço foi o uso do giratório.

Talvez a narrativa do Astronauta tivesse um pouco a ver com a narrativa desse clipe, porque tenta contar uma historinha e um climinha, mas acho que ele se destaca na minha cinematografia. Astronauta tenta falar um pouco do descontentamento dele com a Terra e da procura de ir para a Lua. Isso também fala um pouco da história do amor. Ou seja, tem ligações diretas e óbvias com a letra. Eu acho que ele tem uma grande idéia para a canção. Esse é um avanço - um momento luminoso de criatividade.

Também há maturidade minha como realizador, porque é uma realização bem ousada em todos os sentidos, a começar por a gente arriscar fazer uma viagem de 150 quilômetros no meio da diária e por muita experiência de set e um trabalho acurado com o diretor de fotografia e com o diretor de produção para fazer dar certo e não virar uma roubada, estando preparado, inclusive, para filmar debaixo de chuva. Em publicidade há um termo chamado weather day. Ou seja, se você chegar e estiver chovendo e o filme precisar de sol, o cliente paga a equipe e os custos por não ter trabalhado naquele dia. Nesse caso não. Em clipe nunca tem weather day. Então a gente tinha que estar preparado para rodar se chovesse ou se fizesse sol.

\section{Relação Imagem-Música}

Tem bastante sinc e respeita a dinâmica da música. Tem uma hora que a música, uma baladinha, cresce e vira rock and roll pedadão. Está claro no ritmo da montagem e na atitude deles. A banda nessa hora explode e começa a pular. Tem um som direto que fiz com Britto. Ele dá um estouro, um grito, "ááááá", bem da época Seattle, do Jack Endino, Tudo Ao Mesmo Tempo Agora e Titanomaquia. Branco também fala um pedaço da música Qualquer Negócio, eu acho. A gente deu uma editada na letra, pegamos algumas frases e ele fez aquela abertura. Tem também um som de elefante, que Dudu Marote nos cedeu da coleção de sons dele. 


\section{$\underline{\text { Marcas }}$}

Busca incansável pela originalidade e não ter medo de propor alguma coisa para os artistas - fosse propor ao (Paulo) Miklos que contracenasse com um elefante, que era difícil para ele, fosse convencer os Titãs a permitirem que Paulo tivesse papel preponderante, principal, digamos assim, dentro dessa história. Eu vinha de trabalhos com Cidade Negra, banda que fazia questão de certo equilíbrio da participação de todos os músicos. Achava que nos Titãs fosse assim também e que teria um pouco de trabalho ao tentar convencê-los. Mas foi bem tranquilo, talvez pela história tão legal que a gente criou. Em nenhum instante, eles se opuseram a que isso acontecesse.

Planejamento bem feito te deixando tranquilo para improvisar muito na hora. A gente planejou muito - vamos viajar às 4 da manhã para chegar à locação às 6 , junto com o Sol, e começar pelo dib dib, que é o equipamento mais demorado para se montar, e começar a rodar com a primeira luz. $E$ foi isso o que aconteceu. O planejamento técnico foi perfeito, mas, na hora, Bambi começou a comer umas plantinhas, a correr, jogar areia. Então foi uma excelente combinação das duas coisas. Na hora da luz mais linda, o equipamento estava montado, como tinha sido planejado. A partir daí, a gente estava livre para aproveitar os improvisos que a Bambi nos proporcionou ali 
"DOIS RIOS" - SKANK

Data: 2003

Roteiro: Oscar Rodrigues Alves e Nando Cohen

Direção: Oscar Rodrigues Alves

Assistente: ...

Produção: ....

Fotografia: Adriano Goldman

Operador de Câmera (VT): ...

Direção de Arte: ...

Figurinos: Oscar Mesevá

Edição e Montagem: ...

Edição de som: ....

Animação: Nando Cohen

Figurantes: ...

Contratante/Financiador: ...

Premiação: Melhor videoclipe pop no VMB2005 e Melhor fotografia em videoclipe pela ABC Materiais Utilizados: ...

(Associação Brasileira de Cinematografia)

História do Videoclipe

Eu fui um dia com Branco Mello num show do The Silvas, banda de Liminha, na Marina da Glória, no Rio de Janeiro, onde ele ia dar uma canja. Quem cantava na mesma noite era Carolina Lima, cantora mineira casada com Fernando Furtado, empresário do Skank. Eu já tinha encontrado com Fernando algumas vezes no escritório da Sony no Rio. Uma vez Hugo Prata fez um clipe do Barão Vermelho e Fernando foi ao estúdio fazer umas fotos para o livro dele. A gente trocou umas idéias e ele tinha acabado de ver Isso. Enquanto todo mundo chegava para me falar: "Que genial a história do elefante com o Miklos"; ele achou genial o jeito como eu filmei a banda. Ele falou: "O que você usou? A banda parece que está meio girando. Skank vai lançar disco novo agora. Assim que for a hora eu vou te ligar, vamos ver se dá certo". E assim foi.

Primeiro, ele me ligou e, na fissura, botou a música ao telefone para eu ouvir. Já a achei linda e percebi um novo caminho do Skank, melódico, harmônico. Depois, me mandaram uma passagem e fui a Belo Horizonte. O Fernando foi muito gentil, como sempre, e me recebeu no aeroporto. Antes de me levar ao estúdio, fez um tour comigo por $\mathrm{BH}$, mostrou os marcos da cidade. Fernando é um cara muito ligado em arquitetura. Levou a mim para ver os Niemeyer todos. O que é uma delícia. Foi uma gentileza que eu nunca esqueço. Ali começou uma amizade forte.

Cheguei ao estúdio, ouvi quase o disco inteiro com os caras. Também não os conhecia. Já tinha encontrado rapidamente. Trocamos uma primeira idéia e depois voltamos a nos encontrar quando eles estavam mixando o álbum no Rio de Janeiro, na Toca do Bandido, que era o estúdio do saudoso Tom Capone. Entre ouvir e ter o primeiro papo com eles em BH, e a minha ida à Toca do Bandido para mostrar a idéia final e juntos fazermos uma prova de roupa, mostrei a música para Nando Cohen e juntos trabalhamos na idéia.

Eu voltei de $\mathrm{BH}$ com The Wall na cabeça, com aquela cena lindérrima do pássaro e de duas flores se não me engano - uma orquídea ou um lírio - e rola uma cópula e depois uma mordida. Voltei com isso e mostrei para Nando, que, obviamente, já conhecia. Partimos dali. Tinha os rios e a água. O Nando começou a mostrar algumas técnicas que ele estava começando a utilizar para trabalhar com água.

Animação tem sempre que levar em conta o prazo. É um processo bastante trabalhoso e que requer você planejar muito bem, porque despende bastante tempo. Então a gente ouviu a música várias vezes e fez uma decupagem muito objetiva do que precisava fazer para contar a história. Aí Nando veio com a idéia de transformar as flores na história 
de uma flor e de um pássaro. O encontro que eu via no The Wall gostaria que acontecesse também em animação. Então o pássaro sobrevoa o rio, a flor vem nadando e eles se encontram numa pororoca qualquer, digamos assim.

Essa historinha nós fomos desenhando junto com a equipe dele também, na qual estava Luis Carone, que hoje é diretor premiado pelos clipes de Autoramas e Sepultura. Tive um puta retorno. Foi muito bom trabalhar com Luis. Gosto bastante dele. Pegamos a letra e criamos cenas com os tempos definidos.

Paralelamente, eu desenvolvi, com Adriano Goldman, a pegada que teria. Nando desenvolveu uma estética muito interessante, meio japonesa, para a animação, e eu não queria que a parte filmada brigasse esteticamente com ela. Eu sabia que descarregaria uma boa parte do orçamento e, com isso, boa parte das possibilidades estéticas em cima da animação e que não poderia fazer, por exemplo, um cenário que, de alguma maneira, grudasse ou compusesse com ela. Fui pelo outro lado.

\section{$\underline{\text { Heranças e avanços }}$}

Aí, sim, tem claramente uma herança e um avanço no meu trabalho. A gente optou por filmar Skank com fundo preto, assim como tínhamos filmado no Titãs, Isso, mas queríamos pintar esse fundo com flairs, distorções óticas que as lentes causam quando você enxerga um ponto de luz direta. São luzes que você vê a fonte, pois geram uma bola e podemos usar como efeito ou defeito especial, como você gostar mais de chamar. Mostrei uma referência para Adriano de um clipe do U2 chamado Staring at the Sun, do Jake Scott, que eu conheci em Los Angeles. Acabou ficando bem diferente, mas partimos desse clipe para chegar aonde chegamos.

O Goldman elencou diversas fontes diferentes de luz. Ou seja, diversos refletores diferentes, moving lights de shows, fresnéis, elipsoidais, diversos tipos de refletores que pudessem dar flairs diferentes para a gente. Pensamos numa captação bem simples. Eu tinha pensado num piano de caldas para Henrique Portugal e cheguei com referências da animação que Nando Cohen me deu e da parte filmada da banda. Ou seja, fui muito explicativo e quis ser muito respeitoso com eles e falar: "Trouxe aqui vários elementos para tentar mostrar para vocês o que vai ser". E eles me disseram que se sentiram muito respeitados.

Fizemos uma prova de roupa lá. Figurinos do Oscar Metsavaht, da Osklen. Enquanto eu ia mostrando, Tom Capone veio daquele jeito dele: "Véio, porque você não usa um piano de parede, mostrando a máquina do piano de parede, sem aquela proteção que vem na frente. Vai ficar lindo, véio". E ficou lindo mesmo. Foi muito melhor do que ter usado um piano de caudas e ficou uma marca do querido Tom Capone no clipe, que ganhou melhor videoclipe pop na MTV e melhor fotografia em videoclipe no prêmio da ABC (Associação Brasileira de Cinematografia), em 2005.

A gente criou uma coisa legal: filmamos a banda e fizemos, num telecine, escolha de cores. Isso é uma coisa legal da minha parceria com o Nando e começou no Até Quando?, do Gabriel. A gente sempre filma antes e, às vezes, a animação vai correndo na paralela ou rola depois. Mas eu sempre monto uma base filmada e mostro ao Nando e ele fala: "Essa banda está muito boa". Aí chama a equipe dele e começa a melhorar a animação. Ele pegou a parte filmada e usou cores da parte filmada na animação. A gente tentou integrar um pouco as coisas através das cores das distorções que o flair causou. Então tem sempre uma instigadinha que dou no Nando a partir de imagens filmadas.

Skank e Fernando viram o modelo da flor, como seria o pássaro, a estética, e, depois, o clipe prontaço.

\section{Relação Imagem-Música}

Esse foi um clipe totalmente criado em cima da letra e da música. "O céu está no chão", daí nós falamos: "Vamos fazer uma poça d'água e o pássaro e o céu refletidos no chão". Fomos exatamente em cima da letra, criando imagens poéticas que contassem 
histórias e as traduzissem. Não há edição de som. Foi o fonograma tal qual ele é no disco. Ele já tem dinâmica muito louca. Tem solo de guitarra. Começa só com piano e voz, aí entra baixo, depois batera. Respeitamos na filmagem essa dinâmica.

\section{Marcas}

Ele foi o primeiro clipe que tirou lágrimas das pessoas. Por exemplo, eu entreguei o clipe para a Sony e para a banda no mesmo dia. Fernando Furtado estava representando a banda, dei play e todo mundo adorou. Daí Fernando levou uma cópia pra BH e mostrou para a banda, e outra cópia ficou na Sony. Daí os "Skanks" começaram a me ligar. O primeiro a ligar foi Samuel (Rosa) e falou: "Véio (grande adjetivo mineiro), nunca vi um clipe assim. Minha mulher chorou copiosamente. Ficou super emocionada. A gente ficou sabendo que a mulher do Liminha também, quando assistiu o clipe no Rio de Janeiro, ficou super emocionada". Então foi o primeiro clipe onde tive feedback de que as pessoas tinham se emocionado muito e chorado.

$\mathrm{Eu}$, particularmente, tenho dificuldade em chorar. Então se alguém chega para mim e fala: "Faz um clipe para as pessoas chorarem". Eu já digo: "Não sei fazer isso". Eu fiz um clipe com sensibilidade, claro. Acho que a sensibilidade está sempre presente nos meus clipes, mas jamais pensei que fosse levar às pessoas a chorarem, ainda mais num videoclipe. Tudo bem que a carga dramática da música ajuda muito e já encaminha, mas é um negócio que é muito curtinho. É difícil você fazer uma pessoa se emocionar, chegar às lágrimas, com um videoclipe. Foi a primeira vez que aconteceu e não era esperado nem planejado.

Todos eles curtiram muito, mas Samuel gastou bastante tempo comigo falando do clipe, incluindo uma coisa que tomei como elogio, um padrão de qualidade do meu trabalho: "Véio, quando a gente deixou de ser uma banda independente e foi contratado pela Sony Music, falou: 'Agora vamos virar uma banda'. A gente sempre quis ser filmado desse jeito". Engraçado. Acho que ele quis dizer que aquilo está muito bem feito, que a banda estava muito bem filmada musicalmente. Aquele vídeo tinha uma cara de clipe gringo, digamos assim. 
Clipeografia (de acordo com memória de Mauricio Eça)

\begin{tabular}{|c|c|c|c|}
\hline ANO & ARTISTA & MÚSICA & DIREÇÃO \\
\hline 1994 & Volkanas & When 2R1 & Mauricio Eça \\
\hline 1994 & Cidade Negra & Downtown & Mauricio Eça \\
\hline 1995 & Arnaldo Baptista & Balada do Louco & Mauricio Eça \\
\hline 1996 & Tom Cavalcante & Unidos da Branca Pura & Mauricio Eça \\
\hline 1996 & Pus & Seu Verino & Mauricio Eça \\
\hline 1996 & Hip Monsters & $\begin{array}{l}\text { Um Minuto a Menos na } \\
\text { Vida }\end{array}$ & $\begin{array}{l}\text { Mauricio Eça e Rui } \\
\text { Mendes }\end{array}$ \\
\hline 1996 & Hip Monsters & Mucho Loko Angels & $\begin{array}{l}\text { Mauricio Eça e Rui } \\
\text { Mendes }\end{array}$ \\
\hline 1996 & Che Leal & MP Black & Mauricio Eça \\
\hline 1996 & Che Leal & MP Black & Mauricio Eça \\
\hline 1996 & Che Leal & MP Black Versão 2 & Mauricio Eça \\
\hline 1997 & Anjos da Noite & Sangue nas Mãos & Mauricio Eça \\
\hline 1997 & Dr. Sin & $\begin{array}{l}\text { Futebol, Mulher \& } \\
\text { Rock'n'Roll }\end{array}$ & Mauricio Eça \\
\hline 1997 & Racionais MCs & Diário de um Detento & $\begin{array}{l}\text { Mauricio Eça, Tony } \\
\text { Tiger e } \\
\text { Corpani }\end{array}$ \\
\hline 1997 & Racionais MCs & Mágico de Oz & Mauricio Eça \\
\hline 1997 & Virgulóides & Bagulho no Bumba & $\begin{array}{l}\text { Mauricio Eça, Rui } \\
\text { Mendes e Zé Carratu }\end{array}$ \\
\hline 1998 & Virgulóides & Cê Tá Com Medo & Mauricio Eça \\
\hline 1998 & DMN & H. Aço & Mauricio Eça \\
\hline 1998 & CDM & Click, Clack, Bang & Mauricio Eça \\
\hline 1999 & Viper & I Fought the Law & Mauricio Eça \\
\hline 1999 & Viper & 8 de Abril & Mauricio Eça \\
\hline 1999 & Baia e os Rockboys & Overdose de Lucidez & Mauricio Eça \\
\hline 1999 & Israel do Carmo & Cabelo de Sansão & Mauricio Eça \\
\hline 2000 & Jair Oliveira & Bom Dia Anjo & Mauricio Eça \\
\hline 2000 & Forróçacana & $\begin{array}{l}\text { Menina Mulher da Pele } \\
\text { Preta }\end{array}$ & Mauricio Eça \\
\hline 2000 & Demenoscrime & Rap das Quebradas & Mauricio Eça \\
\hline 2000 & Face da Morte & Bomba $\mathrm{H}$ & Mauricio Eça \\
\hline 2000 & $509-\mathrm{E}$ & Oitavo Anjo & Mauricio Eça \\
\hline 2000 & 509-E & Triagem & Mauricio Eça \\
\hline 2000 & $509-E$ & Só os Fortes & Mauricio Eça \\
\hline 2001 & Roberto Carlos & $\begin{array}{l}\text { Eu Te Amo, Te Amo, } \\
\text { Te Amo }\end{array}$ & $\begin{array}{lll}\text { Mauricio } & \text { Eça, } & \text { Felipe } \\
\text { Segall } & \text { e } & \text { Kelly } \\
\text { Marciano } & & \\
\end{array}$ \\
\hline 2001 & Cláudio Zoli & Noite do Prazer & Mauricio Eça \\
\hline 2001 & Kelly Key & Escuta Aqui Rapaz & $\begin{array}{l}\text { Mauricio Eça e Sérgio } \\
\text { Mastrocola }\end{array}$ \\
\hline 2001 & CPM 22 & Regina Let's Go & $\begin{array}{l}\text { Mauricio Eça e Felipe } \\
\text { Segall }\end{array}$ \\
\hline 2001 & Orbitais & Loco da Cachola & Mauricio Eça \\
\hline 2001 & Gerson King Combo & Brigas & Mauricio Eça \\
\hline 2001 & Bidê ou Balde & Melissa & Mauricio Eça \\
\hline 2001 & Moraes Moreira & Nordeste Cosmopolita & Mauricio Eça \\
\hline 2001 & Os Kmaradas & Já Disse Pra Você & Mauricio Eça \\
\hline 2001 & Supla & Garota de Berlim & Mauricio Eça \\
\hline
\end{tabular}




\begin{tabular}{|c|c|c|c|}
\hline 2002 & CPM 22 & Desconfio & $\begin{array}{l}\text { Mauricio Eça e Kelly } \\
\text { Marciano }\end{array}$ \\
\hline 2002 & CPM 22 & Dias Atrás & $\begin{array}{l}\text { Mauricio Eça e Felipe } \\
\text { Segall }\end{array}$ \\
\hline 2002 & CPM 22 & $\begin{array}{l}\text { Não Sei Viver Sem Ter } \\
\text { Você }\end{array}$ & Mauricio Eça \\
\hline 2002 & Supla & Língua Falou & Mauricio Eça \\
\hline 2002 & Supla & De Janeiro a Janeiro & Mauricio Eça \\
\hline 2002 & Aliados 13 & Sem Sair do Lugar & $\begin{array}{l}\text { Mauricio Eça e } \\
\text { Marcos Mion }\end{array}$ \\
\hline 2002 & Realidade Urbana & Vida de Cão & Mauricio Eça \\
\hline 2003 & LS Jack & Sem Radar & Mauricio Eça \\
\hline 2003 & For Fun & História de Verão & Mauricio Eça \\
\hline 2003 & Frejat & $\begin{array}{l}\text { Eu Preciso Te Tirar do } \\
\text { Sério }\end{array}$ & $\begin{array}{l}\text { Mauricio Eça e Felipe } \\
\text { Segall }\end{array}$ \\
\hline 2003 & Engenheiros do Hawaii & Até o Fim & Mauricio Eça \\
\hline 2003 & Engenheiros do Hawaii & Na Veia & Mauricio Eça \\
\hline 2003 & Da Guedes & Dr. Destino & Mauricio Eça \\
\hline 2003 & CDM & Super Billy & Mauricio Eça \\
\hline 2003 & Marcelo D2 & Vai Vendo & $\begin{array}{l}\text { Mauricio Eça e J.R. } \\
\text { Alemão }\end{array}$ \\
\hline 2003 & Marcelo D2 & Profissão MC & Mauricio Eça \\
\hline 2003 & Rodox & Olhos Abertos & $\begin{array}{l}\text { Mauricio Eça e Felipe } \\
\text { Segall }\end{array}$ \\
\hline 2003 & Falamansa & 100 Anos & Mauricio Eça \\
\hline 2003 & Pitty & Máscara & Mauricio Eça \\
\hline 2003 & Pitty & Admirável Chip Novo & Mauricio Eça \\
\hline 2003 & Pitty & Semana Que Vem & $\begin{array}{l}\text { Mauricio Eça, Sérgio } \\
\text { Mastrocola e Pablo } \\
\text { Nobel }\end{array}$ \\
\hline 2003 & Pitty & Teto de Vidro & Mauricio Eça \\
\hline 2003 & Pitty & I Wanna Be & Mauricio Eça \\
\hline 2004 & Falamansa & Tempo de Paz & Mauricio Eça \\
\hline 2004 & KLB & Carolina & $\begin{array}{l}\text { Mauricio Eça e Sérgio } \\
\text { Mastrocola }\end{array}$ \\
\hline 2004 & KLB & A llha & Mauricio Eça \\
\hline 2004 & Vinimax & Neurótico & Mauricio Eça \\
\hline 2004 & Karyme Hass & Faces e Fases & Mauricio Eça \\
\hline 2004 & Emo & Primeira Emoção & Mauricio Eça \\
\hline 2004 & Black Alien & Babylon By Gus & Mauricio Eça \\
\hline 2004 & Hateen & A New Way To Die & Mauricio Eça \\
\hline 2004 & SNJ & Viajando na Balada & Mauricio Eça \\
\hline 2005 & Silveira & Canto & Mauricio Eça \\
\hline 2005 & Ksis & Beijos, Blues e Poesia & Mauricio Eça \\
\hline 2005 & Ksis & Experimento & Mauricio Eça \\
\hline 2005 & Gláucia Nasser & Balanço Zona Sul & Mauricio Eça \\
\hline 2005 & Vodka Frog & 15 Minutos & Mauricio Eça \\
\hline 2005 & Natiruts & Natiruts Reggae Power & Mauricio Eça \\
\hline 2005 & Natiruts & Não Chore Meu Amor & Mauricio Eça \\
\hline 2005 & Ludov & Estrelas & $\begin{array}{l}\text { Mauricio Eça e J.R. } \\
\text { Alemão }\end{array}$ \\
\hline 2005 & Daniel & Desatino & Mauricio Eça \\
\hline 2005 & Shaman & Innocence & Mauricio Eça \\
\hline
\end{tabular}




\begin{tabular}{|c|c|c|c|}
\hline 2006 & Reação em Cadeia & Os Dias & Mauricio Eça \\
\hline 2006 & Kelly Key & Barbie Girl & Mauricio Eça \\
\hline 2006 & Leandro Sapucahy & $\begin{array}{l}\text { Numa Cidade Muito } \\
\text { Longe Daqui }\end{array}$ & $\begin{array}{l}\text { Mauricio Eça e J.R. } \\
\text { Alemão }\end{array}$ \\
\hline 2006 & Ritma & Desejos & Mauricio Eça \\
\hline 2006 & Vanessa da Mata & $\mathrm{Ai} \mathrm{Ai} \mathrm{Ai}$ & $\begin{array}{l}\text { Mauricio Eça, Sérgio } \\
\text { Mastrocola e Pablo } \\
\text { Nobel }\end{array}$ \\
\hline 2006 & Beirollos & Mais de Uma Vez & Mauricio Eça \\
\hline 2006 & $\begin{array}{ll}\text { Detonautas } & \text { Roque } \\
\text { Clube } & \\
\end{array}$ & Não Reclame Mais & Mauricio Eça \\
\hline 2006 & $\begin{array}{l}\text { Detonautas Roque } \\
\text { Clube }\end{array}$ & Dia Comum & Mauricio Eça \\
\hline 2006 & Hateen & 1997 & $\begin{array}{l}\text { Mauricio Eça, Tony } \\
\text { Tiger e } \\
\text { Martinelli }\end{array}$ \\
\hline 2006 & Nila Branco & Pra Ninguém & Mauricio Eça \\
\hline 2007 & Lola & O Que Eu Queria & Mauricio Eça \\
\hline 2007 & Andreya Vieira & Por Você & Mauricio Eça \\
\hline 2007 & Falamansa & Segue a Vida & Mauricio Eça \\
\hline 2007 & Capital Inicial & Eu Nunca Disse Adeus & Mauricio Eça \\
\hline 2007 & Capital Inicial & $\begin{array}{llcc}\text { A Vida é } & \text { Minha } & \text { (Eu } \\
\text { Faço O } & \text { Que } & \text { Eu } \\
\text { Quiser) } & & \end{array}$ & Mauricio Eça \\
\hline 2008 & Huecco & Pa Mi Guerrera & Mauricio Eça \\
\hline 2008 & Lucas Scudeller & Deixa & Mauricio Eça \\
\hline 2008 & Moxine & $\begin{array}{l}\text { I Wanna Talk About } \\
\text { You }\end{array}$ & Mauricio Eça \\
\hline 2008 & Mirábilis & Sempre Tão Linda & Mauricio Eça \\
\hline 2008 & Marcelo Mira & Passos pela Rua & Mauricio Eça \\
\hline 2008 & Mafalda Morfina & Sonhos Contrários & Mauricio Eça \\
\hline 2008 & Altitude Zero & Êpa & Mauricio Eça \\
\hline 2009 & Camila Maia & Eu Não Sou Sua Flor & Mauricio Eça \\
\hline 2009 & Metanol & Veloset & Mauricio Eça \\
\hline
\end{tabular}




\section{Entrevista Completa de Mauricio Eça}

\section{Como você chegou ao videoclipe?}

Meu pai é redator publicitário, que lê e escreve muito. Desde pequeno, eu fui influenciado para ler e ir ao cinema. Talvez tenha entrado num set de filmagem quando era moleque, para ser figurante de comercial que meu pai fazia para o Unibanco, com Pelé. Fui a outras filmagens e achei um barato. Como muitos jovens da minha idade (16, 17 anos), que não têm a menor noção de escolher o que vai fazer da vida, eu prestei (vestibular para) Jornalismo e não passei. Também queria cinema e acabei entrando na Faap à noite, no meio do ano. Cursei seis meses e já fui fazer estágio numa produtora de cinema e comercial, chamada Mix Som, como assistente de produção num programa de TV, Cadeira de Barbeiro, que tinha Cacá Rosset e Lucinha Lins. Trabalhei também em alguns comerciais. Aí tranquei matrícula e fui para a Europa ser sorveteiro e lavar prato. Viver um pouco. Lá eu saquei que queria muito fazer cinema e voltei rápido para continuar a faculdade. A partir daí, trabalhei em tudo o que dava, desde fazer muita produção em várias produtoras de comercial até trabalhar na produção do filme do Ugo Giorgetti, Sábado, e como contra-regra de Perfume de Gardênia, de Guilherme de Almeida Prado. Comecei também a fazer meus curtinhas. Alguns de um minuto.

Sempre tive um envolvimento super forte com música. Então fui ser assistente de direção de Odorico Mendes, na produtora Croma. Fui assistente de direção dele durante anos. Esse cara me ensinou muito, porque, além de ser diretor, tinha diversas empresas. Então começou a jogar na minha mão muita responsabilidade. Para aprender, foi ótimo. E, como tinha experiência de produção, eu acho que consegui segurar essa onda. Isso mais ou menos em 1994, 1995.

A Croma virou Adrenalina Filmes, produtora que, com o estouro da MTV, destacouse como grande realizadora de videoclipes, um pouco antes do que a Conspiração (Filmes). Então eu vivia numa produtora que tinha diversos diretores e todo mundo queria fazer videoclipe, mercado que começamos a conquistar, de certa forma. Odorico era enlouquecido por hip hop, adorava Racionais MCs e era um megalômano total. Investia grana no que ele curtia e fez alguns videoclipes praticamente de graça. Dentre eles, alguns de hip hop, como Fórmula Dinamental, para DMN, banda do Xis. O clipe tinha exatamente zero reais e foi de primeiro mundo - quatro diárias de filmagem. Super produção. Acho que foi o primeiro em que trabalhei como assistente. Odorico fez clipes também para Sistema Negro, Gabriel O Pensador, Cidade Negra (Onde Você Mora, no qual fiz o take), Sublimes. $\mathrm{Na}$ produtora, também tinha outros caras fazendo muitos videoclipes, tipo MC Fernandes. Nesse meio tempo, eu comecei também a ficar a fim de fazer os meus trabalhos pessoais.

No começo dos anos 90, quando me formei, era a época do Collor, que acabou com a Embrafilme. Não tinha como fazer cinema no Brasil. Passamos de um período em que se fazia mais de 100 filmes por ano para outra em que se fazia cinco. Então quem se formava em cinema, não tinha outra opção, senão se sentir obrigado a entrar no mundo da publicidade. Não que isso seja um problema, até porque fazer publicidade é uma forma de você conviver com profissionais, ter grana e experimentar. Você realiza com condições e exercita uma narrativa, que pode vir a usar depois no cinema. Eu comecei a ver isso no videoclipe também. Já que tinha baixo orçamento, você estava a fim de fazer e tinha tesão. Para mim, essa sempre foi a essência um pouco de fazer videoclipe no Brasil. É você ser um apaixonado, que se entrega para essa parada e faz. Além disso, é uma vitrine e uma forma de você experimentar linguagens e, mais do que isso, começar a realizar.

Normalmente, quem faz os roteiros nos videoclipes do Brasil são os próprios diretores, muitas vezes com a ajuda da banda ou do cantor. Então, é diferente de um cara que é diretor e trabalha com publicidade, em que o roteiro vem da agência e só é preciso realizar e dar o seu olhar. Então, eu, já há algum tempo assistente do Odorico, em pelo menos 10 videoclipes (Jorge Benjor, Gabriel O Pensador, Cidade Negra, Sublimes, DMN, Sistema Negro), estava querendo começar a dirigir. Assistente é um caminho para aprender 
e chegar lá. Eu ainda não podia ser diretor de publicidade, porque não tinha nome e as pessoas não me conheciam. Então fazer videoclipe era uma forma de eu começar a criar um nome, ser visto e, mais do que isso, praticar, acertar, errar e contar uma história.

O primeiro clipe que pintou foi o das Volkanas, uma banda de metal brasileira, de meninas. Só o baterista era homem. O orçamento era muito baixo, tipo 3 mil reais. Elas já tinham tido certa notoriedade na época do Viper, quando cantavam em inglês, mas estavam meio em baixa e eram distribuídas não me lembro se pela Paradoxx. Dos 3 mil reais, uma parte era paga por uma pizzaria, 1900, então eu era obrigado a fazer merchandising de qualquer forma. Lembro que era uma cena que a cantora estava no quarto bagunçado, pensando na vida, e tinha uma pilha de pizza. Uma parte foi paga em grana e a outra parte em permuta para eu ir à pizzaria. Mas, como na época a Croma era uma produtora grande e os caras estavam querendo investir em novos talentos que começavam a despontar, eles me deram uma estrutura - estúdio, equipamento, ilha de edição. Então, a pouca grana foi o suficiente para eu fazer o meu primeiro trabalho.

$\mathrm{Na}$ Croma, que depois virou Adrenalina e voltou a se chamar Croma, eu comecei a fazer meus videoclipes e a ser diretor de publicidade, até que ela começou a ir mal das pernas e ficaram devendo uma grana para mim. Fui para uma produtora chamada Side By Side, que depois virou Side Cinema. Eu fiz alguns trabalhos lá, tanto de publicidade, quanto de clipes. Vivi um primeiro ano muito ruim, um segundo bom e tive uma oferta para ir para uma produtora melhor, Moviearte, onde foi a mesma coisa. Também era uma produtora genial, só que estava num momento de transição, tanto que mudou de casa e saíram alguns diretores. Depois eu fui para a Cinema Centro, onde fiquei uns dois anos e tive altos e baixos; para Open Filmes, onde, no segundo ano, vim a ser sócio. No terceiro ano, a pessoa que era mais ligada a mim saiu e eu fiquei alguns meses muito mal, com pouco trabalho. Estava numa maré meio baixa de trabalho e tive proposta bacana de ir para a Mixer, que não é só uma produtora de publicidade, mas atua em programa de televisão, documentários, novas mídias. Não sou diretor de publicidade apenas. Quero fazer um pouco de tudo e vejo essa possibilidade. Nesse momento, preparo um projeto para Internet, ao mesmo tempo em que tem um piloto de um programa de tevê. Acho que é mais a minha cara, além deles terem me dado uma segurança financeira legal. É um lugar onde sinto que vou ficar mais tempo.

\section{Você percebe, no clipe das Volkanas, o cerne do que seria o Mauricio Eça, diretor de videoclipes?}

Acho que tinha minha preocupação em contar a história da melhor forma possível. É a eterna briga de forma e conteúdo. Talvez ali já tenha sujeira, crueza e necessidade de identificar aquele público e tipo de som. Apesar de ser o primeiro clipe, ingênuo, inseguro e ansioso, eu tentei mostrar um pouco daquele universo do heavy metal. Até então, ainda não era diretor, mas assistente de direção. Foi uma oportunidade. Ali eu queria mostrar serviço e, ao mesmo tempo, tinha tesão em fazer aquele primeiro trabalho.

Era um trabalho com o que é muitas vezes um problema dos diretores brasileiros de cinema - esperam tanto tempo para fazer um filme, que ele passa pela cabeça de " $\mathrm{n}$ " formas possíveis e, quando vai fazê-lo, está tão ansioso e inseguro que acaba botando mais coisas nele do que deveria. Acho que botei coisas a mais, porque queria mostrar que sabia fazer ou que queria fazer porque não sabia se faria outro. Você não pensa muito. Faz.

\section{Você se considera autor dos seus videoclipes?}

Eu me considero co-autor, a partir do momento em que o cantor ou a banda fez a música. Normalmente, muitos desses clipes que eu fiz, independente de ser a música de trabalho, não era só a música que tocava no rádio, mas a que tinha apelo visual. Acho que os artistas também começaram a compor muito pensando em imagens. Tenho sensação de que a composição mudou muito a partir do momento em que rolou o videoclipe. 
Considero-me autor a partir do momento em que faço o roteiro, penso na idéia e na criação do clipe, absolutamente junto com a banda. Não sei se em $100 \%$, mas em muitos dos meus videoclipes, a banda é muito importante no que ela pensa e sonha. Tem muitos artistas que não têm a menor idéia e deixam totalmente aberto. Outros dão uma idéia, que acho uma bobagem, e acabo convencendo-os a fazer algo totalmente diferente. Mas muitos artistas, já no primeiro bate-papo, dizem como pensaram a música quando a compuseram ou até como imaginaram o clipe, e me ajudam a criar.

Há um limite entre criação e autoria. Muitos trabalhos ainda têm a gravadora por trás, às vezes impedindo um arroubo de criatividade ou de loucura. Então tem muitos artistas com quem falava: "Isso é legal, mas vamos tentar focar numa coisa que venda um pouco mais, no sentido do que você representa e que imagem quer passar". Não é que fosse empecilho ou entrave, mas algo que a gente tinha que levar em conta com alguns artistas. Muitos deles queriam chocar e ser de verdade e totalmente diferentes. Não fazer nada que fosse comercial. Acho que o grande barato do videoclipe sempre foi provocar ou causar algum tipo de reação no espectador e, para isso, tinha que ter imagem interessante, que te atraísse. Esse foi o grande desafio que eu sempre tive.

\section{Para você é fácil identificar a sua autoria num videoclipe?}

Teve uma época que sim. Não é que eu tinha uma marca ou uma cara. Mas acho que teve uma época, quando, principalmente, a Conspiração fazia muito mais clipes, sempre bastante estéticos, em que minha estética era diferente da deles. A deles era uma estética quase publicitária, e minha estética sempre foi mais da realidade e suja. Talvez, nesse momento, fosse mais fácil identificar do que hoje. Hoje, as pessoas imitam umas às outras e buscam referências em coisas que já existem. Então é mais complicado.

Rui Mendes, parceiro em alguns trabalhos, falava que eu era o "David Lynch brasileiro". Mas era uma época mais pirada. Acho que minha história tem muitas mudanças - clipes mais pirados, clipes de hip hop, clipes rock and roll e clipes meio pop. Se for olhar um pouco de tudo, tem imperfeição, que, se contar a história e dizer a verdade, está beleza. Outros caras eu acho que cortariam a cena e tentariam de novo. Talvez muito pelo que aprendi em ter que filmar rápido, muito e barato, e ser criativo, acho que tirei da minha cabeça o conceito da perfeição e filmei o que vendia e era importante para contar a verdade daquele artista. A minha preocupação é que cada clipe tenha essa cara.

\section{Mas você tem preocupação autoral?}

Não o autoral de Mauricio autor, mas o autoral que respeita o perfil e a característica de cada artista. Talvez você olhe um clipe do KLB, um do D2 e outro do Virgulóides, e diga: "Os três foram você quem fez". Mas eles são absolutamente diferentes. Você entende que é por conta da minha preocupação na estética de cada artista e não minha. Aquilo é do D2. Tem a ver com a música, com a estética, com as roupas, com o movimento, com o estilo musical dele e com o que ele acredita.

Era muito fácil, por exemplo, pegar os Virgulóides e fazer deles um grupo absolutamente pop. Não era o que a gente queria, mas, sim, manter o que eles tinham de mais essencial. Sempre busquei a verdade do artista, porque, se você acredita naquilo, está vendida a obra.

O clipe da Pitty não pode ser igual ao do KLB, nem igual ao dos Virgulóides. Mas eles podem ter uma coisa: "O Mauricio faz clipe desse tipo". O que estou querendo dizer é: você vê o trabalho de alguns artistas que é igual ao de outros. Tinha uma época, principalmente quando se estava fazendo muito clipe, que você não sabia se era clipe da Ivete Sangalo ou do Jota Quest. Era tudo muito parecido. E não dá para ser parecido. É diferente o que eles acreditam e são. 


\section{Você se mantém autoral quando co-dirige um videoclipe?}

Alguns dos clipes que eu fiz, não muitos, tiveram co-direção. Em co-direção, você tem que ter algum tipo de comunicação com a pessoa com quem está trabalhando amizade, parceria ou respeito profissional. Não é um processo fácil. Você tem que saber ceder algumas horas, ainda mais com baixo orçamento. É como um casamento. Você tem que trabalhar com uma pessoa que não tenha um ego maior do que o seu (risos). Como eu já tinha o desapego de: "Não tem dinheiro, vamos trabalhar do jeito que dá e ser criativos e felizes, e achar que é do caralho"; não dava para trabalhar com um cara que na hora falava: "Não tem o gato preto e agora?", e perdia metade da diária de filmagem para resolver a cena do gato. Ele vai perder um puta tempo numa cena que vai durar três segundos daquele clipe, ao invés de fazer outras mil cenas.

O processo de co-direção nos meus clipes é realmente a união de forças de pessoas que fazem muitas vezes coisas diferentes. Cada parceiro é diferente. Às vezes você divide o que cada um vai fazer, um vai cuidar mais dos artistas, e outro vai cuidar mais da câmera, da técnica. É um modo de dividir essa autoria. Um diretor e um fotógrafo que co-dirigem, mas cada um cuida mais especificamente de certas coisas. Não que não possa dar palpite um no trabalho do outro. Foi algo que aprendi a trabalhar: com parceiros fortes que dividiam problemas (risos) e as idéias artísticas. Fui louco muitas vezes de trabalhar com pessoas que eu não conhecia direito como trabalhava. Mas de louco todo mundo tem um pouco.

\section{O videoclipe te dá mais liberdade autoral do que a publicidade?}

Como diretor publicitário, eu recebo o roteiro pronto da agência, que tem a ver com posicionamento estratégico do cliente, apólices, o que pode e o que não pode ser falado. Existe um público alvo e uma série de regras. O diretor de publicidade, óbvio, ajuda, dando idéias e outro olhar para aquela criação do redator publicitário. Tem, inclusive, alguns trabalhos que é só executar. Mas você executa aquele roteiro da melhor forma possível. Agora há outros em que realmente você dá muitas idéias e até consegue mudar um pouco a visão inicial do (departamento) criativo.

O clipe é totalmente diferente. Para começar, quem escreve o roteiro somos nós, os diretores, na maioria das vezes. Então, por si só, já é um grande desafio e um grande barato. Os orçamentos publicitários são maiores. Não tem nem comparação. O videoclipe no Brasil sempre engatinhou quanto à indústria e ao mercado. A indústria que se criou foi absolutamente ilusória. As gravadoras sempre souberam disso e a usaram muito bem, porque fazer videoclipe, no momento principalmente de maior explosão da MTV e da mídia, era uma coisa que chamava atenção. Vide a Conspiração ter se lançado a partir do videoclipe. Fazer videoclipe era uma vitrine e uma experimentação interessante que os publicitários olhavam bem: "Pô, esse cara faz videoclipe. É moderno". São certos cultos e dogmas que existem sempre. o que é moderno e o que não é. Virou um grande laboratório, muitas vezes. Por ter orçamentos, no meu caso principalmente, muito pequenos, era um exercício mesmo, de chamar pessoas que tivessem tesão de trabalhar de graça ou por muito pouco. Era uma gincana muitas vezes buscar a melhor solução para orçamento pequeno e fazer algo legal.

Para mim, como diretor hoje, ter feito e fazer videoclipe, foi uma grande escola. Muitas vezes eu entrava num set de filmagem de um videoclipe e tinha que experimentar e ser criativo em todos os aspectos, principalmente na dificuldade. Eu concebia a coisa de um jeito e, na hora, via que não dava para ser daquele jeito por falta de grana ou por alguma coisa do gênero. Então precisava, naquele momento, ser criativo, mudar e continuar feliz. Não podia ser: "Ah, se não tiver três gatos pretos, o clipe não sai". Não. Tinha que sair de um outro jeito e ficar do caralho. Ou seja, tinha que ter desprendimento e desapego, e ser rápido. Saber que, muitas vezes, em cima da coisa que não deu certo, ter outra idéia criativa, que depois funcionava muito mais.

Às vezes eu vejo ou alguém me conta que trabalhou com esse ou aquele diretor e que ficou fazendo um clipe durante 30 horas. Eu até já fiz clipes que demoraram muito 
tempo, mas, muitas vezes, eles têm um resultado final que você fala: "Demorou tanto tempo assim!?. Consigo realizar coisas parecidas em muito menos tempo". Então acho que minha velocidade e, muitas vezes, clareza são legais para o videoclipe, no sentido de ter certeza do que quero fazer. Também sinto falta de, em alguns trabalhos, ter suado um pouco mais. É válido você, de repente, sofrer um pouco mais e pensar em outras formas. Ao mesmo tempo, também acho que para esse tipo de trabalho que você muitas vezes não tem muita grana ou condições técnicas, é legal criar em cima do que você quer e tentar fazer o maior número de imagens diferentes e possíveis para aquele clipe. Assim, apesar de ser barato fazer, ele parece um pouco mais caro, em função de ter muitas cenas diferentes.

\section{Ir para a filmagem com tudo definido é a principal diferença entre publicidade $e$ videoclipe?}

Em videoclipe, você também vai, até porque filma sem grana e, por isso, não pode errar. Tem que planejar muito bem. Se tiver contratempos, tem que ser criativo e não pode perder tempo. Se quebrar um negócio, você não pode ficar esperando ele arrumar. $\mathrm{Na}$ publicidade, você fica. Em clipe, não pode. Tem que resolver, desistir ou fazer outra coisa enquanto arruma. Ser criativo e estar sempre aberto a mudar a coisa muito facilmente é a grande diferença. Você também pode se valer do que está acontecendo na hora, principalmente quando não tem grana. É óbvio, se é um clipe com começo, meio e fim; se não for super planejado e preparado, um erro pode ser fatal. Se errar sem grana, você está fodido. Pode comprometer. Por isso, meus clipes talvez não tenham essa necessidade da perfeição. A partir do momento em que eu tenho essa necessidade, se errar, fodeu. Nos meus trabalhos, há a liberdade de fazer diferente e ficar legal igual.

\section{O videoclipe dá mais visibilidade do que a publicidade?}

Durante certa época, eu tinha até medo das pessoas falarem em diretores clipeiros, criando um rótulo, um estigma. Meio que dei um tempo de fazer videoclipe para entrar fundo na publicidade e não ficar com esse estigma. Hoje, não temo esse clichê, porque sou um diretor que faço e gosto de fazer videoclipe, com minha linguagem, que é a mesma para publicidade e cinema.

O videoclipe dá visibilidade, para o meio publicitário te ver como um cara moderno. Ele também teve alguns momentos bem fortes no Brasil. Quando você faz um trabalho realmente legal, ele chama atenção. Eu me lembro da época daquele programa da MTV, Ponto Zero, que sempre que estreava um clipe, você ficava: "Que barato!". Para mim, essa é a sensação que eu tenho quando faço um clipe: tem que ter alguma coisa diferente, seja na linguagem ou na fotografia. Na verdade, ele conta uma história e vende uma música ou um conceito, mas as pessoas olham para aquilo sempre com um frescor. Para mim, é sempre um desafio ser diferente.

\section{O fato de o videoclipe exibir os créditos e a publicidade não faz diferença?}

O clipe é um trabalho onde a gente realmente trabalha sem ganhar, mas assina e tem crédito. Você bota sua cara ali para bater mesmo. Tem peso e força enormes. Se não estou ganhando dinheiro, tenho que fazer por tesão e vontade de fazer. Eu não vou fazer publicidade de graça. Não faz sentido.

\section{Você leva mais coisas da publicidade do que do cinema para o videoclipe?}

A publicidade nunca foi referência para eu fazer videoclipe. Talvez tenha sido em pouquíssimos trabalhos. O que a publicidade me ensinou é que cada trabalho tem que ter a sua cara e ser direcionado para um público ou para um tipo de estética. Você não pode fazer um clipe da Pitty que se adeque só para um cara de 80 anos de idade ou botá-la 
absolutamente estetizada, lindinha, tudo perfeitinho. A publicidade me ensinou a entender cada movimento, cada artista, e traduzi-los em imagem. Ela me direciona o foco. O cinema é como eu conto a história e vejo o que é importante - a crueza e a realidade. Talvez o cinema, o documentário e a fotografia sejam muito mais referências. $\mathrm{O}$ clipe das Volkanas, por exemplo, tem relação com as capas dos discos e o tipo de foto, mais do que com os clipes de metal. Sempre vou atrás não dos clichês, mas do que essa estética representa.

\section{Você costuma ver videoclipes? Há diretores que o tenham influenciado?}

Eu gosto de clipe, mas não sou fanático. É raro eu ver um clipe inteiro, ainda mais agora que o zapping ficou tão mais fácil. Eu nunca tive muita paciência. Acho que a minha grande influência é cinema, fotografia, literatura, música e também clipe. Tem vários diretores bacanas: (Michel) Gondry, Spike Jonze, Chris Cunningham. São feras que fizeram coisas boas. No Brasil, Andrucha (Waddington) já fez coisas boas, o próprio Oscar (Rodrigues Alves), Jarbas Agnelli. Admiro e respeito o trabalho de vários caras como esses.

\section{Como você determina a equipe que vai trabalhar num videoclipe?}

Trabalho audiovisual é um trabalho de equipe. Então você tem que ter pessoas em quem confie e com quem goste de trabalhar. Em set de filmagem, é como estar na sua casa e o que é feito ali é impresso no negativo. Se o clima é ruim e pesado, se as pessoas te tratam mal e não fazem com vontade e tesão, a imagem terá alguma coisa diferente. Então aprendi que tenho que trabalhar com pessoas que admire, tenha afinidade, respeite ou as três coisas. Como cada trabalho tem sua cara, procuro ver se um clipe é mais fashion e, daí, trabalhar com pessoas que tenham essa cara e misturar sempre pessoas e estilos diferentes.

Tem fases em que eu trabalho com as mesmas pessoas, depois eu mudo. Mas tenho grandes parceiros. Essas parcerias são imprescindíveis para poder realizar muitos desses clipes, que são verdadeiras roubadas, em termos de grana. Tony Tiger, por exemplo, editou pelo menos $60 \%$ dos meus videoclipes. J. R. Alemão também produziu grande parte. Fotógrafo era no começo de carreira mais o Marcelo Corpani, agora mais o Mauro Nicoloti. Esses três cargos são fundamentais para mim - fotógrafo, produtor e editor.

\section{Quais são as diferenças entre fazer democlipe e clipe de gravadora?}

A diferença está, basicamente, na banda, porque a qualidade, num clipe de cem mil ou cinco mil, tem que ser a mesma, guardada a devida proporção. Tem que chegar ao mesmo lugar. A gente tem tanta necessidade de vender um disco de uma banda que já é famosa, como de lançar ou de dar cara para banda que ninguém conhece. Às vezes é até muito mais importante fazer clipe de uma banda demo do que de uma banda consagrada, porque aquilo pode matar ou ajudar a carreira de alguém. Também é muito mais legal, às vezes, fazer um clipe demo, porque são pessoas que não têm vícios, nem problemas. Estão ali confiando muito em você, botando uma responsabilidade bacana, porque te admiram e respeitam. Tem também frescor e paixão muito maiores. Não que não tenham artistas consagrados que não tenham, mas, normalmente, banda demo tem energia diferente. Quando curto o trabalho dos caras, vejo que a coisa é de verdade e tem algo a se passar, entro de cabeça também.

\section{Quem determina o diretor de um videoclipe?}

Muitas vezes é o cara da gravadora, que já te conhece ou trabalhou com você e te indica para outro artista; muitas vezes o artista que viu o clipe e quer trabalhar com você; ou o empresário. Não tem muita regra. Acho que o que determina é o seu próprio trabalho, que é visto por alguém que te procura. Normalmente, quem paga o clipe também é a gravadora. 
Muitas vezes o artista faz parte dessa bolada. Quando o clipe custa um pouco mais do que a verba que a gravadora destina e o artista está a fim de fazer daquele jeito, um clipe mais legal, ele também põe do bolso. Tive o caso de uma banda demo que o pai pagou (risos), como já tive casos de merchandising e de bandas que conseguiram patrocínio para fazer o clipe.

\section{O que você acha de merchandising em videoclipe?}

Eu acho uma solução muito legal, desde que merchandising tenha a ver com o clipe e não seja grotesco e fora de contexto. Os americanos fazem tão bem merchandising, porque a gente não pode fazer? Eu acho uma coisa super bacana para fazer um clipe de maior qualidade. Quando o merchandising é sutil, não tem problema. No clipe do CPM 22, Dias Atrás, tem merchandising de lata de cerveja Crew, numa cena em que o Badauí está suadão e dá um gole. Você vê o nome, mas é pequeno e não incomoda. Poderia ser um pouco mais sutil, mas não me incomodou. O clipe da Pitty, Semana Que Vem, tem um merchandising da Volkswagen, mas sem close de marca. Aparece ela envelhecendo dentro de um carro, como se estivesse dirigindo na estrada. Até tinha uma cena que aparecia a marca, mas o cara da Volkswagen falou: "Não precisa. Está ali já. Ficou super bacana". O orçamento era " $x$ " e os caras pagaram " $4 x$ " a mais. Então, se não saísse essa grana, o clipe não teria tido a qualidade que teve. Foi o clipe mais caro da história da Pitty.

\section{Você gosta de sair filmando para arquivo?}

Que eu possa usar em outros trabalhos? Não tenho estoque de imagens. Às vezes, filmo coisas a mais, depois lembro: "Preciso de cena assim". Aí tenho ali. Mas, normalmente, não tenho tempo para isso (risos). É sempre uma correria.

\section{Você arquiva e cataloga seu trabalho?}

É um caos meu arquivo, tanto que não sei quantos comerciais já fiz e nem tenho todos os meus trabalhos. Já mudei de produtora algumas vezes e, em todas as vezes, tento fazer cópia do que fiz lá. Às vezes, fica faltando alguma coisa e esqueço de pegar.

\section{Como funciona a questão de direito autoral em videoclipe?}

Esse é um problema sério, porque hoje as gravadoras fazem contratos absurdos, que protegem basicamente a elas. Por que motivo? Está cada vez mais difícil ganhar dinheiro com venda de disco. Então clipe virou um produto e querem botá-lo no site e disponibilizar em celular, mas o orçamento continua o mesmo. A gente tem que aceitar, senão não faz o trabalho. Se vendem o clipe para uma companhia telefônica, a gente não ganha um tostão. Na verdade, clipe no Brasil é muito amor à vontade de fazer uma imagem em movimento com música, que dará visibilidade e aparecerá na tevê. Mas ganhar dinheiro com clipe, eu ganhei muito pouco na minha vida. Além disso, você tem que assinar um contrato cedendo essas imagens para fazerem o que quiserem com elas. Não há respeito pelos diretores. A única coisa que tem é um crédito na MTV. Assinei uma vez o contrato de um clipe dos Engenheiros do Hawaii, onde dizia que, quando fizesse DVD, ele seria incluído e eu ganharia uma porcentagem na vendagem. Como não lançaram DVD de clipe, queriam incluir, como extra do Acústico MTV, os dois clipes que fiz para eles. A MTV não quis ceder os direitos para mim e mandou um contrato para eu assinar cedendo os clipes de graça. Vai falar o quê? Acaba cedendo, porque não quer se indispor e quer continuar trabalhando. 


\section{Como foi fazer o videoclipe, produzido pela MTV, de Eu Te Amo, Te Amo, Te Amo, para divulgar o Acústico, do Roberto Carlos?}

A MTV tinha feito o Acústico, do Roberto Carlos, mas os direitos das imagens eram da Globo. Como a MTV era sócia do disco, ela tinha que divulgar aquilo de alguma forma. A MTV já tinha feito um clipe internamente, com imagens no Centro, e queria fazer mais um, dessa música. Chamaram a mim, Felipe Segall e Kelly, e pediram algumas idéias. Tinha que fazer super rápido para dali a dois dias entrar no ar. A MTV bancou e cedeu a Marina Person para ser atriz.

Como não podia usar imagem do Roberto, tinha que ser um clipe de historinha. Ele ficou no ar tipo uma semana, porque o Roberto ou alguém viu e pediu que saísse do ar. $\mathrm{A}$ história era a Marina Person se arrumando, tomando café feliz, indo a uma loja, comprando roupa, bolo, flores, e, na hora em que chega em casa com o carro, abre o porta-malas e aparece um cara amarrado. Ela, então, põe o cara amarrado na sala e faz comida e drinques para ele, que tinha sido seqüestrado por ela e a quem estava amarrado. Era hiper bem-humorado e divertido. Foi feito em $35 \mathrm{~mm}$, só com o negativo em círculo. Não tinha um tostão e fizemos na brodagem. Quem fotografou foi Zé Bob, que era namorado da Marina Person na época.

\section{Quais são as etapas de realização de um videoclipe? E qual é a interferência do intérprete ou compositor da música?}

Normalmente, eu recebo a música, troco uma idéia com a banda ou com o cantor, para ver se eles têm alguma idéia e se a canção tem algum significado. Em cima do que falam ou se não falam nada, eu busco as minhas referências. Pesquiso, leio, assisto alguma coisa e crio, a partir de algumas idéias. A banda fala: "Gosto dessas". A gravadora: "Gosto dessas". Daí chega-se a um consenso. Faço um roteiro, pesquiso locações, atores, etc., e filmo. Mais ou menos esse é o meu processo criativo.

Sou um débil mental que chamam para fazer videoclipe com o prazo de uma semana, 10 dias, porque sabem que vou lá e faço normalmente em uma diária. Dificilmente, consigo fazer em duas diárias. Só quando o orçamento é maior ou há a necessidade de filmar mais cenas em lugares diferentes. Então tudo precisa ser muito bem pensado para chegar pronto na filmagem, seguro e com o preciso para realizar e sair um pouco do que pensei. Pode demorar um, três, cinco ou dez dias, dependendo do caso. A complexidade do trabalho requer isso. Quando é um trabalho que tem cenário ou não sei o quê, precisa de um pouco mais. Mas eu improviso muito na hora de filmar, até por conta de orçamentos baixos.

Já a edição é botar tudo que a gente realizou para frente. Normalmente, é durante a edição que a gente, muitas vezes, desfragmenta ou busca coisas muito diferentes do imaginado, mas sempre partindo do que foi pensado inicialmente. Quando tem computação ou muito efeito, pode demorar um pouco mais. Se não, eu me interno com meu editor, normalmente Tony Tiger, e editamos muito rápido. Até porque já filmo um pouco com olho de editor. Sei mais ou menos os cortes que preciso, o que vem da experiência de já ter feito bastante coisa.

\section{Quais são os artistas com quem você trabalhou que gostam de participar ativamente da criação do videoclipe?}

Vários gostam e são cheios de idéia. Pitty tem inspirações em filmes que gosta. Tico (Santa Cruz), (vocalista) do (grupo) Detonautas (Roque Clube), gosta de algumas coisas. D2 já chega com uma coisa basicamente pronta na cabeça. Só temos que traduzir em imagens, para uma narrativa, aquilo que ele idealizou. São vários artistas que curtem fazer clipes e têm alguma coisa a falar. Muitos outros não tem a menor idéia. Há ainda artistas que não se preocupam tanto, que estão ali porque sabem que aquilo é mais uma ferramenta 
de marketing do que um sonho que ele quer contar em imagens. Às vezes, nem tem tanto tempo.

\section{Você já fez mais de um videoclipe ao mesmo tempo?}

Já. Não filmei vários no mesmo dia, mas consigo de, em uma mesma semana, falar de uns quatro clipes ao mesmo tempo. Filmo hoje um, amanhã outro, a semana que vem outro. Por isso, é preciso ter a cabeça no que precisa para cada um deles. Eu gosto quando isso acontece, porque me motiva a pensar em várias coisas ao mesmo tempo. Não me atrapalha. É uma forma de me organizar mentalmente.

\section{Como funciona a relação entre imagem e música nos seus videoclipes?}

Depende do clipe e do artista. Clipes de hip hop, por exemplo, que numa época eu fiz uma porrada, são altamente cinematográficos, com grandes roteiros. Por mais que você tente buscar alguma metáfora por trás da letra, eles têm uma necessidade de falar do que vivem e do que acreditam, e as imagens precisam estar absolutamente ligadas ao que a letra diz.

Com outros artistas, é óbvio que a letra tem que inspirar. Muitas vezes, eu faço uma coisa que não tem nada a ver com a letra, mas que tem de contar alguma coisa do momento do artista. Às vezes, também tem que procurar uma imagem que chame atenção de maneira diferente. Por isso, às vezes, a letra fica em segundo plano. A regra é fazer algo em que a gente acredite.

\section{Se fosse possível, você acha que valeria a pena viver de videoclipe no Brasil?}

Com certeza, mas quero fazer cinema e várias mídias diferentes. É a minha forma de ver e o meu prazer. Mas se desse para viver de clipe, por que não?

\section{Como você define o formato do videoclipe - película, super-8, etc.?}

Normalmente, pela grana (risos). Eu busco fazer quase sempre em cinema. Fazer em $35 \mathrm{~mm}$ é muito difícil com os orçamentos que há no Brasil. Eu fiz pouquíssimos. A maioria foi em $16 \mathrm{~mm}$. Faço em vídeo quando o orçamento é realmente mais baixo. Às vezes, tenho necessidade de misturar formatos, bitolas, fotografia. Vai pela linguagem do que quero imprimir.

\section{Qual é a variação de orçamento das gravadoras para videoclipe?}

O orçamento básico, de um artista médio para consagrado, é mais ou menos 40 mil reais. Agora, bandas menores e independentes têm menos ainda. Só que, no Brasil, é cada vez menor.

\section{Quais são as facilidades da tecnologia digital em relação à analógica?}

Hoje em dia, todo moleque pode ter uma câmera DVzinha e editar o seu clipe no próprio computador. Eu vivo falando, para quem vem me perguntar onde começar, que comece pegando uma câmera, uma banda de um amigo e fazendo. A facilidade que tem agora é bem diferente de quando comecei, porque os equipamentos, naquela época, eram muito mais caros. Agora dá para fazer um clipe com o celular ou com uma câmera digital de fotografia. É só não ter medo de experimentar. 

(VMB)?

\section{Qual é a importância de ser premiado em eventos como o Video Music Brasil}

Prêmio é visibilidade e, mais do que isso, recompensa. Mas, para mim, o maior prêmio é a banda, a gravadora e os fãs curtirem. Claro que eu adoro ganhar prêmio, como todo mundo, mas também não morro quando perco. Sei que, às vezes, tem umas panelas e você pensa: "Hum, será que era para eu ter ganho mesmo? Será que era para ter perdido?". Mas é legal. Dá uma mexida no seu ego, te infla a fazer outras coisas legais.

\section{Como você vê a evolução do videoclipe no Brasil, desde os tempos do Fantástico?}

Eu tenho 36 anos e é engraçado, porque, naquela época dos clipes do Fantástico, havia uma estética dos anos 80 mesmo - a maioria era em vídeo e meio propaganda do artista. Era um pouco da explosão do rock brasileiro. Sempre curti Realce e Som Pop. Com o advento da MTV, a gente começou a ver os clipes gringos, principalmente do Michael Jackson e da Madonna. Foi quando os diretores daqui começaram a ver o videoclipe como uma forma de expressão, no começo dos anos 90 . Eu lembro de clássicos como o clipe da Marisa Monte, Segue o Seco; e dos Paralamas, Ela Disse Adeus, que eram grandiosos. Hoje, acho que todo ano sempre tem dois ou três clipes de grande destaque, com linguagens diferentes e coisas interessantes. Mas caiu muito a produção brasileira, em termos de criatividade principalmente. Já tivemos momentos melhores. O boom talvez tenha sido no final dos anos 90, quando havia Paralamas, Marisa, O Rappa, Skank e Cidade Negra, e já passou um pouco. Eu acho que as pessoas já meio que cansaram de não ter grana (risos).

Agora vamos ter boom de experimentalismos, de diretores novos querendo fazer e se lançar com videoclipe, pelo motivo que qualquer um, com uma câmera e uma final cut no laptop, consegue fazer. Já os diretores mais consagrados vão ter cada vez menos tempo para fazer videoclipe e vão deixar de fazer pelo fato de as gravadoras estarem cada vez mais fodidas e com verbas de marketing cada vez menores. Eu acho que tem que se pensar videoclipe de outra forma, para celular e Internet.

\section{Você tem diminuído a quantidade de clipes realizados?}

São fases. Tem épocas em que eu faço bastante e outras em que não faço. Acho que sou grande termômetro para a situação econômica das gravadoras (risos). Quando você vir meu nome bastante na MTV, é que está rolando. Quando não aparecer bastante, é porque as verbas estão escassas (risos).

\section{A entrada das novas mídias muda no aspecto autoral?}

É relativo, porque essa mudança de foco é até ingênua. Algumas pessoas já me procuraram: "Se você vai fazer clipe só para o Youtube, uma telinha pequena, então pode ser mais barato e qualquer merda". Não é qualquer merda. A idéia criativa continua tendo que existir, porque, se o clipe não for interessante, ninguém vai querer ver, por menor que seja a tela. Agora, é mais barato, porque, às vezes, você não precisa fazer em cinema. Óbvio que, se fizer, ficará melhor. Mas não mudou muita coisa na maneira de captar.

Talvez também a Internet tenha quebrado um pouco essa estética em prol da criatividade. No videoclipe, principalmente dos anos 80 e 90, a estética era um absurdo e absolutamente necessária. Os meios digitais enveredaram para lado mais da criatividade. Então, hoje em dia, ter uma idéia criativa é muito mais importante. 


\section{O que é um bom videoclipe para você?}

O videoclipe é a junção de várias linguagens e formas de expressão. Então bom videoclipe é o que traduz de alguma forma a música, o artista, ou traz uma linguagem nova ou com certa qualidade estética, ou conta boa história. É meio subjetivo. Já me perguntaram: "O que é melhor - boa idéia com pouca grana ou péssima idéia com muita grana?". Acho que o melhor é uma boa idéia com muita grana (risos), mas ainda acho que uma boa idéia muitas vezes é melhor do que uma má idéia bem custeada. Óbvio que uma boa idéia que necessite de um mínimo é importante. Às vezes, podemos matar uma boa idéia por uma má realização, mas uma boa idéia, bem realizada com pouco ou muito dinheiro, é muito melhor do que uma má idéia realizada com um milhão de dólares. Para mim, videoclipe tem que ter alguma coisa que chame atenção e faça seus olhos brilharem. 


\title{
Videoclipes Comentados de Mauricio Eça
}

\author{
WHEN 2R1 - VOLKANAS \\ Data: 1994 \\ Roteiro: Mauricio Eça \\ Direção: Mauricio Eça \\ Assistente: ... \\ Produção: .... \\ Fotografia: Jubel Magrão (eletricista) \\ Operador de Câmera (VT): Mauricio Eça \\ Direção de Arte: ... \\ Figurinos: Volkanas \\ Edição e Montagem: Tony Tiger \\ Edição de som: ... \\ Figurantes: .... \\ Contratante/Financiador: Cacá Prates (com patrocínio da Pizzaria 1900 e apoio da Chroma \\ Filmes). \\ Premiação: ... \\ Materiais Utilizados: HI8, material de stock shot realizado em Beta e 35mm.

\section{História do Videoclipe}

Esse foi o primeiro videoclipe que eu dirigi mesmo. Na verdade, me apresentaram um cara chamado Cacá Prates, empresário de muitas bandas mais alternativas na época. Ele me procurou e falou: "Você está a fim de fazer clipe? Não tem grana. Eu sei que você trabalha numa produtora bacana que faz um monte de clipes". Era a Adrenalina, que estava estourando como a produtora do momento no começo de MTV.

Volkanas é uma banda de menina (só o baterista é homem) que tinha passado por um momento legal, parado e voltado, meio sem grana, com uma vocalista nova. $O$ disco estava saindo e não me lembro se era distribuído pela Paradoxx ou se era independente.

Graças a Deus, eu tive respaldo da produtora, que me deu estrutura, estúdio, edição, luz, porque a grana era muito baixa. Parte vinha do Cacá Prates e outra parte era de permuta de merchandising que ele fez com a Pizzaria 1900, paga em jantar (risos).

Foi um barato fazer, mas ainda é muito ingênuo. É a história da cantora que estava sofrendo problemas e tinha alucinações (risos). Ela aparecia no quarto de um motel, com as caixas de pizza, sonhando. Havia também cenas urbanas e da banda tocando no estúdio, que ficaram bem bonitas. O clipe foi gravado em um hotel no Bexiga, na Cinemateca e nos estúdios da Chroma Filmes.

O clipe tinha alguns clichês, mas o que sempre busquei, desde o início, eram as referências, que aproveito da melhor forma possível para cada trabalho. No caso deste, era bacana usar um ou outro clichê dos clipes de metal ou de rock da época. Não tinha vergonha. O negócio era fazer bem feito.

Foi uma diária só, que normalmente é o que se faz em todo e qualquer videoclipe, e demorei dois ou três dias para editar, apresentar e aprovar. Editei meio junto com Tony Tiger, que tinha uma banda e uma coisa musical legal, o que sempre ajuda na edição ritmo, ouvido e olho musical, de entender o que é melhor para as batidas. Por conta disso, ele é um editor excelente para clipes e foi o meu grande parceiro desde o início.

Por ser o primeiro clipe, eu fiquei bem feliz com o resultado, porque a qualidade estética ficou bacana, bem editadinho e vendeu bem a imagem da banda. Lembro até que alguém falou: "Está gringo". Não é um tipo de elogio que levo em conta, mas achei que ficou honesto. Não me envergonhou. Tinham imagens bem ingênuas e outras bem bonitas. As meninas me deixaram super a vontade e é um clipe muito orgânico. 


\section{Heranças e Avanços}

Pela falta de grana, é inerente ao meu trabalho de criação de videoclipe descobrir coisas na hora da produção e da edição. Aprendi, desde o início, fazendo orçamento de clipe, a trabalhar com muito pouco e ser rápido e criativo. O que é ser rápido em videoclipe? Eu acho que um clipe tem que ter quantidade e qualidade de imagens quanto mais, melhor, para ser rico e não ter repetição. Mudar a câmera e já fazer mais coisas. Não perder muito tempo com elucubração. Óbvio que tem momentos em que a gente precisa ter tempo até a cena ficar o ideal, mas nem sempre o ideal é o necessário. Ideal talvez seja passar um vigor, uma quantidade de coisas que contem melhor a história. Então sempre busquei tirar leite de pedra mesmo.

Esse é um clipe realmente bem atípico (risos). Você vê que não teve um enfoque. Era só uma mistura de linguagem, em prol da estética heavy metal. Também tem algumas coisas que, não é que estejam no lugar errado, mas, sim, numa quantidade absurda de elementos, o que, com o tempo, fui aprendendo a dosar. Tem ainda o fato de que as ilhas de edição estavam mudando do analógico para o digital. Então havia efeitos digitais que você punha meio a torto e a direito, sem dosar.

\section{Relação Imagem-Música}

A melodia ou o que a música diz e me passa sempre foi uma tônica no meu trabalho. Então nem sempre o clipe tem a ver com a letra. Nesse caso, acho que o que eu tinha que passar mais era uma mensagem e uma estética heavy metal, com força na esquisitice ou no sonho. As imagens tinham que ir por aí.

\section{Marcas}

Acho que não tinha marcas. 


\section{BAGULHO NO BUMBA - VIRGULÓIDES}

Data: 1997

Roteiro: Mauricio Eça, Rui Mendes e Zé Carratu

Direção: Mauricio Eça, Rui Mendes e Zé Carratu

Assistente: ...

Produção: Renata

Fotografia: Rui Mendes

Operador de Câmera (VT): Mauricio Eça e Rui Mendes

Direção de Arte: Zé Carratu e Beto Grimaldi

Figurinos: ...

Edição e Montagem: Carmine Bagnato

Edição de som: ...

Figurantes: ...

Contratante/Financiador: Excelente Discos

Premiação: ....

Materiais Utilizados: $16 \mathrm{~mm}$

\section{$\underline{\text { História do Videoclipe }}$}

Os Virgulóides estavam na Excelente Discos, selo do (Carlos Eduardo) Miranda, da Trama, e do Brian Butler, distribuído não sei por quem, prestes a estourar. O orçamento era melhor que os anteriores, mas, mesmo assim, baixo. Na concepção, foi um parceria minha, do Zé Carratu e do Rui Mendes, que falava: "Os Virgulóides são os novos heróis brasileiros, no sentido tropicalista da palavra". Então o que buscamos foi entender um pouco da estética desses caras, que vinham da periferia, de bairros mais afastados de São Paulo, e eram mais populares. Era muito fácil fazer deles um grupo absolutamente pop. Mas não era isso 0 que queríamos, mas manter o que eles tinham de mais essencial. Trouxemos também as coisas divertidas e loucas que eles faziam e que a música falava.

O clipe tem várias participações de amigos deles muito loucos. Por exemplo, um cara que trabalha no estúdio de som Bebop tira a dentadura no clipe. Tem um anão, Líder, que eles conheciam de balada e fazia o cobrador do ônibus. O motorista era o Tio Dedé, tio do baixista, Beto, puta de um figura. Os Virgulóides também deram muitas idéias, principalmente dessas figuras e de cenas que eles já tinham visto, vivido, gostado ou pirado, que nós conseguimos traduzir em imagens e montar uma narrativa. O clipe tem uma historinha, que a gente meio que vai por ela, mas depois foge.

Lembro que estávamos montando o cenário do ônibus - feito com restos de outros ônibus e várias outras coisas, como um banco de várias cores -, e sofrendo para imaginar como filmaríamos. A idéia era filmá-lo no estúdio, passando, na janela, vários cenários pintados pelo Zé Carratu, como no teatro, com aquele ciclorama, que mexe só a roldana. Só que a gente começou a bater cabeça porque não tinha grana para isso e não ia dar certo. Quando estávamos no estúdio, com o cenário quase pronto, passou um marceneiro, pirotécnico, e falou: "Por que vocês não botam esse ônibus numa caçamba de caminhão?". Aí Zé Carratu, cuja família tem caminhões, conseguiu um aberto para o dia seguinte, botamos o casco do ônibus no caminhão e saímos filmando pelas ruas de São Paulo, com pessoas interagindo. Ficou muito mais louco. No ônibus, estava o tio Dedé, o anão, mais alguma figura bizarra e a banda cantando atrás.

Outra idéia era que, na real, o ônibus era uma lata de sardinha. Então tem a parte de fora do ônibus, que a gente filmou em estúdio, como uma lata de sardinha, e a cena final com a banda dentro dela literalmente, vem alguém e fecha. Tem também um momento em que a letra menciona delegacia, porque descobriram que tinha bagulho no ônibus e os Virgulóides vão presos. No clipe, a delegacia é o inferno, com o anão vestido de diabo, umas gostosas e um cenário pegando fogo. É um clipe superdivertido e com estética real e descompromissada. A edição também foi tranqüila, mas talvez tenha demorado um pouco mais, por ter um ou outro efeito. 
Heranças e Avanços

De herança, tem os tipos estranhos e o fato de descrever uma cena de maneira direta. As cenas são fortes e bem-humoradas. Ou seja, eu realizei da melhor forma possível, e criativa, o problema.

De avanço, talvez ter alguns cenários e um compromisso diferente com a estética pop. Esse clipe foi um hit, não só pela música, como pelo fato de o clipe ser muito divertido, ainda mais para a época. Dos clipes bem-humorados, esse talvez tenha sido um dos primeiros.

Relação Imagem-Música

O clipe era uma viagem em cima da letra da música.

\section{Marcas}

A partir daí, eu sempre busquei a verdade do artista, porque, se você acredita naquilo, está vendida a obra. 


\section{DIÁRIO DE UM DETENTO - RACIONAIS MC'S}

Data: 1997

Roteiro: Mauricio Eça e Mano Brown

Direção: Mauricio Eça, Marcelo Corpanni e Tony Tiger

Assistente: Mariana Fresnot

Produção: Renata

Fotografia: Marcelo Corpanni

Operador de Câmera (VT): Marcelo Corpanni

Direção de Arte: ...

Figurinos: ...

Edição e Montagem: Tony Tiger

Edição de som: ...

Figurantes: Amigos dos Racionais MC's e detentos do Carandiru

Contratante/Financiador: Zimbabwe e Cosa Nostra

Premiação: 2 VMBs e premiação nos festivais É Tudo Verdade e Rio Cine.

Materiais Utilizados: $16 \mathrm{~mm}$, Beta, stock shot, fotografias de época e imagens cedidas pela TV Bandeirantes

\section{$\underline{\text { História do Videoclipe }}$}

A história de Diário de um Detento é marcada por uma porrada de coincidências. Eu era assistente do Odorico Mendes e a gente tinha feito um festival de rap e reggae no Anhangabaú. Racionais era uma das bandas que tocaria no festival, mas eles deram o cano e ficaram devendo show para o Odorico. Puta treta. Um dia, o William, da Zimbábue na época, disse que estava lançando o disco dos Racionais, tinha dois clipes para fazer e, assim, pagaria parte do que devia. Daí o Odorico me chamou: "Eu faço um e você faz o outro". Apesar de eu gostar do primeiro disco dos Racionais e de já ter feito alguns clipes com o Odorico para DMN e Sistema Negro, não manjava muito da linguagem do hip hop e dessa realidade toda.

Foi quando Odorico falou: "O clipe é Diário de um Detento e eles querem filmar no Carandiru. Não vai dar certo e não estou a fim. Faz você". Beleza. Aí, numa sala de reunião, Mano Brown, com birra para cima de mim, começa a falar: "Tem que filmar no Carandiru, porque, se não filmar, não tem clipe. Tem que ser de verdade". "Mas se a gente não conseguir autorização? Pode simular num estúdio". "Não, mano. Ou é lá ou não é". A conversa foi um pouco tensa e fiquei com essa porra na cabeça. Tinha ouvido a música pouquíssimas vezes e não tinha entendido ainda a importância e a força dela.

Por uma série de sortes, a gente conseguiu autorização, na época do (governador Mário) Covas, para filmar no Carandiru. Eu não tinha a menor idéia do que fazer e de como era lá dentro. Os caras não deixaram a gente ir antes para ver. No dia da filmagem, toda a equipe chegou de manhã no Carandiru, umas dez e pouco, assim como o Brown, que levou alguns amigos dele para fazerem o papel de presos. Os moleques com calça bege. Foi quando o diretor (do presídio) falou: "Vocês estão loucos! Não vai entrar ninguém com calça bege. Os equipamentos que vocês estão trazendo. Luz?! Nada entra". Em suma, entramos com uma equipe minúscula, quase sem luz, e sabendo que tínhamos que sair até, sei lá, quatro da tarde. Não tinha segurança e entramos no meio dos presos, só que autorizados porque os Racionais eram alter-ego dos caras e estavam contando a realidade deles. Eram tão admirados que todos queriam participar do clipe. Ao mesmo tempo, eu, pelo menos, tive medo no começo por estar no meio daquela galera que não tinha a menor idéia de quem eu era. Nesse dia, lembro que não fiz xixi, não bebi água, não fiz porra nenhuma. Só queria filmar. Tudo para mim era novo e forte. Também queria ir embora dali o mais rápido possível.

A gente não esperava nada, só que, por isso mesmo, tinha uma ingenuidade de fazer com tanta dedicação e com o nosso olhar que, sem perceber, já estava imprimindo uma linguagem. Câmera lenta foi um pouco a tônica do clipe, nas filmagens. Por quê? Ao 
mesmo tempo em que podia filmar muito, não podia, porque tinha que seguir o tempo das autorizações e dos Racionais. Brown não é um cara que você fala: "Ficou bom aqui. Agora vai ali". "Peraí, será que ficou bom? Depois a gente vai fazer ali, porque agora preciso conversar com três ou quatro manos". Ele era cheio de idéias do que tinha que ser filmado e participou da edição. Ainda negociamos com o diretor um segundo dia e conseguimos. Fizemos algumas cenas em estúdio e no Capão Redondo, porque tínhamos filmado pouco lá dentro, e outras no Capão Redondo. Também consegui imagens de alguns fotógrafos que registraram o massacre.

Foi a conjunção de um monte de coisas que fui conseguindo e resultou num trabalho muito legal. Documental demais. Essa é a grande força de Diário de um Detento. Nós ficamos com a coisa do "tem que ser de verdade e real", dita pelo Brown, e acho que o clipe imprimiu isso e entrou num momento muito forte, porque as pessoas viviam marasmo no Brasil, naquela época

\section{Heranças e Avanços}

Foi um avanço, no sentido de mostrar imagens com força e reais. Quando eu tinha que mostrar quem eram os Virgulóides, no que eles acreditavam e na simplicidade deles, eu mostrei. Quando passei, a partir dos Racionais, a ter que mostrar a realidade da periferia e o que eles vivem, sofrem e sonham, foi um avanço absurdo, na busca da verdade do outro.

A partir dali também, eu comecei a fazer muito mais videoclipes. Tive uma temporada de clipes de hip hop. Por quê? Por eu ter feito o clipe dos Racionais, ter ficado bom e as pessoas terem visto: "O cara conseguiu trabalhar com os caras e fazer uma coisa do caralho, entendendo a nossa linguagem da periferia, com narração do nosso cotidiano, sem filtrar tanto, e sendo um grande porta-voz dessa estética".

Por já ter realizado outros clipes, não me assustei em chegar num lugar sem prévia preparação. Podia ser um outro cara que: "Como é que vou conceber o negócio sem estar tão preparado?”. Eu não estava preparado especificamente para aquilo, mas, sim, para enfrentar uma aventura como aquela. Já tinha feito mil coisas sem grana e tendo que criar, ser criativo e rápido. Então essa foi minha cancha.

\section{Relação Imagem-Música}

O clipe foi feito em ritmo de observação, mais simbiótico com a letra, que mostra uma rotina tão pesada e quebrada por algo violento e ainda não resolvido. Depois, fiz uma série de clipes de hip hop sempre tentando imprimir alguma coisa a mais do que dizem as letras, que já são super cinematográficas. Muitas vezes queriam que as imagens fossem bem ao pé da letra, foto-legenda, e eu tentava sair um pouco e puxar alguma coisa mais estética e metafórica.

\section{$\underline{\text { Marcas }}$}

Essa foi a primeira grande filmagem no Carandiru, antes (do filme) Carandiru. E, mais do que tudo, tem essa linguagem de documental super forte, com uma estética suja e fotográfica, tipo Sebastião Salgado, que a gente buscou. Não sei como, a molecada começou a pedir, pedir, pedir o clipe e ele entrou no Disk MTV, às seis da tarde, tendo 8 minutos. Então rompeu um padrão, ocupando o espaço de 2 clipes e com palavrões e cenas de violência. Foi impossível não passar.

Diário de um Detento foi mais forte do que qualquer coisa e admirado por outros meios. Foi para Los Angeles e, depois, participou do festival Rio Cine e do É Tudo Verdade, como documentário. Também foi considerado o videoclipe brasileiro mais importante da história da MTV e entrou na mostra Made in Brasil, do Itaú Cultural, com os vídeos mais importantes do Brasil. Até hoje, ele é uma referência e, durante muito tempo, as pessoas 
falavam de mim e remetiam a ele. Virou um pouco estigma, mas pelas pessoas admirarem e respeitarem. Para mim, foi muito legal. 
REGINA LET'S GO - CPM 22

Data: 2001

Roteiro: Mauricio Eça e Felipe Segall

Direção: Mauricio Eça e Felipe Segall

Assistente: Kelly Marciano

Produção: J.R. Alemão

Fotografia: Marcelo Corpani

Operador de Câmera (VT): Mauricio Eça e Marcelo Corpani

Direção de Arte: Max Pochon

Figurinos: David Parizotti

Edição e Montagem: Tony Tiger

Edição de som: ...

Figurantes: ...

Contratante/Financiador: Abril Music

Premiação: ...

Materiais Utilizados: $16 \mathrm{~mm}$ e Super $8 \mathrm{~mm}$.

\section{História do Videoclipe}

Eu estava na Moviearte e conhecia o Luciano, guitarrista que trabalhava no artístico da MTV e gostava dos meus clipes de hip hop. Regina Let's Go, da Abril Music, é do primeiro CD do CPM 22. Antes, eles tinham feito um clipe independente e pintaram na produtora também muito por conta do Mario, que trabalhava comigo e é irmão da Ana Butler. Tinha um orçamento minúsculo. Na primeira reunião que eu e Felipe Segall tivemos com os moleques, eles tinham acabado de assinar com uma gravadora, estavam ainda meio confusos e falaram: "A única idéia que a gente tem é indo de carro para a praia". Olhamos e falamos: "Indo de carro para a praia ... Que legal, hein?! Idéia boa. Volta daqui a uma semana" (risos). Puta bosta. Mais clichê impossível.

Começamos, então, a ter idéia que, teoricamente, não tinha nada a ver com a letra, mas, depois de pronto, parece que tem algum sentido que, no meio do processo, fomos buscar. Acho que foi o Felipe que sugeriu fazer um clipe japonês legal. Fomos atrás de referências e vimos algumas fotos meio de máfia, que achamos divertidas. Pensamos, a partir daí, numa história em que a banda estivesse inserida meio ao acaso e que deixasse o clipe com cara meio de trailer de cinema, meio filminho.

Mais do que mostrar o que a banda faz, a gente iria apresentá-la por meio de uma história. Foi essa a viagem com as referências nipônicas. Quando eles voltaram, contamos um pouco da história com máfia japonesa e meio cíclica. Ela começa no final, com o cara fugindo de uma máfia, que quer a grana de uma aposta. Daí a gente resolveu botar luta no meio e Regina, causa da briga e da aposta, seria a assassina no final. Os caras do CPM 22 adoraram. Disseram que não tinham entendido nada e que não tinha nada a ver com a música, mas chaparam. Era uma idéia que eles nunca tinham pensado, mas infinitas vezes melhor que a deles, o que sacaram na hora.

Buscamos uma equipe que a gente gostasse de trabalhar e tivesse a ver. Brifamos para ir atrás de uma estética de máfia, sem muito clichê japonês. A idéia era ser uma Tóquio de hoje, mais suja, pobre e não tão estética. Os trabalhos de direção de arte, figurino e maquiagem foram bem legais. As roupas eram meio sujas e usadas. $O$ trabalho de casting também, de buscar atores japoneses. $O$ ator principal estava fazendo uma novela na Globo na época, ex-modelo e com algo triste no olhar. Era interessante.

Fomos atrás também do nosso velho e bom Cambridge, que, nessa época, ainda estava em boas condições de uso. Acho que deve ter sido o meu segundo clipe no Cambridge (risos), de muitos. Ao mesmo tempo, por sorte, um dia a gente foi na Liberdade e estava tendo uma festividade chinesa, com fitinhas da sorte. Tinha uma coisa meio Tóquio mesmo. Levamos o ator para correr, numa perseguição. Ele corria no meio da multidão real, que estava na festa, e a gente ia de Super-8 atrás dele. Não víamos a cara das pessoas, 
mas uma multidão. Foi mais uma coisa, sem planejar, sem proteção e sem polícia. Fomos na louca, como fiz muitas vezes (risos).

A primeira diária foi em Super-8 para buscar uma sujeira diferente, uma coisa meio de filme antigo. A segunda diária foi com a banda, quando falamos: "Vamos botá-la tocando num bar com cara meio de karaokê japonês, meio Yakuza". Então tem uma mesa com um velho, sem dedo, com aquela coisa da Yakuza de cortar o dedo, e uma menina mais nova. A gente caracterizou o bar do Cambridge e filmou cenas da ação, de brigas e do cara com a Regina, no começo e no fim do clipe. Também fomos atrás de lutadores. As cenas de perseguição no hotel e na rua têm muita coisa super crua de câmera na mão. Tem uma cena que eu pego a câmera na mão e corro atrás do cara. A gente virou uma rua e vieram em cheio em cima de mim. Eu fui para o chão, a câmera voou e eu ainda consegui pegá-la, sem quebrar. Mas fodi o joelho.

$\mathrm{Na}$ fotografia e no telecine, a gente fez uma fotografia não tão colorida, mais cromada, com cara de filme. Já na edição, Tony Tiger sacou uma coisa de ritmo, que era uma coisa de cortes, de ter uns pipocos, um momento que a cena dá uma freada e depois volta. Ele fez algo diferente, tanto que concorreu a melhor edição no VMB. Conforme fomos editando, começamos a perceber coisas que tinham a ver com a letra. Construímos uma narrativa na filmagem e depois mais na edição, o que, na nossa cabeça, tinha tudo haver com a letra. É engraçado. Quando você vai se acostumando com uma coisa, no meio do processo, acha sentidos onde não existem (risos).

É um clipe com pegada super forte e as pessoas adoram. Muita gente acha que é o melhor do CPM 22 até hoje. Enfim, teve aceitação bacana porque tem essa cara de filminho e uma crueza, uma sujeira, de apresentá-los de uma forma: "Esses caras tem a ver com isso. Eles fazem coisa boa e não se preocuparam apenas em mostrar ao mundo como tocam bem".

\section{Heranças e Avanços}

Isso é difícil de falar. Não é nem por não lembrar, mas por achar que tudo que a gente faz veio do que fez antes. O que posso dizer é que havia a preocupação em ter uma cara para o CPM 22. Eu acho que a gente vendeu e os apresentou muito bem para o Brasil. $\mathrm{O}$ original desse clipe talvez seja a edição e a estética. Acredito que, a partir dele, comecei a me preocupar um pouco mais com a minha estética, crua, suja e diferente a cada trabalho, e não com a estética publicitária. Talvez esse clipe tenha sido realmente um pouco menos de conteúdo e um pouquinho mais de estética, até em função do momento tecnológico que estávamos vivendo, de telecines; e também de meu trabalho na publicidade já buscar uma coisa diferente de estética. Pode ser que esse clipe tenha sido o pulo do gato. Virgulóides era sujo e feio; Racionais, apesar de ter uma estética, é de documentário, de cinema.

\section{$\underline{\text { Relação Imagem-Música }}$}

A música é curta e tem quebrada interessante na levada e crueza. Então fomos mais pelo sentido do que a música passava, do que pelo que a letra dizia. Tem também uma introduçãozinha, com uma música japonesa, de um CD de um artista qualquer, comprado na Liberdade, girada ao contrário, num sampler total. Não dá para perceber que porra de música é. Já, no final, tem o som do tiro. Numa primeira edição que a gente queria para o clipe, no meio, rolaria uma coisa de som direto e depois voltaria à música. A banda não quis. Por isso, não rolou. Acharam que matava a crueza da música ter essa quebrada. Foi uma discussão.

\section{$\underline{\text { Marcas }}$}

Câmera na mão. Apesar de ter certa estética e a gente procurar uma caracterização japa, sem requinte, esse clipe vai mais pelo lado do submundo. Talvez tenha a ver com hip hop e coisas esquisitas e pobres. Não somos bonitinhos e ordinários. Era uma banda de 
hardcore. Acho que CPM 22 é muito mais pop hoje do que era naquela época, onde ainda não tinha o conceito de emo e de hardcore melódico, que, teoricamente, veio do independente e estava se lançando. Havia preocupação de apresentá-los de maneira interessante e de mostrar que não eram popzinhos e acreditavam numa coisa mais poderosa e com atitude. A sujeira e a crueza tinham uma razão. Se fosse uma banda mais pasteurizada, talvez fosse diferente a parada. 


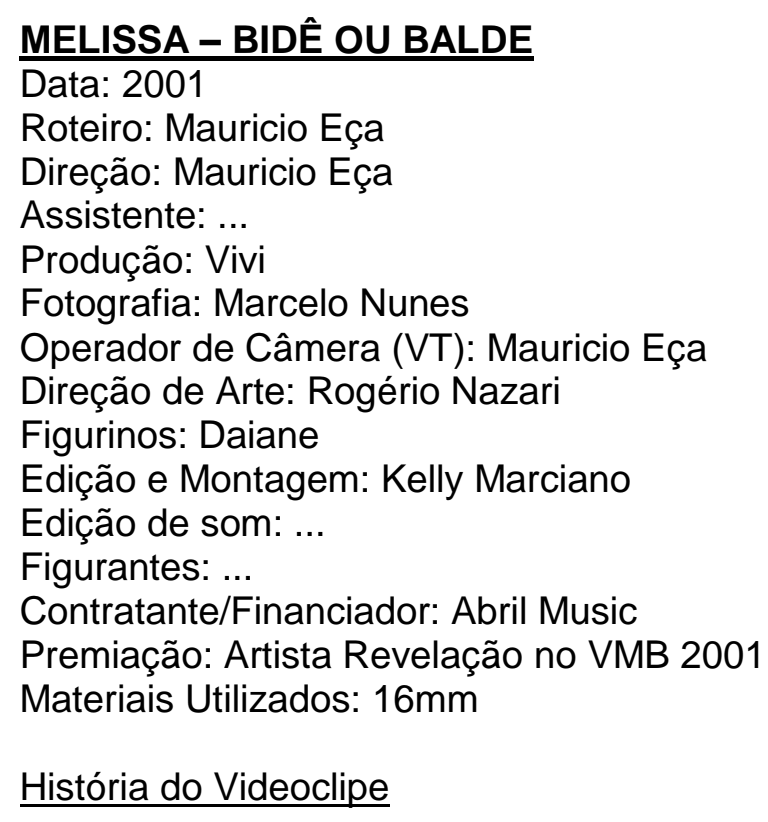

Eu estava fazendo alguns trabalhos de publicidade para uma produtora de Porto Alegre, TGD, e um dia o pessoal de lá me perguntou: "Você não quer fazer o clipe de uma banda gaúcha, Bidê ou Balde? Tem orçamento ridículo". Mas a produtora estava a fim de investir e fazer. Fui com eles num show do Bidê ou Balde, em Bento Gonçalves, cidade de vinho, perto de Porto Alegre. Foi divertido para caralho. Conversei com os caras e tivemos uma comunicação legal. Esse foi um trabalho de criação junto com o cantor, Carlinhos, que dava idéias e já tinha um monte de coisas na cabeça, com referências ao David Lynch. Eu também dei inúmeras outras e a gente sacou que, como tinha pouquíssima grana, era preciso filmar tudo num só lugar.

A locação foi muito importante para editar as cenas. Através dela, fiz o roteiro com outras cenas e idéias. Achamos o Dado Beer, uma cervejaria louca, meio tecnológica, com banheiros esquisitos e um lugar de vidro com algumas cortinas. Levamos um piso quadriculado para o lugar onde a banda tocaria. Essa música o Carlinhos fez para Melissa, colega de faculdade por quem ele era a fim, mas ela não dava bola. Então tem algumas auto-referências no clipe. Por exemplo, na cena final, a menina que aparece ao lado deles é a própria Melissa. Há outra cena em que um anão fala ao contrário trecho de uma fala de Twin Peaks, de David Lynch. Foi uma homenagem que a gente quis prestar. O problema é que não achávamos um anão em Porto Alegre. Aí descobrimos que tinha um catzo de um deputado gaúcho em Brasília com sete anões gaúchos no comitê dele (risos). A produtora botou até anúncio na rádio e achou um anão que trabalhava num bingo (risos).

Carlinhos queria a banda tocando numa festa. A música era absolutamente descontraída e pop. A estética tinha a ver também com o som meio Weezer, pop, desencanado. Construímos a locação e a estética em conjunto com o que a canção divertida trazia. "Vamos botar um cara esquisito num banheiro". Daí tinha um ator com quem já tinha trabalhado e que gostava, no qual botamos um nariz estranho para uma cena totalmente nonsense dele no banheiro. "Ah, vamos botar duas meninas lindas se beijando". Por quê? A música tinha uma coisa de proibido. Aí botamos. Tem uma menina que tinha feito um comercial que passa desfilando. Havia ainda uma parte da letra engraçada, que eu falei: "Vamos botar uma menina sem sal". Como é uma menina sem sal? "Acharemos uma menina sem peito". "Ah, legal". Daí uma menina da equipe falou: "Eu tenho umas estrelinhas tatuadas no meu peito". "Ah, você mostra?". "Mostro". Tem uma cena na cozinha, ela levanta a camisa e bota sal no peito (risos). Então esse clipe foi meio gincana e a filmagem foi divertida, por conta do clima descompromissado de criação coletiva, de work in progress. Em Porto Alegre, a equipe é muito desencanada. 


\section{Herancas e Avanços}

O clipe do Bidê ou Balde foi todo feito em locação que ajudasse na cara dele. Tinha direção de arte e fotografia preocupadas em ter a cara da banda. Ele foi bem mais orgânico, louco e menos programado e estudado que clipes que eu vim a fazer, como o da Pitty, Máscara. Aqui era mais como os meus velhos tempos no quesito de ser orgânico e deixar as coisas rolarem, claro que em cima de idéias pré-concebidas de arte, fotografia, atores e locação.

\section{Relação Imagem-Música}

O clipe era o que a letra transmitia de sensações. Não tinha nada a ver com a letra, que trata de um cara que diz: "Se quiser que eu te leve, eu aprendo a dirigir". Era a apresentação de uma banda nova, totalmente desencanada, divertida. Um clipe gostoso, despreocupado e desencanado.

\section{$\underline{\text { Marcas }}$}

Crueza e estética que tem a ver com a banda. Foi um clipe totalmente no espírito de gincana e feito com raça. Não tem nada de muito trabalhado e, por conta disso, muita alma. Foi uma grande festa fazer, com pessoas com muito tesão. Numa filmagem, tudo o que você está vivendo naquele momento imprime na imagem. Esse clipe imprimiu muito o que vivíamos naquele momento. Foi engraçado, porque ele concorreu ao VMB de clipe de banda revelação e, naquele ano, estavam estourados Falamansa e KLB. Era barbada um dos dois ganhar e ganhou Bidê ou Balde. Os caras fizeram uma puta festa. Anos depois, eu fui fazer clipe dos dois e eles falavam a mesma coisa: "Como é que aquela bosta do Bidê ou Balde foi ganhar?!". Eu falei: "Fui eu que fiz". Lembro que olharam feio: "Pô" (risos). É engraçado. Mas eu acho que é um clipe que passa alegria. As pessoas vêem e dão risada. 


\title{
GAROTA DE BERLIM - SUPLA
}

\author{
Data: 2001 \\ Roteiro: Mauricio Eça \\ Direção: Mauricio Eça \\ Assistente: ... \\ Produção: Mauricio Eça e Michael (produtor alemão) \\ Fotografia: Mauri Nicolotti \\ Operador de Câmera (VT): Mauricio Eça e Mauri Nicolotti \\ Direção de Arte: ... \\ Figurinos: Supla \\ Edição e Montagem: Tony Tiger \\ Edição de som: .... \\ Figurantes: Modelo alemã, George e Nina Hagen, entre outros. \\ Contratante/Financiador: Abril Music \\ Premiação: .... \\ Materiais Utilizados: $16 \mathrm{~mm}$

\section{$\underline{\text { História do Videoclipe }}$}

A música Garota de Berlim é de 1985, quando Nina Hagen veio para o Brasil, o Supla teve um caso com ela e eles gravaram. Eu fui ao show da Nina Hagen, que o Tóquio (banda do Supla na época) abriu, depois do Rock in Rio. Gostava dela. Eu tinha 14 anos na época. Por isso, trabalhar com ele e com ela foi louco. Supla estava na Abril Music e esse clipe caiu no meu colo. Tinha um cara que iria fazer e começou a embaçar. Um amigo me falou: "Estou aqui com o Supla e fulano está embaçando". Falei: "Quero fazer". Tive uma reunião com ele e soltei: "Vamos para Berlim, né?". Ele: "Não dá a grana". O orçamento não era bom e ele sugeriu um castelo da família dele em Petrópolis (RJ). Fomos, no dia seguinte, lá ver e era muito louco o castelo, medieval mesmo, no meio do Rio. Falei: "É o máximo esse castelo, mas quero ir a Berlim. A gente tem que encontrar a Nina Hagen. Você tem contato com ela?". Fiz contas e ele não acreditou: "Você é louco". Tinha acabado de sair da Casa dos Artistas e estava hypado total.

A grana dava para ir, mas pegando equipe em Berlim. Então, comecei uma pesquisa de produtoras e achei uma de documentário. Mandei um e-mail dizendo: "Vou fazer um clipe e o que preciso é saber se, para filmar na rua, com câmera na mão, sem botar tripé, preciso pagar autorização?". Na Europa, se você não botar a câmera num tripé, é como turista. "Você me ajuda, me dá infra-estrutura, uma van e fotografa umas locações que eu preciso assim, assim, assim? Quanto é?".

Para filmar em Berlim, uma cidade histórica e grande, é preciso aproveitar a grandiosidade do lugar como cenário. Não poderia ser clipe com cara de vídeo turístico. Mas há certos cartões postais que não tem jeito de fugir, como a praça com a estátua de Alice no País das Maravilhas, prédios históricos e a torre da tevê, que servem para identificar que estávamos em Berlim. Eu precisava também de coisas que mostrassem um pouco mais a cidade e a estética dela, e tratá-la como personagem. Já conhecia um pouco Berlim e o cara me mandou umas fotos. Achei do caralho. Ao todo, foram seis locações. Ele me fez um preço legal só para ir e eu fui armando a minha produção. Do Brasil, fui eu, Supla, Jorge, guitarrista dele na época, e Mauri Nicolotti, que tinha uma câmera $16 \mathrm{~mm}$.

A gente foi de classe turística da KLM e o Supla tinha acabado de fazer Casa dos Artistas. A aeromoça, então, nos botou em primeira classe. Upgrade. Show. Chegamos em Berlim e fizemos uma reunião. Era tipo fim de março, inverno e estava meio frio e chuviscando. O cara buscou a gente no aeroporto. Aquela coisa alemã, cheia de regras. $\mathrm{Na}$ hora em que ele viu a câmera, falou: "Vocês já a declararam?". A gente falou: "Não. Declaramos que estávamos saindo com ela do Brasil". "Tem que declarar". Foi uma cagada. Ficamos cerca de quatro horas declarando, porque os caras não tinham formulário específico. Chegaram a conclusão que eu tinha que deixar um depósito e, na hora que 
saísse de lá, pegaria o depósito de volta. Ou seja, a grana já estava contada e eu tive que deixar um depósito. Foi uma bosta.

A idéia do clipe, com um quê documental, era o Supla caminhando pela cidade, vendo a foto de uma mulher, pela qual se apaixona e fica o clipe inteiro atrás dela, procurando e nunca encontrando, conseguindo beijá-la apenas em sonho. Na verdade, não se sabe se era sonho ou se realmente ele conheceu ela, temática da música. A garota deveria ser a filha da Nina Hagen, Cosma Shiva, atriz alemã super famosa. Na véspera da filmagem, a gente ficou sabendo que a Cosma estava doente em Hamburgo e não poderia ir a Berlim. Fizemos casting e arranjamos uma modelo alemã, filha de portuguesa, por coincidência, super bonita, que fez e foi ótimo. Com Nina Hagen não podendo mais ser a "garota" por ter passado alguns punhados de anos, a gente entrou em contato com ela, que fez participação super afetiva, com três personagens - policial que dá uma geral no Supla, cigana num sasquatch, lugar meio abandonado transformado em centro cultural, e mulher super elegante no cinema, onde dois gêmeos, amigos dela, contorcionistas de circo, fazem umas acrobacias.

Quando filmamos fora do Brasil, pelo menos temos que revelar o negativo lá para não voltar fosco e poder passar pelo raio-X a vontade. Então, Supla voltou para o Brasil e eu e Mauri ficamos mais uns dois dias de turismo para revelar o negativo. Foi legal porque a luz na Europa é contínua, não varia muito no dia e é muito baixa. Estava super nublado e tem cenas embaixo de chuva. A fotografia é o máximo. Ao mesmo tempo, tinha um mistério e as ruas não estavam tão cheias. Também tem edição absolutamente louca e inspirada do Tiger, com acelerações, e procuramos estética que tivesse a ver com o Supla - uma coisa meio urbana. O clipe foi indicado à escolha da audiência (no VMB).

\section{Heranças e Avanços}

Herança é a câmera muito solta e a vontade, até porque era uma necessidade. Filmar numa cidade histórica como Berlim, se fosse pedir autorização nos lugares e pagar por tal, não seria possível fazer esse clipe com o orçamento baixo que havia. Com uma câmera na mão, é possível fazer o que quiser, como estudante ou turista. Então, nesse clipe, a câmera está basicamente na mão. Não tem quase cenas com tripé. Filmava rápido e ia para outro lugar. Tinha que filmar o máximo de cenas possível em lugares diferentes com essa coisa meio documental, que veio dos outros clipes, começando com Racionais. Esse também foi acho o primeiro clipe de viagem que fiz (risos).

\section{Relação Imagem-Música}

A gente procurou criar uma estética em cima da música, que é super forte e tem batida que vem dos anos 80 , misturada com rock and roll mais de hoje. A edição é bem alucinada, como tem de ser em muitos momentos da música e era a cara do Supla, principalmente nesse momento da carreira, em que tinha uma coisa super forte, não sei se popular é a palavra. No começo do clipe, tem o som de metrô, para colocá-lo lá: "Estamos num lugar esquisito, na Alemanha". O Supla anda sozinho, com uma coisa meio de abandono e solidão.

Marcas

As marcas são: câmera na mão, edição maluca e muito orgânica, sem se preocupar com as perfeições, mas, sim, com a música e a emoção que tem que passar. $E$ a experiência. $O$ clipe não pode ser maior do que o artista, talvez seja isso. 


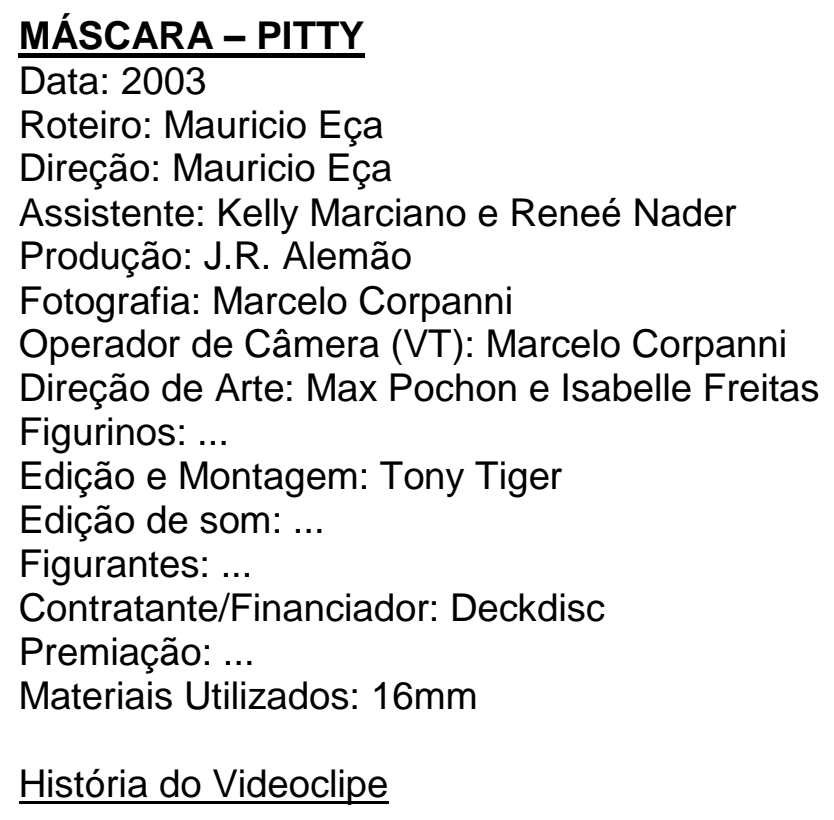

Eu fiz o clipe do Baba Cósmica, que foi meu primeiro contato com o Rafael Ramos. Tempos depois, ele estava abrindo a Deckdisc e me procurou para conversar a respeito de um artista novo que ele tinha - Pitty, cantora de rock baiana. Ele me mandou um vídeorelease dela no estúdio, gravando e acho que dando umas entrevistas. Achei legal. Desta vez, quem me indicou para o Rafael foi a Alice Pelegatti, mulher do Frejat, de quem eu tinha feito um clipe (Eu Preciso Te Tirar do Sério).

O clipe seria de uma outra música e não de Máscara, mas decidiram trocar. Eu ouvi a música e achei divertida aquela voz baiana, de uma mulher cantando rock, com aquele "bizarro, bizarro, bizarro". Depois conversei com a Pitty por telefone e ela foi super simpática e humilde no sentido de querer ouvir as minhas idéias. Acho que ela estava muito aberta por ser seu primeiro trabalho e por ainda estar meio se posicionando, com muitas outras coisas para decidir - disco, divulgação, etc. Ela deixou na minha mão e confiou muito em mim. E deu uns inputs, umas idéias do que gostava e do que não gostava.

Conversamos muito a respeito de cinema, que ela gostava de (Stanley) Kubrick e David Lynch. Acho que escrevi algumas idéias para ela, que gostou de algumas e não gostou de outras. Começamos meio a pensar juntos e fomos misturando idéias. Ela deu a idéia de um reality show e pensei na gaiola. Pensei também nos jurados que estão ali vendo pessoas bizarras, e a banda tocando atrás, como se fosse um ambiente só, que na câmera seria dividido. Às vezes, teria só os jurados ou os jurados com a banda atrás. E outras vezes só a banda, os jurados com os bizarros ou só os bizarros. Com isso, meio que criamos espécie de narrativa desse freak show. É mistureba de tudo um pouco.

Tinha um livro de um fotógrafo tcheco chamado Jand Salbeck, que eu gosto bastante e é maluquíssimo. A Pitty adorou todos esses tipos loucos, que tiveram caracterização super forte. Também privilegiamos as cores verdes, amarelas e azuis na direção de arte, no cenário e na fotografia. Lembro também de um filme que usei um pedaço como referência, cuja história é um menino que fica preso num porão até sei lá que idade e um dia sai, pira no mundo e vira meio popstar e meio monstro. Uma coisa meio maluca. No clipe, tem um carinha que é criado pela mãe e é meio lixo.

Trabalhei mais ou menos com a mesma equipe de Regina Let's Go, mas estava em outra produtora, o que foi uma grande sorte, porque ela tinha muita estrutura, com estúdio e cenário. Então consegui muita coisa de graça que deixou o clipe muito grande. Se você olhar Máscara, acha que é um clipe que custou uma grana e com cara gringa. Tem estética suja de novo e, para o primeiro trabalho dela, acho que foi super importante e forte. 


\section{$\underline{\text { Heranças e Avanços }}$}

De heranças, tem um pouco da estética que já veio de Regina Let's Go, de direção de arte, edição e fotografia mais suja e característica de uma artista de rock. Com Pitty, sempre tivemos afinidades nas referências, sejam literárias ou cinematográficas. A gente se entendia por música (risos). Ali há fotografia suja, mas estética, direção de arte cuidada, assim como figurino e cenografia. Tudo isso já indo para um lado estético, muito pensado e tentando traduzir em imagem a atitude da música e um pouco do que pensava a artista. $O$ clipe tinha que ter sintonia com todo o trabalho de divulgação e lançamento dela. A idéia era impressionar e impressionava, porque era sujo na medida certa, sempre respeitando a artista.

Talvez o avanço fosse eu já cuidar mais da estética e, como sempre, pensar numa "cara" para o clipe; ter a coisa sensorial, mas do ponto de vista de câmera, ângulos e movimentos; ser um pouco mais cuidadoso e um pouco menos orgânico que os anteriores. Já era evolução muito ligada a condições de trabalho melhores, equipe mais cuidada e, claro, experiência. Havia vontade de me superar e fazer algo diferente.

\section{Relação Imagem-Música}

Não tem nada de áudio fora da música, mas a relação entre imagem e música é total. Na verdade, a música fala de uma coisa de aceitação, de baixa estima, de ser feliz, apesar de você ser feio, louco, bizarro, diferente. Então teve essa coisa de freak show e do personagem que é o cara que mata e é criado pela mãe.

\section{Marcas}

Algo que sempre fiz nos clipes da Pitty é ter um monte de histórias e de referências misturadas, além de coisas que só a gente entende e as outras pessoas entendem alguns sentidos. Eles são muito sensoriais. Aqui fomos descobrindo uma máscara que depois usei em Teto de Vidro, Admirável Chip Novo e Semana Que Vem. Menos no Semana Que Vem e mais nesses outros três, há o sensorial. Então são misturas de referências e de sensações que a gente bota e não parecem ter muito sentido, mas que tem essa coisa sensorial muito forte. Até depois que a gente fez Admirável Chip Novo, Pitty falou: "Tem um monte de coisa nesse clipe que ninguém vai entender, mas é do caralho". É o encontro de um monte de sensações que fazem uma coisa mais forte. É loucura, sonho. Deixa você pensando muito mais no que aquilo quer dizer. A Pitty permitia, eu pirava e ela ia junto. Um dos jurados era cego. Por que um cego está ali sendo jurado? Ele saca as coisas pela sensação, pelo que está percebendo, cheiro, sei lá. O outro é um careca esquisito. 